UNIVERSIDADE DE SÃO PAULO

FACULDADE DE FILOSOFIA, LETRAS E CIÊNCIAS HUMANAS

PROGRAMA DE PÓS-GRADUAÇÃO EM GEOGRAFIA HUMANA

VIVIAN FIORI

AS CONDIÇÕES DOS CURSOS DE LICENCIATURA EM GEOGRAFIA NO BRASIL: UMA ANÁLISE TERRITORIAL E DE SITUAÇÃO

(Versão Revisada) 
VIVIAN FIORI

\section{AS CONDIÇÕES DOS CURSOS DE LICENCIATURA EM GEOGRAFIA NO BRASIL: UMA ANÁLISE TERRITORIAL E DE SITUAÇÃO}

Tese de Doutorado apresentada ao Programa de Geografia Humana da FFLCH- USP.

Orientadora: Profa Dra Nidia Nacib Pontuschka

São Paulo, Outubro de 2012 
FIORI, Vivian. As condições dos cursos de licenciatura em Geografia no Brasil: uma análise territorial e de situação. Tese apresentada ao Departamento de Geografia, da Faculdade de Filosofia, Letras e Ciências Humanas, da Universidade de São Paulo, para a obtenção do título de Doutora em Geografia Humana.

Aprovado em: 20/01/2013.

\section{Banca Examinadora}

Profa. Dra. Maria Laura Silveira

Instituição: FFLCH- Departamento de Geografia- Universidade de São Paulo.

Assinatura:

Prof. Dr. Fábio Contel

Instituição: FFLCH- Departamento de Geografia- Universidade de São Paulo.

Assinatura:

Profa. Dra. Nuria Hanglei Cacete

Instituição: Faculdade de Educação- Universidade de São Paulo

Assinatura:

Profa. Dra. Maria Isabel de Almeida

Instituição: Faculdade de Educação- Universidade de São Paulo

Assinatura:

Profa. Dra. Nidia Nacib Pontuschka

Instituição: Faculdade de Educação e FFLCH- Departamento de Geografia- USP

Assinatura: 
Dedico esta tese a minha mãe, pelo esforço com que sempre me incentivou a estudar 


\section{AGRADECIMENTOS}

A minha mãe por ter me ensinado a lutar pela vida.

Aos meus irmãos Vagner e Valmir pelo apoio dado ao longo de minha existência.

Ao Marco Antonio Gomes, meu marido, pelo apoio, incentivo, conforto e paciência neste período da elaboração da tese.

Aos meus amigos e amigas de trabalho Dirceu de Oliveira, Adriana Furlan, Gabrielli Cifelli, Flávio Bezerra da Silva, Carlos Eduardo Martins e Inês Confuorto pelo apoio e por sugestões que enriqueceram este trabalho.

Aos meus amigos do grupo de pesquisa, Carla, Eustáquio, Edjailson, Marcos, Tiago, Claudivan, Amália, Márcio, Edna, Gustavo, Robson, Ari e Dulcinéia.

Aos meus amigos, Lenice Mancini, Genny Cavallaro, Marco Latorre, André Araujo, Fernando Sarle e, em especial, ao Maurício Yamada pela ajuda na produção dos mapas.

À profa Amélia Maria Jarmendia por auxiliar-me na revisão linguística do texto.

À profa Nidia Nacib Pontuschka pela orientação, amizade e apoio para na construção desta pesquisa.

Aos professores Maria Laura Silveira e Fábio Contel pelas inúmeras contribuições na banca de qualificação e também na defesa final.

Às professoras Nuria Hanglei Cacete e Maria Isabel de Oliveira que compuseram a banca de defesa.

Aos professores Manoel Fernandes, Sandra Zakia, Afrânio Catani e Maria Adélia de Souza pelas aulas e referências bibliográficas de suas disciplinas, que contribuíram para a fundamentação desta tese.

À Universidade Cruzeiro do Sul por ter me apoiado ao longo de minha carreira nesta instituição.

Aos meus queridos alunos do Curso de Geografia, que me desafiam a conhecer sempre mais.

Aos professores, coordenadores e alunos de cursos de Geografia, cujos depoimentos foram fundamentais para a finalização desta pesquisa.

Ao Inep e aos funcionários por terem disponibilizado informações sobre os docentes dos cursos de Geografia.

A todos os autores citados nesta pesquisa, pois, sem eles, não conseguiria desenvolver este trabalho. 
"Mestre não é quem sempre ensina, mas quem, de repente, aprende" Guimarães Rosa. 


\section{RESUMO}

Esta tese trata da análise das condições existentes nos cursos de licenciatura em Geografia com a mediação do território brasileiro. A existência destes cursos tem relação com os processos históricos, sociais, políticos e espaciais. Os eventos, sobretudo os relativos à educação superior, são fundamentais para o entendimento de algumas de suas principais características. Nesta pesquisa, constatou-se que algumas das problemáticas destes cursos, embora em novas condições políticas, educacionais e espaciais, permanecem ainda hoje, tais como: a relação dos perfis dos cursos de licenciatura e bacharelado, a dicotomia entre Geografia Física e Humana, bem como a falta de professores, entre outras. Para operacionalizar esta pesquisa, privilegiou-se a análise dos cursos no período pós 1996, devido à influência das políticas estabelecidas pela Lei de Diretrizes e Bases da Educação Nacional (1996), pela legislação própria das licenciaturas (2002), pelas Diretrizes Curriculares Nacionais para os cursos de Geografia (2002), pelo sistema de avaliação de cursos e pelo Plano de Expansão das IES Federais (2007). Os dados qualitativos e quantitativos nesta tese são, principalmente, provenientes de depoimentos de docentes, coordenadores e discentes das licenciaturas em Geografia no Brasil; do Instituto Nacional de Estudos e Pesquisas Educacionais Anísio Teixeira (Inep); do questionário socioeconômico dos estudantes de Geografia, que fizeram o Exame Nacional de Desempenho dos Estudantes (Enade), nas dimensões docente, discente e de elementos curriculares dos cursos, a partir dos quais foram produzidos gráficos, tabelas e mapas. Após uma apresentação geral dos cursos, realizou-se uma análise pormenorizada da situação das licenciaturas em Geografia na Amazônia, Maranhão, Piauí, Pernambuco e dos cursos de Geografia oferecidos a Distância, que se interiorizaram no território brasileiro. Decorre como resultado da pesquisa que o processo de interiorização criou algumas singularidades nas licenciaturas pesquisadas, que têm relação com a formação e dinâmica territorial do Brasil, com o tipo de IES no qual o curso está inserido e com a modalidade na qual a licenciatura em Geografia é oferecida.

Palavras-chave: Licenciatura. Geografia. Território. Interiorização. Análise de Situação. 


\begin{abstract}
This thesis analyses the existing conditions of the Geography Teaching Courses with the mediation of the Brazilian territories. These courses have a strict relation with the historical, social, political and spatial processes. The events, especially those related to Higher Education, are centrally for understanding some of their main characteristics. Although within new political, educational and spatial conditions, some problematic aspects of these courses - that remain even these days - were detected in this research, such as the relation of the profile of undergraduate Geography Teaching Courses and Bachelor's Degree Courses, the dichotomy between Physical and Human Geography, as well as the lack of teachers, among others. For carrying this research out, courses created after 1996 were focused on in the analysis, especially due to the influence of the policies established by the Law of Guidelines and Bases of National Education (1996); by the specific legislation of Teaching Courses (2002); by the National Curricular Guidelines for the Geography Courses (2002); by the evaluation system of courses and by the Expansion Plan of Federal Institutions (2007). The qualitative and quantitative data of this thesis were, mainly, gathered from the testimony of teachers, coordinators and students of undergraduate Geography Teaching Courses in Brazil; from The Anísio Teixeira National Institute of Studies and Educational Research (Inep); from the social economical questionnaire answered by Geography students, who did the National Exam of Students Performance (Enade), on the dimensions related to teachers, students and curricular elements of the courses. With these data, graphics, tables and maps were produced. After a general overview of the courses, a detailed analysis of the current situation of the Geography Teaching Courses offered in Amazônia, Maranhão, Piauí, Pernambuco - all regions/ cities in the North and Northeast of Brazil - was provided. Geography courses offered in the Distance Modality, which were implemented in an inner Brazilian territory, were also analysed. The research results highlighted that the implementation of courses in the inner territory of Brazil has created some singularities in the researched courses. These singularities are related to the formation and the territorial dynamics of Brazil and also to the kind of institution in which the course is offered, as well to the type of modality of the course.
\end{abstract}

Keywords: Teaching Courses. Geography. Territory. Interiorization. Situation Analysis. 


\section{LISTA DE SIGLAS E ABREVIAÇõES}

AGB -

AGE -

Anpege -

AVA -

CAPES -

CESA -

CESVASF -

CFE -

CNE-

CES-

CNG -

$\mathrm{CP}-$

CPA -

CPC -

DAES-

DINTER -

EAD -

ECS -

Enade -

ENC -

ENEM -

$\mathrm{FNFi}-$

FACHUSC -

FAFOPA -

FAFOPST -

FAMASUL -

FAROL -

FFLCH -

FFPG -

$\mathrm{FHC}-$

FIAR -
Associação dos Geógrafos Brasileiros

Atlas Geográfico Escolar

Associação Nacional de Pós-Graduação e Pesquisa em Geografia Ambiente Virtual de Aprendizagem

Coordenação de Aperfeiçoamento de Pessoal de Nível Superior

Centro de Ensino Superior de Arcoverde

Centro de Ensino Superior do Vale São Francisco

Conselho Federal de Educação

Conselho Nacional de Educação

Câmara de Educação Superior

Conselho Nacional de Geografia

Conselho Pleno

Comissão Própria de Avaliação

Conceito Preliminar de Curso

Departamento de Avaliação de Ensino Superior

Doutorado Interinstitucional

Educação a Distância

Estabelecimentos Científicos Superiores

Exame Nacional de Desempenho dos Estudantes

Exame Nacional de Cursos

Exame Nacional do Ensino Médio

Faculdade Nacional de Filosofia

Faculdade de Ciências Humanas do Sertão Central

Faculdade de Formação de Professores de Araripina

Faculdade de Formação de Professores de Serra Talhada

Faculdade de Formação de Professores da Mata Sul

Faculdade de Rolim Moura

Faculdade de Filosofia Letras e Ciências Humanas

Faculdade de Formação de Professores de Goiana

Fernando Henrique Cardoso

Faculdades Integradas de Ariquemes 
FIESC

FNDE -

FOCCA -

FNFi -

FTC -

GATT-

IBGE -

IDD-

IDEB -

IES -

IESPs -

IFPE -

IHGB -

Inep -

LDB-

LDBEN -

MEC -

OCDE -

OMC-

Parfor -

PND-

PQD -

PUC-

RBG-

REGIC -

RENEX -

RJU -

REUNI-

SEED -

SESu- -

SGRJ -

Sinaes -
Faculdade Integrada de Ensino Superior de Colinas

Fundo Nacional de Desenvolvimento da Educação

Faculdade de Olinda

Faculdade Nacional de Filosofia

Faculdade de Tecnologia e Ciências

Acordo Internacional de Tarifas e Comércio

Instituto Brasileiro de Geografia e Estatística

Indicador de Diferença entre os Desempenhos

Índice de Desenvolvimento da Educação Básica

Instituições de Ensino Superior

Instituições de Ensino Superior Públicas

Instituto Federal de Pernambuco

Instituto Histórico e Geográfico Brasileiro

Instituto Nacional de Estudos e Pesquisas Educacionais

Lei de Diretrizes e Bases

Lei de Diretrizes e Bases da Educação Nacional

Ministério da Educação

Organização para Cooperação e Desenvolvimento Econômico

Organização Mundial do Comércio

Plano Nacional de Formação de Professores da Educação Básica

Plano Nacional de Desenvolvimento

Programa de Qualificação Docente

Pontifícia Universidade Católica

Revista Brasileira de Geografia

Regiões de Influências das Cidades

Rede Nacional de Extensão

Regime Jurídico Único

Programa de Apoio de Planos de Reestruturação e Expansão das Universidades Federais

Secretaria de Educação a Distância

Secretaria de Educação Superior

Sociedade de Geografia do Rio de Janeiro

Sistema de Avaliação da Educação Superior 


\begin{tabular}{|c|c|}
\hline SUFRAMA - & Superintendência da Zona Franca de Manaus \\
\hline TCC - & Trabalho de Conclusão de Curso \\
\hline TIC - & Tecnologia de Informação e Comunicação \\
\hline UDF - & Universidade do Distrito Federal \\
\hline UEA - & Universidade Estadual do Amazonas \\
\hline UEFS - & Universidade Estadual de Feira de Santana \\
\hline UEG - & Universidade Estadual de Goiás \\
\hline UEL - & Universidade Estadual de Londrina \\
\hline UEM - & Universidade Estadual de Maringá \\
\hline UEMA - & Universidade Estadual do Maranhão \\
\hline UEPA - & Universidade Estadual do Pará \\
\hline UEPB - & Universidade Estadual da Paraíba \\
\hline UEPG - & Universidade Estadual de Ponta Grossa \\
\hline UESPI - & Universidade Estadual do Piauí \\
\hline UERJ - & Universidade do Estado do Rio de Janeiro \\
\hline UERN - & Universidade Estadual do Rio Grande do Norte \\
\hline UESB - & Universidade Estadual do Sudoeste da Bahia \\
\hline UF - & Unidade da Federação \\
\hline UFAC - & Universidade Federal do Acre \\
\hline UFAM - & Universidade Federal do Amazonas \\
\hline UFBA - & Universidade Federal da Bahia \\
\hline UFCE- & Universidade Federal do Ceará \\
\hline UFES - & Universidade Federal de Feira de Santana \\
\hline UFF - & Universidade Federal Fluminense \\
\hline UFG - & Universidade Federal de Goiás \\
\hline UFMG - & Universidade Federal de Minas Gerais \\
\hline UFMT - & Universidade Federal do Mato Grosso \\
\hline UFOPA - & Universidade Federal do Oeste do Pará \\
\hline UFPA - & Universidade Federal do Pará \\
\hline UFPB - & Universidade Federal da Paraíba \\
\hline UFPE - & Universidade Federal de Pernambuco \\
\hline UFPI - & Universidade Federal do Piauí \\
\hline UFPR - & Universidade Federal do Paraná \\
\hline
\end{tabular}




\begin{tabular}{|c|c|}
\hline UFRA - & Universidade Federal Rural da Amazônia \\
\hline UFRGS - & Universidade Federal do Rio Grande do Sul \\
\hline UFRJ - & Universidade Federal do Rio de Janeiro \\
\hline UFRN- & Universidade Federal do Rio Grande do Norte \\
\hline UFRR - & Universidade Federal de Roraima \\
\hline UFS- & Universidade Federal do Sergipe \\
\hline UFSC - & Universidade Federal de Santa Catarina \\
\hline UFT - & Universidade Federal do Tocantins \\
\hline UFU - & Universidade Federal de Uberlândia \\
\hline UnB- & Universidade de Brasília \\
\hline UNEB - & Universidade do Estado da Bahia \\
\hline UNEMAT - & Universidade Estadual do Mato Grosso \\
\hline UNESCO & $\begin{array}{l}\text { Organização das Nações Unidas para a Educação, a Ciência e a } \\
\text { Cultura }\end{array}$ \\
\hline UNESF - & União das Escolas Superiores - \\
\hline UNESP - & Universidade Estadual Júlio de Mesquita \\
\hline UNIAM - & Universidade Federal da Integração da Amazônia \\
\hline UNIASSELVI- & Centro Universitário Leonardo da Vinci \\
\hline Unicamp - & Universidade de Campinas \\
\hline UNICASTELO- & Universidade Camilo Castelo Branco \\
\hline Unicentro - & Universidade Estadual do Centro-Oeste do Paraná \\
\hline UNIFAP - & Universidade Federal do Amapá \\
\hline UNIFESSPA - & Universidade Federal do Sul-Sudeste do Pará \\
\hline UNIMES - & Universidade Metropolitana de Santos \\
\hline UNIOESTE - & Universidade Estadual do Oeste do Paraná \\
\hline UNINORTE - & Centro Universitário do Norte \\
\hline UNIR - & Universidade Federal de Rondônia \\
\hline UNISA - & Universidade Santo Amaro \\
\hline UNITINS - & Universidade do Tocantins \\
\hline UPE - & Universidade de Pernambuco \\
\hline USP - & Universidade de São Paulo \\
\hline URCA - & Universidade Regional do Cariri \\
\hline
\end{tabular}




\section{LISTA DE MAPAS}

Mapa 1- Evolução do Número de Instituições de Ensino Superior, por Unidade da Federação - Brasil 1933- 1953

Mapa 2- Cursos de Geografia em Bacharelado e Licenciatura no Brasil 1959

Mapa 3- Evolução do Número de Instituições de Educação Superior, por Unidade da Federação - Brasil - 1971 - 1988.

Mapa 4 Cursos de Geografia em Bacharelado e Licenciatura no Brasil 1989

Mapa 5- Municípios com Cursos de Geografia do Parfor - 2010

86

Mapa 6- Evolução do Número de Instituições de Educação Superior, por Unidade da Federação - Brasil 1998-2008.

Mapa 7- Cursos de Geografia em Bacharelado e Licenciatura no Brasil 2009

Mapa 8- Os Cursos de Licenciatura em Geografia no Interior do Brasil 2009.

Mapa 9- Total da População dos Municípios com Cursos de Licenciatura em Geografia no Brasil - 2009

Mapa 10- Municípios com Cursos de Geografia - 1996

Mapa 11- Municípios com Cursos de Geografia - 2009

Mapa 12- Discentes matriculados no curso de Geografia, por período noturno

Mapa 13 - Renda Familiar dos Discentes do Curso de Geografia

Mapa 14- Tipo de Ensino Médio cursado pelos discentes do Curso de Geografia (Todo em escola pública) 
Mapa 15- Cursos de Pós-Graduação em Geografia - 2010 (por

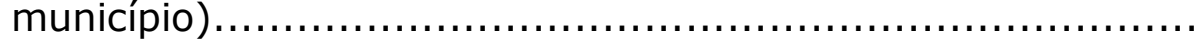

Mapa 16 - Número de Docentes Mestres do Curso de Geografia - 2008 ...

Mapa 17 - Número de Docentes Doutores do Curso de Geografia - 2008.. 159

Mapa 18- Escolaridade dos docentes dos Cursos de Licenciatura em Geografia - 2009

Mapa 19 - Número de docentes com regime parcial-integral do Curso de Geografia - 2008

Mapa 20 - Regime de Trabalho dos Docentes dos Cursos de Licenciatura em Geografia - 2009

Mapa 21 - Avaliação discente sobre a integração do currículo do curso de Geografia

Mapa 22 - Cursos de Geografia no Brasil - 2009 (Licenciatura e Bacharelado).

Mapa 23 - Principal razão para escolher o curso de Licenciatura em Geografia

Mapa 24- Condições das instalações físicas do curso de Geografia (salas de aulas, laboratórios, ambientes de estudo)

Mapa 25- Condições das Instalações Físicas do Curso de Geografia (salas de aulas, laboratórios, ambientes de estudo)

Mapa 26- Avaliação discente do curso de Geografia sobre atualização do acervo da biblioteca

Mapa 27- Freqüência da utilização dos discentes da biblioteca em sua IES - Curso de Geografia

Mapa 28 - Fonte de pesquisa para as disciplinas do Curso de Geografia... 222 
Mapa 29 - Material indicado pelo seu professor durante o Curso

Mapa 30 - Atividade acadêmica desenvolvida por mais tempo, além das obrigatórias no curso de Geografia

Mapa 31 - Apoio do curso de geografia para participação dos discentes em eventos de caráter científico (congressos, encontros, seminários etc.)

Mapa 32 Contribuição da Iniciação Científica para formação discente do curso de Geografia e....

Mapa 33- Contribuição da Extensão para Formação Discente do Curso de Geografia

Mapa 34 - Como você avalia a contribuição do curso para sua formação?.

Mapa 35 - Cursos de Licenciatura em Geografia em IES públicas Pernambuco 250

Mapa 36 - População dos Municípios com Cursos de Licenciatura em Geografia nas IES Públicas dos Estados do Pará e Amapá 2012

Mapa 37 - População dos Municípios com Cursos de Licenciatura em Geografia nas IES Públicas do Estado do Amazonas 2012........

Mapa 38 - População dos Municípios do Maranhão com Cursos de Licenciatura em Geografia

Mapa 39 Municípios com IES-Sede, com Cursos de EAD em Licenciatura em Geografia-2012.

Mapa 40 - Polos de Apoio de Educação a Distância Cadastrados - Cursos de Licenciatura em Geografia - 2012 


\section{LISTA DE GRÁFICOS}

Gráfico 1- Número de Cursos de Licenciatura em Geografia - (Por Tipo

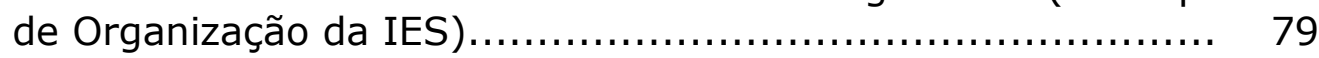

Gráfico 2- Total de Cursos de Licenciatura em Geografia - 2000 2009.

Gráfico 3- Número de Cursos de Geografia no Brasil por tipo de formação.

Gráfico 4- Distribuição das Notas na prova por grupos de estudantes ENADE / 2005 - Geografia

Gráfico 5- Distribuição das notas nas questões discursivas de componente específico por grupos de estudantes ENADE / 2005 - Geografia

Gráfico 6- Qual o período em que você está matriculado?

Gráfico 7- Faixa de renda familiar dos discentes do curso de Geografia (em salários mínimos).

Gráfico 8- Condição de trabalho dos discentes do curso de Geografia (exceto estágio).

Gráfico 9- Tipo de Ensino Médio cursado pelos discentes do curso de Geografia.

Gráfico 10- Tipo de Ensino Médio cursado pelos discentes do curso de Geografia.

Gráfico 11- Disponibilidade dos docentes do curso de Geografia na IES para orientação extraclasse

Gráfico 12- Existência no currículo do curso de licenciatura em Geografia de disciplinas pedagógicas 
Gráfico 13- Avaliação da integração do currículo do curso de

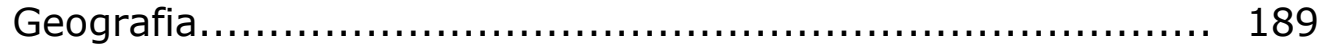

Gráfico 14- Conhecimento Prévio da área de atuação do profissional de Geografia ao optar pelo curso de Geografia

Gráfico 15- Exposição no curso de licenciatura em Geografia em atividades que permitissem a tomada de consciência sobre o que é ser professor

Gráfico 16- Qual a sua preferência para atuação profissional, na área de Geografia?

Gráfico 17- Exercício da função de professor(a) durante o curso de Geografia.

Gráfico 18- Você quer ser professor?

Gráfico 19- Principal Razão da Escolha da Licenciatura em Geografia 208

Gráfico 20- Principal Contribuição do Curso de Geografia

Gráfico 21 - Condições das instalações físicas do Curso de Geografia (salas de aula, laboratórios, ambiente de estudo)

Gráfico 22 - Condições dos equipamentos dos laboratórios do curso de Geografia

Gráfico 23 - Avaliação dos discentes do curso de Geografia sobre atualização do acervo da biblioteca

Gráfico 24 - Avaliação dos discentes sobre o número de exemplares disponíveis na biblioteca no curso de Geografia

Gráfico 25 - Avaliação dos discentes do curso de Geografia sobre atualização dos periódicos da biblioteca

Gráfico 26 - Frequência dos discentes na atualização da biblioteca em sua IES 
Gráfico 27 - Atividades de pesquisa como estratégia de aprendizagem nas disciplinas do curso de Geografia ....................................

Material mais utilizado por indicação de seus professores

Gráfico 28- durante o curso de Geografia......................................... 225

Atividade acadêmica desenvolvida por mais tempo, além das

Gráfico 29- obrigatórias no curso de Geografia................................. 228

O curso de Geografia oferece o Programa de Extensão

Atuação dos discentes do curso de Geografia em iniciativas e

Gráfico 31- Programas Comunitários ..................................................... 236 


\section{LISTA DE TABELAS}

Tabela 1 Área de formação de professores que lecionam Geografia 2007 -

Tabela 2 - Conceitos do ENC 2003, Geografia

Tabela 3 - Estatísticas das questões de múltipla escolha da prova de Geografia, por categoria administrativa - ENC/2003...........

Tabela 4 - Evolução do número de Instituições segundo a Categoria Administrativa Brasil 1996 a 2008

Tabela 5 Características dos docentes dos cursos de Geografia IES públicas e privadas de São Paulo e Rio de Janeiro -2009 (\%)

Tabela 6 Dados das cidades com cursos de Licenciatura em Geografia em IES Municipais - Pernambuco - 2012.

Tabela 7 - Características dos docentes das licenciaturas em Geografia - IES Municipais - Pernambuco - 2009

Tabela 8 - $\quad$ Características dos discentes das licenciaturas em Geografia - IES Municipais - Pernambuco - 2008 (\%)

Tabela 9 - Características dos cursos de licenciatura em Geografia da

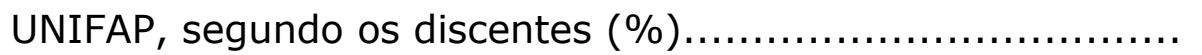

Tabela 10 - Dados dos Municípios com cursos de licenciatura em

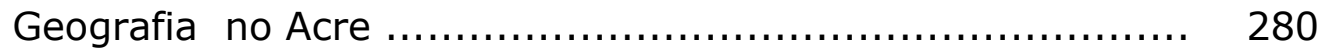

Tabela 11 - Características dos docentes dos cursos de licenciatura em Geografia da UFAC - 2009.

Tabela 12 - Características dos discentes dos cursos de licenciatura em

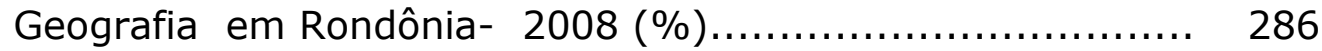

Tabela 13 - Características dos docentes dos cursos de licenciatura em Geografia em Rondônia

Tabela 14 - Característicos dos cursos de licenciatura em Geografia Tocantins - (\%)

Tabela 15 - Características de alguns cursos de Geografia - Maranhão e Piauí - 2008 (\%)

Tabela 16 - Dados do curso de licenciatura em Geografia em Palmeirais - Piauí - 2008 (\%)

Tabela 17 - Características dos docentes dos cursos de licenciatura em Geografia do Maranhão e Piauí - 2009 - (\%)

Tabela 18 - Características de alguns cursos de licenciatura em Geografia - Maranhão - (\%) 


\section{SUMÁRIO}

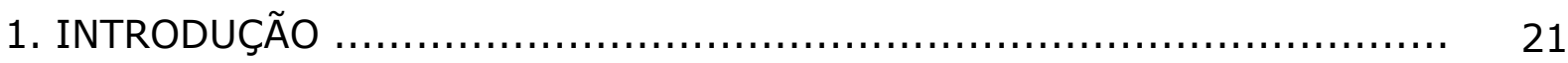

1.1. A delimitação e o método da pesquisa................................... 24

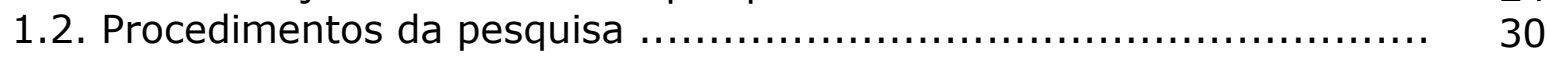

2. HISTÓRIA E PROCESSO DE EXPANSÃO DOS CURSOS DE GEOGRAFIA NO

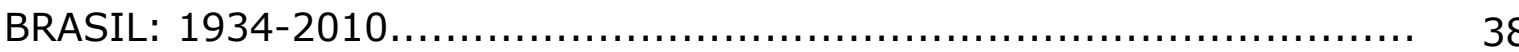

2.1. A história e historiografia dos primeiros cursos do Brasil............... 41

2.1.1. As características dos primeiros cursos de Geografia ........... 53

2.1.2. A expansão dos cursos de Geografia ........................... 59

2.2. O período de 1996-2010: as políticas públicas e as características dos cursos de Geografia....

3. DA AVALIAÇÃO DOS CURSOS DE GEOGRAFIA NO BRASIL MEDIANTE POLÍTICAS DO GOVERNO FEDERAL À ANÁLISE TERRITORIAL DOS

3.1. O sistema de avaliação e sua relação com os cursos de Geografia..

3.2. Por uma análise dos cursos que considere a mediação do território.

3.2.1. A relação das IES e dos cursos com o território brasileiro.

3.2.2. Os cursos de Geografia e sua dinâmica no território

3.3. As dimensões e elementos de análise dos cursos de Geografia....... 136

3.3.1. A dimensão das características dos discentes

3.3.2. As características da dimensão docente: formação e regime de trabalho

4. ANÁLISE DAS CONDIÇÕES DE ENSINO DOS CURSOS DE GEOGRAFIA.....

4.1. O currículo como um processo que se constrói historicamente....

4.2. A questão curricular nos cursos de Geografia no Brasil e suas dicotomias...

4.2.1. As especificidades da formação na licenciatura em Geografia...

4.3. A infraestrutura dos cursos de Geografia e sua relação com as atividades curriculares

4.4. O ensino, a pesquisa e a extensão

5. ANÁLISE DE SITUAÇÃO DOS CURSOS DE LICENCIATURA EM GEOGRAFIA NO BRASIL 
5.2. As situações dos cursos na Amazônia ................................ 256

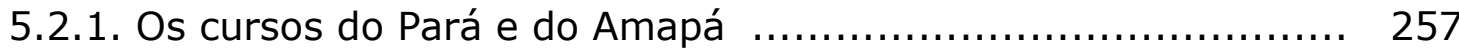

5.2.2. O Amazonas ............................................... 273

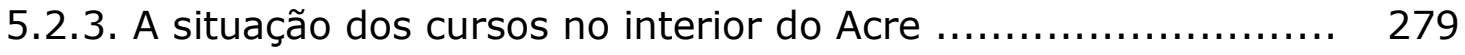

5.2.4. Rondônia e suas duas formas de extensão...................... 283

5.2.5. Os cursos da Fundação Universidade Federal do Tocantins no interior do estado do Tocantins.

5.3. A interiorização dos cursos de Geografia no Maranhão e Piauí........ 293

5.4. Os cursos de Educação a Distancia em Geografia..................... 300

5.4.1. As características e o arranjo espacial dos cursos de EAD no Brasil.

CONCLUSÃO.

REFERÊNCIAS

APÊNDICE A - Renda familiar dos estudantes de Geografia. 350

APÊNDICE B - Tipo de escola que o discente cursou no Ensino Médio. 350

APÊNDICE C - Nome dos cursos de pós-graduação em Geografia no Brasil.. 351

APÊNDICE D - Avaliação dos discentes sobre currículo do curso. 353

APÊNDICE E - Algumas reflexões sobre Geografia Crítica. 354

APÊNDICE F- Quantas horas por semana, aproximadamente, você dedica/dedicou aos estudos, excetuando as horas de aula?... 356

APÊNDICE G - Indique qual a contribuição do programa de extensão para sua formação? 356

APÊNDICE H - Formação Docente- UFPA- 2011 357

ANEXO A- Questão Dissertativa do ENC-2003.............................. 358

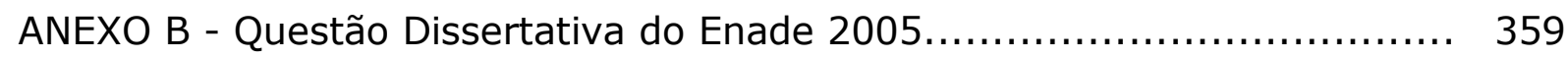

ANEXO C- Exemplo de currículo de uma IES da Amazônia.................... 360 


\section{INTRODUÇÃO}

Uma pesquisa sempre passa por inúmeras etapas e verdadeiramente é o resultado de um longo processo histórico e dialético, que, em princípio, não é só de acumulação de conhecimentos, mas também é fruto de contradições, dúvidas, idas e vindas. Toda pesquisa e mesmo sua elaboração final constituem, na verdade, uma produção coletiva, para a qual diferentes pessoas contribuem das mais diversificadas formas e em variados momentos.

Concomitantemente, há a nossa visão de mundo, as peculiaridades de nossa formação, que não se dão apenas na vida escolar, em seus diversos níveis, mas igualmente são produto das experiências que tivemos na vida e de opções teórico-metodológicas.

Tendo vivenciado, como graduanda, o bacharelado e licenciatura em Geografia da Universidade de São Paulo e, posteriormente, como docente ${ }^{1}$ do curso de Geografia da Universidade Cruzeiro do Sul, na cidade de São Paulo, tive experiências que, de alguma forma, contribuíram para o desenvolvimento desta tese.

Como docente, vivenciei o período dos currículos mínimos em Estudos Sociais e Geografia (CFE/ Parecer no 412/62 e Resolução no 8, do Conselho Federal de Educação, 9/8/1972), bem como também sua transformação a partir das Diretrizes Curriculares Nacionais de Geografia (MEC, 2001c), de que resultou a extinção de Estudos Sociais e a criação do curso específico de Geografia na Universidade Cruzeiro do Sul.

Minha experiência não se restringiu à docência, pois vivi o momento de transformação das Faculdades Integradas Cruzeiro do Sul em

\footnotetext{
Ao iniciar minha experiência como docente, trabalhei na primeira turma de Geografia da Universidade Cruzeiro do Sul, instituição privada, na Zona Leste de São Paulo. Naquela época, na instituição, havia o curso de Estudos Sociais, noturno, em dois anos e habilitação plena em Geografia, a ser obtida nos terceiro e quarto anos. Iniciei exatamente na primeira turma específica de Geografia, no terceiro ano. Em 2003, o curso de Geografia passou a ser gratuito e matutino.
} 
Universidade e, em alguns momentos, atuei como coordenadora do curso, participando da discussão e elaboração de seu currículo.

Quando surgiu a nova legislação específica sobre as licenciaturas (CNE 009/20012 e Parecer CNE/CP 28/20013), participei, em minha instituição, de um minicurso de extensão, com 30h, denominado "Mudanças nas licenciaturas", que buscava informar sobre a nova legislação e discutir sua operacionalização nos cursos.

Já com as novas políticas do Ensino Superior e a necessidade de criar o projeto pedagógico do curso, participei com um grupo de professores da elaboração do projeto, assim como recebemos comissões do Ministério da Educação (MEC) de reconhecimento e depois de avaliação do curso por duas vezes, em 2002 e 2007. Isto possibilitou maior contato com a legislação e documentos de avaliação, já que o MEC solicitava para a visita o preenchimento on-line dos formulários de avaliação, bem como o projeto pedagógico ${ }^{4}$.

Mais recentemente, o governo federal instituiu a Avaliação do Ensino Superior dos cursos. A avaliação da Geografia deu-se principalmente por meio do Exame Nacional de Cursos (ENC), em 2003; posteriormente em 2005 e 2008 com o Exame Nacional de Desempenho dos Estudantes (Enade).

2 Parecer CNE/CP 009/2001, que trata das Diretrizes Curriculares Nacionais para a formação de professores da Educação Básica, em nível superior, curso de licenciatura, de graduação plena (MEC, 2001a).

3 Parecer CNE/CP 28/2001, que estabelece a duração e a carga horária dos cursos de formação de professores da Educação Básica, em nível superior, curso de licenciatura, de graduação plena, assim como a Resolução CNE/CP 2/2002, que institui a duração e a carga horária dos cursos de licenciatura, de formação de professores da Educação Básica. Segundo este último parecer, fica estabelecido que os cursos de formação de professores para Educação Básica terão a seguinte divisão: Prática como Componente Curricular, Estágio Curricular Supervisionado, Conteúdos Curriculares de Natureza Científico-Cultural e, por fim, de Atividades Acadêmico-Científico-Culturais.

4 No projeto pedagógico, segundo o MEC, deve haver informações sobre as seguintes dimensões: dimensão pedagógica: características do curso, perfil do curso, objetivos, perfil do egresso, número de vagas, conteúdos curriculares, metodologias, grade curricular, ementas, bibliografias usadas nas disciplinas, atendimento aos discentes, atividades acadêmicas, estágio supervisionado e atividades complementares; dimensão dos docentes: titulação e formação acadêmica, regime de trabalho, titulação e regime do trabalho do coordenador, colegiados; infraestrutura física: salas de aulas, bibliotecas, laboratórios etc. 
A partir desta situação, envolvi-me no processo de avaliação e pude conhecer melhor como se realiza. Lendo os relatórios disponibilizados pelo Instituto Nacional de Estudos e Pesquisas Educacionais Anísio Teixeira (Inep) sobre as avaliações dos cursos de Geografia do Brasil, intrigavamme as diferenças e as singularidades destes.

Portanto, a experiência de ter vivenciado diferentes momentos das políticas públicas numa instituição de Ensino Superior privada, dentro do curso de Geografia, concomitantemente à participação na extensão em equipes multidisciplinares, levou-me a pensar na importância de um estudo dos cursos de Geografia no Brasil.

A definição final por um estudo sobre as licenciaturas em Geografia no Brasil foi motivada pela análise da produção sobre o Ensino Superior, a qual revelou que parte significativa dos trabalhos concentra-se nas áreas de Educação, Ciências Sociais e História, abordando temas recorrentes, como: políticas públicas do Ensino Superior, avaliação (REAL, 2007), acesso à universidade, trajetórias de universidades brasileiras, egressos, reformas do Ensino Superior, docência, mercantilização do ensino, questão racial e o ensino, cursos tecnológicos etc.

Embora existam pesquisas em ensino de Geografia, geralmente estão vinculadas à temática da Geografia escolar nos Ensinos Fundamental e Médio (ROCHA, 2001) ou principalmente aos cursos de Geografia nas universidades públicas (PIMENTEL, 2010). Há também alguns sobre formação em Geografia (LOPES, 2010; LEÃO, 2008, CACETE, 2002), mas não com o enfoque proposto nesta pesquisa.

Percebi, mais recentemente, ao participar do Encontro Nacional de Geografia em 2008 e 2010 e do Encontro da Associação Nacional de PósGraduação e Pesquisa em Geografia (Anpege), uma crescente preocupação com o Ensino Superior vinculada mais a pós-graduação em Geografia e com a própria avaliação das pós-graduações pela Coordenação de Aperfeiçoamento de Pessoal de Nível Superior (CAPES) ou, ainda, com a atuação dos formados em Geografia nos Ensinos 
Fundamental e Médio. Observa-se, pois, uma carência de estudos sobre as licenciaturas em Geografia; por isso, justifica-se a proposta desta tese.

\subsection{A delimitação e o método da pesquisa}

Esta tese trata de um estudo das licenciaturas em Geografia no Brasil, analisando-as mediante o método histórico e dialético e apreendendo-as como existência processual que se dá no território brasileiro. Busca-se compreendê-las como fenômeno espacial, em sua apreensão no território brasileiro, com sua dinâmica territorial, no qual se imbricam a existência das Instituições de Ensino Superior (IES) e das licenciaturas em Geografia, condições que são indissociáveis.

A problemática central é analisar em que medida a mediação territorial, dos tipos de IES e das modalidades dos cursos se relacionam com as suas condições.

Como objetivo principal, busca-se compreender e propor como método a análise das condições das licenciaturas em Geografia no Brasil, numa abordagem processual e de situação, com as mediações do território, dos tipos de IES e das modalidades dos cursos.

Os objetivos específicos desta pesquisa são:

- Evidenciar o processo histórico de existência dos cursos de Geografia, sua expansão e as políticas públicas do Ensino Superior no Brasil e sua relação com o atual momento;

- Relacionar a existência das licenciaturas em Geografia aos tipos de Instituição de Ensino Superior, às modalidades dos cursos e ao território brasileiro;

- Analisar as dimensões dos cursos de Geografia, mediante elementos das características discente, docente, da infraestrutura e de alguns elementos curriculares;

- Analisar a situação das licenciaturas que se interiorizaram em Pernambuco, na Amazônia, no Maranhão e Piauí e nos cursos de Educação a Distância (EAD). 
Desse modo, o foco serão os cursos de Geografia no Brasil, principalmente as licenciaturas, partindo das políticas do Ensino Superior, situação que pode ser uma abstração se forem omitidas as mediações dos tipos de instituições onde os cursos são produzidos, se for deixado de lado o entendimento do território e dos lugares onde estão inseridos.

Logo, nesta tese, a apreensão dos cursos de licenciatura em Geografia no Brasil foi desenvolvida considerando os processos históricos existentes, contextualizando-os, buscando entender como se dá o movimento destes no espaço e no tempo, categorias indissociáveis.

Entende-se a categoria tempo como processo histórico social, mediado pelas possibilidades de cada época, pelas necessidades, desequilíbrios e escassez existentes no território brasileiro e nos cursos.

As situações do passado interessam para desvendar o movimento que vem do passado para o presente, como dizia Milton Santos (2006), já que no presente está contido o passado nas formas e nas ações. Assim, busca-se evidenciar, sobretudo, aquilo que aparentemente permanece, ainda que em novo contexto social e político, portanto, espacial.

Neste processo histórico, os fenômenos não são isolados, muito menos são analisados aqui como processos que têm um começo e um fim. Não são produções acabadas, há sempre um devir ${ }^{5}$, que está sempre em movimento e em contradição.

Não se trata da contradição em geral, nem tampouco externa ao processo a ser desvendado, mas de "unidade de contradições", que é inerente aos processos que se pretendem investigar.

Pretende-se apreendê-la não apenas em sua condição interna ou em suas conexões, mas principalmente no movimento que é resultante dela (LEFEBVRE, 1995). Considera-se que, no movimento dialético, não há

5 Nas palavras de Henri Lefebvre, cujo texto foi publicado originalmente em 1946: "Deixando de isolar os fatos e os fenômenos, o método dialético reintegra-os em seu movimento interno, que provém deles mesmos, e movimento externo, que os envolve no devir universal. Os dois movimentos são inseparáveis" (LEFEBVRE, 1995, p. 238). 
uma entidade superior que defina a história, mas os agentes sociais, que criam as contradições ${ }^{6}$.

Neste sentido, os licenciados ou bacharéis em Geografia participam do sistema-mundo e também de suas organizações mais singulares (Instituições de Ensino Superior, associações de geógrafos, escolas geográficas etc.), cuja mediação tem relação também com o território nacional e com os seus usos pelos diversos agentes sociais, que criam condições e acesso desigual aos cursos.

Há verticalidades e horizontalidades nestes processos de existência das licenciaturas. Horizontalidades porque criam solidariedade entre os grupos e solidariedade organizacional em alguns momentos; concomitantemente, porém, tais docentes e discentes, em seus cursos de Geografia, submetem-se a demandas, leis, regras, normas, cujas decisões estão cada vez mais distantes, que se constituem em verticalidades.

Entende-se por "verticalidades" intervenções, normas e regras geralmente impostas por atores ou agentes hegemônicos ao local, que vêm de longe e são estranhas ao lugar "[...] enquanto as horizontalidades levam em conta a totalidade dos atores e das ações" (SANTOS, 2006, p. 259).

Importante ressaltar que não se trata de visões dualistas: o interno e o externo, as verticalidades e horizontalidades, a universalidade e a singularidade, mas são pares dialéticos. Assim como os conceitos de "universalidade" e de "mediações", que Sartre7 (2002) define como

6 No dizer de Sartre, cujo texto foi publicado em 1960: "[...] o movimento dialético não é uma pujante força unitária que se revela como vontade divina por detrás da História, mas sim, antes de tudo, uma resultante; não é a dialética que impõe aos homens históricos vivam sua história através de terríveis contradições, mas são os homens, tais como são, sob influência da escassez e de necessidade, que se enfrentam em circunstâncias que a História ou a economia podem enumerar. Antes de ser um motor, a contradição é um resultado [...] (SARTRE, 2002, p. 157).

7 Nas palavras de Sartre: "Nosso método é heurístico, ensina-nos algo novo porque é, como a do marxista, encontrar o lugar do homem no seu contexto. Pedimos à história geral para nos restituir as estruturas da sociedade contemporânea, seus conflitos, suas contradições profundas, e o movimento de conjunto que estas determinam. Assim, temos a partida do conhecimento totalizante do momento considerado, mas, em relação ao objeto de nosso estudo, esse conhecimento permanece abstrato" (SARTRE, 2002, p. 103). 
importantes no entendimento da realidade, embora faça ressalvas a alguns marxistas pelo que chama de universalidade exagerada, que a torna demasiadamente abstrata, como se houvesse um ente superior que nos conduzisse ou que reduzisse a ação humana à intencionalidade do agente histórico.

Fundamental para esta pesquisa é encontrar o contexto em que ocorrem estas mediações e considerar as dimensões e elementos analisados em relação às licenciaturas em Geografia, destacando os agentes sociais que participam do processo.

Dessa maneira, a história dos cursos não será analisada como uma história acabada, nem mesmo como totalmente nova. Não se trata de imaginar que o entendimento deste processo tenha uma lógica formal (LEFEBVRE, 1995), no qual um novo modo de existência substitui um antigo, nem tampouco que uma nova Geografia surja mediante uma quebra formal do que antes havia.

Há circularidade dialética neste processo (SARTRE, 2002); sendo assim, as condições atuais das licenciaturas em Geografia não constituem uma reprodução simples da condição anterior e nem são produtos inteiramente novos.

Há um pouco neles de condições que vieram do passado, de tradições que se cristalizaram com o tempo, mas há também algumas transformações que não chegaram a todos os lugares. Sendo assim, há alguns arranjos espaciais que criam algumas situações peculiares nos cursos.

Considera-se que os cursos são produzidos por diversos agentes sociais, entre eles o Estado, e, portanto, fazem parte de processos universais, que agem, de forma dialética, sobre eles: econômicos, sociais e políticos, assim como com a dinâmica do território brasileiro. 
Levando em conta tais premissas, esta análise dos cursos considera as teorias maiores ${ }^{8}$, dos processos globais, que fogem ao entendimento apenas da escala local ou mesmo nacional.

Processos globais que podem ser evidenciados pela universalização das características de mercado da Educação Superior, mesmo nas IES públicas, que acabam por se constituir em "quase mercado" (SOUSA; OLIVEIRA, 2003), pois trazem em seu bojo concepções de administração cada vez mais empresarial.

Embora existam universalidades e verticalidades neste processo, na estruturação dos cursos de Geografia no Brasil, como é o caso das políticas públicas brasileiras que definiram os Currículos Mínimos (CFE) Parecer no 412/62) para o curso de Geografia ou ainda mais recentemente as Diretrizes Curriculares Nacionais de Geografia (Parecer CNE/CES 492/2001), há também mediações nestes processos, que produzem singularidades.

Portanto, cabe verificar se tais processos universais se relacionam da mesma forma nas IES públicas e privadas, por exemplo, já que existem mediações que são organizacionais, territoriais e de grupos.

Há também estruturas internas dos cursos as quais serão abordadas nas seguintes dimensões e elementos: características da formação e do trabalho docente, perfil dos discentes, infraestrutura, algumas condições de ensino evidenciadas por elementos curriculares, que, de forma integrada, se relacionam às condições de existência das licenciaturas.

Ressalta-se que não são dimensões totalmente internas ou isoladas; estão sempre em um movimento que é dialético e que as arrasta do interno para o externo e vice-versa, ou, ainda, do universal para o singular.

Ao longo do texto, evidenciam-se quais são os elementos fundamentais que se relacionam com a avaliação em Geografia e busca-se identificar suas conexões, tais como: contexto das políticas públicas

8 Por "teorias maiores" entende-se, por exemplo, as universalidades - caso dos processos capitalistas que, de forma dialética, se opõem à teoria das mediações. 
brasileiras do Ensino Superior; tendências mundiais na organização e avaliação do Ensino Superior; universo dos cursos de Geografia brasileira e sua hierarquia de mediações, principalmente organizacionais e espaciais.

Para operacionalizar esta pesquisa, foram definidas as seguintes seções subsequentes:

2. História e processo de expansão dos cursos de Geografia no Brasil: 1934-2010. Nesta seção, apresenta-se o processo histórico da existência e a expansão dos cursos de Geografia no território brasileiro; discorre-se sobre sua historiografia, as características e os problemas existentes, destacando-se as políticas de Ensino Superior.

3. Da avaliação dos cursos de Geografia no Brasil mediante políticas do governo federal à análise territorial (1996-2010). Evidenciamse as políticas do governo federal para a avaliação dos cursos e propõe-se a mediação do território para esta análise em Geografia. Esta proposta de análise espacial inicia-se com a discussão de autores e conceitos sobre território, extensão e centralidade; com a relação do tipo de organização das IES e dos cursos de Geografia; por fim, destacam-se as dimensões docente e discente e sua relação com o território brasileiro.

4. Análise das condições de ensino dos cursos de Geografia. Esta seção aborda a questão curricular dos cursos, mostrando suas condições no ensino, pesquisa e extensão, mediante análise de gráficos e mapas produzidos sobre o tema, baseando-se também em pesquisas desenvolvidas sobre o assunto.

5. Análise de situação dos cursos de licenciatura em Geografia no Brasil. Por fim, discutem-se algumas situações ocorridas no processo de existência das licenciaturas em Geografia no Brasil, que se interiorizaram, numa análise que considera principalmente as ideias desenvolvidas sobre o conceito de situação. 
A tese aqui desenvolvida é que a mediação do território nacional e dos tipos de Instituições de Ensino Superior (IES), bem como as modalidades de licenciaturas oferecidas é fundamental para a compreensão das condições dos cursos de Geografia.

Sendo assim, propõe-se que a tese possa servir de referência de método para análise de condições de cursos, considerando-se as mediações já citadas.

O princípio é que as existências das licenciaturas são processuais e ocorrem num tempo contínuo, cujos eventos vão criando certas rupturas ou continuidades, ao mesmo tempo em que certas características permanecem ainda que sob novos contextos espaciais.

Então, entendê-las numa relação espaço e tempo, torna-se uma condição fundamental de análise.

\subsection{Procedimentos da pesquisa}

Para operacionalizar a análise espacial nesta pesquisa, definiu-se principalmente o período pós 1996. Contudo, há uma revisão histórica e historiográfica anterior a este período, como forma de entender o processo de existência dos cursos de Geografia no Brasil, sobretudo das licenciaturas.

As ideias desenvolvidas sobre "período" baseiam-se em concepções desenvolvidas por Milton Santos (2008b) e Roberto Lobato Corrêa $(1990,2006 a)$, pelas quais o período define-se pelos eventos, já que há inúmeros eventos que criam rupturas e continuidades no tempo, como uma "flecha do tempo" que parte do universal para o lugar, pois é no lugar que há o acontecer. O evento é uma ação proveniente de um ou mais agentes sociais e precisa ser compreendido como fenômeno que também ocorre espacialmente.

Logo, ao tratar de período, leva-se em conta a totalidade em movimento, cuja definição do tempo histórico ocorre pelos eventos; neste caso, relacionados principalmente aos cursos de Geografia no Brasil, seja 
mediante a normatização do Ensino Superior, seja pela ação das redes de afinidades geográficas, ou, ainda, por mudanças econômicas e dinâmicas no território brasileiro.

Nesta periodização ${ }^{9}$, antes e pós 1996, procura-se contextualizar e analisar as problemáticas dos cursos de Geografia com destaque aos elementos que com eles se relacionam, caso das políticas de Ensino Superior, provenientes do Estado brasileiro, que é um agente fundamental no processo de existência dos cursos.

A seção 2, inicia-se com o processo de existência dos cursos de Geografia no Brasil e sua expansão no território, tanto da licenciatura como do bacharelado.

Para esta discussão, há, no texto, muitas citações ${ }^{10}$ de professores de Geografia que participaram do processo de construção da Geografia brasileira ou de interessados em Geografia que escreveram ou deram depoimentos, principalmente, na Revista Brasileira de Geografia (RBG), no Boletim Geográfico, Boletim Paulista de Geografia, Boletim Carioca de Geografia, Boletim Goiano de Geografia; nas Revistas Geosul, Mercator e Terra Livre, assim como em dissertações e teses da área (CACETE, 2002; PEREIRA, 1997; ROCHA, 2001, AMORIM, 2010) e em livros sobre a temática (MACHADO, 2009; MONTEIRO, 1980; MOREIRA, 2008, 2009, 2010; PEREIRA, 1955).

9 Sobre a concepção de período e periodização, consideram-se as palavras de Milton Santos (1994, p. 81) que disse: "O conselho de Sartre é mais preciso que o de Simmel: o entendimento do mundo é dado pelas coisas e pelo Período, a Época. Quando falamos em período, já estamos qualificando o Tempo, permitindo-lhe um enfoque empírico, de modo a evitar, justamente, que se trabalhe com o 'esqueleto abstrato da universalidade'"'.

10 Tais citações foram extraídas de artigos, depoimentos e notícias principalmente da Revista Brasileira de Geografia, publicada pelo Instituto Brasileiro de Geografia e Estatística (IBGE) nos anos de 1940, 1941, 1943, 1944, 1945, 1946, 1958, 1962, 1963, 1965 e 1982; do Boletim Geográfico, também publicado pelo IBGE/CNG, nos anos 1944, 1945, 1949 e 1958; pelo Boletim Carioca de Geografia dos anos 1944 e 1954; no Boletim Paulista de Geografia, publicado pela Associação dos Geógrafos Brasileiros (AGB), seção São Paulo, nos anos 1946, 1949, 1953, 1954, 1955, 1960, 1961, 1976, 1977, 1978 e 1994). Há também a Revista Geosul (2001, 2002, 2003, 2005, 2007) da Universidade Federal de Santa Catarina (UFSC); a Revista Mercator (2002, 2005, 2009), publicada pela Universidade Federal do Ceará (UFCE); O Boletim Goiano de Geografia (1992, 1995, 1997, 2001, 2005) da Universidade Federal de Goiás (UFG) e a Revista Terra Livre (1986, 1987 e 1994), publicada pela AGB. 
No início da seção 2, buscou-se dar ênfase aos discursos dos geógrafos da época ou daqueles que fizeram sua historiografia ou participaram da história da Geografia em Instituições de Ensino Superior brasileiras, principalmente de professores universitários de São Paulo, Rio de Janeiro, Minas Gerais e Pernambuco.

Após 1960, as produções sobre Ensino Superior nos Boletins e Revistas Geográficas no Brasil escasseiam-se. Os depoimentos e artigos dos professores universitários que eram mais comuns sobre a formação da Geografia no Ensino Superior perdem espaço para estudos sobre regionalização, estudos com métodos quantitativos, pesquisas em Geografia Urbana, Geografia Agrária, Geomorfologia etc.

Ressalta-se que, mesmo no passado, as questões sobre Ensino Superior não se constituíam em estudos numerosos, mas havia mais depoimentos, relatos que apareciam comumente nos periódicos da Geografia brasileira. Apesar disso, a partir dos anos 80, ampliam-se as discussões sobre a Geografia escolar, mas com pouca discussão relativa à graduação no Ensino Superior.

Em virtude dessa situação, no período principal deste estudo, pós 1996, optou-se pelo uso de informações quantitativas, principalmente do MEC e do Inep. Todavia, não se desenvolveram, nesta pesquisa, inscrições da enésima ordem (LATOUR, 2000), mediante grandes formulações estatísticas ou mesmo modelos de análise e classificações por meio destes números.

Neste período houve a maior influência global nas políticas de educação, bem como a incorporação dos processos de mercantilização no Ensino Superior, bem como há uma expansão das licenciaturas em Geografia, com um novo processo de interiorização pelo território nacional, vinculado principalmente às demandas do território pela formação de docentes, bem como induzido pelas políticas governamentais.

A ênfase no período pós 1996 ocorre devido às políticas públicas de Ensino Superior, com a nova Lei de Diretrizes e Bases da Educação 
Nacional (BRASIL, 1996b), a nova legislação específica sobre as licenciaturas (Parecer CNE/CP 28/2001 e Parecer CNE 009/2001), a avaliação do Ensino Superior promovida pelo governo federal, a partir de 1995, e pelo Programa de Apoio de Planos de Reestruturação e Expansão das Universidades Federais (REUNI), em 2007.

Embora haja discordância de alguns aspectos da avaliação promovida pelo governo federal, reconhece-se a existência de procedimentos positivos neste processo, a saber: o questionário socioeconômico aplicado aos estudantes no período das provas do Enade, por conter dados significativos sobre os cursos; as informações disponibilizadas pelo Inep sobre a formação de mestres e doutores, por IES, que constam como parte dos dados que compõem o Conceito Preliminar de Curso (CPC). Tais informações são importantes, pois permitem vislumbrar algumas condições dos cursos de Geografia.

Assim, realizou-se, com tais dados, representativos das IES e seus cursos de Geografia, uma análise mais geral, processual, numa escala nacional, e outra com a mediação da formação e da dinâmica do território nacional e das organizações de ensino, mediante mapas e suas interpretações espaciais.

A escolha destes dados quantitativos ocorre devido à abrangência desta pesquisa no território nacional porque seria difícil captar tais informações numa pesquisa própria, com um número de graduandos tão significativo. Os dados ${ }^{11}$ disponibilizados pelo Inep, mediante questionário respondido por estudantes de Geografia que participaram do Exame

11 Em 2003, segundo Inep (2003) participaram do ENC 252 cursos de Geografia no Brasil, com a presença de 11676 graduandos concluintes do curso de bacharelado e licenciatura. Em 2005, foram 321 cursos, e a escolha dos alunos foi por amostragem, com 11146 concluintes correspondendo a 52\% do total do Brasil. Em 2008, no mesmo sistema de 2005, foram 312 cursos de Geografia, com 9743 graduandos concluintes, perfazendo $67,5 \%$ do total de concluintes naquele ano. Para dados gerais de 2003, 2005 e 2008 foram produzidos gráficos. A partir dos gráficos escolheram-se algumas questões para criar os mapas, todos com dados de 2008, para realizar a análise espacial. Para identificar tais informações buscaram-se, em relatórios disponibilizados pelo Inep de cada Instituição de Ensino Superior (IES), as respostas dadas pelos estudantes concluintes para detalhar as médias por Unidade da Federação (UF) e criar um banco de dados por IES. 
Nacional de Cursos (ENC) em 2003 e do Exame Nacional de Desempenho dos Estudantes (Enade) em 2005 e 2008, possuem uma amostragem bastante significativa do universo de alunos de Geografia no Brasil.

Em relação aos docentes utilizaram-se informações dos cursos que realizaram Enade 2008, assim como dados do Inep (2009) com as seguintes informações: o regime de trabalho e a formação dos docentes que lecionam nos cursos de Geografia, o que permitiu a construção de mapas com as médias por Unidades da Federação (UF) e análises de acordo com o tipo de IES, se pública ou privada.

Além disso, baseou-se a análise nos seguintes dados do Inep, contidos nos Relatórios Sinopses de 2000 a 2009 sobre os cursos de Geografia: número de cursos de licenciatura e bacharelado no Brasil; licenciaturas por tipo de IES (públicas e privadas) e por tipo de organização da IES (universidades, centros universitários, faculdades e centros tecnológicos). Tais informações foram disponibilizadas, mediante gráficos, abrangendo os anos 2000 a 2009.

Nesta análise, não se utilizou um padrão de "qualidade" dos cursos, nem se definiu se são melhores ou piores. A ideia principal é relacionar algumas dimensões, como características docentes, discentes, infraestrutura e alguns elementos curriculares, na apreensão no território, mostrando as relações entre as necessidades dos cursos, a escassez e as desigualdades espaciais existentes.

Parte-se do princípio que a existência das IES e dos cursos de Geografia relacionam-se com o território e o nível de centralidade ${ }^{12}$ urbana vai interferir nas características dos cursos e nas diversas dimensões e variáveis analisadas.

12 Entende-se por centralidade urbana nesta tese uma comparação entre cidades dentro de uma ou mais redes urbanas, considerando-se a hierarquia urbana e o papel delas na divisão territorial do trabalho; destaca-se aqui principalmente o nível de serviços da educação superior. Neste sentido, as cidades de maior centralidade no nível hierárquico ocupam um papel de destaque na divisão territorial do trabalho e acabam concentrando o maior número de IES e de diversidade de cursos, entre outras características que serão apresentadas nas próximas seções (CORRÊA, 1990, 2006a; SANTOS, 2008a). Relaciona-se também ao nível de centralidade considerando-se o nível intraurbano, que diferencia os lugares da mesma cidade. Dessa forma, refere-se às relações inter e intraurbanas. 
Estas análises ocorreram principalmente nas seções 3 e 4, destacando-se as condições mais extremas em relação aos elementos e variáveis usadas. Para aprofundar tais análises de dados discutiram-se algumas pesquisas que tratam da dimensão discente, docente e das condições curriculares da Geografia no Ensino Superior, principalmente em dissertações e teses.

$\mathrm{Na}$ última seção buscou-se uma analise que mostra algumas situações peculiares no processo de existência das licenciaturas em Geografia no Brasil, condição evidenciada principalmente a partir da discussão sobre o conceito de situação, definido por Maria Laura Silveira (2010), e suas respectivas análises espaciais.

A definição das situações encontradas ocorreu principalmente devido à análise dos processos de interiorização das licenciaturas em Geografia e suas peculiaridades, sobretudo no interior de Pernambuco, na Amazônia, no Maranhão e no Piauí e nos cursos de Educação a Distância (EAD).

Para o aprofundamento e análise das situações, entrevistaram-se pelo sistema de Skype, em 2012, 33 coordenadores, professores e alunos de cursos de licenciatura em Geografia, dos seguintes estados e instituições ${ }^{13}$ :

- Do Pará, da Universidade Federal do Pará (UFPA), campi Belém e Marabá, e dos núcleos de Parauapebas e Oriximiná; da Universidade Federal do Oeste do Pará (UFOPA) em Santarém e da Universidade Estadual do Pará (UEPA);

- Do Amazonas, da Universidade Estadual do Amazonas (UEA) campi de Manaus, Tefé e Tabatinga, e do núcleo de Manacapuru;

- Do Piauí, da Universidade Estadual do Piauí, do núcleo em Pedro II;

- Do Maranhão, da Universidade Estadual do Maranhão (UEMA), campus de Imperatriz e Caxias;

13 Algumas IES e/ou coordenadores e professores preferiram não ser citados; nestes casos, preservou-se a identidade dos entrevistados. 
- De Roraima, da Universidade Federal de Roraima (UFRR), campus de Boa Vista;

- Do Acre, da Universidade Federal do Acre (UFAC), campi na capital e interior;

- De Rondônia, da Universidade Federal de Rondônia (UNIR) em Porto Velho e das Faculdades Integradas de Ariquemes (FIAR) na cidade de Ariquemes;

- De Goiás, da Universidade Estadual de Goiás (UEG), campus Iporá e outros;

- Do Tocantins, da Universidade Federal do Tocantins (UFT), campi Porto Nacional e Araguaína;

- Do Amapá, da Universidade Federal do Amapá (UNIFAP), campi em Amapá, e núcleos do interior;

- Do Mato Grosso, da Universidade Federal do Mato Grosso (UFMT), campus de Barra do Garças;

- De Santa Catarina, do Centro Universitário Leonardo da Vinci (UNIASSELVI), em Indaial (SC) e de seus núcleos de apoio a distância em Feira de Santana (BA) e em Canoas (RS);

- De Pernambuco, da Faculdade de Formação de Professores de Belo Jardim (FABEJA) em Belo Jardim (PE); da Universidade de Pernambuco (UPE) em Nazaré da Mata e de outras IES municipais no interior;

- De São Paulo, da Universidade Metropolitana de Santos (UNIMES), situada no município de Santos; da Universidade de Santo Amaro (UNISA) e da Universidade Camilo Castelo Branco (UNICASTELO), ambas na cidade de São Paulo.

Os depoimentos ${ }^{14}$ de coordenadores, professores e discentes sobre as condições dos cursos, ocorreram por meio de entrevista por telefone

${ }^{14}$ Os depoimentos foram principalmente de coordenadores de cursos. Para o contato inicial foi enviado e-mail para os coordenadores, cujo nome encontra-se geralmente no sistema $E-M E C$ (site disponibilizado pelo MEC), a partir disso busquei no site das IES um contato telefônico ou por e-mail. A partir do contato inicial, geralmente por email, definia-se um dia para o contato telefônico pelo sistema Skype. Com o uso do programa MX Skype Recorder foi possível gravar todas as entrevistas. 
pelo Skype, as quais foram gravadas e transcritas trechos e/ou as ideias principais. As entrevistas possibilitaram aprofundar e qualificar o entendimento das licenciaturas em Geografia de uma forma integrada, considerando-se as dimensões curriculares, a infraestrutura, as condições do discente e do docente.

Logo, a análise das situações dos cursos na última seção tem como intuito evidenciar o conjunto dos elementos analisados nas outras seções, de uma forma integrada, na qual se imbricam as dimensões, os elementos e variáveis com seu arranjo espacial.

É fundamental o entendimento das condições dos cursos levando-se em conta sempre as categorias espaciais, caso de território, lugar, extensão ${ }^{15}$, centralidade, situação, entre outras, cujos conceitos serão definidos nas seções a seguir.

Espera-se que esta tese contribua para uma análise das licenciaturas em Geografia, considerando as condições de como os cursos se realizam. Há clareza que isto não significa entender o curso em sua totalidade, pois há outros elementos internos, caso da relação professoraluno, de como se realizam as aulas e os estágios, quais as bibliografias utilizadas e outros, que não foram condições expostas nesta tese.

Pretende-se ainda evidenciar que a história do pensamento geográfico no Brasil, bem como a dos cursos devem considerar como opção de método a análise que leve em conta as categorias espaciais.

Considerando-se as premissas apresentadas ao longo desta seção, será discutido, na próxima, a história e o processo de expansão dos cursos de Geografia no Brasil.

15 O termo "extensão" é usado nesta tese em duas concepções distintas. A primeira diz respeito às atividades de extensão, comumente definidas como parte do tripé das IES: o ensino, a pesquisa e a extensão. Concerne, pois, a um tipo de atividade curricular. A outra tem relação com uma categoria espacial, usada na Geografia. Neste caso há nesta tese duas ideias, a de extensão geométrica e a existencial (SILVEIRA, 2006). Estas expressões não são dicotômicas, mas concepções diferentes, assim, enquanto a extensão geométrica é uma visão mais tradicional, com a métrica como forma de entendimento do espaço; na concepção existencial, as relações humanas, sociais e espaciais têm relação com o cotidiano, com o acesso, não somente do ponto de vista métrico. 


\section{HISTÓRIA E PROCESSO DE EXPANSÃo dOS CURSOS DE GEOGRAFIA NO BRASIL: 1934-2010.}

Nesta seção, busca-se apreender a existência dos cursos de Geografia no Brasil, iniciando com a história e historiografia destes, num processo histórico e espacial, enfatizando o período de 1996 a 2010, por conta das políticas públicas que possibilitaram a expansão mais recentemente do Ensino Superior, particularmente das licenciaturas em Geografia.

As políticas públicas relacionadas ao Ensino Superior são evidenciadas em sua universalidade, bem como as características dos cursos de Geografia e algumas de suas problemáticas, mostrando em que condições ocorreram o processo de criação e expansão destes no território brasileiro.

Compreende-se que a existência das licenciaturas em Geografia ocorre num movimento histórico, contínuo, dialético, e os seus problemas atuais não ocorrem nas mesmas situações do passado, mas alguns destes, como a mescla dos perfis de bacharelado e licenciatura permanecem, porém sempre em novos contextos espaciais, daí a importância de entendê-los numa relação espaço-tempo, que é indissociável. O que é novo e velho varia conforme o lugar.

Sendo assim, a produção dos cursos de Geografia no Brasil tem relação com o tempo social e histórico. O tempo considerado como social, mediado pela sociedade de cada época, que não se realiza uniformemente e vivido socialmente, cria um eterno ir e vir, que acrescenta ao mundo possibilidades em cada período da história, definido aqui principalmente mediante os eventos.

Os eventos são momentos marcantes na história e precisam ser compreendidos sob a ótica dos agentes que se relacionam com os mesmos e com os lugares. Os que interessam nesta pesquisa são principalmente os sociais, políticos e econômicos, que dão novo significado 
e conteúdo aos lugares e transformam os cursos de Geografia, sobretudo os relacionados às políticas públicas do Ensino Superior.

Assim, o tempo, embora contínuo, tem rupturas e continuidades, que se realizam por meio dos eventos. Tais rupturas no tempo não são instantes de descontinuidade total com o passado, nem são absolutas, mas se realizam num processo regressivo-progressivo, que contém um pouco do passado no presente, seja nas formas, seja nas ações.

Dessa forma, os eventos não são universalidades absolutas, realizam-se num lugar e num tempo; são, portanto, a matriz do tempo e espaço, conforme a afirmação de Milton Santos:

Os eventos operam essa ligação entre os lugares e uma história em movimento. A região e o lugar, aliás, definem-se como funcionalização do mundo e é por eles que o mundo é percebido empiricamente (SANTOS, 2006, p. 165)

Logo, o evento precisa ser entendido concretamente no lugar, já que o lugar é onde há o acontecer e os eventos se realizam. Ou no dizer de Maria Laura Silveira (2006):

O mundo só existe nos lugares, pois a história se constrói nos lugares. Entre essas possibilidades e esses existentes concretos temos os eventos. São os eventos que transformam as possibilidades em existentes, mas os eventos não são alheios nem indiferentes ao que existe. Não há evento sem objeto, não há evento sem ator. [...] Por isso, o evento é o veículo da história, produz a existência (SILVEIRA, 2006, p. 88).

Na educação do Ensino Superior no Brasil há as políticas públicas e as normas do governo federal, como eventos importantes para a compreensão dos cursos de Geografia, criadas principalmente pelo MEC e mais recentemente pelo Inep, assim como outros mais especificamente geográficos, que fazem parte do entendimento deste processo.

Considera-se, nesta pesquisa, que toda produção e formação em Geografia ocorrem como processos em movimento, dialéticos, nos quais as ações sociais, políticas, educacionais, administrativas acontecem dentro e fora das instituições geográficas, seja em instituições formais de Geografia (associações geográficas e instituições de ensino), seja na sociedade e em suas diversas instâncias sociais, culturais e políticas. 
Há uma circularidade dialética (SARTRE, 2002) nos processos de existência da consolidação da Geografia no Brasil, bem como uma relação do contexto social e político com as atividades mais propriamente internas da Geografia. Não se deve, pois, cair na armadilha do internalismo e externalismo ${ }^{16}$ (SHAPIN, 2005), como propostas dicotômicas.

Portanto, o entendimento da Geografia no Brasil não se dá por processo evolutivo, linear, numa repetição ou transposição das produções da Geografia de outros países. Os cursos de Geografia também não evoluíram numa lógica formal (LEFEBVRE, 1995).

Ao longo do tempo histórico, houve mudanças na Geografia brasileira e em seus cursos, mas isto não deve ser dissociado da política, das possibilidades históricas de cada tempo social, das escolhas que são feitas mediadas por questões ideológicas e também de como os fenômenos relacionados ao Ensino Superior se expressam no espaço geográfico.

O entendimento do desenvolvimento das licenciaturas em Geografia, portanto, é bastante complexo, passa pela compreensão dos processos universais que acabam se materializando concretamente nas instituições e em seus cursos de Geografia, bem como pela relação destas com a dinâmica do território nacional, que acaba produzindo singularidades ou situações peculiares em suas existências.

Se, por um lado, é possível dizer que, ao longo do século $X X$, a Geografia brasileira superou-se ${ }^{17}$; por outro, cumpre afirmar que ainda hoje existem questões que já eram apontadas como problemáticas no começo do século XX, tais como: a dicotomia entre Geografia Física e Geografia Humana; Ensino Superior versus Ensino Secundário; o ensino e a pesquisa; o perfil de formação dos licenciados e bacharéis, entre outras.

16 Não se trata de uma proposição externalista. A proposição externalista tem como princípio que a atividade científica sofre influência externa à própria ciência, opondose assim ao internalismo.

17 Superação segundo a lógica dialética com diz Henri Lefebvre: "[...] a verdadeira superação é obtida não através de uma amortização das diferenças (entre doutrinas e as idéias), mas, ao contrário, aguçando essas diferenças" (LEFEBVRE, 1995, p. 229). 
Há também dificuldade em isolar, numa leitura geral, apenas as especificidades das licenciaturas em alguns momentos, já que havia e, em alguns casos, ainda há relações históricas entre a formação do bacharel e do licenciado, conforme se discutirá a seguir.

\subsection{A história e historiografia dos primeiros cursos do Brasil}

Nesta pesquisa, considera-se que há sempre uma mediação dos lugares, das instituições geográficas e dos agentes que a produzem, interferindo e produzindo diferenças e singularidades nos cursos de ensino superior em Geografia.

Logo, apesar do esforço empreendido em revisitar o "passado" da Geografia acadêmica brasileira, não se pode afirmar que se trata da história da Geografia universitária no Brasil, pois as fontes de apreensão para elucidação desta temática, sobretudo do período anterior a 1996, referem-se a apenas algumas instituições geográficas, cujas publicações em periódicos foram mais comuns, caso principalmente de São Paulo e Rio de Janeiro.

A criação dos cursos de Geografia na Universidade de São Paulo (1934), da Universidade do Distrito Federal ${ }^{18}$ (1935) e da Universidade do Brasil (1939) é considerada por alguns autores, como Carlos Augusto de Figueiredo Monteiro (1980) e José Veríssimo da Costa Pereira (1955), como o momento da institucionalização da Geografia universitária no Brasil.

No entanto, antes deste período, já havia produção geográfica institucionalizada. Embora não houvesse cursos de Geografia nas Instituições de Ensino Superior (IES), a produção do conhecimento geográfico se fazia pelas mãos de autodidatas, historiadores, religiosos,

18 A Universidade do Distrito Federal (UDF) foi criada em 1935, e a implantação do primeiro curso de Geografia fluminense fez parte de ações modernizadoras do governo Getúlio Vargas com objetivos nacionalistas. A UDF foi extinta e incorporada à Universidade do Brasil em 1939. 
engenheiros civis e militares, entre outros, ainda que fora do âmbito acadêmico universitário ${ }^{19}$.

Manoel de Sousa Neto (2008) destaca a ideia de que a Geografia brasileira já tinha instituições importantes antes do Ensino Superior, tais como: o Instituto Histórico e Geográfico Brasileiro (IHGB), de 1838; o Colégio Imperial Pedro II, de 1837, e a Sociedade de Geografia do Rio de Janeiro (SGRJ), de 1883.

Antes que a formação em Geografia fosse institucionalizada pelas IES, havia aqueles alunos que estudavam no secundário e iam tornandose professores de Geografia, mesmo sem formação universitária.

Havia também a formação de engenheiros geógrafos (PEREIRA, 1997; ANDRADE, 1977), concedida como especialização na Engenharia, embora se tratasse de uma formação mais técnica, mais próxima aos estudos cartográficos.

No início da institucionalização acadêmica da Geografia no Brasil, houve um papel importante dos estrangeiros, sobretudo franceses. Contudo, a Geografia brasileira do início do século XX não sofreu apenas influência francesa, tampouco sua institucionalização deu-se somente a partir da criação dos cursos superiores.

Também importa reconhecer o papel que a disciplina de Geografia no Ensino Secundário teve antes mesmo da criação das IES, bem como o papel das produções de caráter geográfico ocorridas antes da sua institucionalização universitária, principalmente com a criação das sociedades geográficas no Brasil.

Entretanto, é notável que a produção geográfica se ampliou e se diversificou após a criação das Instituições de Ensino Superior (IES) e de seus cursos de Geografia; do Conselho Nacional de Geografia (CNG), em 1937; do Instituto Brasileiro de Geografia e Estatística ${ }^{20}$ (IBGE), em 1937;

19 O termo acadêmico é usado nesta tese no sentido de participar de um grupo de ciências e letras, assim como se refere ao que participa do mundo das Instituições de Ensino Superior.

20 O IBGE editava a Revista Brasileira de Geografia, desde 1939, assim como o Boletim Geográfico. 
bem como da Associação dos Geógrafos Brasileiros (AGB), em 1934. Esta produção geográfica é considerada por alguns como científica só a partir da criação destas instituições.

José Veríssimo da Costa Pereira (1955, 1957), geógrafo e professor fluminense, fez um trabalho historiográfico pormenorizado sobre a evolução da Geografia no Brasil, no qual, embora discorde da perspectiva historiográfica bassaliana ${ }^{21}$, apresentava muitas informações de autores pioneiros $^{22}$ da Geografia no Brasil, bem como tratava da atuação dos estrangeiros.

Ainda sobre o período anterior à Geografia universitária no Brasil, Sérgio Luiz Nunes Pereira (1997), em sua dissertação de mestrado, identificou Capistrano de Abreu e Gentil Moura como autores de trabalhos geográficos relevantes neste período. Leo Waibel (1950), professor alemão, contratado pelo IBGE, também tratou da importância de estudos de autores da literatura geográfica brasileira. Segundo o autor, tais pesquisadores,

Contentam-se com o estudo da literatura geográfica no sentido limitado não dando a devida atenção à rica literatura histórica existente no país. Eu incidi no mesmo erro e só no último ano comecei a estudar obras históricas. Com isso, fiz uma descoberta surpreendente: que historiadores e sociólogos como CAPISTRANO DE ABREU, OLIVEIRA VIANA e CAIO PRADO JÚNIOR possuem uma extraordinária compreensão das inter-relações geográficas (WAIBEL, 1950, p. 420).

Outro estudioso que pesquisou sobre o período anterior à criação da Geografia nas IES brasileiras é Nilson Cortez Crocia de Barros (2008), que definiu o Brasil como um arquipélago cultural no final do século XIX, início

21 Segundo Bassala, a perspectiva da difusão da ciência ocorre da Europa para os demais lugares. Esta ideia parte do princípio de que a produção científica se faz, sobretudo a partir da ciência moderna européia, desconsiderando os conhecimentos pré-existentes nos lugares (BASSALA, 1967).

22 Ele cita no texto, entre outros pioneiros: Alexandre Ferreira, conhecido como "Humboldt brasileiro"; Aires de Casal (1817), com sua "Corografia Brasilica"; Raimundo José da Cunha Matos, com "Chorographia histórica da Província de Goyas" (1824); José Vieira Couto Magalhães, com "Viagem ao Araguaia" (1863); Eduardo José de Morais, com sua classificação das bacias hidrográficas brasileiras; João Martins da Silva Coutinho, que publicou oito trabalhos sobre a região Amazônica (1857 a 1866). 
do $X X$, que importava serviços educacionais, já que havia muitos professores e produções acadêmicas oriundos de outros países.

O autor apresentou Delgado de Carvalho ${ }^{23}$ como uma figura que publicou intensamente obras nas áreas de humanidades, mas também em fisiografia e sobre a questão territorial do Brasil, assim como sobre ensino, e que teve grande importância para a Geografia:

A grande exposição de Delgado aos ambientes envolvidos com a geografia deu-se anteriormente à institucionalização propriamente dita, isto é, nos sítios pioneiros de antes da domesticação aplicada da disciplina nas faculdades e no executivo federal. Delgado não foi partícipe da fase realmente significativa da legitimação do geógrafo pelo trabalho de campo, após a metade dos anos 1930 e adiante. Celebrara a importância da ida ao campo de forma mais doutrinária e educacional, como um difusor precoce de proposições de novas atitudes metodológicas (BARROS, 2008, p.326-327).

Outro geógrafo que retrata a historiografia da Geografia brasileira é Carlos Augusto de Figueiredo Monteiro (1980), que publicou o livro $A$ Geografia no Brasil (1934-1977): avaliação e tendências ${ }^{24}$. Sua historiografia iniciou-se com o que chamou de implantação da "Geografia científica", de 1934 a 1948, cujo desenvolvimento foi pautado por grande dependência externa de geógrafos de outros países, sobretudo franceses. Ele destacou, principalmente, as figuras de Pierre Monbeig, Francis Ruellan ${ }^{25}$ e Leo Waibel, professores respectivamente da Universidade de São Paulo (USP), da Universidade do Brasil e do IBGE.

23 Carvalho atuou no Instituto Histórico e Geográfico Brasileiro e na Sociedade Geográfica do Rio de Janeiro (1920). Os livros mais próximos a conhecimentos geográficos são: "Geographia do Brasil" (1913); "Météorologie du Brésil" (1917); "Physiografia do Brasil" (1923), "Introdução a Geografia Política" (1925) e "Metodologia do Ensino Geográfico" (1925). Foi docente do Colégio Pedro II, sendo professor de Geografia e Sociologia. Em 1935, torna-se professor de Geografia Humana na Universidade do Distrito Federal.

24 Além desse período, o autor identificou mais quatro períodos, a saber: 1948 -1956, com destaque para o papel da AGB como difusor da Geografia no Brasil; de 19561968, como momento de afirmação da Geografia nacional, destacando o XVII Congresso Internacional de Geografia, no Rio de Janeiro, e, por fim, o período de 1968-1977, com uma nova realidade política, ampliação do mercado de licenciados em Geografia, novas práticas de análise geográfica, caso da Geografia Quantitativa.

25 Francis Ruellan chegou ao Brasil em 1940, tornou-se professor da Universidade do Brasil e trabalhou também no IBGE, atuando principalmente na área de Geomorfologia. 
Já Nilo Bernardes (1982) periodizou ${ }^{26}$ as etapas de evolução da Geografia no Brasil e afirmou que a institucionalização da Geografia só ocorreu a partir da criação dos cursos de Geografia da USP e da Universidade do Brasil, assim como ressaltou a relevância do papel do Conselho Nacional de Geografia (CNG) e da Associação dos Geógrafos Brasileiros (AGB) na produção e difusão de conhecimentos geográficos no Brasil.

Destacou ainda a importância de outros geógrafos estrangeiros que contribuíram para a consolidação do conhecimento geográfico brasileiro, tais como: Pierre Deffontaines, Pierre Monbeig, Francis Ruellan, Leo Waibel, Preston James, Pierre Gourou, Jean Tricart e Beaujeau-Garnier.

Em outro livro recém-publicado sobre o assunto, $O$ pensamento geográfico brasileiro: as matrizes brasileiras, Ruy Moreira (2010) relata que este período foi do encontro entre o conhecimento informal dos cronistas, dos viajantes, da intelligentsia brasileira e dos romancistas que escreviam sobre o Brasil, e a Geografia, além do conhecimento formal dos professores e pesquisadores que vieram ao Brasil, cujas influências são, segundo o autor, principalmente de três matrizes teóricas ${ }^{27}$ :

[...] a francesa de Vidal, a franco-germânica de Brunhes e a germânica de Hettner, além de uma quarta, a norteamericana de Sauer e Hartshorne, vindo a acrescentar-se tardiamente. A perspectiva vidalina nos chega através de

26 Ele destacou quatro períodos na Geografia Brasileira, até a década de 1980, a saber: a primeira fase, com forte influência da escola francesa (Lablachiana); a segunda fase, com trabalhos de Preston James e Waibel, com ênfase econômica; a terceira, com novos métodos, caso da Geografia Física de Tricart, Geografia Urbana de Rochefort e regionalização, marcada na década de 60 por trabalhos de Geografia Tópica e os primeiros trabalhos de regiões polarizadas e homogêneas; a quarta fase, de Geografia Teorética, na década de 1960, e, por fim, da Geografia Radical Crítica, a partir dos anos 1980.

27 A concepção de matriz teórica utilizada pelo autor contrapõe-se em parte à ideia fundada das escolas geográficas vinculadas ao Estado-Nação e considera as concepções filosóficas dos autores. Hettner, alemão, é considerado de matriz teórica diferente, pois traz à Geografia a concepção de estudo de diferenciação de áreas, numa perspectiva regional. Hettner produziu trabalhos entre 1890 e 1910, sendo suas obras consideradas uma terceira via nos estudos geográficos da época, conforme concepção de Moraes (1995), além do determinismo e possibilismo geográficos. Esta perspectiva foi abraçada por geógrafos como Jorge Zarur no Brasil. 
Monbeig e Ruellan, a brunhiana através de Deffontaines e a hettneriana através de Waibel ${ }^{28}$ (MOREIRA, 2010, p. 12).

A concepção de conhecimento formal e informal, proposta por Ruy Moreira, desconsidera que tais conhecimentos produzidos na época não eram mais formais porque eram produzidos nas instituições de ensino. 0 que ele denomina não formal, outros autores dirão que se trata de conhecimento não científico.

Outros trabalhos, como o de Antonio Carlos Robert Moraes (1991, 2005a) e Lia Machado (1995), abordam o processo de institucionalização da Geografia no Brasil como instrumento de um projeto nacional ${ }^{29}$.

Sobre o projeto nacional de Vargas e sua relação com a Geografia, Moraes afirma:

Uma Geografia de levantamento (Estatística, na denominação clássica) é a meta, claramente exposta por Vargas nos documentos de fundação destes órgãos. O ditador fala de uma Geografia que sirva como instrumento do "poder nacional", num discurso de grande paralelismo com o proferido por Napoleão Bonaparte na fundação do Instituto de Geografia da França. A velha máxima de Estrabão - de que o geógrafo escreve para o Príncipe - em plena vigência (MORAES, 2005a, p. 130).

Essa afirmação relaciona-se à existência de entidades como IBGE e CNG como portadores da concepção nacionalista do governo Vargas, de forma que a ciência geográfica era importante para desvendar o território brasileiro, e o Ensino Básico servia como disseminador desta ideologia.

28 Há dúvida nesta afirmação sobre Waibel já que este foi uma voz dissonante nesta perspectiva regional e de estudos da paisagem comum na Geografia brasileira da época. Leo Waibel diz, na Revista Brasileira de Geografia: "Desde o início compreendi que o geógrafo que pretenda apenas permanecer no Brasil temporariamente terá que se especializar em Geografia Regional ou Sistemática. Escolhi a última e concentrei meu trabalho em dois problemas: a utilização da terra e a colonização" (WAIBEL, 1950, p. 420).

29 Neste período de Vargas, foi criado o sistema universitário brasileiro, mediante o qual foram criadas as Faculdades de Educação, Ciências e Letras. Conforme informação que consta no site do Inep: "O ministro Francisco Campos mediante o Decreto n¹9851, de 11 de abril de 1931, criou o sistema universitário. Dispõe que o Ensino Superior no Brasil obedecerá, de preferência, ao sistema universitário, podendo ainda ser ministrado em institutos isolados, e que a organização técnica e administrativa das universidades é instituída no presente decreto, regendo-se os institutos isolados pelos respectivos regulamentos, observados os dispositivos do seguinte estatuto das universidades brasileiras" (INEP, 2010, s/p.). 
Esta concepção foi corroborada pelo depoimento do prof. Pierre Deffontaines:

O Brasil, é por certo, um dos mais vastos e mais frutíferos campos de manobras da Geografia moderna [...] A Geografia tem, pois, uma missão especial a cumprir: mais do que alhures, acha-se a serviço do país. Conservando-se tão científica, tão desinteressada, cumpre-lhe indicar ao país o seu destino, seu potencial, seu futuro. Deve ser uma das bases essenciais da vida pública brasileira (DEFFONTAINES, 1946, p. 252).

Percebe-se, pelas leituras das revistas e boletins geográficos, que havia o pensamento de que a Geografia seria importante para desvendar - Brasil, mas também para um planejamento futuro, com uma crença num destino professo da Geografia como ciência também do futuro, uma forma de conhecimento que contribuiria para a solução dos problemas do país.

Esta crença na ciência geográfica como mote do desenvolvimento é uma visão simplista, porque vê a ciência só como técnica, como possibilidade de progresso, sem considerar que o conhecimento tem relação com a ideologia, com a política e com diversificados tipos de intencionalidades, que não se resumem apenas à dimensão técnica.

Então, a concepção de ciência neutra, desinteressada e científica, como diz Deffontaines (1946), deve ser questionada.

Esta visão da Geografia e desenvolvimento foi corroborada ainda por Leo Waibel (1950, p. 78), que disse: "A meu ver, portanto, para a solução dos problemas de um país ainda não desenvolvido, como é o Brasil atualmente, nenhuma ciência é mais indicada do que a Geografia".

A mesma concepção foi formulada por Monbeig, dando ênfase ao papel da Geografia no ensino:

A menos também que possamos provar a sua utilidade num mundo onde toda e qualquer ciência é também uma técnica, onde toda pesquisa leva a dar um instrumento útil à coletividade. É mister, portanto, estabelecer o valor à geografia no ensino e determinar sua utilidade como moderno instrumento de trabalho (MONBEIG, 1954, p. 56).

Recentemente, em outra pesquisa historiográfica, Mônica Sampaio Machado (2009) descreveu a trajetória da Geografia universitária no Rio 
de Janeiro, dando ênfase à Universidade do Brasil, atual UFRJ. Segundo ela, a criação desta instituição tinha como fundamento o ideário nacional e a construção de "um clima nacional", no qual a cidade do Rio de Janeiro e suas instituições contribuíram para a disseminação deste ideal.

Esta concepção também está atrelada à própria criação do IBGE e do CNG, já que houve uma nítida relação entre o Conselho Nacional de Geografia e as proposições do governo Vargas em criar formas de conhecer melhor o território nacional. No artigo $1^{\circ}$, da criação do CNG, em 1937, está:

Fica instituído o Conselho Brasileiro de Geografia, incorporado ao Instituto Nacional de Estatística e destinado a reunir e coordenar, com a colaboração do Ministério da Educação e Saúde, os estudos sobre a geografia do Brasil e a promover a articulação dos serviços oficiais (federais, estaduais e municipais), instituições particulares e dos profissionais que se ocupem de geografia do Brasil, no sentido de ativar uma cooperação geral para um conhecimento melhor e sistematizado do território pátrio (IBGE, 1962a, p. 289).

Contudo, Mônica Sampaio Machado (2009) ressalta a existência de outros cursos da Geografia fluminense ${ }^{30}$, de caráter mais regional, criados neste período no Rio de Janeiro, caso das atuais - Universidade do Estado do Rio de Janeiro (UERJ) e Universidade Federal Fluminense (UFF), que inicialmente eram privadas, o que demonstra a centralidade urbana da capital do país.

Já na região Nordeste do Brasil, o primeiro curso de Geografia foi implantado em 1941, na Bahia, com licenciatura e bacharelado em Geografia e História, na Faculdade de Filosofia, Ciências e Letras da Universidade Federal da Bahia (UFBA). Na década de 1950, os cursos se separaram. Os formados atuavam na educação, já que naquela época não

30 A UERJ, por exemplo, foi criada com a implantação da Faculdade de Filosofia do Instituto La-Fayette. Em 1950, ela foi incorporada à Universidade do Distrito Federal (a segunda que foi criada) e, em 1958, passou a ser denominada de Universidade do Rio de Janeiro, depois Universidade do Estado da Guanabara e, em 1975, recebeu a denominação atual. Já a UFF, situada em Niterói, foi criada com a Faculdade de Filosofia de Niterói em 1947 e, em 1966, passou a ter a denominação atual. Ambas as instituições foram criadas inicialmente como entidades privadas, e o curso de Geografia surgiu desde o princípio nas instituições (MACHADO, 2009). 
havia ainda, na região, trabalho para geógrafos além da atuação no ensino.

Em Pernambuco, o primeiro curso de Geografia da Universidade Federal de Pernambuco (UFPE) foi criado em 1950, tanto de bacharelado como de licenciatura. Manuel Correia de Andrade (2007) dizia que antes mesmo da criação dos cursos universitários houve um concurso para catedráticos de Geografia para o Ginásio em Recife em 1939, no qual três professores participaram com teses baseadas nas ideias de autores franceses, dois deles tornaram-se professores da UFPE posteriormente.

Com a instalação do curso de Geografia na UFPE, os professores Gilberto de Osório de Andrade, de Geografia Física, e Mario Lacerda de Mello, de Geografia Humana, realizavam seus trabalhos de campo, com ajuda de seus assistentes Manuel Correia de Andrade e Hilton Sette e com outros professores, historiadores e antropólogos. Cita ainda a criação da seção da AGB local, como evento importante para a Geografia local:

Em 1952, a AGB - Associação de Geógrafos Brasileiros, fundada em São Paulo, em 1934, pelo professor Pierre Defonttaines, resolveu realizar sua Assembléia Geral, anual, na Paraíba, iniciando o conclave em Campina Grande e encerrando o mesmo em João Pessoa. Os dois principais diretores dessa associação, os professores da USP João Dias da Silveira e Aziz Ab'Saber, vieram ao Recife para convocar os geógrafos locais a participarem da assembléia. Alguns professores de geografia participaram do conclave, $[\ldots]$ ao voltarem ao Recife, fundaram o núcleo estadual da AGB (ANDRADE, 2007, p. 12).

Esta condição demonstra o papel que a AGB teve na divulgação do conhecimento geográfico existente em algumas IES do período e que não estava circunscrito apenas a São Paulo e Rio de Janeiro.

Outra questão quase sempre apontada sobre o período da criação dos primeiros cursos é a de que a Geografia institucionalizada nas IES foi orientada pela Geografia francesa. Não se pode questionar tal afirmação, tampouco a importância do trabalho dos mestres franceses, contudo há evidências de outros autores também importantes para a Geografia no Brasil. 
Foi o caso de Friedrich Ratzel ${ }^{31}$, Karl Ritter, Alexander Von Humboldt, Alfred Hettner, Élisée Reclus (este último, embora francês, não fazia parte da rede de afinidade científica e acadêmica de Paul Vidal de La Blache), além de outros autores influentes no período.

Em entrevista concedida a José Borzacchielo da Silva (2002), Milton Santos também reitera que a Geografia brasileira sofreu influência principalmente dos franceses no período que chamou de "infância" da Geografia no Brasil, dividindo-a em duas fases: uma na qual cita Delgado de Carvalho como expoente e, outra, com a vinda dos professores universitários, caso de Monbeig, Ruellan e Deffontaines, influências estas destacadas como principalmente paulista e fluminense.

É importante este destaque dado por Milton Santos, pois de fato poucos citam que, além da criação da Universidade de São Paulo (USP), em 1934, da Universidade do Distrito Federal (UDF) em 1935, e da Universidade do Brasil (atual UFRJ), em 1939, houve a criação de cursos de Geografia na Universidade Federal do Paraná (UFPR), em 1938; na Pontifícia Universidade Católica do Rio Grande do Sul (PUCRS), em 1940; na Pontifícia Universidade Católica do Rio de Janeiro (PUC-Rio), em 1941; na Universidade do Estado do Rio de Janeiro (UERJ), em 1941; na Universidade Federal de Minas Gerais (UFMG), em 1941; na Universidade Federal da Bahia (UFBA), em 1941; na Pontifícia Universidade Católica de Campinas (PUC-Campinas), em 1942 e na Universidade Federal do Rio Grande do Sul (UFRGS), em 1943 (MEC, 2009a).

Portanto, afirmar que a influência francesa foi única em todas as Instituições de Ensino Superior (IES) do período requer uma pesquisa

31 A discussão sobre a "Geografia Moderna" é comum nos artigos sobre método de Geografia, publicados na Revista Brasileira de Geografia (RBG) e no Boletim Geográfico da época, e mostram que as influências de Ratzel e sua "Antropogeografia" também estão presentes em estudos no Brasil. Ao ser perguntado pela RBG sobre qual o conceito moderno de Geografia, Max Fleiuss diz: "O conceito moderno da história da Geografia ainda é o estabelecido por Friedrich Ratzel, em fins do século passado em sua "Antropogeographie". A geografia não pode mais deixar de ser estudada, senão tendo em vista a espécie humana, e principalmente o homo economicus" (FLEIUSS, 1940, p. 446). 
mais aprofundada sobre as outras instituições, geralmente pouco citadas na historiografia da Geografia brasileira.

Na USP, o projeto de criação tinha relação com os interesses da elite paulista, que, após a derrota da Revolução Constitucionalista (1932), buscava utilizar a criação da Universidade como estratégia de poder, baseando-se no ideário paulista capitaneado pelo crescimento econômico e urbano paulistano.

A Geografia tinha também este papel ideológico da ciência empírica que poderia desvendar o Brasil, com "[...] os discursos sendo produzidos, sendo legitimados, pelo conteúdo empírico de um conhecimento científico pretensamente neutro", conforma aponta Moraes (2005b, p.128).

Na Universidade do Brasil, no Rio de Janeiro, tinha estreita relação com os interesses do governo Vargas em criar uma Universidade de caráter nacional, com maior incentivo aos Ensinos Secundário e Superior, bem como do interesse pelo conhecimento geográfico no levantamento de informações sobre o território nacional para fins de planejamento, ao mesmo tempo, difundindo o nacionalismo brasileiro e a ideologia do Estado Novo, também disseminado pela Escola Básica da época.

Havia ainda os cursos de Geografia em instituições religiosas, caso das IES Católicas, entidades privadas, transformadas em posteriormente em PUCs ${ }^{32}$.

32 Segundo informações obtidas nos sites das próprias instituições, a PUC-RS originalmente foi fundada a partir de uma Congregação Marista, em 1940, com a Faculdade de Filosofia, Ciências e Letras à qual o curso de Geografia estava vinculado. Só em 1948 tornou-se Universidade Católica do Rio Grande do Sul. Já na PUCCampinas o início de Geografia e História ocorreu nas Faculdades Campineiras, integrando a Faculdade de Filosofia Ciências e Letras, cuja formatura da primeira turma ocorreu em 1945, tendo, portanto, três anos de duração. Posteriormente as Faculdades Campineiras se transformaram na Universidade Católica de Campinas, e o curso de Geografia e História passa a funcionar como cursos específicos. O curso de Geografia da PUC-Campinas passou a ser o formador da maioria dos professores da região e contou, em seu quadro docente, com nomes conhecidos da Geografia brasileira como Aroldo de Azevedo, Aziz Ab'Saber e Antonio Christofoletti. Na PUCRio um decreto assinado pelo presidente Vargas autorizou a instalação da Faculdade de Direito, com bacharelado, e da Faculdade de Filosofia em 1940, denominada Faculdades Católicas, com vários cursos de licenciaturas, entre eles História e Geografia. Em 1946, transforma-se em Universidade Católica e, em 1947, PUC-Rio. 
Neste período, há relação entre o governo Vargas e a criação destas IES, conforme afirma Luiz Antônio Cunha:

[...] durante a era Vargas houve decidido apoio para a criação da Universidade Católica, uma instituição particular. Para esse apoio concorreu, certamente, o pacto informal de colaboração recíproca, proclamada do lado do Estado pelos discursos de Francisco Campos ${ }^{33}$ e Capanema; pela política favorável ao ensino religioso, isto é, da igreja católica, nas escolas estatais [...] Do lado da Igreja, a difusão da ideologia da ordem, na versão corporativa, reforçava a doutrina do Estado Novo, contribuindo para sua legitimidade (CUNHA, 2007c, p. 282).

Dessa forma, cumpriam um papel de apoio ideológico na construção do ideário do Estado Novo (1937-1945), numa política de educação autoritária, já que havia interesses recíprocos nesta relação entre o Estado e a Igreja Católica, buscando conservar o trinômio: religião, família e pátria.

Outro exemplo desta tentativa do controle estatal do Estado Novo foi a intervenção na Universidade do Distrito Federal (UDF), cujo projeto de Anísio Teixeira ${ }^{34}$ era considerado mais liberal, e sua fusão com a Universidade do Brasil, em 1939.

Logo, este é um panorama de onde estavam inseridos os primeiros cursos de Geografia no Brasil, com diferentes tipos de intencionalidades, e afirmam o papel ideológico que a criação das IES e de seus cursos de Geografia tinham.

33 Francisco Campos foi secretário do Interior de Minas Gerais, instituição que tinha a incumbência de tratar de questões ligadas à educação. Cabe ressaltar que o estado de Minas Gerais foi o primeiro onde houve aproximação entre a igreja católica e o ensino religioso formalmente, já que na Primeira República fora abolido o ensino religioso obrigatório em instituições públicas. Com a criação do Ministério de Educação e Saúde Pública (1930) tornou-se o primeiro titular do Ministério e a partir daí foi autorizado o ensino religioso nas escolas federais (CUNHA, 2007c).

34 Anísio Teixeira foi um jurista, educador e intelectual brasileiro, adepto da Escola Nova, que atuou no Ensino Superior e se contrapunha ao interesse da educação autoritária e nacionalista, comum no governo Vargas. Do ponto de vista da estrutura das Universidades, tratava da importância da existência da integração das diversas áreas do conhecimento e de seus institutos e faculdades, os quais quase sempre eram isolados. Para ele o ensino universitário deveria contemplar a formação profissional, desenvolver o saber humano e alargá-lo. Deveria ainda, por fim, servir como transmissora da cultura brasileira, em sua diversidade (TEIXEIRA, 1967). 


\subsubsection{As características dos primeiros cursos de Geografia}

O primeiro curso de formação em Geografia era junto com História e foi criado na USP em 1934, tendo em seu currículo a disciplina de "Geografia35", sendo depois desmembrada em "Geografia Física" e "Geografia Humana" em 1939; em 1942, foi criada "Geografia do Brasil" (AZEVEDO; SILVEIRA, 1949).

Nesse período, o curso era oferecido em quatro anos junto com História, com três anos básicos, nos quais havia também disciplinas de História, além de matérias como "Elementos de Geologia" e "Elementos de Cartografia". Na formação pedagógica, havia as disciplinas de "Didática" e "Psicologia Educacional". Formava-se em licenciatura de História e Geografia, e, no quarto ano, todos os que terminassem a formação básica de três anos poderiam também fazer especialização em Geografia, numa formação mais técnica.

$\mathrm{Na}$ Universidade do Brasil era vinculado à Faculdade Nacional de Filosofia (FNFi), até 1945; a formação ocorria em três anos, em mais um ano, com um segmento de Didática, obtinha-se a formação de licenciado. Em 1946, por meio do Decreto-Lei $n^{\circ} 9092$, o curso passou a ter quatro anos, com especialidade em bacharel ou em licenciatura, este último com "disciplinas pedagógicas". A partir de 1956, o curso separa-se de História e passa por uma nova reestruturação curricular.

Logo, os cursos da época formavam em História e Geografia. Segundo Aroldo de Azevedo, a divisão curricular em "Geografia Física", "Geografia Humana" e "Geografia do Brasil" não era a ideal, assim como a divisão em História e Geografia:

O ideal seria um curso fundamental, de no mínimo três anos, no qual fossem estudadas apenas as matérias básicas, dando direito a quem o completasse de exercer o magistério secundário ou, quem sabe, somente o ensino ginasial; e a

35 No início do curso da USP, havia mais disciplinas de História do que de Geografia, aos poucos foram ampliando a matriz curricular com disciplinas geográficas. A cátedra de "Geografia", em 1934, ficou sob responsabilidade de Pierre Deffontaines e, em 1935, passou ao professor Pierre Monbeig, que ficou no cargo até 1946, já com "Geografia Humana"; o professor João Dias da Silveira lecionava "Geografia Física". 
seguir, um curso de especialização, constituído por dois ou três anos, no qual imperasse (agora sim) a separação absoluta entre a Geografia e a História, com matérias selecionadas que assegurassem uma cultura especializada (AZEVEDO, 1946, p.236-237).

Já Monbeig era mais cético em relação à separação da História e Geografia, pois achava que havia necessidade de uma formação mais ampla, mantendo-se a necessária pluridisciplinaridade (SALGUEIRO, 2006).

Ressalta-se que o curso de Geografia da UDF $^{36}$ tinha menos vínculo com a História do que na USP, embora houvesse relações entre as duas disciplinas. No entanto, quando a UDF foi acoplada à Universidade do Brasil, tornaram-se um só curso, com habilitações em História e Geografia. Em depoimento ao "O Jornal", em maio de 1936, Afonso Penna Junior, o então reitor da UDF fez um relato sobre o curso de Geografia:

Já no segundo ano o curso de conteúdo ficará acrescido com o ensino de organização de programa e material didático de Geografia e História, e com prática de Geografia. No terceiro ano, enfim, haverá no curso de conteúdo trabalhos de campo, sendo o curso de fundamentos substituído por um de integração profissional, que é de importância capital, em que o aluno aprenderá, além de outras matérias, a Filosofia da Educação e das Ciências, a Psicologia do adolescente e medidas educacionais e a prática de ensino (PENNA JUNIOR apud MACHADO, 2009, p. 67).

Verificava-se, na UDF, uma característica diferenciada na formação do licenciado em Geografia da época, com disciplinas voltadas à formação da docência não apenas no final do curso, como se tornou comum nas outras IES. Interessante observar que, na matriz curricular da UDF,

36 Os professores específicos de Geografia da UDF e suas respectivas disciplinas foram: Fernando Antônio Raja Gabaglia (Fisiografia), formado em Direito, foi professor de Geografia do Colégio Pedro II e autor de livros didáticos; João Capistrano Raja Gabaglia (Práticas de Geografia); Pierre Deffontaines, geógrafo francês, fundador da AGB carioca, e seus assistentes José Junqueira Schmidt e Ernesto Street e Phillippe Arbos (Geografia Humana), Mathias de Oliveira Roxo foi do Serviço Geológico (Paleogeografia e Geologia), Alberto Betim Paes Leme (Geografia Regional) era diretor do Museu Nacional e, por fim, Christovam Leite de Castro (Desenho Cartográfico), engenheiro, mas estudou na segunda turma de Geografia da UDF. Dos formados na UDF que se destacaram na Geografia há ainda, Orlando Valverde, Jorge Zarur, Fábio Macedo Soares Guimarães, Segismundo Steves e Hildegard Sternberg (MACHADO, 2009). 
constava "trabalho de campo", com desenvolvimento disciplinar, situação menos comum naquele período.

Tanto Azevedo e Monbeig, na USP, como Ruellan, na Universidade do Brasil, e Waibel, no IBGE, relatam a importância que tinham as "excursões" ${ }^{17}$ de campo no ensino de Geografia, momento de integração dos cursos, já que eram comuns as atividades de campo conjuntas entre várias disciplinas (VALVERDE, 1994; AB'SÁBER ${ }^{38}$, 1994; MACHADO, 2009).

Os professores e alunos retratavam a organização destas atividades, assim como a importância delas como uma possibilidade de integrar os conhecimentos que, aparentemente, se encontravam fragmentados na matriz curricular dos cursos. Machado (2009) ressalta que os trabalhos de campo eram importantes na Universidade do Brasil, embora não constassem na matriz curricular. A importância dos trabalhos de campo também foi reiterada por Orlando Valverde, que foi aluno da primeira turma da UDF, com o seguinte relato:

O fator básico que tornou a AGB a mais fértil organização privada de estudos geográficos em nosso País foram os trabalhos de campo em equipe, guiados por geógrafos experientes. Os debates que se seguiam envolviam questões teóricas para a solução de problemas práticos; não derivavam de situações hipotéticas (VALVERDE, 1994, p. 122).

Outra questão muito comentada no início da Geografia universitária no Brasil era a falta de formação acadêmica dos professores, tanto no Ensino Superior quanto no Secundário, já que havia muitos professores

37 Os termos mais comuns usados na época eram excursões de campo, trabalho e atividade de campo.

38 A importância dos trabalhos de campo também foi reiterada em depoimento sobre o Prof. Monbeig, no qual Aziz Ab'Saber (1994) diz: "Fiel ao lema de introduzir seus alunos em tarefas de iniciação, feitas diretamente no campo, Pierre Monbeig exigia deles estudos múltiplos sobre subáreas da região de São Paulo e de seus arredores. Ele sabia que nós, alunos egressos de classes pobres, não tínhamos recursos para realizar pesquisas em áreas distantes, que exigissem despesas de viagens, estadia e transportes. Não existiam, na época, agências financiadoras para pesquisas [...]" (AB'SABER, 1994, p. 6). 
leigos ou formados em outras áreas do conhecimento diferentes daquela que lecionavam.

Em São Paulo, por exemplo, os jornais da época, dos anos 1920-30, advogavam a necessidade destes profissionais do Ensino Superior, por conta da criação da Faculdade de Filosofia, Ciências e Letras, que segundo eles deveria contar com professores estrangeiros. Mas havia os que eram radicalmente contra a vinda destes profissionais (WITTER, 1984).

Na Universidade do Brasil, por exemplo, na fase de 1939 a 1955, a maioria dos professores não tinha formação específica em Geografia, caso de Victor Leuzinger (engenheiro); Josué de Castro (médico); Delgado de Carvalho (cientista político), que, com o geógrafo francês Francis Ruellan, tiveram importância na produção acadêmica da Universidade. Orlando Valverde (1994), em depoimento sobre a sua formação na UDF, bem como sobre a Geografia fluminense do período, afirma:

Como não havia no Rio de Janeiro, naquele tempo, ninguém formado em Geografia, em curso superior, os colaboradores de Deffontaines eram sobretudo geólogos, engenheiros de minas, professores de geografia; engenheiros civis dedicados à geodésia e topografia, à economia; médicos, bacharéis [...] (VALVERDE, 1994, p. 118).

Devido à inexistência da formação de geógrafos no Ensino Superior, muitos professores do curso de Geografia eram formados em diferentes áreas do conhecimento.

O professor Monbeig era mais um preocupado com esta questão nos diferentes níveis de ensino. Discutia a importância da formação do professor de Geografia, nos seguintes termos:

Ninguém pode improvisar-se professor. Salvo casos excepcionais, aquele que exerce uma certa profissão não está, só por isso, apto a ensinar uma disciplina científica, da qual nada aprendeu desde a juventude. Nenhum professor de geografia pensaria improvisar-se engenheiro ou advogado (MONBEIG, 1954, p. 68). 
A mesma situação era vivida pelos formados em Geografia pela Universidade Federal do Rio Grande do Sul, curso criado em 1943, segundo depoimento da Profa Alba Gomes ${ }^{39}$, aluna da Geografia.

Portanto, faltavam professores de Geografia no Ensino Superior, situação que evidenciava a condição do Brasil no mundo, já que a educação superior estava em "plena infância" em nosso território, o que redundou na necessidade de buscar professores em outros países considerados centralidades em relação à produção do conhecimento científico.

Para suprir essa escassez na área de Geografia, os professores vieram, principalmente, da França, mas isto se deu mais diretamente em São Paulo e Rio de Janeiro do que em cursos de outras cidades do Brasil. Isto, porém, não ocasionou uma mera transposição de ideias francesas e suas referências teórico-metodológicas para o Brasil, pois, em organizações como IBGE e CNG, havia também ideias provenientes de matrizes geográficas distintas, como de Hettner, de Reclus e Ratzel, assim como havia produções geográficas além do Ensino Superior.

Em 1946, Aroldo de Azevedo ${ }^{40}$ fez um balanço de suas atividades no Ensino Superior, em seus primeiros dez anos de docência. Ele apontava quais os principais problemas encontrados naquela época no curso de Geografia da USP: "Nota-se, antes de mais nada, uma falta de base geográfica. Os alunos se apresentam aos exames de habilitação e, freqüentes vezes ignorando noções gerais, quando não princípios rudimentares da Geografia [...]"(AZEVEDO, 1946, p. 228).

39 Conforme depoimento da professora Alba: "E então esses professores que acho foram surpreendidos porque trabalhavam em outras disciplinas, surpreendidos em terem que trabalhar com geografia. Geografia Humana o professor "Prumes", Geografia Física com professor "Nei Crisortemam" que era Engenheiro, História professor "Dante Laitano" que era do Direito também, professor "Francisco Carrion" de História Contemporânea. E assim foram se formando as disciplinas com a curiosidade, com a boa vontade do estudo e da dedicação destes professores [...]" (GOMES, 2007, p. 90).

40 Tendo lecionado na cadeira de "Geografia Humana", em 1946, inicia-se em "Geografia do Brasil" e, a partir de 1943, tornou-se também professor de Geografia na Faculdade de Filosofia de Campinas. 
Monbeig (1944) também apontava o mesmo problema, mas considerava que a formação deficitária dos alunos ocorria devido à condição social de alguns, fato que os obrigava a estudar e trabalhar concomitantemente, assim como os baixos salários dos professores do nível Secundário, como se constata no excerto a seguir:

Em última análise, a causa essencial dessa fraqueza relativa dos novos licenciados reside, em grande parte, nas deficiências dos cursos secundários onde foram alunos. Não tendo nunca aprendido a trabalhar com método, a pensar e a ler com espírito crítico, têm atraso considerável a vencer e a boa vontade nem sempre é suficiente para preencher as falhas de formação de criança (MONBEIG, 1944, p. 8).

Portanto, a condição social dos alunos e a formação considerada deficiente no Ensino Secundário eram motivos apontados como problemas que dificultavam o aprendizado dos alunos no Ensino Superior, geralmente numa visão de causa e efeito.

Os professores da época criticavam também os resumos e apostilas de Geografia usadas na formação dos estudantes universitários e secundários. Sobre isto assim se manifestou Azevedo (1946, p. 230):

Dentro dessa mentalidade errada, o aluno sofre de entrada uma grande desilusão: não encontra possibilidade de estudar em um compêndio [...] A solução que se the apresenta é uma só: lançar-se furiosamente às anotações, usar e abusar das famosas apostilas.

O professor Mario Lacerda de Melo ${ }^{41}$ (1955, p. 59) dizia, porém, que "[...] a freqüente deturpação do papel das apostilas, muitas vezes, não significa puro comodismo. Exprime a dificuldade em consultar uma bibliografia básica, em dois ou três idiomas além do nosso...". De fato, condição já atestada por outros professores segundo os quais muitos livros, neste período, eram escritos principalmente em francês, e os alunos não tinham domínio desta língua.

Esta questão, portanto, também se relacionava à falta de bibliografia em português, o que dificultava a formação dos geógrafos deste período no Brasil com leituras mais diversificadas, situação que foi

41 Foi presidente da AGB e catedrático de Geografia Humana da Faculdade de Filosofia da Universidade do Recife. 
sendo minimizada com as obras geográficas no Brasil, cuja produção e acesso eram maiores em São Paulo e Rio de Janeiro, mediante publicações em periódicos e em livros sobre Geografia.

Logo, havia uma seletividade espacial na produção acadêmica no Brasil, fosse geográfica ou não. Os boletins geográficos eram publicados principalmente no Rio de Janeiro pelo IBGE, caso do Boletim Geográfico e da Revista Brasileira de Geografia, assim como o Boletim Paulista de Geografia e o Boletim Carioca de Geografia, pela AGB.

\subsubsection{A expansão dos cursos de Geografia}

Após esta breve explanação sobre a história e historiografia dos primeiros cursos de Geografia no Brasil, neste item propõe-se considerar a existência e a expansão destes cursos com a mediação espacial.

A concepção do termo "existência" dos cursos considera que esta ocorre num movimento histórico e espacial, contraditório, e com relações e conexões com as dimensões sociais, econômicas e políticas, especialmente das políticas públicas de Ensino Superior.

A visão adotada de espaço é o de instância social, que não é apenas reflexo social, como diz Milton Santos:

[...] o espaço organizado pelo homem é, como as demais estruturas sociais, uma estrutura subordinada-subordinante. E como outras instâncias, o espaço, embora submetido à lei da totalidade, dispõe de uma certa autonomia [...] (SANTOS, 2004, p. 181).

Nesta perspectiva considera-se a relação da distribuição espacial das IES e do nível de centralidade econômica e urbana das cidades onde se situam os cursos, como uma condição subordinada e subordinante. Há uma circularidade dialética entre as condições territoriais onde estão inseridas as instituições e seus cursos, já que ora subordinam-se às condições políticas e socioeconômicas de cada época, ora são subordinantes, atribuindo assim diferentes valores e situações às IES e aos cursos de Geografia. 
Em 1933, por exemplo, conforme o mapa 1, as IES já se encontravam concentradas em São Paulo, Minas Gerais e no Distrito Federal (atual Rio de Janeiro), que eram os mais populosos e com maior densidade técnica, expressa em infraestrutura e nos sistemas de engenharia da época.

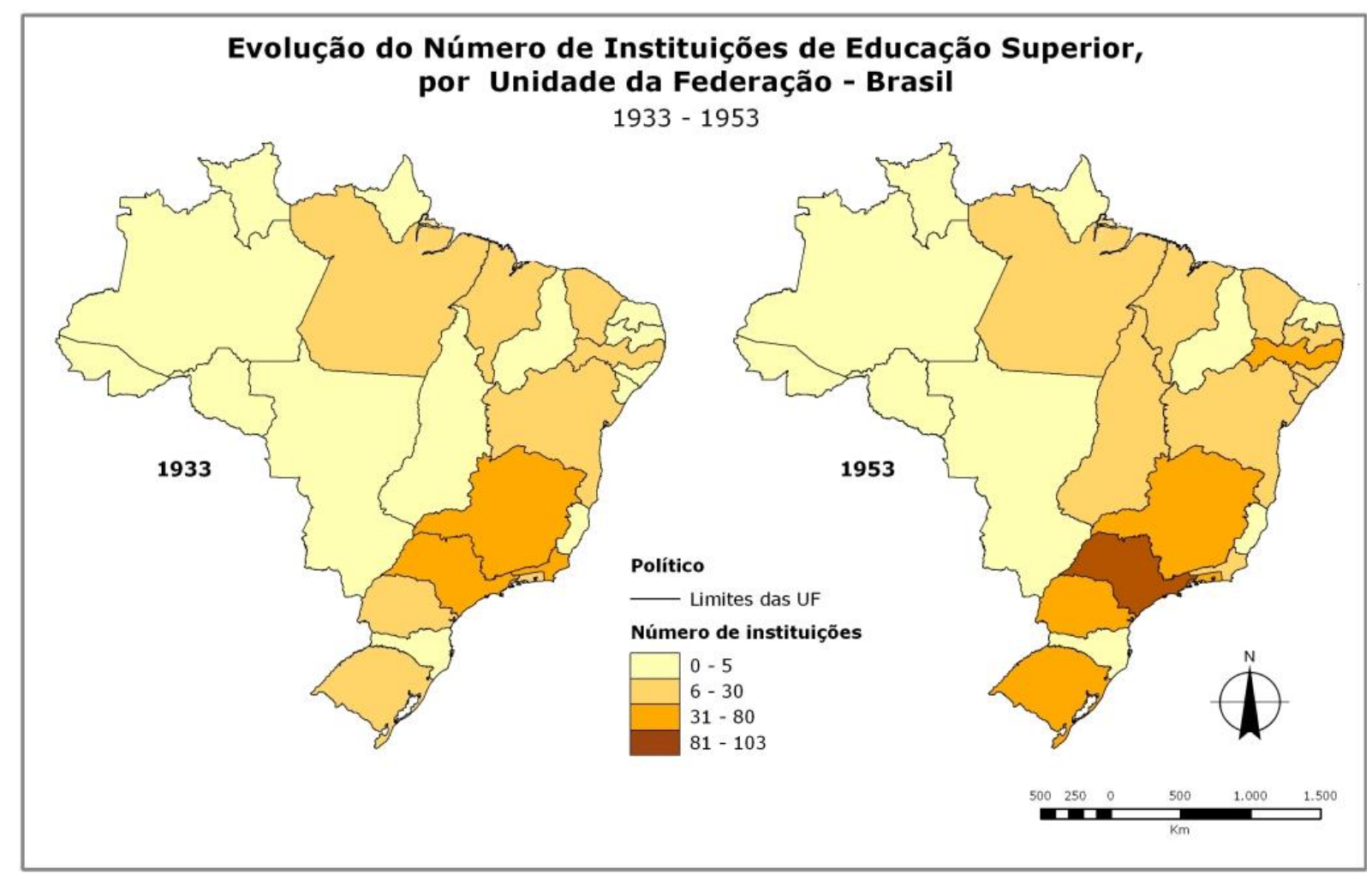

Mapa 142- Fonte: Séries Históricas, IBGE, 1933 e 1953.

Elaborado por Maurício Yamada e Vivian Fiori, 2010.

Neste período inicial, o governo Getúlio Vargas (1930-45), em seu projeto nacionalista, buscou criar instituições brasileiras, entre elas o Ministério da Educação e Saúde, as IES e também os cursos de Geografia.

Essa época, segundo Antonio Carlos Robert Moraes (2005b), tornase o tempo do Brasil Moderno, do discurso "civilizador" e da "modernização" mediante a (re)organização e ocupação do território brasileiro por meio de novas normas territoriais e sistemas de engenharia, criação de órgãos e instituições públicas, bem como do ideário da brasilidade e do caráter nacional.

42 Observação: O estado de Mato Grosso do Sul não existia até 1977, sendo todo denominado Mato Grosso; o Tocantins foi criado em 1988, antes seu território era parte de Goiás. 
A concentração de IES no estado de São Paulo devia-se ao crescimento e destaque paulista na economia nacional, na concentração industrial, principalmente a indústria têxtil, que abrigava grande número de trabalhadores, se comparado a outros estados brasileiros, assim como na participação na exportação e importação no total do Brasil.

A indústria era um dos motores da economia paulista ${ }^{43}$, juntamente com o ideário modernizador paulista, a partir do qual se dotou o território de sistemas de movimento e de serviços que tornaram a capital paulista a principal centralidade do país, juntamente com a cidade do Rio de Janeiro.

Em 1953, percebe-se maior centralidade do Ensino Superior no Estado de São Paulo e no Distrito Federal (Rio de Janeiro), seguidos de Minas Gerais, Rio Grande do Sul, Pernambuco e Paraná.

Logo, houve um aumento e expansão das IES pelo território brasileiro, de 1933 a 1953, que tem relação com a intensificação da urbanização ${ }^{4}$, bem como a maior pujança econômica de algumas unidades da federação no país, dotadas também de infraestrutura de transporte, como no caso da ferrovia e das estradas que tinham um papel dinamizador, principalmente nas economias paulista e mineira.

Entre estas IES tínhamos principalmente as públicas, caso da Universidade do Brasil e USP, e algumas privadas, principalmente as Universidades Católicas.

O fato de serem públicas não tinha relação com sua gratuidade, já que, em alguns casos, mesmo as IES públicas eram pagas. Cunha (2007c, 2007b) analisou esta questão apontando que, desde o século XIX, o Ensino Superior brasileiro foi pago. Em IES, como a Universidade do Brasil, os cursos inicialmente foram pagos; pagava-se pela taxa de inscrição, por disciplina/cátedra, diploma, matricula anual etc.

43 Como exemplo desta concentração paulista, citamos que, segundo dados do Anuário Estatístico do Brasil, IBGE, (1950) e Apêndice Estatístico (CANO, 1977), a concentração da indústria têxtil paulista em relação ao Brasil era de $45,4 \%$ em 1939, e a participação do Estado de SP no total de exportação do Brasil era da ordem de $55,5 \%$.

44 Embora nesta época a maioria da população fosse rural no Brasil, segundo os anuários estatísticos do IBGE $(1940,1950,1960)$, o índice de crescimento urbano da década de 1940 foi de $37,19 \%$, em 1950 , de $72,46 \%$ e em 1960 , de $70,13 \%$. 
Tal situação foi se tornando menos comum após 1950 e sendo abandonada pelas IES públicas, embora formalmente só em 1988 o Ensino Superior público tenha sido declarado gratuito, exceção feita às fundações ou autarquias municipais.

Em relação à gratuidade, o estado de São Paulo constituía-se numa exceção já que a constituição paulista de 1947 estipulava gratuidade para todos os graus de ensino público oficial, e não havia necessidade de o discente provar sua condição social de pobreza, como ocorria com as IES públicas que não eram gratuitas.

$\mathrm{Na}$ década de 1950, o governo federal inicia um processo de federalização de algumas IES, incluindo a Universidade Federal do Paraná (UFPR) que anteriormente era privada.

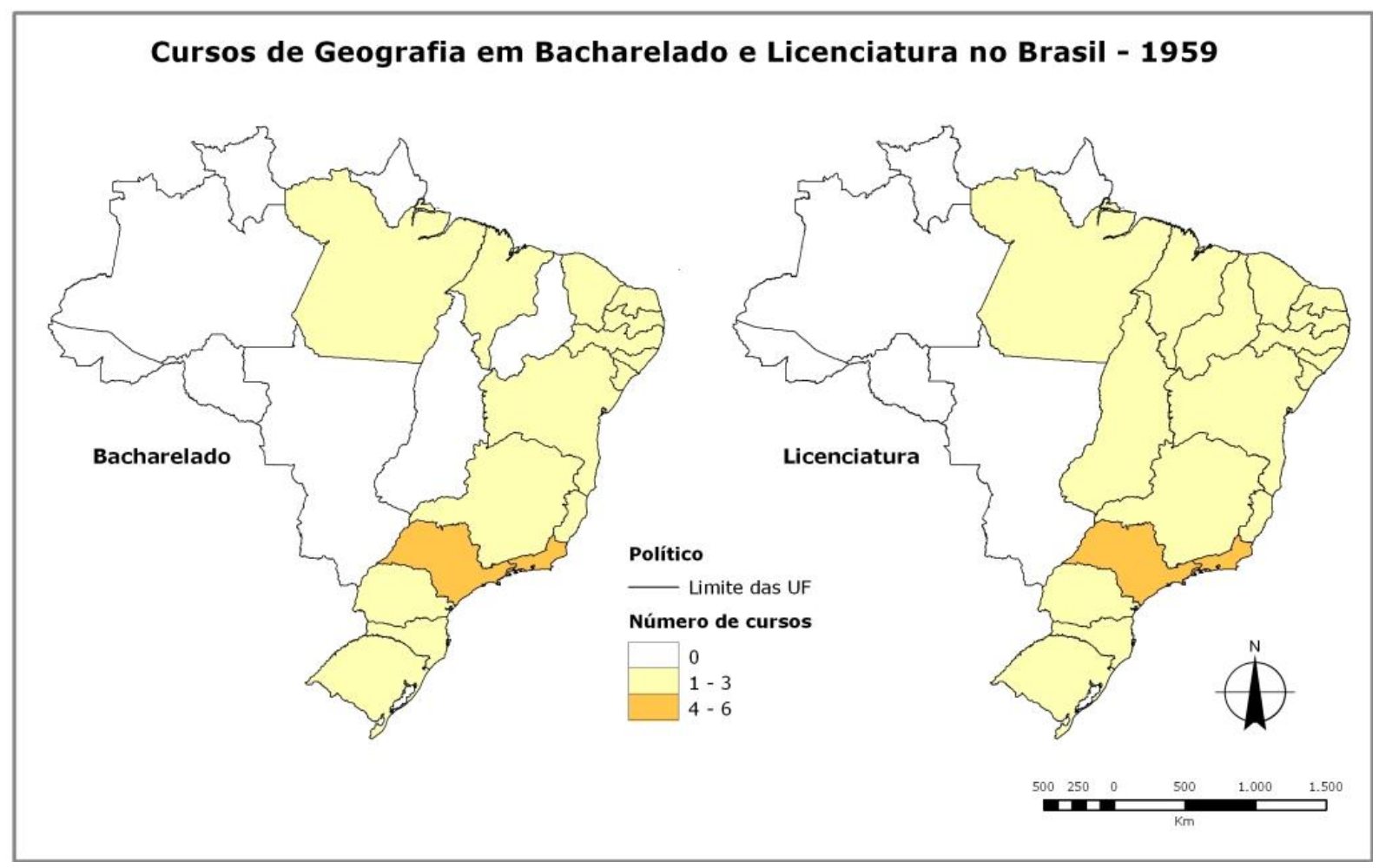

Mapa 2 - Fonte: MEC, 2009. Dados organizados por Vivian Fiori. Elaborado por Maurício Yamada e Vivian Fiori, 2010.

Em relação ao número de cursos de Geografia (mapa 2), observa-se que, em 1959, tanto a licenciatura como o bacharelado estavam localizados na região de maior concentração de IES. 
Constata-se também que não havia muita diferença entre o número de cursos de licenciatura e bacharelado nesta época, já que eram mais comuns as duas habilitações.

Havia maior centralidade urbana do Rio de Janeiro e de São Paulo, o que se evidenciava quer pelo maior número de cursos de Geografia, quer pela concentração da produção geográfica da época.

Porém, existiam peculiaridades na produção geográfica nas duas cidades, pois, no Rio de Janeiro, devido ao fato de ser a capital do país, havia maior relação com o CNG, com o IBGE e com a centralização de alguns eventos geográficos neste primeiro período de 1934-1959.

É possível, então, considerar que a centralidade destas cidades tinha relação com a difusão deste conhecimento geográfico pelo território brasileiro, pois estas cidades, além de deterem o maior número de cursos e entidades geográficas, eram agentes da produção e difusão do pensamento geográfico, da pesquisa e do ensino em Geografia da época.

Então, a dinâmica do território deve ser considerada como dimensão fundamental nesta história e historiografia dos cursos de Geografia (SANTOS, SILVEIRA, 2001b), pois, havia e ainda há relação direta entre a formação e a dinâmica do território brasileiro, de seu processo de urbanização e da hierarquia urbana com as características e a existência das IES e dos cursos.

Em 1959, os estados do Norte e Centro Oeste do Brasil tinham ainda uma ocupação incipiente, poucas IES e nenhum curso de Geografia, exceções ao Pará e Goiás. Logo, a existência dos primeiros cursos tinha uma relação com a urbanização existente no Brasil, pois estes foram implantados nas regiões em que se consolidava uma infraestrutura de transporte e de serviços.

Ou seja, a urbanização gerava a necessidade de novos saberes, que se relacionavam à sociedade da época, num processo de seletividade espacial, criando novas condições para o processo de expansão das IES no território. 
As regiões mais dinamizadas economicamente tanto pela indústria como pela agropecuária, caso do Sudeste-Sul, atraiam migrantes provenientes de áreas rurais destes próprios estados bem como do Nordeste. As indústrias e a urbanização aumentaram a concentração da população, assim como provocaram a necessidade da ampliação de serviços de saúde e educação.

A concentração dos cursos de Geografia no final dos anos 1950 dava-se, principalmente, nas capitais ${ }^{45}$ dos estados. Uma exceção era o estado de São Paulo, que já despontara como centralidade econômica do país, no setor industrial e em serviços, entre eles os da educação superior.

Em 1959, em São Paulo, além da Universidade de São Paulo, instalada na capital, havia cursos de Geografia em Rio Claro ${ }^{46}$, Bauru, Presidente Prudente, Sorocaba e Lins (AB'SABER, 1960).

Contudo, como todo processo dialético, havia contradições entre as necessidades dos lugares e as IES existentes, bem como desequilíbrios entre as demandas sociais dos lugares e os cursos de Geografia, sobretudo na formação de professores.

Isso tinha relação com o contexto sócio-histórico do período até 1960, mas também foi mediado pelo território brasileiro à medida que, em São Paulo e Rio de Janeiro, por serem centralidades na produção geográfica e terem maior número de cursos de Geografia nas IES, suprimiam um pouco mais esta carência de professores.

No Rio de Janeiro (antigo Distrito Federal), isto se deu em função de ser a capital do Brasil e ter, em seu território, diversas instituições públicas e administrativas do governo federal. Além disso, concentrava,

45 No Paraná, além de Curitiba, havia o curso de Geografia em Ponta Grossa, com a criação da Faculdade Estadual de Filosofia, Ciências e Letras de Ponta Grossa em 1949 e com o curso de Geografia e História em 1950. A existência desta IES no interior do Paraná ocorreu devido ao crescimento econômico ocasionado pelo comércio madereiro, de gado e da erva mate, assim como pela construção da Estrada de Ferro São Paulo-Rio Grande do Sul que tinha Ponta Grossa como uma parada (PIMENTEL, 2010).

46 Em Rio Claro, em 1958, o curso de Geografia foi implantado na Faculdade de Filosofia, Ciências e Letras de Rio Claro, pelo Prof. João Dias Silveira, catedrático de Geografia Física, da USP e contou também com alguns professores do IBGE (LANGENBUCH, 1983). 
em seu território, IES e cursos de Geografia, além de organizações geográficas como o IBGE e o CNG, com apoio estatal.

No caso de São Paulo, despontava como centralidade econômica e também da produção geográfica em razão da criação da AGB, da USP e das demais IES e da formação em Geografia na capital e no interior, demonstrando estreita relação com o crescimento econômico da região paulista. Rio de Janeiro e São Paulo eram, portanto, duas metrópoles distintas considerando-se as relações existentes no Ensino Superior e seus cursos de Geografia.

Estas centralidades das duas metrópoles brasileiras geravam áreas de influência e uma polarização destes dois centros em relação à produção acadêmica e à própria disseminação do conhecimento geográfico no Brasil.

Segundo depoimentos existentes nos periódicos de Geografia, a influência da USP foi maior na criação e formação dos cursos do interior de São Paulo e da região Sul, principalmente do Rio Grande do Sul. Já os geógrafos do Rio de Janeiro influenciaram mais os cursos de Geografia de Minas Gerais.

Conforme diz Aziz Ab'Saber (1960), nesta época, havia vários professores de universidades paulistas formados pela USP, tais como: Joaquim Alfredo Fonseca, Maria Conceição Vicente de Carvalho, Antonio Rocha Penteado, Renato Silveira Mendes, Eli Picolo, Pasquale Petrone, Gerson Costa, Luiz Melo Rodrigues, Wanda da Mota Navarra, Odilon Nogueira de Matos, Wanda de Campos Tourinho, Hilton Federici, Augusto Titarelli, Alvanir de Figueiredo e Armen Mamigonian, entre outros.

Este processo não foi geral, sendo mais comum nas IES públicas do que nas privadas. Esta influência ocorria de diferentes formas, tanto mediante publicações, quanto por meio da ação de docentes: como professores visitantes, ministrando cursos em certos períodos, participando de comissões, apoiando a criação de novos cursos ou tornando-se diretores de departamentos ou docentes dos mesmos. 
Apesar da relevância destes primeiros cursos de Geografia no Brasil, o número de formados no Ensino Superior era incipiente. Para complementar a formação dos recém-formados, o Conselho Nacional de Geografia (CNG) desenvolvia, no Rio de Janeiro, anualmente, cursos de extensão para os interessados, provenientes de várias regiões do Brasil.

Estas atividades, no período de férias, contavam com professores associados ao CNG, em alguns casos com apoio da Sociedade Geográfica do Rio de Janeiro, e outros convidados, através de atividades como palestras, excursões de campo, visitas a instituições especializadas em Geografia, exibição de filmes, entre outras. Os participantes eram diplomados ${ }^{47}$ mediante participação no curso e uma avaliação final.

Além disso, havia os Encontros e Congressos de Geografia pelo Brasil, promovidos principalmente pela AGB e CNG, que colaboravam na formação dos geógrafos brasileiros, ainda que a participação em tais eventos se desse só com docentes e discentes de algumas instituições de Ensino Superior. Mas para alguns era a única formação geográfica que recebiam.

Em 1949, houve a primeira reunião Pan-Americana de consulta à Geografia, promovida pelo Instituto Pan-Americano de Geografia e História, e, no Brasil, pelo CNG, no qual houve a formação de um "Comitê de Didática e divulgação geográfica", que apresentou algumas recomendações, a saber:

- A ampliação de cursos de Geografia no nível primário e secundário;

- A inclusão de temas referentes à conservação dos recursos naturais;

- Currículos apropriados no Ensino Universitário para a formação de professores secundários e de geógrafos

\footnotetext{
Estas atividades davam direito aos participantes de lecionarem, como apontado pela RBG: "Esse curso, que se realizou sob patrocínio do Conselho Nacional de Geografia, foi oficializado pelo Departamento Nacional de Educação, tendo para esse efeito, o prof. Abgar Renault, diretor daquele Departamento determinado que o diploma conferido aos alunos do Curso dê direito à extensão para o $2^{\circ}$ ciclo dos registros de professores de geografia já concedidos para o $1^{\circ}$ ciclo" (IBGE, 1945, p. 347).
} 
profissionais, para cada caso de tipo de habilitação (IBGE, 1949).

Sendo assim, o perfil do bacharel e do licenciado era discutido desde a existência dos primeiros cursos de Geografia.

Estas atividades para o aperfeiçoamento de professores continuaram nos anos 1960, promovidas pelo CNG; em 1963, por exemplo, participaram 43 professores ${ }^{48}$ de todo Brasil.

Comparando-se ao ano de 1965, o mesmo curso parece ser mais direcionado, com menos conteúdo político. Em 1963, por exemplo, havia temáticas sobre Teoria e Metodologia de Geografia, Geografia Física e Humana, Geografia Regional e Geral etc., ministrado pelo Prof. Pedro Geiger, assim como Geografia Agrária, por Orlando Valverde, incluindo assuntos como reforma agrária. Em 1965, conforme relato a seguir:

O curso de Férias para Aperfeiçoamento de Professores de Geografia do Curso Secundário (CAGE) vai se restringir, no ano de 1965; à análise e aplicação dos temas geográficos que cada mapa do Atlas Geográfico Escolar (AGE) proporciona. [...] Assim treinado, pode finalmente 0 professor dirigir o interesse do seu aluno, tornando de fato a Geografia uma disciplina educativa no mais amplo sentido, como preceitua a Lei de Diretrizes e Bases de Educação Nacional (IBGE, 1965, p. 175-176).

Esta situação demonstra que, nos anos 1960, a intervenção do governo se fez mais presente nas políticas de Ensino Superior, definindo um novo período para os cursos de Geografia. Este período inicia-se com a Lei de Diretrizes e Bases (LDB 4024/61), que definiu as políticas de Ensino Superior e conferiu ao Conselho Federal de Educação (CFE) a definição dos currículos mínimos para o Ensino Superior.

Outro evento importante, após 1960, é a chegada do regime militar no Brasil (1964-1985), intensificando-se com a Lei $n^{\circ}$ 5540/68 (BRASIL, 1968) sobre normas do Ensino Superior, através de uma gestão autoritária com medidas restritivas às IES. Estas resultaram em

48 Segundo a notícia divulgada pelo IBGE (1963, p. 139): "A estes cursos têm acorrido professores do curso secundário, de vários colégios e ginásios dos estados da Federação, o que bem mostra sua utilidade para os professores do interior do país". Tivemos professores dos seguintes estados: AM (1), PA (3), PI (1), CE (2), PB (2), PE (1), BA (2), MG (5), ES (1), RJ (8), GB (15), SC (1), RS (2). 
perseguições políticas a docentes e discentes, demissões de reitores e diretores, manipulações políticas diretas em algumas IES, intervenção direta do governo federal, impedimento de experiências mais liberais no ensino. Neste período passamos a conviver basicamente com os seguintes cursos com habilitação para Geografia:

- Bacharelado, geralmente nas IES públicas;

- Licenciatura em variados tipos de IES;

- Formação de professores em Estudo Sociais, com formação geralmente em dois anos, denominada "licenciatura curta", que habilitava para os anos finais do Ensino Fundamental (antigo Ginasial $/ 1^{\circ} \mathrm{Grau}$ ). A formação em Estudos Sociais habilitava em História, Geografia e Organização Social e Política Brasileira;

- Estudos Sociais, acrescido de disciplinas de formação em Geografia, com habilitação plena, geralmente em mais dois anos, que habilitava a lecionar Geografia nos anos que correspondem atualmente ao Ensino Médio (antigo Colegial $\left./ 2^{\circ} \mathrm{Grau}\right)$.

A novidade do período é o curso de Estudos Sociais. Em outubro de 1964, o Conselho Federal cria cursos de formação de professores, com habilitação para várias disciplinas, denominado de polivalentes, em três anos, surgindo, entre outros, Estudos Sociais.

Em 1972, Estudos Sociais passa a ter apenas 1200 horas, denominada licenciatura curta. Neste novo currículo mínimo para Estudos Sociais (Resolução CFE no 8, de 9/8/1972), foram definidas as seguintes disciplinas: de História (do Brasil, Antiga, Medieval, Moderna e Contemporânea), de Geografia (Humana e do Brasil), Fundamentos da Ciência Social, Organização Social e Política do Brasil, Filosofia, Educação Moral e Cívica, Teoria Geral do Estado e Educação Física.

Uma nova ideologia permeava a criação dos cursos e disciplinas, caso de Educação Moral e Cívica, as quais serviam para corroborar o discurso nacionalista e o ideário de civismo, amor à pátria, no qual estava 
embutida a integração nacional. A maioria das licenciaturas curtas estava nas IES privadas, mas também em algumas municipais e até federais, caso da licenciatura no Acre.

Nas IES públicas, principalmente federais e estaduais, havia muitos cursos específicos de Geografia com duas habilitações- de bacharelado e licenciatura, sendo que, no caso de licenciatura, geralmente tratava-se do bacharelado acrescido de disciplinas pedagógicas.

Exemplifica-se com o caso da USP, na qual, em 1962, houve a criação do Departamento de Educação e, em 1969, da Faculdade de Educação ${ }^{49}$, isolando a formação pedagógica, pois anteriormente todas as licenciaturas estavam vinculadas à Faculdade de Filosofia, Ciências e Letras, inclusive formação de professores das áreas de exatas.

Segundo Cunha (2007b), a concepção das Faculdades de Ciências e Letras como integradora da Universidade, sobretudo das licenciaturas, já estava desgastada na década de 1960, pois havia disciplinas duplicadas nos departamentos e nos institutos e também havia o interesse dos pedagogos de criarem as Faculdades de Educação. Conforme relata o pesquisador:

A fragmentação das faculdades de Filosofia resultou da ação dos pedagogos do Conselho Federal de Educação, interessados na autonomização de sua atividade no âmbito das universidades. [...] convergiram, decerto, com os de outras seções que aspiravam transformarem-se em institutos (CUNHA, 2007b, p. 78).

As transformações na política brasileira, sobretudo nos governos militares, conduziram a mudanças na Geografia brasileira. Em 1967, por exemplo, o IBGE foi transformado em fundação e incorporado ao Ministério de Planejamento, levando-o a um maior distanciamento da produção geográfica das IES.

49 A Lei $n^{\circ} 5540 / 68$ definiu que formação de professores estaria vinculada à Faculdade de Educação, modelo que foi inspirado no Brasil a partir da Universidade de Brasília em 1960 (PIMENTEL, 2010), sendo que, nas IES federais onde os cursos de licenciatura estavam vinculados às Faculdades de Filosofia, Ciências e Letras passaram a ser relacionados à Faculdade de Educação. 
Por outro lado, o planejamento ganhava destaque, com a estatística tornando-se fundamental na produção do IBGE e, principalmente, nos cursos que formavam bacharéis há esta aproximação com a leitura geográfica mediante técnicas estatísticas e por modelos matemáticos, conhecida como Geografia Teórico-Quantitativa ou Teorética.

Ainda em 1967, a Revista Brasileira de Geografia (RBG) passou a tratar de temas relativos a outros países do mundo, mantendo-se, assim, até 1976, situação que aponta o controle dos governos militares em relação às publicações geográficas da RBG.

Além disso, no final dos anos 1960, os cursos de Geografia das IES federais passaram a ser parte dos Institutos de Geociências ou similares e não mais das Faculdades de Filosofia. Isto mostra o interesse do governo em torná-los mais técnicos e mais distantes de discussões políticas.

$\mathrm{Na}$ USP, por ser estadual, deliberou-se que a Geografia permanecesse na Faculdade de Filosofia, Letras e Ciências Humanas, mas muitos cursos pelo Brasil estiveram atrelados a Institutos de Geociências ou similares e ainda hoje estão inseridos nestes Institutos ou Departamentos.

Entre os anos 1960-70, há uma expansão dos cursos de Geografia, segundo Monteiro (1980), com apoio de professores da USP ${ }^{50}$ :

Aqueles mais experientes foram solicitados para implantar Departamentos de Geografia em outros Estados (J. D da Silveira, em Sta. Catarina) ou mesmo neles colaborar (A. Ab'Sáber, no Rio Grande do Sul). Durante a administração Jânio Quadros, o governo do Estado implantou vários institutos isolados no interior do Estado, nos quais se encontravam nada menos do que três cursos de Geografia (Rio Claro, Presidente Prudente e Franca). [...] Os recursos distribuídos, às vezes, fartamente na esfera desses novos centros, passaram a minguar na USP, tendo havido mesmo um período de ressentimento e rivalidade aberta entre a célula mater e os novos organismo (MONTEIRO, 1980, p. 24).

50 Langenbuch (1983) reforça esta afirmação dizendo que em Rio Claro o curso de Geografia contou com apoio de José Ribeiro de Araújo Filho, Dirceu Lino de Mattos, Ary França, Aziz Ab'Saber, além de João Dias Silveira, professor da USP de Geografia Física, que foi o fundador e diretor da Faculdade. 
Apesar dos cursos de Geografia estarem em sua maioria nas capitais e nas grandes cidades, havia um processo de interiorização destes no território brasileiro, mais comum no Sul-Sudeste e em Pernambuco. Este foi o caso do curso de Uberlândia, em Minas Gerais, sobre o qual Rita de Cássia Anselmo ${ }^{51}$ e Junia Knychala $(2009$, p. 7) transcorreram:

Esse curso tendo sido criado em 1971 por professores advindos das universidades paulistas e cariocas expressa, em grande parte, o amálgama das geografias produzidas no país, uma vez que aqui se supõe que eles trouxeram consigo as orientações metodológicas aprendidas em suas formações originais.

Esta informação é corroborada por Oswaldo Bueno Amorim Filho ${ }^{52}$, que em depoimento disse:

A Geografia mineira no início era muito caudatária do Rio de Janeiro, principalmente do IBGE e da UFRJ. No meu tempo de estudante é que começou a se abrir relacionamento com a USP e logo em seguida com a UNESP que teve crescimento grande naquele período [...] engraçado, mas a geografia mineira sempre teve uma influência muito grande da escola francesa e da escola alemã. A ponto de nós termos um acordo com o Ministério da Educação da França (REVISTA GEOSUL, 2005, p. 204).

Após 1978, embora não houvesse formalmente a abertura política ${ }^{53}$ no Brasil, já havia prenúncio desta condição. Transcorre um período de transição nas políticas públicas para o Ensino Superior, mantendo-se o panorama dos cursos de Geografia e Estudos Sociais já expostos anteriormente.

Monteiro (1980) apontava que as condições da formação de professores em Geografia nos anos 70 tornavam-se mais precárias, por causa do vestibular pouco seletivo e devido à formação em Estudos

51 É docente da Universidade de Uberlândia, pesquisadora de cursos de Geografia em MG.

52 Estudou graduação entre 1967-70, na UFMG. Professor titular aposentado da UFMG e docente da Pós-Graduação da PUC-MG onde leciona "Teoria da Geografia" e "Evolução do Pensamento Geográfico".

53 Em 1979, houve a Lei de Anistia, aprovada pelo Congresso no governo do general João Baptista Figueiredo, que possibilitou que intelectuais e outros pessoas, exiladas, pudessem voltar ao Brasil. 
Sociais, com redução de carga horária em Geografia e uma precarização na formação mediante a habilitação pelas licenciaturas curtas.

Portanto, a solução que o governo deu para a necessidade de formação de professores neste período foi, principalmente, a formação de professores "polivalentes" em Estudos Sociais.

Concomitante a este processo da existência de diversificados tipos de formação de professores em Geografia, com licenciaturas curta e plena, um grupo de consultores geógrafos, no período de 1981 a 1984, subsidiou a Secretaria de Educação Superior (SESu/MEC) em relação à elaboração de um diagnóstico com proposições para o curso de Geografia no Ensino Superior (AGB, 1986).

Neste diagnóstico, o grupo indicava a deficiência na formação oferecida por Estudos Sociais, assim como a inadequação dos currículos mínimos para a Geografia.

Segundo o grupo, os cursos de Geografia deveriam formar geógrafos para a pesquisa, para as práticas e reflexões de questões teóricas, bem como para tornarem-se professores. Por isso, propunham a manutenção de um curso único, com a opção da escolha pela licenciatura e bacharelado, situação à qual se opunha a AGB da época, conforme expresso na Revista Terra Livre num editorial ${ }^{54}$ :

A formação do Geógrafo não deve estar sujeita a adjetivações apriorísticas e portanto, todos os Cursos de Geografia devem formar Bacharéis, deixando para 0 profissional a liberdade de escolher sua especialização a posteriori (AGB, 1986, p. 77).

Logo, ao fim dos anos 1980, havia, ainda, a velha problemática do perfil de formação em Geografia, bem como a questão da pesquisa como inerente ou não à formação de professores. Ao mesmo tempo, os cursos começaram a se interiorizar mais no Sul-Sudeste, chegando a novos lugares.

54 A Revista Terra Livre é uma publicação da AGB e surge nesta época, em 1986. Outro evento que ocorre no final deste período é o $1^{\circ}$ Encontro Nacional de Ensino de Geografia "Fala professor", promovido pela AGB, que ocorre com a participação de professores do Ensino Básico. 
A hegemonia paulista e a centralidade da cidade de São Paulo, como territórios de produção de conhecimento, que concentram e difundem informações, nas décadas de $1970-80$ se amplia. Conforme se observa no mapa 3, em 1971, havia maior concentração de IES no estado de SP (233 ao todo), seguidos do estado do Rio Janeiro e Minas Gerais.

Já em 1988, esta concentração se amplia ainda mais em São Paulo com 537 IES, chegando a ter duas vezes e meio a mais do que no Rio de Janeiro e três vezes mais do que o número de IES em Minas Gerais.

O Rio de Janeiro diminui sua importância política e econômica com a transferência da capital brasileira para Brasília em 1960 e a posterior extinção do estado de Guanabara em 1975.

Considerando a expansão dos cursos de Geografia, conforme mapa 4, no final dos anos 80 , há uma distinção clara entre o número de cursos de licenciatura e de bacharelado, com aumento das licenciaturas. Isto ocorria devido à demanda pela formação de professores, isso sem se considerar o aumento das licenciaturas curtas em Estudos Sociais que também habilitavam à formação de professores para o Ensino Fundamental de $5^{\mathrm{a}}$ a $8^{\mathrm{a}}$ séries (antigo $1^{\circ} \mathrm{Grau}$ ).

São Paulo despontava com o maior número de cursos, seguido de Minas Gerais, Rio de Janeiro, Goiás, Paraná e Pernambuco. No Norte e Nordeste, até 1989, o número de licenciaturas em Geografia era pequeno, exceção feita a Pernambuco e Ceará ${ }^{55}$. Na maior parte destes estados, havia apenas de um a três cursos, em sua maioria nas capitais.

Em Roraima, Amapá e Tocantins, não havia qualquer curso de Geografia. Roraima foi transformado em estado membro com a constituição de 1988, assim como o Amapá, que se transformou, efetivamente, em Estado em 1991. Já o Tocantins não existia como estado antes de 1988, tendo sido desmembrado do estado de Goiás.

55 No Ceará, o curso de Geografia na Universidade Estadual do Ceará (UECE), em Fortaleza, é o mais antigo do estado, iniciado em 1947; em 1968, a UECE criou o curso em Limoeiro do Norte. Na Universidade Federal do Ceará (UFC), em Fortaleza, em 1963; na Universidade Regional do Cariri (URCA), no Crato, em 1959. Portanto, a interiorização dos cursos no estado é antiga. 


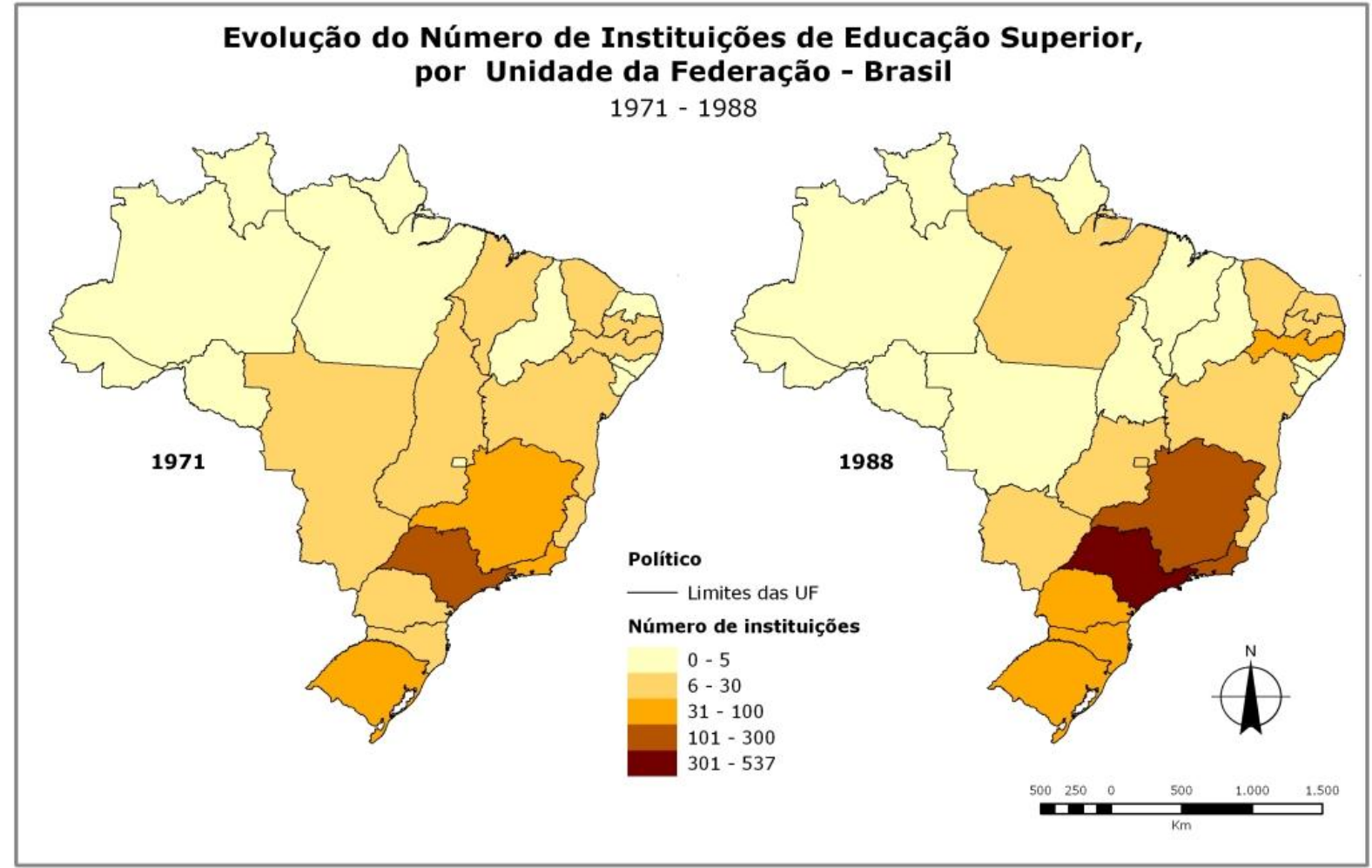

Mapa 3- Fonte: Séries Históricas, IBGE, 1972 e 1990.

Elaborado por Maurício Yamada e Vivian Fiori, 2010.

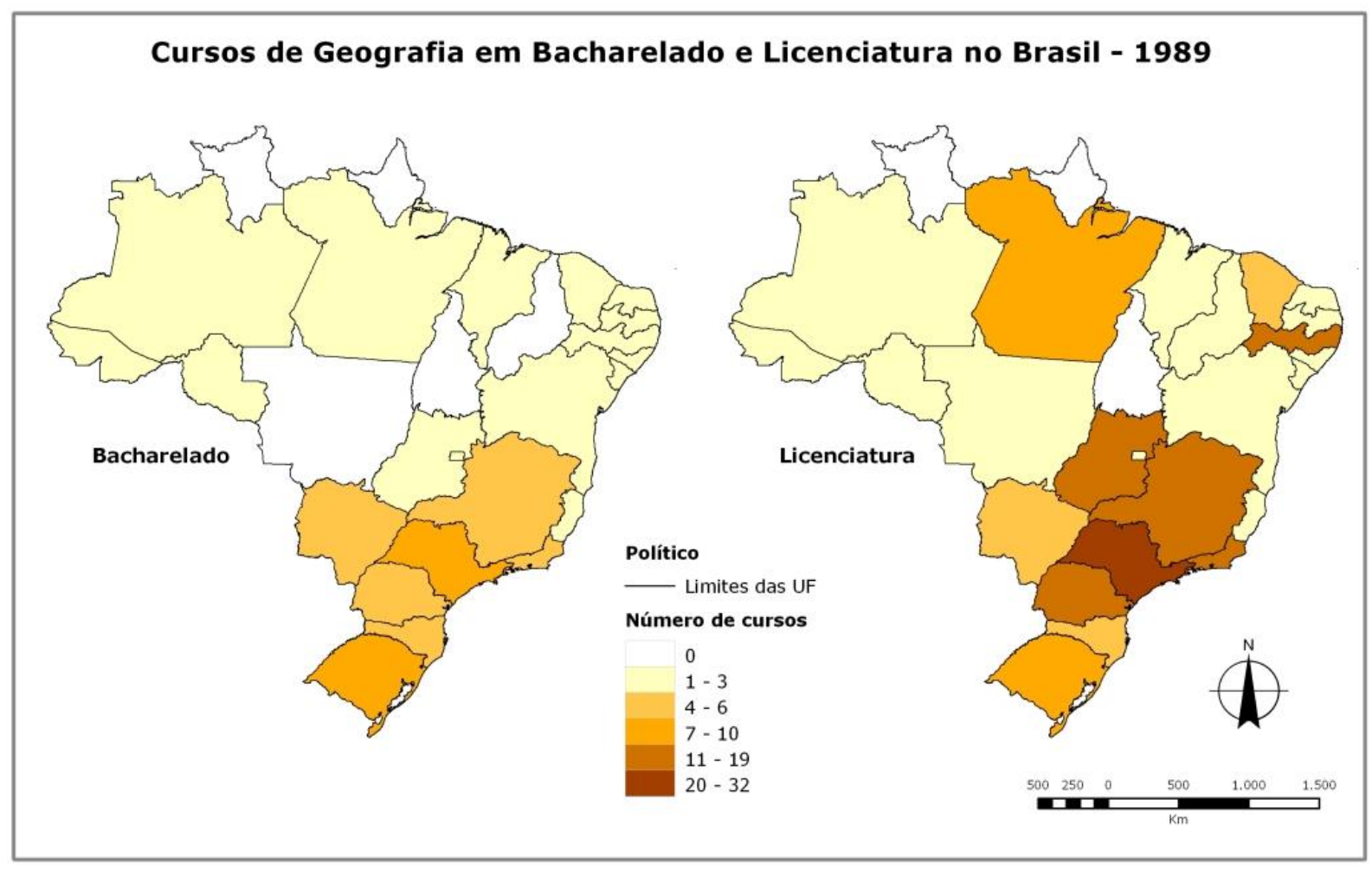

Mapa 4- Fonte: MEC, 2009. Dados organizados por Vivian Fiori. Elaborado por Maurício Yamada e Vivian Fiori, 2010. 
Esta situação de ocupação incipiente, com pouca urbanização, nestes recentes estados explica a falta ou o pequeno número de cursos de Geografia naquela época, geralmente apenas de licenciaturas.

Em Pernambuco havia uma situação peculiar nos anos 80 , quando algumas licenciaturas em Geografia foram criadas por instituições municipais ${ }^{56}$, todos noturnos, em municípios como Arcoverde, Belém do São Francisco, Palmares, Araripina, Belo Jardim e Serra Talhada, localizados no Agreste e Sertão de Pernambuco.

De um lado foi uma importante forma de expansão das licenciaturas pelo interior nordestino, atendendo a necessidade de formação de professores, em regiões de pequenos municípios, onde havia carência de IES e de licenciaturas. De outro, embora sejam considerados públicos, os cursos municipais destas IES são pagos, com mensalidades, constituindose em uma peculiaridade no Brasil.

Nesta época da existência de Estudos Sociais, à medida que algumas IES privadas buscavam criar a habilitação específica de licenciatura em Geografia, havia baixa procura, pois o interesse maior era por Estudos Sociais, com formação de dois anos, pois legalmente habilitavam ao ensino de Geografia, História, Organização Social e Política do Brasil e Educação Moral e Cívica.

De um lado faltavam professores de Geografia, de outro, os futuros docentes $^{57}$ buscavam cursos mais rápidos. Esta situação vai ser

56 Foi o caso das seguintes IES e municípios: Centro de Ensino Superior de Arcoverde (CESA), em Arcoverde (1980); Centro de Ensino Superior do Vale São Francisco (CESVASF), em Belém do São Francisco (1985), que criou um curso inicialmente de Estudos Sociais, desmembrado em 1985 em História e Geografia; Faculdade de Formação de Professores da Mata Sul (FAMASUL), em Palmares (1984); Faculdade de Formação de Professores de Araripina (FAFOPA), em Araripina (1987); Faculdade de Formação de Professores de Belo Jardim (FABEJA), em Belo Jardim (1985); Faculdade de Formação de Professores de Serra Talhada (FAFOPST), em Serra Talhada (1983).

Cito minha experiência por 10 anos como docente da Universidade Cruzeiro do Sul, em São Paulo, no curso de Estudos Sociais com habilitação plena em História ou Geografia. O curso em seus dois primeiros anos era de licenciatura curta e após mais dois anos havia a habilitação plena. O curso começava geralmente com 80 alunos em Estudos Sociais e, no terceiro e quarto anos, havia geralmente de 10 a 15 alunos na Geografia, formado em sua maioria por estudantes trabalhadores. 
modificada após 1996, quando o governo federal cria novas legislações, que implicam no fim dos Estudos Sociais, o que em algumas IES privadas redundou na criação do curso específico em Geografia.

\subsection{O período de 1996-2010: as políticas públicas e as características dos cursos de Geografia}

A partir das mudanças políticas no Brasil, introduzidas com a promulgação da Constituição de 1988, a educação em geral passou por contínuas transformações, que se tornaram mais intensas a partir de 1996, com a promulgação da Lei de Diretrizes e Bases da Educação Nacional (LDBEN) no 9394 (BRASIL, 1996b), das legislações específicas para as licenciaturas em 2001, assim como com a existência da política neoliberal e a estabilidade política e financeira do período que permitiram um avanço do Ensino Superior no Brasil.

Isto resultou na expansão dos cursos de Geografia no território brasileiro, sobretudo de licenciatura, em situações bastante diferentes do que tínhamos até então, com um novo processo de interiorização. De comum com os períodos anteriores, a antiga discussão entre perfil de licenciatura e bacharelado, bem com os problemas na formação e na falta de professores de Geografia.

Em relação às políticas institucionais do governo federal para o Ensino Superior e especificamente para a Geografia, são promulgadas, neste período, as Diretrizes Curriculares Nacionais de Geografia (MEC, 2001c), e os alunos destes cursos participam do sistema de avaliação do governo federal em 2003, 2005 e 2008.

Outro evento importante para a ampliação do Ensino Superior no Brasil foi o Plano Real ${ }^{58}$ instituído em 1994, que permitiu a estabilização econômica brasileira, ampliando as possibilidades de as IES privadas de

58 O Plano Real foi um plano econômico lançado em 1994 com intuito de conter a hiperinflação e estabilização econômica, com uma reforma monetária e a criação de uma nova moeda, o real. Com a estabilização macroeconômica e política, foi possível uma retomada do crescimento econômico, sobretudo a partir do século XXI. 
planejarem-se e criarem novos cursos, assim como de os governos federais e estaduais expandissem suas IES pelo interior em novos campi, utilizando-se da lógica da expansão como forma de criar acesso às classes populares ao Ensino Superior, discurso comum do período.

A existência do Plano Real se coadunou com uma política mais ampla neste período, caso da privatização de setores essenciais da economia, como transporte e energia, assim como com o incentivo à privatização do Ensino Superior, com a defesa da necessidade da ampliação do número de vagas, devido ao aumento do número de estudantes no Ensino Médio. Este processo foi facilitado mediante a autorização e credenciamento de novas IES e de cursos, sendo renovados periodicamente (LIMA; CONTEL, 2011).

Segundo Luiz Antonio Cunha (2003), esta política buscava uma mudança administrativa, almejando a diminuição da capacidade ociosa das IES com abertura de cursos noturnos, que vinculasse a autonomia universitária a avaliações e produtividade das IES. Ou seja, de um lado incentiva-se a expansão; de outro, o Estado torna-se o avaliador do processo.

Desde a nova Constituição brasileira de $1988^{59}$, evento importante também para o Ensino Superior, alguns parâmetros foram definidos para a educação brasileira. Assim, conforme artigo 206, o ensino deve ter: "[...] pluralismo de idéias e de concepções pedagógicas, e coexistência de instituições públicas e privadas de ensino" (BRASIL, 1988).

Em seu art. 207, específico sobre universidades ${ }^{60}$, tem-se que "As universidades gozam de autonomia didático-científica, administrativa e de gestão financeira e patrimonial, e obedecerão ao princípio de indissociabilidade entre ensino, pesquisa e extensão".

Estas instituições podem ser públicas ou privadas, sendo que as privadas podem ser particulares no sentido estrito, comunitárias (Redação

${ }^{59}$ Constituição Federal. Seção I. I - DA EDUCAÇÃo - artigos 205 a 214 (BRASIL, 1988).

60 A concepção do que seria Universidade historicamente foi mudando ao longo do tempo. 
dada pela Lei no 12020, de 2009) ou confessionais, com orientação confessional e ideológica específicas.

Diversificaram-se os tipos de Instituições ${ }^{61}$ de Ensino Superior; assim, passa a haver, ao lado das Universidades, os Centros Universitários, as Faculdades Isoladas e Integradas, bem como os Centros de Educação Tecnológicos.

A distinção que se faz entre Centros Universitários e Universidades tem relação com a pesquisa, visto que cabe às universidades o papel principal de produtora de pesquisa e extensão segundo as normas brasileiras.

Sobre a pluralidade das IES brasileiras, Eunice R. Durham disse:

[...] o fato de que as Universidades, tanto no Brasil como em todos os demais países, constituem um tipo específico de instituição que coexiste, creio que necessariamente, com outros tipos de estabelecimentos de Ensino Superior, [...] é que não se dá a devida consideração à profunda diversidade existente no próprio conjunto das Universidades brasileiras, que integra, além das públicas, instituições privadas muito diversas, incluindo as comunitárias e as lucrativas, a maioria das quais, aliás, não preenche os requisitos constitucionais que definem as Universidades porque não associa o ensino à pesquisa (DURHAM, 2006, p. 83).

De fato, só a definição do tipo de IES no Brasil requer um maior aprofundamento sobre como é administrada esta instituição, já que há universidades privadas e públicas, e estas podem municipais, estaduais e federais, contendo algumas especificidades.

Neste período, observando-se as características de formação de professores em Geografia, conforme gráfico 1 (2000-2009), percebe-se um crescimento no número de licenciaturas em Geografia.

$\mathrm{Na}$ categoria Universidade, o incremento foi de 30,3\%, mas o crescimento maior se verificou nas Faculdades/Institutos com $80 \%$, instituições que são principalmente privadas e municipais.

No caso das Universidades, verifica-se que, de 2001 a 2004, houve um incremento maior do número das licenciaturas, da ordem de 55,1\%.

61 Esta classificação foi usada a partir do Decreto-Lei no 2306/97 (BRASIL, 1997), posteriormente revogado pelo Decreto no 5773/2006, classificando-as como Faculdades, Centros Universitários e Universidades. 
Já o maior decréscimo se deu entre 2008 e 2009, em decorrência principalmente do fechamento de cursos em IES públicas que os haviam aberto em pequenos municípios do interior, mas que não se constituíam em campus formal.

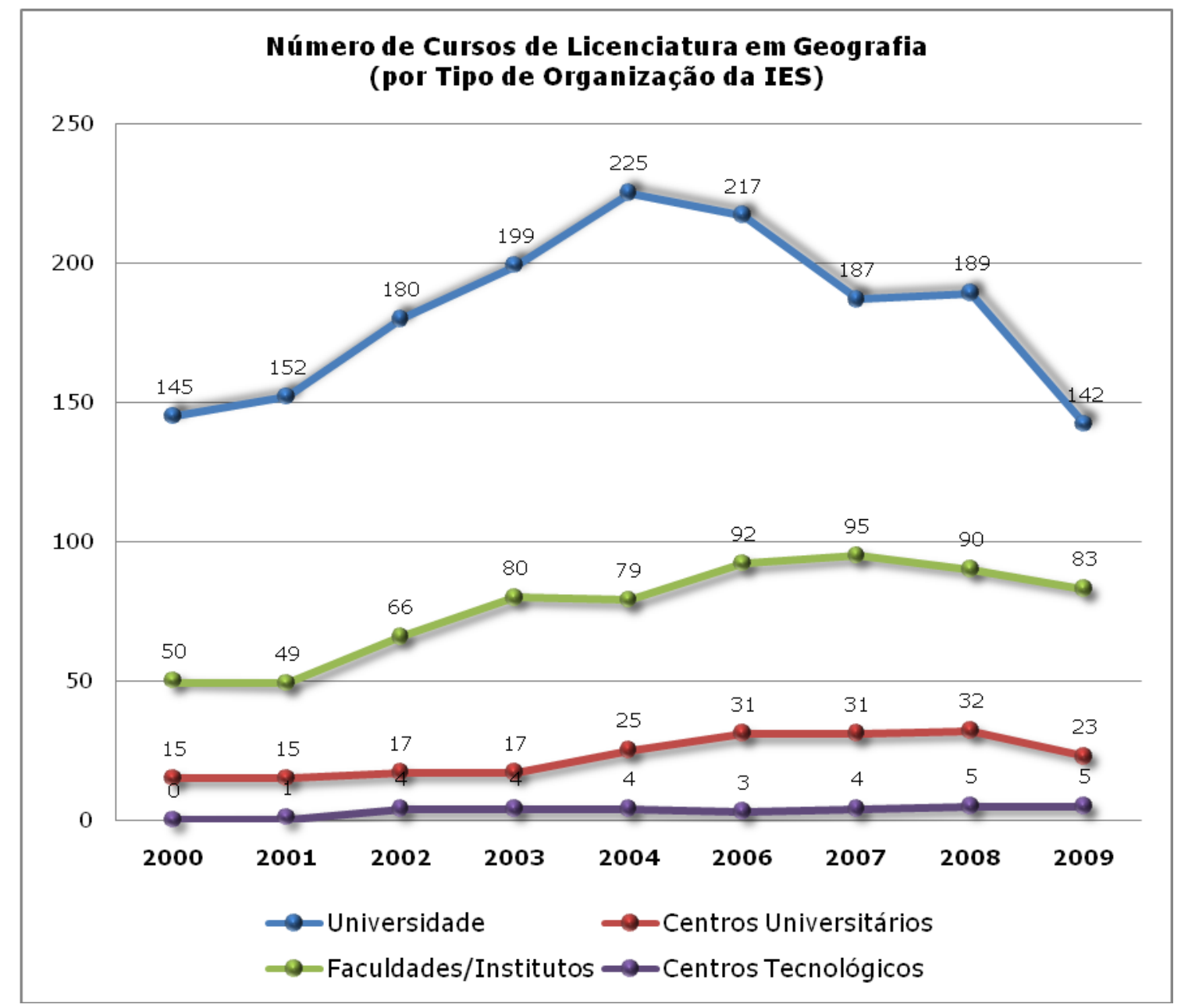

Gráfico 1 - Fonte: DAES/Inep, Relatórios Sinopse, de 2000 a 2008.

Elaborado por Vivian Fiori, 2009.

Contudo, considerando-se apenas o ano de 2009, as Universidades detinham um total de $56,1 \%$ dos cursos superiores do Brasil, enquanto os Centros Universitários, apenas 9,1\%. Mas estes nas universidades ocorrem principalmente em instituições públicas, enquanto que os das faculdades e institutos, que em 2009 perfaziam 32,9\% do total; tem lugar principalmente em instituições privadas.

De um lado, há o fato de que algumas IES privadas e municipais, que tinham os antigos cursos de Estudos Sociais, passaram a oferecer os cursos de licenciatura específica em Geografia; de outro, há um aumento na criação de Universidades tanto públicas como privadas. 
No caso das privadas, ocorre a transformação de Faculdades Integradas em Universidades, processo comum neste período, assim como a criação de novas IES estaduais e federais, como no caso da Universidade Federal do Tocantins, em 2000.

Há ainda disparidades existentes entre a quantidade de licenciaturas em Geografia quando se estabelecem relações entre as IES públicas e privadas. Conforme se observa, no gráfico 2, o maior número de cursos de formação de professores de Geografia, no período de 2000 a 2009, estava nas IES públicas.

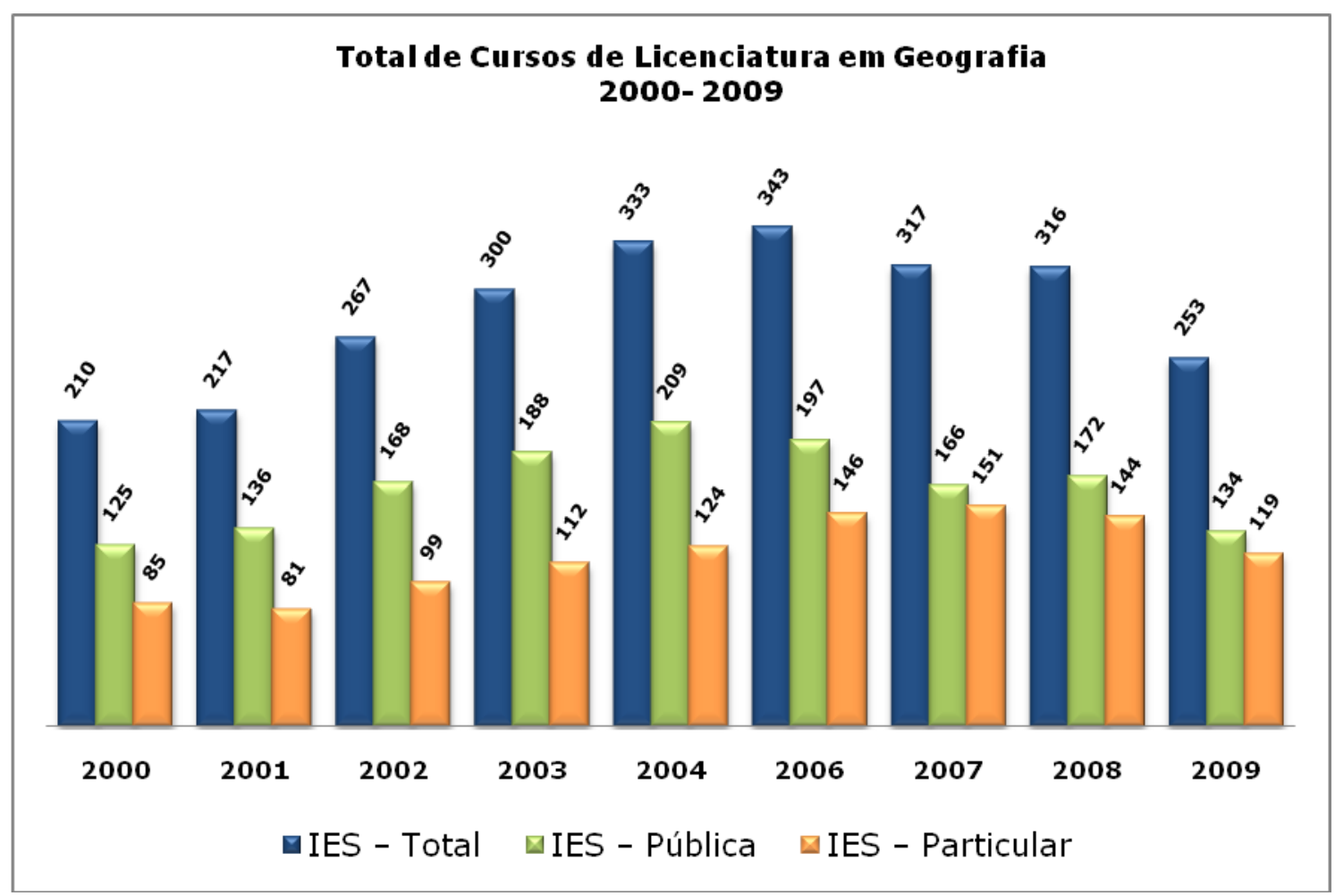

Gráfico 2- Curso por tipo de IES. Organizado por Vivian Fiori, 2009.

Fonte: DAES/Inep, Relatórios Sinopse, de 2000 a 2008.

Houve um incremento de número de cursos neste período de $50,4 \%$, sendo que o crescimento foi maior nas IES privadas $(69,4 \%)$ do que nas públicas $(37,6 \%)$, apontando uma tendência da expansão no Ensino Superior privado ${ }^{62}$.

62 Se compararmos o ano do Plano Real, em 1994, havia um total de 851 IES no Brasil, sendo $25,6 \%$ de instituições públicas e $74,7 \%$ de privadas; dez anos depois, há 2237 IES, com $10 \%$ de IES públicas e $90 \%$ privadas, ou seja, o crescimento das IES privadas foi maior neste período. Fato que foi intensificado também pelas políticas públicas federais de Educação. 
Este segmento, ainda, abarca a maioria das licenciaturas em Geografia no Brasil, já que, apesar da demanda pela formação de professores, os cursos de licenciatura não representam a área de maior interesse em algumas IES privadas.

Em 2009, houve uma diminuição da ordem de 19,9\% das licenciaturas em Geografia, decorrente da crise econômica deste ano, de que resultou o fechamento de alguns cursos em IES privadas, assim como o final de algumas licenciaturas promovidas em IES públicas pelo interior da Amazônia e Nordeste. Passa a haver 253 cursos, a maioria, ainda, nas IES públicas (52.9\%).

Neste período, segundo o Conselho Nacional de Educação (Parecer CNE/CES 492/2001), as Instituições de Ensino Superior passaram a estruturar seus cursos de Geografia em "[...] 4 níveis de formação (de bacharéis, aplicada-profissional, de docentes e de pesquisadores) e devem indicar sua organização modular, por créditos ou seriada" (MEC, 2001c).

O que ocorre na maioria absoluta dos casos que tem mais de uma habilitação é a existência de cursos de bacharelado e de licenciatura como no passado nos quais se misturam os perfis de formação.

Em relação à licenciatura, para sua criação, devem ser consideradas, também, as novas diretrizes de formação de professor (CNE 009/2001 $1^{63}$ e Parecer CNE/CP 28/200164), que não são específicas para a formação em Geografia, mas constituem-se na legislação própria para a formação de professores e definem a terminalidade particular para a licenciatura em relação ao bacharelado.

63 Parecer CNE/CP 009/2001, que trata das Diretrizes Curriculares Nacionais para a formação de professores da Educação Básica, em nível superior, curso de licenciatura, de graduação plena (MEC, 2001a).

64 Parecer CNE/CP 28/2001, que estabelece a duração e a carga horária dos cursos de formação de professores da Educação Básica, em nível superior, curso de licenciatura, de graduação plena, assim como a Resolução CNE/CP 2/2002, que institui a duração e a carga horária dos cursos de licenciatura, de formação de professores da Educação Básica. Segundo este parecer, fica estabelecido que as matrizes curriculares dos cursos para Educação Básica terão a seguinte estrutura: Prática como Componente Curricular, Estágio Curricular Supervisionado, Conteúdos Curriculares de Natureza Científico-Cultural e, por fim, Atividades Acadêmico-Científico-Culturais, num total de 2800 horas no mínimo. 
Na prática, a questão se complexifica, pois há cursos de bacharelado, por exemplo, que se tornam licenciaturas com a complementação da carga horária com disciplinas pedagógicas. Esta situação é mais comum no Centro-Sul do país e principalmente nas IES públicas.

Todavia, esta nova legislação deu novo impulso à criação das licenciaturas, pois a formação de professores de Educação Básica que até 1996 poderia ocorrer mediante a formação em Magistério, que habilitava à formação de professores, passou, a partir da LDBEN n 9394, a ocorrer mediante a formação em curso superior, conforme artigo 62:

A formação de docentes para atuar na educação básica farse-á em nível superior, em curso de licenciatura, de graduação plena, em universidades e institutos superiores de educação, admitida, como formação mínima para o exercício do magistério na educação infantil e nas quatro primeiras séries do ensino fundamental, a oferecida em nível médio, na modalidade Normal (BRASIL, 1996b, p.22).

Então, para suprir a falta de professores com formação em Ensino Superior, muitas licenciaturas foram criadas pelo interior do país. Atualmente, conforme demonstra o gráfico 3 (2000 a 2008), o número absoluto de licenciaturas é muito maior que os de bacharelado no Brasil.

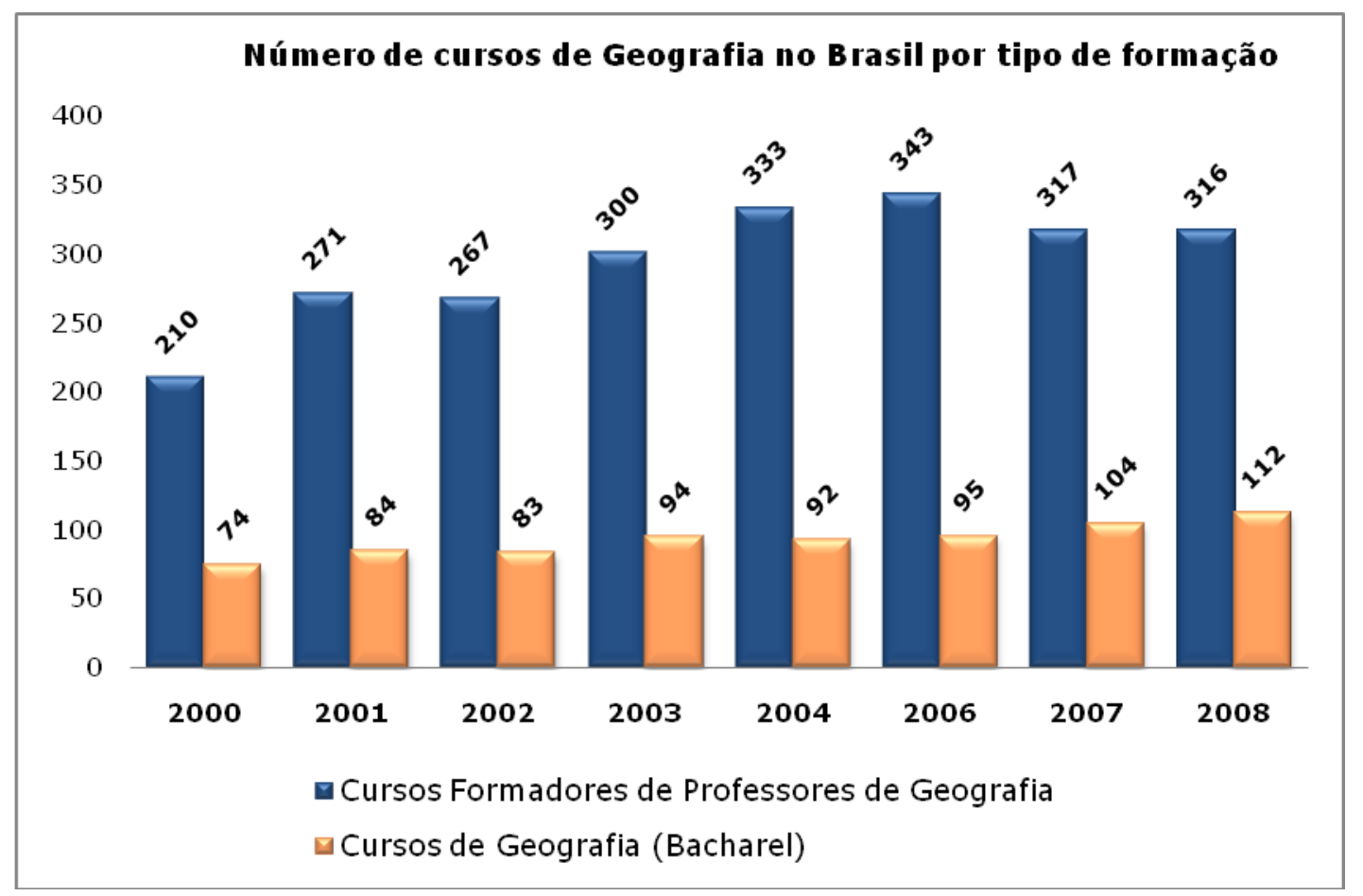

Gráfico 3- Número de Cursos de Geografia no Brasil. Organizado por Vivian Fiori, 2009. Fonte: DAES/Inep, Relatórios Sinopse de 2000 a 2008. 
Em 2008, havia 316 cursos de licenciatura, correspondendo a 73,8\% do total de cursos de Geografia. Apesar disso, no período houve crescimento de $50,4 \%$ dos cursos de licenciatura e $51,3 \%$ de bacharelado.

Em relação aos cursos de Estudos Sociais, que também formavam professores de Geografia, neste período, houve uma diminuição gradativa. Segundo pesquisa de Núria Hanglei Cacete, no caso paulista, havia:

Em 1975, no Estado de São Paulo, existiam aproximadamente 90 instituições isoladas constituídas como faculdades de filosofia, ciências e letras que mantinham cursos de formação de professores, particularmente de Geografia. Em 2002 restaram apenas 20 instituições, a maioria delas foi incorporada nos processos de fusão de instituições e os cursos de formação de professores, via de regra, foram suprimidos ou descontinuados (suspensão temporária) com a criação de outros cursos mais sensíveis à demanda de mercado [...] (CACETE, 2004, p. 27).

Em Minas Gerais, onde também havia muitos cursos de licenciatura em Estudos Sociais nas IES privadas, a situação foi semelhante a do estado de São Paulo (LEÃO, 2008).

Com a nova legislação requerendo que todos professores tenham Ensino Superior, aumenta a demanda de formação de professores de Geografia no Ensino Médio e Fundamental. Mediante dados de pesquisa do Inep (2007), verifica-se a existência de muitos professores no Brasil sem qualquer formação ou formados em outra área do conhecimento diferente daquela em que atua, conforme demonstra a tabela 1.

\begin{tabular}{|l|c|l|c|}
\hline \multicolumn{2}{|c|}{ Tabela 1- Área de formação de professores que lecionam Geografia- 2007} \\
\hline \multicolumn{1}{|c|}{ Ensino Fundamental } & Total & \multicolumn{1}{c|}{ Ensino Médio } & Total \\
\hline Geografia & 44449 & Geografia & 27954 \\
\hline Pedagogia/Educação & 20837 & História & 5400 \\
\hline História & 15526 & Pedagogia/Educação & 3517 \\
\hline Estudos Sociais & 4979 & Estudos Sociais & 1865 \\
\hline Letras/Língua Portuguesa & 4062 & Ciências Sociais/Sociologia & 1215 \\
\hline Ciências Sociais/Sociologia & 2446 & Letras/Língua Portuguesa & 998 \\
\hline Matemática & 1774 & Filosofia & 530 \\
\hline Letras/Língua Estrangeira & 1285 & Matemática & 419 \\
\hline Ciências Biológicas & 1154 & Ciências Biológicas & 277 \\
\hline Filosofia & 930 & Letras/Língua Estrangeira & 273 \\
\hline Ciências & 756 & Educação Física & 242 \\
\hline Outros Cursos & 12070 & Outros Cursos & 2846 \\
\hline TOTAL & $\mathbf{1 1 0 2 6 9}$ & & $\mathbf{4 5 5 3 6}$ \\
\hline
\end{tabular}

Fonte: Inep, 2007. Organizada por Vivian Fiori, 2010. 
Há, portanto, enorme carência de professores, situação que não é diferente nas demais licenciaturas. Esta carência é grande no interior do país, mas, mesmo nas capitais onde há maior número de licenciaturas, há um déficit de professores, motivado por baixos salários, condições de trabalho inadequadas, entre outros problemas. Em decorrência disso, nem todos os formados nos cursos de licenciatura tornam-se professores.

Por conta dessa situação e para complexificar ainda mais a questão das licenciaturas em Geografia, em janeiro de 2009, por meio do Decreto MEC n० 6755/2009 (BRASIL, 2009a), foi institucionalizada a Política Nacional de Formação de Profissionais do Magistério da Educação Básica ${ }^{65}$, cuja premissa é a preparação de professores que não tenham formação nas áreas que lecionam ou não sejam formados em qualquer área e já atuem como professores nas redes estaduais e municipais no Brasil.

Tal política se operacionaliza mediante o Plano Nacional de Formação de Professores da Educação Básica (Parfor ${ }^{66}$ ) com apoio da Fundação da Coordenação de Aperfeiçoamento de Pessoal de Nível Superior (CAPES), que estabelece as metas, monitora e institui orientações aos coordenadores e docentes bolsistas dos cursos, bem como tem a responsabilidade pela indução, fomento e avaliação do Parfor. Os cursos têm, segundo discurso do MEC, as seguintes condições:

O Parfor propõe cursos em períodos de férias e outras datas extra aula comum dos cursos já existentes. Cada estado ao aderir ao Programa define uma ou no máximo duas IES para participarem do Programa. O Plano Nacional de Formação é

65 Destaca-se ainda que a formação de Fóruns Estaduais Permanentes de Apoio à Formação Docente, com participantes de representantes de conselhos de educação, do fórum das licenciaturas das instituições superiores públicas, entre outros grupos representativos, podendo haver mais adesões (MEC, 2009a).

${ }^{66}$ O Fundo Nacional de Desenvolvimento da Educação (FNDE) é o órgão responsável pelo pagamento de bolsas dos cursos especiais presenciais de primeira e segunda licenciatura e de formação pedagógica. Em relação aos docentes, a adesão ao Plano é feita pela "Plataforma Freire", sistema on-line no qual se encontram informações sobre o Parfor e onde os docentes se cadastram para participar. A definição dos pagamentos dos professores e coordenadores é feita mediante bolsas de estudos e de pesquisa concedidas pela CAPES e pagas pelo FNDE. Só participam do Programa os cursos que já existam na IES de forma regular. 
destinado aos professores em exercício das escolas públicas estaduais e municipais sem formação adequada à LDB, oferecendo cursos superiores públicos [...] (MEC, 2009b).

Por meio deste Plano, o professor sem formação adequada à docência no Ensino Básico poderá se graduar nos cursos de $1^{\text {a }}$ Licenciatura, com carga horária de 2800 horas, mais 400 horas de estágio para professores sem graduação; de $2^{a}$ Licenciatura, com carga horária de 800 a 1200 horas para professores que atuam fora da área de formação, e de Formação Pedagógica, para bacharéis na área em que lecionam, mas sem habilitação para licenciatura.

Pretende-se com este Plano diminuir o número de professores de Geografia que não sejam formados na área específica, mas criam-se dois tipos de alunos e modalidades de cursos na mesma instituição: regulares, cujo currículo desenvolve-se ao longo do ano letivo; e do Parfor, cujas atividades ocorrem no período de férias ou finais de semana. Em princípio, porém, ambos têm a mesma matriz curricular e carga horária (exceção aos que já fizeram outras licenciaturas e são dispensados das disciplinas pedagógicas ou já fizeram bacharelado na mesma área e são dispensados das disciplinas específicas).

Conforme se observa no mapa 5, a distribuição dos cursos do Parfor é maior no Norte e Nordeste, contudo não está nestas regiões o maior número absoluto de professores não formados em Geografia, portanto a adesão ao Parfor é maior onde há mais instituições públicas, sobretudo federais e estaduais.

De qualquer forma, esta é mais uma tentativa federal de resolver o antigo problema da falta de formação de professores no Brasil, sobretudo aumentando esta formação pelo interior do país. Embora, após a nova LDBEN no 9394 (BRASIL, 1996b), tenha havido a expansão das IES pelo território nacional, ainda assim, em 1998, havia grande concentração delas em torno das capitais e na Região Concentrada. 
Municípios com Cursos de Geografia do Parfor- 2010

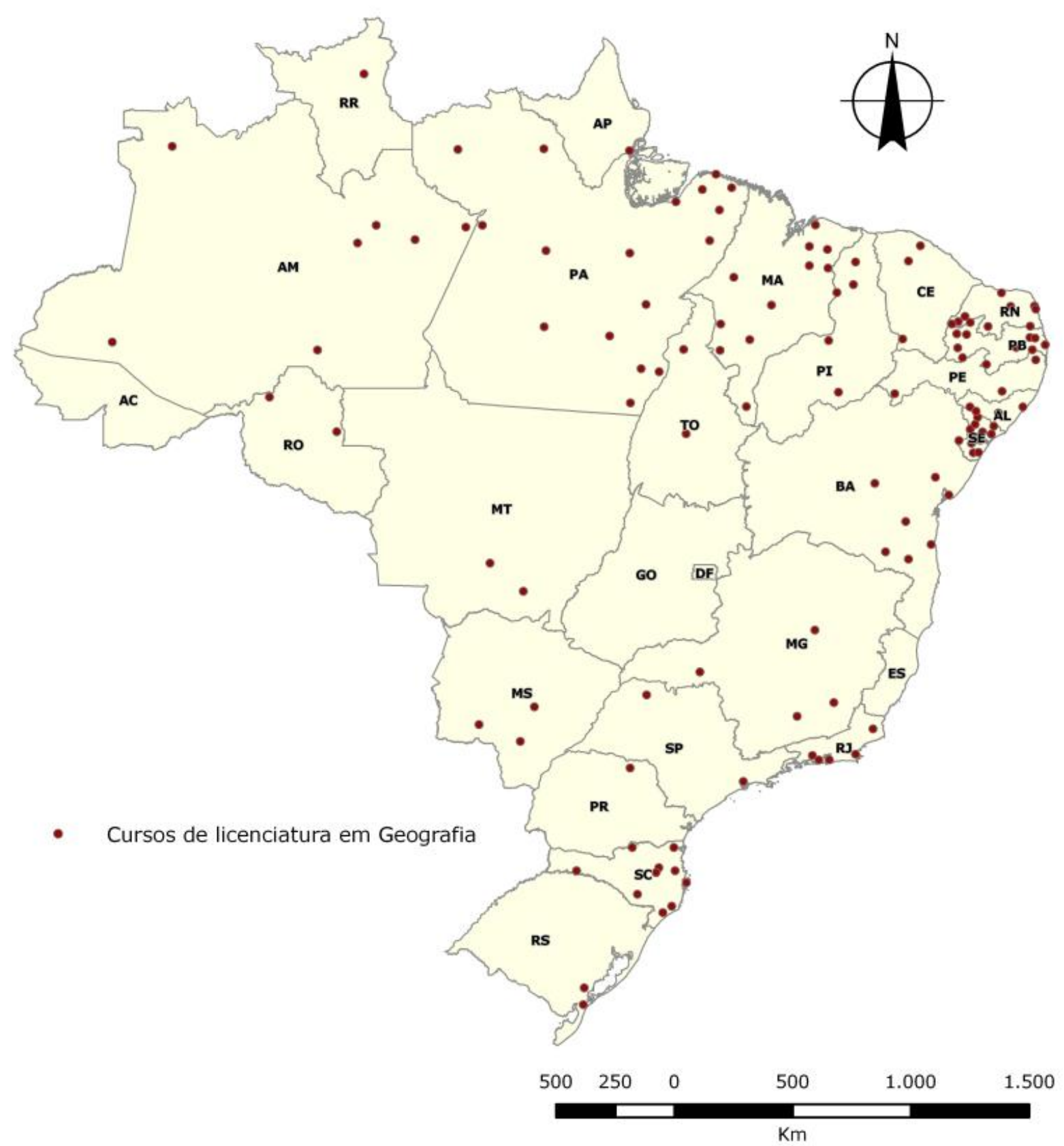

Mapa 5 - Fonte: Plataforma Freire, 2010. Organizado por Maurício Yamada, 2010.

O conceito de Região Concentrada, utilizado por Milton Santos e Ana Clara Torres Ribeiro, refere-se à região de maior densidade técnica e econômica, formada, sobretudo, pelos estados de Minas Gerais, Rio de Janeiro, São Paulo, Paraná, Santa Catarina e Rio Grande do Sul (SANTOS; SILVEIRA, 2001a).

Observando-se o mapa 6, verifica-se que, em 1998, havia uma centralidade na produção do Ensino Superior na Região Concentrada, 
principalmente em São Paulo $(33,7 \%)$ e Minas Gerais $(12,8 \%)$, que se relacionam às regiões de maior dinamismo econômico do Brasil.

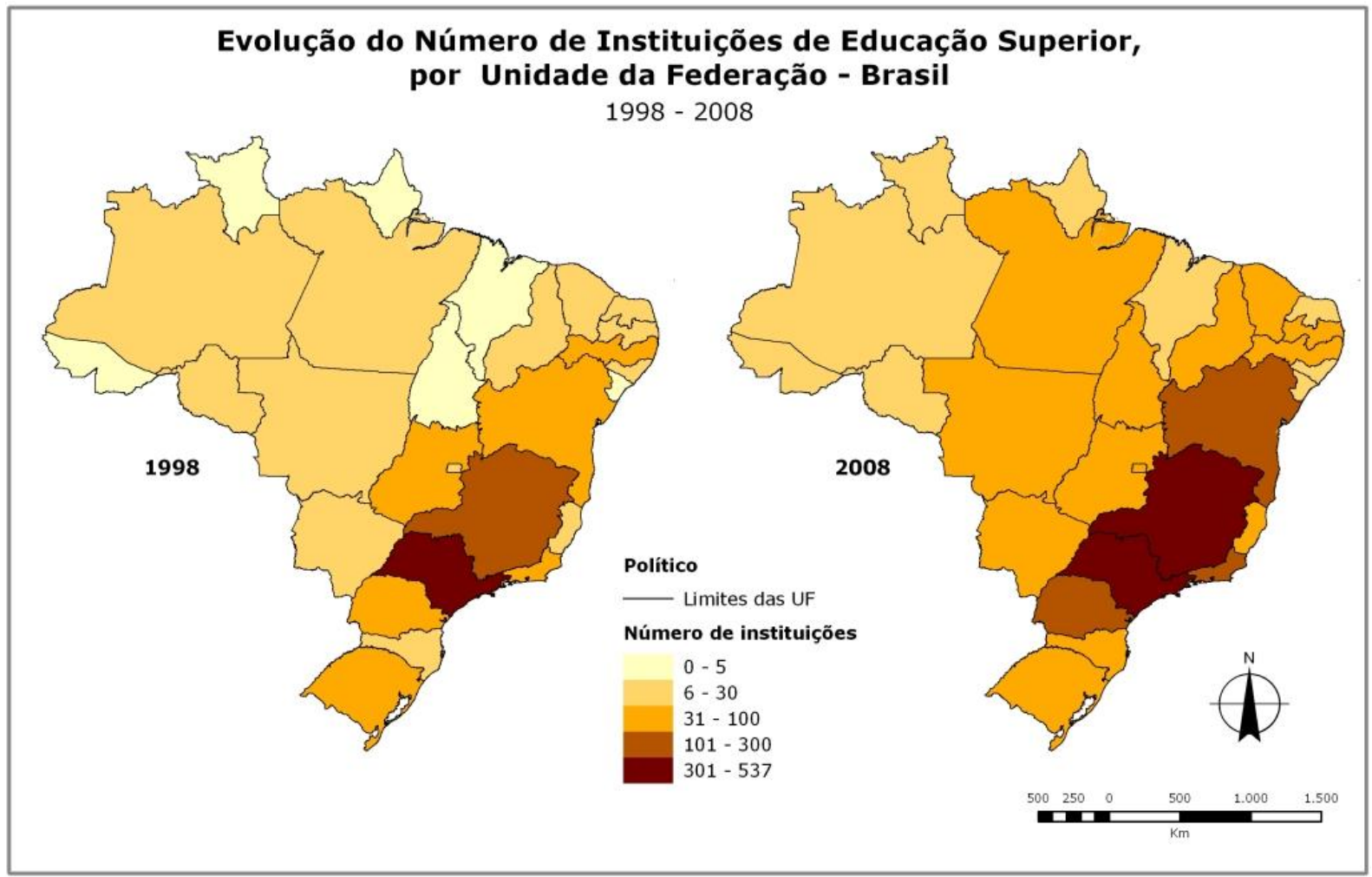

Mapa 6- Fonte: Inep, 2008. Elaborado por Vivian Fiori e Maurício Yamada, 2010.

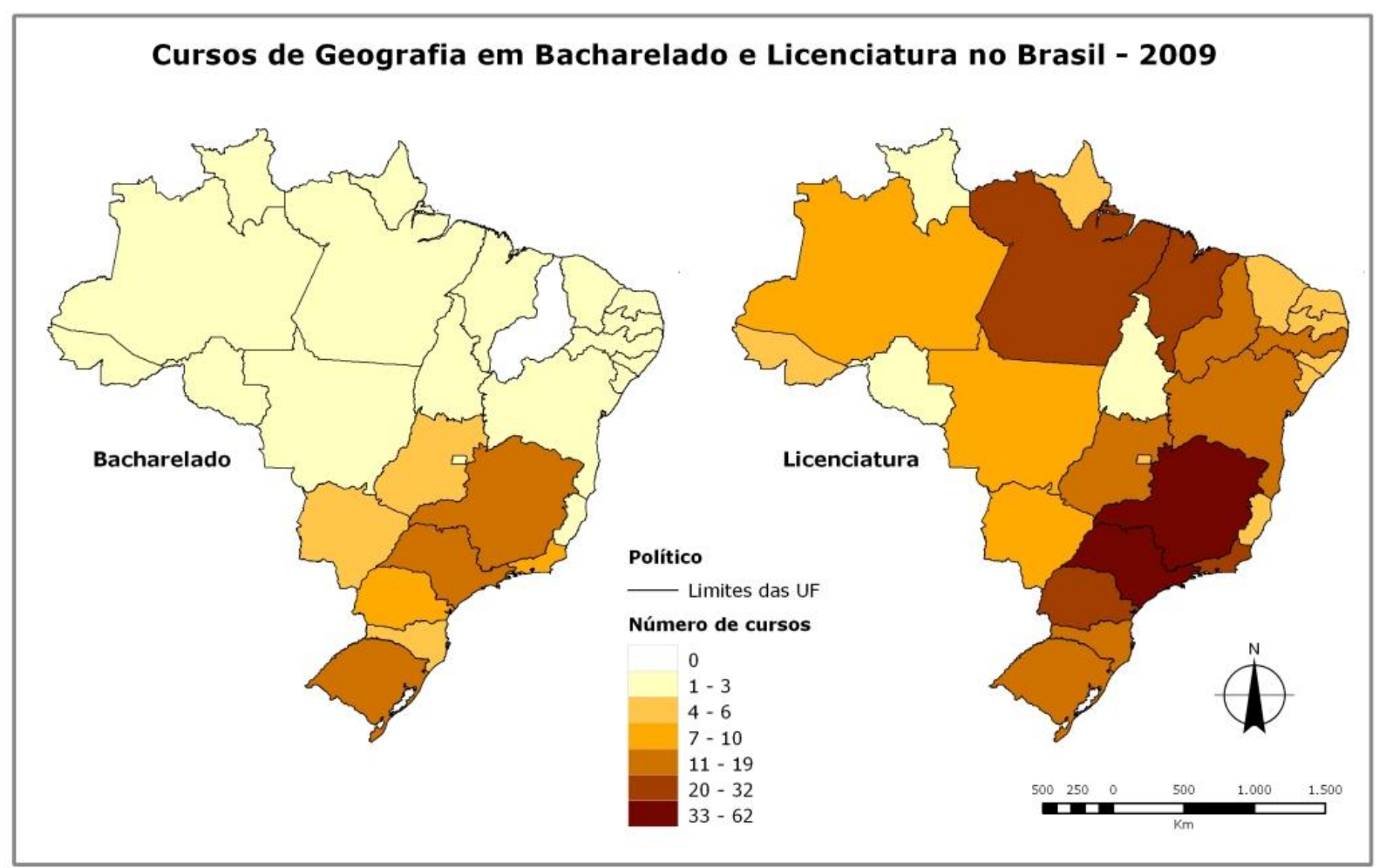

Mapa 7- Fonte: MEC, 2009. Dados organizados por Vivian Fiori.

Elaborado por Maurício Yamada e Vivian Fiori, 2010. 
Os estados que tinham menor número de IES neste período eram Acre (1), Roraima (1), Amapá (2), Tocantins (4), Maranhão (5), Alagoas (5), Piauí (6) e Rio Grande do Norte (6).

De 1998 a 2008, ocorreu um aumento de 136,0\% no número de IES, reforçando a concentração já preexistente e demonstrando a relação com as políticas públicas do Ensino Superior, já comentadas anteriormente. Houve um processo de interiorização das IES públicas federais e estaduais, como no caso do Maranhão e Piauí, por exemplo.

Verificando-se a evolução das IES entre 2002 a 2008, percebe-se que a expansão deu-se principalmente pelas entidades privadas. Contudo, a maioria das licenciaturas em Geografia encontra-se em instituições públicas, já que a procura pelas licenciaturas nas regiões metropolitanas e nas grandes cidades, percentualmente, é menor do que no interior. Por isso, esta situação não tem estimulado a criação de cursos em algumas instituições privadas.

Em 200967, conforme mapa 7, observa-se que os estados de São Paulo, Minas Gerais e Rio Grande do Sul continuam, como no passado, tendo a maior concentração de bacharelado. Há uma distinção entre o número de cursos de bacharelado e licenciatura no território nacional, já que, em toda a região Norte e Nordeste, só há, no máximo, três cursos de bacharelado por Unidade da Federação (UF).

Já as licenciaturas em Geografia tiveram a maior expansão no território brasileiro, por causa das demandas dos lugares pela formação de professores, bem como das novas políticas de Ensino Superior que incentivaram a criação de cursos de licenciatura.

Contudo, em estados como Rondônia, Roraima e Tocantins, o número de cursos é bem menor, já que se trata de estados com menor população e com frentes de expansão no processo de ocupação do território brasileiro, situação que será melhor explicita na seção 5 .

67 Para elaborar os mapas de bacharelado e licenciatura em Geografia por UF, utilizou-se o sistema do E-MEC. Pesquisou-se, então, um a um dos cursos para saber se eram licenciaturas, período dos cursos, ano de sua criação e o período da IES. 
Por conta do aumento do número de IES, neste período, o governo federal institui formas de avaliação de cursos, das quais as licenciaturas em Geografia no Brasil vêm participando desde 2003, que serão discutidas na próxima seção. 


\section{DA AVALIAÇÃO DOS CURSOS DE GEOGRAFIA NO BRASIL MEDIANTE POLÍTICAS DO GOVERNO FEDERAL À ANÁLISE TERRITORIAL DOS CURSOS (1996-2010).}

Nesta seção, evidenciar-se-á o sistema de avaliação do qual os cursos de Geografia participaram, o que se constitui num evento e numa verticalidade promovida pelo MEC/Inep. Além disso, propõe-se uma análise que leve em conta a relação com a dinâmica do território brasileiro no entendimento das condições dos cursos, já que o MEC desconsidera esta possibilidade de análise.

Na década de 1990, as políticas de avaliação de Ensino Superior tornaram-se comuns pelo mundo, promovidas por instituições internacionais como Banco Mundial, Organização das Nações Unidas para a Educação, a Ciência e a Cultura (UNESCO), Organização para Cooperação e Desenvolvimento Econômico (OCDE). Na Europa, por exemplo, o acordo de Bolonha definiu os parâmetros do sistema europeu no Ensino Superior, buscando criar uma meta-avaliação com padrões comuns aos países da União Européia (LIMA; AZEVEDO; CATANI, 2008).

Não se trata de uma política nacional circunscrita ao território brasileiro, mas sim global que é replicada em diversos níveis de governo, bem como em vários países (KROTSCH, 2002; DIAS SOBRINHO, 2003). Sobre esta questão Almerindo Janela Afonso, pesquisador português de educação, informa que:

Ao longo da década de oitenta, a emergência de políticas neoliberais e neoconservadoras veio dar novo impulso aos mecanismos de responsabilização em grande medida porque se tornou evidente a convergência de valores entre alguns modelos de prestação de contas [...] A avaliação dos sistemas educativos aparece doravante associada pela responsabilização pelos resultados escolares dos alunos, sendo estes obtidos, sobretudo, pela utilização de testes estandardizados (AFONSO, 2005, p. 44).

A mesma questão foi discutida pela pesquisadora argentina Sonia Marcela Araujo (2001) em artigo no qual apontou que as avaliações de 
desempenho promovidas no Ensino Superior, tanto na graduação como na pós-graduação, estão relacionadas à obtenção de prêmios ou recompensas simbólicas, tanto para os grupos, individualmente, quanto para instituições. Afirma ainda:

La anatomía de la institución es observada en cada una de sus partes y es objeto de juicios que, finalmente tienen como propósito orientar la mejora y desarrollo institucional en una dirección específica y predeterminada. En este sentido, la actividad más novedosa para los universitarios, la evaluación institucional, introducida en diferentes países en la década de los 90 en el marco de la institucionalización del Estado Evaluador, constituiría la estrategia de gestión con esta finalidad (ARAUJO, 2001, p. 24).

A noção de padrão de qualidade e de gestão deixa de ser domínio das áreas de administração e passa a ser utilizada na educação. Segundo Marcelo Lopes de Souza (2006a) no atual período deixa-se de pensar em planejamento e fala-se cada vez mais em gestão, sem autonomia, mas com políticas heterônomas, cujas decisões são definidas sem participação dos diversos segmentos, constituindo-se em verticalidades.

No entanto, tais políticas revestem-se de um discurso social, segundo o qual para o bem público há necessidade de se avaliar, aqui como sinônimo de controlar, para buscar a "qualidade" dos cursos.

Há uma opacidade da política, pois sua essência não fica clara, a forma que aparece esconde seu conteúdo, é uma pseudoconcreticidade (KOSIK, 2002), que é mais medida do que avaliação, mais controle do que autonomia.

Passa-se a ideia de que o controle é necessário para se buscar a qualidade na educação, qualidade aqui vista como algo positivo, como adjetivo. Contudo, cabe ao pesquisador buscar entender a educação além das leis e normas. É necessário fazer uma leitura crítica dos processos que embasam as políticas, conforme diz Roberto Leher:

Por isso, ainda que necessário, não basta elencar, classificar, hierarquizar e catalogar projetos de lei, medidas provisórias, decretos e portarias. É preciso apreender as suas conexões com as grandes orientações das políticas governamentais. [...] Como a organização e a classificação das medidas governamentais não fornecem os elementos heurísticos para 
entender o movimento do real, cabe ao pesquisador enfrentar o problema dos conceitos e das categorias que permitem tornar pensável o real (LEHER, 2004, p.869).

Como diz Dennis Palumbo (1989, p. 35), "[...] uma política é como um alvo em movimento", analisá-la subentende-se verificar o processo e contexto no qual acontece esta política educacional.

O período objeto da análise das políticas de avaliação de cursos é de 1996-2010, pois é a fase em que vários eventos ocorrem no Ensino Superior brasileiro em relação às políticas de avaliação. Trata-se de um marco importante no entendimento das novas mudanças no território brasileiro, bem como nas políticas de educação, sendo analisada não como uma continuidade orgânica, uniforme, mas como um processo contraditório.

Neste período, as IES utilizam-se, cada vez mais, de uma visão empresarial (SOUZA, 2006a) na gestão e no planejamento, ou, como dizem alguns autores, produzem uma gestão na educação que é "quase mercado", pois mesmo pública adere aos procedimentos de gestão privada, ainda que parcialmente, como relatam os autores:

Ao mesmo tempo em que o capital e a lógica de mercado penetram em áreas em que até então sua presença era limitada, a educação passa a constituir um mercado em acentuada expansão, em escala mundial. [...] Inclui-se todo o processo educacional na esfera do mercado e generalizamse os procedimentos e valores típicos do capitalismo competitivo na gestão dos sistemas e das instituições educacionais. O debate em curso acerca do Acordo Internacional de Tarifas e Comércio no âmbito da Organização Mundial do Comércio (GATT-OMC) é uma expressão do primeiro aspecto, a generalização dos sistemas de avaliação em larga escala, do segundo (SOUSA; OLIVEIRA, 2003, p. 875).

A partir da psicosfera ${ }^{68}$ do discurso existente, ganha conteúdo e forma a avaliação, embora esconda suas intencionalidades. Esta política

68 Segundo Milton Santos (2006, p. 256) "A psicosfera, reino das idéias, crenças, paixões e lugar da produção de um sentido [...] fornecendo regras à racionalidade ou estimulando o imaginário". Ou ainda, "A psicosfera é o resultado das crenças, desejos, vontades e hábitos que inspiram comportamentos filosóficos e práticos, as relações interpessoais e a comunhão com o Universo" (SANTOS, 1994, p. 32). 
vai ganhando apoio, mas, ao mesmo tempo, há contradições no processo. Uma delas refere-se ao fato de que o Estado neoliberal usa dos mecanismos de "quase mercado" e é cobrado a controlar ou propagandeia que o controle de "qualidade" é fundamental, já que a expansão existente no Ensino Superior foi grande. Passa a ser um Estado regulador e avaliador, conforme aponta Afonso:

Em termos de política educativa, mais especificamente, trata-se agora de tentar conciliar o Estado-avaliador preocupado com a imposição de um currículo nacional comum e com o controlo dos resultados (sobretudo acadêmicos) - e a filosofia de mercado educacional assente, nomeadamente, na diversificação da oferta e na competição entre escolas (AFONSO, 2005, p. 119).

Neste processo de existência do Ensino Superior, muitas vezes há racionalidade e solidariedade entre agentes hegemônicos e o Estado, mas também há diferentes racionalidades e irracionalidades no processo de produção da avaliação do Ensino Superior. Esta solidariedade é organizacional, mas não exclui os diferentes interesses a cada momento.

Logo, os resultados de "avaliação" das IES servem também ao marketing e à disputa de candidatos aos vestibulares nas instituições privadas, assim como a classificação tem sido utilizada como parâmetro de qualidade de ensino, mesmo entre as públicas, podendo servir para definição de verbas para pesquisa no caso das instituições federais e estaduais.

Portanto, em meio a tantas contradições, que tipo de avaliação daria conta de atender, ao mesmo tempo, os interesses da autonomia universitária, do mercado educacional e do Estado avaliador? Uma política que prima por uma forma única de avaliar é válida?

São esclarecedoras as palavras de Simon Schwartzman:

Dizer que o objetivo da avaliação é identificar as instituições e cursos de boa e má qualidade não é suficiente. Todas as pessoas - professores, alunos, pais, diretores, governantes - têm idéias próprias sobre o que é qualidade, mas que nem sempre são compartidas pelos demais. Quais são as prioridades? [...] Esta situação é claramente incompatível com sistemas de avaliação unidimensionais, que aplicam a 
mesma métrica para avaliar todos os cursos ou instituições pelo mesmo critério (SCHWARTZMAN, 2008, p. 3).

Deve-se considerar que existem várias abordagens e dimensões para avaliar. Como diz Robert Stake (1997, p.79), "[...] não existe um método único de avaliação de programas educacionais que convenha a todas as situações".

Muito do que se vê hoje em relação à avaliação do Ensino Superior é mais medida do que avaliação propriamente dita, já que se baseia principalmente em medidas de desempenho de alunos e de métricas definidas para se distinguir um curso do outro.

Nas palavras de Heraldo Marelim Vianna (2000, p.25), "A medida pode ser um momento inicial de uma avaliação, mas não é condição essencial para que se tenha avaliação". Ou seja, não se deve confundir medidas de desempenho de alunos com avaliação, cuja concepção é mais ampla.

Nas políticas recém-implantadas, confunde-se, muitas vezes, supervisão com avaliação, assim como nem sempre este processo tem servido para retroalimentar os cursos e criar possibilidades de transformação para sua melhoria, mas, como em todo processo, há contradições.

Há algumas IES que buscam alcançar os índices de qualidade definidos pelo Inep e acabam produzindo melhorias em algumas das variáveis definidas pelo sistema de avaliação.

No entanto, a avaliação deveria ser a de construção com os agentes mais diretamente envolvidos como protagonistas do processo. Porém, concretamente se torna uma medida e forma de controle por parte do Estado.

O entendimento do processo e a implantação das políticas de avaliação do Ensino Superior nos cursos de Geografia no Brasil podem elucidar as características e contradições existentes neste período analisado, no qual o Inep instituiu um exame de desempenho de alunos da graduação em larga escala. 
A Geografia participou dos exames em larga escala em 2003, denominado, naquela época, de "Provão", e, em 2005 e 2008, do Exame Nacional de Desempenho dos Estudantes (Enade), realizados com estudantes dos cursos.

Além disso, definiram-se os procedimentos de avaliação, inclusive criando um indicador denominado Conceito Preliminar de Cursos (CPC), de que se tratará a seguir.

\subsection{O sistema de avaliação e sua relação com os cursos de Geografia}

No início desse processo de avaliação do Ensino Superior, o governo federal buscou tratar da questão pelo reconhecimento e credenciamento dos cursos mediante avaliação de Comissões de Cursos, que iam até a Instituição de Ensino Superior e realizavam um levantamento das condições de ensino, sendo estes renovados por um processo regular dessas visitas a cada três/quatro anos.

Caso a avaliação fosse negativa, haveria um tempo para sanar seus problemas e uma nova comissão faria a avaliação. Se o curso tivesse novamente uma avaliação negativa, O MEC poderia intervir na IES suspendendo-o.

Em 1995, o governo criou o ENC, conhecido como "Provão" (MP 967/95; Lei n 9131/95); a Geografia foi inserida no processo em 2003. O exame era obrigatório a todos os estudantes concluintes de curso superior; o MEC definia quais fariam parte do exame. Wlademir dos Santos (2002) chamava à atenção para o fato de a mídia, seja por desconhecimento seja por adesão política, ter contribuído para fazer a apologia do Provão.

Cabe lembrar que, na Lei n 9131/95, definia-se a avaliação de forma mais ampla como:

[...] avaliações periódicas das instituições e dos cursos de nível superior, fazendo uso de procedimentos e critérios abrangentes dos diversos atores que determinam a 
qualidade e a eficiência das atividades de ensino, pesquisa e extensão (BRASIL, 1995).

Na prática, o ENC ganhou notoriedade em relação às outras formas de avaliação. O Inep classificava os cursos com conceitos A, B, C, D e E. Todavia, a nota "A" não correspondia, necessariamente, a um curso cujos alunos tinham realizado uma boa prova, dependia da média dos desempenhos individuais. Otaviano Helene (2006) chama a atenção sobre o fato descabido desta classificação:

Esses conceitos eram distribuídos em comparação com a média: um curso cujo desempenho dos estudantes estivesse significativamente acima da média nacional, receberia $A$; se estivesse significativamente abaixo, E. [...] Por exemplo, a média nacional em uma determinada área era de 1,5 (com desvio padrão 1,5 ) em uma escala de zero a dez. [...] Assim, se os estudantes de um determinado curso obtivessem uma média próxima de 3,0, ou seja, significativamente acima da média nacional, este curso teria conceito A. Ou seja, nesta área muitos cursos com conceito A não tinham nível aceitável (HELENE, 2006, p. 317).

Wlademir dos Santos (2002) diz do problema da representatividade da prova em casos de turmas muito pequenas, já que a comparação era feita entre os diversos cursos em detrimento do número de alunos, o que, do ponto de vista da estatística, não deveria acontecer.

Em outubro de 1996, o Decreto nº 2026 (BRASIL, 1996a) estabeleceu os procedimentos para o processo de avaliação do Ensino Superior, que se resume a:

I - análise dos principais indicadores de desempenho global do sistema nacional de Ensino Superior, por região e unidade da federação, segundo as áreas do conhecimento e o tipo ou a natureza das instituições de ensino; II avaliação do desempenho individual das instituições de Ensino Superior, compreendendo todas as modalidades de ensino, pesquisa e extensão; III - avaliação do ensino de graduação, por curso, por meio da análise das condições de oferta pelas diferentes instituições de ensino e pela análise dos resultados do Exame Nacional de Cursos; IV - avaliação dos programas de mestrado e doutorado, por área do conhecimento (BRASIL, 1996a).

Além disso, a avaliação do Ensino Superior utilizar-se-ia de uma autoavaliação, bem como de outra feita por Comissão Externa relativa às condições da oferta dos cursos de graduação, nas seguintes dimensões: 
I - a organização didático-pedagógica;

II - a adequação das instalações físicas em geral;

III - a adequação das instalações especiais, tais como laboratórios, oficinas e outros ambientes indispensáveis à execução do currículo;

IV - a qualificação do corpo docente;

V - as bibliotecas com atenção para o acervo bibliográfico, inclusive livros e periódicos, regime de funcionamento, modernização dos serviços e adequação ambiental.

O princípio deste sistema de avaliação mais amplo parecia adequado, contudo, em 2002, a avaliação foi deslocada de avaliação institucional e de curso para a dimensão individual, isto é, medindo-se o desempenho dos alunos, avaliavam-se os cursos.

Em razão da Portaria n 990, 2/4/2002, que instituiu uma taxa para as IES com cursos a serem avaliados, houve um bloqueio judicial das avaliações in loco até 2003. Além disso, na mídia, eram divulgadas apenas as informações do ENC.

Seguem dados da medida de desempenho do ENC 2003 para licenciatura e bacharelado em Geografia.

\begin{tabular}{|c|c|c|c|c|}
\hline \multicolumn{5}{|c|}{ Tabela 2- Conceitos do ENC 2003, Geografia } \\
\hline CONCEITO & $\begin{array}{c}\text { Nota } \\
\text { mínima } \\
\text { Observada }\end{array}$ & $\begin{array}{c}\text { Nota } \\
\text { máxima } \\
\text { Observada }\end{array}$ & $\begin{array}{c}\text { Número } \\
\text { de } \\
\text { Cursos }\end{array}$ & $\begin{array}{c}\text { Percentual } \\
\text { de cursos }\end{array}$ \\
\hline A & 35,8 & 45,6 & 34 & 15,0 \\
\hline B & 32,2 & 35,7 & 34 & 15,0 \\
\hline C & 25,0 & 32,0 & 88 & 38,9 \\
\hline D & 21,3 & 24,9 & 44 & 19,5 \\
\hline E & 0,0 & 21,1 & 24 & 10,6 \\
\hline S/C & --- & --- & 2 & 0,9 \\
\hline
\end{tabular}

Fonte: DAES/Inep, MEC-ENC, Relatório do Exame Nacional de Cursos 2003. p. 81.

Organizado por Vivian Fiori, 2009.

Como se vê na tabela 2, a maioria dos cursos de Geografia ficou com o conceito $C$, o que, em princípio, poderia parecer que tem nível de desempenho médio, mas, mesmo a maior nota (nota máxima observada), foi 45,6 numa escala de 0 a 100 . Ou seja, a maior nota média por curso foi ainda abaixo de $50 \%$ de rendimento. Em relação ao desempenho dos alunos, considerando o tipo de IES (organização acadêmica), segundo o Inep, houve: 
Comparando-se os dados por organização acadêmica da instituição observa-se que a maioria dos graduandos e graduados que respondeu à prova de Geografia $(68,6 \%)$ era proveniente de universidades, dentre os quais se verificou a média mais alta $(31,3)$ e o maior desvio padrão $(12,7)$. Os centros universitários tiveram 29,8 de média, um pouco menor do que a nacional $(30,0)$. Os estudantes originários das faculdades integradas representaram $8,6 \%$ das provas válidas e alcançaram média igual a 28,1. Nas faculdades, escolas e institutos superiores, foi registrada a média mais baixa $(25,7)$ (INEP, 2003b, p.31.).

Ressalta-se que não serviram para análise técnica as provas em branco. A pior média nacional foi das instituições de ensino municipais $(30,4)$, e a melhor, das instituições federais $(45,0)$, conforme tabela 3 . Em relação à prova discursiva, para fins estatísticos, as médias foram convertidas numa escala de 0 a 100.

\begin{tabular}{|c|c|c|c|c|}
\hline \multicolumn{5}{|c|}{ Tabela 3 - Estatísticas das questões de múltipla escolha da prova de Geografia, } \\
por categoria administrativa - ENC/2003 \\
\hline VARIÁVEIS & Federal & Estadual & Municipal & Privada \\
\hline Número de graduandos & 2815 & 3523 & 566 & 3938 \\
\hline Média & 45,0 & 40,4 & 30,4 & 37,9 \\
\hline Nota máxima & 95,0 & 92,5 & 75,0 & 92,5 \\
\hline
\end{tabular}

Fonte: DAES/Inep, MEC-ENC, Relatório do Exame Nacional de Cursos 2003. Organizado por Vivian Fiori, 2009.

Não se pretende discutir aqui, ainda, o mérito ou não deste tipo de exame em larga escala, pois isto será feito ao longo do texto. Contudo, houve problemas em leituras básicas de gráficos, mapas e usos de conceitos pertinentes à Geografia, o que demonstra dificuldades básicas dos graduandos concluintes dos cursos de Geografia, em 2003.

Os conteúdos da parte discursiva em Licenciatura eram os seguintes, considerando-se por ordem da questão: 1. Políticas públicas educacionais e o ensino de Geografia; 2. Formação do professor e a prática em sala de aula de Geografia; 3. Projeto Pedagógico e o ensino de Geografia; 4. Construção do conhecimento geográfico e psicologia da aprendizagem e do desenvolvimento. 5. Conteúdos e Práticas no ensino médio de Geografia.

Do ponto de vista estatístico, eram corretos, pois foram medidos cinco conteúdos, com cinco questões. Um dos problemas da prova era o pequeno espaço dado para as respostas, geralmente 10 linhas, embora 
houvesse algumas com itens a, b e c. A questão 4 (INEP, 2003a), reproduzida em Anexo $A$, foi a que teve o menor número de acertos.

Nesta questão, o total de resposta em branco $(14,5 \%)$ e o de nota zero totalizaram $56,7 \%$ das provas corrigidas. Somente $2,1 \%$ dos estudantes tiraram notas iguais ou acima de 31 pontos. Ou seja, é um resultado bastante ruim. Segundo a Comissão do ENC 2003, o intuito da questão era:

[...] esperava-se dos licenciandos o domínio das teorias da psicologia da aprendizagem, que tomam como fundamentais o repertório e a linguagem dos alunos no processo de construção do conhecimento. Um outro caminho de raciocínio, também considerado, diz respeito àquele baseado nos conceitos da Geografia. Em outras palavras, é pressuposto na questão que a elaboração do conceito de espaço geográfico é gradativa, mobilizando-se, ao longo do ensino fundamental, categorias analíticas (paisagem, território, lugar, dentre outros) e diferentes escalas espaços temporais (do local ao global), que constituem o núcleo central do método geográfico (INEP, 2003, p. 53).

Então em 2003, o aspecto positivo da prova foi a separação das provas de licenciatura e bacharelado na parte dissertativa. O fato de a maioria dos discentes ter dificuldades na articulação das ideias, na redação e de entendimento dos conceitos geográficos denota problemas nos cursos.

Em Abril de 2004, a Lei $n^{\circ} 10861 / 2004$ instituiu o Sistema de Avaliação da Educação Superior (Sinaes), que busca avaliar as IES, a graduação e o desempenho acadêmico dos estudantes.

Em seu artigo $2^{\circ}$, parágrafo III, estabelece que o Sinaes deve assegurar "[...] o respeito à identidade e à diversidade de instituições e de cursos". Define, ainda, que a avaliação do Ensino Superior resulta de uma classificação em 5 níveis de escala ( 1 a 5), para cada uma das dimensões avaliadas, bem como em seu conjunto, utilizando-se de procedimentos diversificados, entre eles: a autoavaliação e a avaliação externa in loco.

Segundo a Lei: "A avaliação dos cursos de graduação tem por objetivo identificar as condições de ensino oferecidas aos estudantes, em 
especial as relativas ao perfil do corpo docente, às instalações físicas e à organização didático-pedagógica" (BRASIL, 2004).

Além disso, define que cada IES constitua uma Comissão Própria de Avaliação (CPA), para sua autoavaliação. Em relação ao desempenho de estudantes, a Lei criou o Enade, cujas inovações em relação ao antigo "Provão" foram, principalmente, a introdução do IDD (Indicador de Diferença entre os Desempenhos Observado e Esperado), que mede o desempenho dos ingressantes e os compara ao desempenho dos concluintes, o período de prova a cada três anos para o mesmo curso e a prova e análise de desempenho para alunos concluintes e ingressantes. Os conceitos de IDD também variam de 1 a 5 .

Em princípio, as IES tinham um posicionamento favorável ao Sinaes, pois trazia, em seu bojo, também, a autoavaliação, institucionalizando-a, assim como diminuía o papel de desempenho individual do aluno, já que havia outras dimensões a serem avaliadas.

Contudo, na prática, o peso maior acaba sendo dado ao Enade, pois seus resultados, por curso e IES, são amplamente divulgados pela mídia impressa e on-line, classificando os melhores e piores cursos do Brasil, segundo este processo avaliativo.

Conforme o Relatório Síntese do Enade de 2005 do curso de Geografia, verifica-se uma diferença de desempenho dos estudantes seja qual for o critério adotado, a saber: por regiões brasileiras, por tipo administrativo de IES (públicas, privadas etc.) ou por tipo de estrutura organizacional (Universidades, Centros Universitários, Faculdades e Centros Tecnológicos).

É contraditório que o mesmo Estado que cria as classificações por estrutura organizacional, compara-as, utilizando-se do mesmo instrumento de desempenho para depois declarar que as Universidades são melhores avaliadas do que as Faculdades, por exemplo.

Estabelecem-se diferenças no princípio de sua existência, caso da necessidade de pesquisa nas Universidades, e depois as comparam como se fossem iguais. Pode efetivamente ser considerada a mesma avaliação, 
quanto o próprio MEC classifica entre tipos de IES, como universidade, aquelas que farão pesquisa; as demais como centros universitários, faculdades, que não são obrigados a fazê-la?

Numa análise de estatística básica da prova de $2005^{69}$, a média dos concluintes foi 39,0 . Entre os concluintes, a maior faixa de notas concentrou-se entre $41-50$, correspondendo a $25,4 \%$ das notas, conforme gráfico 4.

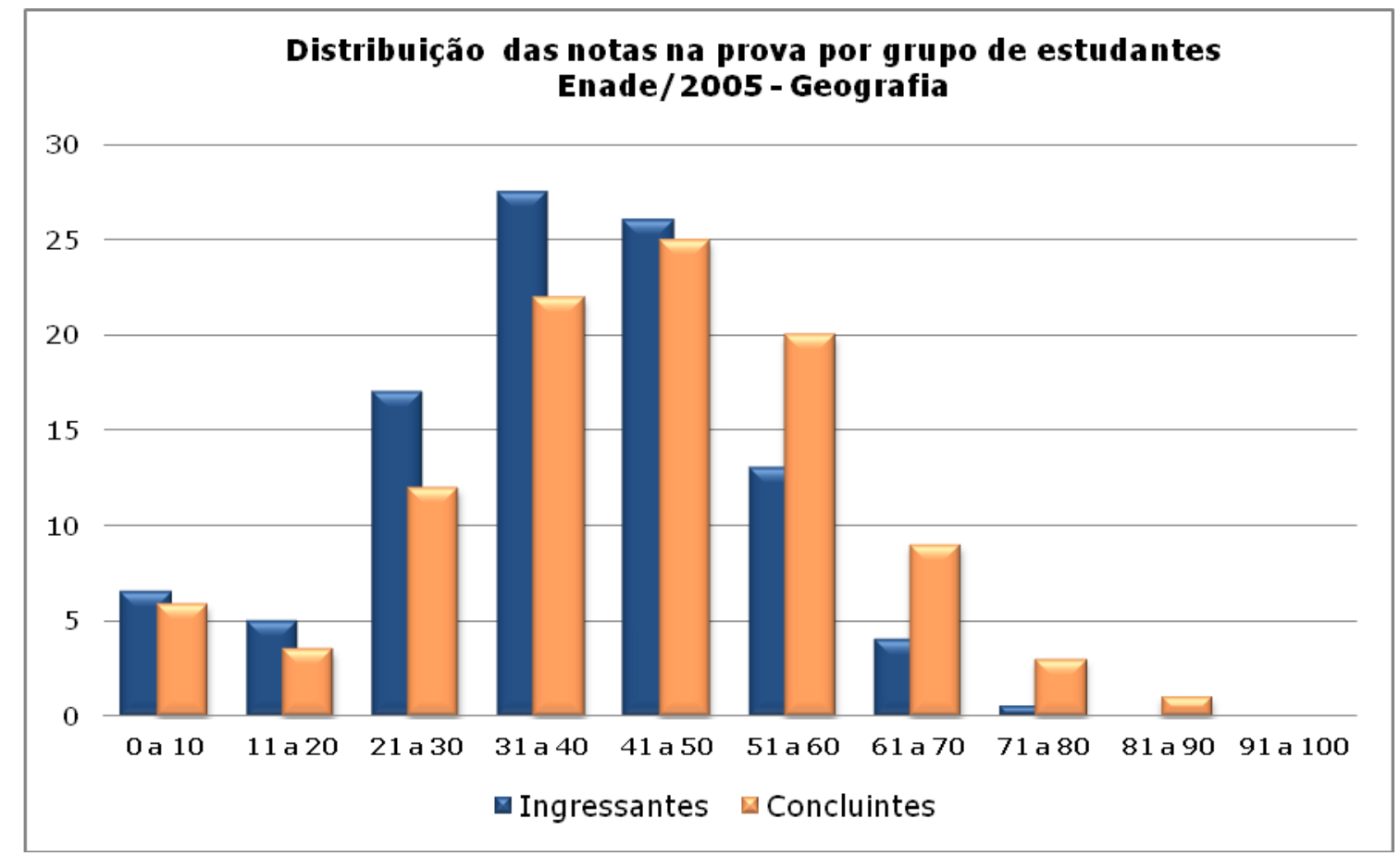

Gráfico 4- Fonte: Inep, Enade 2005, Relatório Síntese, Área de Geografia, 2006, p.25.

Comparando-se ${ }^{70}$ os resultados do ENC 2003 e do Enade 2005 por categoria administrativa, observa-se que as instituições mantiveram a mesma ordem em 2003 e em 2005, sendo que as Universidades tiveram as melhores médias, e as Faculdades e Escolas, as piores. Excetuando-se os Centros Tecnológicos, que não participaram desta avaliação em 2003 e do Enade em 2005, tiveram a melhor média de concluintes $(52,8)$.

69 A definição da média ocorre por análise estatística, e comparam-se as notas dos ingressantes entre si e dos concluintes entre si. Assim a média dos ingressantes foi 36,7 , e dos concluintes 41,2 .

70 Cabe ressaltar que não é possível comparar as médias das provas, pois são diferentes. Em 2003 (INEP, 2003), os graduandos que consideraram a prova "difícil" ou "muito difícil" foram 53,5\%; no Enade 2005 (INEP, 2006), o índice foi de 32,0\% para os concluintes. Logo, na concepção dos alunos, em 2003 a prova foi mais difícil. 
Os pesos que, no ENC 2003, eram de $50 \%$ nas questões de múltipla escolha e 50\% nas dissertativas, mudaram para 30\% no Enade 2005 nas questões dissertativas; manteve-se o mesmo em 2008. Ou seja, a habilidade de escrever e redigir um texto foi preterida em relação ao acerto em testes de múltipla escolha.

A prova do Enade, com dez questões de formação geral e trinta de conhecimentos específicos, consegue medir o número muito maior de objetivos a que se propõe? Estes são só alguns dos problemas.

Em 2005, os conceitos foram distribuídos de 1 a 5, sendo que 93 instituições foram classificadas como Sem Conceito (S/C), pois só tinham turmas de ingressantes ou o número de concluintes não atingia o mínimo estipulado de 10 por causa da estatística. Ressalta-se que, em 2005, turmas menores de 10 não recebiam conceito, condição diferente de 2008.

Os problemas da classificação dos conceitos dos cursos mediante desempenho dos estudantes são os mesmos já apontados anteriormente para o Provão 2003. Muitas questões foram entregues sem resposta (S/R) (gráfico 5), e os que responderam tiveram muita dificuldade em articular suas ideias e usar conceitos geográficos.

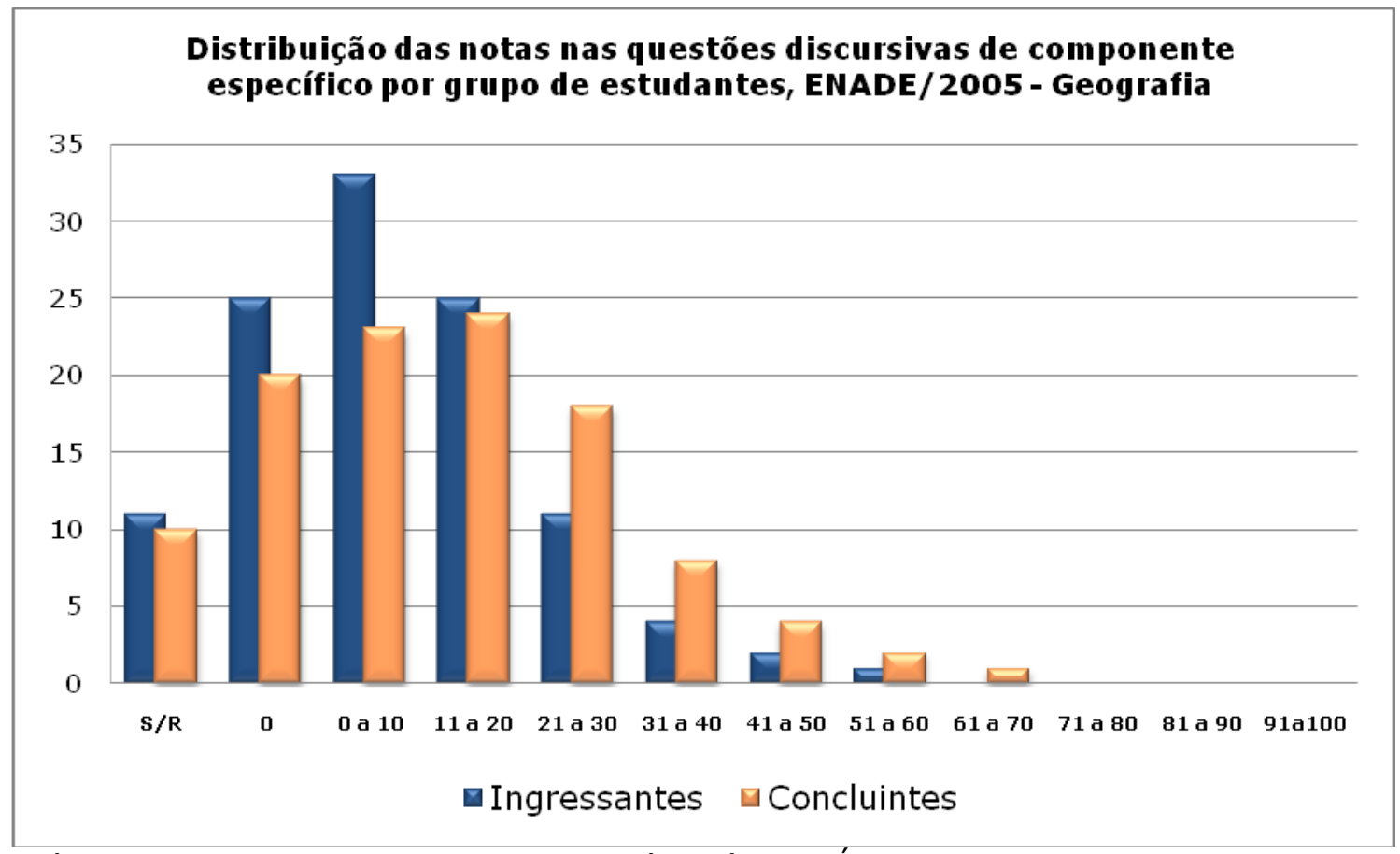

Gráfico 5- Fonte: Inep, Enade 2005, Relatório Síntese, Área de Geografia, 2006, p.48. Re-elaborado por Vivian Fiori, 2009. 
A questão 5 da prova do Enade 2005, por exemplo, aquela na qual os estudantes tiveram o pior desempenho e que requeria conhecimento de Geomorfologia relacionados ao de Geografia Humana (Anexo B), além da habilidade de leitura de gráficos, teve a seguinte avaliação pela comissão do Enade de Geografia:

Não se constata, na maioria das provas, um repertório próprio da geografia. Os termos utilizados derivam do senso comum. Exemplos: buracos, crateras, casas, plantio, ganância, dinheiro, garagens, processo de escavação, afundamento do terreno. Em relação à leitura do gráfico, foi perceptível que muitos estudantes somente faziam menção ao tempo passado, dando os exemplos de Roma e do Egito. Isso demonstrou a insuficiência da habilidade da própria leitura de gráficos, já exigida no ensino médio e própria da formação em Geografia (INEP, 2006, p.52).

O Relatório apontava falta de conhecimento dos conceitos básicos de Geografia, falta de articulação entre conteúdos e os conceitos geográficos e dificuldade na leitura de gráficos e mapas. Portanto, apesar de estarem concluindo o curso, havia deficiências básicas na formação destes discentes.

$\mathrm{Na}$ formulação da prova de Geografia do Enade 2008, houve problemas ainda maiores. Primeiro, porque novamente não houve uma separação das provas para os formandos em bacharelado e licenciatura, nem mesmo na parte dissertativa. Segundo, a maioria das questões era de Geografia aplicada e com conteúdos mais específicos para os bacharéis, algumas com situações-problema para o trabalho de gestor.

Embora exista um número maior de IES com licenciatura em Geografia, apenas três questões foram específicas para este tipo de formação, entre as trinta questões específicas de Geografia propostas. As três questões específicas de licenciatura eram todas de múltipla escolha.

Além disso, a prova tinha incorreções, alguns mapas ilegíveis, conteúdos regionais muito específicos e muitas questões visavam apenas a confundir os estudantes, o que se convencionou chamar no Brasil de "pegadinhas". 
Cabem, então, algumas reflexões: O que efetivamente se espera de uma prova que não considera a diversidade regional existente e a diversidade de instituições? Como uma prova pode ser em escala nacional quando as próprias definições do MEC dizem que o currículo deve ser criado considerando-se as condições onde a IES está inserida?

Ainda, que embora, haja, em princípio, autonomia para a definição do projeto pedagógico de cada instituição (perfil do curso e matriz curricular, entre outros aspectos), na hora de medir o desempenho de estudantes é necessário um conteúdo curricular comum? Pela legislação atual não há mais currículo mínimo e sim diretrizes curriculares.

Há contradição, pois se afirma que existe autonomia na definição curricular, mas tende-se a uniformizar conteúdos mediante uma prova aplicada em larga escala para todo território brasileiro.

Os formuladores do Enade deveriam considerar o território e as diferenças dos lugares existentes no Brasil ao formularem as provas, ou seja, seria mais eficaz se as provas fossem elaboradas regionalmente, considerando-se efetivamente o que está definido no Sinaes: a diversificação dos procedimentos avaliativos.

Sendo assim, é interessante verificar outras possibilidades de avaliar o Ensino Superior e seus cursos, além do ENC. Num estudo das IES do Mato Grosso do Sul, em relação ao Provão e às avaliações produzidas pelos docentes em visitas in loco, Giselle Real (2007) demonstrou que houve casos nos quais os cursos eram mal avaliados nos Exames, mas iam bem na avaliação mediante visitas; em outros casos, ocorria o contrário, como se verifica a seguir:

De uma forma geral, os instrumentos de avaliação adotados indicam avanços no setor privado, no que se refere às condições de oferta dos cursos, sobretudo as instituições universitárias, considerando as categorias organização didático-pedagógica, corpo docente e instalações. Também o percentual de professores titulados e contratados em regime de tempo integral vem crescendo significativamente no decorrer do período de 1995 a 2002 [...] No entanto, os avanços identificados nestas categorias, particularmente aqueles registrados nas instalações físicas, não foram 
determinantes de efeitos no rendimento dos alunos, quantificados pelo "provão" (REAL, 2007, p. 146).

Além disso, a pesquisadora apontava que o fator "instalações físicas" ou infraestrutura tem um limite na melhoria da avaliação em geral, criando uma "qualidade" de ensino mais formal do que real. Levanta, ainda, a questão de que a presença de diversos professores de IES nas comissões de avaliação do Inep contribuiu para dar credibilidade ao próprio sistema.

Mais recentemente, o governo regulamentou (Portaria Normativa no 4, de 5 de Agosto de 2008), a aplicação do Conceito Preliminar de Curso (CPC), Quadro 1, para fins dos processos de renovação de reconhecimento dos cursos. Mediante esta portaria, os cursos com conceito preliminar 3 ou mais podem ser dispensados de avaliação in loco para casos de renovação de reconhecimento.

Cabe às IES solicitar a avaliação se o CPC for de 3 a 4; se não o fizer, o conceito será automaticamente confirmado. Seguem variáveis e pesos do CPC em 2009:

\begin{tabular}{|c|c|c|}
\hline \multicolumn{3}{|l|}{ Quadro 1 - Conceito Preliminar de Curso (CPC) } \\
\hline VARIÁVEIS & \multicolumn{2}{|c|}{ PESO \% } \\
\hline INSUMOS (Cadastro Docente e questionário sócio-econômico) & \multicolumn{2}{|c|}{30,0} \\
\hline ENADE & \multicolumn{2}{|c|}{40,0} \\
\hline IDD & \multicolumn{2}{|c|}{30,0} \\
\hline TOTAL & \multicolumn{2}{|c|}{100,0} \\
\hline \multicolumn{3}{|l|}{ Variáveis de Insumos } \\
\hline $\begin{array}{l}\text { Infraestrutura e instalações físicas - os equipamentos disponíveis } \\
\text { são suficientes para o número de estudantes (aulas práticas). }\end{array}$ & \multicolumn{2}{|c|}{10,2} \\
\hline $\begin{array}{l}\text { Recursos didático-pedagógicos - os planos de ensino contêm todos } \\
\text { os seguintes aspectos: objetivos; procedimentos de ensino e avaliação; } \\
\text { conteúdos e bibliografia da disciplina. }\end{array}$ & \multicolumn{2}{|c|}{27,2} \\
\hline $\begin{array}{l}\text { Corpo docente - percentual de professores (no mínimo) doutores no } \\
\text { curso. }\end{array}$ & 38,9 & \\
\hline $\begin{array}{l}\text { Corpo docente - percentual de professores que cumprem regime } \\
\text { parcial ou integral (não horista) no curso. }\end{array}$ & 23,8 & 62,7 \\
\hline
\end{tabular}

Fonte: Nota Técnica. Conceito Preliminar de Cursos de Graduação, Inep, 2008.

Organizado por Vivian Fiori, 2009.

Pensando que a definição do conceito do curso, que de preliminar não tem nada, dependerá desse índice, tem-se a impressão que todo o esforço de docentes, discentes e instituições, assim como das discussões 
em torno da Geografia, mediante trabalhos de pesquisa em Geografia no Brasil, se reduzem a variáveis discutíveis, a começar pelo peso de $40 \%$ que a nota do Enade tem.

A variável "corpo docente" - cujo percentual considera apenas o "percentual de professores doutores" - em princípio, é um elemento importante para a condição de existência de um curso de Geografia. Entretanto, desconsidera-se a grande concentração da pós-graduação stricto sensu no território brasileiro, o que dificulta a possibilidade, em alguns lugares de haver mais doutores.

Se, na própria criação e classificação das IES, diz-se que umas terão pesquisa e outras não necessariamente, como conciliar esta solicitação agora? E, ainda, há de considerar-se a autonomia das IES para a definição de qual geógrafo se quer formar, condição esta definida pelas próprias Diretrizes Curriculares de Geografia. Há norma para licenciaturas no Brasil, mas não em relação a conteúdos programáticos comuns.

Sobre o CPC, Schwartzman diz:

Comete o erro de transformar indicadores "low stakes", como IDD e o índice de insumo, produzidos por processos de estimações estatísticas, em um conceito de altas consequências que, ao ser publicado, afeta o prestígio e a reputação das instituições eventualmente mal avaliadas, enquanto que atribuí qualidades as instituições que talvez não a tenham (SCHWARTZMAN, 2008, p. 20).

Portanto, tem-se como consequência mais um indicador de "qualidade" de curso no qual, efetivamente, não se consideram as diferenças territoriais no Brasil.

Há contradições entre as Portarias, Leis e Decretos sobre avaliação do Ensino Superior brasileiro e do curso de Geografia, visto que, em alguns casos, tais legislações definem que a avaliação de Ensino Superior seja ampla e diversificada, mas que, pelo uso que se fez dos conceitos do "Provão" e do Enade, divulgados pela mídia, acaba por ranquear os cursos. 
Reitera-se que o padrão de "qualidade" buscado tem sido unidimensional, e concebe-se a avaliação mais como medida do que como avaliação de uma forma mais abrangente.

Como todo processo, contraditório, há elementos positivos em relação aos instrumentos usados, caso, por exemplo, do questionário socioeconômico aplicado aos estudantes do ENC/Enade, permitindo (re)conhecer o perfil dos estudantes e como "avaliam" seus cursos.

Positiva também é a institucionalização do processo de autoavaliação, mas que infelizmente pouco tem sido considerado na avaliação in loco, nem é considerado no CPC.

Logo, ao analisar alguns relatórios do Inep com formação em Geografia, foi possível encontrar aspectos interessantes para uma análise educacional, caso da análise da parte dissertativa das provas.

O problema é que, ao transformar relatórios do Enade e das Comissões de cursos em apenas um índice, perde-se a dimensão qualitativa possível de ser apreendida em alguns destes relatórios, condição esta que será relatada na sequência numa dimensão territorial e por tipo de IES.

Ao estudar os teóricos e especialistas em avaliação, verifica-se que esta tem um limite para a mudança. Os cursos não necessariamente mudam para melhor apenas a partir do diagnóstico e da divulgação destas informações quantificadas, divulgadas pela mídia. É necessário que as condições de existência deles sejam transformadas.

Concordo com a ideia de Daniel Stufflebeam (apud VIANNA, 2000) que discute a avaliação como possibilidade para tomada de decisões, para buscar as mudanças em que houver necessidade. Senão, a avaliação torna-se apenas diagnóstico e como tal não contribui para a melhoria das condições existentes nos cursos.

Em algumas situações, o instrumento torna-se perverso, pois pune os que têm os piores índices como se fossem problemáticas apenas das condições internas dos cursos. Esquecem-se dos processos e 
verticalidades existentes, econômicas, políticas e sociais. Desconsideram o espaço geográfico e os lugares onde estes estão inseridos.

Ao contrário do que deveria ser, há premiações aos melhores, via direcionamento de verbas, por exemplo, quando deveria existir um mecanismo para melhorar os que têm os piores índices.

Logo, embora não se assuma posição contrária as avaliações de cursos e do Ensino Superior como um todo, considera-se que os moldes atuais do sistema de avaliação não leva em conta as várias mediações existentes e nem sempre servem para retroalimentar os cursos no sentido de repensá-los e provocar as mudanças necessárias.

Ao mesmo tempo, desconsideram-se as transformações empreendidas nos lugares por estes cursos. Ainda que com problemas, produzem existência, cabe então identificar quais são, condições que se tratará nesta e nas próximas seções.

\subsection{Por uma análise dos cursos que considere a mediação do território}

Considera-se que os cursos de Geografia sofreram modificações ao longo do tempo histórico, mas, atualmente, possuem diversas temporalidades $^{71}$. Tal diversidade é também provida pelo território nacional, com suas hierarquizações e suas instâncias sociais e políticas. Há mediações dos lugares, dos sujeitos que produzem os cursos, de suas organizações.

O espaço geográfico e o território são importantes categorias de análise para a compreensão das características dos cursos de Geografia no Ensino Superior brasileiro. É fundamental considerar como método uma análise da história disciplinar da Geografia, bem como dos cursos que considere o espaço e suas categorias analíticas.

71 Entende-se por temporalidade um tempo específico que se diferencia dos demais pela ação de um ou mais agentes sociais, num determinado momento. 
O espaço geográfico é definido como um sistema ${ }^{72}$ de objetos e de ações (SANTOS, 2006), que não é apenas materialidade, mas, de uma forma articulada, é também um sistema de ações que se materializam no território por diferentes agentes, entre eles o Estado, com suas políticas, intencionalidades, normas e leis que, muitas vezes, se impõem como verticalidades.

É, portanto, uma totalidade em movimento que se efetiva concretamente mediante a ação dos diversos agentes sociais, sendo assim território usado.

Entende-se o território brasileiro em constante transformação, no qual o Ensino Superior faz parte e contribui para sua produção como elemento cuja função principal deveria ser a produção e veiculação de conhecimento e a formação profissional.

Assim entendido, é importante considerar por quais normas, leis e políticas, ou seja, por quais ações vai se produzindo a sua estrutura e funcionamento no território brasileiro, considerando suas diferenças e as intencionalidades dos diversos agentes.

Ao Estado têm cabido as ações vinculadas às normas e às políticas destinadas à Educação Superior, bem como instituir e regulamentar o sistema de avaliação dos cursos.

Participando do processo, há também diferentes agentes, cujos interesses e intencionalidades podem ser variados, tais como: docentes, coordenadores de cursos, mantenedores de instituições privadas e públicas, discentes em diferentes condições socioeconômicas, entre outros.

72 Tal visão de sistema não deve ser confundida com a "Teoria Geral dos Sistemas" de Bertalanffy (1975), nem com a visão do sistema como um organismo vivo. A concepção do autor é: "É necessário estudar não somente partes e processos isoladamente, mas também resolver os decisivos problemas encontrados na organização e na ordem que os unifica" (BERTALANFFY, 1975, p. 53). O sistema aqui não é tratado como um organismo, nem de forma mecânica, como se fosse uma engrenagem, mas sim como elementos que se relacionam num processo dialético, elementos que se solidarizam. Solidariedade que não é moral, mas sim orgânica e organizacional. 
Há de um lado uma práxis roubada (SARTRE, 2002), uma escassez; de outro, uma abundância, uma racionalidade planejada, que atende a alguns agentes específicos. Há, também, questões conjunturais em escala global interferindo nas IES e em seus cursos, como a globalização e a aceleração do tempo do capitalismo no atual período do meio técnicocientífico-informacional ${ }^{73}$.

À luz das teorias maiores da globalização e das especificidades do fenômeno da expansão dos cursos de Geografia no Ensino Superior brasileiro, busca-se captar o processo, a totalidade em movimento no território.

A produção do Ensino Superior e dos cursos de Geografia no território brasileiro, apreendida num processo dialético, numa totalidade que não nega as diferenças, não esquece as singularidades.

Este processo gera escassez, no qual a ação de educar se refere a uma produção de conhecimento a que nem todos têm acesso, que não universaliza os produtos do conhecimento, que cria territórios de produtividade espacial, de conhecimento geográfico, de densidade técnica e de informação, mas, ao mesmo tempo, cria desequilíbrios e hierarquizações, mesmo dentro das metrópoles.

Observam-se desequilíbrios entre a pesquisa e o ensino; nos interesses dos diversos tipos de IES; entre as necessidades empíricas dos lugares e os cursos de Geografia existentes; entre os interesses do mercado e a produção do conhecimento na universidade; entre as políticas públicas e sua realização nos cursos.

Há diferentes atores ou agentes sociais que são responsáveis pela produção dos cursos de Geografia de formas diferentes, porque há uma mediação espacial, com suas condições sócio-históricas, culturais, econômicas e políticas, ou seja, com suas condições territoriais.

73 O conceito definido por Milton Santos $(2006,1994)$ diz respeito ao atual período da história no qual a ciência, a técnica e a informação se imbricam e se subordinam às lógicas globais, alterando as relações sociais, as formas de organização, o trabalho, enfim, o espaço. 
Além disso, há peculiaridades de formação docente, perfil socioeconômico dos discentes, características curriculares e infraestrutura dos cursos cuja mediação é espacial. O espaço não é determinante das condições existentes nos cursos, mas atua como um processo dialético e não como determinação material. Lembrando Marx e Engels:

A doutrina materialista que pretende que os homens sejam produtos das circunstâncias e da educação, e que, conseqüentemente, homens transformados sejam produtos de outras circunstâncias e de uma educação modificada, esquece que são precisamente os homens que transformam as circunstâncias e que o próprio educador precisa ser educado (MARX; ENGELS, 2002, p. 100).

Logo, nesta pesquisa, considera-se o território como instância para a compreensão da existência das Instituições do Ensino Superior e dos cursos de Geografia no Brasil. O termo território e suas definições variam conforme as concepções geográficas e os autores (MORAES, 2005b; SANTOS, 1996; RAFFESTIN, 1993; HAESBAERT, 2002; SOUZA, 2006b, CORRÊA, 2006b).

Para Claude Raffestin (1993), há uma diferença entre espaço e território, já que o espaço precede o território e este último só existe a partir de um agente social, denominado por ele de ator sintagmático. O ator transforma o espaço em território.

Já para Milton Santos (1996, 2001a), o território usado e o uso do território se fazem por atores sociais; seu uso é humano, portanto é espaço social, humanizado, dialético, ou seja, espaço geográfico. Assim sendo, os usos do território são providos de contradições, usos corporativos, transnacionalizados e normatizados.

Antonio Carlos Robert Moraes (2005b) lembra que é importante não desconsiderar o papel do Estado como agente fundamental na construção e normatização do território, assim, por si, o Estado é territorial, conforme enfatiza o autor:

Estado e território, dois conceitos profundamente entrelaçados no mundo moderno, em que o Estado é de imediato definido como um Estado dotado de um território. [...] está o fato de ele possuir um espaço demarcado de exercício de poder, o qual pode estar integralmente sob seu 
efetivo controle ou conter partes que constituem seu apetite territorial. De todo modo, a modernidade fornece uma referência espacial clara para o exercício do poder estatal: uma jurisdição. Trata-se, pois, de um Estado territorial (MORAES, 2005b, p. 51).

Assim, o entendimento da formação territorial brasileira é importante para a compreensão da existência das Instituições de Ensino Superior e dos cursos de Geografia, tanto porque há normas técnicas e políticas específicas para ambos no Brasil, no marco jurídico brasileiro, quanto porque se levam em conta as características dos lugares e a dinâmica do território para a compreensão de suas especificidades.

Compartilha-se com Rogério Haesbaert (2002) a ideia de que a existência do mundo nos coloca numa multiplicidade de escalas, de eventos e de vivências do território que não estão apenas na escala nacional. Assim como com Milton Santos (2006; 1996) pela concepção de que os usos do território ocorrem num movimento histórico, desigual, que subordina as condições do território e, ao mesmo tempo, num processo de circularidade dialética, torna o território ator ou agente.

Logo, entende-se, nesta tese, por território o espaço geográfico, apropriado por diferentes agentes sociais, com diversos níveis de poder que o transformam em território usado.

O território é uma construção sócio-histórica, não um mero palco ou substrato para que as ações ocorram, com uma forte dimensão política, socioeconômica e de poder em sua multidimensionalidade, que vivida produz usos e apropriações distintas, daí a desigualdade de acesso e de extensão que não cria capilaridade a todos os lugares.

Os lugares são vistos aqui como o espaço do acontecer, onde há normas técnicas, usos sociais e vivência do cotidiano, que é o mundo também, mas contém sua individualidade, como diz as palavras de Milton Santos (2006, p. 314): "[...] cada lugar, irrecusavelmente imerso numa comunhão com o mundo, torna-se exponencialmente diferente dos demais. A uma maior globalidade, corresponde uma maior individualidade". 
Então é necessário entender a relação dos cursos com o território brasileiro e as diversidades de arranjos espaciais, constituídos nos lugares.

\subsubsection{A relação das IES e dos cursos com o território brasileiro}

O processo de ocupação no território e nas regiões brasileiras ${ }^{74}$ é bastante desigual. O território brasileiro, no período de 1996-2010, traz consigo as questões do processo de formação territorial brasileira e tem especificidades sociais e dos processos de ocupação.

De um lado há maior densidade de povoamento próxima ao litoral e uma concentração populacional e de atividades produtivas nas metrópoles da região Sudeste, sobretudo nos estados de São Paulo (SP), Rio de Janeiro (RJ) e Minas Gerais (MG), provenientes de outros períodos da história brasileira que se intensificaram ao longo do século $X X$.

Contudo, nas regiões metropolitanas destes estados há as maiores desigualdades sociais e espaciais, pois concentram maior população e tornam-se centralidades econômicas, ao mesmo tempo, que possuem a maioria absoluta dos pobres. Por um lado, estar no Sudeste-Sul do Brasil nos coloca num mundo maior de possibilidade de acesso aos serviços de educação; por outro, são lugares de grandes desigualdades.

Além disso, ainda existem os "fundos territoriais", expressão usada por Antonio Carlos Robert Moraes (2005b) para designar lugares ainda em processo de ocupação, caracterizados ainda pela forte presença da natureza, principalmente no Norte e Centro-Oeste do Brasil. No dizer do autor (2005a):

74 Uma das classificações de região no Brasil é definida pelo IBGE em cinco macroregiões: Norte, Nordeste, Centro-Oeste, Sudeste e Sul. Já formalmente o Brasil é uma federação dividida em 27 unidades federativas: 26 estados membros e o Distrito Federal, onde se localiza Brasília - a capital do país. Na Região Norte, há os estados do Amazonas, Pará, Acre, Rondônia, Roraima, Amapá e Tocantins; na Região Nordeste, há o Maranhão, Piauí, Ceará, Rio Grande do Norte, Paraíba, Pernambuco, Alagoas, Sergipe e Bahia; no Centro-Oeste, Mato Grosso, Mato Grosso do Sul, Goiás e Distrito Federal; no Sudeste, Minas Gerais, Espírito Santo, Rio de Janeiro e São Paulo, e, por fim, no Sul, Paraná, Santa Catarina e Rio Grande do Sul. 
Com dimensões continentais, o Brasil é um dos poucos países do mundo atual a não ter o seu território ainda plenamente construído. Possui frentes pioneiras em grande dinamismo. Na verdade, a história brasileira é um contínuo processo de expansão territorial, ainda em curso na atualidade (MORAES, 2005a, p. 94).

Tais frentes de expansão ${ }^{75}$ levam a uma maior ocupação territorial no atual período, nas regiões Norte, como o caso de Rondônia, Roraima e Tocantins, no interior do Maranhão e Piauí, ambos da região Nordeste, e juntas as IES e as licenciaturas em Geografia.

Este processo de ocupação tem relação com a materialidade existente, com os objetos produzidos, verdadeiras próteses do território nas palavras de Milton Santos (2006), tanto dos sistemas de engenharia para circulação de mercadorias, quanto da instalação de campus ou núcleos de IES que se espalharam pelo interior do país.

Assim, as Instituições do Ensino Superior constituem objetos geográficos que podem ser analisados em relação ao espaço. E, no caso desta pesquisa, são objetos fundamentais para o entendimento do processo de criação, expansão e caracterização dos cursos, já que um não existe sem o outro.

Portanto, tratar de cursos universitários passa pela compreensão da existência espacial criada pelas IES, não apenas em sua materialidade, mas também em suas ações. São, portanto, formas-conteúdo, pois seu valor e significado vão mudando conforme a história acontece. A

${ }^{75}$ A ideia de frente de expansão é discutida na tese de Márcio Douglas Brito Amaral (2010) na qual, mediante revisão bibliográfica de autores como Otávio Guilherme Velho, discutem-se conceitos de fronteira em movimento e fronteira móvel de Bertha Becker. O autor trata também das ideias de José de Souza Martins com a concepção de que a fronteira não ocorre apenas na interação com o econômico, mas também se dá pelo conflito de tempos sociais diferentes. A tese traz uma distinção entre frente pioneira, termo mais comumente usado por geógrafos principalmente no sentido da expansão territorial capitalista, e o termo frentes de expansão, usado pelos antropólogos geralmente no sentido sociocultural. Seja como for, nesta pesquisa, o conceito dado a frente de expansão refere-se à ideia do movimento social e econômico no território principalmente na Amazônia, sem desconsiderar que já havia ocupação anterior de indígenas, caboclos e outros, com diferentes formas de vida e de trabalho, que são bastante alterados pela lógica capitalista. Logo, trata-se do próprio território em movimento. 
existência das IES relaciona-se ainda ao processo de urbanização brasileira, já que é um fenômeno urbano.

Considerando-se que o processo de urbanização deu-se, em maior medida, nas regiões próximas ao litoral, bem como nas metrópoles do Sudeste-Sul, caso de São Paulo, Rio de Janeiro, Belo Horizonte e Porto Alegre, é aí que há uma concentração de IES, vinculadas principalmente às demandas econômicas, sociais e de serviços destes lugares.

Cria-se, portanto, um sistema de objetos interdependentes, pois junto com as IES, as infraestruturas de transportes, de serviços e de comércio são produzidas, assim como políticas públicas que criam as ações.

Entretanto, como todo processo dialético, há contradições entre as necessidades dos lugares e as IES existentes, bem como desequilíbrios entre as demandas sociais e o perfil dos cursos e as profissionalidades oferecidas pelas IES.

As hierarquizações urbanas têm relação intrínseca com alguns cursos e com o modo de vida de cada período e das especificidades de cada território; assim, há mais cursos vinculados ao trabalho no campo em municípios do interior, como de Agronomia e Zootecnia, e outros como Administração, Gestão e Contabilidade nas grandes cidades, sobretudo nas metrópoles.

Milton Santos e Maria Laura Silveira, em pesquisa sobre a relação entre o Ensino Superior e o território brasileiro, afirmam:

Em consonância com as necessidades do período, o ensino se desenvolve e suas ofertas ajudam a configurar $o$ território. É, sobretudo, a vocação de homogeneização dos saberes que leva à expansão de uma fronteira educacional. Daí a importância alcançada pelas áreas de Administração (incluindo Administração Empresarial, Relações Públicas, Administração para Executivos, Secretariados) que atingem praticamente 500 cursos, distribuídos em todos os estados, menos o Amapá; Direito e Ciências Contábeis, evidenciando o papel da regulação e das finanças hoje; Agronomia e Veterinária, fornecendo a formação indispensável ao manejo de um campo cientificizado; [...] as Engenharias, indicando as especializações da técnica, a busca de soluções técnicas, as grandes infra-estruturas e a miniaturização; o campo da 
Saúde com suas novas manifestações e o ensino (SANTOS; SILVEIRA, 2001b, p. 54.).

Ao mesmo tempo, as formas espaciais e as ações provenientes da existência das IES e dos cursos transformam os espaços nos quais estão inseridos. A chegada do Ensino Superior a um determinado território implica certas transformações, principalmente nas suas dimensões sociais e econômicas, tais como a valorização dos imóveis urbanos, com aumento de aluguéis, além de mudanças das condições de acessibilidade e a possibilidades de formação profissional no Ensino Superior, à medida que passam a ser ofertados cursos onde as instituições se instalam.

Além disso, novas demandas de serviços surgem para estudantes, alunos e funcionários, caso de restaurantes, serviços de fotocopias, moradias de aluguel etc.

Em relação à formação em Geografia, há demanda para o geógrafo bacharel, mas neste caso é mais comum a busca deste profissional em empresas de consultorias localizadas nas metrópoles, principalmente no Centro-Sul ${ }^{76}$ ou na Região Concentrada, regiões que se tornam centralidade neste tipo de produção de conhecimento, portanto cumprem um papel de destaque na divisão territorial do trabalho, como áreas especializadas em consultorias ambientais, das normas técnicas, do planejamento territorial.

Ao mesmo tempo, é fato que muitos destes profissionais trabalham em consultorias e acabam viajando por todo o Brasil, o que demonstra uma necessidade e/ou demanda do território que não está circunscrito aos espaços metropolitanos.

Há uma demanda institucional e territorial ainda maior pela formação para a docência; por isso, faz-se necessário ampliar o número de cursos de licenciatura porque faltam professores, conforme foi demonstrado na seção anterior. Tanto porque existem as escolas de

76 Pedro Pinchas Geiger, geógrafo fluminense, propôs em 1967 a divisão regional do Brasil em três grandes complexos regionais: a Amazônia, o Centro-Sul e o Nordeste, cujo critério principal é a formação histórica do Brasil e seus aspectos econômicos. 
Ensino Básico que requerem o trabalho do docente, quanto porque há indução da expansão das licenciaturas por parte do governo.

Como nem sempre há procura pela licenciatura no Brasil (CACETE, 2004; INEP, 2009), nas IES públicas encontra-se a maioria das licenciaturas em Geografia, neste período de 1996-2010. Mas há variação desta condição mediada pelo território nacional e pela diversidade dos lugares, mediante ações dos agentes que atuam no setor de Ensino Superior.

Por isso, há uma divisão territorial do trabalho que amplia o número de IES pelo interior do país, para a formação de professores, principalmente em instituições públicas, orientadas principalmente pelas políticas governamentais federais e estaduais.

A divisão territorial do trabalho é entendida como a repartição geográfica do trabalho, que faz parte da totalidade mundo, mas, ao mesmo tempo, distingue a produção e difusão do conhecimento numa divisão que é desigual e combinada no território.

Nesta divisão social e territorial do trabalho, criam-se centralidades de produção acadêmica, que não são apenas geométricas e produz-se a partir da extensão e de um processo que gera concentração de forças e tensão com outros lugares.

Raffestin (1993) traz uma discussão relevante para este estudo: a relação existente entre a centralidade, o poder econômico, a ciência e a técnica, produzindo uma tensão constante entre a centralidade e os demais lugares, o que o autor denomina de "marginalidade", sendo ambas as formas espaciais e relacionais - uma expressão das relações de poder.

Então, define-se o nível de centralidade pela relação hierárquica entre os lugares, condição sempre relativa no espaço e no tempo, alterando ou reforçando o seu papel na divisão territorial do trabalho ao longo da história e criando uma tensão dialética entre o processo de polarização e descentralização das atividades.

Há mais densidade técnica e de produção de conhecimento nos lugares centrais, mas a acessibilidade a estes sempre é relativa, 
considerando-se, entre outros aspectos, a condição social de quem os acessa e as atividades existentes no território e nas instituições.

Embora ela sirva de inspiração inicial, não se trata da teoria dos "lugares centrais", de Walter Christaller (CORRÊA, 1990), já que o autor usa esta expressão para designar localidades com funções centrais em relação à distribuição de bens e serviços a uma população externa residente na região complementar, denominada de hinterlândia.

De acordo com Christaller, a centralidade se estabelece pelo número de população atendida fora da localidade central, ou seja, da sua hinterlândia e pelo maior número de funções dos lugares. Estas duas variáveis expressam sua maior centralidade.

Contudo, define-se centralidade, nesta tese, não pela medida de fórmulas e modelos matemáticos de funções urbanas dos lugares ou de sua hinterlândia, mas pela centralidade que se estabelece no território a partir das atividades econômicas, sejam serviços ou não, assim como pode se estabelecer dentro de uma ou mais redes urbanas em diferentes níveis de escala.

Logo, concerne principalmente às redes interurbanas e responde a algumas das condições das dimensões docentes, discentes e de componentes curriculares dos cursos de Geografia expressas nesta e nas próximas seções.

Há uma tensão dialética entre a polarização das metrópoles e das capitais dos estados, que concentram a educação de nível superior em relação ao interior, cuja dinâmica e hierarquias interferem nas diversas dimensões, elementos e variáveis dos cursos. Então, a expressão centralidade tem relação com uma hierarquia entre os lugares, que pode ser expresso numa comparação entre cidades, numa hierarquia urbana, entre regiões ou até mesmo no nível intraurbano.

Recentemente, estudo elaborado pelo IBGE (2008), denominado Regiões de Influências das Cidades (REGIC), desenvolveu a análise das redes e centralidades urbanas existentes no Brasil. 
Esta pesquisa privilegiou a função de gestão do território nas dimensões administrativa, jurídica e econômica mediante elementos e variáveis, tais como: equipamentos de gestão pública e de empresas privadas, equipamentos de serviços, oferta de bens e serviços, atividade financeira, número de Instituições de Ensino Superior, rede de transportes, entre outros, buscando estabelecer a hierarquia urbana e suas áreas de influência.

No elemento Ensino Superior - nível de graduação, as seguintes variáveis foram analisadas: número de alunos matriculados nos cursos presenciais; o número de grandes áreas do conhecimento abrangidas pelos cursos oferecidos e o número de tipos de formação existentes.

A partir daí, estabeleceram-se seis níveis de centralidade dos cursos de graduação, sendo São Paulo e Rio de Janeiro as únicas centralidades definidas como número 1, e com centralidade 2, Campinas, Belo Horizonte, Porto Alegre, Goiânia, Brasília, Recife, Salvador e Fortaleza.

Apesar de ser um trabalho pormenorizado, que possibilita inclusive a análise específica de quaisquer dos elementos, sem necessidade de estabelecer graus de hierarquia a partir da metodologia adotada, há uma preocupação com a extensão geométrica, que é pertinente, mas sem atentar que há mediações sociais e territoriais neste processo do Ensino Superior, que não são apenas geométricas.

As redes interurbanas podem estabelecer relações que são baseadas na distância métrica entre uma maior centralidade e outras que não são, mas também há a distância existencial que marca as relações sociais em todos os lugares. Sendo assim, não há apenas extensão geométrica, mas também um conjunto de relações que se estabelecem no cotidiano de cada um, sobretudo no nível intraurbano.

Estar na Região Concentrada no Brasil significa estar num mundo de possibilidades, de liberdade, em princípio, de escolha dos cursos, definição de carreira, porque existe abundância de serviços, neste território, de educação em nível superior. 
Mas é nesta mesma região que encontramos os maiores desequilíbrios entre o que é ou não centralidade, desequilíbrios que criam extensões diversas mediadas pela condição espacial, pelos diversos usos do território, que nem sempre criam solidariedade orgânica, e nem sempre têm horizontalidades que possibilitem acesso aos interessados em cursar o Ensino Superior.

Pode-se, portanto, estar em uma metrópole brasileira, vivendo um cotidiano de proximidade com a ciência, do lócus de produção do conhecimento, mas esta proximidade geométrica não se traduz em extensão, em possibilidade real de cursar o Ensino Superior, de a pessoa escolher a formação universitária de que gostaria.

As relações que medeiam este processo, muitas vezes, nos distanciam muito mais desta possibilidade do que as distâncias concretas do território nacional, logo não produzem extensão.

A categoria extensão, definida de forma existencial, não considera apenas a métrica ou distância concebida comumente na Geografia Clássica ${ }^{77}$, como a distância e limite formais, que revelem as formas fixas, a visão do continente, dos limites definidos pela natureza, da distância métrica e do tamanho.

Nem tampouco diz respeito à proposição da Geografia TeóricoQuantitativa que transforma o espaço numa visão geométrica, com fórmulas e modelos que não conseguem apreender a diversidade da existência social, que esquadrinha o espaço, numa visão matemática.

Entende-se por extensão nesta pesquisa uma ação de um ou mais agentes que possibilitam o ato de estender-se, de difundir, mediante as relações humanas, sociais e espaciais. Logo, o conceito pode ser também sinônimo de distância, mas não pensada apenas como métrica, como

77 A visão mais tradicional em Geografia usa comumente a expressão extensão considerando a métrica, o limite, o extenso e a distância como categorias analíticas do saber geográfico. A concepção de Max Sorre (1967, 2003, p. 140), por exemplo, é: "Já a idéia de área de extensão inclui a de limite, inseparável dela e que apresenta diversos graus de determinação, desde o limite linear até a zona limite $[\ldots] " .$. 
limite rígido, como distância euclidiana, mas também as relações que permeiam o cotidiano dos homens, vivido no espaço geográfico.

São os eventos que possibilitam a extensão, mas para isso é necessário que os usos do território e as possibilidades sejam viabilizados, técnica, política, social e economicamente, conforme diz Maria Laura Silveira (2006):

Por isso, o evento é o veículo da história, produz a existência. E o evento surge do casamento entre o que é possível e o que existe. Não partimos do mundo das ideias de Platão, trata-se de uma dialética entre, de um lado, o que existe, o prático-inerte, a configuração territorial e, por outro, as possibilidades do período. Essa é a razão pela qual nem todos os dados do período existem em todos os lugares, nem produzem as mesmas extensões. [...] Os eventos transformam as essências e possibilidades em qualidades e quantidades num lugar determinado. São os eventos que operam a metamorfose entre possibilidade e existência (SILVEIRA, 2006, p. 88).

Assim, partindo-se deste princípio, considera-se a existência dos cursos de Geografia no Brasil. Esta extensão, pensada como rede de relações, se estabelece, por exemplo, na dificuldade de um professor universitário de certos lugares do Brasil cursar uma pós-graduação em Geografia, ou de discentes matriculados na graduação de participarem de eventos científicos promovidos por entidades como a AGB, ou ainda, de publicarem livros e textos que se refiram à análise das suas realidades ou aos seus lugares, já que a produção científica é bastante concentrada no território brasileiro, situações que serão explicitadas nas próximas seções.

\subsubsection{Os cursos de Geografia e sua dinâmica no território}

Quanto à distribuição dos cursos de Geografia no território brasileiro, observam-se as disparidades existentes entre esta distribuição geográfica por regiões brasileiras, entre municípios da capital e do interior, por IES públicas e privadas e pelos tipos de organização administrativa (Universidade, Centro-Universitário, Faculdades e Centros Tecnológicos). 
A partir da nova LDBEN (1996b), houve incentivo à criação de novos cursos de Ensino Superior, condição que se intensificou tanto por conta do estabelecimento de normas específicas para as licenciaturas, quanto da condição econômica do país pós Plano Real (1994), com maior estabilização econômica, fatos que possibilitaram um planejamento, a longo prazo, da criação e a ampliação do número de IES no território brasileiro, conforme se verifica na tabela 4 .

\begin{tabular}{|c|c|c|c|c|}
\hline \multicolumn{5}{|c|}{ Tabela 4: Evolução do número de IES, segundo a categoria administrativa - } \\
Brasil (1996 a 2008) \\
\hline \multirow{2}{*}{ ANOS } & & \multicolumn{4}{c|}{ Pública } & \multirow{2}{*}{ Privada } \\
\cline { 2 - 4 } & Federal & Estadual & Municipal & \\
\hline 1996 & 57 & 74 & 80 & 711 \\
\hline 1998 & 57 & 74 & 78 & 764 \\
\hline 2000 & 61 & 61 & 54 & 1004 \\
\hline 2002 & 73 & 65 & 57 & 1442 \\
\hline 2004 & 87 & 75 & 62 & 1789 \\
\hline 2006 & 105 & 83 & 60 & 2022 \\
\hline 2008 & 93 & 82 & 61 & 2016 \\
\hline
\end{tabular}

Fonte: MEC/Inep, Resumo Técnico. Censo da Educação Superior 2008: Dados preliminares, p. 8.

A ampliação das IES ocorre principalmente no setor privado, conforme se verifica na tabela 4 , com acréscimo de $283,5 \%$ no período, de 1996 a 2008. Com a estabilidade econômica, algumas IES abriram novos campi ou mesmo novas IES surgiram no interior do Brasil, levando as licenciaturas em Geografia a um novo processo de interiorização, resultando na produção de algumas singularidades na estrutura e funcionamento dos cursos relacionadas às demandas e especificidades dos lugares onde estão inseridos.

Uma das peculiaridades diz respeito ao fato de a maioria das licenciaturas em Geografia estarem nas IES públicas, sobretudo na Amazônia, parte do Centro-Oeste e no Sertão Nordestino, regiões que, apesar do atual crescimento econômico, têm menor densidade técnica, econômica e populacional do que a Região Concentrada.

Há uma distinção temporal na existência dos cursos de Geografia no Brasil. São tempos espaciais distintos na existência dos cursos. Em 
relação ao tempo espacial Milton Santos (2008) e Roberto Lobato Corrêa (2006a) dizem que cada lugar possui uma idade e variáveis que combinadas criam tempos espaciais diferentes. Como diz Corrêa:

Alguns segmentos incorporam vários momentos da história, enquanto outros podem ser muito recentes, incorporando apenas o presente. Ou seja, essas diferenças refletem os momentos históricos em que cada segmento foi gerado, sua inércia dinâmica ou o modo como manteve continuidade e permanece vivo no presente, expressando variáveis que têm significado e pesos específicos para a totalidade social (CORRÊA, 2006a, p. 41).

Por isso, os cursos contêm uma espessura de história distinta, pois estão em diferentes lugares e situações que levam a diferentes significados os elementos analisados dos cursos.

Como já destacamos na seção 2, os primeiros cursos de Geografia interiorizados foram criados no estado de São Paulo, alguns já no final da década de 1950, nas cidades de Rio Claro, Lins, Presidente Prudente, Bauru e Sorocaba.

Esta situação já apontava a centralidade deste Estado cuja metrópole paulistana destaca-se como metrópole onipresente no território brasileiro (SANTOS, 2008a), sobretudo após a década de 1940, por isso, atraiu muitos imigrantes entre os anos 1960-70. Algumas cidades paulistas tornaram-se centralidades regionais, devido à intensa urbanização e ao crescimento econômico, como região industrial e como centro de informação e produção de conhecimento.

Conforme diz Cassiano Caon Amorim, em sua tese, sobre este processo de industrialização do território brasileiro neste período:

A partir dos anos 1940-1950, é a lógica da industrialização que prevalece: o termo industrialização não pode ser tomado, aqui, em seu sentido estrito, isto é, como criação de atividades industriais nos lugares, mas em sua mais ampla significação, como processo social complexo, que tanto incluiu a formação de um mercado nacional, quanto os esforços de equipamento do território para torná-lo integrado, como a expansão do consumo em formas diversas, o que impulsiona a vida das relações (leia-se terceirização) e ativo o próprio processo de urbanização. Essa nova base econômica ultrapassa o nível regional, para situar-se na escala do país [...] (AMORIM, 2010, p.129). 
Esta lógica da industrialização incorporou novas áreas do território brasileiro, sobretudo na Região Concentrada, intensificando a urbanização e a ampliação dos serviços existentes. Os Estados do Rio de Janeiro, Rio Grande do Sul, Paraná, Ceará e Minas Gerais vieram na sequência neste processo de interiorização dos cursos, nas décadas de 1960-70.

Importa ressaltar que, nos $\operatorname{anos}^{78} 1960-80$, também houve a expansão dos cursos de Estudos Sociais pelo território brasileiro nas Faculdades de Ciências e Letras, principalmente nas IES privadas da Região Concentrada, ocasionada pela regulamentação do governo com a criação dos Estudos Sociais (1964) e com as licenciaturas curtas (1972), bem como pelo interesse do setor privado e de algumas IES municipais por estes cursos devido à alta demanda pela formação para a docência em cursos mais rápidos de dois anos, o que os tornava mais rentáveis já que a demanda era grande.

Outro momento de interiorização dos cursos de licenciatura em Geografia vai ocorrer na década de 1980, em Pernambuco, Pará, Bahia e Goiás, mas foi uma expansão que atingiu poucas cidades, com a criação de IES públicas.

No Pará, este início de interiorização das licenciaturas em Geografia deu-se principalmente em torno da rede urbana entre Belém e Marabá, com a criação de cursos em municípios como Cameta, Abaetetuba e Marabá, cidades em torno do Rio Tocantins, cuja dinâmica econômica relaciona-se com o sistema viário da porção oriental do Pará. Assim como em outros eixos de urbanização, como no caso de Castanhal do Pará, Altamira, Bragança, Santarém e Soure, todos pela Universidade Federal do Pará $^{79}$, em 1987.

78 Nos anos 1960, a urbanização brasileira intensificou-se ainda mais, segundo o IBGE a taxa de crescimento urbano entre $1960-70$ esteve na ordem de $65,5 \%$ e de $1970-80$, foi de $55,01 \%$. Foi o período do êxodo rural e do crescimento das grandes cidades principalmente da Região Concentrada e das capitais. Na Amazônia, por exemplo, em 1960, Belém e Manaus concentravam juntas 54,5\% da população urbana regional (CORRÊA, 2006a).

79 O curso de Geografia na UFPA foi criado em 1954, em Belém, pertencia ao Departamento de Geociências e em 1971 integra-se ao Centro de Filosofia, Ciências e Letras. 
Esta expansão ocorreu principalmente em municípios de pequeno e médio porte, concentradas principalmente na porção oriental do estado, à exceção de Santarém e Altamira.

\section{Os Cursos de Licenciatura em Geografia no Interior do Brasil (2009)}

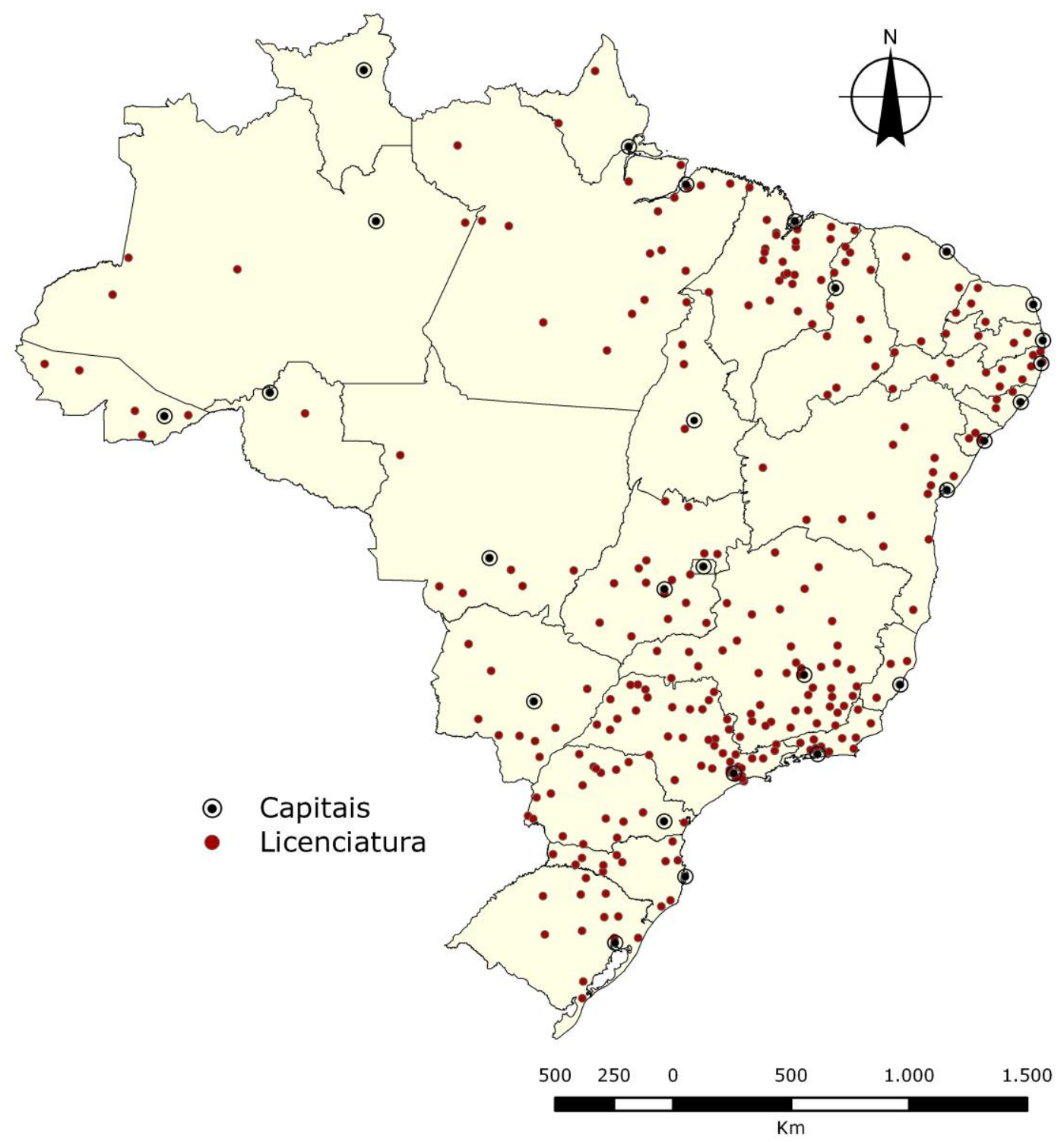

Mapa 8- Fonte: MEC, 2009. Dados organizados por Vivian Fiori.

Elaborado por Maurício Yamada, 2010. Obs. O mapa tem apenas os cursos dos municípios do interior.

Já o processo de interiorização dos cursos de Geografia mais recente ocorreu principalmente no Acre, Amapá, Tocantins, Maranhão, Piauí e Rondônia, regiões fronteiriças do país, pós 1996, além da ampliação ocorrida com a transformação de Estudos Sociais em cursos de 
licenciatura em Geografia em muitas IES privadas, principalmente na Região Concentrada.

Conforme se observa no mapa 8 , algumas licenciaturas em Geografia localizam-se em municípios bastante distantes das capitais, caso das localizadas em municípios dos estados do Acre, Maranhão, Piauí, Bahia, Tocantins, Goiás, São Paulo, Paraná, Santa Catarina, Rio Grande do Sul, entre outros.

Há também o componente político, sobretudo na criação de novos campi de IES públicas em cidades do interior, cuja decisão nem sempre se dá por caráter de necessidade ou centralidade do município na região e sim por questões de definições político-partidárias.

Neste caso, não se trata apenas do binômio IES-Curso, mas também das características econômica, político-administrativa e de infraestrutura que criam capilaridade e produção de conhecimento mais em alguns lugares do que em outros.

Conforme se verifica no mapa 9, as licenciaturas em Geografia se localizam principalmente nas capitais, exceção ao município de Palmas em Tocantins que é a única capital que não tem curso de Geografia. A maioria concentra-se nas cidades com mais de 1 milhão (cidades de grande porte), e algumas destas são consideradas metrópoles, caso de Brasília, Rio de Janeiro, Belo Horizonte, Recife, Salvador e Porto Alegre.

Tais municípios possuem as seguintes características principais na divisão social e territorial do trabalho: maior infraestrutura de serviços e de comércio; consolidam-se como centros de gestão administrativa e de negócios; sediam um número maior de IES públicas e privadas e possuem um mercado consumidor expressivo, o que favorece a existência de IES privadas. Por isso, tornam-se centralidades de seus respectivos estados.

Portanto, nesse processo de hierarquização, há centralidades vinculadas mais ao nível estadual, caso principalmente dos municípios que são capitais. Mesmo que sejam cidades de porte médio, destacam-se por serem capitais e concentrarem a maioria dos serviços de seus respectivos estados; há outras regionais (em diversos níveis de escala) e há, ainda, 
aquelas como São Paulo que são centralidades num nível nacional, tornando-a gestora de informação e de produção de conhecimento.

Esta afirmação não desconsidera as outras existências, tampouco se considera que, por adquirir um papel de centralidade nacional, há extensão e capilaridade a todos os lugares da cidade e do estado de São Paulo, por exemplo.

Ao analisar o total da população nas localidades onde existem licenciaturas em Geografia (mapa 9) verifica-se que há um grande número de municípios de pequeno porte, com menos de 100 mil habitantes, cujas IES e seus cursos conquistaram novos territórios, geralmente cursos relacionados à educação, com formação de professores.

Reconhece-se que o termo município de pequeno porte, referente aqueles com até 100 mil habitantes, pode ser relativo, já que tem diferente valor, por exemplo, um município na Amazônia e outro na Região Concentrada do Brasil em relação ao grau de importância que podem ter em suas regiões ou estados e de suas conexões interurbanas. Contudo, optou-se por este termo já que tem relação com a quantidade absoluta de população e a necessidade da formação de professores.

Este é o caso, entre outros, dos municípios da Amazônia ${ }^{80}$ e CentroOeste que dispõem de cursos de licenciatura em Geografia: Brasiléia, Cruzeiro do Sul, Sena Madureira, Senador Guiomard e Tarauaca no Acre; Benjamin Constant, Tefé, Parintins e Tabatinga no Amazonas; Laranjal do Jarí, no Amapá; Brejo Grande do Araguaia, Breu Branco, Breves, Juruti, Oriximiná, Ourilândia do Norte, Altamira, Rondon do Pará, Soure e Tucuruí no Pará; Rolim de Moura e Ariquemes em Rondônia; Colinas do Tocantins e Porto Nacional no Tocantins.

80 A divisão em quatro grandes complexos regionais definidos por Amazônia, CentroOeste, Nordeste e Região Concentrada foi apresentada por Milton Santos (2001a). Nesta proposta a Amazônia compreende os estados do Amazonas, Pará, Amapá, Roraima, Rondônia e Acre. 


\section{Total da População dos Municípios com Cursos de Licenciatura em Geografia -2009}

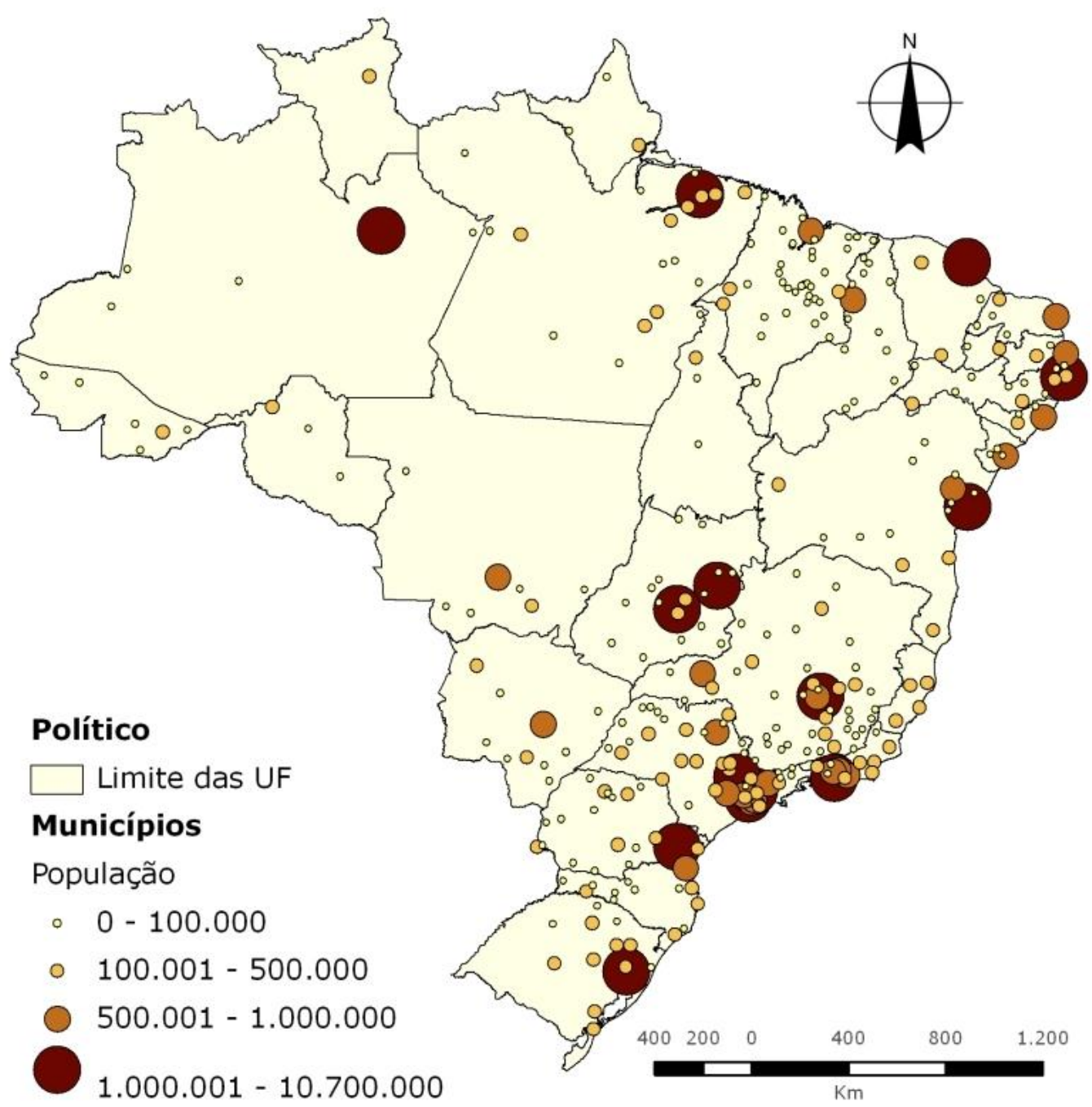

Mapa 9- Fonte: Censo, IBGE, 2010. Dados organizados por Vivian Fiori.

Elaborado por Maurício Yamada, 2010.

As hierarquias urbanas no mundo atual são mais complexas que no passado, e sua hinterlândia já não se estabelece no binômio local-regional apenas, assim como não se dá somente num nível estadual entre municípios da capital e do interior.

Assim, como exemplo, o fato de o atual Exame Nacional do Ensino Médio (ENEM) realizar provas nacionais que servem como acesso ao Ensino Superior fez com que estudantes oriundos de regiões, como Nordeste, por exemplo, fossem estudar no Sul do Brasil. 
Esta relação do discente com a sua localidade de origem é maior nas IES privadas do que nas públicas estaduais e federais, cujos alunos podem vir de outras localidades, sobretudo mediante um vestibular mais seletivo ou mesmo pelo processo atual do ENEM.

Dessa forma, consideramos a afirmação de Milton Santos sobre a situação da formação das redes urbanas no atual período:

Houve tempo em que se podia tratar a rede urbana como uma entidade onde as cidades se relacionavam segundo uma hierarquia de tamanhos e funções. Este tempo passou. Hoje, cada cidade é diferente da outra, não importa o seu tamanho, pois entre as metrópoles também há diferenças (SANTOS, 2008a, p. 5).

Reitera-se ainda a existência de modelos mais tradicionais de hierarquias, que tem correspondência com a teoria de Christaller, mas também surgem novas formas de urbanização e hierarquias urbanas, cujo modelo tradicional já não mais explica.

Após 1990, as taxas de urbanização diminuem segundo o IBGE. No período de 1991-2000 foi de 31,3\% e intensifica-se a urbanização das cidades de porte médio em detrimento das grandes cidades e/ou das metrópoles. Esta situação já vinha ocorrendo desde os anos oitenta, o que leva alguns autores a denominar o processo de desmetropolização ou involução da metrópole (SANTOS, 1994, 2008a).

Sobre este papel das cidades de médio porte Milton Santos (2008a, p. 53) diz: "Esse fenômeno de difusão do trabalho intelectual na rede urbana, alcançando não apenas as grandes cidades, mas também cidades médias e os centros locais, parece ser geral, isto é, em escala de todo o território".

Nesta atual complexidade de concentração e descentralização de atividades, de tensão dialética entre territórios que polarizam e, ao mesmo tempo, da seletividade da descentralização das atividades de educação superior, interessa especialmente evidenciar a distribuição espacial dos tipos de IES onde se localizam as licenciaturas em Geografia, bem como seus conteúdos e situações. 
Em 1996, ano a partir do qual se destaca o período nesta tese, conforme se observa no mapa 10 , ainda se percebia uma rarefação de cursos de Geografia na Amazônia, todos localizados em IES públicas federais. Esta situação evidencia o papel do governo federal ou estadual criando IES onde havia maior rarefação de densidade técnica e populacional neste período. A Universidade do Estado do Amazonas (UEA), por exemplo, foi criada só em 2001.

No Centro-Oeste e Nordeste havia também um predomínio de licenciaturas em IES públicas federais e estaduais, estas localizadas principalmente em Goiás, cujos cursos de licenciatura em Geografia se interiorizaram já na década de 1980-90, em municípios como Anápolis, Goiás, Ipora, Itapuranga, Morrinhos, Pires do Rio, Porangatu, Jataí, Quirinópolis e Catalão, em sua maioria pela Universidade Estadual de Goiás ${ }^{81}$.

No Nordeste, existia pouca interiorização das licenciaturas em Geografia nesta época, exceção feita a Pernambuco com as IES municipais, que, embora situados em IES públicas, são cursos pagos. No estado da Bahia, ocorreu principalmente pela inserção em novos territórios de IES estaduais como a Universidade do Estado da Bahia (UNEB), Universidade Estadual de Feira de Santana (UEFS) e Universidade Estadual do Sudoeste da Bahia (UESB), que já possuíam cursos no interior do estado antes de 1996.

Na Região Concentrada, havia maior presença de cursos em IES privadas, sobretudo no estado de São Paulo, evidenciando o poder econômico e a existência de um grande contingente populacional com condições financeiras de arcar com os custos de um curso superior, cujo

81 Segundo site da Instituição, a criação da Universidade Estadual de Goiás ocorreu em 1999, com a transformação da antiga Universidade Estadual de Anápolis e com a incorporação de outras 12 Faculdades Isoladas, mantidas pelo poder público. Logo, algumas destas IES já tinham cursos de licenciatura em Geografia antes 1999. O processo de urbanização em Goiás está ligado também à criação de Brasília, capital do Brasil, na região Centro-Oeste em 1960, assim como com o uso do território para a agricultura moderna em diversos espaços do cerrado (SANTOS, 2008a). 
público principal é formado por alunos trabalhadores. Esta região torna-se cada vez mais território do meio técnico-científico-informacional.

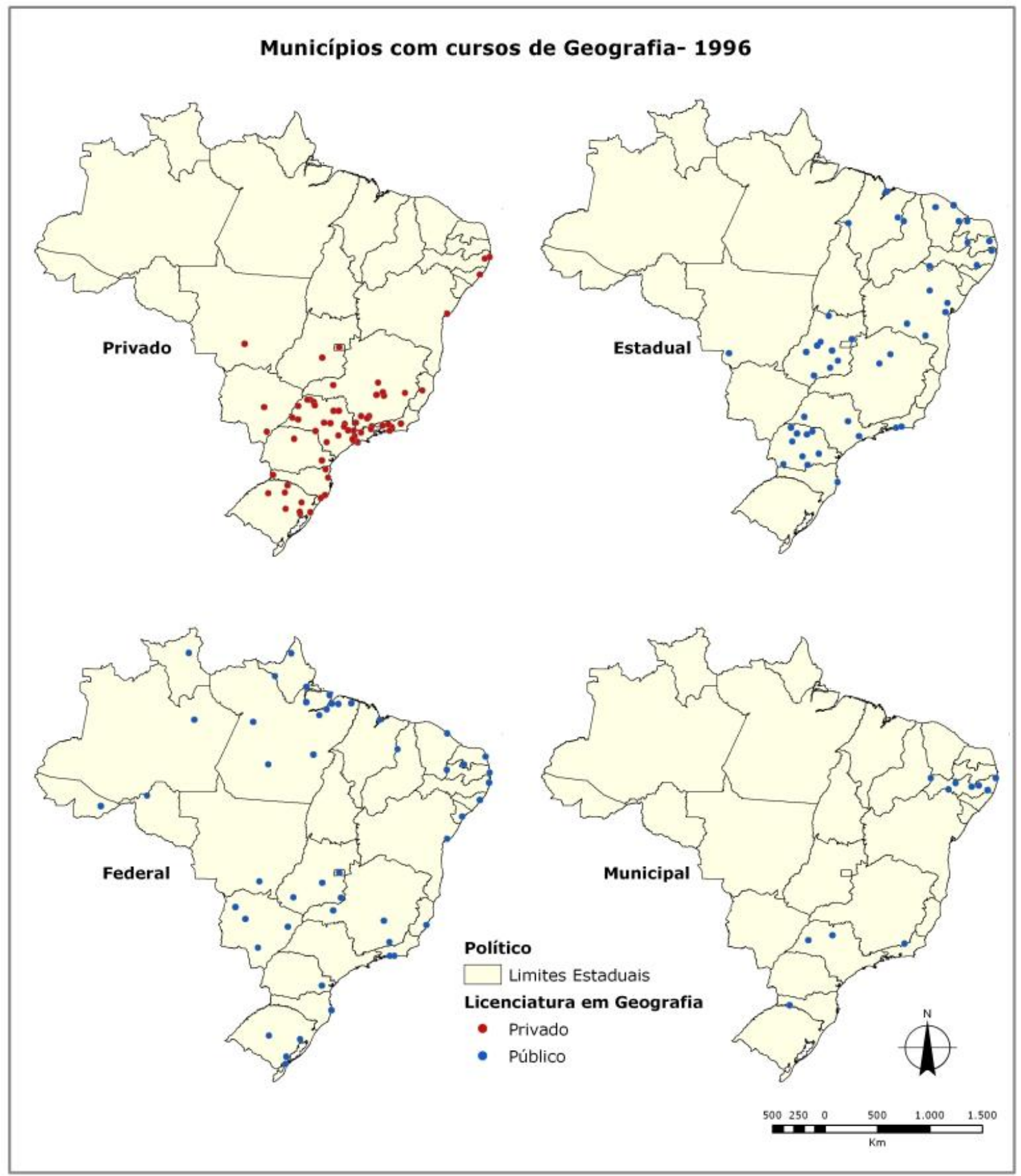

Mapa 10 - Fonte: MEC, 2009. Dados organizados por Vivian Fiori. Elaborado por Maurício Yamada, 2010.

Além disso, a maior demanda por vestibulares das grandes IES públicas fazia e ainda faz com que parte dessa população interessada em ir para um curso superior não tivesse acesso à instituição pública. 
Outra situação peculiar é que no estado de São Paulo não havia nenhum curso de Geografia em IES federal até $1996^{82}$. A presença de tais instituições federais era maior no Rio Grande do Sul, Minas Gerais e Rio de Janeiro e já vinha de períodos anteriores a 1996.

Devido à maior centralidade econômica de São Paulo, desde a década de 1930, período no qual foram criados os primeiros cursos de Geografia do Brasil, o próprio estado assumiu a criação das IES públicas, primeiramente com a USP, depois com a UNESP e Unicamp.

A maior mecanização e modernização de parcelas do território brasileiro após anos 1990-2010 permitiram que novos contextos urbanos e econômicos surgissem, alterando ou reforçando a divisão territorial já existente.

De um lado, áreas de expansão de fronteira agropecuária, que já haviam alcançado o estado do Mato Grosso, chegam cada vez mais ao Maranhão, Oeste do Piauí, Tocantins, Oeste da Bahia e mais recentemente na Amazônia brasileira.

Esta expansão, embora realizada principalmente pela atividade agropecuária, gerou demandas urbanas e acrescentou novos investimentos nestas regiões. Há, portanto uma fluidez no território comandada principalmente por atores hegemônicos, grandes empresas mineradoras, commodities agroindustriais entre outros agentes que chegam a novas porções do território brasileiro.

A estabilidade monetária e econômica facilitou esta incursão do grande capital pelo interior do país, possibilitado também pelas políticas governamentais neoliberais a partir dos anos 1990, que acarretaram a privatização ou a concessão de serviços voltados à criação e à ampliação de infraestrutura de transporte e energia. Tais atividades são fundamentais para a ampliação da mecanização e de novos usos do território, com certas especializações.

82 No Brasil, entre as décadas de 1950-60, algumas IES públicas e privadas foram federalizadas, caso da UFMG (1949), UFPR (1950), UFRGS (1950), UFBA (1950), UFPA (1959), UFRN (1960), UFAL (1960), UFJF (1960), UFF (1960), (UFES (1961). 
Contudo, há também movimento dos mais pobres, do migrante, do tempo mais lento e menos moderno, dos circuitos espaciais das atividades dos garimpos, dos caiçaras, dos serviços e do comércio informal que abundam principalmente nas cidades médias e grandes.

Logo, há desequilíbrios dos usos sociais dos territórios, grandes desigualdades que possibilitam a existência de formação em Geografia em lugares com diversificada condição social e econômica, já que as licenciaturas após 1996 alcançaram cidades de pequeno e médio porte e, ao mesmo tempo, continuam concentradas nas capitais.

Tânia Bacelar (2000) aponta que, além das atividades agropecuárias, a indústria também passou a ser mais desconcentrada, movimento que já vinha de período anterior (1970-90) e foi reforçado nos anos 1990. Isto não significa que a Região Concentrada tenha perdido sua hegemonia e tais atividades ainda não sejam fortemente concentradas, mas houve maior dispersão destas pelo território, num processo seletivo, gerando demandas urbanas do setor terciário, entre elas os serviços educacionais.

Há, pois, um processo de urbanização cujo indutor não se dá somente pelo processo de industrialização, mas também ocasionadas pelas atividades no campo, que criam núcleos urbanos mais adensados, sejam provenientes de demandas dos commodities agroindustriais, sejam em núcleos oriundos de uma urbanização em torno de garimpos etc.

Há relação entre estas demandas do território por serviços educacionais, a expansão das IES e das licenciaturas em Geografia. Não que a demanda em si pela formação de novos professores seja o único motivo da criação de novos cursos de licenciatura, mas sim de forma integrada relaciona-se à existência das IES, ao processo de urbanização e às políticas educacionais existentes, que acabam criando novas licenciaturas em Geografia.

$\mathrm{Na}$ Geografia do Ensino Superior brasileiro, o agente principal da existência das licenciaturas em Geografia no interior é público, principalmente em Universidades. Já nas capitais que se constituem em 
centralidades urbanas, coexistem vários tipos de IES, com maior presença das privadas, principalmente na Região Concentrada.

Neste novo processo de interiorização, o caso do Maranhão e do Piauí chama a atenção devido ao grande número de cursos de licenciatura espalhados pelos municípios interioranos (mapa 11). Até 1989, o número de licenciaturas em Geografia nestes estados era de três e dois, respectivamente.

Segundo Vadenildo Pedro Silva (2007), professor do curso de mestrado da UFRN, os cursos criados pelo interior do Nordeste possuem baixa carga horária e baixa qualificação docente, muitas vezes por clientelismo político, já que a criação destes pelo interior dá visibilidade política aos governos que propiciam essa ação.

Em 2010, chega-se a vinte e seis e quinze. No caso do Maranhão, os cursos de licenciatura em Geografia ocorrem na Universidade Estadual do Maranhão (UEMA), e, conforme dados do Sistema E-MEC (2010), havia uma mesma coordenadora dos cursos, ao menos formalmente, em vinte e dois municípios, assim como parte do corpo docente, segundo o site da UEMA, também é o mesmo em alguns municípios.

Cita o caso da expansão das licenciaturas em Geografia, promovida pela Universidade Estadual do Rio Grande do Norte (UERN), para os municípios de Pau de Ferros, Caraúbas e Açu, no interior do Rio Grande do Norte, com qualificação docente inadequada e sem infraestrutura condizente com as necessidades dos cursos, conforme se constata no excerto abaixo:

[...] a distribuição dos cursos de geografia pelo país, podemos afirmar que em estados como Maranhão e Piauí, por exemplo, houve uma verdadeira banalização dos cursos de formação de professor de Geografia, dado o fato de que antes da vigência da nova LDBEN, existiam em média três cursos funcionando nesses dois estados e em poucos anos esse número foi elevado para 37 e 32 cursos de geografia, respectivamente (SILVA, 2007, p. 177).

Além das condições nas quais ocorre este processo de interiorização das licenciaturas de Geografia pelo Brasil, necessárias pela demanda de formação de professores, deve-se considerar por quais tipos de IES estão 
distribuídas (mapa 11). No Piauí, por exemplo, este processo ocorre por meio de uma IES estadual, portanto, pública. Não há qualquer curso no interior do Piauí que seja privado e nem de bacharelado em Geografia.

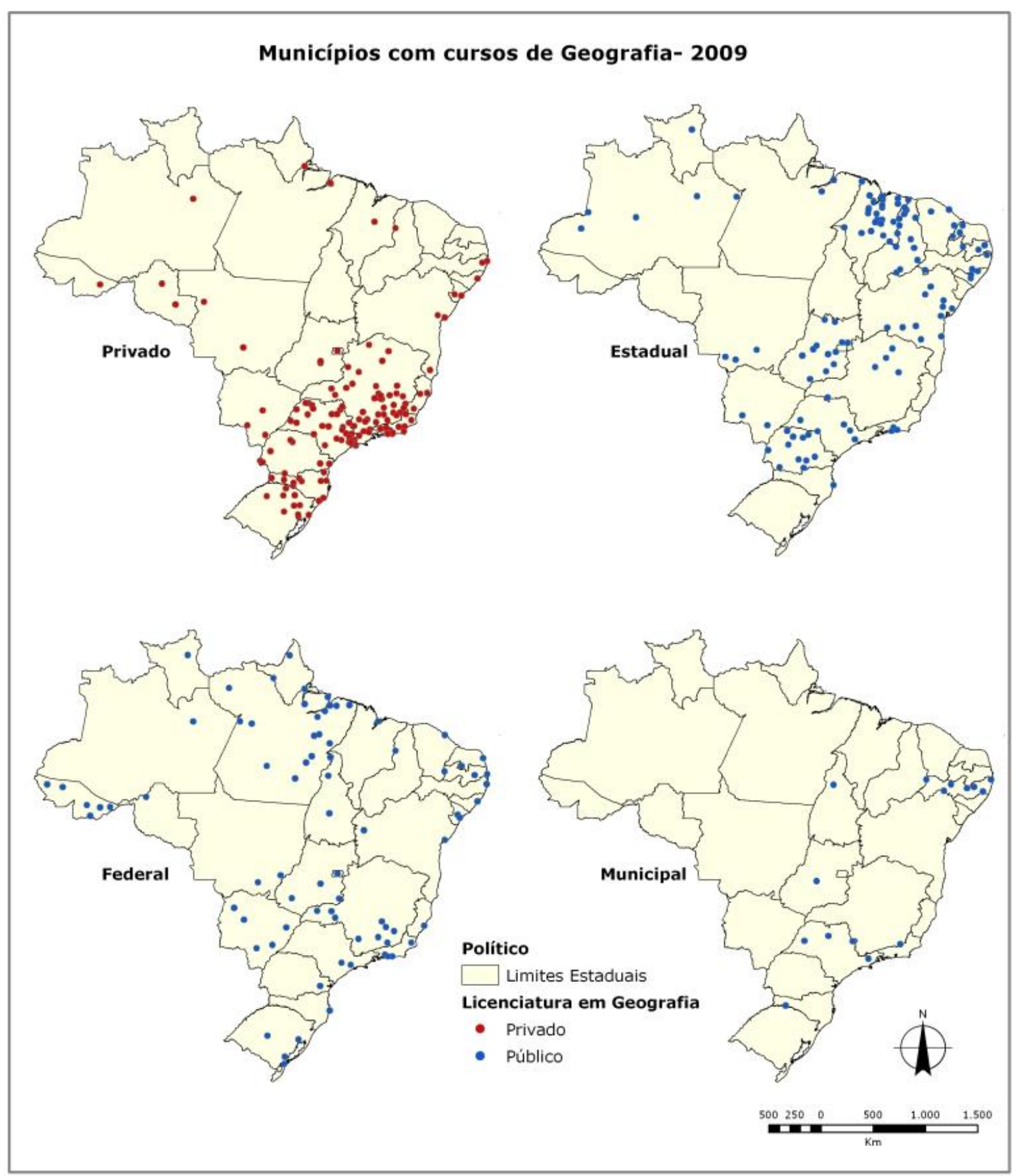

Mapa 11 - Fonte: MEC, 2009. Dados organizados por Vivian Fiori. Elaborado por Maurício Yamada, 2010.

No Acre e em Tocantins, a expansão ocorreu pelas instituições federais. Em situações diferentes há, em Pernambuco, as IES públicas estaduais e municipais, e, em São Paulo, principalmente as privadas. No 
mapa 11, verifica-se que as IES privadas estão localizadas mais na Região Concentrada do país, já as municipais, no interior de Pernambuco.

Então, deve-se considerar que tal processo ocorre de forma diferente pelo território nacional, mas, ao mesmo tempo, é um processo dialético, já que o grande número de instituições privadas em São Paulo, por exemplo, reflete a economia, e a grande densidade técnica, de serviços e populacional do estado. Ou seja, o território é subordinado e subordinante.

A seguir, os cursos de Geografia serão analisados nas dimensões docente, discente, de infraestrutura e de elementos curriculares, sempre os relacionando às condições espaciais. Ou seja, os elementos ganham conteúdo nos lugares onde estão inseridos. Há uma circularidade dialética entre as dimensões e os lugares onde os cursos acontecem e tem sua existência.

\subsection{As dimensões e elementos de análise dos cursos de Geografia}

Como se verifica, nas análises já expostas, há novos processos de capilaridade que levaram IES e cursos de Geografia, principalmente licenciaturas, até as regiões de frentes de expansão, bem como ao interior de regiões onde esta ocupação já existia, mas onde não havia cursos de Geografia. Há ainda os cursos de educação a distância que, em princípio, podem chegar a vários lugares. Considerando-se as diversas dimensões dos cursos, de uma forma integrada, é importante que os novos processos sejam compreendidos como espaciais.

Os seus elementos e suas dimensões devem ser analisados de forma integrada, sobretudo porque eles têm valor na medida em que são analisados espacialmente, num processo dinâmico, no qual interagem elementos, variáveis e lugares.

A dimensão de análise de discentes, docentes, infraestrutura e de elementos curriculares permitem entender em que situações se encontram os cursos de Geografia. Estas dimensões, explicitadas no Quadro 2, são 
expressões de um estado e precisam ser contextualizadas, não tendo sentido em si mesmas senão no contexto no qual ocorrem.

\begin{tabular}{|c|c|}
\hline \multicolumn{2}{|r|}{ Quadro 2- Principais elementos e variáveis analisados } \\
\hline Dimensões & Elementos e/ou Variáveis \\
\hline Discente & $\begin{array}{l}\text { Renda; Período de estudo; Trabalho; Tipo de Escola que cursou no } \\
\text { Ensino Médio; Interesse em ser professor. }\end{array}$ \\
\hline Docente & Formação do Docente; Regime de Trabalho Docente. \\
\hline Infraestrutura & $\begin{array}{l}\text { Condições das instalações físicas dos cursos; Condições dos } \\
\text { equipamentos dos laboratórios; Atualização do acervo da Biblioteca; } \\
\text { Número de exemplares disponíveis na Biblioteca; Atualização dos } \\
\text { periódicos; Frequência de uso da Biblioteca; Fonte de Pesquisa no } \\
\text { Curso. }\end{array}$ \\
\hline Currículo & $\begin{array}{l}\text { Integração do Currículo; Características da matriz curricular; } \\
\text { Conhecimento prévio da formação em Geografia; Consciência do que } \\
\text { é ser professor; Preferência de atuação na área de Geografia; } \\
\text { Principal razão da escolha do curso de licenciatura; Material Didático } \\
\text { mais utilizado no Curso de Geografia; Atividade Acadêmica mais } \\
\text { utilizada além das obrigatórias; Oferecimento do Programa de } \\
\text { Extensão e de Iniciação Científica. }\end{array}$ \\
\hline
\end{tabular}

Elaborado por Vivian Fiori, 2012.

Assim como os elementos podem tornar-se variáveis quando quantificados; considera-se que a quantidade é expressão de uma qualidade e não tem existência sem se relacionar a uma condição ou estado específico (SANTOS, 2008b).

É necessário, também, que as dimensões sejam entendidas num processo histórico, dialético, que, integrado com outros elementos e variáveis, se imbricam com os lugares e com a dinâmica de uso e organização do território, sendo condição indissociável a relação espacial com as dimensões e elementos analisados, conforme se verá a seguir.

\subsubsection{A dimensão das características dos discentes}

A expansão do Ensino Superior no Brasil ocorre desde a década de 1970 e ampliou-se a partir dos anos 1990, levando ao Ensino Superior, cada vez mais, as classes sociais populares.

Estudos como o de Nadir Zago (2006) demonstram que, apesar desta ascensão, ainda há muitos jovens que nem pensam em chegar ao 
Ensino Superior, quer por não acreditarem nesta possibilidade devido às dificuldades do processo seletivo para ingressar no curso que pretendem, quer por terem dificuldades em se sustentar e estudar ao mesmo tempo, devido à baixa renda que de dispõem.

Além disso, não basta ter acesso ao Ensino Superior. É necessário, também, permanecer nele, fato que dificulta ainda mais a situação dos mais pobres. Estes geralmente buscam estudar no período noturno, já que necessitam trabalhar durante o dia, e, muitas vezes, ao perderem 0 emprego, acabam desistindo do curso, que para estes grupos geralmente é realizado em IES privada, faculdades ou centros universitários mais comumente.

Esta condição do estudante de nível superior que estuda à noite $\mathrm{e}$ trabalha, segundo pesquisadores (BARREIRO; TERRIBILI FILHO, 2007), é relativamente recente no Brasil, vem principalmente da década de 1960, com a luta dos estudantes por novas vagas e devido ao crescimento econômico e à urbanização do Brasil, mudando-se a lógica de "estudar para trabalhar" para "trabalhar para poder estudar".

Não se trata de um ciclo e sim de situações condicionantes, que não determinam o percurso dos estudantes das classes populares, já que há estudos mostrando que os mais pobres também ingressam nos cursos em IES públicas, mesmo os mais concorridos.

Trata-se geralmente de estudantes que foram muito bem nos Ensinos Fundamental e Médio públicos, geralmente contam com apoio da família para estudar, mas é comum que seja minoria, sobretudo nas IES onde o processo seja mais seletivo e concorrido.

Neste caso, a centralidade de algumas IES públicas e sua condição no território brasileiro é fundamental, já que historicamente construíram uma imagem de boas instituições e são as mais requeridas pelos estudantes. Há, portanto, uma hierarquia na disputa e no acesso ao Ensino Superior, fundada nos processos seletivos do ingresso, mas também nas condições demográficas, sociais e educacionais e no território onde estão inseridos os estudantes, as IES e seus cursos. 
No território, há relações de poder que concretamente fazem com que sua apropriação seja desigual. Como disse Milton Santos:

Cada homem vale pelo lugar onde está: o seu valor como produtor, cidadão depende de sua localização no território. Seu valor vai mudando, incessantemente, para melhor ou para pior, em função das diferenças de acessibilidade (tempo, freqüência, preço) [...] Por isso, a possibilidade de ser mais ou menos cidadão depende, em larga proporção, do ponto do território onde está (SANTOS, 2002, p. 107).

Como propôs Milton Santos (2006), o espaço deveria ser o espaço de todos, o espaço banal, e não apenas o uso por alguns grupos e classes sociais das formas e ações provenientes dos direitos. Em muitos casos, os estudantes deixam de ser cidadãos para ser consumidores, clientes da educação. Então, aos mais pobres nem sempre é dada a possibilidade efetiva de escolher a formação almejada nas IES que gostariam. Há uma seletividade pautada nas condições sociais e espaciais de vida destes estudantes.

Segundo pesquisas de José Marcelo Biagioni Baroni (2010) e Valéria Cordeiro Fernandes Belletati (2011), a escolha da carreira é mediada principalmente pela condição socioeconômica do estudante. Baroni (2010) aponta elementos fundamentais na escolha do curso: o desempenho escolar do estudante, o tempo disponível para estudar, o grau de competição das carreiras e sua condição socioeconômica.

Cita, ainda, estudos que consideram a hierarquia das carreiras relacionadas à condição socioeconômica dos estudantes em pesquisas principalmente em IES públicas como USP, Unicamp, UFMG e UNESP. Uma delas baseada em Pierre Bourdieu ${ }^{83}$ com conceitos de capital cultural,

83 Pierre Bourdieu, em algumas de suas obras (2008), utiliza conceitos tais como o de capital linguístico, que tem origem principalmente na família e na classe social, e capital cultural, que, segundo o autor, é alcançado mediante diplomas, formação e nível de conhecimento geral. Esta aquisição de capital cultural ocorre num sistema de relações sociais e culturais que se dá em diversos meios sociais, entre eles nas instituições de ensino superior, e no próprio local de onde é proveniente o estudante. Há, segundo ele, uma reprodução do sistema, sendo necessária uma análise multivariada, não apenas pelo sexo, classe social e poder econômico, mas também pelo capital cultural e linguístico que os grupos sociais têm. O sistema reproduz e cria violências simbólicas e coerção social. 
social e simbólico, cria uma classificação das carreiras mediadas pela condição sociocultural do estudante da USP.

Sendo assim, carreiras como as de Medicina, Economia e Direito estariam entre as mais seletas, já as mais populares seriam, por exemplo, Filosofia e as licenciaturas como História e principalmente Pedagogia. Evidencia-se, nestas pesquisas, que há uma relação entre os estudantes mais pobres, que vieram de escolas públicas no Ensino Médio e que buscam cursos considerados mais populares.

Outra pesquisa que corrobora esta ideia foi realizada pelo Inep (2009), mediante questionário respondido por alunos que fizeram o Exame Nacional do Ensino Médio (ENEM) em 2007, acerca da opção relativa à área que pretendiam seguir profissionalmente. Nesta pesquisa, dos $72,7 \%$ que responderam que já escolheram a profissão, apenas $5,2 \%$ optaram pela docência, de cinco opções possíveis, a saber: Engenharias e Ciências Tecnológicas, Ciências Biológicas e da Saúde, Ciências Humanas, Artes e Formação de Professores de Ensinos Fundamental e Médio.

Observa-se, segundo a pesquisa, que a maioria dos interessados em tornar-se professor é formada por mulheres, que estudaram em escola pública, assim como a possibilidade é três vezes maior entre os de menor renda. Núria Hanglei Cacete (2004) aponta que as licenciaturas geralmente são vistas como cursos menos nobres em detrimento de carreiras consideradas de maior prestígio social e/ou de retorno financeiro maior.

Contudo, considerando-se a atual realidade e expansão das IES e das graduações pelo território brasileiro, é necessário considerar diversas mediações neste caso. Uma é a distinção organizacional da IES, se é privada ou pública; a outra, a condição social e cultural do estudante, e uma terceira, a característica do território onde se vive e onde a IES e seus cursos estão instalados. Na verdade, no território, estão contidas as demais mediações, e todas estão relacionadas. 
Portanto, ao escolher um curso, há uma multiplicidade de fatores relacionados, desde a opção livre do estudante, até as relações que permeiam sua vida, o local onde vive e de suas experiências vividas.

As escolhas também dependem das materialidades existentes, tais como a própria existência ou não da IES em seu município, a rede de transporte que lhe permita chegar a IES, o trajeto e o tempo e dinheiro gastos, a necessidade ou não de trabalhar, a sua condição socioeconômica e também se onde vive há o curso que quer.

Logo, há extensões geométricas e existenciais neste caso, ou seja, há casos que devido à distância métrica há dificuldade de acessar o Ensino Superior, de outro, sobretudo nas metrópoles nem sempre estar perto significa acesso ao curso que se gostaria.

Há, também, horizontalidades, pois as relações que permeiam o cotidiano de cada estudante também têm a ver com as escolhas da carreira, com exemplos familiares, no trabalho, ao estudar. No cotidiano do lugar onde se vive, nas relações com outros lugares, tudo isso medeia a escolha profissional.

Assim, ao chegarem ao Ensino Superior para uma formação em Geografia, cabe pensar quem é este aluno, por que escolhe a licenciatura, em que tipo de instituição estudou o Ensino Básico, sua renda familiar, entre outros elementos e variáveis que ajudam a traçar as características gerais destes discentes e entender melhor as condições nas quais se encontram nos cursos de Geografia.

Atualmente, a maioria dos alunos de Geografia trabalha; por isso, estuda no período noturno (Gráfico 6 ). Em 2005, eram 58,5\% dos alunos matriculados no período noturno, e 55,6\%, em 2008.

Considerando-se a distribuição dos discentes que estudavam no período noturno, em 2008, nos cursos de Geografia (mapa 12), há maior concentração no Centro-Sul do Brasil e em Pernambuco. Nos estados de São Paulo, Espírito Santo, Minas Gerais, Pernambuco, Tocantins, Goiás, Mato Grosso do Sul e Paraná, há uma variação de $69,29 \%$ a $87,93 \%$ dos alunos matriculados no período noturno. Estabelece-se uma relação entre 
as condições sociais e econômicas do estudante, o território onde está inserido o curso, e entre elementos e variáveis como renda, trabalho e período de estudo.

Isto também tem relação com os turnos em que se implantam os cursos. Assim, por exemplo, no Maranhão, a UEMA, e no Piauí, a Universidade Estadual do Piauí (UESPI), implantaram as licenciaturas do interior somente no turno diurno, condição diferente da Fundação Universidade Federal do Tocantins (UFT), que, em municípios como Porto Nacional e Araguaína, tem cursos diurnos e noturnos, assim como nas IES públicas municipais de Pernambuco, em que as licenciaturas em Geografia estão fundamentalmente no período noturno.

Há uma tendência das IES privadas serem noturnas já que há maior demanda de estudantes neste período, pois a maioria trabalha. No estado de São Paulo, por exemplo, onde se concentra o maior número de IES privadas, quase todos os cursos de Geografia funcionam no período noturno; mesmo as IES públicas, como a UNESP e a USP, têm, em seus campi, cursos nos dois períodos.

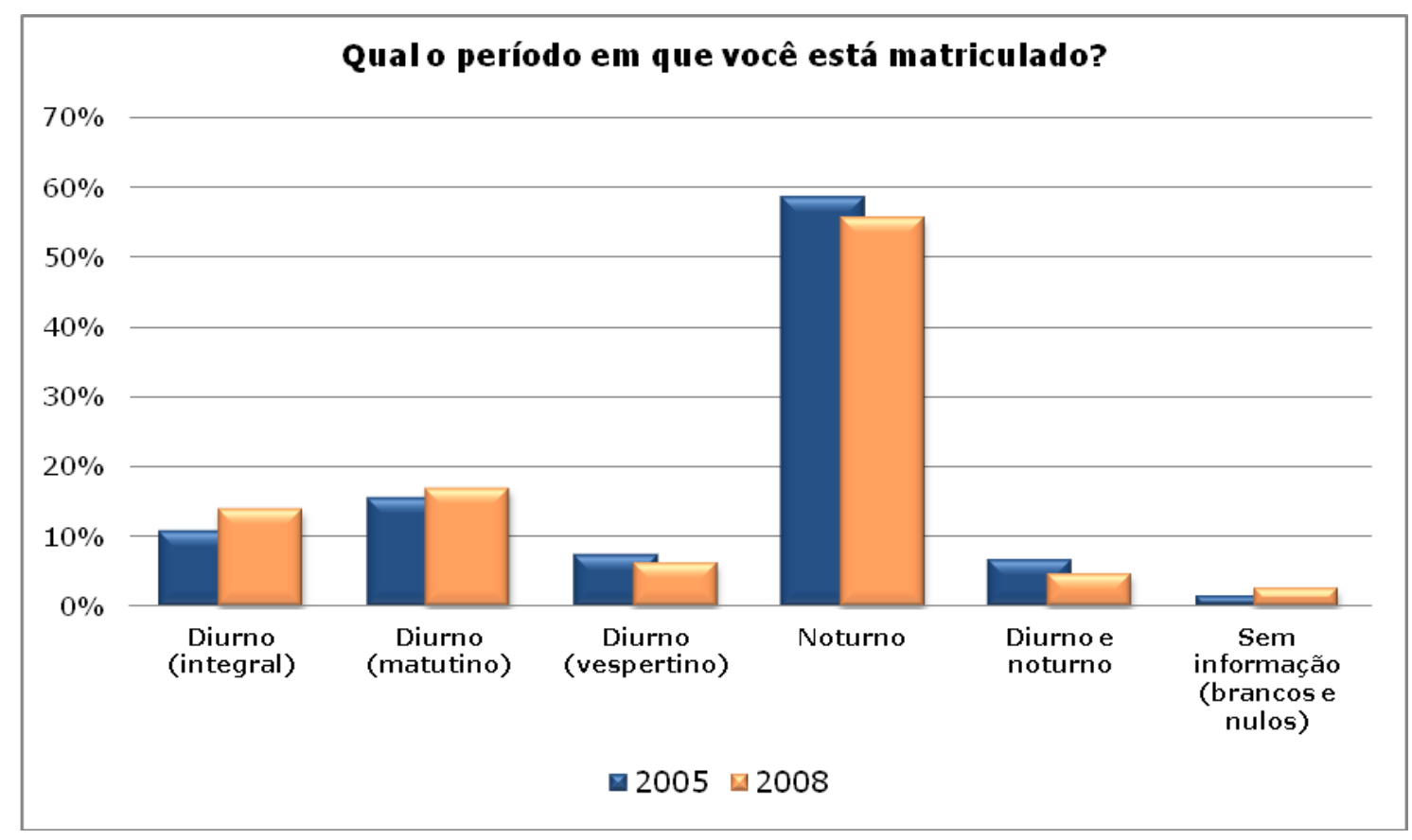

Gráfico 6. Fonte: Inep, Relatórios Sínteses/Cursos de Geografia, Enade 2005 e 2008. Dados organizados por Vivian Fiori, 2009. 


\section{Discentes matriculados no curso de Geografia, por período noturno}

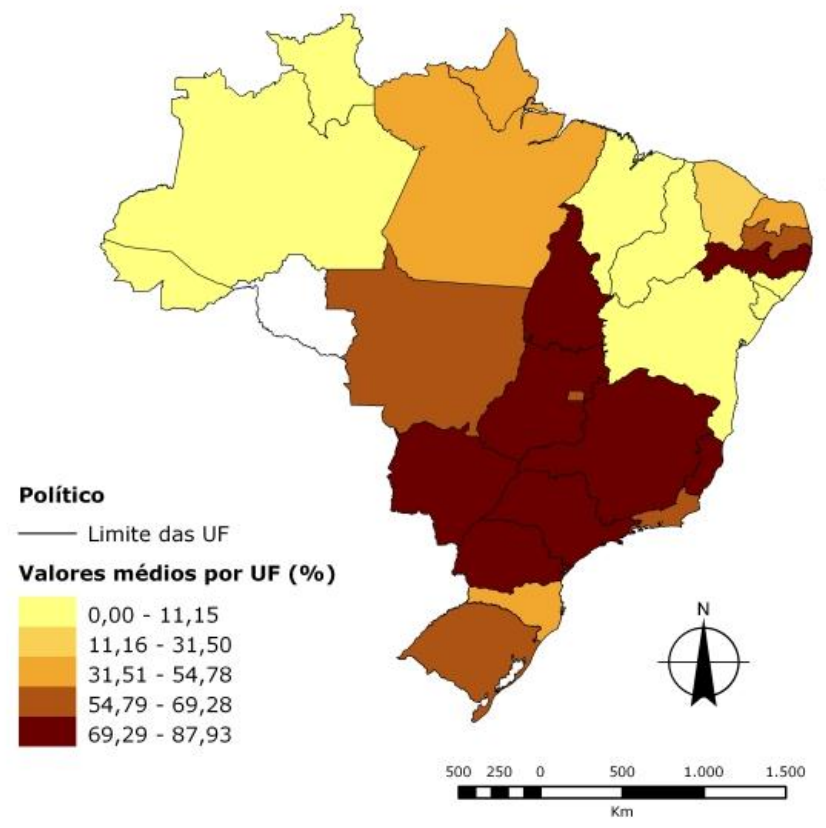

Mapa 12- Fonte $^{84}$ Inep, Relatórios de Cursos de Geografia no Enade, por IES, 2008. Elaborado por Vivian Fiori e Mauricio Yamada, 2010.

Em relação à renda, no Enade de Geografia, em 2008, a maioria dos alunos (53\%) respondeu que tinha uma renda familiar de até três salários mínimos ${ }^{85}$, conforme se verifica no gráfico $7 ; 37 \%$ deles tinham renda familiar de três a dez salários mínimos. Acima desta renda, havia apenas $10 \%$.

Percebe-se, no gráfico, que de 2003 a 2008 a renda dos estudantes de Geografia caiu. Em 2005 a maioria (51\%) encontrava-se na faixa salarial de três a dez salários mínimos, já, em 2008, a renda familiar caiu. Há uma relação desta condição com a expansão das licenciaturas para o interior.

Ao pesquisar-se onde se encontravam os estudantes com menor renda no Brasil (mapa 13), por Unidade da Federação (UF), observou-se que, nos estados do Maranhão, Piauí, Tocantins e Pernambuco, onde os

84 Em todos os mapas elaborados a partir do Enade 2008 não há dados para Rondônia, pois, embora tenham participado, não havia turmas de concluintes, portanto os dados não foram disponibilizados pelo Inep. Neste caso, há dados apenas dos ingressantes. Para esta síntese, foram analisados um a um dos relatórios do Enade 2008 por IES, num total de $\mathbf{3 1 2}$ relatórios.

85 Em 2003 o salário mínimo nacional era de R\$240,00; em 2005, R\$300,00 e, em 2008, $\mathrm{R} \$ 415,00$. 
cursos se interiorizaram, havia uma concentração maior de estudantes de menor renda por UF, chegando até $88,30 \%$ dos que responderam até três salários mínimos em 2008.

Trata-se de uma condição diferenciada comparativamente ao que comumente as pesquisas sobre Ensino Superior mostram, já que, nestes quatro estados, os discentes de menor renda estudam em IES públicas; não se trata de IES particulares.

Esta condição demonstra a existência de IES e licenciaturas em Geografia chegando a localidades mais pobres, principalmente no Sertão Nordestino, e muda a dinâmica de formação e acesso ao Ensino Superior nestas localidades, geralmente municípios pequenos, com baixo dinamismo econômico. São, em princípio, locais pouco populosos que não possuem mercado consumidor que interesse a uma IES privada.

Quando se comparam os dados já mapeados de renda familiar em IES públicas e privadas (Apêndice $A$ ), verifica-se que novamente 0 território brasileiro, e sua formação e diferenças espaciais têm relação com a condição da renda familiar dos discentes.

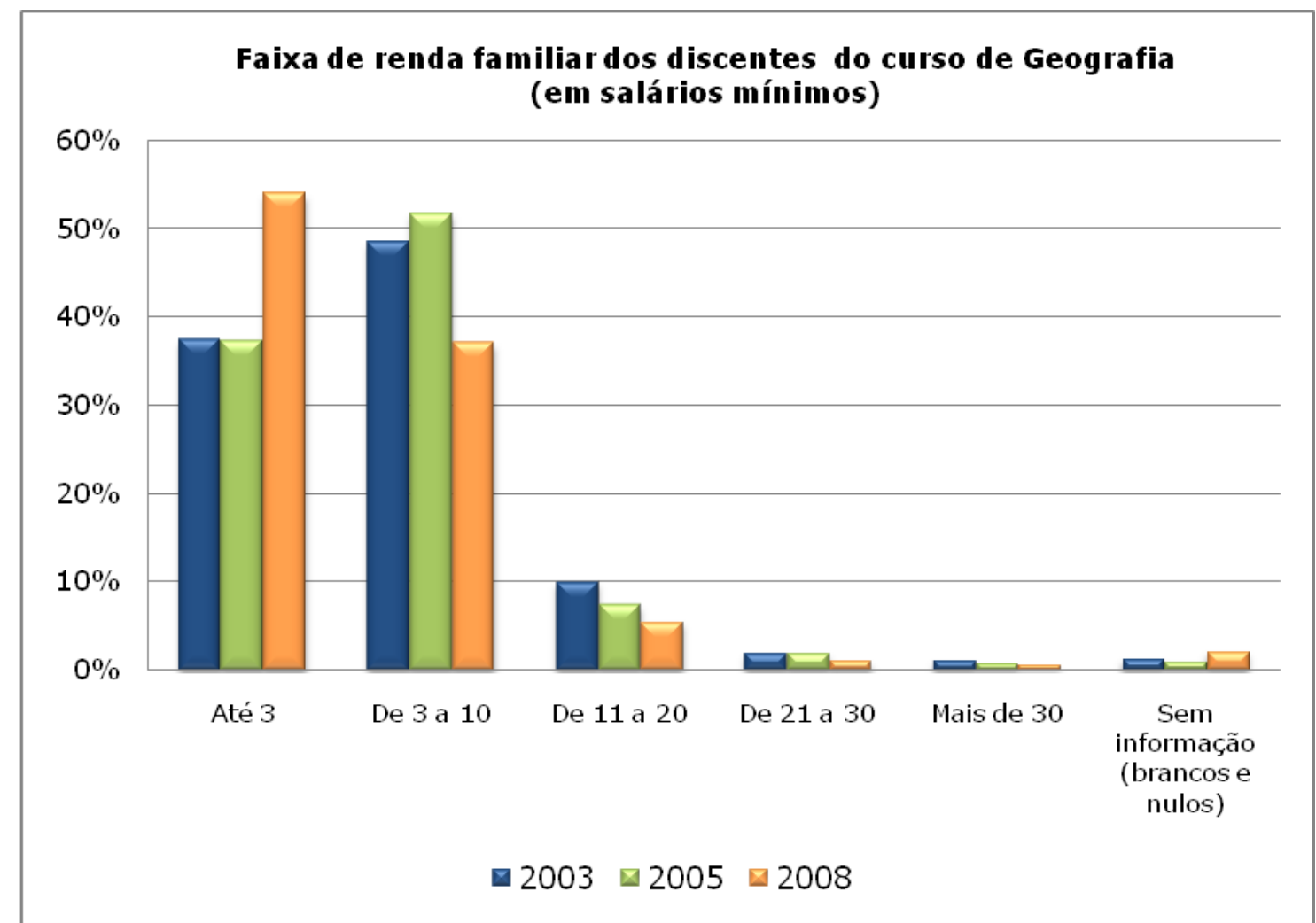

Gráfico 7- Fonte: Inep, Relatórios Sínteses/Cursos, Área de Geografia, ENC 2003 e Enades 2005 e 2008. Dados organizados por Vivian Fiori, 2009.

obs. Em 2003 o salário mínimo nacional era de R\$240,00, em 2005, R\$300,00 e em 2008, R\$415,00. 


\section{Renda familiar dos discentes do curso de Geografia}

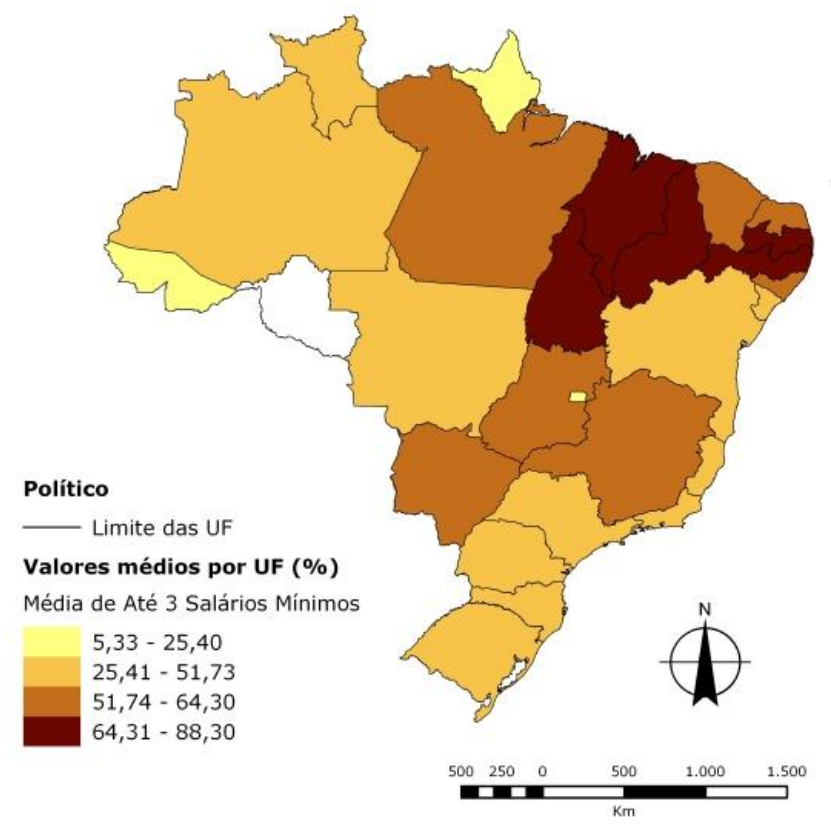

Mapa 13- Fonte Inep, Relatórios de Cursos de Geografia no Enade, por IES, 2008. Elaborado por Vivian Fiori e Mauricio Yamada, 2010.

Assim, no Nordeste ${ }^{86}$, que historicamente constitui-se em uma região, sobretudo o Sertão, de dinâmicas sociais excludentes, com uma estrutura fundiária concentrada e de baixo dinamismo econômico, é onde há maior número de alunos com renda de até três salários mínimos, mesmo nas IES públicas.

Licenciaturas chegando a pequenos municípios, geralmente em cursos temporários, muitos com população inferior a 30 mil habitantes, como é o caso das licenciaturas em municípios do Piauí, Maranhão e Pernambuco, situados em instituições publicas estaduais e municipais.

Já a Região Concentrada, há uma diferença maior de renda entre os estudantes de Geografia das IES públicas e privadas, principalmente nos estados onde existe mais densidade técnica e econômica. Comparando-se renda dos estudantes das IES, com até três salários mínimos, há a seguinte condição:

86 Sobre esta região Milton Santos, comparando-a as demais regiões brasileiras, no período 1960-80, afirmou: "Outra é a realidade do Nordeste, onde uma estrutura fundiária, hostil desde cedo à maior distribuição de renda, ao maior consumo e à maior terciarização, ajudava a manter na pobreza milhões de pessoas e impedia uma urbanização mais expressiva (SANTOS, 2008a, p. 69). 
- Públicas: em MG $(41,7 \%)$, no RJ $(35,6 \%)$ e no PR $(44,7 \%)$;

- Privadas em MG com $(62,6 \%)$, RJ com $(43,4 \%)$ e o PR $(52, \%)$; a exceção está no Rio Grande do Sul onde há maior número de estudantes com menor renda nas IES públicas.

Isto evidencia as desigualdades encontradas em grandes cidades, nos espaços metropolitanos ${ }^{87}$ e/ou nas Regiões Metropolitanas, sobretudo na Região Concentrada que se configura cada vez mais como espaços de centro de decisão e gestão do território, mas de grandes desigualdades sociais.

Em relação ao trabalho, a maioria dos estudantes de Geografia dizia trabalhar; os que não trabalham, em 2008, são cerca de 9\%. De 2003 a 2008, houve um aumento dos que trabalham como se observa no gráfico 8. Além disso, a maioria, aproximadamente $48 \%$, diz trabalhar em tempo integral, 40 horas ou mais.

Não há diferenças significativas para esta resposta entre os tipos de IES, seja por categoria administrativa (privadas ou públicas), seja por organização acadêmica (Universidades, Centros Universitários, Faculdades e Centros Tecnológicos). Os estudantes dos cursos noturnos geralmente precisam trabalhar, então, pode-se considerar o binômio noturnotrabalho.

Geralmente estes alunos têm maior dificuldade em acompanhar o curso devido às horas de trabalho, cansaço, tempo escasso para estudar além das horas que fica em sala de aula, atrasos na aula devido ao trabalho, menor tempo para atividades curriculares extraclasse. Isto, no entanto, não é uma determinação para que seja um aluno com baixo rendimento acadêmico.

87 O conceito de espaços metropolitanos é usado por Sandra Lencioni (2003), segundo a qual estes espaços são territórios globalizados, mas onde há também grande heterogeneidade de usos. Os espaços metropolitanos são territórios de gestão de negócios e serviços especializados, que envolvam criação e inovação, entre eles alguns vinculados ao Ensino Superior. Não se pode confundir a definição de metrópole ou mesmo de espaços metropolitanos com o número de população e nem com o de Região Metropolitana, já que este último é definido tecnicamente e formalmente, seja pelo governo federal ou estadual. Assim, pode haver espaços metropolitanos que não se constituíram como regiões metropolitanas e também o processo contrário. 


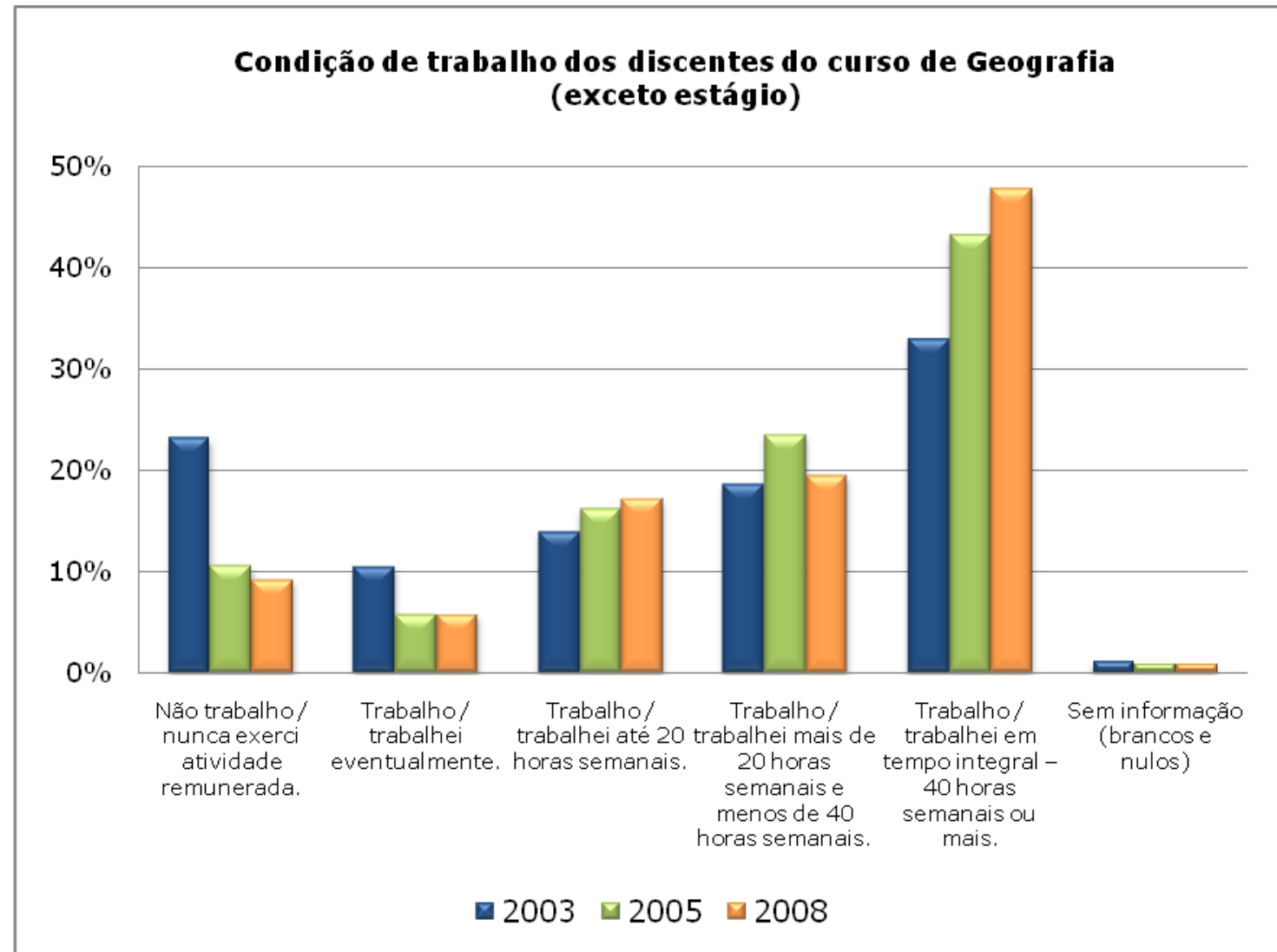

Gráfico 8 - Fonte: Inep, Relatórios Sínteses/Cursos, Área de Geografia, ENC 2003 e Enades 2005 e 2008. Dados organizados por Vivian Fiori, 2009.

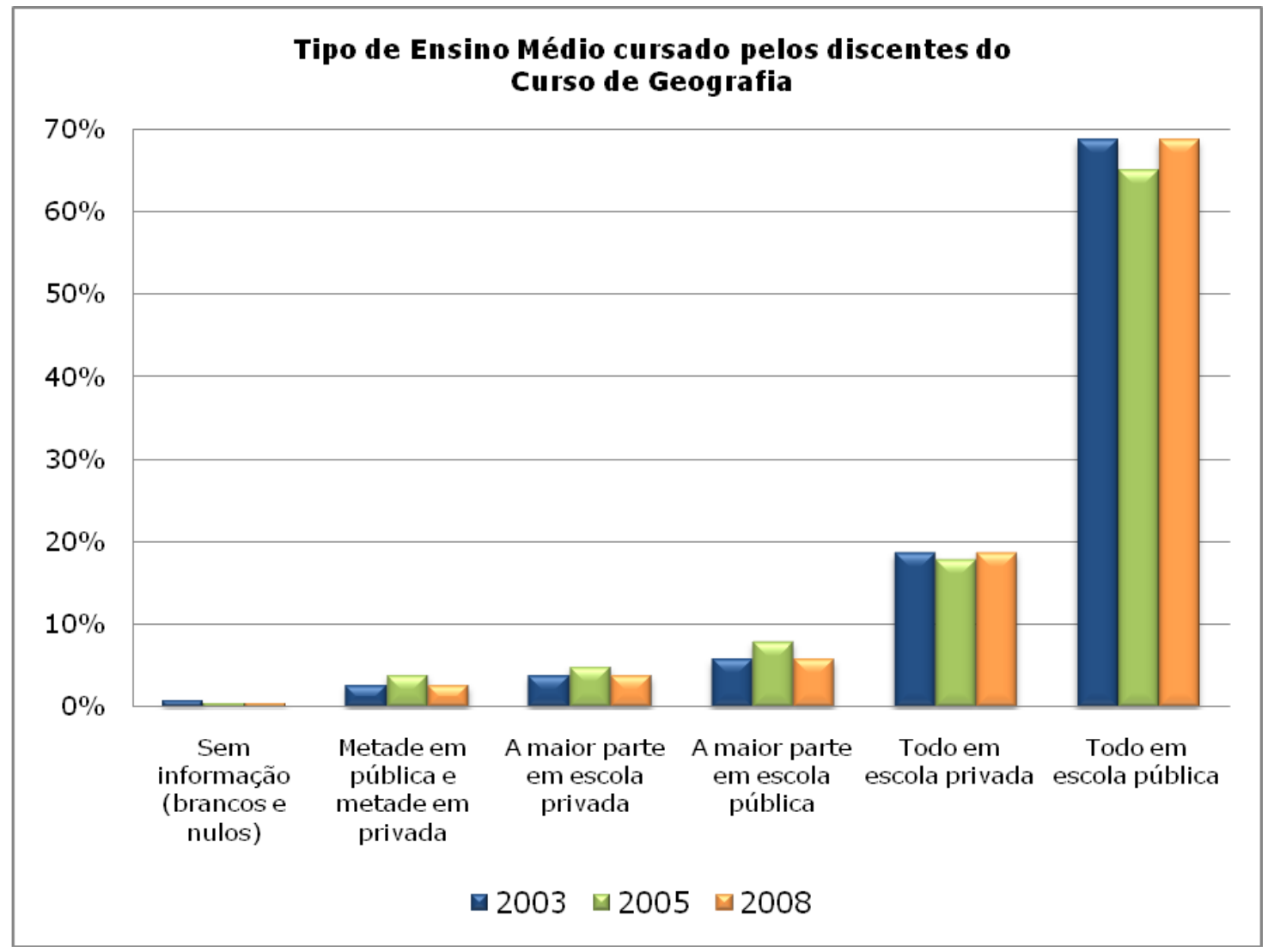

Gráfico 9- Fonte: Inep, Relatórios Sínteses/Cursos, Área de Geografia, ENC 2003 e Enades 2005 e 2008. Dados organizados por Vivian Fiori, 2009. 
Analisando-se os gráficos 7 e 8, observa-se que o aumento do número de estudantes com vínculos empregatícios é concomitante à diminuição da sua renda familiar nos anos 2003 a 2008. Verifica-se, também, que o número dos que trabalham é bem maior dos que só estudam no período noturno.

Em relação à formação anterior dos estudantes de Geografia, a maioria dos alunos, segundo relatório do ENC $2003^{88}$, fez o Ensino Médio totalmente em escola pública. Conforme gráfico 9, eram 63,6\% em 2003, $65 \%$ em 2005 e 68,7\% em 2008, ou seja, seguiu-se a mesma tendência.

Um dado interessante (gráfico 10) é que, em 2003, apareceram os cursos de Magistério como segunda opção em relação ao tipo de Ensino Médio que fizeram.

A maioria destes cursos concentrava-se nas instituições municipais, que, no mesmo ano, foram as que atingiram as piores médias na prova escrita de licenciatura do ENC. Com a nova legislação sobre a necessidade de professores de educação básica cursarem Ensino Superior, verifica-se que houve diminuição de estudantes provenientes do Magistério de 2003 a 2008, aumentando o número dos que estudaram em Ensino Regular em 2008 , com $58 \%$.

A maioria dos alunos inquiridos cursou o Ensino Médio todo em escola pública, em quase todo o território brasileiro, por UF (mapa 14). A maior concentração de alunos com este perfil estava nos estados de Mato Grosso, Tocantins, Goiás, Paraná, Acre, Piauí, Roraima e Amapá.

Verificando se havia diferenças marcantes entre as IES públicas e privadas $^{89}$ (Apêndice $B$ ), observa-se que há variação, mas ela tem mais relação com o território. Em alguns estados não há diferenças

88 Em 2003, segundo o Inep, os graduandos de Geografia que cursaram o Ensino Médio predominantemente em escolas públicas eram principalmente da região Norte $(77,8 \%)$ e da Região Centro-Oeste $(76,3 \%)$, das instituições municipais (71\%) e das faculdades, escolas e institutos superiores (70,3\%). Os que estudaram o Ensino Médio em escolas privadas eram $18,7 \%$ dos graduandos.

89 Os dados de IES públicas e privadas, provenientes dos cursos de Geografia das IES que realizaram o Enade 2008, mostram que há menos IES privadas na região Norte e Nordeste. Apesar de haver algumas, nestes mapas, as UFs que aparecem em branco não tinham turmas de Geografia, com alunos concluintes no Enade de 2008. 
significativas entre estudantes das IES públicas e privadas, que cursaram o Ensino Médio todo em escolas públicas, como no caso de São Paulo, Rio Grande do Sul, Bahia e Pará.

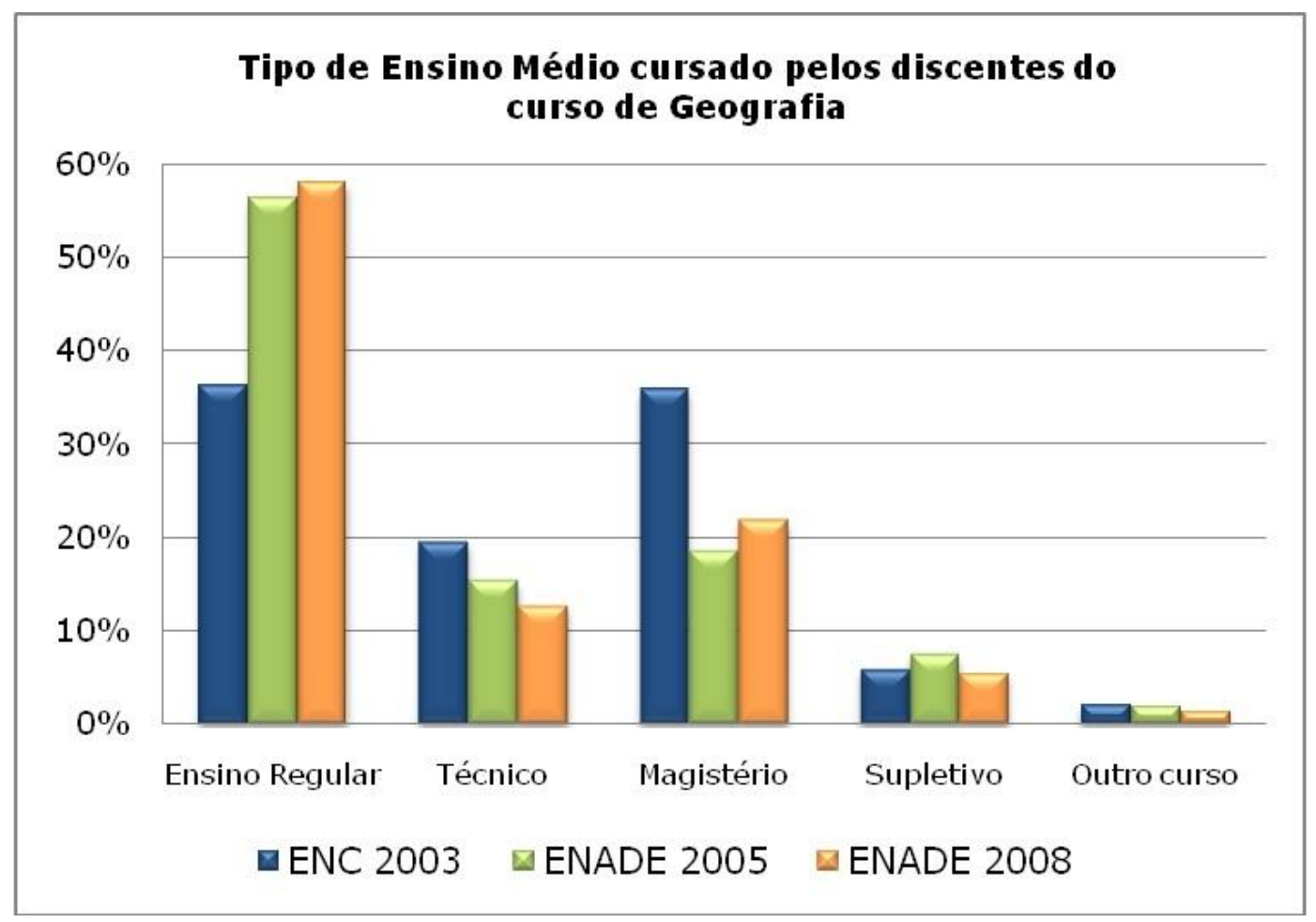

Gráfico 10- Fonte: Inep, Relatórios Sínteses/Cursos, Área de Geografia, ENC 2003 e Enades 2005 e 2008. Dados organizados por Vivian Fiori, 2009.

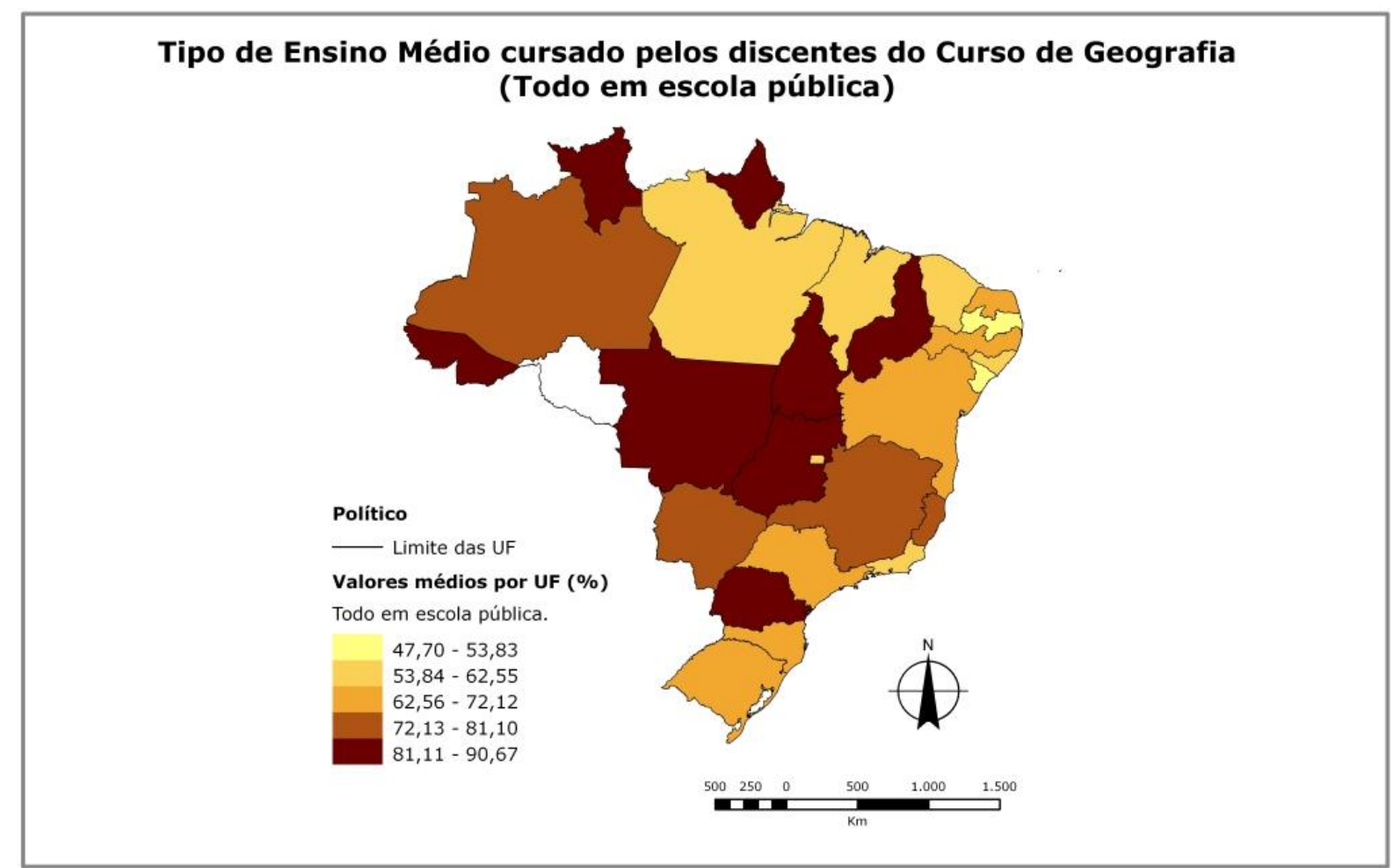

Mapa 14- Fonte Inep, Relatórios de Cursos de Geografia no Enade, por IES, 2008. Elaborado por Vivian Fiori e Mauricio Yamada, 2010. 
Outros estados, como Minas Gerais, Espírito Santo e Santa Catarina têm mais estudantes provenientes de escolas públicas nas instituições privadas. A ideia, comumente divulgada, de que os discentes das IES públicas estudam no Ensino Médio em escolas particulares também não se expressa nestes dados.

Considerando-se, também, à formação dos pais destes discentes, a maioria destes só tinha Ensino Fundamental de $1^{\text {a }}$ a $4^{a}$ séries: em 2003, eram 43,1\%; em 2008, 38,6\%. Isto mostra uma evolução positiva do maior acesso e escolaridade das novas gerações.

Sendo assim, a maioria dos estudantes de Geografia no Brasil tem baixa renda familiar, estudou em escolas públicas, com pais com baixa escolaridade, e trabalham em tempo integral. Estas situações são mais comuns nas instituições municipais, nas faculdades e institutos isolados.

Para além de possíveis problemas envolvidos nestas condições dos discentes, há fatores positivos como a ascensão na formação dos discentes, comparando-se com os pais cuja maioria tem apenas Ensino Fundamental incompleto, conforme dados de 2003 e 2008.

Positiva, também, é a interiorização das licenciaturas, que trouxe a possibilidade de ascensão social dos estudantes por meio da incursão de cursos de formação à docência em municípios pequenos e médios, nos quais as oportunidades de ingressar no Ensino Superior são bem pequenas, condição que será melhor explicitada na seção 5 .

\subsubsection{As características da dimensão docente: formação e regime de trabalho}

Em relação às características docentes, no início da institucionalização dos cursos de Geografia no Brasil, eram comuns professores de outras áreas do conhecimento ministrar aulas em tais cursos, conforme explicitamos na seção 2. A situação e o contexto mudaram, mas permaneceu o problema numa nova condição espacial. 
O contexto deve ser considerado, portanto numa dimensão de espaço e tempo, já que o problema da falta de professores no passado devia-se ao fato de que, nas décadas de 1930-40, ainda vivia-se na infância dos cursos de Geografia no Brasil, no Ensino Superior, fato que fez com que não houvesse bacharéis e licenciados no Ensino Superior na própria área. Esta condição levou engenheiros, advogados, religiosos, médicos, entre outros, a tornarem-se professores de Geografia.

A centralidade das cidades de São Paulo e Rio de Janeiro, naquele período, fizeram com que houvesse a possibilidade da vinda de professores estrangeiros, principalmente franceses como foi o caso de Pierre Monbeig, Pierre Deffontaines e Francis Ruellan para a USP, para a Universidade do Distrito Federal e para a Universidade do Brasil.

Quanto maior a distância destas centralidades, maior dificuldade de haver professores de Geografia formados na área; tratava-se de uma extensão principalmente geométrica. Assim, os primeiros que tiveram essa formação tornaram-se professores universitários nas instituições em que se formaram ou em outras IES, principalmente do Rio de Janeiro e de São Paulo.

Atualmente, há diferentes situações que se relacionam com esta falta de professores formados em Geografia no Ensino Superior. Uma semelhança com o passado é que, em certas localidades, ainda existem professores de outras áreas do conhecimento lecionando disciplinas específicas de Geografia.

Já a diferença é que, no passado, nem se esperava que este docente tivesse formação em pós-graduação. Esta é uma condição recente na maior parte do território brasileiro.

Não se pretende entrar na discussão de que só é geógrafo quem é formado em Geografia, já que há a possibilidade de se conhecer Geografia, inclusive teorias, mesmo sem cursar uma graduação específica.

Contudo, em princípio, quem está diretamente envolvido numa formação específica em Geografia deverá ter maior contato com as mudanças teóricas e metodológicas pelas quais a Geografia tem passado. 
Numa breve pesquisa, coletaram-se informações sobre o perfil do corpo docente em alguns sites de cursos de Geografia, principalmente na Amazônia e Nordeste do Brasil.

Tanto nos sites das próprias IES como no Sistema Lattes, constatouse que, em certas localidades e tipos de IES, principalmente privadas e nos lugares onde os cursos se interiorizaram recentemente, são muito comuns profissionais de outras áreas ministrarem aulas de disciplinas consideradas específicas de Geografia.

Encontrou-se, por exemplo, o caso de um professor de Engenharia Mecânica lecionando "Metodologia de Ensino de Geografia"; de agrônomos lecionando Geografia Agrária. Assim, um engenheiro que se torna professor universitário traz consigo mais experiências que vivenciou como aluno nos Ensinos Fundamental e Médio do que propriamente conhecimento geográfico pensado e vivenciado nas redes de afinidades do Ensino Superior.

Logo, as mudanças empreendidas na Geografia brasileira ao longo do século XX e começo do XXI parecem não chegar a todos os lugares, nem a todas as pessoas que lecionam na graduação.

Segundo José Borzacchiello da Silva e Márcio Piñon de Oliveira (2009), é muito recente a formalização da pós-graduação no Brasil, já que somente com o Parecer 977/1965 sobre as políticas públicas federais dos programas de pós-graduação no Brasil houve a definição e normatização sobre a existência destes cursos no país.

As definições acerca disto eram vagas até então, embora já existisse, por exemplo, formação de doutores na USP desde 1944 em um sistema próprio, mas antes desta norma não havia o título de mestre em Geografia no Brasil.

No entanto, a maioria da formação em pós-graduação em Geografia é muito recente: alguns pós 1998, e a maioria depois de 2003. Fazem, portanto, parte do mesmo processo pós 1996, que começou com a descentralização dos cursos de graduação para o interior e mais 
recentemente também de programas de mestrado em Geografia, estes ainda mais circunscritos às capitais do país.

Observando-se o mapa 15, verifica-se a centralidade da Região Concentrada nos programas de pós-graduação de mestrado e doutorado em Geografia, tornando-se territórios especializados principalmente em cursos de doutorado. Esta polarização é maior nas cidades de São Paulo e Rio de Janeiro com dois programas de doutorado e três de mestrados, respectivamente em cada município:

- Em São Paulo, a USP conta com dois programas: o de "Geografia Física" e o de "Geografia Humana". Na PUC-SP, há o programa "Territorialidades e Análise Sócio-Ambiental", apenas com mestrado.

- No Rio de Janeiro, há os programas da UFRJ: "Organização e Gestão do Território e Planejamento e Gestão Ambiental". Na UERJ, há o programa "Gestão e Estruturação do Espaço Geográfico" e por fim, na PUC-RJ, o programa "Geografia e Meio Ambiente", apenas com mestrado.

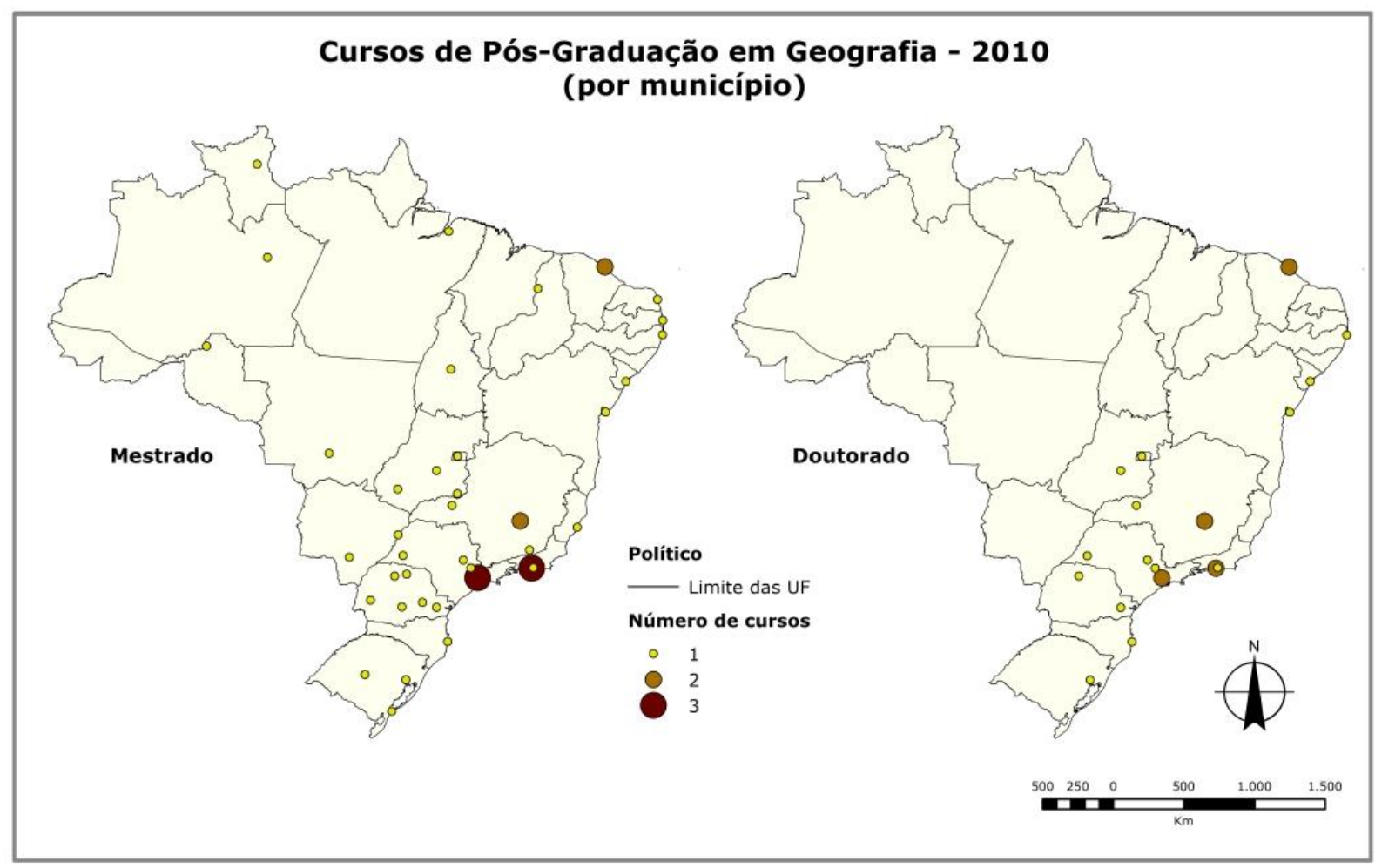

Mapa 15- Fonte: CAPES, 2011. Elaborado por Vivian Fiori e Maurício Yamada, 2012. 
No caso dos programas de mestrado em Geografia, mantém-se a centralidade de São Paulo e Rio de Janeiro, seguidos de dois cursos em Belo Horizonte, na UFMG e PUC-MG, e em Fortaleza, na UFC e na UECE, onde os cursos de graduação em Geografia são antigos e tradicionais.

No Paraná, a maioria dos programas em Geografia encontra-se localizado no interior. Estes são recentes, todos criados após 1998, principalmente em municípios ${ }^{90}$ ou cidades de porte médio como Londrina, pela Universidade Estadual de Londrina (UEL), em 2001; em Maringá, pela Universidade Estadual de Maringá (UEM), em 1998; em Ponta Grossa, pela Universidade Estadual de Ponta Grossa (UEPG), e, em municípios pequenos, como Guarapuava, pela Universidade Estadual do CentroOeste do Paraná (Unicentro), em 2008, e Francisco Beltrão, pela Universidade Estadual do Oeste do Paraná (UNIOESTE), em 2007.

Isto se deve devido à grande quantidade de cursos de graduação de Geografia no estado do Paraná, ao crescimento econômico brasileiro e principalmente porque há maior descentralização das IES estaduais do Paraná com cursos de Geografia do que em outros estados da Região Concentrada.

Há também uma tendência à especialização da formação docente na pós-graduação, que contribui para a disseminação de um saber especializado e para a formação do pesquisador, mas pouco contribui para sua ação pedagógica, para a aquisição de conhecimentos sobre o Ensino Superior, como a questão do currículo e das condições de trabalho; normas, legislações etc. Como diz Maria Isabel da Cunha:

Nessa perspectiva, o professor, ao fazer a sua formação pósgraduada, via de regra constrói uma competência técnicocientífica em algum aspecto de seu campo de conhecimento, mas caminha com prejuízo rumo a uma visão mais ampla, abrangente e integrada de sociedade. Nem mesmo espaços para discutir a universidade, suas funções e relações são privilegiados nos currículos, como se a ciência pudesse ser feita fora das relações de poder que regulam o institucional e o estrutural (CUNHA, 2000, p. 45).

90 Segundo dados do IBGE (2010), segue o número de habitantes destes municípios: Londrina (506701), Maringá (357077), Ponta Grossa (311611), Guarapuava (167328) e Francisco Beltrão (78943). 
Como diz a autora, há os que se tornam especialistas conforme se verifica nas áreas de concentração de programas de pós-graduação em Geografia (Apêndice $\mathrm{C}$ ), as quais são bastante variadas. Atualmente há uma tendência de estudos focados mais em questões ambientais e territoriais. De qualquer forma, a questão do Ensino Superior acaba ficando restrita a cursos na área de Educação e não há nenhum curso cujo nome vincule-se ao ensino ou à formação de professores especificamente.

De outro lado, há os docentes que pouca formação têm e acabam reproduzindo os conhecimentos adquiridos nos Ensinos Médio e Superior. Seja como for, ambos têm carências em conhecimentos sobre a profissionalidade docente no Ensino Superior, suas necessidades e especificidades, um conhecimento relevante para uma melhor atuação do professor na graduação em Geografia.

Reproduzem, assim, muito do que viram em sua própria experiência quando eram alunos universitários. Neste sentido, a pós-graduação não teria de formar somente pesquisadores, mas preocupar-se também com a formação para a docência, considerando-se entre outros aspectos: reflexões sobre o Ensino Superior, as especificidades dos saberes docentes neste nível de ensino, as características e normas sobre os cursos de Geografia, a questão curricular etc.

Não se trata de discutir temáticas que sejam adequadas a todas as situações, mas levar em conta o contexto social, político e educativo que medeia as condições de Ensino Superior e as especificidades da Geografia.

Cabe, pois, a existência de programas com suas especificidades de pesquisa, com áreas de concentração como "Organização do Espaço nos Domínios do Cerrado Brasileiro", vinculado ao Programa de PósGraduação da Universidade Federal de Goiás, mas isso não exclui a responsabilidade destes programas de tratarem de temáticas sobre o Ensino Superior e a formação para a docência, não deixando isto a cargo apenas da pós-graduação nas Faculdades de Educação. 
Afinal, a finalidade da formação de um pós-graduando pode ser exclusivamente a formação um pesquisador, mas também pode ser a formação para a docência.

Outra questão é a experiência no magistério para docência no Ensino Superior. Em pesquisa de doutorado sobre cursos de graduação em Geografia em Minas Gerais, Vicente de Paula Leão (2008) comenta uma questão que parece pertinente a este estudo. O autor relata que, entre das formas de acesso de professores nas IES públicas, estão as publicações que contam mais pontos que a própria experiência de magistério. Diz ele:

Outro aspecto que merece destaque é o fato de os editais distribuírem mais pontos para a produção científica do que para a experiência profissional no magistério. Valorizam-se os artigos pela quantidade e não pela qualidade ou pertinência em relação à vaga em disputa. Dessa forma, vários candidatos ao cargo - formadores de novos professores - ingressam nos cursos de licenciatura sem nunca terem escrito uma linha sobre educação ou ensino de Geografia (LEÃO, 2008, p. 32).

Ou seja, para tornar-se professor do Ensino Superior, em geral, dáse maior importância à experiência na pesquisa do que no ensino. Não que sejam condições excludentes, mas é importante a experiência docente, sobretudo na graduação.

Parece que, nas IES privadas, é o oposto, já que a experiência em sala de aula geralmente é bastante considerada nestas instituições, mas, por outro lado, há um menor número de mestres e doutores. Daí a velha dicotomia entre ensino e pesquisa. No caso das públicas, onde há pósgraduação, há também a questão dos mais experientes geralmente preterirem a graduação em relação às aulas na pós-graduação.

Outra situação que permanece diz respeito ao grande número de professores nos cursos de Geografia não formados em Geografia. Ao analisar as matrizes curriculares de muitas IES pelo Brasil, constata-se que há uma grande variedade de disciplinas não específicas, principalmente nos primeiros semestres. Talvez este também seja um dos 
motivos tanto de bacharelado quanto da licenciatura terem um número grande de professores de outras áreas do conhecimento.

Há, também, o fato de a Geografia permanecer com a dicotomia Geografia Física e Humana, de que decorre, em alguns casos, que docentes de Geografia Física pertençam ao Departamento de Geociências ou até mesmo todo curso estejam nestes departamentos ou institutos.

Em 2005, o Inep disponibilizava dados em seu site, mediante o sistema Sinaes, sobre a formação dos docentes tanto de bacharelado quanto de licenciatura em Geografia, de todas as IES do Brasil. Tais dados permitiram a seguinte síntese:

- Nos cursos de bacharelado, os professores eram mais titulados do que os de licenciatura em Geografia;

- As instituições públicas tinham o maior número de doutores; os mestres eram maioria nas privadas, e os especialistas estavam proporcionalmente divididos entre ambas;

- Nas licenciaturas em Geografia, as cinco maiores classes informadas pelos professores sobre sua formação em graduação eram as seguintes: Formação de professores e Ciências da Educação (25,8\%), Não informadas (19,5\%), Ciências Sociais e Comportamentais (10,9\%), Ciências Físicas $(15,3 \%)$ e Humanidades e Letras $(13,8 \%)$.

Nos dados disponibilizados pelo Conceito Preliminar de Curso (CPC) com os cursos de Geografia que realizaram o Enade $2008^{91}$ observa-se que o número de docentes mestres em geral é maior nas IES públicas (mapa 16).

Considerando-se a distribuição por UF no Rio Grande do Sul, Santa Catarina, ambos no Sul do Brasil e em Pernambuco, há mais mestres nas IES privadas, condição que se assemelha aos dados gerais já apresentados anteriormente pelo Inep em 2005.

91 Os estados cujos dados estão em branco correspondem às Unidades da Federação (UF) que não tiveram nenhuma IES privada participando do Enade 2008. 
Em Pernambuco isto se dá devido ao fato que há muitas IES públicas municipais no interior, cujos salários e a localização dos cursos não têm atraído docentes com pós-graduação.

Isto não significa que o mestrado seja específico em Geografia, mas nos últimos anos as exigências para a formação de mestres e doutores nas IES aumentaram, sobretudo com o sistema de avaliação que passou a considerar a formação docente um elemento a ser avaliado ${ }^{92}$.

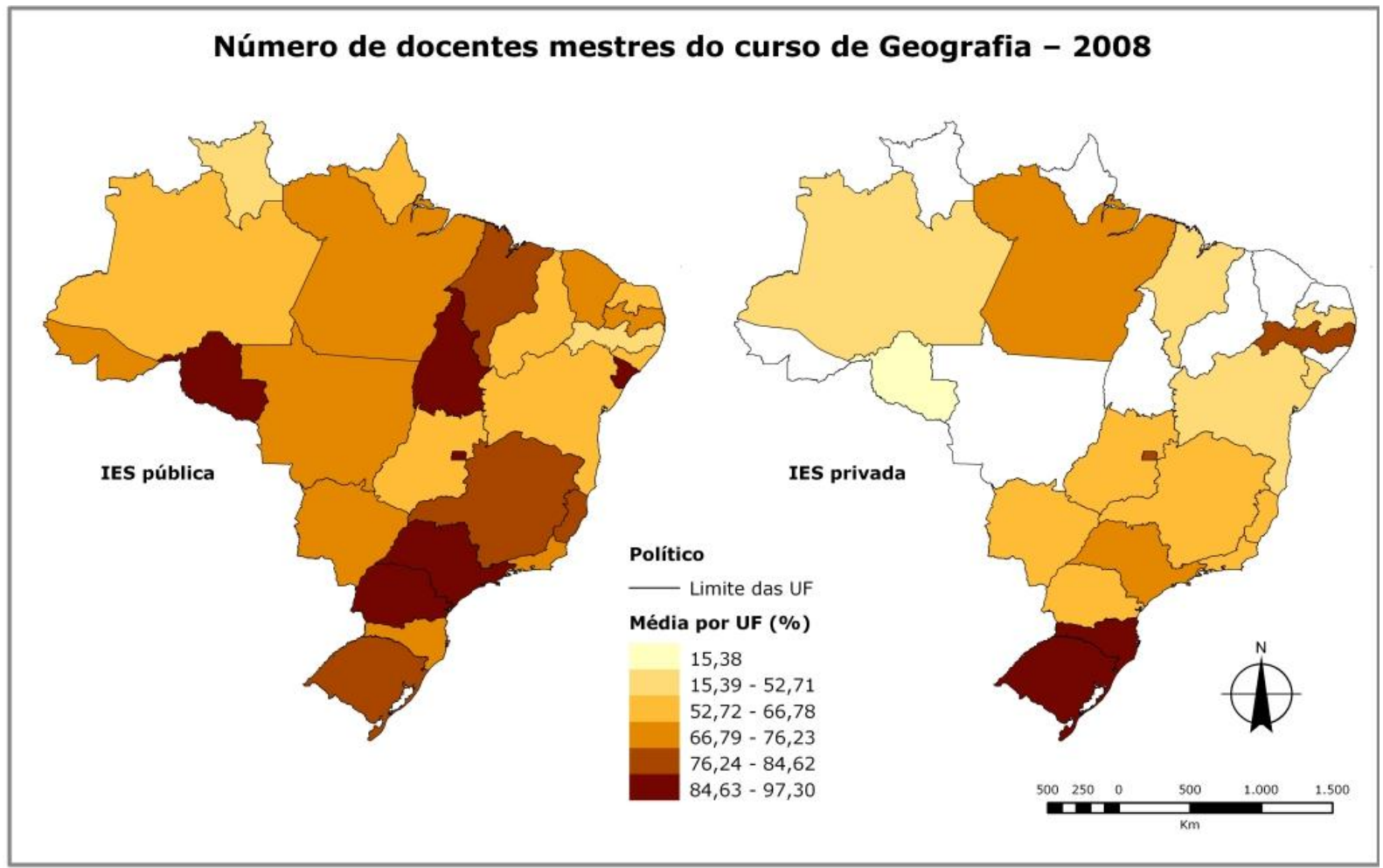

Mapa 16 - Fonte: Dados do CPC, Inep, 2008. Elaborado por Vivian Fiori e Maurício Yamada, 2010.

92 O indicador de avaliação da formação docente dos cursos, do sistema Sinaes atual, tem os seguintes indicadores e conceitos: A) Titulação do corpo docente, conceitos: 1- Quando o percentual dos docentes do curso com titulação obtida em programas de pós-graduação stricto sensu é menor que $15 \%$; 2. Quando o percentual dos docentes do curso com titulação obtida em programas de pósgraduação stricto sensu é maior ou igual a $15 \%$ e menor que $30 \%$. 3. Quando o percentual dos docentes do curso com titulação obtida em programas de pósgraduação stricto sensu é maior ou igual a $30 \%$ e menor que $50 \%$; 4. Quando o percentual dos docentes do curso com titulação obtida em programas de pósgraduação stricto sensu é maior ou igual a $50 \%$ e menor que $75 \%$. 5. Quando o percentual dos docentes do curso com titulação obtida em programas de pósgraduação stricto sensu é maior ou igual a 75\%. B) Titulação do corpo docente com doutorado, conceitos: 1. Quando não há doutores do curso; 2. Quando o percentual de doutores do curso é menor ou igual a $10 \%$; 3 . Quando o percentual de doutores do curso é maior que $10 \%$ e menor ou igual a $20 \%$; 4 . Quando o percentual de doutores do curso é maior que $20 \%$ e menor ou igual a $35 \%$; 5 . Quando o percentual de doutores do curso é maior que $35 \%$. 
O artigo 52 da LDBEN (1996b) diz que nas Universidades há necessidade que um terço do corpo docente, pelo menos, com titulação acadêmica de mestrado ou doutorado e um terço do corpo docente em regime de tempo integral.

Em relação à distribuição de doutores do curso de Geografia, mapa 17, verifica-se que há uma disparidade maior quando comparamos as IES privadas e públicas, já que a concentração de doutores é bem maior nas públicas, principalmente em Rondônia, São Paulo, Rio de Janeiro, Espírito Santo, Rio Grande do Sul e Sergipe.

Em Rondônia e Sergipe, estados que estão fora da Região Concentrada, isto se dá em virtude da presença de IES federais, respectivamente, Fundação Universidade de Rondônia (UNIR) e Universidade Federal do Sergipe (UFS), com concursos públicos com regime de trabalho de trabalho integral, condição que atraí mais docentes doutores.

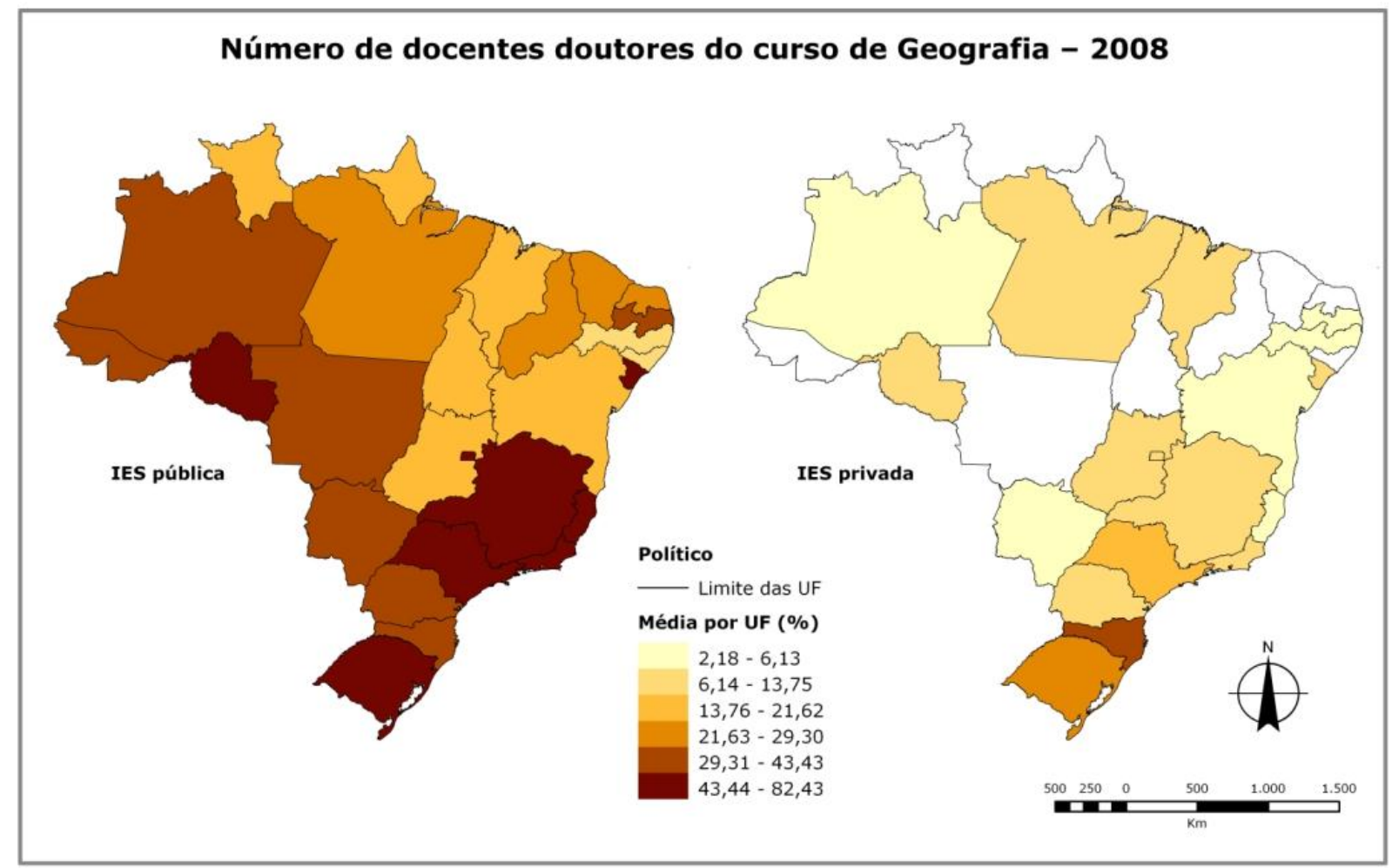

Mapa 17- Fonte: Dados do CPC, Inep, 2008. Elaborado por Vivian Fiori e Maurício Yamada, 2010.

Tanto nas públicas quanto nas privadas estão mais presentes na Região Concentrada, o que demonstra a maior densidade de pósgraduação nesta região, seja na área de Geografia ou não. 
Em Goiás, Tocantins, Maranhão, Bahia, Pernambuco e Alagoas, nas IES públicas, há menor porcentagem de doutores, variando $13,76 \%$ a $21,62 \%$ em média apenas. No Maranhão, por exemplo, não há programas de mestrado/doutorado em Geografia, nem na capital.

Em Goiás o baixo percentual de mestres e doutores tem relação com a política da UEG, que, segundo um coordenador de curso do interior, não faz concursos há muito tempo o que faz com que os docentes tenham contratos a cada ano letivo, o que afugenta o interesse de professores doutores no deslocamento para as cidades do interior.

São cursos que se interiorizaram mais, cujas condições dos municípios onde estão inseridos dificultam o interesse e a existência de professores doutores, seja devido aos baixos salários ou mesmo devido à localização dos cursos em municípios distantes da capital, já que a formação na pós-graduação com doutorado ainda está bastante concentrada nas capitais e, no caso da Geografia, principalmente na Região Concentrada.

No caso das instituições privadas, apenas os estados de Santa Catarina e Rio Grande do Sul têm patamares acima disso - 31,8\% e 27,9\%, respectivamente. Esta condição demonstra a necessidade de formação na pós-graduação de mestres e doutores para as IES públicas e privadas no Brasil.

Há, neste caso, duas situações, uma principalmente dos estados da Amazônia e do Nordeste e de Goiás que têm menor número de doutores, sobretudo no interior; outra dos docentes das IES privadas, em todo o território nacional, que têm menor titulação do que nas públicas.

São duas situações distintas de extensão: uma mais geométrica, dada às grandes distâncias existentes, por exemplo, na Amazônia, e ambas formas de extensão vistas como de rede de relações, já que há muitos casos de IES privadas na Região Concentrada que não têm professores doutores.

Cabe, neste ponto, uma reflexão importante. Em São Paulo, por exemplo, considerada uma centralidade do ponto de vista da produção do 
conhecimento, que historicamente construiu uma posição de destaque nesta produção na pós-graduação, só há $52 \%$ de doutores nas IES públicas nos cursos de graduação de Geografia, excetuando-se a USP e a Universidade de Campinas (Unicamp), e apenas 16,2\%, nas privadas.

No Rio de Janeiro, Minas Gerais e Pernambuco, estados cujos cursos de Geografia são antigos, a situação não é diferente. Isto demonstra que parte desses doutores não chega às licenciaturas em Geografia, principalmente nas IES localizadas no interior e nas privadas.

No mapa 18 , que se refere a todos os docentes das licenciaturas em Geografia do Brasil em 2009, há a divisão por formação em graduação, especialização, mestrado e doutorado. Observa-se que os que têm apenas graduação constituem minoria, alcançando, no máximo, $8 \%$ na maioria dos estados.

No entanto, em alguns estados estes valores são maiores, caso do Mato Grosso (20,48\%), Ceará $(21,21 \%)$ e Bahia $(22,42 \%)$. O Ceará é um caso peculiar, pois são IES públicas, estaduais e federais, que têm cursos de mestrado e doutorado em Geografia.

Considerando-se a classificação usada, verifica-se, no mapa 18, que a maioria dos docentes tem mestrado atualmente. Isto evidencia que houve uma evolução na formação dos docentes das licenciaturas em Geografia no Brasil, já que, antes de 1996, era menos comum professores mestres e doutores em Geografia.

Em Rondônia, há uma distinção entre as IES privadas, com cursos no interior do Estado, com a maioria de docentes com especialização, e a IES pública federal, na capital, com maioria de doutores.

Em São Paulo e no Rio de Janeiro, há a maior concentração de doutores, mas ela ocorre principalmente na USP, na UFRJ e na UFF. É comum que a maioria dos docentes destes estados tenha feito pósgraduação no próprio estado ou na Região Concentrada.

Já o Rio Grande do Norte, que também tem a maior parte dos docentes com doutorado, a maioria fez a pós-graduação em outros estados, principalmente os docentes específicos de Geografia. 


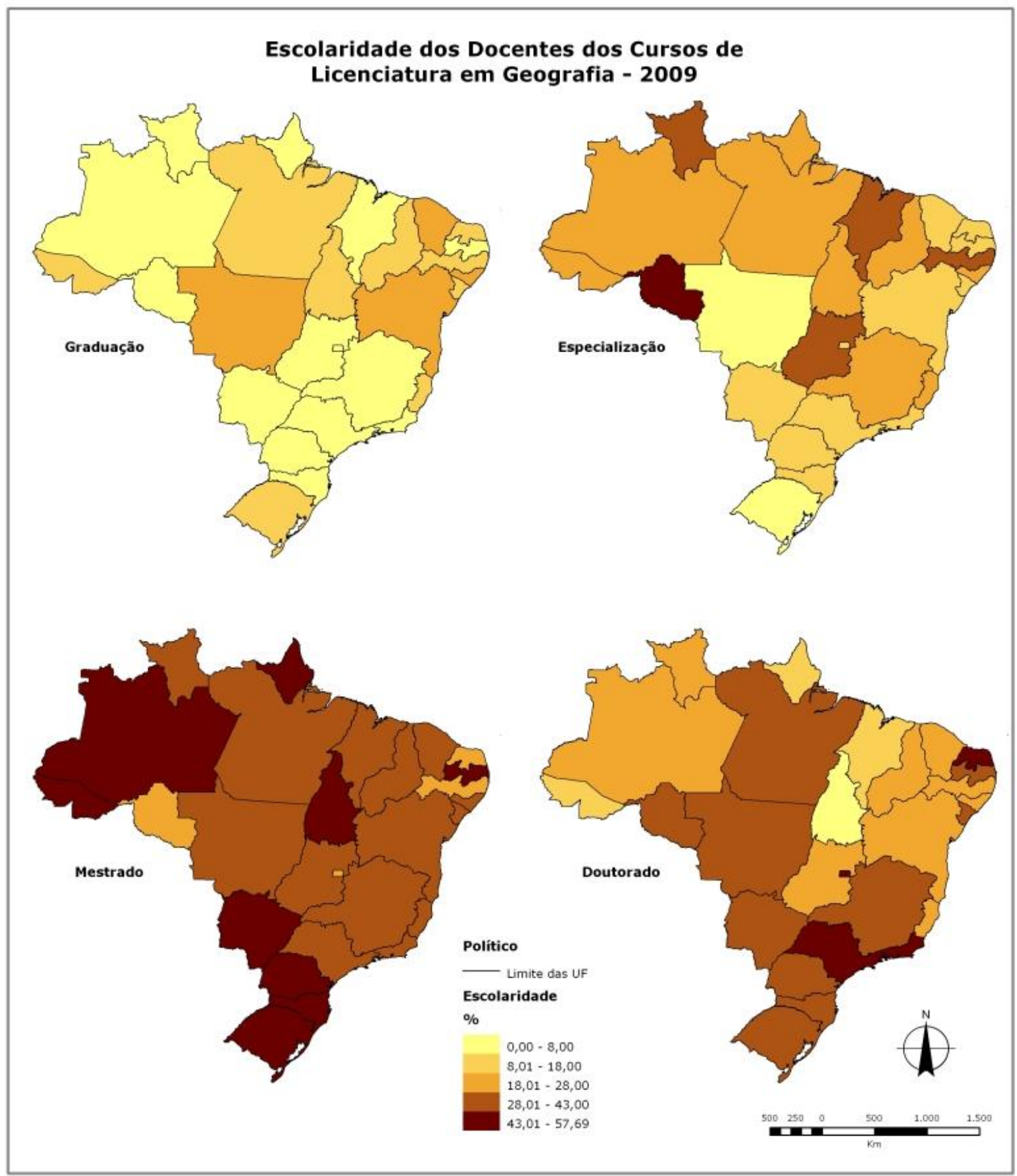

Mapa 18- Fonte: Dados do Inep, 2009. Elaborado por Vivian Fiori e Maurício Yamada, 2011.

Observação: Estes dados não são apenas das IES que participaram do Enade.

No Quadro 3 fica evidente que os docentes da Universidade do Rio Grande do Norte (UFRN) fizeram a pós-graduação, principalmente em São Paulo, pela UNESP de Presidente Prudente ou de Rio Claro, Unicamp, USP ou UFSCar, ou ainda no Rio de Janeiro, pela UFRJ, todos cursos provenientes da Região Concentrada. 


\begin{tabular}{|c|c|c|c|}
\hline \multicolumn{4}{|c|}{ Quadro 3 - Formação dos Docentes do Curso de Geografia da UFRN ${ }^{93}-2010$} \\
\hline Disciplina & Graduação & Mestrado-UF & Doutorado \\
\hline $\begin{array}{llll}\begin{array}{l}\text { Antropologia } \\
\text { Cultura }\end{array} & \text { Estudo da } \\
\end{array}$ & $\begin{array}{l}\text { Ciências } \\
\text { Unicap- PE }\end{array}$ & & \\
\hline Astronomia & Física- UFRN-RN & $\begin{array}{ll}\text { Astronomia- } & \text { Obs. } \\
\text { Nacional - RJ } & \\
\end{array}$ & Ciências- França \\
\hline Biogeografia & Ecologia- UFSCar- SP & Ecologia- UFRGS & Ecologia- UFSCar \\
\hline $\begin{array}{l}\text { Cartografia Temática } \\
\text { Cartografia Geral } \\
\text { Cartografia para o Ensino de } \\
\text { Geografia }\end{array}$ & Geografia- UFRN-RN & $\begin{array}{l}\text { Geografia- UNESP- } \\
\text { SP }\end{array}$ & $\begin{array}{l}\text { Geografia- UNESP- } \\
\text { SP }\end{array}$ \\
\hline $\begin{array}{l}\text { Educação Ambiental } \\
\text { Geografia Regional do Brasil } \\
\text { Teoria e Métodos em Geografia }\end{array}$ & $\begin{array}{ll}\text { Geografia } & \text {-UNESP- } \\
\text { SP } & \end{array}$ & Geografia- USP-SP & Geografia- USP-SP \\
\hline $\begin{array}{l}\text { Estágio de Formação de } \\
\text { professores de Geografia I e II }\end{array}$ & Pedagogia- UFRN-RN & $\begin{array}{ll}\text { Ciências } & \text { Sociais- } \\
\text { UFRN-RN } & \\
\end{array}$ & \\
\hline $\begin{array}{l}\text { Formação Econômica } \\
\text { Territorial do Brasil } \\
\text { Geografia da População }\end{array}$ & $\begin{array}{lr}\text { Geografia- } & \text { Fac. } \\
\text { Católica } & \text { de } \\
\text { Uberlândia- MG } & \\
\end{array}$ & $\begin{array}{l}\text { Geografia- UFSE- } \\
\text { SE }\end{array}$ & UFU \\
\hline $\begin{array}{l}\text { Fundamentos da Psicologia } \\
\text { Educacional }\end{array}$ & Psicologia- UFRN & & \\
\hline $\begin{array}{l}\text { Fund. Sócio-Filosóficos da } \\
\text { Educação }\end{array}$ & Pedagogia- UFRN & $\begin{array}{ll}\text { Educação } & \text {-UFRN- } \\
\text { RN }\end{array}$ & \\
\hline $\begin{array}{l}\text { Geografia Agrária } \\
\text { Geografia Política } \\
\text { Geografia Urbana do Brasil }\end{array}$ & $\begin{array}{l}\text { Geografia- } \quad \text { FFLCH- } \\
\text { Jales- SP }\end{array}$ & $\begin{array}{l}\text { Geografia-UNESP- } \\
\text { SP }\end{array}$ & $\begin{array}{l}\text { Geografia- UNESP- } \\
\text { SP }\end{array}$ \\
\hline Geografia do RN & Geografia -UFRN-RN & $\begin{array}{l}\text { Geografia - UFPE- } \\
\text { PE }\end{array}$ & Geografia -UFRJ \\
\hline Geografia Econômica & $\begin{array}{l}\text { Geografia -Unesp - } \\
\text { SP }\end{array}$ & $\begin{array}{l}\text { Geografia } \\
\text { SP }\end{array}$ & Geografia- UFRJ \\
\hline $\begin{array}{l}\text { Geografia Física do Brasil } \\
\text { Pedologia }\end{array}$ & Geografia -UFRN-RN & Geociências -UFPE & $\begin{array}{l}\text { Geodinâmica- } \\
\text { UFRN }\end{array}$ \\
\hline Geografia Regional do Mundo & Geografia -UFRN-RN & $\begin{array}{ll}\text { Geografia } & \text {-UFRN- } \\
\text { RN } & \\
\end{array}$ & \\
\hline Geografia Urbana & Geografia -UFRN-RN & Geografia- UFRJ & Geografia- UFRJ \\
\hline $\begin{array}{l}\text { Geologia Geral } \\
\text { Geografia das } \\
\text { Hidrográficas }\end{array}$ Bacias & Geologia- UFRN & $\begin{array}{l}\text { Geociências } \\
\text { UNESP }\end{array}$ & \\
\hline Geomorfologia & Geografia- UFPB & Geociências -UFBA & Geografia -UFRJ \\
\hline Introdução a Geografia & Geografia- UFRN & Geografia- UFPE & Geografia- UNESP \\
\hline $\begin{array}{l}\text { Meteorologia e Climatologia } \\
\text { Climatologia Sistemática }\end{array}$ & Geografia-USP & Geografia-USP & Geografia-USP \\
\hline Metodologia da Ciência & Filosofia- UFSC & Filosofia- UFCS & Filosofia-USP \\
\hline Organização do Espaço & Geografia- UFRN & Geografia-USP & Geografia-USP \\
\hline Introdução a Educação Especial & Pedagogia- UFRN & Educação -UFRN & Educação -UFRN \\
\hline $\begin{array}{l}\text { Organização da } \\
\text { Brasileira }\end{array}$ & Pedagogia- UFRN & Educação -UFRN & Educação -UFRN \\
\hline Didática & Pedagogia- UFRN & Educação -UFRN & Educação -UFRN \\
\hline
\end{tabular}

Fonte: Site da UFRN- Curso de Licenciatura em Geografia, 2010 e Plataforma Lattes, 2011.

Elaborado por Vivian Fiori, 2012.

93 Para elaboração deste quadro, pesquisaram-se, no site da UFRN, os professores que lecionaram no ano de 2010, com suas respectivas disciplinas, depois analisou-se o currículo Lattes de todos os professores, por fim, comparou-se com a matriz curricular do curso de Licenciatura em Geografia, disponível no site da UFRN. 
Na Região Nordeste há alguns docentes oriundos de pós-graduação em Pernambuco (UFPE) e da própria UFRN, principalmente os das disciplinas pedagógicas. O Quadro 3, evidencia esta condição das centralidades em relação à pós-graduação no Brasil no nível nacional e regional. Outro aspecto a ser observado neste quadro é que há diversas disciplinas, cuja formação de docentes na graduação é variada, embora em sua maioria sejam da própria UFRN.

Então, houve uma migração dos formados em Geografia pela UFRN principalmente para os estados de $\mathrm{SP}, \mathrm{RJ}$ e $\mathrm{PE}$, centralidades de formação em pós-graduação em Geografia. Como outros programas foram criados mais recentemente, é possível que este destino mude no futuro. Quanto às disciplinas pedagógicas, como há curso de doutorado na própria UFRN, todos os docente são da própria instituição. Já, nos cursos da Universidade Estadual do Rio Grande do Norte (UERN), todos são mestres.

Um aspecto positivo do sistema de avaliação criado pelo governo federal foi a melhoria na formação dos docentes das IES brasileiras.

Quando se trata de regime de trabalho, a questão se complexifica devido ao fato de que, embora existam normas federais para o trabalho docente no Ensino Superior, há uma diversidade de situações cuja mediação é estadual, pelos acordos sindicais e pelo tipo de organização administrativa ou organizacional da IES, já que há diferenças entre elas.

No exercício da função docente, a legislação atual prevê que esta atividade possa ser realizada no ensino, na pesquisa e na extensão, sobretudo nas universidades nas quais é obrigatório que existam tais atividades.

Em relação ao regime de trabalho, há uma divisão, a saber: horistas, regime parcial e integral, havendo ainda a possibilidade de ser integral com dedicação exclusiva. A maior diferença entre as IES públicas e privadas tem relação com o regime de trabalho, conforme mapa 19, com dados das IES que participaram do Enade 2008. 


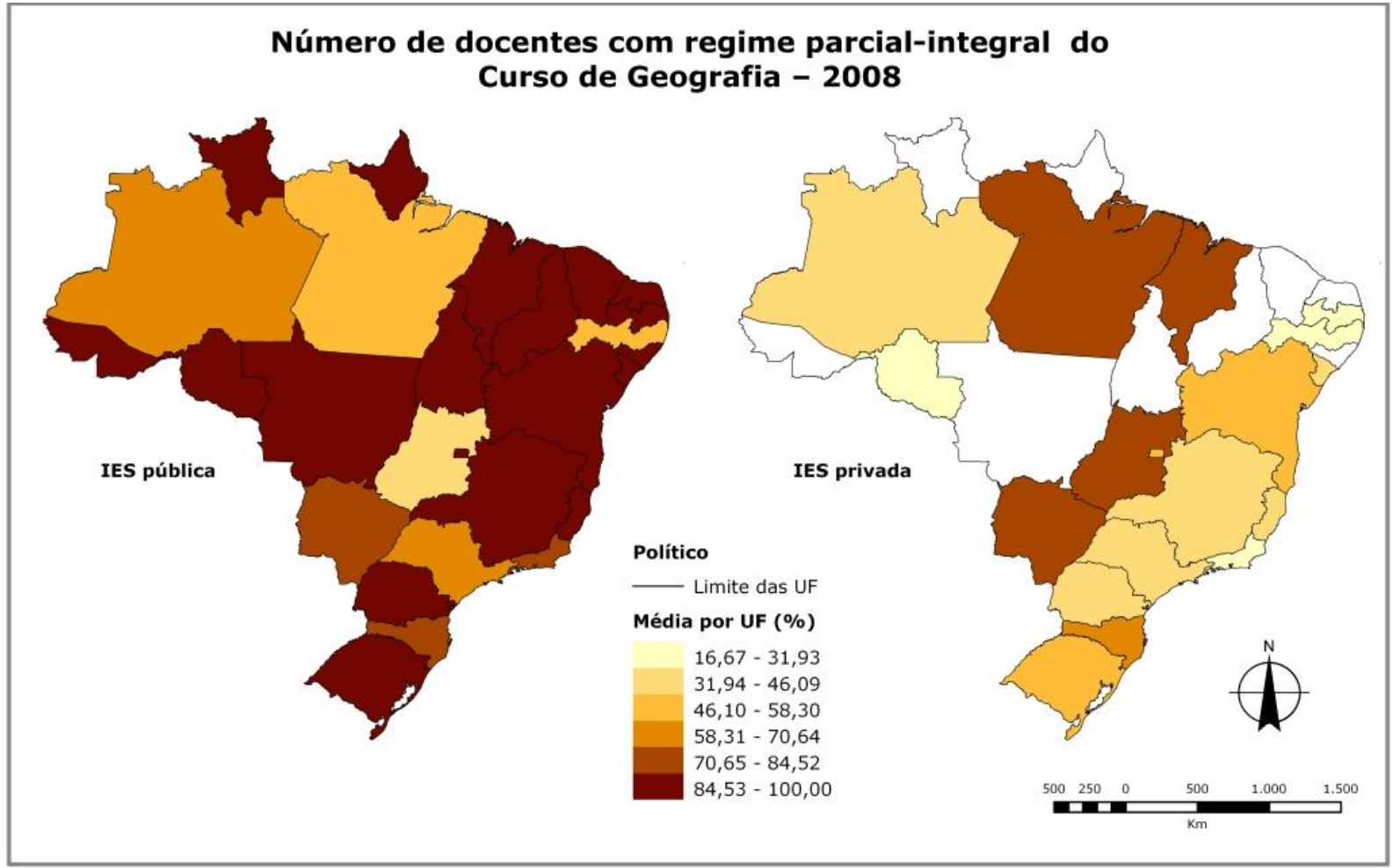

Mapa 19 - Fonte: Dados do CPC, Inep, 2008. Elaborado por Vivian Fiori e Maurício Yamada, 2010.

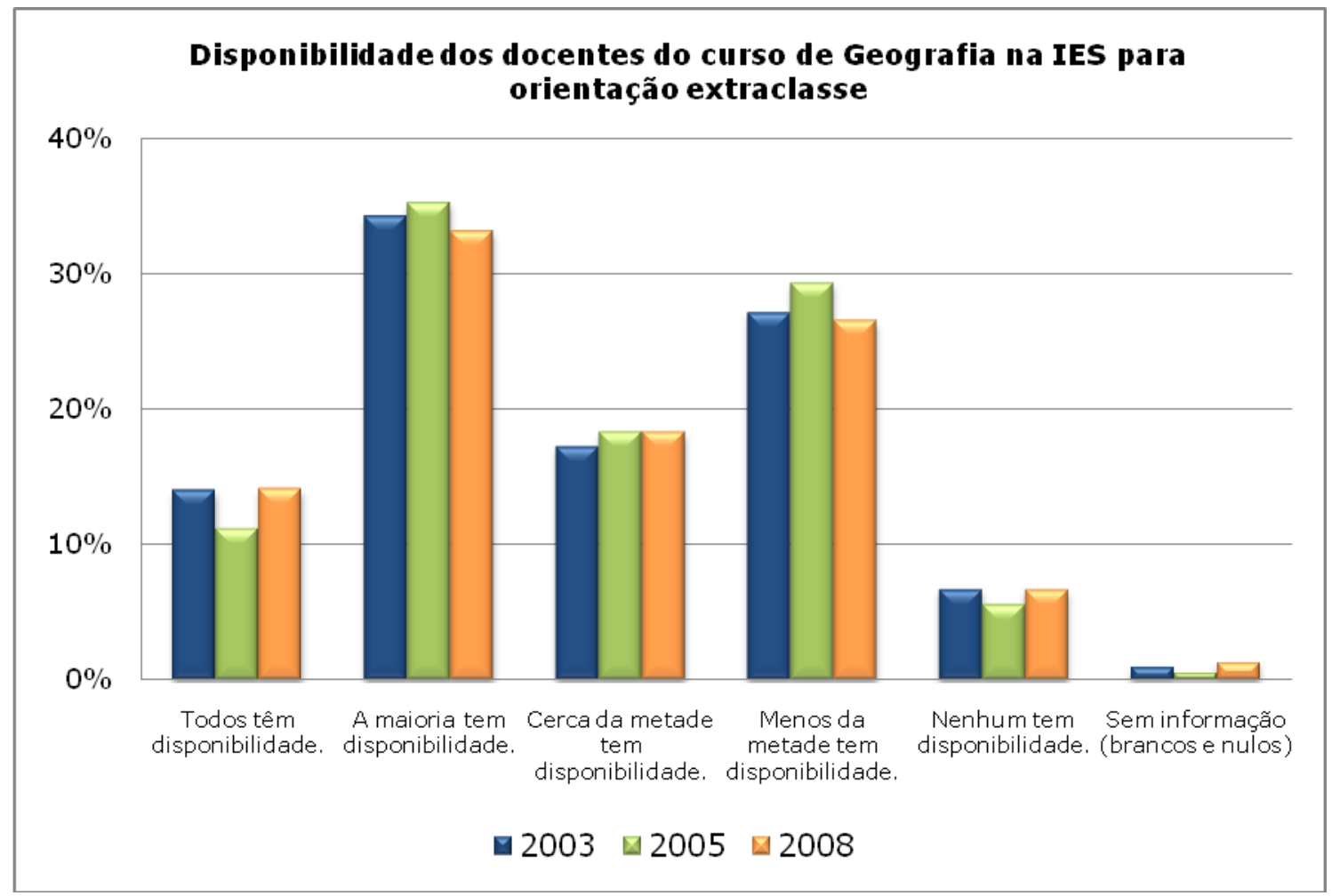

Gráfico 11- Fonte: Inep, Relatórios Sínteses/Cursos, Área de Geografia, ENC 2003 e Enades 2005 e 2008. Dados organizados por Vivian Fiori, 2009. 
Nas IES públicas, a exceção é o estado de Goiás com percentual para o regime parcial-integral de $46 \%$. Nas privadas, os estados com um número maior de cursos de Geografia, caso de São Paulo, Minas Gerais, Rio de Janeiro e Paraná, têm variação de 31,9\% a 46\% de docentes com regime parcial-integral.

Tais informações são corroboradas com os dados respondidos pelos estudantes sobre a disponibilidade dos professores na instituição para atendimento extraclasse, no Enade 2008, pois mais de $30 \%$ responderam que "a maioria tem disponibilidade", seguindo-se de "menos da metade tem disponibilidade", com aproximadamente 27\%, conforme gráfico 11 .

Em relação ao trabalho classificado como horista, trata-se em princípio de um professor cujas hora-aula referem-se somente às atividades de docência em sala de aula. Contudo, na prática, esta é uma questão complexa, pois a hora/aula, comumente no Brasil, pode ser de 45-50 minutos ou 1 hora, e isto significa tempo diferente de trabalho.

A Portaria n²45/1945, que tratava desta questão, dizia que a aula do período diurno deveria ter 50 minutos e a do noturno 45 min. Já a LBDEN (1996b) diz que há necessidade de cumprimento dos dias letivos e horas-aula definidos. Isto significa que há uma mediação do tipo de IES e também dos acordos coletivos, que geralmente estão no nível estadual.

Além disso, pensar na hora-aula como o único horário despendido pelo professor é desconsiderar que o trabalho docente vai além da sala aula, pois envolve a preparação de sua aula, de reuniões, de correção de trabalhos e provas, a organização de atividades extraclasse, como trabalhos de campo etc.

Tal situação varia dependendo dos acordos coletivos, com termos como "descanso semanal remunerado" ou ainda horas de "atividade extraclasse". Segundo a Portaria n 40 (Brasil, 2007), cumpre tempo parcial o "[...] docente contratado atuando com 12 ou mais horas semanais de trabalho na mesma instituição, reservado pelo menos $25 \%$ do tempo para estudos, planejamento, avaliação e orientação de estudantes". 
$\mathrm{Na}$ outra ponta, estão os professores com regime de trabalho integral e com dedicação exclusiva. A ideia de tempo integral remete a instituições públicas ${ }^{94}$, e, em alguns casos, é seguida também por IES públicas estaduais.

Há, portanto, uma distinção entre as IES públicas e privadas neste caso, também devido à origem e ao percentual do orçamento destinado ao pagamento dos docentes, que é bastante diferente nos dois casos.

Segundo o pesquisador André Magalhães Nogueira, esta questão do horista remete à situação das IES privadas e cria distinções entre IES públicas e privadas:

Ora, há, por assim dizer, um "confronto de tradições". Do "lado público", teve o longo processo de integração entre ensino e pesquisa que desembocaria, não apenas por razões acadêmicas, no conceito de isonomia, manifesto no Plano Único de Classificação e Retribuição de Cargos e Empregos e no Regime Jurídico Único (RJU). Do "lado privado", veio o processo de construção institucional pautado em atividades docentes presenciais, mensuradas em horas-aula. Também nesse caso, a questão não se resume apenas a motivações acadêmicas, já que horas-aula se traduzem em contratos de trabalho, mediados por acordos sindicais, os quais variam não apenas entre Estados, mas também de município a município (NOGUEIRA, 2006, p.26).

O Decreto no 5773/2006 (BRASIL, 2006) diz respeito ao regime de trabalho docente em tempo integral, que "[...] compreende a prestação de quarenta horas semanais de trabalho na mesma instituição, nele reservado o tempo de pelo menos vinte horas semanais para estudos, pesquisa, trabalhos de extensão, planejamento e avaliação".

Logo, há necessidade de, no mínimo, de metade das horas para outras atividades além das horas destinadas à docência em sala de aula.

Em relação ao regime de trabalho em tempo integral com dedicação exclusiva, criado pelas normas federais, prevê-se que o professor esteja mais envolvido com a IES. Neste caso, é mais comum que sejam

94 Tratam deste aspecto a Lei no 3780, de 12 de julho de 1960; a Lei no 4345, de 26 de junho de 1964, e outras específicas sobre as IES públicas federais: a Lei no 4881-A, de 6 de dezembro de 1965 e o Decreto no 59676/66; a Lei no 7596, de 10 de abril de 1987 e o Decreto no 94664, de 23 de julho de 1987. 
professores doutores e estejam vinculados, também, à pesquisa na pósgraduação.

No caso das Universidades, segundo a LDBEN (1996b), é necessário que tenha um terço dos professores em regime de trabalho em tempo integral. A questão é que isto é por instituição, logo pode haver cursos com mais de um terço e outros, menos.

Portanto, ao analisar-se a questão do regime de trabalho dos docentes do Ensino Superior é necessário considerar as premissas citadas e que as definições para as classificações existentes variaram ao longo do tempo e têm alguns problemas conceituais. De qualquer forma, refletem, principalmente, as diferenças existentes entre os tipos de IES, se são universidades ou não, se públicas ou privadas e, em sendo públicas, se são federais ou não.

Quando se considera o território como mediação na questão do regime de trabalho dos docentes de licenciatura em Geografia no Brasil, conforme mapa 20, verifica-se que a dimensão do tipo de organização da IES tem relação direta com os dados apresentados.

É territorial também na medida em que nos territórios de menor densidade técnica e populacional, caso do Mato Grosso, Amapá e Tocantins, o governo federal cria as IES federais. Portanto, o regime de tempo integral com dedicação exclusiva é mais comum neste tipo de IES.

Em São Paulo, a maioria dos docentes neste regime de trabalho está na USP e na Unicamp e, no Paraná, nas estaduais de Maringá, Londrina, Guarapuava e Cascavel e na Federal localizada em Curitiba.

Em Rondônia, há duas extensões, uma da Universidade Federal de Rondônia (UNIR), situada na capital, onde há maioria de professores em tempo integral com dedicação exclusiva; outra das IES privadas do interior do Estado, com maioria de horistas. Em Pernambuco, a maioria dos horistas está nas IES públicas municipais do interior. 


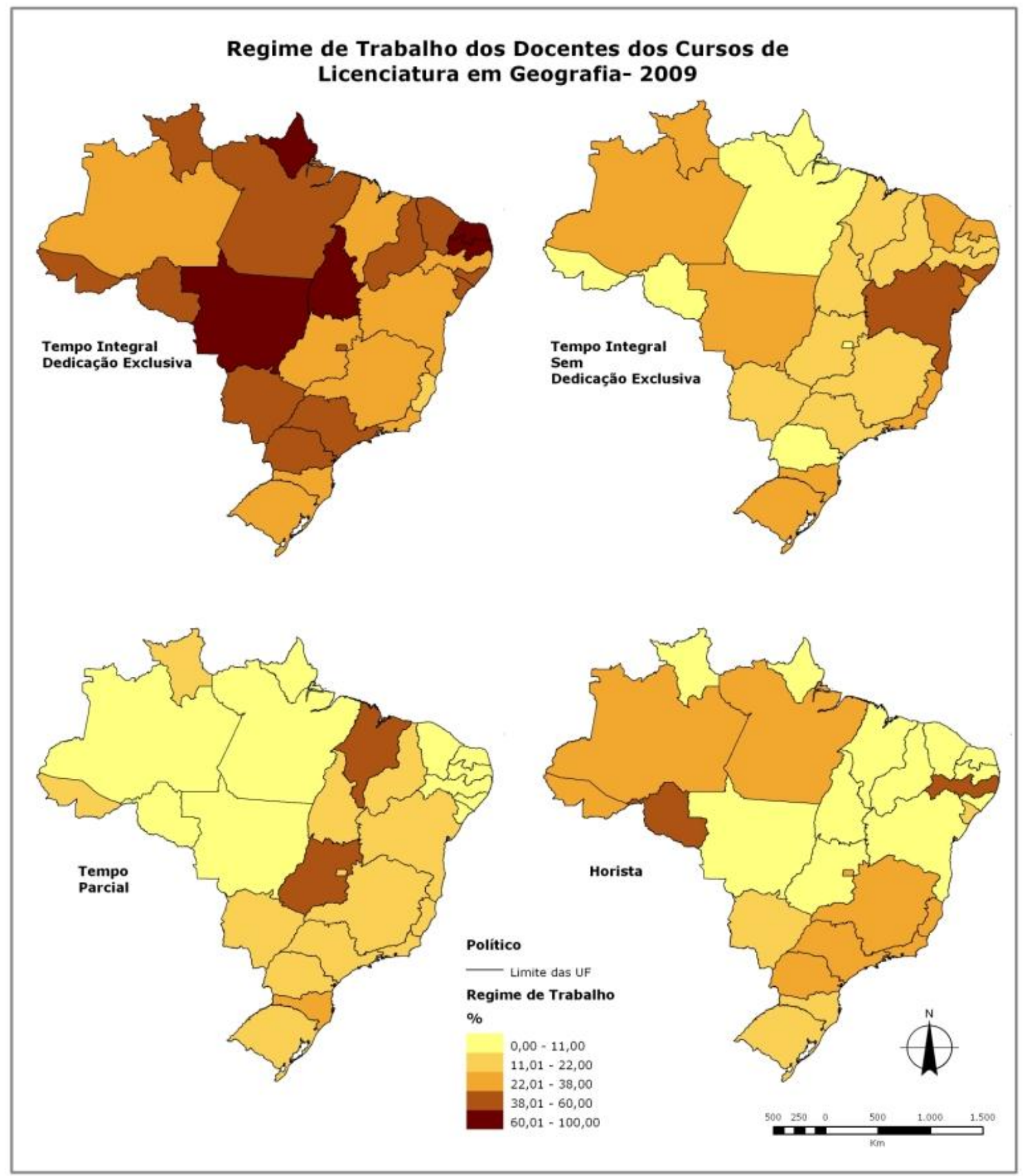

Mapa 20- Fonte: Dados do Inep (2009). Elaborado por Vivian Fiori e Maurício Yamada, 2011.

Levando-se em conta a situação existente nos estados de São Paulo e Rio de Janeiro, localizados na Região Concentrada, onde há maior densidade técnica no Brasil e grande número de IES, principalmente privadas, percebe-se, pelos dados sobre docentes (Tabela 5), tanto quanto à formação docente, como quanto ao regime de trabalho, que há duas situações distintas. 
Nas IES privadas há mais mestres e poucos doutores, o que reflete alguns aspectos mais comuns nestas IES: trabalho em regime horista e em alguns casos, baixos salários, o que não tem atraído professores doutores.

\begin{tabular}{|c|c|c|c|c|c|c|c|}
\hline \multicolumn{8}{|c|}{$\begin{array}{l}\text { Tabela 5: Características dos docentes dos cursos de Geografia } \\
\text { IES públicas e privadas de São Paulo e Rio de Janeiro -2009 (\%) }\end{array}$} \\
\hline \multirow[b]{2}{*}{ ESTADO } & \multicolumn{4}{|c|}{ FORMAÇÃO DOCENTE } & \multicolumn{3}{|c|}{ REGIME DE TRABALHO } \\
\hline & Graduação & Especialização & Mestrado & Doutorado & $\begin{array}{c}\text { Tempo } \\
\text { Integral }\end{array}$ & $\begin{array}{l}\text { Tempo } \\
\text { Parcial }\end{array}$ & Horista \\
\hline \multicolumn{8}{|c|}{ PRIVADA } \\
\hline SP & 5,63 & 24,4 & 52,17 & 18,16 & 26,6 & 25,1 & 48,3 \\
\hline $\boldsymbol{R J}$ & 3,19 & 29,26 & 51,06 & 16,49 & 17,1 & 15,4 & 67,5 \\
\hline \multicolumn{8}{|c|}{ PÚBLICA } \\
\hline SP & 4,55 & 5,68 & 14,77 & 75,0 & 69,9 & 15,9 & 14,2 \\
\hline$R \boldsymbol{J}$ & 4,93 & 3,52 & 34,51 & 57,4 & 78,9 & 20,4 & 0,7 \\
\hline
\end{tabular}

Fonte: Inep, 2009. Elaborado por Vivian Fiori, 2012.

Logo, apesar de estes cursos estarem inseridos em regiões de grande centralidade urbana, onde existe o maior número de programas de pós-graduação no Brasil, não se criam condições para a ampliação do número de doutores em seus quadros de docentes.

Tanto porque os formados na pós-graduação em nível stricto sensu nem sempre se interessam pelas IES privadas, quanto porque muitos professores destas IES têm uma jornada de trabalho que dificulta seu acesso à pós-graduação, principalmente de doutorado.

No cotidiano de trabalho destes docentes, seja universitário apenas ou não, perdem-se em suas inúmeras tarefas e distanciam-se cada vez mais da rede de relações que possibilitem voltar ao Ensino Superior como alunos de mestrado ou doutorado.

$\mathrm{Na}$ próxima seção serão discutidas as condições de ensino dos cursos de Geografia no Brasil e sua mediação com o território brasileiro. 


\section{ANÁLISE DAS CONDIÇÕES DE ENSINO DOS CURSOS DE GEOGRAFIA}

Ao realizar uma análise sobre as condições de ensino dos cursos de Geografia, destacam-se alguns elementos curriculares como fundamentais para a compreensão do contexto em que eles se inserem.

Ao mesmo tempo há relação destas condições com as características docentes, discentes, já discutidas anteriormente. São elementos que interagem numa dinâmica dialética, que precisa ser explicitada para clarificar as situações dos cursos de Geografia, especialmente das licenciaturas.

Para esta compreensão, a análise curricular dos cursos de Geografia mostra-se importante para o entendimento dessas condições de ensino. Como o termo currículo é polissêmico, cabe pensar o que é currículo no Ensino Superior: as disciplinas escolhidas no curso fazem parte do currículo? As metodologias e conteúdos desenvolvidos também? As atividades extraclasses, caso de iniciação científica e extensão são curriculares? Há mediação do território brasileiro a estas atividades?

O currículo existe por meio das práticas pedagógicas existentes nos cursos e de sua organização, mediante os seguintes aspectos: as normas e leis sobre a organização do curso; as diretrizes e os planos propostos; o projeto pedagógico; a matriz curricular; os conteúdos e metodologias; assim como o desenvolvimento destes em sala de aula.

Além disso, considera-se, nesta pesquisa, que a participação em atividades extraclasses, tais como pesquisa de campo, iniciação científica e atividades de extensão constituem-se em atividades curriculares.

Busca-se compreender as condições dos cursos, considerando principalmente alguns elementos curriculares, tais como: a integração dos currículos, a iniciação científica, a extensão, entre outros elementos, e a dinâmica destes no território brasileiro. 


\subsection{O currículo como um processo que se constrói historicamente}

O termo currículo ${ }^{1}$ é polissêmico (SACRISTÁN, 2000a; GOODSON, 2005) tendo inúmeros usos e conceitos. No ensino é comumente utilizado para designar uma forma de organizar as práticas educativas, em níveis, etapas, um percurso a ser desenvolvido na vida escolar, que tem diversas relações e mediações. Em torno da questão curricular há sempre conflitos e diversificados interesses, com diferentes opções teórico-metodológicas e ideológicas, sendo historicamente constituído.

Alguns autores estabelecem etapas no processo pelo qual ocorre o currículo. Para Ivor F. Goodson (2005) há um currículo pré-ativo, período no qual o currículo é discutido, definido enquanto política ou lei, e o momento ativo, no qual ele é implementado efetivamente pelos agentes do processo, sobretudo os professores.

Gimeno Sacristán (2000a, 2000b) e Henry Giroux (1997) trazem os termos currículo formal ou prescrito e currículo oculto. Tais autores definem que existe uma diferença entre o que é proposto formalmente através de normas, leis, diretrizes e planos - e o que se vivencia em cada situação, no ensino, levando-se em conta que há diversas mediações possíveis, entre elas: as condições socioeconômicas, culturais, organizacionais e as práticas docentes.

Em princípio, há relação entre o currículo previsto e o vivido. No entanto, não se trata de serem pré-ativos ou ativos, porque, enquanto práxis o currículo contempla a reflexão e a ação como processo contraditório, em ambas as situações, tanto quando é elaborado, quanto quando é vivido.

Logo, não são etapas numa lógica formal, pois, mesmo quando se vivência o currículo nas IES, há diferentes concepções, reflexões, interpretações do currículo prescrito sobre o entendimento do que é o currículo e de como é vivenciado concretamente.

Não há dicotomia, portanto, entre as normas, diretrizes e planos curriculares e como são vivenciados os currículos nas IES, mas sim 
contradições nestes dois momentos, sendo ambas as condições que se expressam em ações ativas, não sendo, portanto, ocultos.

Neste processo, há conflito na produção e existência do currículo, no nível teórico-metodológico, epistemológico, ideológico, sociocultural, entre outros.

O currículo ocorre num processo histórico, que se estabelece numa determinada realidade social, cultural, econômica, política e escolar, sendo, portanto, um fenômeno espacial, que interfere concretamente nos lugares e em suas instituições de ensino, por meio de diferentes grupos e redes de afinidade.

Há grupos na Geografia brasileira ao longo de sua história, que formam redes verticais e horizontais, com flexibilidade de aderência dos participantes, com diversas mediações possíveis, de que decorre a proposta do uso do conceito de grupos e "redes de afinidades". Por rede entende-se o que propõe Raffestin:

A rede aparece como fios seguros de uma rede flexível que pode se moldar como as situações concretas $e$, por isso mesmo, se deformar para melhor reter. A rede é proteiforme, móvel e inacabada, e é dessa falta de acabamento que ela tira sua força no espaço e no tempo. A rede faz e desfaz as prisões do espaço, tornado território: tanto libera como aprisiona. É o porquê de ela ser o "instrumento" por excelência do poder (RAFFESTIN, 1993, p. 204).

Então, um geógrafo pode aderir a certo tipo de escola, doutrina, metodologia, filosofia ou instituição num período e mudar depois, bem como, por uma questão organizacional, pertencer ou não a um determinado grupo ou a uma rede.

Há uma pluralidade de dimensões vividas no espaço e no tempo. Há também várias possibilidades, várias trocas, na práxis cotidiana, que às vezes são tênues, flexíveis e, em outras situações, marcadas por atos e eventos mais decisivos destas redes.

Foi o que se observou em 1978, no Encontro Nacional de Geógrafos em Fortaleza, considerado por alguns autores (REVISTA GEOSUL, 2001; 
2002) como momento importante da renovação da Geografia no Brasil, com a chamada "Geografia Crítica".

Há redes de afinidade, algumas horizontalidades (SANTOS, 2006), que, por afinidade "científica", doutrinária, ideológica ou teóricometodológica formam grupos e redes de afinidades.

Esta afinidade, porém, não é fechada, não é um círculo como afirma Vincent Berdoulay ${ }^{95}(1981 ; 2000)$. Há solidariedade dentro e entre as redes, mas também divergências, contradições que parecem inerentes ao processo do fazer ciência e de produzir conhecimento.

Não há como dissociar ciência de ideologia ${ }^{96}$, torná-la apolítica, neutra, tampouco os cursos de Geografia. Nem mesmo desconsiderar que a práxis vivida por cada participante da rede seja apenas unidimensional.

Logo, há diversas dimensões, possibilidades e preferências. Ora prefere-se Geografia Física à Humana; ora definem-se apenas como geógrafos, em outros são geógrafos críticos, humanistas ou pragmáticos. Ora são professores de Geografia, ora são bacharéis. Ora são geógrafosprofessores formados em instituições públicas, ora em privadas.

Ou seja, em alguns momentos da história de vida com a Geografia, fazem parte de uma rede de afinidade ou de uma situação, que muitas vezes é fluida, flexível; em outras, aprisiona. Portanto, a afinidade não é

95 Para Berdoulay (2000) o conceito de círculo de afinidade não tem relação apenas com a ciência, é mais amplo: "Ele designa uma rede de comunicação e de afinidades não somente entre os cientistas, mas também homens de letras, filósofos, artistas, homens políticos. Retraçar os encontros, a convivência, as alianças familiares, os campos ideológicos quando das crises na sociedade, as participações em associações, as escolhas de revistas para publicar, suas leituras favoritas etc., são tanto quanto maneiras para cercar estes círculos de afinidade". (BERDOULAY, 2000, p. 317).

Entende-se por ideologia aqui uma visão do mundo, sobretudo na dimensão política: "... a ideologia passa a ser vista como força histórica, uma 'dimensão política' inscrita na práxis. Aqui recupera-se a unidade entre pensamento e ação, onde as idéias cumprem um papel de convencimento e legitimação" (MORAES, 2005, p. 40). E como, em Gramsci, que define a existência de duas ideologias, uma arbitrária, que muitas vezes é individual e outra historicamente orgânica, na qual se vê o poder da ideologia como possibilidade para transformação "Enquanto são historicamente necessárias, as ideologias têm uma validade que é validade 'psicológica': elas 'organizam' as massas humanas, formam o terreno no qual os homens se movimentam, adquirem consciência de sua posição e lutam etc." (GRAMSCI, 2006, p. 237). 
desprovida de inúmeras contradições e nem sempre se dá por adesão formal.

O currículo é uma práxis ${ }^{97}$ educativa, logo com interação entre teoria e prática, reflexão que deve ocorrer em todos os momentos, não sendo, portanto, um produto acabado e sim uma ideia organizada mediante certos critérios e princípios, formalizada em documentos como projetos pedagógicos, diretrizes e planos, que, ao serem vivenciados no cotidiano dos cursos, podem ser modificados e criticados.

É necessário considerar que estes agentes - docentes, gestores, coordenadores, entre outros, constroem em suas IES socialmente a história dos cursos, representando diferentes concepções, assim como ocorre com suas organizações, os seus grupos, os seus coletivos.

Sartre (2002) diz que, se não é possível esquecer a existência dos indivíduos ${ }^{98}$, que concretamente produzem a história cotidianamente; tampouco deve-se desconsiderar o papel do grupo e das organizações no entendimento do processo histórico, dos quais, neste caso, docentes, discentes, mantenedores, coordenadores, entre outros, fazem parte.

Trata-se de uma condição ternária, não somente o binômio indivíduo-coletivo, mas também uma multidimensionalidade de relações, nas quais cada um totaliza a reciprocidade de terceiros no grupo.

97 Compreende-se a ideia de práxis conforme Vásquez (2007, p. 226) "[...] portanto, a simples atividade subjetiva- psíquica- ou meramente espiritual que não se objetiva materialmente não pode ser considerada práxis". Conforme Marx e Engels (2002, p. 100) dizem: "A questão de atribuir ao pensamento humano uma verdade objetiva não é uma questão teórica, mas sim uma questão prática. É na práxis que o homem precisa provar a verdade, isto é, a realidade e a força, a terrenalidade do seu pensamento". Gramsci (2006, p. 104) que escreveu sua obra entre 1929 a 1935, disse: "Todavia, nos mais recentes desenvolvimentos da filosofia da práxis, o aprofundamento do conceito de unidade entre a teoria e a prática permanece ainda numa fase inicial: subsistem ainda resíduos de mecanicismo, já que se fala da teoria como 'complemento' e 'acessório' da prática, da teoria como serva da prática".

98 Apesar de considerar que os indivíduos também constroem a história, Sartre relativiza este papel ao dizer: "E concedemos, de bom grado, a Plekhanov que 'as personagens influentes podem... modificar a fisionomia particular dos acontecimentos e algumas de suas conseqüências parciais, mas não podem mudar-lhes a orientação" (SARTRE, 2002, p. 101). E diz ainda: "Na realidade, existem duas dialéticas bem distintas: a do indivíduo prático, a do grupo como práxis [...] Com efeito, ele está contido entre duas negações radicais: a da ação individual que o reencontra em si mesma [...] e da união em grupos que se constitui nos próprios coletivos [...] (SARTRE, 2002, p. 423). 
Estabelecem-se relações de poder nesses grupos e organizações que não podem ser esquecidos no entendimento de uma pesquisa educacional; relações de poder que são intra e intergrupos e organizações, assim como são territoriais (RAFFESTIN, 1993).

Consequentemente, falar de docentes e discentes e das condições dos cursos pode ser uma grande abstração. É necessário torná-los concretos, objetivá-los em sua realidade como agentes históricos, em suas práxis sociais, que se objetiva nas organizações sociais, pelos atos reais, pelos eventos, cujas marcas, na história, serão maiores ou menores dependendo também da questão do poder emanado de tais atos ou organizações.

Sendo assim, objetiva-se, nesta pesquisa, por meio das organizações geográficas ou pelos tipos de IES e seus cursos de Geografia, ou, ainda, pelo entendimento da legislação proveniente do Estado nacional e sua relação com os diferentes grupos e instituições, isto é, a práxis.

As situações particulares de vivência criam singularidades e há contradições nos diferentes níveis nos quais o currículo ocorre. Portanto, o processo é dialético, dinâmico e multidimensional. No dizer de Sacristán (2000b):

Muitas vezes, de diversos ângulos, atribui-se deficiências à
composição dos currículos no sentido de não conter a cultura
interessante, porque estão compostos de retalhos de saber
desconectados entre si, carentes de estrutura [...] que
oferecem saber descontextualizado de sua gênese histórica,
como se fosse uma criação carente de vida e dinamismo
(SACRISTÁN, 2000b, p. 67).

Trata-se de um processo que cria tradições acerca de certas características do que se considera fundamental na existência curricular, desde a definição das disciplinas que o compõem até os objetivos, os conteúdos e as práticas.

É comum haver disciplinas que são tradicionais nos cursos. Em Geografia, por exemplo, existe a tradição de disciplinas como Geomorfologia, Geografia Urbana e Geografia Agrária, não se questiona 
porquê destas opções, não se busca entender os processos históricos que as consolidaram, não se pensa que se trata de um processo de seleção explícita ou implícita de disciplinas, conteúdos, teorias e metodologias.

Por outro lado, há verticalidades importantes neste processo, com as políticas de governo, com suas normas, leis e diretrizes já explicitadas em seções anteriores. Logo, há uma relação dialética entre estas condições mais universais e de como concretamente são vivenciadas no interior dos cursos de Geografia.

O currículo é visto sempre como fundamental nas reformas de ensino de cunho qualitativo; a cada momento que se pensa em mudar o curso, vem logo a possibilidade de mudança curricular. Mas de qual mudança se trata?

Geralmente, no Ensino Superior brasileiro, confunde-se mudança curricular, cujo conceito é mais abrangente, com mudança de matriz curricular, que se refere ao conjunto de disciplinas do curso.

Dentro dos parâmetros de administração e gestão comuns no universo acadêmico atual, o controle, a eficiência e a racionalidade técnica passam pela mudança curricular, mas que efetivamente é mais troca de disciplina do que transformação de caráter teórico-metodológico.

Comumente, esta mudança é vista como atividade prática, na qual, muitas vezes, a definição técnica e formal parte de órgãos distantes ou de alguém que não vai efetivamente vivenciá-la em sala de aula. Logo, são verticalidades.

Em decorrência destes fatos, muitas vezes, docentes e discentes desconhecem a composição do currículo do curso no qual atuam. Na maioria das vezes, não há clareza sobre os objetivos de seu curso nem das estratégias de ensino-aprendizagem necessárias a seu alcance.

Desconhece-se o perfil do curso, até mesmo as disciplinas que 0 compõem e o porquê desta escolha. Esta parece ser uma questão central, pois muitos docentes e discentes entram num curso sem saber bem o que virá, sem terem um entendimento mínimo do que se dará ao longo do currículo. Mas não se trata somente de um problema que ocorre ao longo 
do curso, pois, mesmo ao final deste, nem sempre há clareza acerca dos pontos levantados sobre o que é o currículo.

Autores como Sacristán (2000a; 2000b) dizem que o entendimento da questão curricular é interdisciplinar, complexo, bastante abrangente e que implica na necessidade de uma metateoria social e educativa. Cabe, portanto, uma maior reflexão sobre tais situações nos cursos, ainda que num nível menor de profundidade.

No caso das licenciaturas de Geografia, há discussão de teorias e práticas sobre ensino, mas quase sempre na perspectiva de sua atuação no nível escolar, nos Ensinos Fundamental e Médio, bem menos no entendimento desta formação no Ensino Superior, da qual o discente está inserido. Ou seja, qual o papel de um curso de licenciatura em Geografia?

Existe, ainda, outro problema. Como não há formação específica para professores do Ensino Superior, e a pós-graduação não responde a este interesse, busca-se mais formar um pesquisador do que um professor Não que sejam situações excludentes, mas a profissionalidade docente no Ensino Superior tem características específicas, que a tornam diferente dos outros níveis de ensino.

Desse modo, docentes provenientes de diferentes formações de graduação e pós-graduação tornam-se professores universitários de Geografia. Há inúmeros trabalhos de pesquisa que se debruçam sobre o fato de qual Geografia é ensinada nos Ensinos Fundamental e Médio. Mas afinal qual é a Geografia que produzimos no Ensino Superior? E em quais condições?

As transformações definidas para o currículo dos cursos também são assimiladas de diferentes formas por docentes e discentes. Muitas vezes são mudanças mais aparentes, uma novidade num contexto de velho modelo.

Em algumas situações o currículo torna-se um mosaico justaposto, eclético, tanto teórico quanto metodologicamente, sem clareza de propósitos, com disciplinas desconexas. 
Ressalta-se que o problema menor é a matriz curricular e os nomes das disciplinas, porque, quando se diz que no curso há "Geografia Urbana", não se tem certeza de quais são as abordagens teóricometodológicas desta disciplina.

Pode haver um entendimento melhor se houver contato com a ementa da disciplina, ou, ainda, com os objetivos propostos e bibliografias usadas. Ainda assim, isto poderá representar apenas uma aproximação provisória, uma pseuconcreticidade ${ }^{99}$.

Consequentemente, ocorre uma troca de uma disciplina por outra no currículo, não se modificando a essência do curso efetivamente, o que seria mais complicado e eventualmente criaria conflitos entre grupos. Ao mesmo tempo, os envolvidos se sentem impotentes para fazer uma reforma mais ampla no ensino, já que isto depende, em grande parte, de agentes que atuam à distância, por meio de um acontecer hierárquico (SANTOS, 2006). É possível retirar "Geografia Humana" do currículo para inserir-se "Geografia Urbana" e "Geografia Agrária", vinculando-se a opção mais ao conteúdo do que à teoria.

Então, a troca de nomes na matriz curricular passa a representar inovação. São palimpsestos, formas novas com conteúdos velhos. Isto não representa necessariamente uma condição pior ou atrasada, mas não há transformações essenciais mais profundas ou reflexões sobre o que é fundamental.

No caso dos cursos de Geografia, há ainda uma disputa comum sobre a necessidade de haver mais disciplinas de Geografia Humana ou Física, assim como, nas licenciaturas, a formação pedagógica termina por ser vista apenas como um apêndice.

99 Conforme diz Karel Kosik (2002, p. 20) "O pensamento que quer conhecer adequadamente a realidade, que não se contenta com os esquemas abstratos da própria realidade, nem como suas simples e também abstratas representações, tem de destruir a aparente independência do mundo dos contactos imediatos de cada dia. O pensamento que destrói a pseudoconcreticidade para atingir a concreticidade é ao mesmo tempo um processo no curso do qual sob o mundo da aparência se desvela o mundo real". 
Os grupos e suas redes de afinidades têm relação com a formação em Geografia, numa interface entre alguns processos universais e aspectos internos de sua formação.

Esta condição se materializa, por exemplo, nos currículos e projetos pedagógicos dos cursos que, erroneamente, acabam por se tornar meros instrumentos técnicos pelos quais se expressam as características pedagógicas do curso.

Há, nos currículos, muito de definição política, de ideologia, de poder, de conflitos entre preferências teórico-metodológicas dos sujeitos que o produzem, intra e inter redes de afinidades.

Há embate e disputa na escolha do perfil do curso, de seus objetivos, sobre quais disciplinas serão elencadas na matriz curricular. Há disputas claras, inerentes aos processos dialéticos da práxis educacional, do concreto pensado e vivido nas IES e em seus cursos de Geografia no Brasil.

Entre os agentes que participam mais diretamente deste processo no Brasil, estão o MEC, com as políticas nacionais para os cursos de Geografia, as instituições de Ensino Superior e seus cursos de Geografia, os discentes, os docentes e os coordenadores de cursos ou de departamentos de Geografia, entre outros.

Há uma mediação importante sobre as formas de organização acadêmica e administrativa das IES no Brasil, participando deste processo de existência dos currículos. Conforme diz Durham (2006):

Nas universidades públicas não existem instrumentos institucionais adequados para a organização do currículo e controle da atividade docente. Nas particulares estas funções estão, em grande parte, sob controle das mantenedoras. De fato, se a antiga Universidade brasileira privilegiava o ensino em detrimento da pesquisa, a atual age exatamente no sentido inverso. Esta tendência é fortalecida pelo fato de a estrutura toda ser altamente verticalizada, dificultando as relações horizontais entre departamentos, as quais ficam subordinadas a decisões de órgãos hierarquicamente superiores: congregações e conselho universitário (DURHAM, 2006, p. 113) 
Se nas IES públicas, há grande verticalização que dificulta a discussão e mudanças curriculares, em algumas IES particulares, as mudanças nem sempre ocorrem de forma democrática, pois, em alguns casos, não há participação dos docentes.

Em sua pesquisa de doutorado, Vicente de Paula Leão (2008), mediante entrevistas com coordenadores de cursos de IES privadas de cursos de Geografia em Minas Gerais, constatou que:

A decisão de mudar a matriz curricular parte das Próreitorias ligadas à administração, prevalecendo, assim, a visão do setor financeiro. A opinião da Pró-reitoria de ensino, da Diretoria de cursos e das Coordenações fica em segundo plano, ou em nenhum plano - conforme constatado nas entrevistas com os coordenadores de cursos das IESPs. O poder de decisão está nas mãos de pessoas que, em sua maioria, não possuem nenhuma afinidade com o pedagógico $\mathrm{e}$, que, inclusive, desconhecem ou desrespeitam as leis (LEẪO, 2008, p. 38).

Ressalta-se que esta condição não é necessariamente comum apenas às IES privadas. Sendo assim, a questão curricular é bastante complexa e tem de ser considerada na mediação dos agentes que a produzem no tempo e no espaço.

\subsection{A questão curricular nos cursos de Geografia no Brasil e suas dicotomias}

Há diversas dicotomias presentes nos cursos de Geografia desde o início de sua existência, tais como: entre os perfis do bacharelado e da licenciatura; entre a Geografia Física e a Humana; entre as disciplinas específicas e as pedagógicas; entre o ensino e a pesquisa, além de outras.

Uma das primeiras dicotomias dos cursos se deu com a formação inicial em História e Geografia, já que os primeiros cursos de Geografia eram juntos com os de História, situação que durou até a década de 1950.

Na década de 1960, foi institucionalizado o currículo mínimo para os cursos de Geografia, bem como criados os cursos de Estudos Sociais, que também habilitavam à formação de professores em Geografia. Esta 
situação continuou até o início dos anos 1990, com a coexistência de cursos de Geografia e de Estudos Sociais.

Considerando-se o período mais recente, pós 1996, houve, no Brasil, duas políticas do MEC que se relacionam mais diretamente à questão curricular de Geografia: a primeira são as Diretrizes Curriculares Nacionais de Geografia (Parecer CNE/CES 492/2001 e Parecer CNE/CES 1363/2001); a outra, a legislação específica sobre a formação de professores (CNE 009/2001 e Parecer CNE/CP 28/2001).

A legislação do Ensino Superior específica para as licenciaturas define que os cursos de licenciatura deverão ter características curriculares próprias, que a diferenciem dos cursos de bacharelado, conforme se estabelece no Parecer CNE/CP 009/2001:

O processo de elaboração das propostas de diretrizes curriculares para a graduação, conduzido pela SESu, consolidou a direção da formação para três categorias de carreiras: Bacharelado Acadêmico; Bacharelado Profissionalizante e Licenciatura. Dessa forma, a Licenciatura ganhou, como determina a nova legislação, terminalidade e integralidade própria em relação ao Bacharelado, constituindo-se em um projeto específico. Isso exige a definição de currículos próprios da Licenciatura que não se confundam com o Bacharelado ou com a antiga formação de professores que ficou caracterizada como modelo " $3+1$ " (MINISTÉRIO DA EDUCAÇÃO, 2001a, p. 6).

A compreensão dos cursos e de sua essência também está no plano das mediações de sua relação com o perfil proposto para o curso. Tal legislação emerge de uma política universal do governo federal para todo o Ensino Superior brasileiro. Entretanto, como se dá a materialização desta lei nas IES? Como saímos da aparência da lei e chegamos à essência neste caso?

Portanto, a lei, ao se empiricizar, cria concretude, deixando de ser uma matéria inerte, uma intenção, tornando-se uma práxis educacional. Sua essência, assim pensada, é cheia de contradições que são inerentes ao próprio processo da práxis. Ou seja, há práxis heterogêneas, que se realizam nas mediações com o território brasileiro, nos diferentes tipos de IES e conforme as modalidades nas quais os cursos são oferecidos. É no 
interior dessa contradição entre a lei e sua existência real que é necessário buscar a compreensão do processo.

Portanto, é importante separar a lei de sua representação, de como é interpretada e vivida pelas diferentes organizações e instituições superiores. Logo, a percepção de cada um sobre a lei não é objeto desta pesquisa, mas interessa concretamente como é vivida, assim como Karel Kosik (2002) diz:

A dialética trata da "coisa em si". Mas a "coisa em si" não se manifesta imediatamente ao homem. Para chegar a sua compreensão, é necessário fazer não só um esforço, mas também um détour. Por este motivo o pensamento dialético distingue entre representação e conceito da coisa, com isso não pretendendo apenas distinguir duas formas e dois graus de conhecimento da realidade, mas especialmente e sobretudo duas qualidades da práxis humana (KOSIK, 2002, p. 13).

Logo, cabe evidenciar os cursos de licenciatura em Geografia buscando sua relação com as políticas públicas, que, em princípio, são mais universalidade e aparência e concretamente precisam ser entendidas num movimento histórico e em sua mediação espacial.

Outro documento importante são as "Diretrizes Curriculares Nacionais de Geografia" (MEC, 2001c), que passou a nortear a produção da matriz curricular, bem como do projeto pedagógico dos cursos de Geografia, conforme aponta o documento:

A geografia, em seu processo de desenvolvimento histórico como área do conhecimento, veio consolidando teoricamente sua posição como uma ciência que busca conhecer e explicar as múltiplas interações entre a sociedade e a natureza. Isso significa dizer que possui um conjunto muito amplo de interfaces com outras áreas do conhecimento científico. Assim, coloca-se a necessidade de buscar compreender essa realidade espacial, natural e humana, não de uma forma fragmentada, mas como uma totalidade dinâmica (MEC, 2001c, p.10).

O documento vislumbrava, em 2001, a mudança pela qual o mundo passava, com a aceleração do tempo e transformações espaciais que faziam que novas áreas de conhecimentos geográficos surgissem ou trouxessem novos caminhos teóricos e metodológicos para a Geografia, com novas disciplinas ou áreas, tais como: Geoprocessamento, 
Geoecologia, Teorias das Redes Geográficas, Geografia Cultural, Geografia Política, Planejamento e Gestão Ambiental, entre outras.

As Diretrizes relacionavam, ainda, o perfil do formando, bem como as competências gerais e específicas do curso.

Apesar de fazer-se algumas ressalvas à forma de pensar Geografia, trata-se de um avanço em relação à política dos currículos mínimos dos anos 1960, porque se configuram como diretrizes e não como currículo obrigatório. Desta forma abrem a possibilidade de maior liberdade na definição curricular em cada IES e de se considerar a diversidade territorial existente no Brasil.

A questão é que esta possibilidade passa a ser controlada por Comissões de Avaliação do MEC, na medida em que elas recomendam mudanças no curso, sobretudo no currículo, especialmente em sua matriz curricular com sugestões de inserção de disciplinas, entre outras ações.

$\mathrm{Na}$ Geografia, em especial, há ainda os perfis dos cursos de bacharelado e de licenciatura, que historicamente foram construídos juntos. No início da existência dos cursos de Geografia, Pierre Monbeig e Aroldo Azevedo destacavam a problemática da diferença de formação do bacharel e do professor de Geografia.

Aroldo Azevedo (1946) contava sobre seu empenho em orientar seus alunos também com vistas à formação de professores, em sua disciplina de "Geografia do Brasil", para que esta formação não ficasse circunscrita à "Didática", disciplina responsável pela formação de professor, segundo a legislação da época. Já Monbeig afirmava:

É preciso não perder de vista que a finalidade exata das faculdades de filosofia, ciências e letras está longe de ser exclusivamente a formação de pesquisadores profissionais, mas também a de professores destinados ao ensino secundário. Por conseguinte, o ensino da geografia nessas escolas superiores deve ser organizado de maneira a atingir esse duplo objetivo (MONBEIG, 1944, p. 7).

Sobre a formação de licenciados e bacharéis, é interessante observar o discurso do professor Jorge Zarur, em 1944, bem diferente de Monbeig e de Azevedo, denominando os bacharéis de "geógrafos 
profissionais", por produzirem uma "Geografia Utilitária", termo cunhado pelo autor:

Nos últimos dez anos, as nossas universidades se têm esforçado em formar professores de Geografia. Geógrafos no verdadeiro sentido da palavra são poucos e quase todos auto-didatas. Tenho esperança de que, no futuro, teremos também o técnico de Geografia, o Geógrafo profissional, como eu vi nas várias regiões americanas por onde passei, pesquisando e não somente ensinando Geografia, mas indo a campo para realizar pesquisas, construindo a Ciência Geográfica (ZARUR, 1944, p. 314).

Tal condição é ainda hoje alvo de discussão na Geografia brasileira, levando-se em conta que, em princípio, apenas bacharelandos fazem pesquisa. Ao mesmo tempo, mostra um desprestigio da carreira do professor- aquele que ensina - em relação ao bacharel.

Como se vê, a formação apropriada para bacharéis e licenciados já era discutida no passado e, ainda hoje, permanece como problemática pesquisada no Brasil.

Logo, é necessário considerar as novidades e as heranças do passado interagindo num processo dialético, o que leva à permanência destas reminiscências do passado no presente, em novos contextos políticos, sociais e espaciais.

Além disso, outra divisão comum na Geografia tem sido a separação da Geografia Física e Humana, que, em alguns casos, leva à separação dos docentes do curso em departamentos diferentes.

Em depoimento sobre o curso de Geografia do campus UNESP em Presidente Prudente, interior de São Paulo, o professor Fernando Salgado dizia na década de 1980:

[...] com a criação da UNESP a nossa Faculdade foi reduzida a 2/5 dos seus cursos e o Departamento de Geografia foi também desestruturado. Assim os professores do setor humano foram colocados no Departamento de Geografia e Planejamento e os do setor físico no Departamento de Ciências Ambientais (SALGADO, 1984, p. 5).

É difícil ter um currículo integrado com uma organização que se configura na divisão dos professores da Geografia. 
A questão, a despeito de seu viés administrativo, é bastante complexa e se reflete no currículo e nas atividades práticas do curso. Há ainda professores lecionando em diferentes cursos que também acabam não tendo vínculos específicos e a compreensão necessária dos cursos de Geografia.

Ao analisar algumas matrizes curriculares ${ }^{100}$ nas licenciaturas em Geografia no Brasil, observa-se que há cursos cujo número de disciplinas específicas é pequeno.

Além das tradicionais, como Antropologia, Sociologia, Política e Geologia, já historicamente comuns nos cursos de Geografia, verifica-se uma grande variedade de disciplinas não específicas, tais como: Informática, Estatística, Elementos da Matemática, Língua Portuguesa, Formação Política e Cidadã, Fotografia da Natureza, Educação Ambiental, Astronomia, Matemática Básica, Física Aplicada à Geociências, Processo Decisório e Criatividade, Ecologia, Responsabilidade Social e Ambiental, Folclore do Brasil, Química Geral, Empreendedor, Astronomia Observacional, Processamento de Dados, entre outras.

Cabe ressaltar que tais disciplinas estão elencadas entre as obrigatórias destes cursos cujas matrizes previstas foram analisadas, tendo algumas, inclusive, denominações bastante incomuns.

Isto ocorre mais nos dois primeiros semestres, conforme exemplo destacado de um currículo, anexo C, aumentando o problema de um currículo vivido sem um perfil claro pretendido, com uma justaposição de diversificadas áreas do conhecimento.

Ao tratar do curso de Geografia da Unicamp, no começo deste século, a Profa Maria Adélia Aparecida de Souza diz:

Começo ensinando para os meninos o conceito de natureza [...] eles não tem uma disciplina que é fundamental: História do Pensamento Geográfico. Eles ficam estudando cálculos, físicas e químicas para se formarem geógrafos. Estudam, do meu ponto de vista, naquele currículo apenas oito disciplinas

100 Analisaram-se 156 matrizes curriculares de todo o Brasil que disponibilizam suas matrizes nos sites das IES. Como há IES com diversos cursos pelo interior, caso da UEMA, o número de cursos cuja matriz é igual pode ser maior. Trata-se, pois, de uma análise do currículo previsto. 
geográficas. Aquele curso acredita que é preciso matematizar o mundo. Eu acho um equívoco (REVISTA GEOSUL, 2003, p. 199).

Esta situação citada pela professora é comum em cursos de Geografia que optaram ou foram vinculados aos Departamentos de Geociências no período dos governos militares. Segundo depoimentos colhidos, nas Geociências ou áreas afins, há mais verbas devido ao fato de que os cursos que o integram serem de interesse dos financiadores de pesquisa mais do que os cursos das Faculdades de Ciências Humanas, Letras e Filosofia.

Assim, o interesse financeiro e o financiamento para as pesquisas e projetos têm relação com o lugar onde o curso está inserido, logo a dimensão econômica tem, em parte, relação com esta situação.

Em princípio, supunha-se que disciplinas não específicas, caso de Estatística e Matemática, fossem mais comuns em cursos de bacharelado do que em licenciatura, mas, na análise das matrizes curriculares, fica evidente que tais disciplinas são bastante comuns também na licenciatura em Geografia. Daí a confusão dos perfis do bacharelado e da licenciatura que se imbricam, mesmo em cursos que são apenas de licenciatura.

Naturalmente, espera-se que um curso de Geografia também tenha disciplinas afins ou complementares, já que é importante que um professor tenha uma formação ampla, além das especificidades de sua ciência ou área do conhecimento. Contudo, há também necessidade de que exista um conjunto de disciplinas mais especificamente geográficas, que permitam ao futuro profissional ter uma formação sólida em sua área, como professor de Geografia.

No Exame Nacional de Cursos (ENC), em 2003, havia uma pergunta específica sobre a existência, nos currículos dos cursos de licenciaturas de Geografia, de disciplinas específicas, de áreas e conhecimentos afins (núcleo comum). A maioria respondeu que a existência de tais disciplinas era "plena" ou "ampla". 


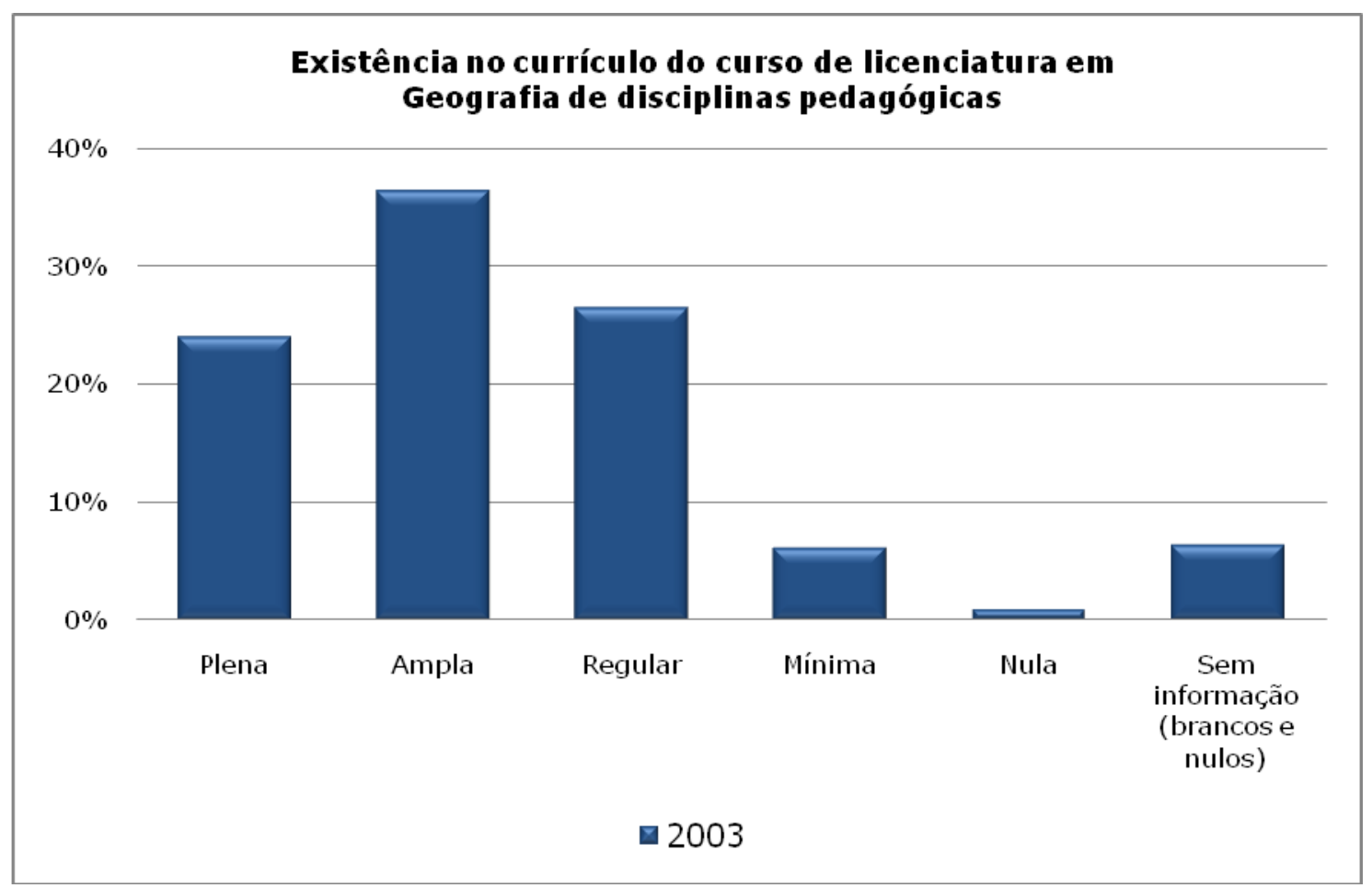

Gráfico 12- Fonte: Inep, Relatório do ENC- Geografia, 2003. Elaborado por Vivian Fiori, 2009.

Em 2003, questionados sobre a existência de disciplinas pedagógicas no curso, gráfico 12 , os estudantes assinalaram, principalmente, a alternativa "plena" (24\%) e "ampla" (36,4\%). A alternativa "regular" foi da ordem de $26,4 \%$, assinalada, em sua maioria, por estudantes de IES estaduais $(28,9 \%)$, federais $(28 \%)$ e das universidades $(28,4 \%)$.

Cabe lembrar que, nas IES estaduais e federais, estão muitos cursos que têm unido a licenciatura e o bacharelado, fazendo com que a licenciatura não tenha terminalidade própria como requer a lei. Por isso, a alternativa "regular" é mais comum neste tipo de IES. No Pará, por exemplo, a UFPA tinha os dois cursos juntos até 2011 em alguns municípios, só recentemente houve a separação.

$\mathrm{Na}$ análise de 156 matrizes curriculares das licenciaturas em Geografia, fica evidente que estas têm variado número de disciplinas não específicas e que, na maioria das vezes, não são optativas.

Apesar disso, verifica-se que todas têm disciplinas específicas definidas como pedagógicas, cumprindo-se a necessidade das licenciaturas, com diversificadas nomenclaturas, tais como: Princípios das 
Práticas Docentes, Arte e Criatividade no Ensino de Geografia, Currículo e Avaliação, Psicologia da Educação, Prática de Ensino em Geografia, Organização e Funcionamento da Educação, Planejamento e Avaliação de Aprendizagem, Prática de Vivência Curricular, Filosofia da Educação, Aspectos Metodológicos e Técnicos da Geografia Escolar, Estrutura e Funcionamento de Ensino, Políticas Públicas de Educação, Educação Inclusiva, Didática, Ação Docente na Sala de Aula, Educação para Relações Étnico-Raciais, Instrumentação de Recursos Didáticos, Ética e Cidadania na Formação do Educador, Libras, entre outras.

$\mathrm{Na}$ maioria dos casos, há uma distribuição das disciplinas ditas "pedagógicas" ao longo do curso, como requer a lei. Contudo, em algumas situações, há uma concentração nos últimos semestres.

No questionário socioeconômico, respondido pelos concluintes de Geografia no Enade 2008, quando indagados sobre como avaliavam o currículo do seu curso, apontaram como alternativa principal que este é: "relativamente integrado, já que as disciplinas se vinculam apenas por blocos ou áreas de conhecimentos afins".

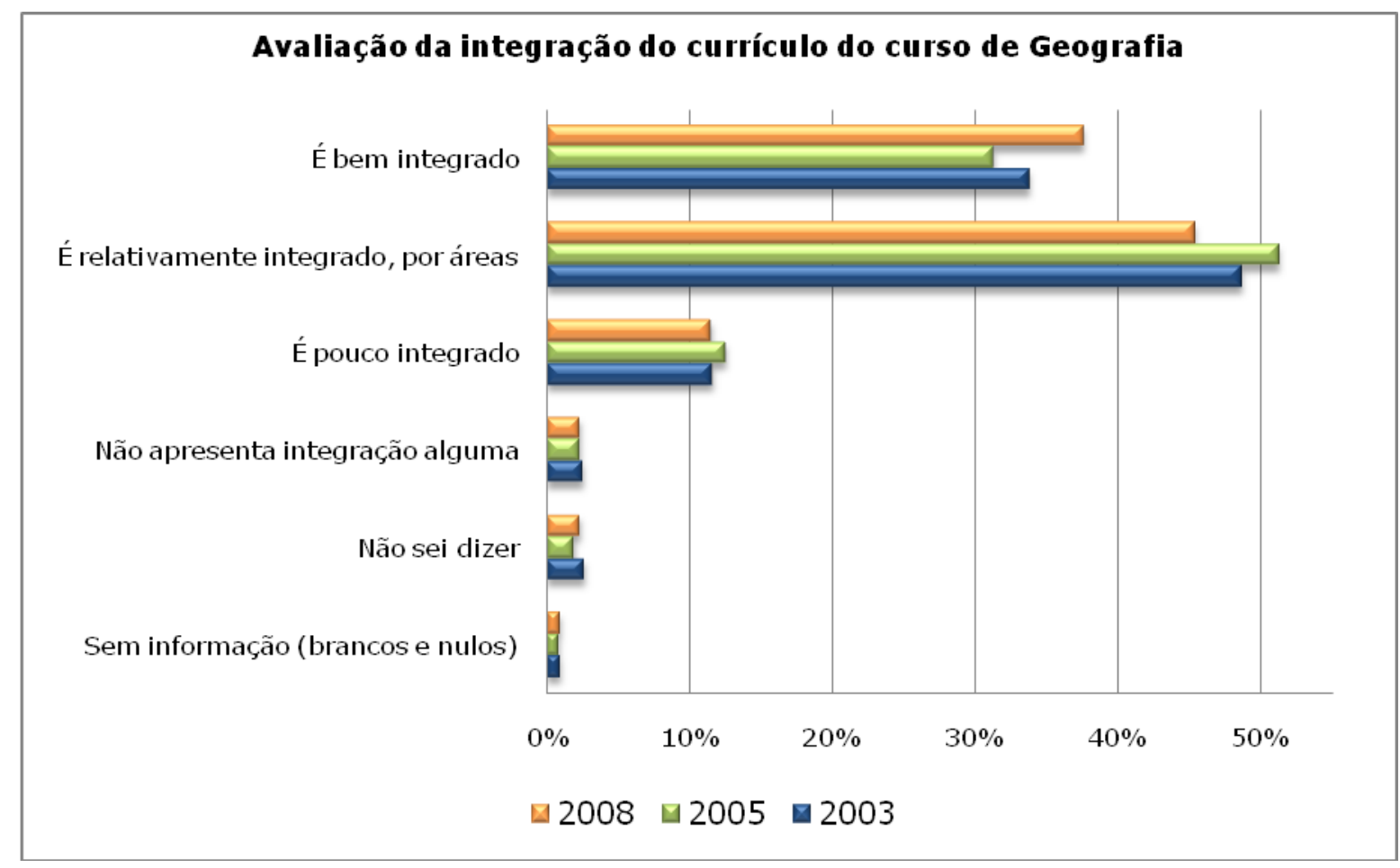

Gráfico 13 - Fonte: Inep, Relatórios Sínteses/Cursos, Área de Geografia, ENC 2003 e Enades 2005 e 2008. Dados organizados por Vivian Fiori, 2009. 
Conforme gráfico 13 , esta alternativa foi assinalada por $48,7 \%$ dos estudantes em 2003; por 51,3\% em 2005 e por 45,4\% em 2008. Esta resposta denota um velho problema da Geografia e suas diversas dicotomias e problemas, que dificultam uma integração necessária: a dicotomia entre Geografia Física e Humana; disciplinas específicas e pedagógicas; perfis da licenciatura e do bacharelado.

Verificando-se como se dá a distribuição pelas unidades da federação, para a avaliação do currículo como "relativamente integrado" observa-se que em São Paulo, Santa Catarina, Rio Grande do Sul e Maranhão estão as menores médias, alcançando-se, no máximo, 38,28\%.

Há uma tendência de que, nas instituições privadas, o currículo seja considerado mais integrado, conforme Apêndice D. Um dos principais fatores para esta condição é o fato de as IES públicas vivenciarem mais a mescla entre cursos de licenciatura e bacharelado do que as privadas, nos quais é mais comum só a existência do curso de licenciatura.

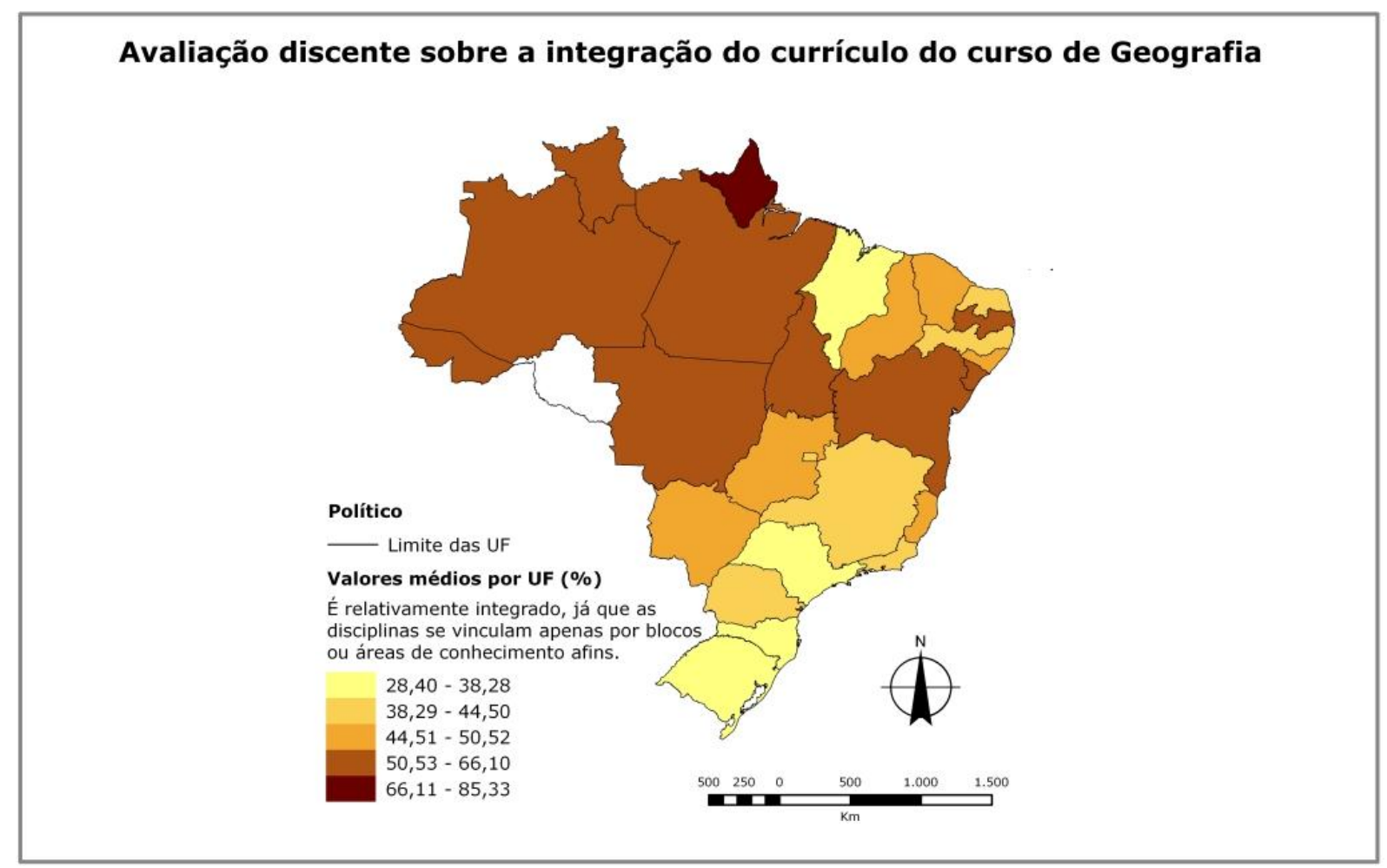

Mapa 21 - Fonte: Inep, Relatórios de Cursos de Geografia no Enade, por IES, 2008. Elaborado por Vivian Fiori e Mauricio Yamada, 2010.

Conforme se observa no mapa 21, os estados onde prevalecem cursos só de licenciatura, caso do Maranhão, Goiás e Piauí, o currículo 
tende a ser considerado mais integrado, assim como, em São Paulo e Rio Grande do Sul, o que se justifica pelo maior número de IES privadas, onde predominam as licenciaturas.

Cabe uma pergunta: até que ponto a formação territorial brasileira e sua dinâmica interferem na produção dos currículos, sobretudo de sua matriz?

Por meio da análise dos currículos previstos, bem como através de depoimentos de docentes e discentes dos cursos verifica-se que há alguns elementos curriculares que se alteram conforme o lugar onde o curso está inserido. Assim, nas capitais há uma tendência maior na possibilidade da construção do currículo que contemple disciplinas optativas, já que nas capitais, sobretudo nas IES públicas e nas Universidades, há maior número de cursos e habilitações sendo oferecidos.

No interior, sobretudo na Amazônia e Nordeste, a matriz dependerá muito dos núcleos que lá se formam. Dessa forma, se numa cidade de pequeno porte não houver campus da IES e sim apenas um núcleo de Educação, há uma tendência que esta matriz tenha mais disciplinas vinculadas à formação à docência. Logo, há uma produção da matriz curricular mediada pela condição do lugar.

A maioria absoluta dos coordenadores entrevistados de curso de Geografia, ao serem questionados sobre as dicotomias existentes nas licenciaturas, dizem que é uma questão histórica, difícil de ser modificada.

As prováveis relações para esta condição seriam a formação dos docentes em que estão enraizadas estas dicotomias e são reproduzidas em suas práticas no Ensino Superior; as diferenças existentes na concepção do que seja um curso de bacharelado e de licenciatura; além da diferença de visão sobre a própria perspectiva teórico-metodológica do que é Geografia.

Esta opção também varia conforme a instituição na qual o docente se formou, já que pode haver uma tradição maior para a Geografia Física ou Humana. Corroborando esta ideia, o coordenador do curso de 
Geografia da Universidade Estadual do Amazonas (UEA) em Tabatinga, relatou:

Nossos professores são bem diversificados, no caso dos docentes formados pela Universidade Federal do Amazonas (UFAM) o perfil maior é mais para a Geografia Humana, outro formado da UFBA também. Eu transito mais nas duas áreas, mas prefiro mais Geografia Física, embora já tenha dado aulas de Geografia Econômica. Acho que com exceção do professor Aziz Ab'Saber, que atuava bem nas duas áreas, sempre há esta dicotomia, por identificação individual, e devido aos concursos pedirem especialização em Geografia Humana ou Física.

Sobre esta dicotomia, Ruy Moreira diz que as raízes desta divisão não se encontram na própria Geografia, mas, nas ciências em geral, com o advento da Ciência Moderna, sobretudo na concepção positivista, conforme afirma o autor:

Até a primeira metade do século XIX chamava-se Física a Geografia existente. Assim a designa Kant. Entendia-se por físico o mundo da captação sensível, isto significando a totalidade dos fenômenos externos que nos cercam [...] 0 germe do conceito moderno está, entretanto, já presente no pensamento oitocentista, caminhando para o sentido do inorgânico (meramente inorgânico) que o termo vai adquirir em nosso tempo, a despeito da reação em contrário dos românticos. [...] Assim, a Geografia Física passa a ser sinônimo de Geografia da natureza inorgânica (MOREIRA, 2008, p. 44).

A origem desta está fundada principalmente no método positivista ${ }^{101}$, que, no caso da Geografia, produziu uma Geografia Humana naturalista e uma Geografia Física desumanizada, calcada na crença da ciência neutra. Contudo, atualmente não é possível definir a Geografia

101 Paulo César da Costa Gomes (2007) apresenta a discussão da ciência e das proposições de Comte e da ciência moderna que, segundo ele, trazia um discurso de único conhecimento rigoroso e válido, portanto, científico. Segundo o autor: "Para que a ciência pudesse ser fundada sobre a excelência do método, uma outra condição deveria ser realizada. $O$ estabelecimento de uma distância entre o sujeito conhecedor e o objeto deste conhecimento. A razão, graças ao método, era considerada como único instrumento capaz de separar a percepção personalizada e imediata do conhecimento geral, universal e objetivo é o método científico" (GOMES, 2007, p. 69). Já Comte (1975), em seu "Discurso de filosofia positiva", diz: "Todos os bons espíritos repetem desde Bacon, que somente são reais os conhecimentos que repousam sobre fatos observados. [...] Pois, se de um lado toda teoria positiva deve necessariamente fundar-se sobre observações, é igualmente perceptível, de outro, que, para entregar-se à observação, nosso espírito precisa duma teoria qualquer" (COMTE, 1978, p. 5). 
Física apenas como inorgânica já que os estudos das paisagens vegetais não são inorgânicos. Esta tradição que veio da Europa, com a ciência geográfica moderna, tornou-se comum nos cursos de Geografia do Ensino Superior brasileiro, mantendo-se esta situação nos currículos vividos no Brasil.

Nas abordagens sistêmicas ${ }^{102}$ mais recentes, busca-se integrar 0 homem e a natureza, mediante análise em sistemas nos quais interagem os sistemas sociais, naturais e econômicos.

Antonio Christofoletti (1997) foi um dos autores brasileiros que propôs um currículo específico para licenciatura e outro para bacharelado, baseando-se no que chamava de campo de ação geográfica, que era o estudo da organização espacial.

$\mathrm{Na}$ concepção dele o que deveria caracterizar o currículo seria o seu objeto de estudo e não apenas o caráter disciplinar, não cabendo, pois, a divisão entre Geografia Física e Humana. Sua proposta apresentava o estudo dos sistemas físicos ou ambientais, por meio do geossistema, bem como os sistemas socioeconômicos. Disse o autor:

No caso da Geografia, as formulações curriculares dominantes encontram-se baseadas no critério do desenvolvimento do pensamento geográfico, procurando absorver proposições e temáticas como indicadoras de novas disciplinas. As circunstâncias que geraram novas especializações temáticas foram sendo valorizadas, como novos ramos subdisciplinares na Geografia, no contexto de perspectiva reducionista, no qual todos os setores

102 As abordagens sistêmicas na Geografia baseiam-se, entre outras, nas seguintes teorias: na "Teoria Geral dos Sistemas", do biólogo Ludwig Von BERTALANFFY (1975), segundo o qual as sociedades são sistêmicas, assim como a natureza deve ser entendida como um sistema; a ordem e organização encontrada na natureza são resultantes da interação dos elementos e de suas partes integradas com o todo. Outra teoria é do geossistema, proposta por Sotchava, em 1962, segundo o qual há inter-relação dos fatores geomorfológicos, climáticos, hidrológicos, da vegetação e engloba ainda fatores sociais e econômicos e sua analise também se dá pela paisagem. Já na proposta de Bertrand, considera-se que há um potencial ecológico (geomorfologia, clima e hidrologia), a exploração biológica (vegetação, solo e fauna) e a ação antrópica, que interagem e criam os geossistemas. (MENDONÇA, 1989; RODRIGUES, 2001). Cleide Rodrigues (2001) chama atenção para o fato de que mesmo só se considerando os conhecimentos da chamada Geografia Física, numa perspectiva mais tradicional, havia duas disposições, sempre dicotômicas: uma da busca da gênese dos fenômenos naturais; outra que procura apontar as relações entre variáveis dinâmicas, caso da relação, por exemplo, entre vegetação e clima. 
encontravam-se no mesmo nível hierárquico. A preocupação das instituições na elaboração curricular defronta-se com a necessidade de concatenar propostas possivelmente diferenciadas, por vezes sugeridas em decorrência de perspectivas teóricas conflitantes e a argumentação valorativa setorial. $\mathrm{O}$ resultado era a dificuldade em se organizar um currículo adequado e coerente (CHRISTOFOLETTI, 1997, p. 2).

A proposta feita por Christofoletti foi uma tentativa de integrar os currículos, orientando-se pela perspectiva geossistêmica.

Contudo, considera-se fundamental discutir o objeto da Geografia, o espaço geográfico, não cabendo a dicotomia homem-natureza. Discutir o currículo a partir do objeto de estudo numa perspectiva crítica talvez seja uma possibilidade de integração curricular nada fácil, por se tratar de uma escolha teórico-metodológica, política e ideológica.

Em relação às abordagens e rede de afinidades geográficas, a que se denomina "Geografia Crítica" (Apêndice E), sua emergência ocorre após 1978 no Brasil. Sua definição não é simples; começa pela própria crítica feita por alguns autores à chamada "Geografia Tradicional"103, bem como também à Geografia Pragmática.

Há autores bastante diversificados ${ }^{104}$ nesta rede de afinidades, mas há predominantemente um discurso voltado ao entendimento do espaço e do território, compreendidos pelas dimensões sociais, políticas e econômicas, com apropriação do espaço por agentes sociais, cujos papéis sociais e suas formas de apropriação tornam o espaço desigual.

No plano teórico do pensamento geográfico, houve transformações mais significativas e mais rápidas do que as ocorridas no interior dos cursos mediante a existência e vivência dos seus currículos. As reflexões

103 A chamada "Geografia Tradicional" no Brasil abarca principalmente a chamada "Geografia Clássica", difundida, entre outros, por Ritter, Ratzel e Vidal de La Blache, segundo a qual a abordagem é fundamentalmente positivista, empirista e descritiva. Há também, nesta proposta, uma naturalização do homem, visto como grupos humanos e não socialmente dividido em classes. No Ensino de Geografia, a "Geografia Tradicional" é sinônima de memorização de nomenclaturas e nomes, da Geografia vista como "ciência dos lugares", da fragmentação do conhecimento (quadro natural, humano e econômico), de classificações, entre outras condições que geralmente são associadas à ideia de "Geografia Tradicional".

104 Alguns autores como Neil Smith, David Harvey, Massimo Quaini e Yves Lacoste, influenciaram o pensamento crítico brasileiro. 
sobre a mudança foram sentidos mais em algumas IES ou por alguns professores e redes de afinidades que estavam mais inteirados das publicações e dos eventos geográficos (Apêndice $E$ ).

Para além destas grandes redes de afinidades, há a convivência, nas práticas educativas de abordagens mais tradicionais da Geografia, positivistas e empírico-analíticas, tanto nos Ensinos Fundamental e Médio, quanto na Educação Superior.

Analisando-se os currículos previstos nas licenciaturas em Geografia, observa-se que estes diferentes tempos da História Curricular da Geografia no Ensino Superior têm relação com as propostas das matrizes curriculares. Há desde disciplinas como "Geografia dos Continentes", "Geografia da Europa e Ásia", que denotam, em princípio, uma visão mais tradicional, até disciplinas como "Território e Circulação", "Organização do Espaço Mundial" e "Estatística", entre outras, que apontam para diferentes abordagens da Geografia.

Estas diferentes abordagens e concepções coexistem na maioria absoluta dos currículos analisados, situação esta corroborada nos depoimentos de docentes e coordenadores entrevistados. No entanto, falta segundo eles um aprofundamento na discussão sobre a formação em Geografia e sua epistemologia.

Além da dicotomia Geografia Física e Humana, há ainda mais uma divisão entre disciplinas específicas e pedagógicas nos cursos de licenciatura, o que compromete uma integração necessária ao saber acadêmico e à futura prática profissional, assim como a discussão do perfil e do currículo dos cursos de licenciatura e bacharelado.

Observando-se o mapa 22, referente à distribuição por unidade da federação das licenciaturas e dos bacharelados em Geografia, verifica-se que, ao discutir-se a necessidade da separação dos cursos, há de observar-se que tal situação ocorre em maior medida, na Região Concentrada, já que, na Amazônia e no Nordeste, há apenas de um a três cursos de bacharelado por unidade da federação, em sua maioria nas capitais. 
Cursos de Geografia no Brasil- 2009

(Licenciatura e Bacharelado)

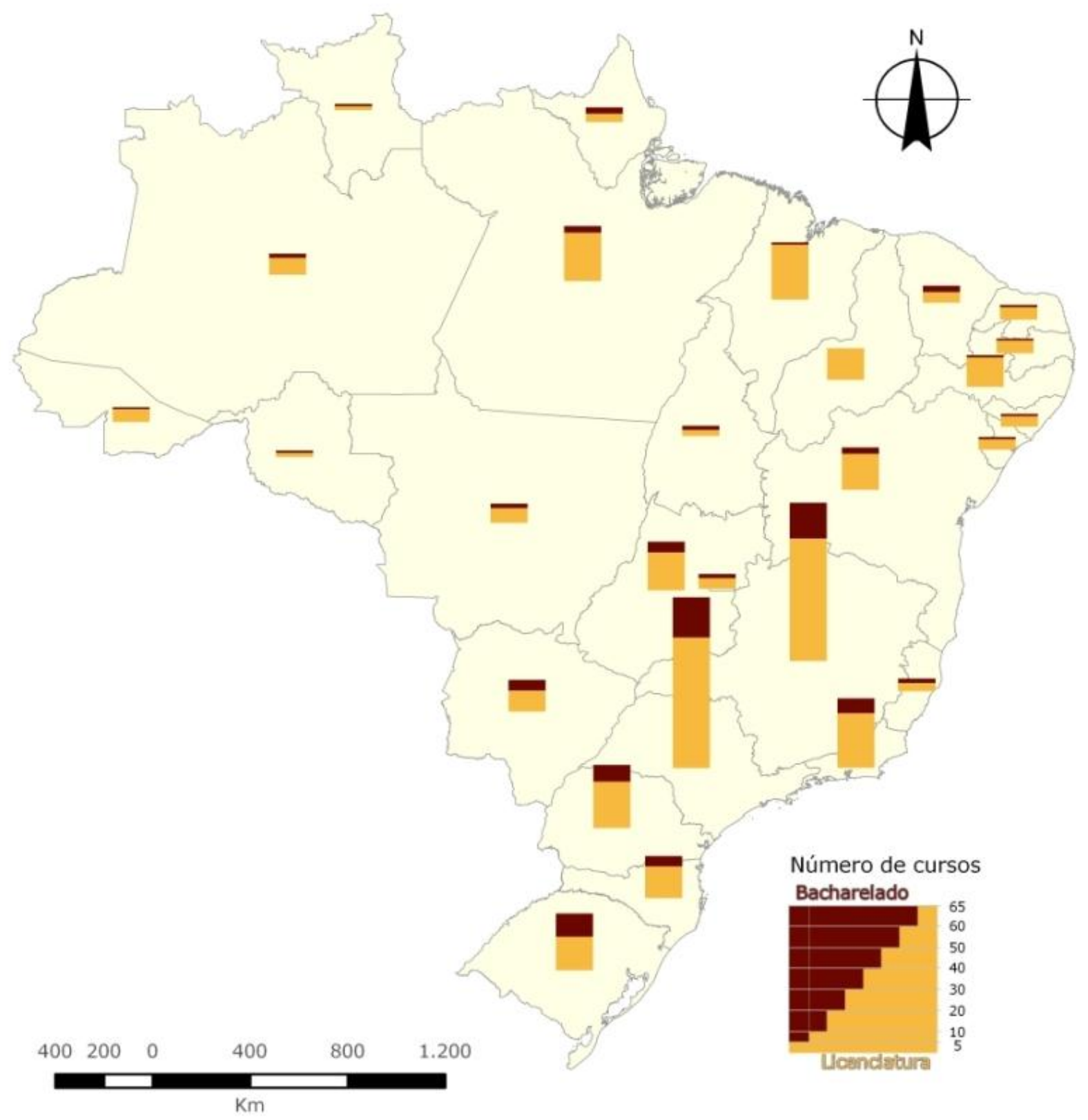

Mapa 22: Fonte: MEC, 2009. Dados organizados por Vivian Fiori.

Elaborado por Maurício Yamada e Vivian Fiori, 2010.

Esta questão bacharelado versus licenciatura aparece principalmente sob as seguintes condições:

- É mais comum na Região Concentrada, onde há maior concentração populacional e densidade técnica e econômica, que acaba atraindo demanda para a formação de bacharéis. Embora não se possa dizer que não haja demanda para o 
bacharel em outras regiões há maior densidade nas metrópoles e nas capitais;

- A mediação do tipo administrativo no qual está a IES, já que é mais comum que, nas IES privadas, tenhamos apenas cursos de licenciaturas, devido à maior procura destes em relação ao bacharelado;

- O incentivo do governo federal para a criação de cursos de formação de professores, sobretudo no interior do país, estando vinculadas principalmente às IES públicas;

- As relações da história da Geografia e do pensamento geográfico no Brasil, que fazem, muitas vezes, que mesmo num curso de licenciatura, o perfil seja de bacharelado, com disciplinas de aplicação mais técnica, como se mostrou na discussão sobre as disciplinas dos cursos. Ora porque a formação em bacharelado é confundida com a formação de um técnico, ora porque a licenciatura é vista como um apêndice do bacharelado. Há, assim, uma divisão social do trabalho do geógrafo entre a técnica e Pedagogia, sem atentar para uma epistemologia interna da Geografia.

Sendo assim, há mediações do tipo administrativo da IES, da dimensão territorial/regional onde os cursos estão inseridos e do incentivo do governo federal para a criação de cursos de licenciatura, principalmente no interior do Brasil. São mediações que se relacionam ao território e a suas maiores ou menores densidades técnicas, populacionais e econômicas.

Há também relação do tempo da história da Geografia no Brasil, já que, desde o início, há uma história comum entre licenciatura e bacharelado. Logo há uma herança passada que permanece mesmo nos tempos atuais, apesar das novas normas específicas para as licenciaturas. Há casos, como o curso da Universidade Federal do Tocantins, em Porto Nacional, no qual há as duas habilitações, e os alunos podem transitar 
entre os dois cursos desde que façam novo vestibular, ou ainda, em Oriximiná, no Pará, no qual as duas habilitações eram juntas até 2012.

Ao fazer isso, muitas vezes, os discentes ficam dispensados das disciplinas consideradas comuns nas duas matrizes curriculares, sobretudo as com os mesmos nomes ou ementas parecidas. Contudo, não necessariamente devessem, já que uma disciplina como Geografia Urbana ministrada num curso de licenciatura pode ter especificidades relacionadas ao ensino que a diferenciam num curso de bacharelado.

Já no interior do Mato Grosso, na cidade de Barra do Garças, houve intervenção do governo federal, fazendo com que o curso priorizado fosse apenas a licenciatura, segundo depoimento do coordenador do curso da UFMT:

Em 2009 foi criado curso de bacharelado e licenciatura em Geografia. O curso é regular. Acabaram com o bacharelado. A opção nossa era ter os dois cursos, mas por exigências do MEC e devido ao REUNI tivemos de optar pela licenciatura. Não aceitaram que fizéssemos os dois cursos juntos, pois a demanda do MEC é formação de professores.

Isso demonstra a força da norma e das políticas públicas federais, influenciando diretamente a criação das licenciaturas em Geografia, principalmente nas IES federais.

Existe relação, neste caso, com a política federal desenvolvida pelo Programa de Apoio de Planos de Reestruturação e Expansão das Universidades Federais (REUNI). Este plano, criado em 2007, propõe a criação de novos cursos em regiões do interior do Brasil, sobretudo noturnos.

Há, assim, diversas dicotomias que resistem ao tempo e permanecem nos cursos de Geografia, ainda que, no currículo previsto, mediante documentos e projetos pedagógicos, este discurso, muitas vezes, seja diferente. Então, na aparência dos documentos, a dissociação e dicotomias parecem não existir. O depoimento de um professor da UFPA, a seguir, traz bem a ideia do que geralmente ocorre:

É uma coisa forte a dicotomia - a separação entre Geografia Física e Humana. No discurso não há a separação, mas quando você lê os documentos e compara o nome das 
disciplinas e suas ementas, verifica a separação. Outra dicotomia que ocorre é a formação em bacharelado e licenciatura; na prática, as disciplinas daqui priorizam claramente $o$ bacharelado. As relacionadas ao ensino aparecem, por exemplo, em Introdução ao Ensino de Geografia, Didática, Metodologia de Ensino de Geografia etc. Parece que o ensino tem de ser discutido à parte. Quando lemos os projetos pedagógicos, os documentos dizem que há superação das dicotomias e quando analisamos as ementas não é isso que ocorre.

Se no projeto pedagógico, no currículo previsto, há sempre termos como "integração" - da relação humana e física, buscando superar as dicotomias - na vivência prática, geralmente, não é isso que acontece.

Em entrevistas com professores, coordenadores e discentes dos cursos de licenciatura em Geografia, a dificuldade em superar as diversas dicotomias na Geografia foi resposta quase unânime.

\subsubsection{As especificidades da formação na licenciatura em Geografia}

Os pesquisadores e teóricos de Educação definem especificidades no trabalho de professor, do saber e da profissionalidade docente. Carla Pimentel (2010) destaca, em sua tese, que o saber docente distingue o professor e tem relação principalmente com o conhecimento curricular, de sua disciplina e da Educação; a ação pedagógica; sua experiência na vida escolar; condições que definem as características formalizadas da profissão de professor. Tais características estão em permanente construção tendo, portanto, relação com o tempo social.

A maioria dos discentes, ao optarem pelo curso de Geografia, não tem conhecimento prévio da atuação profissional em sua área (gráfico 14) como responderam $42,6 \%$ dos estudantes. Acredita-se que, de fato, os que informam saber o que é Geografia têm em mente a experiência que vivenciaram com seus professores na Educação Básica.

Há também uma construção social-histórica sobre o que significa ser professor e especificamente em Geografia. Há uma psicosfera de qual deva ser este papel, construído ao longo da história e que permeia o 
pensamento dos discentes e docentes dos cursos de licenciatura em Geografia.

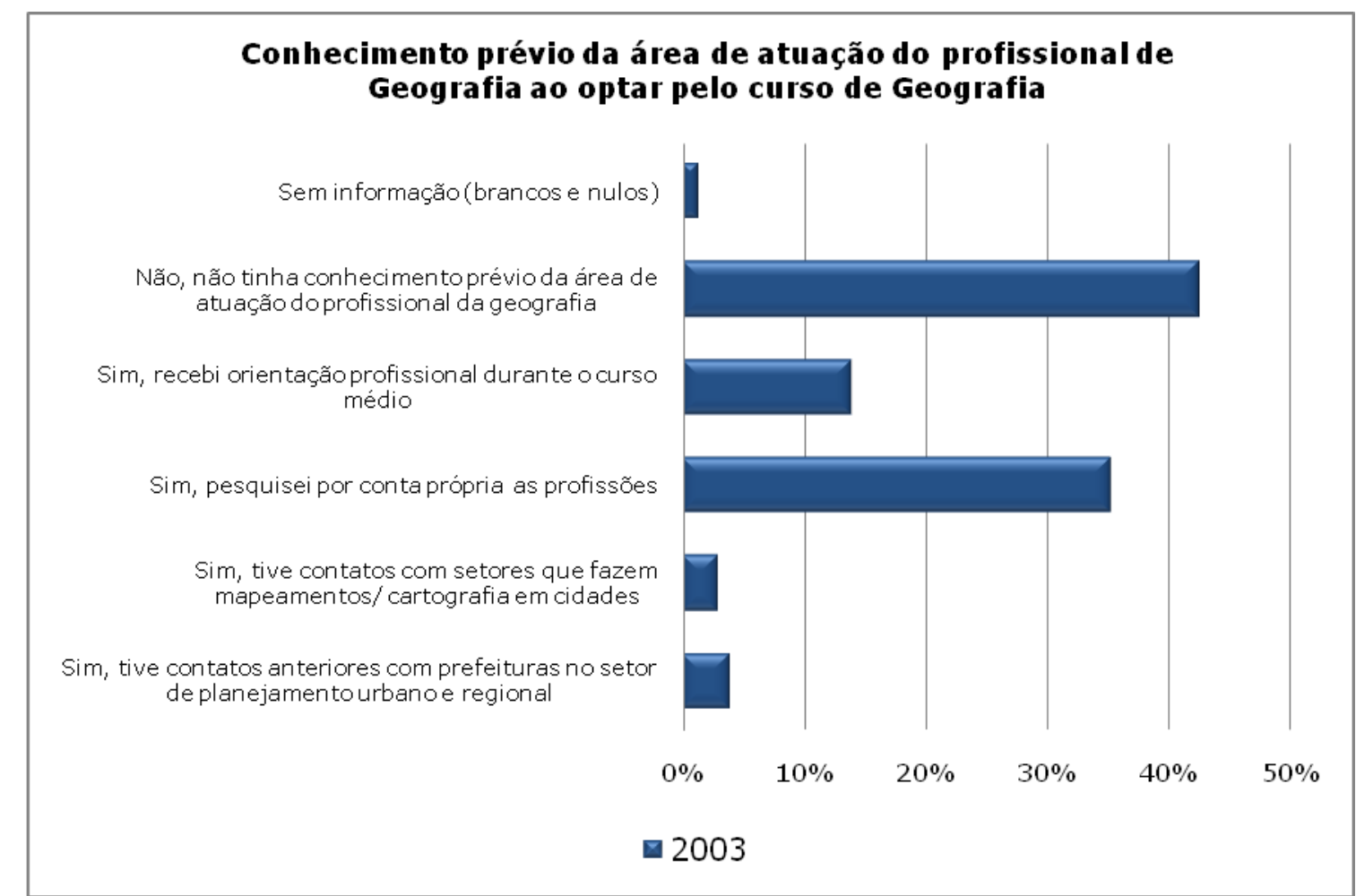

Gráfico 14 - Fonte: Inep, Relatório Síntese -Área de Geografia, ENC 2003.

Dados organizados por Vivian Fiori, 2009.

Muitas vezes, estas práticas referem-se ao que conheceram sobre a ação docente nos Ensinos Fundamental e Médio, assim como no próprio Ensino Superior, tendo como exemplo principalmente a atuação de seus professores, com as especificidades da Geografia, com seus procedimentos metodológicos, matrizes teóricas, conceitos e práticas, mas também se relaciona aos conhecimentos teóricos da Educação, da ação pedagógica, de suas normas e de seu campo de atuação.

Neste sentido, há necessidade de considerar-se esta percepção inicial do ingressante do curso de Geografia, ou seja, de como foi construída esta psicosfera relacionada à visão sobre a profissionalidade docente. Logo, é necessário que as atividades existentes nos cursos de licenciatura criem possibilidades de reflexões sobre estas crenças, hábitos e pensamento sobre o trabalho do professor, buscando desenvolver uma consciência mais ampla além da apreendida apenas com os antigos professores e suas posturas e práticas. 
Este aprendizado anterior não deve ser desconsiderado, mas é importante não ficar como um modelo a ser seguido ou reproduzido, sem reflexões teóricas das abordagens e dos conhecimentos produzidos na Educação e na Geografia.

Sendo assim, o futuro professor tem de ganhar autonomia que the possibilite, mediante conhecimentos teóricos e práticos, suplantar sua visão inicial do professor como simples transmissor e reprodutor de conhecimentos e as práticas já existentes.

Quase sempre há uma visão dicotômica entre o conhecimento teórico e prático, quando seria necessário pensar a práxis educativa de forma integrada, como ação desenvolvida como reflexão e não apenas pensar na prática como um fim em si mesmo.

Claudivan Sanches Lopes (2010) destaca, em sua tese, que se adquire conhecimento mediante a própria ação e prática docente, mas que esta não termina apenas numa mediação tecnocrática e nem se deve supervalorizar a prática em relação à teoria. Conforme diz o autor:

[...] a pesquisa e a análise da prática cotidiana profissional dos professores têm mostrado que esse modelo de orientação tecnicista, legado do positivismo no campo das ciências sociais, não resiste ao presente momento histórico [...] o pressuposto que a ciência pode produzir conhecimentos para guiar, com segurança, a ação profissional dos professores na consecução de sua tarefa tem-se mostrado parcial. Porque ignora, entre outros aspectos, a complexidade e singularidade dada pelo contexto de todo processo educativo (LOPES, 2010, p. 31).

Trata-se de uma situação complexa que precisa ser considerada nas dimensões da formação e das condições de trabalho dos professores, no contexto social, político e educativo, com os lugares nos quais se dão o aprendizado e a prática docente. Como o mundo hoje é mais complexo, com mais elementos sociais que permeiam as relações existentes, o papel do professor sofre mudanças e aumentam suas responsabilidades, ficando sobrecarregado por inúmeras demandas administrativas, sociais e educativas existentes. 
Para além das questões que historicamente eram esperadas, tais como dominar conteúdos específicos de sua área do conhecimento e ter habilidade em ensinar, popularizado no Brasil com o termo "ter didática", surgem inúmeras responsabilidades de cunho psicológico e afetivo em relação aos alunos, do conhecimento das normas e metodologias de ensino, de conhecimentos de sua área e da capacidade de desenvolver atividades interdisciplinares, entre outras, ao mesmo tempo, em alguns casos, aumentando a precarização do trabalho docente.

Considerando os alunos concluintes de licenciatura em Geografia em 2003, conforme gráfico 15, a maioria informa que foi tomando consciência do que é ser professor, "gradualmente ao longo do curso" $(48,9 \%)$, seguem-se os que responderam "sim, nas disciplinas pedagógicas" $(24,1 \%)$. Estes foram principalmente das IES federais $(32,2 \%)$ e das Universidades $(27,2 \%)$, o que demonstra a relação entre a indefinição do perfil dos cursos de licenciatura e bacharelado, comum nestas IES.

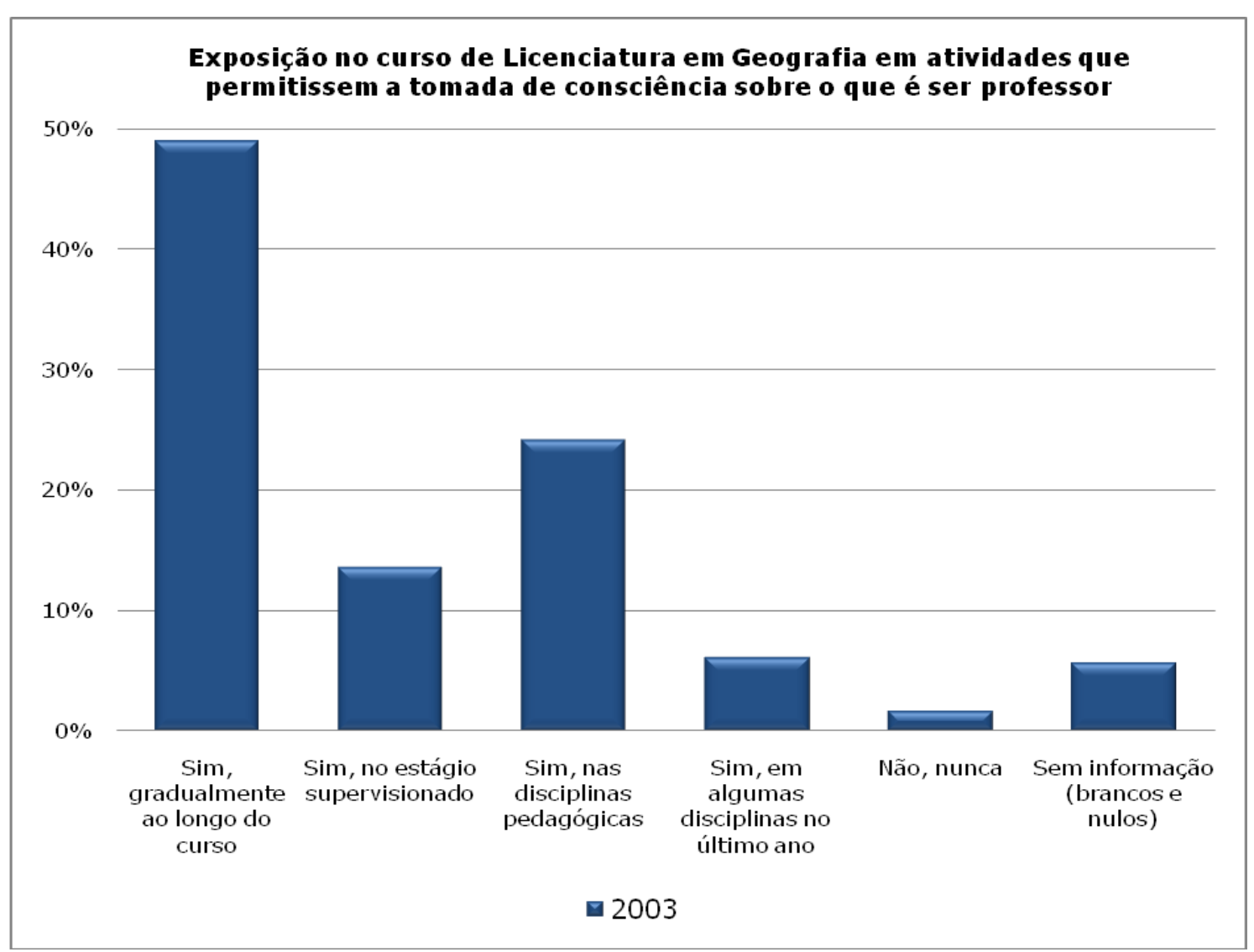

Gráfico 15- Fonte: Inep, Relatório Síntese -Área de Geografia, ENC 2003.

Dados organizados por Vivian Fiori, 2009. 
Um ex-estudante (2007-2011) do curso de licenciatura em Geografia da Universidade Estadual do Piauí, da cidade de Pedro II, diz a respeito do currículo de seu curso:

A parte pedagógica era bem separada, só em algumas disciplinas relacionam as duas áreas, caso de Metodologia de Ensino de Geografia. E Geografia Física e Humana era mais integrado do que as disciplinas pedagógicas.

Esta visão de que só, em algumas disciplinas, o futuro professor de Geografia terá contato com textos e temas relativos à educação é contrária ao que a atual norma dos cursos de licenciatura define.

A condição de entendimento da profissionalidade e dos saberes docentes apreendidos apenas nas disciplinas pedagógicas contraria a legislação sobre a formação de professores, cuja norma estabelece que esta não deve estar circunscrita às disciplinas pedagógicas e que o curso deve ter terminalidade própria em curso de, no mínimo, 2.800 horas. Diz a norma:

O Parecer CNE/CP 9/2001, ao interpretar e normatizar a exigência formativa desses profissionais, estabelece um novo paradigma para esta formação. O padrão de qualidade se dirige para uma formação holística que atinge todas as atividades teóricas e práticas articulando-as em torno de eixos que redefinem e alteram o processo formativo das legislações passadas. A relação teoria e prática deve perpassar todas estas atividades as quais devem estar articuladas entre si tendo como objetivo fundamental formar o docente em nível superior (MEC, 2001a, p.5.)

Dessa forma, não cabe mais que esta formação fique apenas sob responsabilidade das disciplinas pedagógicas ou durante 0 estágio supervisionado. Na prática, continua existindo uma separação entre os conteúdos disciplinares da Geografia e os pedagógicos.

Há, também, um descompasso entre o que apreendem nos cursos de Ensino Superior e a realidade escolar. Existem principalmente duas existências contraditórias no caso dos cursos de Geografia.

A primeira diz respeito à dicotomia do perfil de licenciatura e bacharelado, historicamente construídos no Brasil, citado anteriormente. Como são perfis misturados, sobretudo nos cursos das IES federais, das 
Universidades e principalmente da Região Concentrada este descompasso fica maior.

Outro ponto não exclusivo da Geografia, mas de todas as licenciaturas, concerne à confusão existente entre o conhecimento produzido e reproduzido no Ensino Superior e a finalidade do Ensino Escolar.

Não se trata de uma transposição didática de um conteúdo e teoria do Ensino Superior para o Ensino Escolar, mas da necessidade de conhecimento produzido, realizando-se esta mediação. É comum ouvir de alunos do Ensino Superior que não se pode aplicar na escola os conhecimentos adquiridos no Ensino Superior.

Nos primeiros cursos de Geografia do Brasil, já havia a preocupação com esta situação. Pierre Monbeig e Aroldo Azevedo apontavam problemas, relativos à dificuldade do entendimento do perfil do Ensino Superior e do Ensino Secundário, de que decorria a repetição, no Ensino Secundário, de conhecimentos adquiridos no Ensino Superior, sem qualquer mediação.

Monbeig (1945, p. 165) chegou a dizer: "O geógrafo não está aí para formar geógrafos, mas para participar na eclosão de capacidades intelectuais e fazer com que os alunos criem hábitos razoáveis de trabalho e pensamento".

Trata-se de uma crise constante entre o perfil do curso e sua finalidade, que se amplia no atual período do meio técnico-científico informacional, já que são criadas inúmeras demandas sociais, educativas, ampliando e transformando o papel do professor de Geografia.

O mundo se transforma rapidamente, e o professor tem de adquirir conhecimentos que the permitam entender o mundo em constante transformação e em diversos contextos espaciais.

Neste sentido, a escola e as Instituições de Ensino Superior não podem ser vistas de forma estanque, sem considerar o contexto social e espacial no qual existem. 
Quando perguntados, em 2003, sobre "qual sua preferência para atuação profissional na área de Geografia", gráfico 16, a maioria (64,3\%) dos discentes de licenciatura em Geografia definiu que seria "trabalhar na área de Ensino de Geografia", destes a maioria estava nas IES municipais $(86,6 \%)$; os demais, assim, distribuídos: nas privadas $(69,3 \%)$ e nas Faculdades e Institutos $(80,5 \%)$, ou seja, IES em que os cursos de Geografia, em sua maioria, são de licenciatura.

Os que estudavam nas IES federais e nas universidades, cerca de $40 \%$, não pretendiam atuar na área de ensino. Cabe lembrar que nas Universidades é que está a maioria dos cursos de licenciatura em Geografia, mas muitas têm também bacharelado.

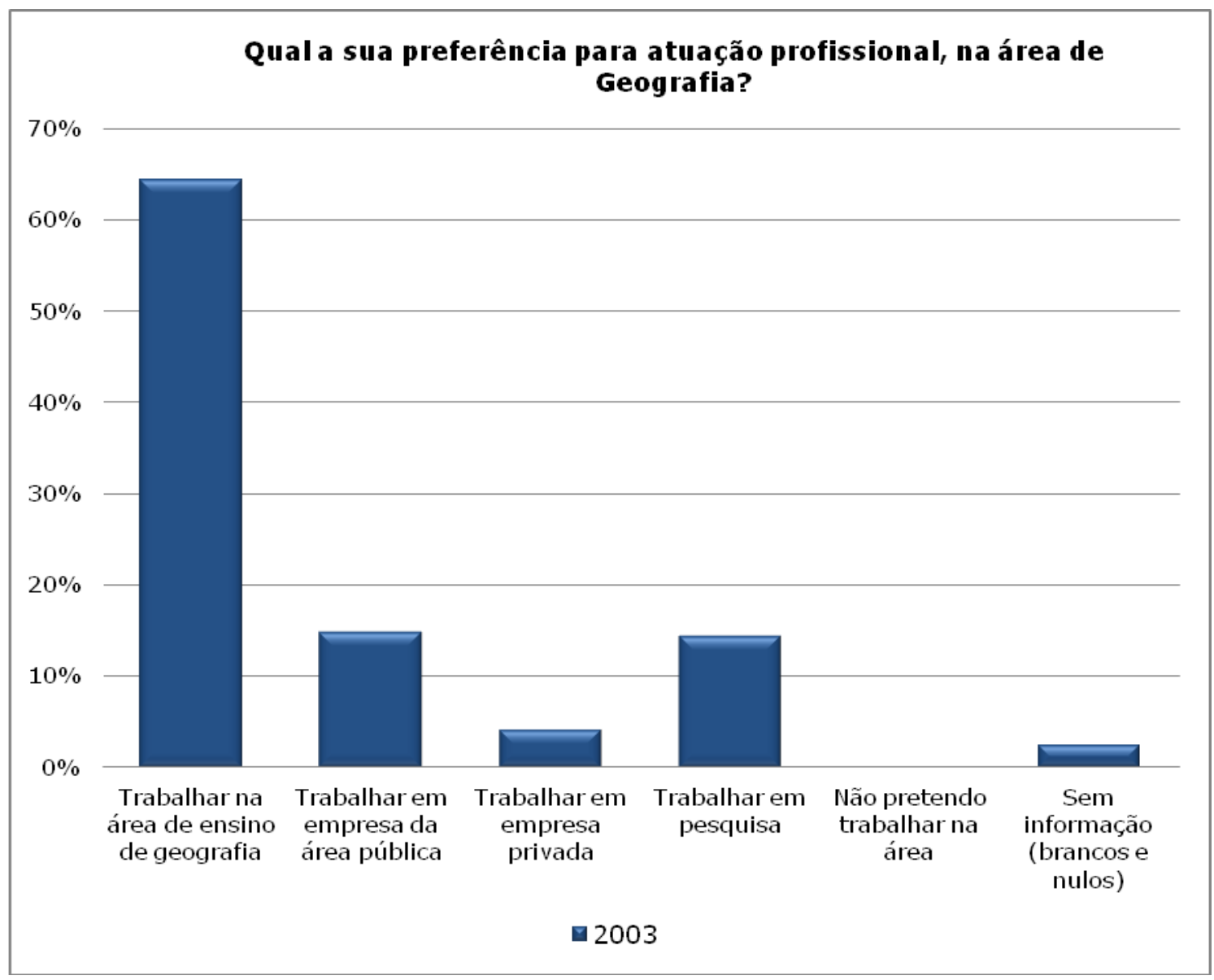

Gráfico 16- Fonte: Inep, Relatório Síntese -Área de Geografia, ENC 2003. Dados organizados por Vivian Fiori, 2009.

Verifica-se, no gráfico 16, que a escolha da maioria, em 2003, foi da licenciatura, ou seja, trabalhar na área de ensino. Contudo, aproximadamente $35 \%$ não pretendiam atuar em sua área de formação. 
Os motivos podem ser os mais variados: salários baixos dos professores e condições de trabalho inadequadas. Outros por terem emprego e não quererem deixá-lo. Há os que buscam emprego em empresa relacionada à Geografia ou não. Ou seja, nem todos os formandos em licenciatura acabam atuando na área de Ensino.

Em 2003, em relação ao questionamento sobre se exerceram a função docente já durante o curso, gráfico 17, a maioria informou que não $(34,2 \%)$; os que responderam "sim, a partir do primeiro ano" foram $27,1 \%$, a maioria de IES municipais $(44,1 \%)$; os de Faculdades representavam $33,7 \%$, cujos cursos são só de licenciatura que atendem fundamentalmente estudantes de baixa renda, que precisam trabalhar para pagar seus cursos, já que as IES municipais e as faculdades, geralmente privadas, são pagas.

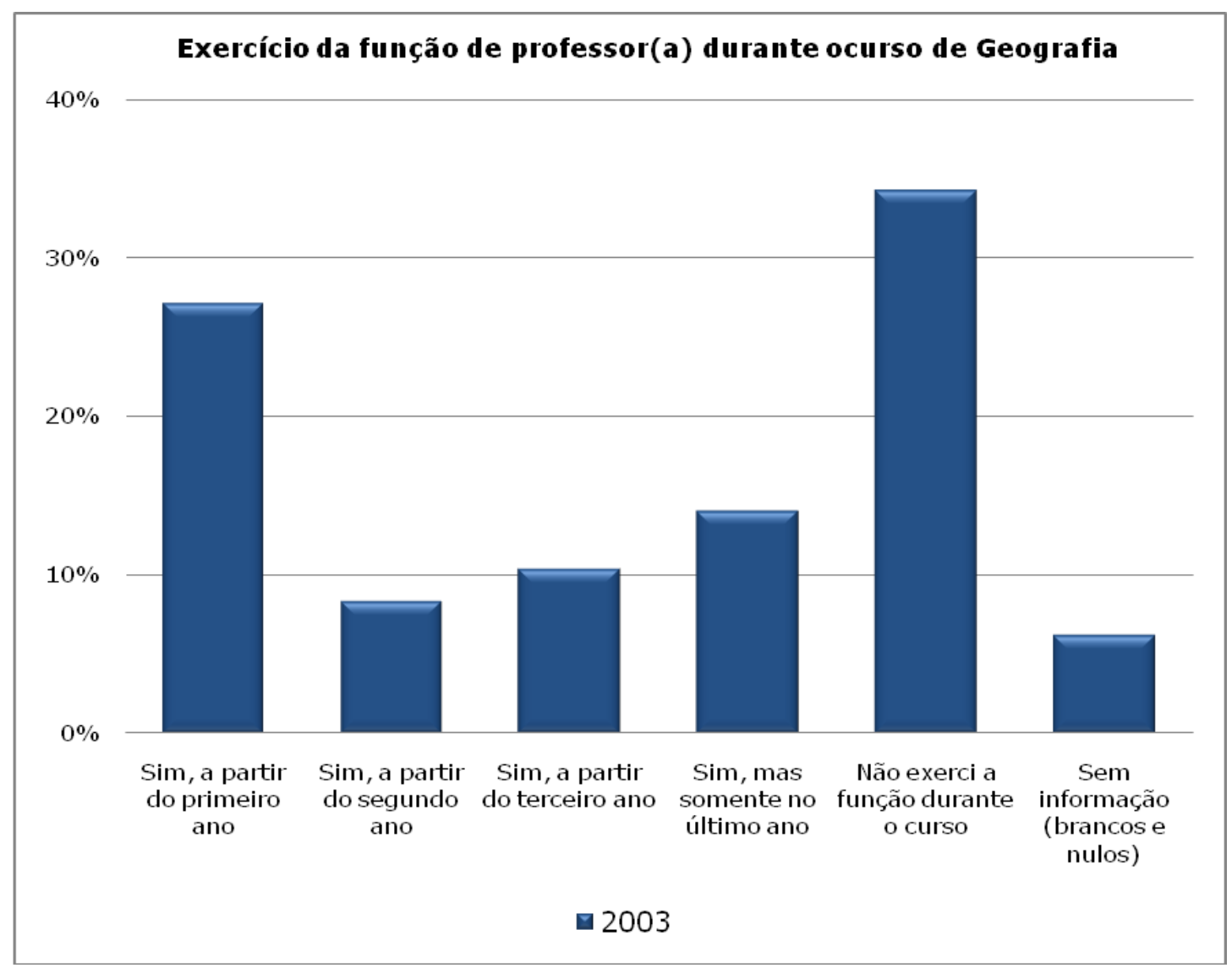

Gráfico 17- Fonte: Inep, Relatório Síntese -Área de Geografia, ENC 2003.

Dados organizados por Vivian Fiori, 2009.

Este exercício da profissão já no primeiro ano, embora contrarie a atual legislação, ocorre na maioria das regiões do país, pois, quando 
faltam professores de Geografia, muitos graduandos e leigos atuam na área de ensino. Esta problemática, que existe desde o início dos primeiros cursos de Geografia, ainda persiste no Brasil.

Sobre esta questão, o professor Vanilton Camilo de Souza, pesquisador da Universidade Federal de Goiás, esclarece:

O motivo que me levou a pesquisar processos relacionados à formação do professor leigo de Geografia advém de dois fatores: [...] Como professor do ensino superior na Unidade Universitária "Cora Coralina" na cidade de Goiás, sempre tive um grande número de alunos que ingressavam no curso de Geografia já exercendo atividade docente nesta disciplina no Ensinos Fundamental e Médio. O segundo resulta de frequentes solicitações feitas pelas escolas públicas da região, para ministrar cursos de aperfeiçoamento para professores de Geografia, durante os quais pude verificar que todos os participantes eram leigos (SOUZA, 2001, p. 119).

Esta situação é comum em todo território nacional, nas pequenas e grandes cidades, como também nas regiões metropolitanas. Ou seja, de um lado, formam-se novos professores, mas nem todos querem atuar como professor devido principalmente aos baixos salários.

Por outro lado, há pessoas não formadas lecionando. Ainda assim há algumas peculiaridades em relação a este elemento, que será melhor explicitado na análise de situação da próxima seção.

Em 2008, gráfico 18, ao ser questionado se quer ser professor, a maioria respondeu que pretende afirmativamente $(61,7 \%)$. Ainda, ao ser questionado sobre qual o principal motivo da escolha da licenciatura, gráfico 19, a maioria (41,4\%) respondeu "porque quero ser professor". Aproximadamente $20 \%$ responderam: "para ter outra opção se não conseguir exercer outro tipo de atividade".

Há, ainda, aproximadamente $14 \%$ que assinalaram a alternativa "porque tive um bom professor que me serviu de modelo", evidenciando que a questão do modelo do professor do Ensino Básico é grande. 


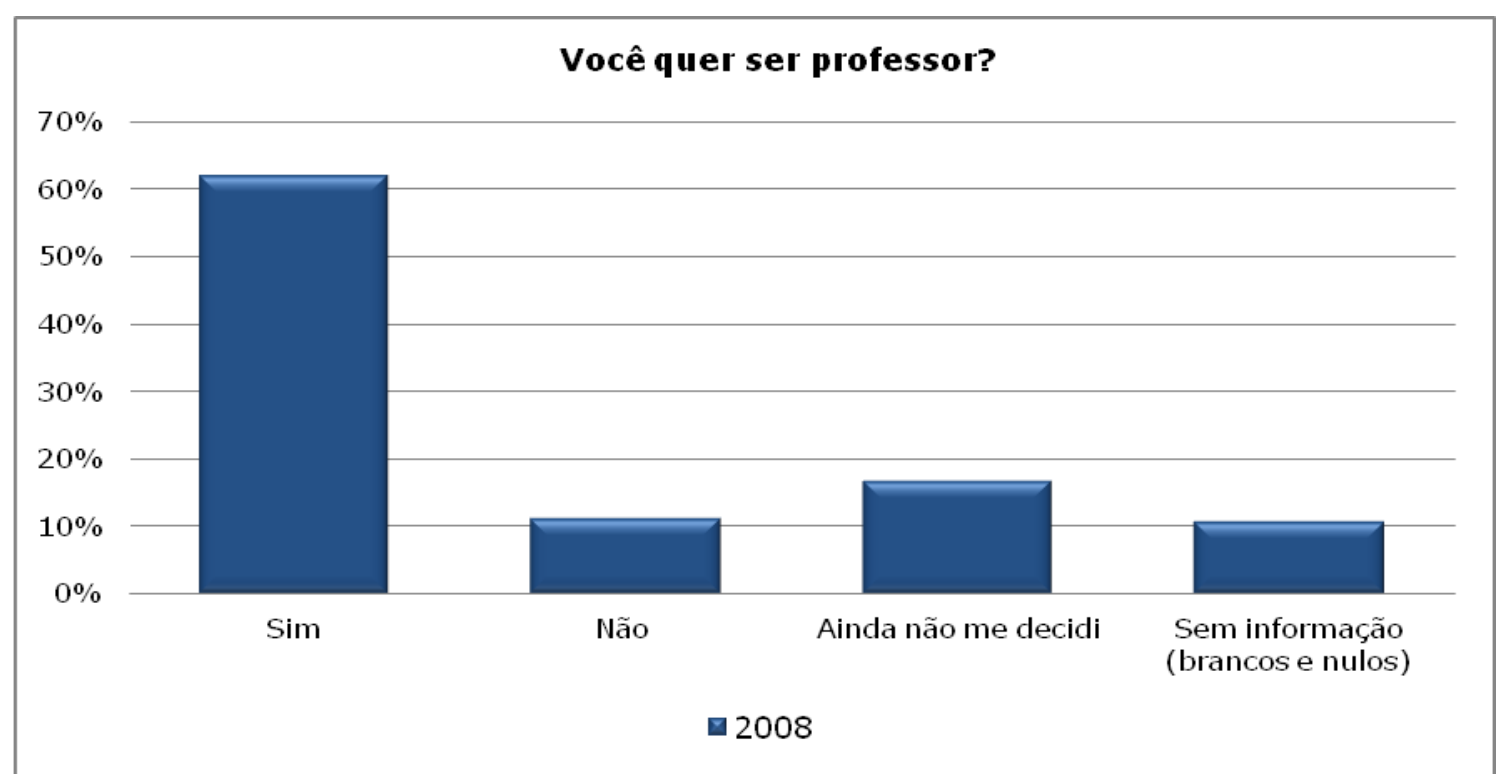

Gráfico 18- Fonte: Inep, Relatório Síntese -Área de Geografia, ENC 2003. Dados organizados por Vivian Fiori, 2009.

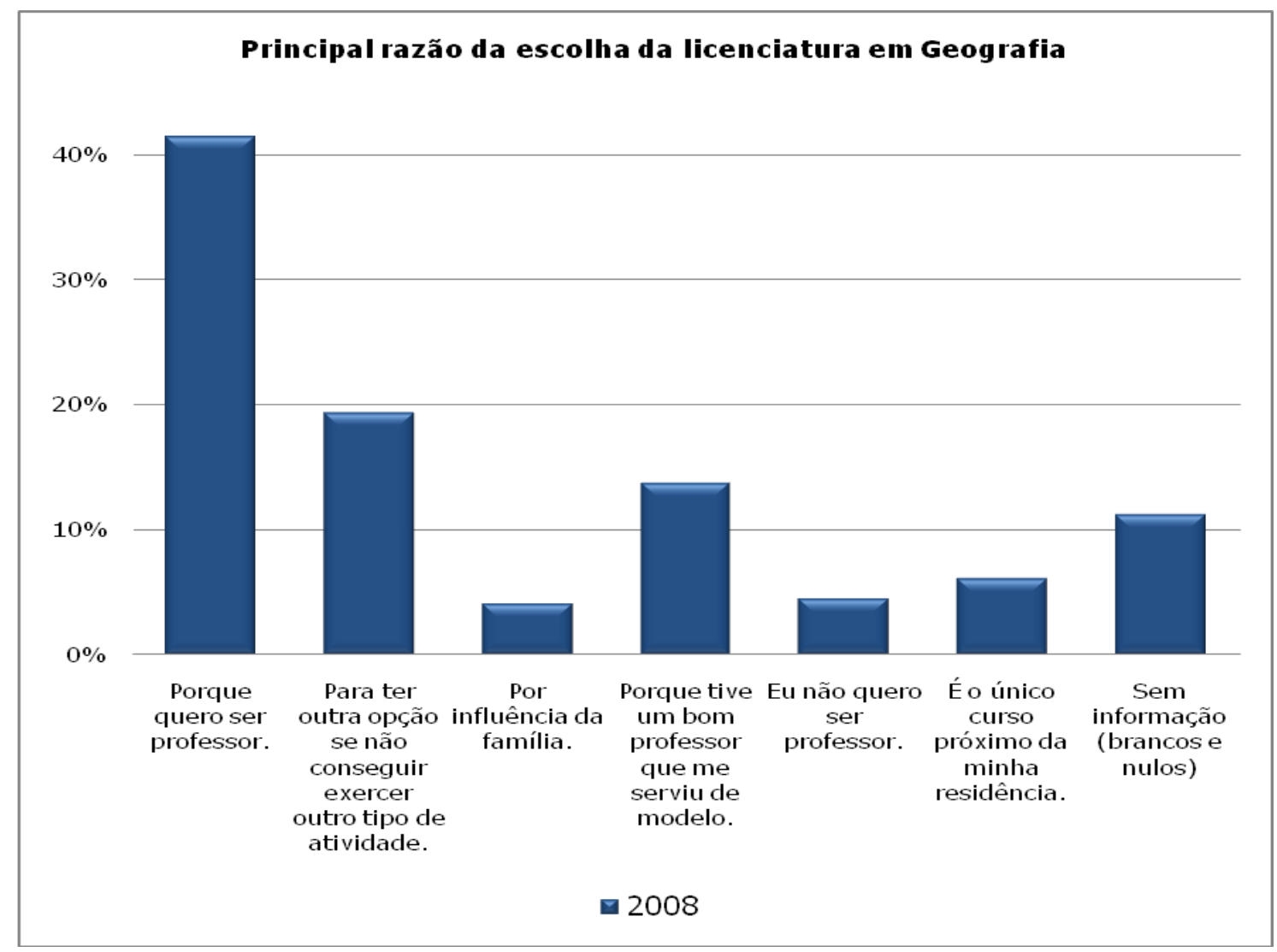

Gráfico 19 - Fonte: Inep, Relatórios de Curso, Área de Geografia, Enade 2008. Dados organizados por Vivian Fiori, 2010. 


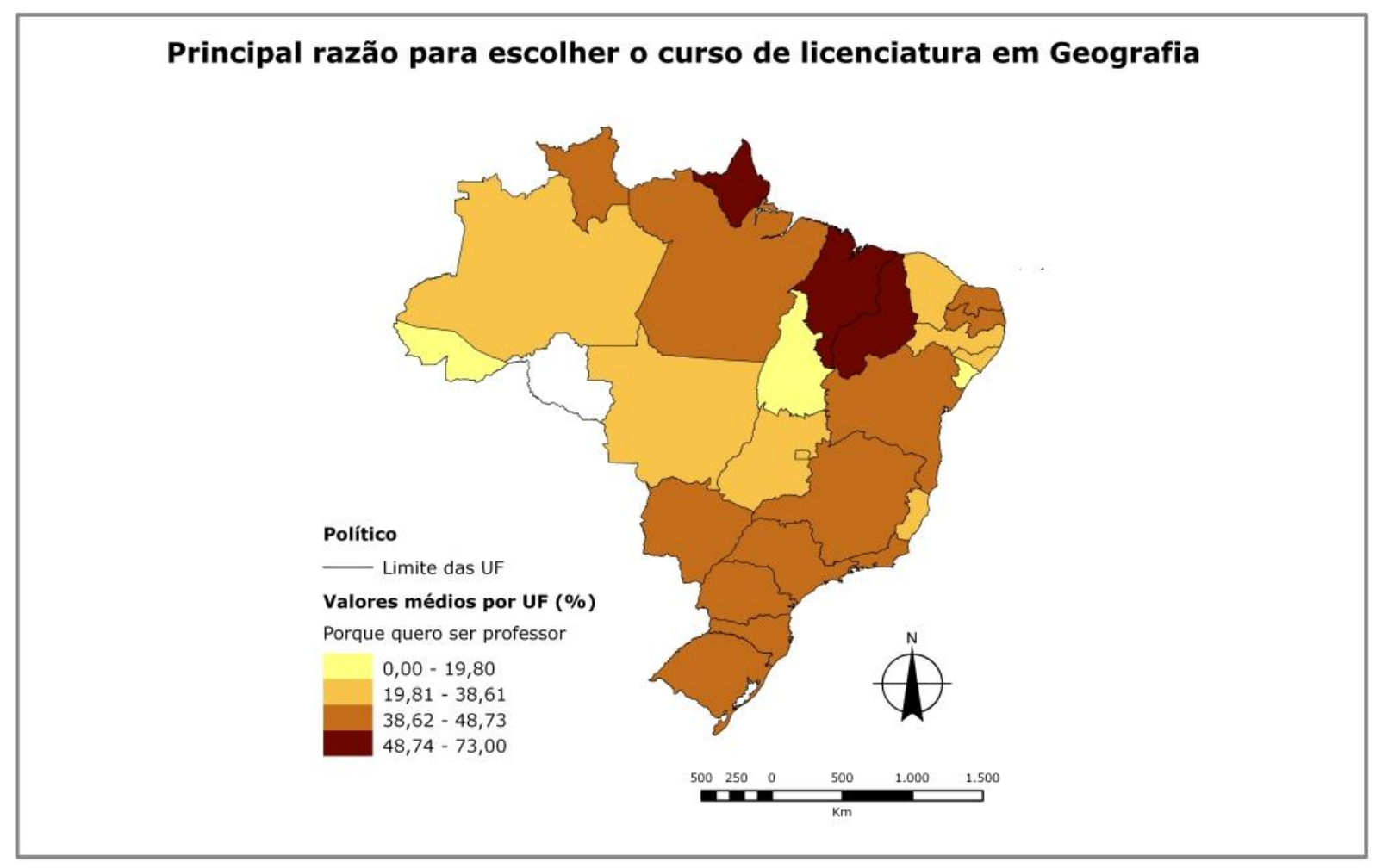

Mapa 23: Fonte Inep, Relatórios de Cursos de Geografia no Enade, por IES, 2008. Elaborado por Vivian Fiori, 2010.

No mapa 23, verifica-se a distribuição daqueles que afirmam ter escolhido a licenciatura "porque querem ser professor". Existe uma concentração no Piauí, Maranhão e Amapá, estados onde prevalecem os cursos de licenciatura pelo interior em 2008.

Estes cursos foram, em sua maioria, criados recentemente, em municípios geralmente de pequeno porte, cujos alunos têm baixa renda, e onde o curso superior tem grande importância. Além disso, são lugares onde os cursos são, em sua maioria absoluta, de licenciaturas, não havendo o contraponto da formação em bacharelado.

No Acre e no Tocantins, nas cidades de Rio Branco e Porto Nacional, onde predominam as IES federais com bacharelado e licenciatura, havia a menor média para o item "porque quero ser professor", com, no máximo, $20 \%$, além do Sergipe, onde há IES federais e privadas.

Logo, este movimento recente de interiorização das licenciaturas em Geografia produziu algumas singularidades nos cursos, como, por exemplo, no interior do Maranhão, Piauí e Tocantins. 
Mas mesmo entre estes cursos há diferenças, já que, no interior do Maranhão e do Piauí, estes ocorrem em IES estaduais onde só há cursos de licenciatura, enquanto, no Tocantins, ocorrem em IES federais, em que há licenciatura e bacharelado no município de Porto Nacional. Portanto, a possibilidade de outras inserções profissionais, além da docência, torna-se maior para os discentes do Tocantins.

Deste modo, há, no Tocantins e no Acre, a possibilidade de formação em bacharelado em algumas cidades que leva o discente a ter interesse em outro tipo de atuação, similarmente ao que ocorre nas IES onde há cursos de bacharelado e licenciatura, situação esta mais comum na Região Concentrada, em que o interesse pela docência é menor.

Em 2008, segundo resposta dos estudantes de Geografia, a contribuição dos cursos de Geografia, conforme gráfico 20, refere-se à aquisição de formação profissional (46\%), à aquisição de cultura geral $(25,5 \%)$ e à obtenção de um diploma de ensino superior" $(14,5 \%)$.

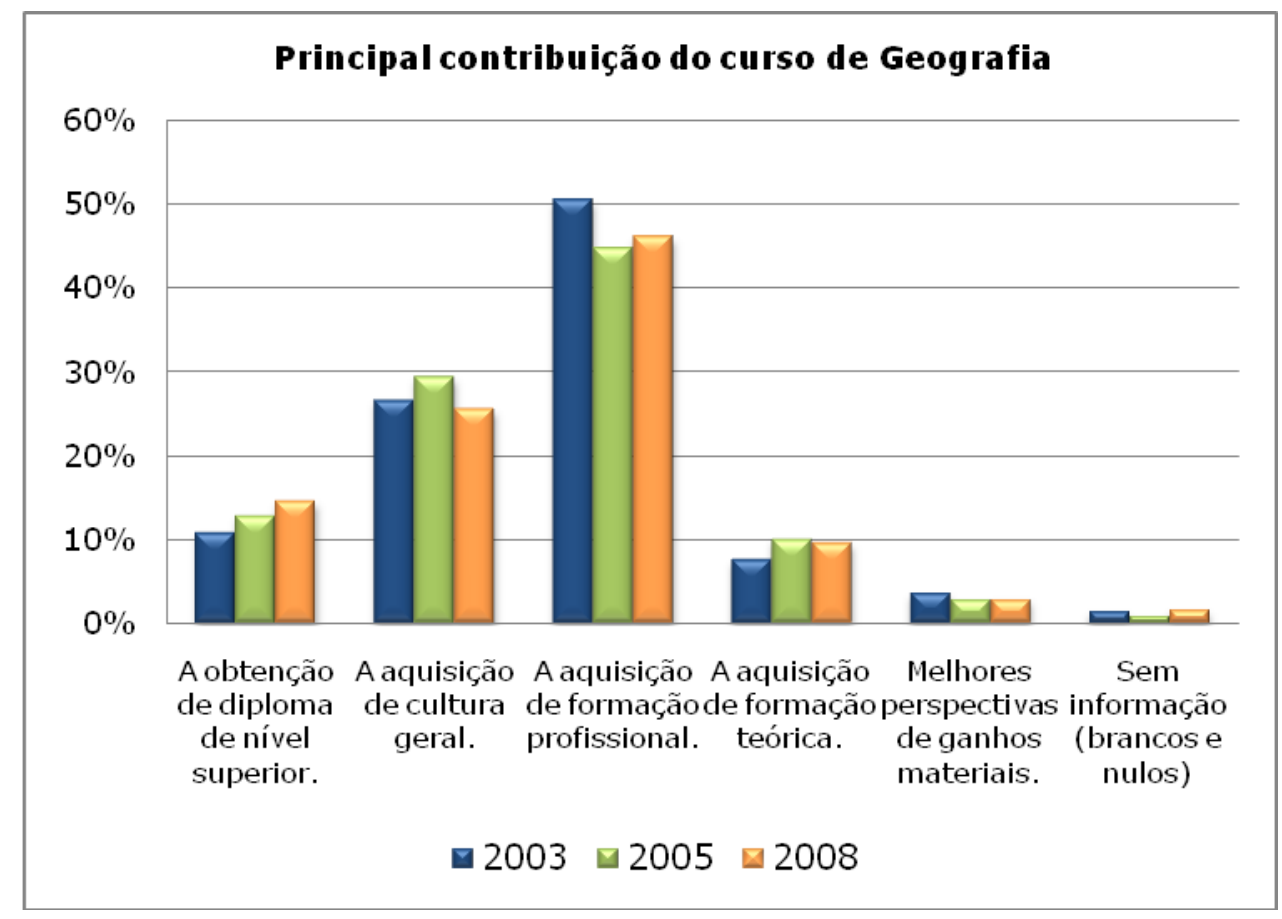

Gráfico 20- Fonte: Inep, Relatórios Sínteses/Cursos, Área de Geografia, ENC 2003 e Enades 2005 e 2008. Dados organizados por Vivian Fiori, 2009.

Há, portanto, diferentes contribuições apontadas pelos estudantes, inclusive a obtenção de um diploma em nível superior, que independe da formação. 
Assim, há algumas mediações sobre o interesse pela formação em Geografia e por ser professor, uma delas é a relação com o tipo de IES, se existe bacharelado e licenciatura nesta IES, e com o lugar onde está inserido o curso, sobretudo relacionado à dinâmica econômica e de emprego.

\section{3. A infraestrutura dos cursos de Geografia e sua relação com as atividades curriculares}

A infraestrutura é uma dimensão importante para as condições de ensino efetivamente se realizem. Neste sentido, é meio para que se realize o trabalho docente e a vivência dos discentes, sendo, portanto, uma mediação importante no processo de ensino-aprendizagem.

Trata-se de um sistema de objetos fundamental para a existência dos cursos, formado principalmente por salas de aula, salas de professores, espaços como laboratórios, bibliotecas e seus acervos, entre outros. Este sistema de objetos, dinamizados pelo sistema de ações produzidos por mantenedoras, coordenadores, docentes e discentes, entre outros, formam os cursos.

A dimensão da infraestrutura é analisada pelo Sistema Nacional de Avaliação da Educação Superior (Sinaes), com os seguintes elementos: sala para coordenação, sala dos professores, salas de aula, acesso a alunos a equipamentos de informática, bibliografia, periódicos especializados e laboratórios didáticos, avaliando-os quanto à quantidade e qualidade.

Há variações desta dimensão, dependendo do tipo de IES e das diferenças existentes no território brasileiro. Na pesquisa de doutorado de Giselle Real, que versa sobre pareceres de avaliadores do MEC em suas visitas in loco de cursos do Mato Grosso do Sul, para fins de autorização e reconhecimento dos cursos de IES públicas e privadas, ela constatou que:

[...] o acervo da biblioteca e os equipamentos de informática são adquiridos no momento anterior à visita de avaliação; os professores com regime de tempo integral possuem quase 
toda a totalidade da carga horária em sala de aula, o que os tornam professores horistas, com grande carga horária; a infra-estrutura física existente não é compatível com o desenvolvimento de pesquisa e de extensão, uma vez que não há salas individualizadas para os pesquisadores; 0 número de laboratórios é fortemente compartilhado entre os cursos da instituição [...] (REAL, 2007, p, 171).

A autora aponta ainda que em geral as IES acatam as solicitações feitas pela Comissão de Pareceristas do MEC que visitam as IES. Geralmente, na dimensão de infraestrutura, tornam os espaços um pouco mais adequados, sobretudo os laboratórios essenciais para o cursos, bem como adquirem novos livros que estejam nos planos de ensino.

Neste caso as IES privadas condicionavam sua melhoria da infraestrutura ao que considerava essencial, ao contrário das IES públicas que tinham dificuldades neste item, devido ao pouco financiamento no período analisado nesta tese, sobretudo devido à expansão dos cursos.

Em relação aos cursos de Geografia, o gráfico 21 demonstra que a maioria, em 2008 (42\%), considerava que as instalações físicas dos cursos de Geografia são "amplas, arejadas, bem iluminadas e com mobiliário adequado".

Não há alterações significativas entre os anos de 2003, 2005 e 2008. Mas os que respondem que as instalações não são adequadas são aproximadamente 23\%. Há, portanto, duas situações distintas para esta questão.

Verificando-se o mapa 24, sobre as condições das instalações físicas dos cursos de Geografia, há uma tendência para as respostas positivas na Região Concentrada e no Pará, neste último principalmente nas privadas. O Maranhão, Tocantins, Acre, Piauí, Amapá e Sergipe têm as médias mais baixas, já que são regiões onde o processo de interiorização dos cursos foi maior recentemente. 


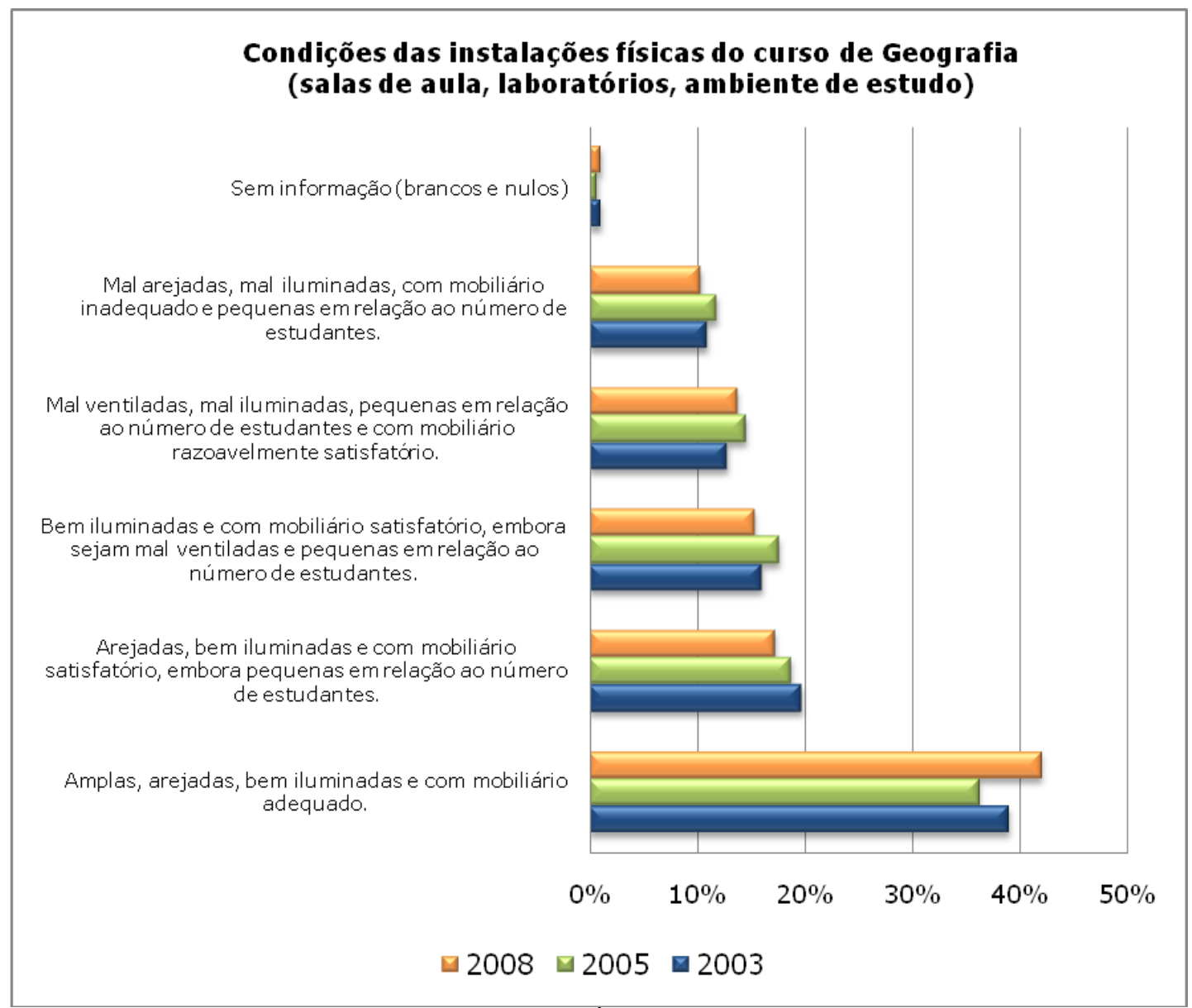

Gráfico 21- Fonte: Inep, Relatórios Sínteses/Cursos, Área de Geografia, ENC 2003 e Enades 2005 e 2008. Dados organizados por Vivian Fiori, 2009.

Quando comparamos a mesma questão em relação às IES públicas e privadas, mapa 25, fica nítida a prevalência das condições mais adequadas das instalações físicas nas IES privadas, em todas as regiões do Brasil.

Esta situação é corroborada pela pesquisa de Giselle Real (2007) na qual constatou que geralmente as IES privadas possuem infraestrutura, como salas de aulas e outros espaços, mais adequada por serem mais amplas, com boa luminosidade, mais arejadas do que as públicas.

Ressalva, no entanto, que estas condições têm um limite como elemento da qualidade dos cursos, pois geralmente há problemas em outros elementos que se relacionam com as condições de ensino, tal como o regime de trabalho do corpo docente nas IES privadas, por exemplo, como já analisado anteriormente. 


\section{Condições das instalações físicas do curso de Geografia (salas de aula, laboratórios, ambiente de estudo)}

Político
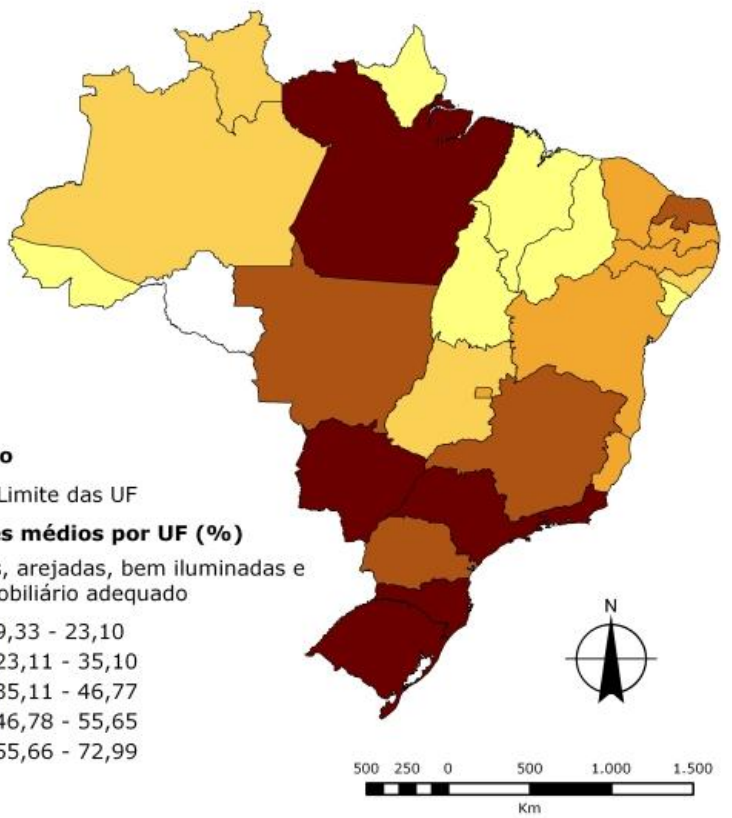

Mapa 24- Fonte Inep, Relatórios de Cursos de Geografia no Enade, por IES, 2008. Elaborado por Vivian Fiori e Mauricio Yamada, 2010.

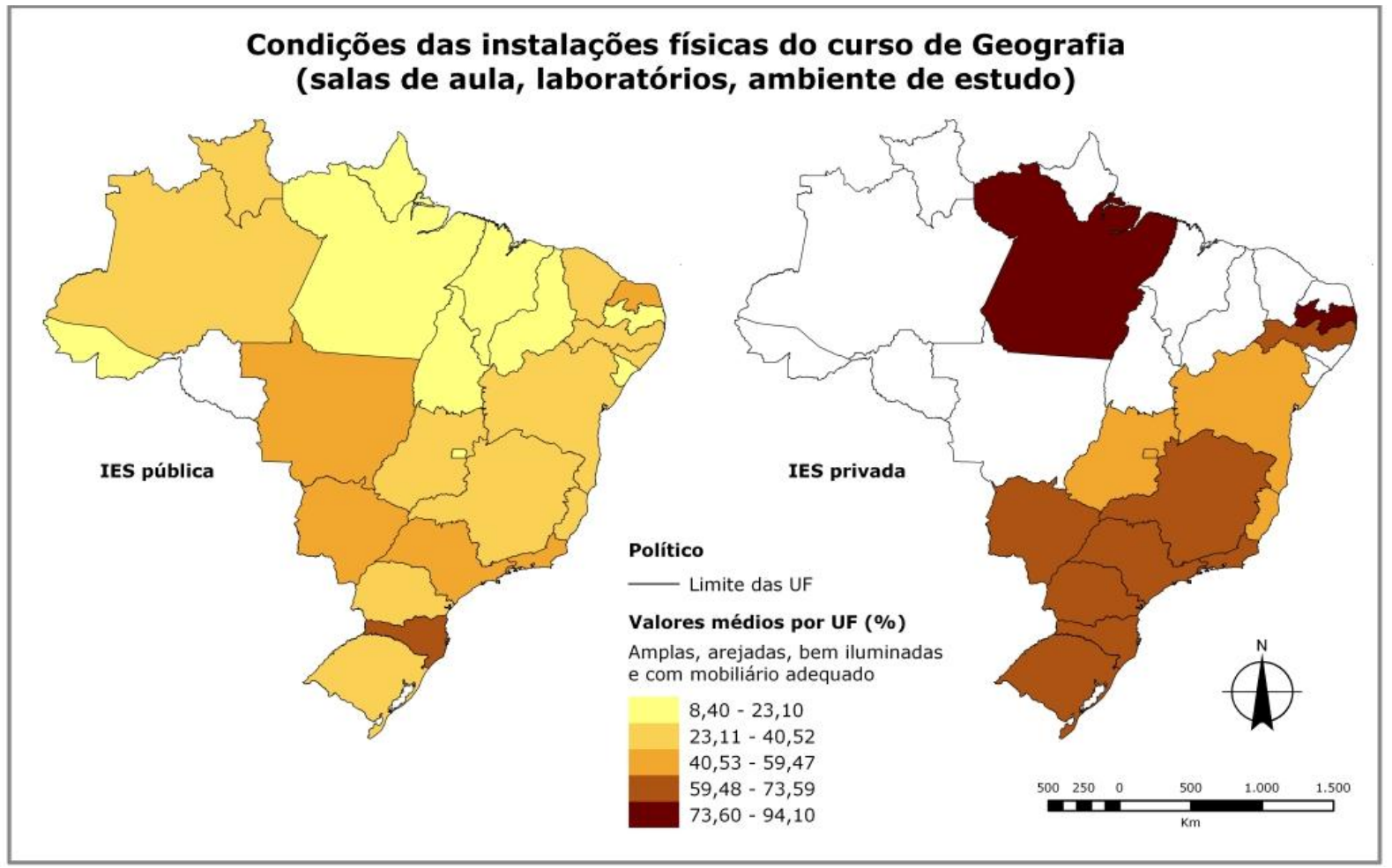

Mapa 25 - Fonte Inep, Relatórios de Cursos de Geografia no Enade, por IES, 2008. Elaborado por Vivian Fiori e Mauricio Yamada, 2010. 
Faltam investimentos públicos para a criação da maioria dos cursos de Geografia no Brasil, principalmente nas IES que se interiorizaram recentemente. A carência é também maior nas licenciaturas do que no bacharelado, tanto nas federais como nas estaduais.

Em depoimentos de alguns coordenadores e alunos de cursos de licenciatura em Geografia, fica nítido que, se houvesse também o curso de bacharelado, haveria mais laboratórios, já que este perfil de curso requer mais infraestrutura, segundo a velha concepção de que o curso de bacharelado tem mais relação com a necessidade de formação do pesquisador do que o de licenciatura. Relaciona-se também à visão que o bacharelado é uma formação mais técnica, sobretudo com a existência das novas tecnologias de informação e do geoprocessamento.

No que concerne à conservação e atualização dos equipamentos de laboratório, verifica-se que em 2003, a maioria, cerca de 30\%, não tinha laboratório. Segundo as respostas dadas em 2008, a situação melhorou, diminuindo para aproximadamente $21 \%$.

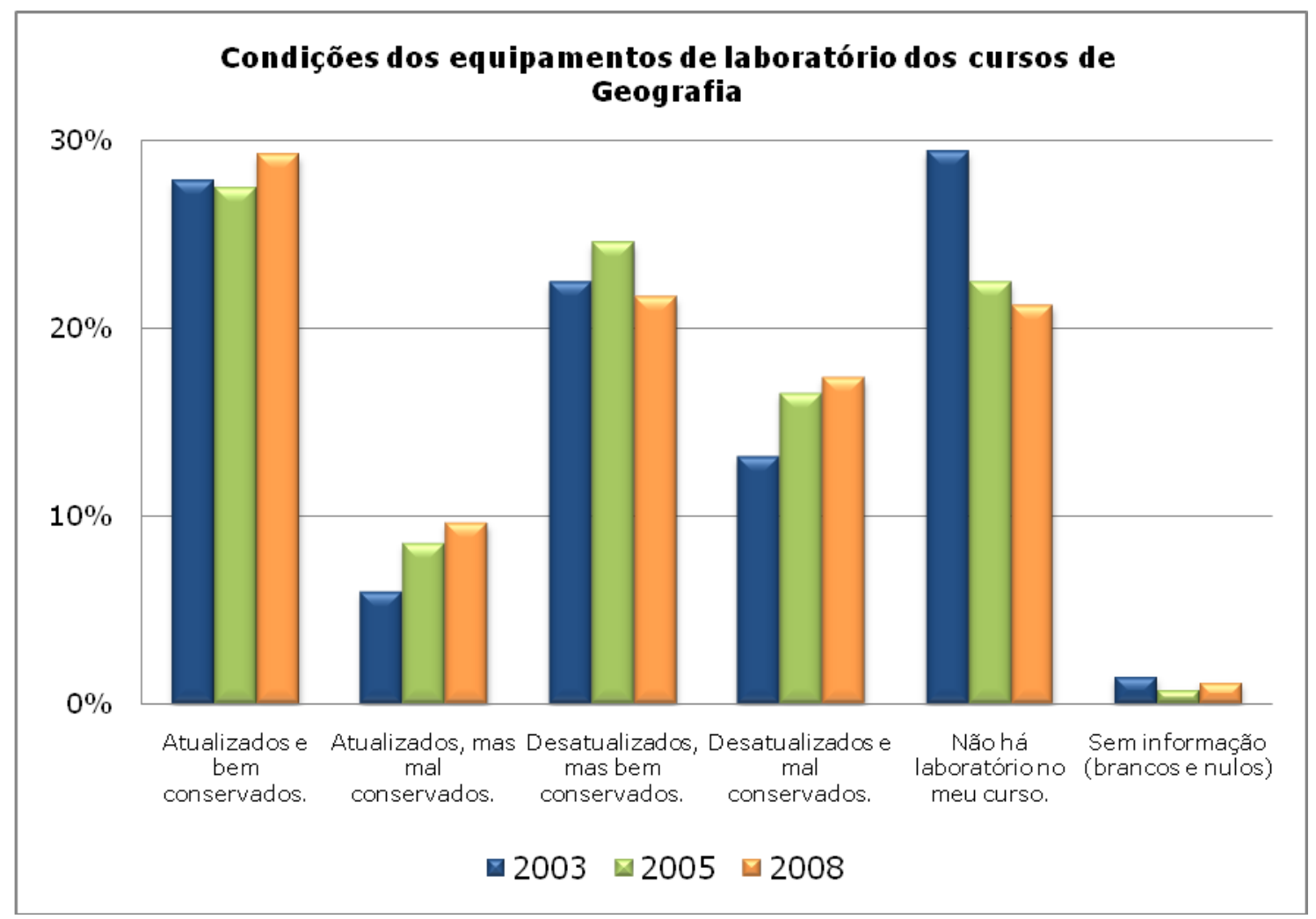

Gráfico 22- Fonte: Inep, Relatórios Sínteses/Cursos, Área de Geografia, ENC 2003 e Enades 2005 e 2008. Dados organizados por Vivian Fiori, 2009. 
Em 2003, a resposta "não há laboratório em meu curso" correspondia às seguintes condições: eram maiores as médias nas Regiões Norte $(41,3 \%)$ e Nordeste $(38 \%)$, nas IES municipais $(41,3 \%)$ e estaduais $(34,7 \%)$ e nas faculdades $(36,5 \%)$. Ou seja, nas IES onde houve um processo de interiorização maior; sobretudo, em IES estaduais e municipais, a condição de falta de laboratório era maior.

Os laboratórios são fundamentais para atividades de estudos regionais e urbanos, usos de cartas e mapas, para produção de mapas temáticos, estudos de imagens, produção de materiais didáticos, pesquisas sobre solos e clima, entre outras atividades.

Considerando-se o acervo da biblioteca e sua atualização, a maioria diz que é medianamente atualizado; em 2008, foram 28\%. Porém, somando-se os percentuais relativos às respostas "pouco atualizado" e "desatualizado", chega-se a 41,5\%, conforme gráfico 23.

Portanto, embora se identifiquem, em algumas matrizes curriculares dos cursos de licenciatura em Geografia, disciplinas como "Organização espacial do semi-árido de Alagoas", "Geografia Humana da Amazônia", "Geografia da Bahia" e "Geografia do Ceará", independentemente de discutir a necessidade e/ou o caráter de tais disciplinas, fica a dúvida de como se realizam em termos bibliográficos.

Estabelece-se uma correlação entre as condições dos cursos e sua extensão no território brasileiro, já que a produção brasileira de livros é extremamente centralizada em São Paulo e Rio de Janeiro, tanto no que se refere às editoras quanto aos autores.

Esta concentração também se dá nas IES mais antigas e consideradas tradicionais, caso principalmente da USP, UFRJ, UNESP e UFF. Há, portanto, publicações e estudos regionais em formato de livros, mas geralmente produzidos por pesquisadores da Região Concentrada e mais comumente sobre a Amazônia. 


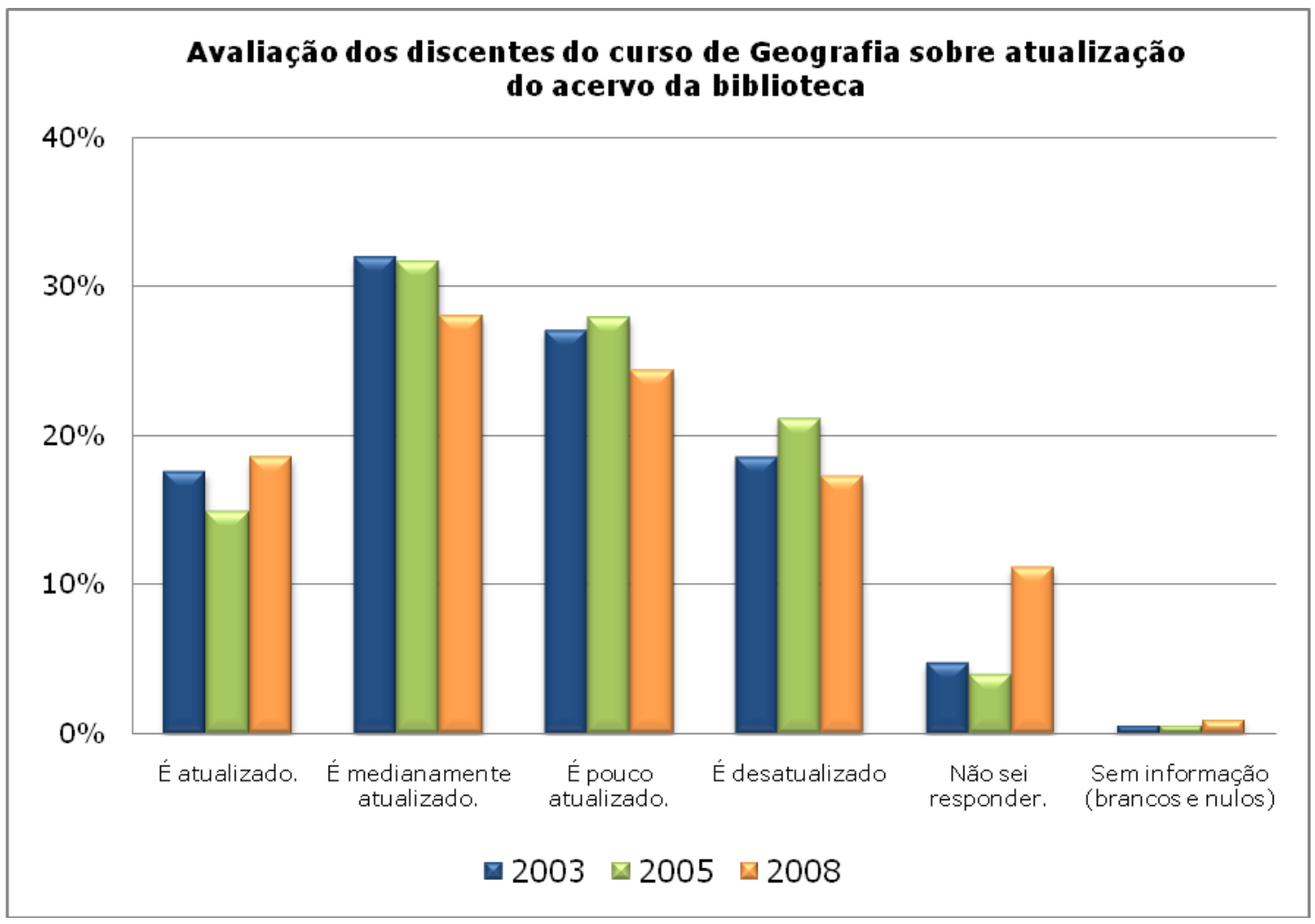

Gráfico 23- Fonte: Inep, Relatórios Sínteses/Cursos, Área de Geografia, ENC 2003 e Enades 2005 e 2008. Dados organizados por Vivian Fiori, 2009.

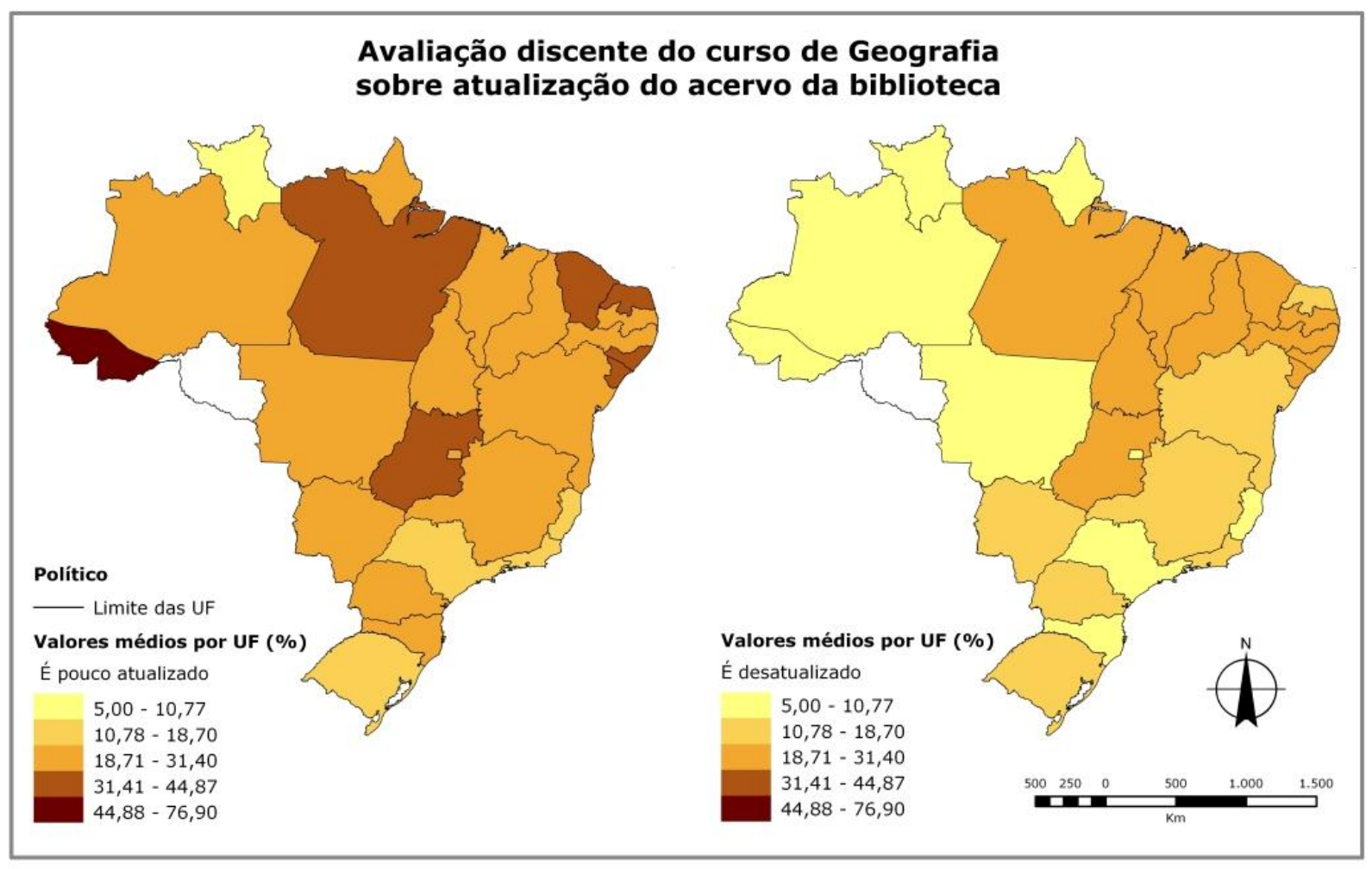

Mapa 26 - Fonte Inep, Relatórios de Cursos de Geografia no Enade, por IES, por UF, 2008. Dados organizados por Vivian Fiori e mapa elaborado por Mauricio Yamada, 2010. 
Conforme se observa no mapa 26, produzidos a partir das respostas dos estudantes em 2008, apenas São Paulo, Rio de Janeiro, Rio Grande do Sul e Espírito Santo tinham médias mais baixas, para a atualização do acervo da biblioteca "pouco atualizado, de 5,0 a 10,77\%; todos estados da Região Concentrada do Brasil.

O Acre é a unidade da federação que apresenta a maior média, chegando a 76,9\% para o acervo da biblioteca "pouco atualizado", devido ao fato de parte das licenciaturas serem interiorizadas pela Universidade Federal do Acre (UFAC), sem infraestrutura adequada, já que se utilizaram, inclusive de espaços da rede pública dos municípios - escolas de Ensino Básico, para ministrarem os cursos.

Esta situação é comum em alguns cursos que se interiorizaram recentemente e denota a fragilidade como este processo tem sido conduzido, sem condições adequadas para o ensino.

Em depoimentos, alguns coordenadores de cursos situados no interior chegaram a dizer: "Hoje a Universidade tem salas alugadas, pois não tem espaço na própria instituição [...] nem para os cursos antigos, nem para os novos". Outro coordenador disse: "Nossa infraestrutura é péssima, já perdemos projetos por falta de espaço. Em termos de livros são muito modestos. Os livros de Pedagogia são em maior número, os de Geografia são poucos".

Sobre o número de exemplares disponíveis na biblioteca, gráfico 24, os estudantes que responderam "atende plenamente" são apenas 9\%; a maioria respondeu que "atende razoavelmente", com percentual de $34 \%$, em 2008.

Em 2008, somando-se os que responderam que "atende precariamente" e "não atende", chega-se a 48,2\%, um número bastante elevado. Em 2003, os que responderam ao item "atende precariamente" eram 28,5\%, principalmente das IES Federais $(37,1 \%)$ e das Estaduais $(31,5 \%)$. 
Em 2008, sobre atualização dos períódicos acadêmicos e científicos, gráfico 25 , a maioria informou que é medianamente atualizado $(37,6 \%)$, e $10 \%$ disseram que "não existe acervo de periódicos especializados". Além disso, não há clareza em relação a se tais periódicos são geográficos ou relacionados ao ensino ou a outras áreas.

Além de haver problemas na atualização do acervo bibliográfico, há falta de bibliografia que discuta algumas especificidades dos lugares ou regiões brasileiras, o que dificulta a formação dos geógrafos no Brasil com leituras mais diversificadas. Esta situação foi sendo minimizada com as produções geográficas no Brasil, mas o acesso a elas é maior nas metrópoles, principalmente em São Paulo e Rio de Janeiro, onde se concentra a maioria da produção geográfica e principalmente as editoras.

Por outro lado, atualmente, há mais períódicos geográficos e dissertações e teses disponibilizados pela internet, produzidos por algumas IES, principalmente as que possuem pós-graduação, pela AGB, pela Anpege e pelo IBGE, entre outras instituições.

Talvez seja uma forma de minimizar a falta dos períódicos em algumas instituições e, portanto, a falta de acesso dos discentes a diferentes textos. Nestes textos, também há maior possibilidade de produção acadêmica que não seja específica da Região Concentrada. Como exemplo, existe a Revista Mercator, Revista Geográfica da Universidade Federal do Ceará, com artigos sobre a Geografia brasileira, mas também com estudos locais. Há, ainda, a Revista Geosul, Boletim Goiano de Geografia, Terra Livre, Revista Território, Espaço e Cultura, Ambiente e Sociedade, Revista Geografares, Ifogeo, Revista Ciência Geográfica, GeoNotas, Cadernos de Geografia, Espaço \& Geografia, entre outras.

Isto possibilita enriquecer as bibliografias e estudos da Geografia sobre temáticas e lugares menos comuns nas publicações da Geografia do Brasil. 


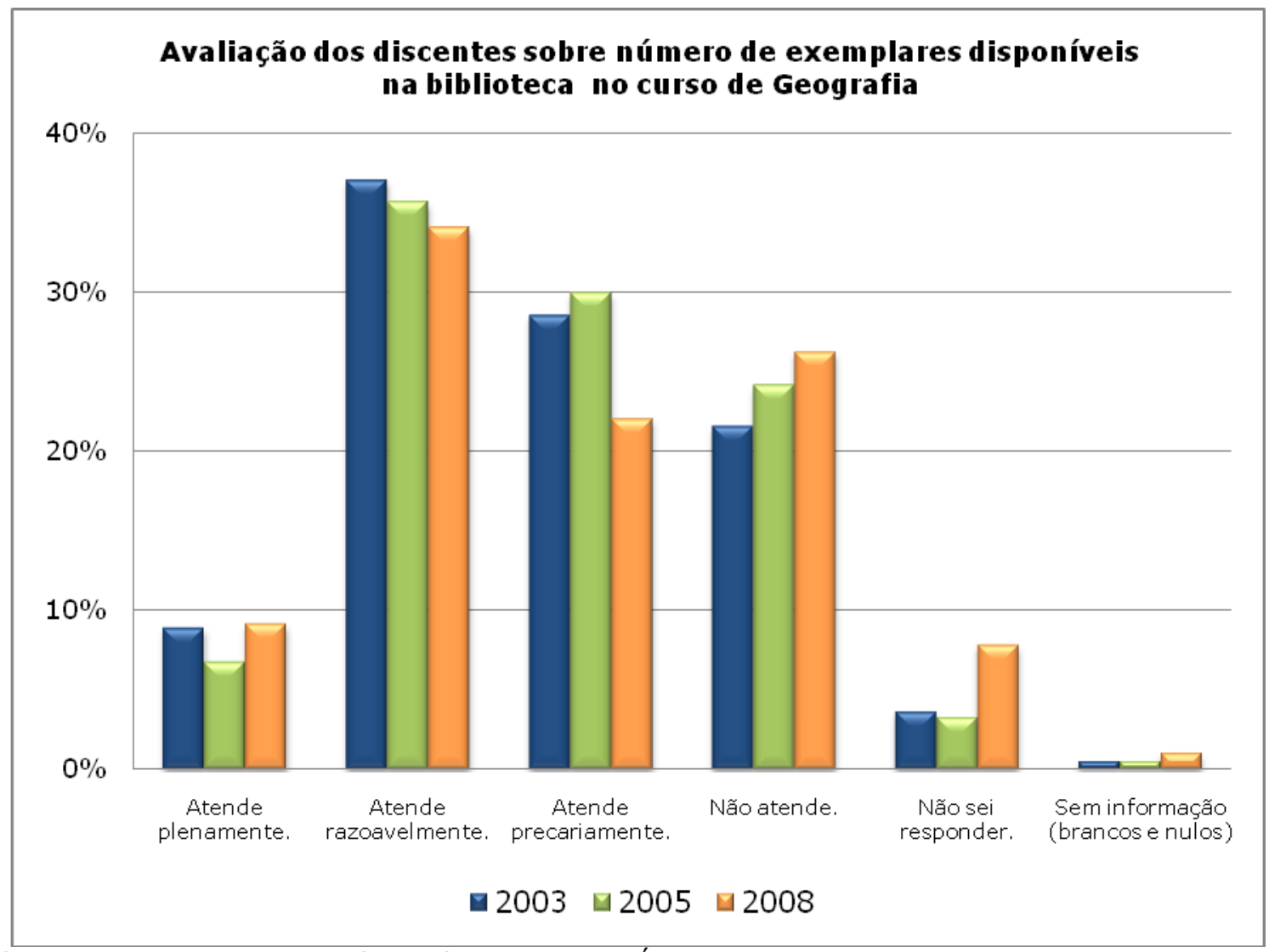

Gráfico 24 - Fonte: Inep, Relatórios Sínteses/Cursos, Área de Geografia, ENC 2003 e Enades 2005 e 2008. Dados organizados por Vivian Fiori, 2009.

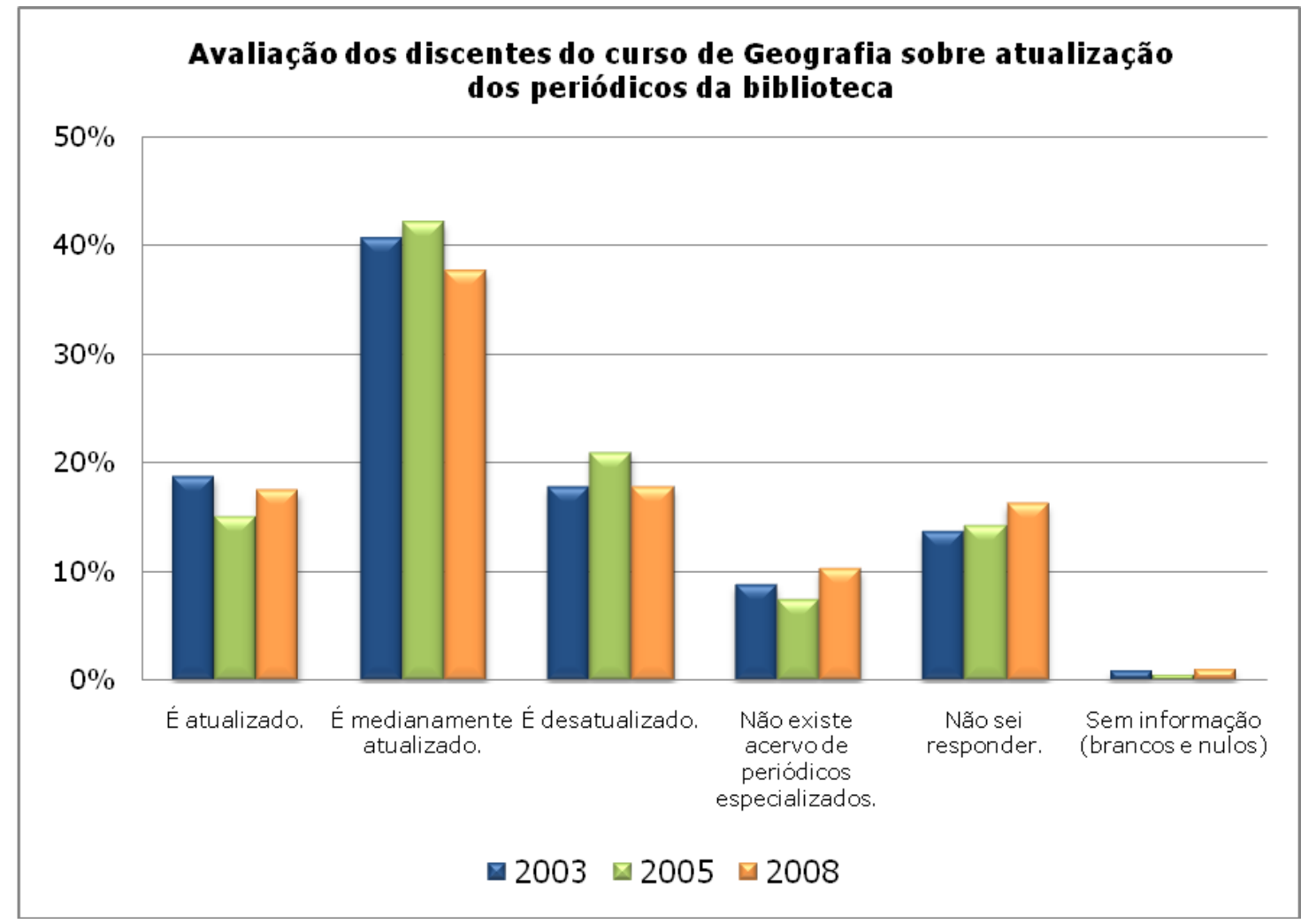

Gráfico 25 - Fonte: Inep, Relatórios Sínteses/Cursos, Área de Geografia, ENC 2003 e Enades 2005 e 2008. Dados organizados por Vivian Fiori, 2009. 
Em relação à frequência com que o discente utiliza a biblioteca (gráfico 26) a maioria diz que "com razoável frequência"; em 2008, foram 40,7\%. Esta média aumentou em comparação com 2003 e 2005, assim como aumentou os que que disseram "utilizo raramente"; em 2008, passou a ser de 27,5\%. Em 2003, os que utilizavam raramente a biblioteca eram 25,9\%, principalmente das IES municipais $(29,7 \%)$ e Centros Universitários $(32, \%)$. Então, há duas respostas distintas para a questão do uso da biblitoeca.

Há várias razões para a baixa frequência à biblioteca da IES, desde o fato concreto de não haver biblioteca na IES, até pouco uso pela disciplina de livros e periódicos, ou ainda, a falta de hábito de leitura dos discentes.

Verificando-se a distribuição territorial dos cursos cujos discentes utilizam raramente a biblioteca, conforme mapa 27, percebe-se que há concentrações significativas no Acre e no Amapá. Em Alagoas, Pernambuco, Ceará, Rio Grande do Norte e Piauí, os valores variam de $31,88 \%$ a 43,87\%, todos na Amazônia e Nordeste do Brasil.

Em contrapartida, em relação ao uso da internet (mapa 28) como forma de pesquisa, no Acre e Ceará, onde é elevada a média dos que raramente usam a biblioteca, há a maior média de uso da internet no Brasil. Contudo, estes usos são maiores nas capitais, dos que nos cursos instalados no interior.

Não se conhece a qualidade das pesquisas existentes na internet, mas, sem dúvida, é uma possibilidade atual de existência de textos, sobretudo com a disponibilidade de periódicos geográficos e educacionais em revistas on-line, alguns já citados anteriormente, publicados pela AGB e principalmente por IES onde há cursos de Geografia.

Há também publicações de teses e dissertações mais recentemente divulgadas on-line, o que possibilita maior acesso das pesquisas realizadas na Geografia por estudantes. 


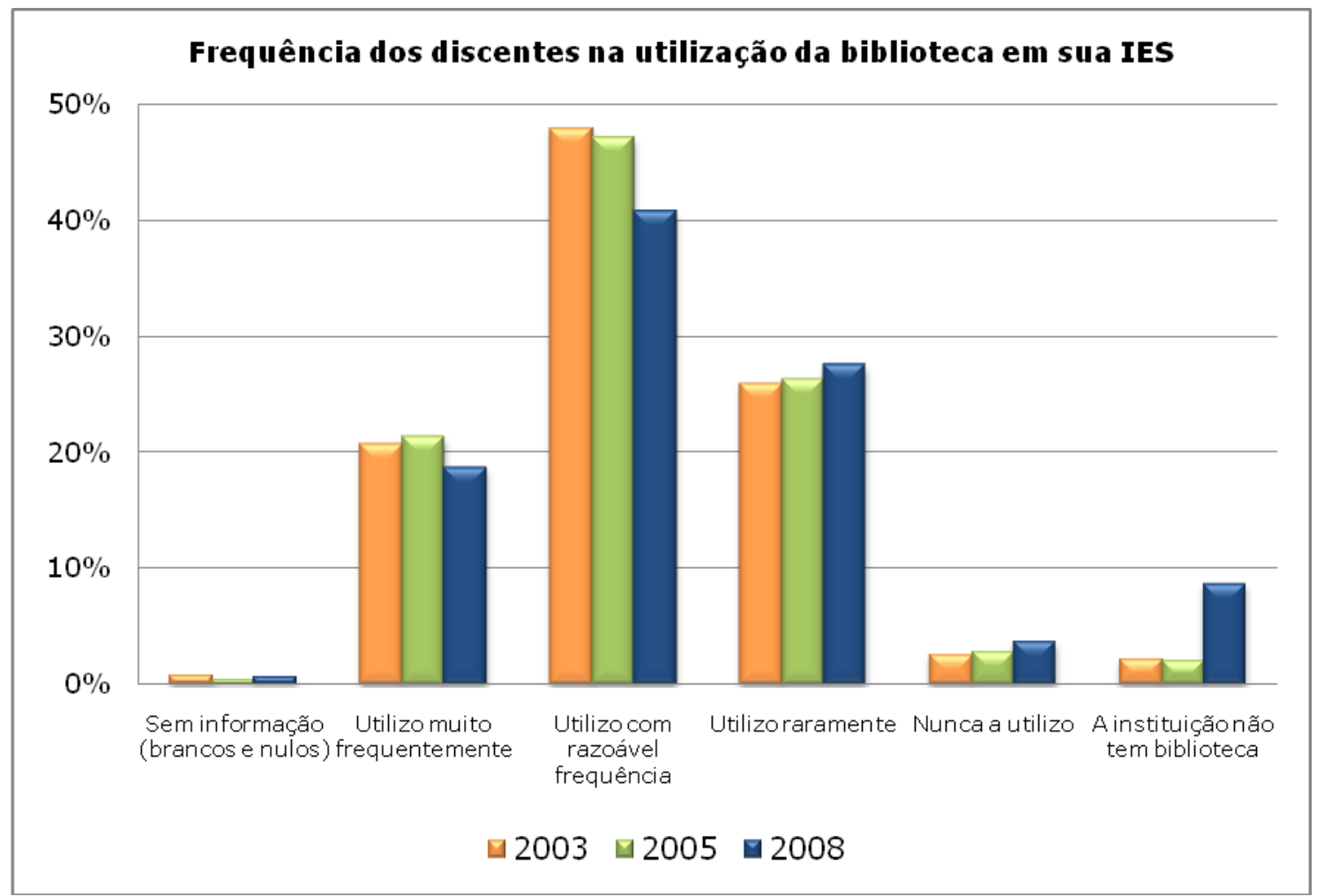

Gráfico 26 - Fonte: Inep, Relatórios Sínteses/Cursos, Área de Geografia, ENC 2003 e Enades 2005 e 2008. Dados organizados por Vivian Fiori, 2009.

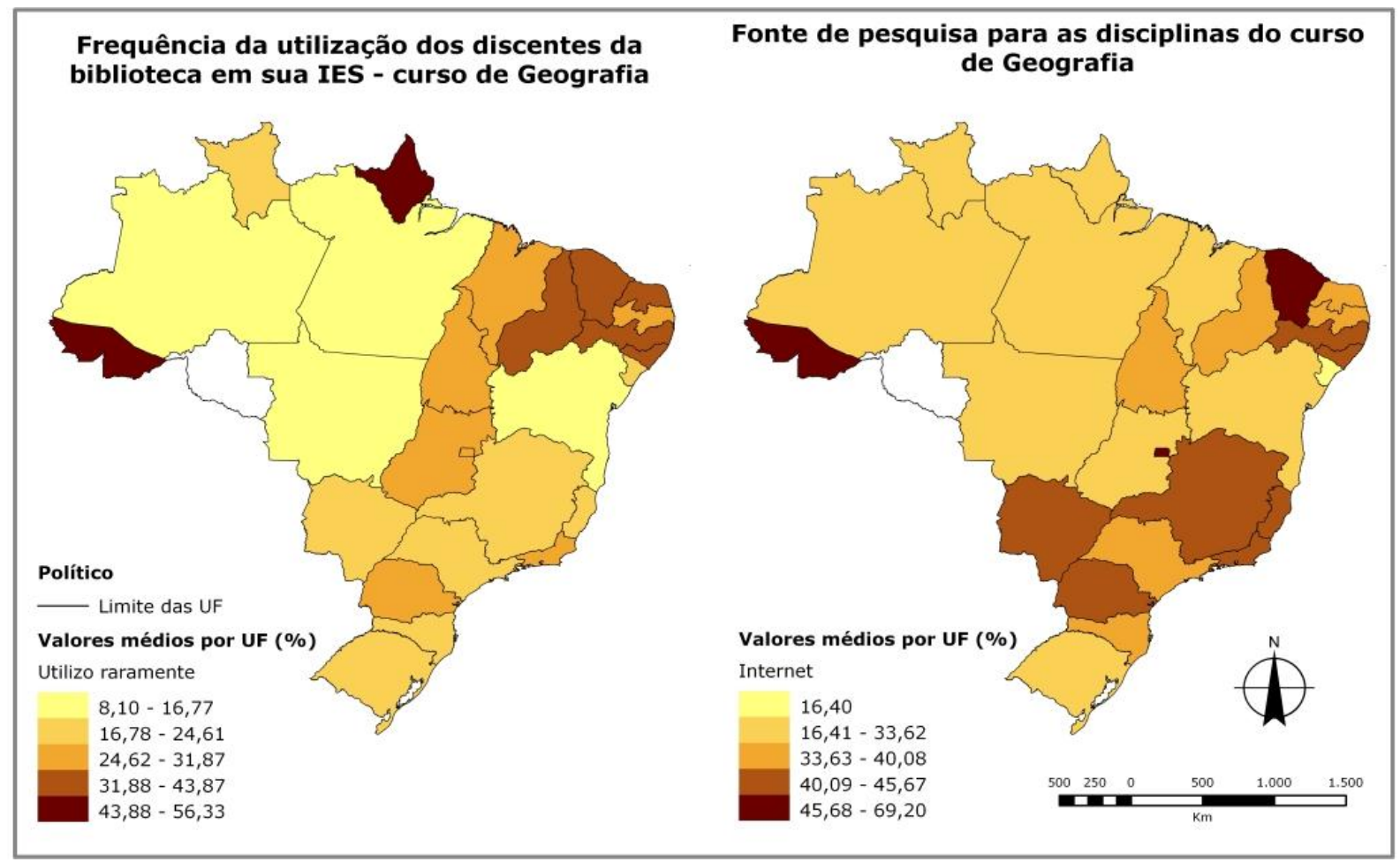

Mapas 27 e 28 - Fonte Inep, Relatórios de Cursos de Geografia no Enade, por IES, por UF, 2008. Dados organizados por Vivian Fiori e mapa elaborado por Mauricio Yamada, 2010. 
Talvez seja uma forma mais rápida e democrática de utilização destes recursos. No atual período do meio-técnico-científico informacional, no qual a informação pode ser acessada on-line, é fundamental que a produção geográfica e em educação alcance o maior número de docentes e discentes dos cursos.

\subsection{O ensino, a pesquisa e a extensão}

Considerando-se que o ensino, a pesquisa e a extensão são atividades curriculares da graduação e que a LDBEN no 9694 (BRASIL, 1996b) trata da indissociabilidade entre estes elementos, observa-se que, na prática, estas atividades parecem estar quase sempre dissociadas nos cursos de Geografia.

Geralmente, o ensino é pensado como condição apenas de transmissão e reprodução do conhecimento já existente, sobretudo nos cursos de licenciatura. A pesquisa alcançou um patamar de maior visibilidade, principalmente porque é validada pelo sistema de avaliação do Ensino Superior; a extensão é relegada à condição de atividade esporádica e geralmente vista como ação de abnegados e assistencialistas, sobretudo a extensão comunitária.

Em 2008, gráfico 27, ao serem questionados sobre se "foi solicitado a realizar atividades de pesquisa como estratégia de aprendizagem", $37,5 \%$ dos discentes respondeu "sim, na maior parte das disciplinas".

Estas atividades de pesquisa são geralmente as mais corriqueiras, vinculadas às disciplinas, na forma de monografias, resenhas, seminários, entre outras, nas quais normalmente os alunos se utilizam de referências bibliográficas, consultando a biblioteca de sua IES ou a internet, e, em alguns casos, dados de pesquisas de campo.

São importantes estratégias no processo de ensino-aprendizagem para a aquisição de novos conhecimentos. 


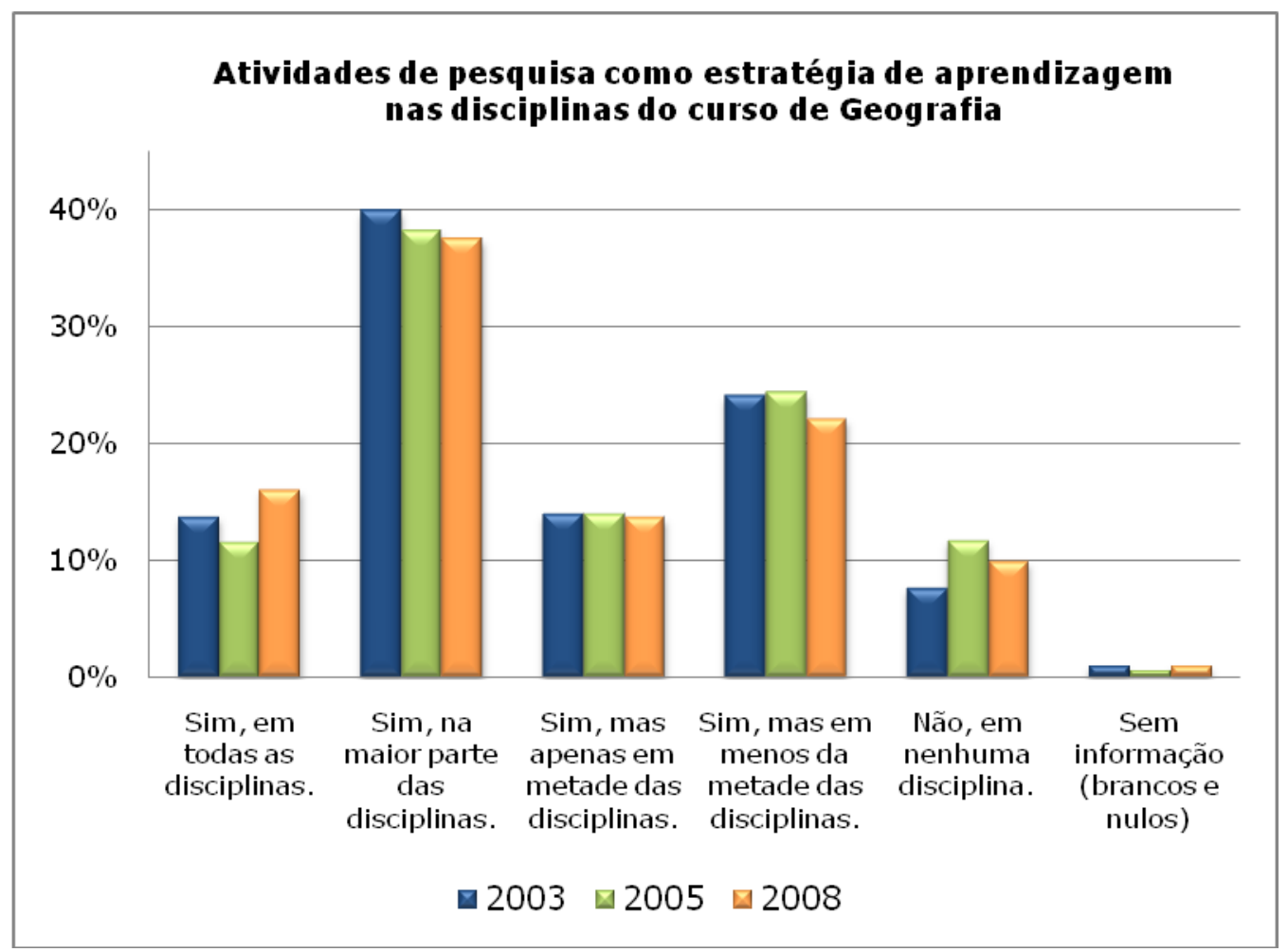

Gráfico 27 - Fonte: Inep, Relatórios Sínteses/Cursos, Área de Geografia, ENC 2003 e Enades 2005 e 2008. Dados organizados por Vivian Fiori, 2009.

Nestas atividades, a dimensão de infraestrutura dos cursos, principalmente da existência da biblioteca e de seu acervo são fundamentais.

Sobre "o tipo de material mais usado por indicação dos professores durante o curso", conforme gráfico 28, os alunos afirmam que, preferencialmente, são indicados: cópias de trechos ou capítulo de livros (44,1\% em 2003; 47,4\% em 2005 e 40,7\% em 2008) e "apostilas e resumos" (35,8\% em 2003; 30,4\% em 2005 e 32,2\% em 2008).

As copias de trechos de livros é muito comum em todas as IES, exceção feita aos cursos de Educação a Distância (EAD), que geralmente se utilizam de apostilas cujo conteúdo é produzido pelos docentes da IES. Há também inúmeros casos relatados, em depoimentos de professores e discentes, que é comum os docentes levarem seus livros para serem copiados, pois não há exemplares na biblioteca.

Já os dados sobre uso de apostilas e resumos para o desenvolvimento das aulas e pesquisas remetem ao passado, já que, segundo os professores universitários das primeiras turmas, havia o uso 
indiscriminado das apostilas. As condições hoje não são as mesmas, pois normalmente o problema não está, como no passado, em ler em outras línguas. Muitos livros são atualmente traduzidos e há ainda a própria produção geográfica de autores brasileiros, estando o problema, principalmente, na falta de acervo na biblioteca ou ainda nas condições dos discentes em entender um livro ou texto mais denso.

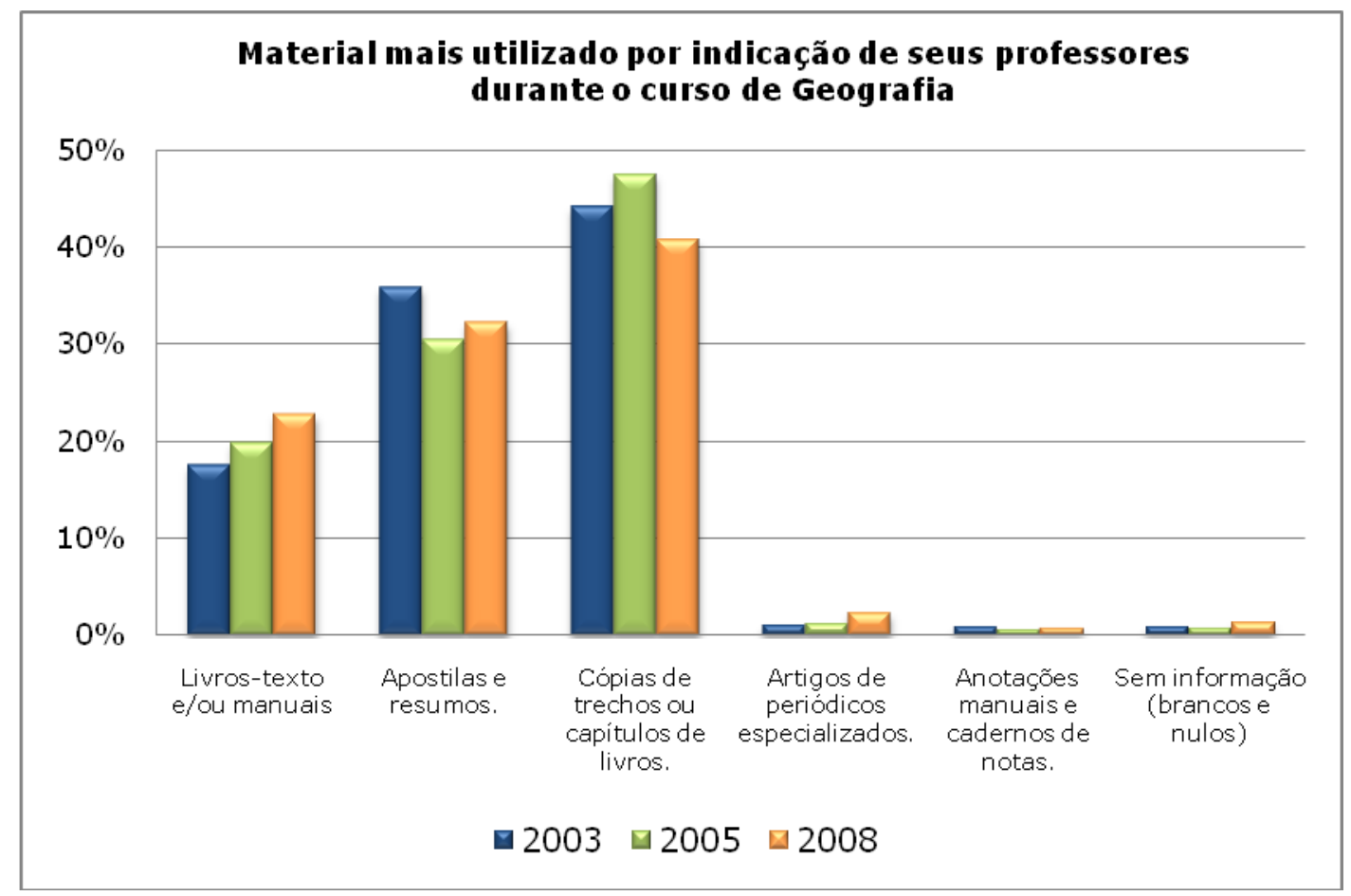

Gráfico 28- Fonte: Inep, Relatórios Sínteses/Cursos, Área de Geografia, ENC 2003 e Enades 2005 e 2008. Dados organizados por Vivian Fiori, 2009.

Esta situação de leitura apenas de apostilas e resumos ficou evidenciada nas provas dissertativas do ENC (2003) e ENADE (2005), em que ficou claro que havia pouco conhecimento dos estudantes formados em Geografia sobre conceitos geográficos, teorias e leituras de mapas e gráficos.

Esta dificuldade em ler um texto mais denso foi citada por muitos professores/coordenadores entrevistados. Alguns chegam a citar que, ao lecionarem no interior, muitas vezes, procuram usar textos mais simples, menos densos teoricamente, pois dessa forma há a possibilidade de entendimento do texto por parte dos discentes.

Isto se deve às deficiências na formação no Ensino Básico dos discentes no interior do país, mais comumente na Amazônia e no 
Nordeste, o que acaba dificultando a aquisição e aprofundamento dos conhecimentos no processo de ensino-aprendizagem no Ensino Superior. Também isto é muito comum em IES privadas onde o processo seletivo foi menos concorrido, mesmo nas capitais e Regiões Metropolitanas.

A leitura de textos de forma crítica ${ }^{105}$ ou de textos cujos conteúdos teóricos são grandes, geralmente com conceitos, torna-se difícil para estudantes cuja formação no Ensino Básico tenha sido deficiente.

Esta situação leva muitas IES a terem a disciplina de Língua Portuguesa em sua matriz curricular, embora seja necessário que textos de diferentes tipos sejam produzidos e lidos em diferentes disciplinas, não apenas em Língua Portuguesa. Tal situação interfere no desempenho do estudante universitário, como têm mostrado algumas pesquisas que envolvem a leitura na Universidade, como afirmam Silva e Santos (2004):

Os resultados encontrados demonstram que a probabilidade de ser bem-sucedido num curso universitário está diretamente relacionada à maturidade do estudante enquanto leitor, que inclui habilidades como, compreensão, ritmo, concentração, flexibilidade, criticidade e criatividade. Outros fatores também parecem estar envolvidos, entre eles o interesse, a motivação e as atitudes frente à leitura (SILVA; SANTOS, 2004, p. 460).

Entretanto, muitos docentes ressaltam que esta condição não é uniforme e pode ser rompida conforme o desenvolvimento das atividades acadêmicas, não sendo, portanto, em si uma determinação, mas uma condição que pode ser superada ou minimizada.

Analisando-se a distribuição por UF do uso de apostila e resumos (mapa 29), há uma concentração no Amapá (70,33\%), no Piauí $(72,27 \%)$ e, a mais elevada do país, 94,57\%, no Maranhão. São médias muito altas, que revelam um comprometimento da formação, visto que, em princípio, a leitura de diversificados autores é importante para a formação do futuro professor.

105 Entende-se por leitura crítica aquela que busca contextualizar o texto, confrontando ideias, estabelecendo relação com outros textos já lidos; procurando ler além da opinião do autor, desvendando os conceitos usados e a forma de apreensão do autor sobre a realidade estudada. 


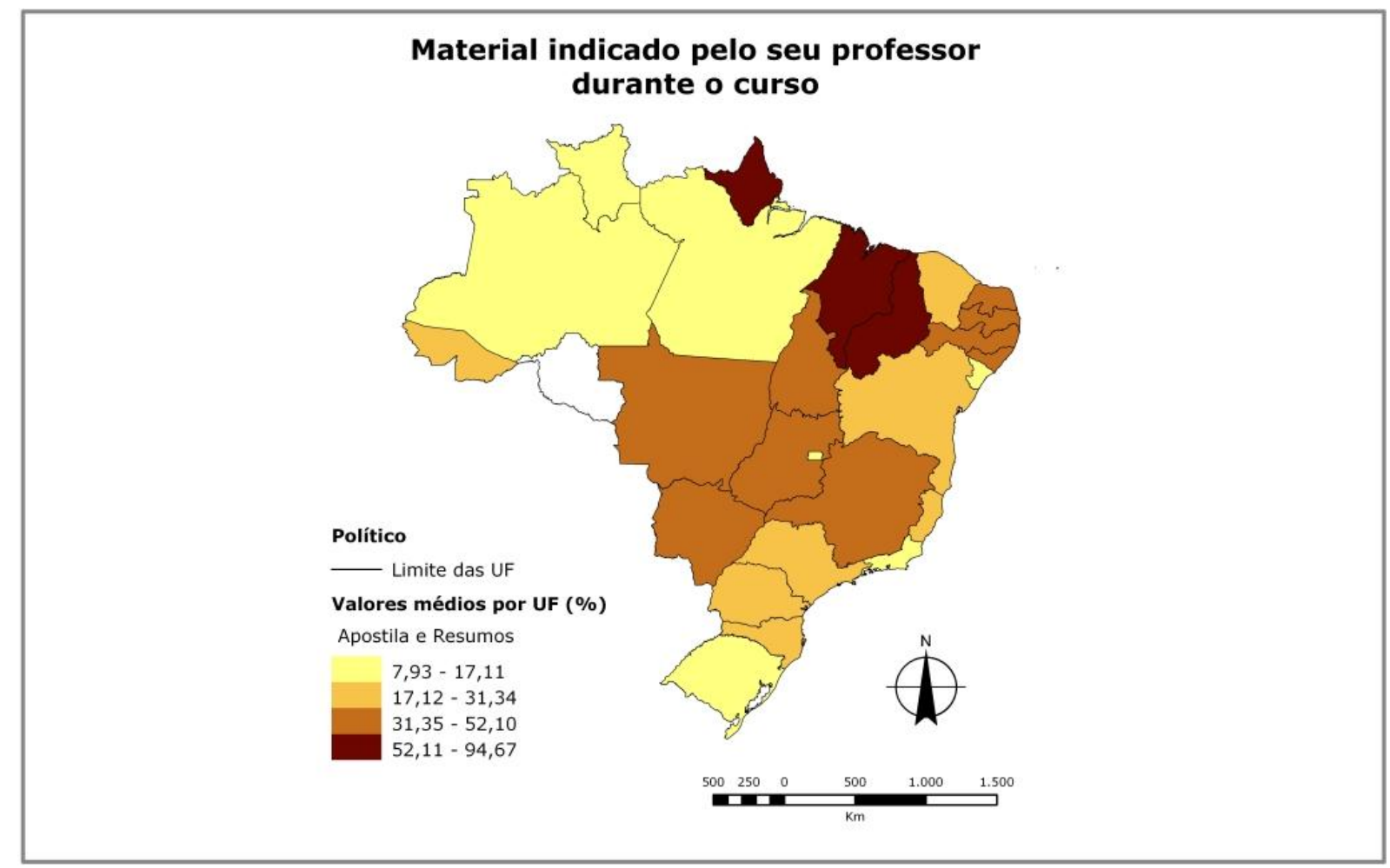

Mapa 29: Fonte Inep, Relatórios de Cursos de Geografia no Enade, por IES, 2008. Elaborado por Vivian Fiori e Mauricio Yamada, 2010.

Em parte do Centro-Oeste, Tocantins, Alagoas, Pernambuco, Paraíba e Rio Grande do Norte, as médias variam de $31 \%$ a $52 \%$.

Esta condição também é territorial, à medida que se relaciona com a falta de infraestrutura, principalmente dos cursos de interior, e também ao fato de alguns destes cursos são modulares, ou seja, são ministrados geralmente em períodos de férias e/ou são temporários. Estes cursos são mais comuns na Amazônia, no interior do Nordeste e na Educação a Distância (EAD).

Refletem as condições de seus territórios e de como se deu o movimento das licenciaturas em Geografia pelo interior destas regiões, bem como pela peculiaridade de alguns cursos a distância, que geralmente se utilizam do sistema de apostilas como material didático fundamental no processo de ensino-aprendizagem.

Das atividades mais citadas como não obrigatórias, gráfico 29, estavam os "projetos de pesquisa", cuja porcentagem caiu de $32,1 \%$, em 2003, para 24,2\%, em 2005, e 27,5\%, em 2008. 


\section{Atividade acadêmica desenvolvida por mais tempo, além das obrigatórias no curso de Geografia}

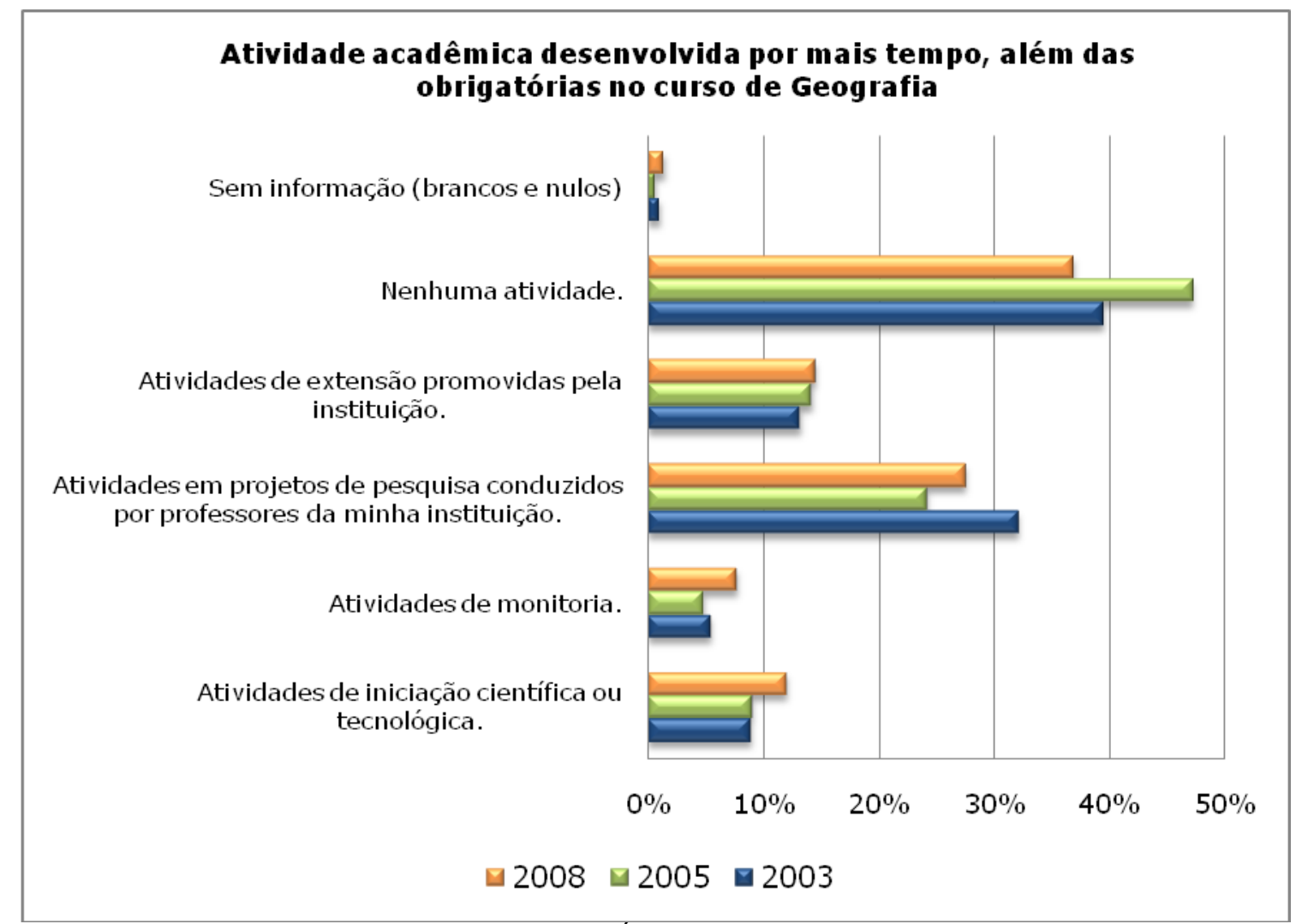

Gráfico 29- Fonte: Inep, Relatórios Sínteses/Cursos, Área de Geografia, ENC 2003 e Enades 2005 e 2008 Dados organizados por Vivian Fiori, 2009.

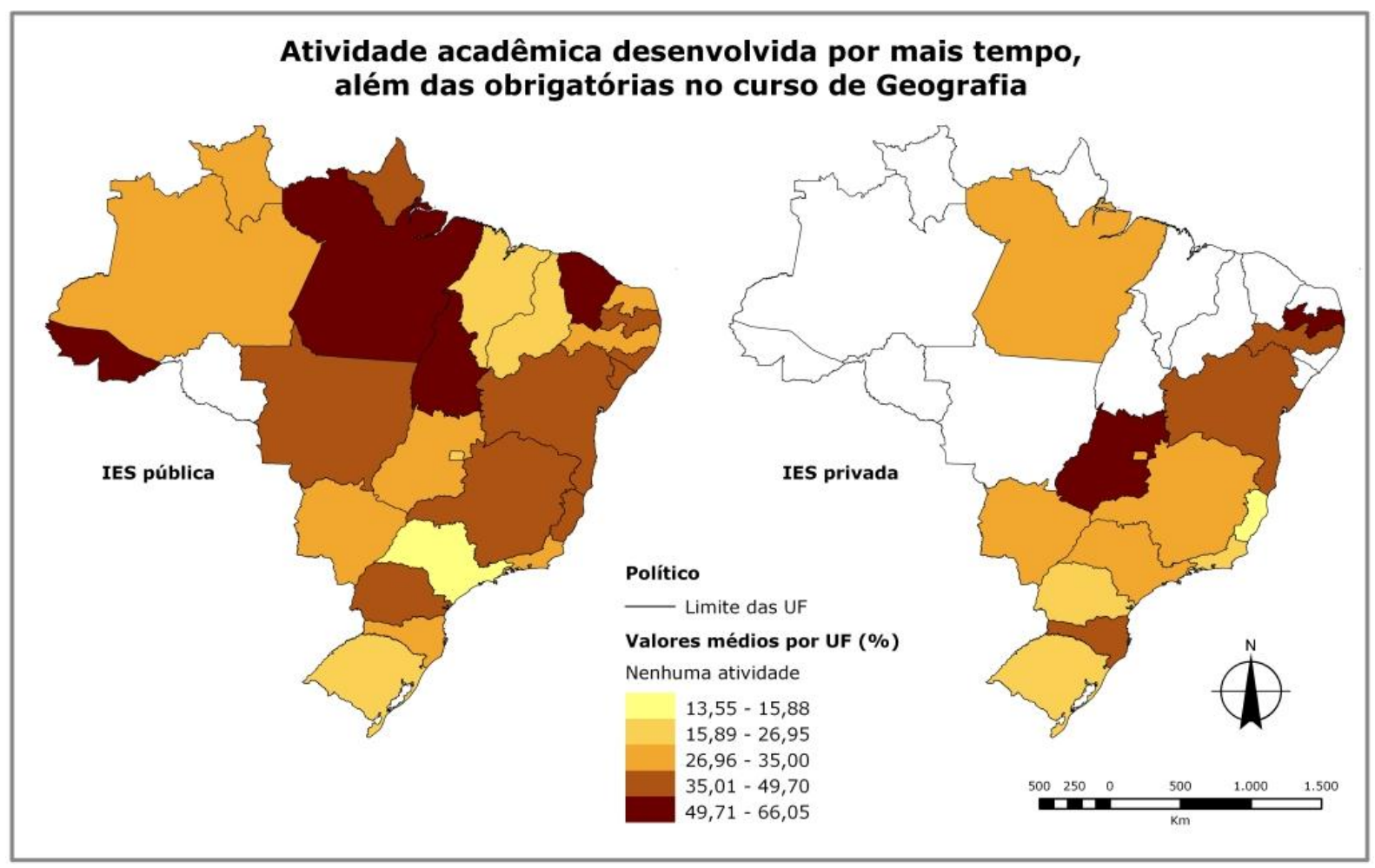

Mapa 30 - Fonte Inep, Relatórios de Cursos de Geografia no Enade, por IES, 2008.

Elaborado por Vivian Fiori e Mauricio Yamada, 2010. 
A maioria cita que não desenvolve "nenhuma atividade" além das obrigatórias (gráfico 29): 2003 (39,5\%), 2005 (47,2\%) e 2008 (36,9\%). $\mathrm{Na}$ prática, isso também se deve aos professores horistas que, em muitas instituições, não têm tempo e exclusividade para orientar trabalho extraclasse.

Conforme mapas 30, as IES públicas de São Paulo têm a menor média entre os que assinalaram que não desenvolvem "nenhuma atividade", evidenciando a maior participação destes discentes em Encontros de Geografia, atividades de pesquisa, além das atividades obrigatórias.

Em Tocantins, Acre, Ceará e Pará, encontram-se as mais altas médias $(49,71 \%$ a $66,05 \%)$ nas IES públicas. Nas instituições privadas, as mesmas médias são encontradas em Goiás e na Paraíba.

Em relação ao tempo disponível para estudar, a maioria (38,9\%), (Apêndice F), em 2008, respondeu que disponibilizava de uma a duas horas além do horário de sala de aula. Trata-se de alunos cujas atividades produzidas ao longo do curso se referem principalmente ao que foi solicitado pelo professor e vale nota. Isto talvez se dê pela falta de opção de sua instituição em promover atividades extraclasses, bem como por falta de tempo ou interesse do próprio estudante.

Sobre o apoio do curso à participação em eventos de caráter científico (congressos, encontros etc.), a maioria diz que há apoio: "Sim, mas apenas com dispensa de presença às aulas para os que participam". Em 2008, foram 40,3\%.

Observando-se o mapa 31, entre as que têm menor apoio ou não têm estão as IES do Acre e Piauí. Ressalta-se que, esta participação é fundamental para aquisição de novos conhecimentos, troca de experiências e contato com diferentes tipos de pesquisa. Estas atividades ressignificam o que se aprende em sala de aula.

Entretanto, há também dificuldades dos estudantes participarem pela dificuldade de acesso aos eventos externos a sua IES ou município, o que ocorre devido à distância, custo e tempo disponível. 


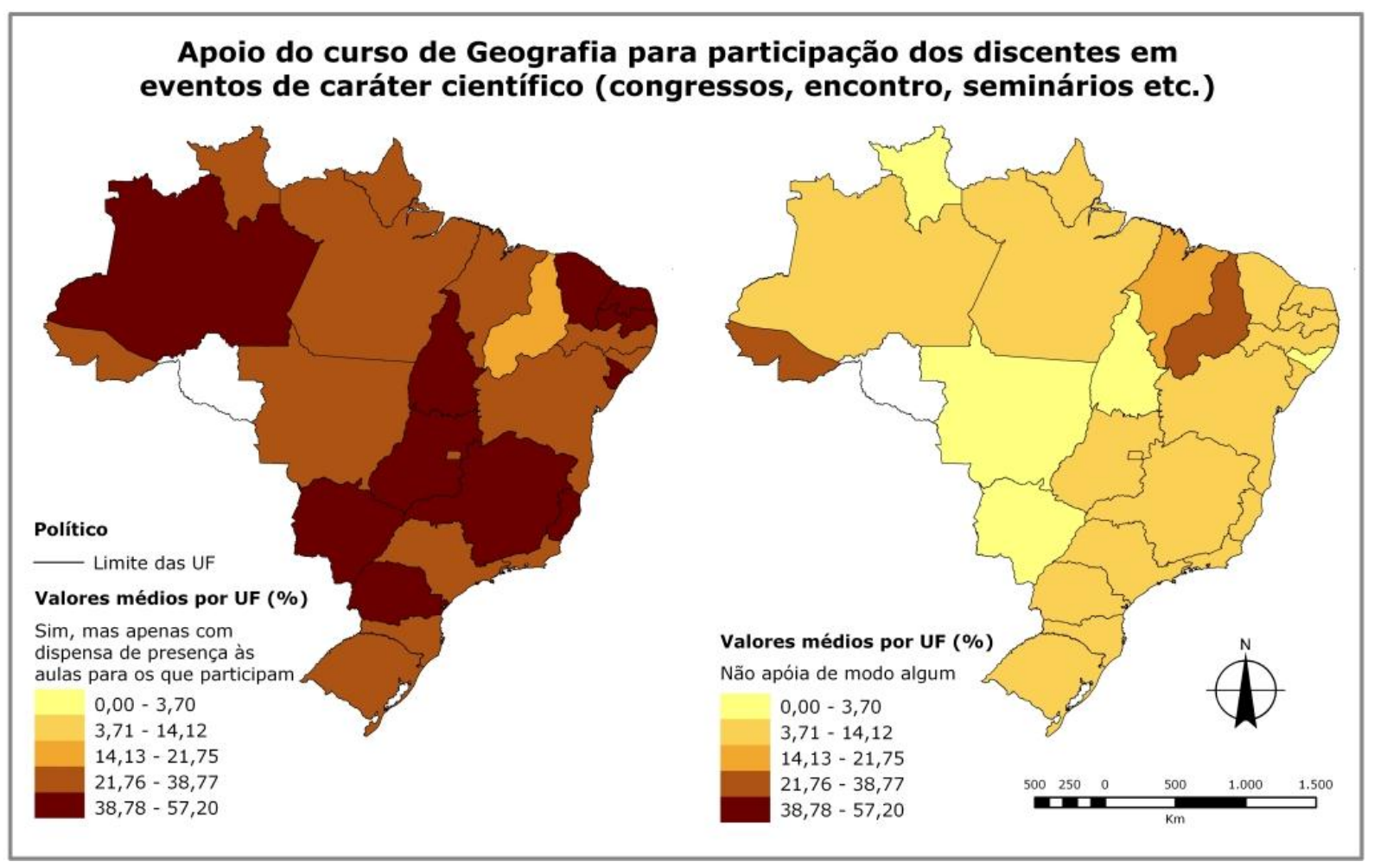

Mapa 31: Fonte Inep, Relatórios de Cursos de Geografia no Enade, por IES, 2008. Elaborado por Vivian Fiori e Mauricio Yamada, 2010.

A difusão dos eventos sofre, portanto, inúmeras mediações, que são organizacionais, territoriais, chegando mesmo a criarem-se algumas hierarquizações. Assim, por exemplo, embora se reconheça a importância da Associação dos Geógrafos Brasileiros (AGB) na difusão de conhecimento geográfico no Brasil, há relação com as características espaciais dos lugares que dificultam o acesso aos eventos promovidas pela AGB.

Dessa forma, há concentrações do conhecimento produzido. Produzem-se centralidades de produção geográfica no território nacional, mas as distâncias aqui têm relação com o acesso, desequilíbrio e escassez, não dizendo respeito somente às distâncias geométricas e sim à "extensão" relativa à rede e sistema de relações existentes (SILVEIRA, 2006).

Assim, o acesso de seus docentes e discentes dos cursos de Geografia ao que é produzido na Geografia nacional e internacional, acesso às publicações e aos eventos geográficos (encontros, congressos etc.) ocorrem de forma bastante desigual. Há um conjunto de 
possibilidades de cada período, de escolhas, nem sempre engendradas dentro da liberdade e necessidade.

Em síntese, há que se verificar se a IES dispõe de biblioteca, de acervo atualizado e diversificado; de professores com tempo disponível para orientar pesquisas, apoiar e orientar trabalhos para participação em eventos geográficos, se no lugar onde está o curso disponibiliza tais condições. Logo, são fatores que se inter-relacionam, com as dimensões das características docente, discente, de infraestrutura e de como os currículos se realizam concretamente na IES e no território.

Igualmente, a pesquisa e a iniciação científica também são fundamentais na formação no Ensino Superior. A concepção do conhecimento científico em qualquer curso de Ensino Superior é importante. Não deveria haver distinção, neste sentido, entre curso de licenciatura e de bacharelado.

Em decorrência do fato de, na maioria das vezes, haver PróReitorias ou Departamentos separados para ensino, pesquisa e extensão, dificulta-se, ainda mais, a necessária integração curricular. Há disputas de verbas e intencionalidades diversificadas entre estes setores e agentes, que nem sempre vão ao encontro dos interesses dos cursos. Tal situação é comum em todos os tipos de IES e por todo o território brasileiro.

Segundo Guilherme de Humboldt, considerado um dos formuladores da ideia da Universidade Moderna ${ }^{106}$, no início do século XIX, havia uma distinção entre Academia e Universidade. A Academia era comum aos pesquisadores e cientistas, e a Universidade era pensada como espaço para ensino e transmissão de conhecimento.

${ }^{106}$ As Universidades eram na Europa Medieval atreladas ao ensino religioso. A transição da universidade tradicional para a moderna foi um processo gradual, e, segundo Fausto Castilho (2008), alguns monarcas apoiaram a criação das academias científicas também como forma de sair do reduto da igreja. Assim, tínhamos as academias de ciência e as universidades que conviviam com alguns conflitos em algumas regiões onde o poder da igreja era maior. Segundo o autor, as razões do atraso em termos das Instituições de Ensino Superior no Brasil, não se encontram apenas em nossa colonização portuguesa, mas em toda península ibérica. Cita Antero de Quental que questiona onde estariam no mundo ibérico os grandes cientistas modernos. 
Humboldt, em seu memorando sobre os Estabelecimentos Científicos Superiores (ECS), em Berlim, 1810, diz:

É manifesto que se prejudica a universidade declarando-a destinada somente a ensinar e a difundir a ciência, ao passo que à academia cabe ampliá-la. As ciências foram certamente desenvolvidas tanto pelos docentes de universidade quanto pelos acadêmicos e, na Alemanha, mais pelos primeiros do que pelos segundos, e esses homens conseguiram fazer que suas disciplinas progredissem precisamente pelo seu magistério. Pois a livre exposição oral perante ouvintes, entre os quais há sempre todavia um número significativo de inteligências que pensam por si e que são participantes [...] (HUMBOLDT, 2008, p. 179).

A ideia de que a Universidade deveria ser o lugar também para a construção de novos conhecimentos científicos e não apenas de transmissão de conhecimentos já existentes parece ser ainda uma problemática atual.

Primeiramente, ao longo dos séculos XIX e XX, a concepção do acadêmico separado da Universidade vai se perdendo, em meio a uma compreensão da Universidade como espaço para ciência.

Por outro lado, o conceito dado à Universidade no Brasil, expresso na própria legislação brasileira, distingue-a de outras formas de IES, exatamente pela inserção da pesquisa, não dando conta de resolver certas situações peculiares. Primeiramente, o mesmo estado avaliador, que considera a pesquisa fundamental, não financia pesquisa nas áreas de humanas como o faz em outras áreas. Aliás, dificilmente se pensa no professor de Geografia como pesquisador.

Além disso, há disputas por verbas entre diferentes IES e entre cursos, havendo deficiência nas condições da formação docente, do discente e da infraestutura, como se mostrou anteriormente, que compromete a pesquisa.

Ao serem indagados sobre se "seu curso oferece, além das atividades teóricas e práticas, o programa de iniciação científica", os estudantes responderam "Sim, com aproveitamento regulamentar de conhecimentos para a integralização curricular": 41,6\% em 2003; 42,1\% em 2005 e 47,7\% em 2008. 
Da mesma forma como se constatou nos questionamentos sobre extensão, a maioria diz que não participou do programa de iniciação científica. Em 2003, os que informaram não participar do Programa de Iniciação Científica foram 30\%, principalmente das IES federais $(40,6 \%)$ e das Universidades (33,2\%). Em 2008, foram 36,4\%.

Em relação à extensão, só mais recentemente foi sendo institucionalizada pelas IES. Embora já existisse em legislações antigas, como o Decreto-Lei n 19851/1931 - o qual citava que, na vida social universitária, a extensão seria elemento fundamental, a visão de extensão quase sempre estava associada ao assistencialismo e à prestação de serviços mediante cursos e ações comunitárias.

No período dos governos militares (1964-1985), a concepção de prestação de serviços foi ampliada, em princípio com a participação de discentes no Projeto Rondon, a partir do qual estudantes desenvolviam atividades de prestação de serviços, especialmente na área de saúde, em comunidades pobres, principalmente na Amazônia e, depois, por meio dos campi avançados.

A ideia de "campus avançado" foi introduzida pelos governos militares como parte da política de integração nacional e teve a região da Amazônia como cenário dessa criação, baseando-se em outras experiências comuns na Europa e EUA.

No caso do Brasil, principalmente as IES federais do Centro-Sul foram cooptadas na criação destes campi avançados; assim em 1974, já havia vinte e dois instalados.

Conforme explicita Ana Luiza Lima Sousa em seu livro sobre a história da extensão brasileira,

A Universidade, ao se integrar ao Projeto Rondon, deixavase servir como instrumento ideológico para repassar a nova ordem política proposta, e as atividades de Extensão eram meros instrumentos para reforçar os Planos Governamentais. [...] proporcionava às IES a realização de suas atividades de Extensão, desde que não fosse criado nenhum tipo de conflito com as propostas do Projeto (SOUSA, 2000, p. 93). 
Dessa forma, quando surgiram os primeiros campi avançados em 1969, houve integração com o Projeto Rondon, que até então estava mais vinculado aos discentes do que à participação formal das IES, assim como era uma ação produzida no Ministério do Interior e não da Educação.

Apesar da cooptação do Estado, da verticalização da concepção política da extensão neste período, as experiências vividas por docentes e discentes possibilitaram a aquisição de conhecimento dos participantes de parte da realidade nacional, ainda que, em parte, houvesse um cunho assistencialista ou centrado na visão da produção do conhecimento com caráter unilateral da IES, para a comunidade, que era vista como receptáculo de conhecimento e informações.

Mais recentemente, as mudanças introduzidas pela abertura na política brasileira e nas novas legislações na educação, houve maior institucionalização das atividades de extensão, com a participação de um novo agente, criado em 1987, o Fórum de Pró-Reitores de Extensão (FORPROEX) das IES públicas.

Este fórum formulou documentos, como o Plano Nacional de Extensão, que versa sobre a concepção e a operacionalização das atividades de extensão - caso da criação do Programa Institucional de Bolsas de Extensão - que mediante a avaliação das IES e dos cursos pelo governo, foi sendo institucionalizado pelas IES em todo o país.

Apesar disso, geralmente, no currículo dos cursos, as atividades de extensão ficam relegadas ao último plano, sendo vistas, muitas vezes, como uma atividade com pouco valor científico.

A LBDEN no 9394 (BRASIL, 1996b), no inciso VII do artigo 43, estabelece que o Ensino Superior deve "[...] promover a extensão, aberta à participação da população, visando à difusão das conquistas e benefícios resultantes da criação cultural e da pesquisa científica e tecnológica geradas na instituição".

Dá-se maior destaque na avaliação dos cursos à produção dita científica, que resulte na publicação de artigos, livros etc. Não se valoriza 
a extensão, como se não produzisse conhecimento, só uma prática sem reflexão.

Quando indagados sobre se "sua instituição oferece programa de extensão", gráfico 30, a maioria informou "sim, com aproveitamento regulamentar de conhecimentos para a integralização curricular". Essa média subiu de $34,8 \%$, em 2003 , para $45,5 \%$, em 2008 , mas os que não sabem informar ou dizem que a IES não oferece somam 32,5\%. É comum os estudantes não terem claro a que se referem às atividades de extensão.

Em relação à participação dos estudantes em programas comunitários, se atuaram ou não (gráfico 31) a maioria respondeu, em 2008, "sim, em algumas disciplinas" (30,5\%), mas os que responderam que o curso não oferece/ofereceu tal possibilidade foram $29,5 \%$.

Considerando-se o questionamento sobre qual a contribuição da extensão na sua formação, conforme Apêndice $G$, a maioria respondeu que não participou deste tipo de programa (33,7\%, em 2003), principalmente alunos das IES federais $(42,6 \%)$ e das Universidades $(37,3 \%)$; em 2008 , foram $36,4 \%$.

Interessante observar que apesar das políticas específicas das IES federais sobre extensão, nestas está a maioria dos que responderam que não participou deste tipo de programa.

O próprio documento da Política Nacional de Extensão, da Rede Nacional de Extensão (RENEX) das IES públicas e do FORPROEX, de maio de 2012, chega a esta conclusão:

O mesmo descompasso é verificado quanto à inserção de ações extensionistas nos planos de ascensão funcional e nos critérios de pontuação em concursos e à consideração dessas atividades na alocação de vagas docentes. Nesses aspectos, também em algumas Universidades ou departamentos, o preceito constitucional e a legislação referida à Extensão Universitária não têm tido qualquer efeito sobre a vida acadêmica (FORPROEX, 2012, p. 14). 


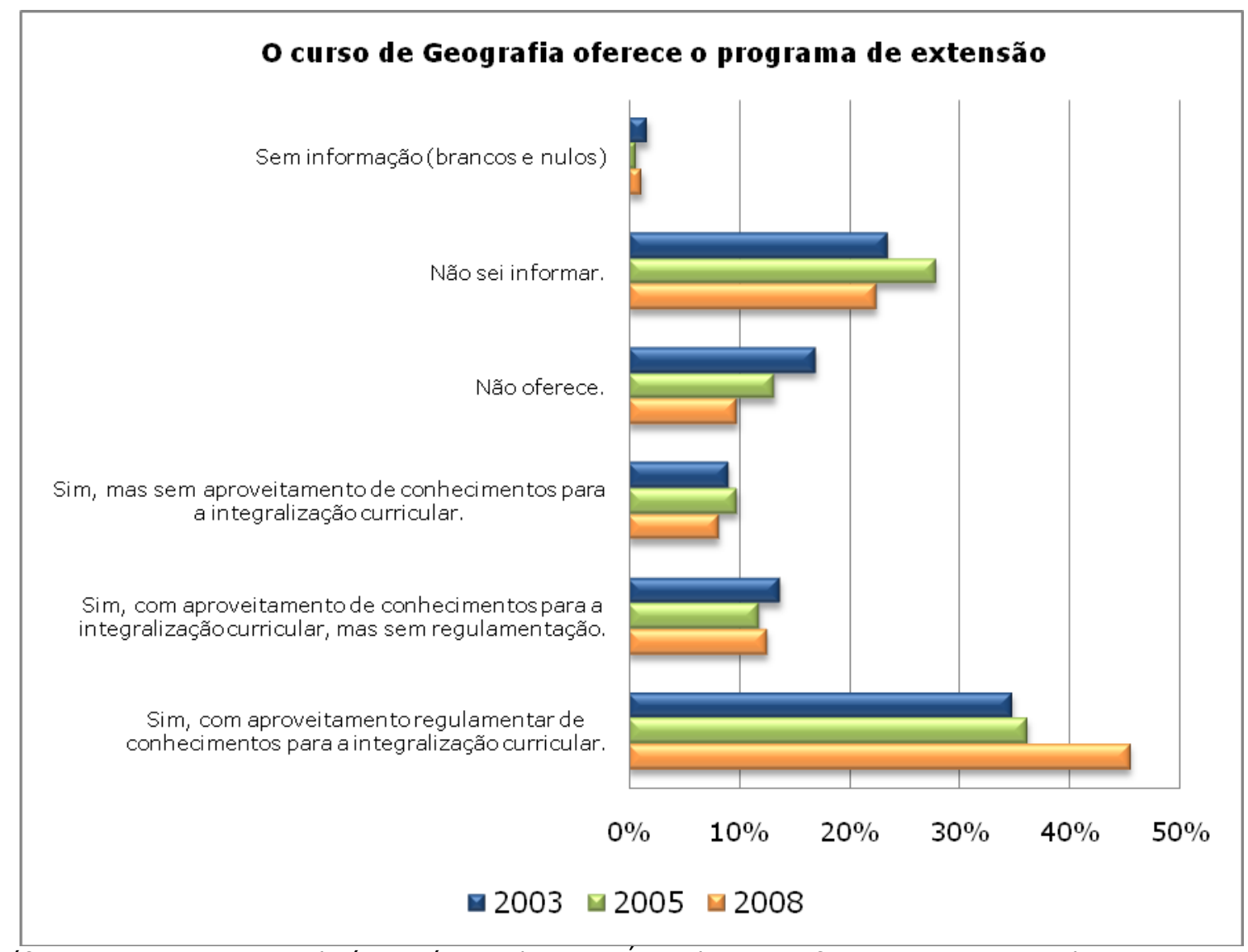

Gráfico 30- Fonte: Inep, Relatórios Sínteses/Cursos, Área de Geografia, ENC 2003 e Enades 2005 e 2008. Dados organizados por Vivian Fiori, 2009.

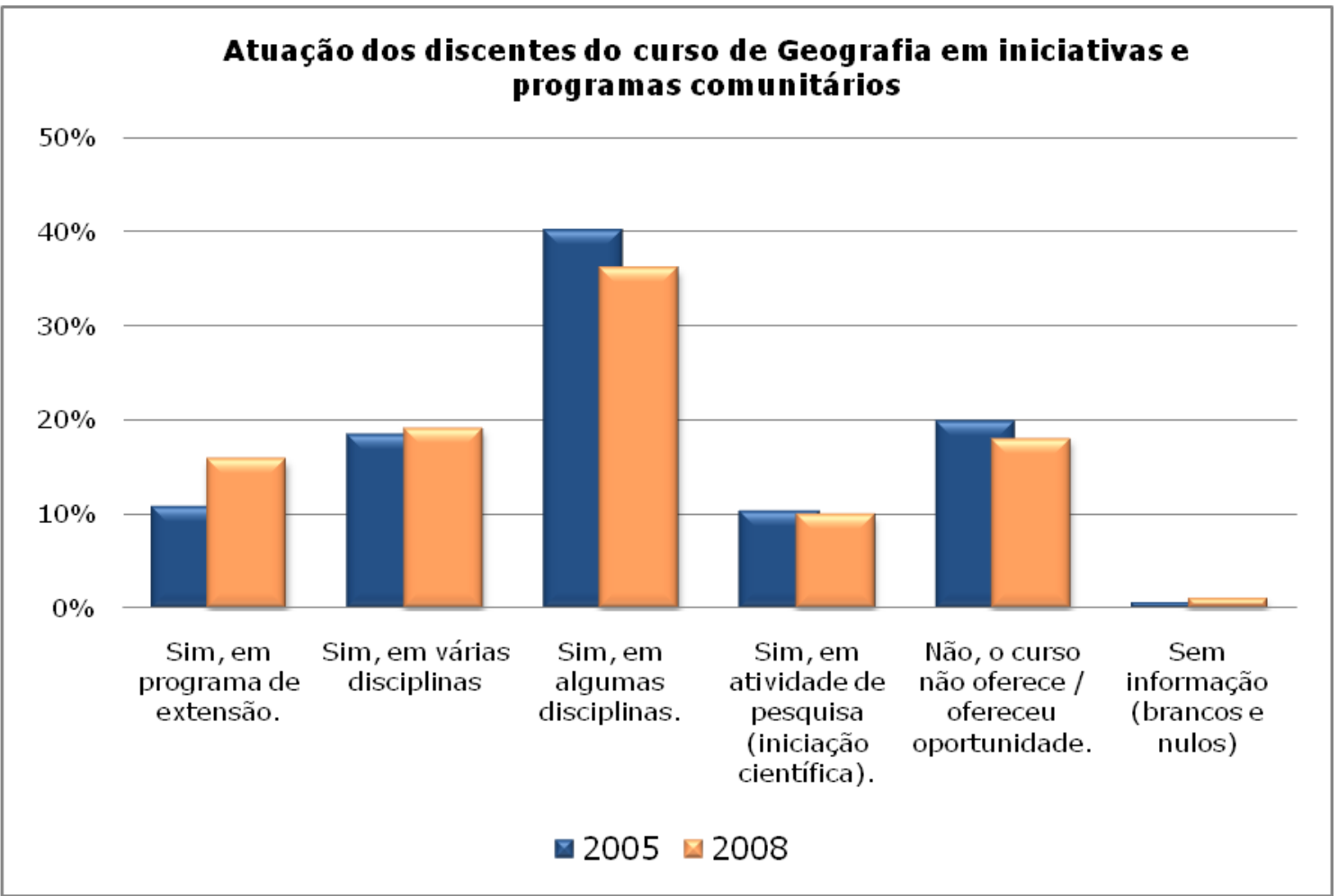

Gráfico 31- Fonte: Inep, Relatórios Sínteses/Cursos, Área de Geografia, ENC 2003 e Enades 2005 e 2008. Dados organizados por Vivian Fiori, 2009. 
A extensão comunitária, por exemplo, propicia vivências práticas múltiplas, nas quais a relação entre teoria e prática se estabelecem no cotidiano da participação em projetos. Para isso, é necessário que os docentes disponham de tempo remunerado para a participação e/ou elaboração de projetos, cursos e eventos de extensão, assim como também é preciso um currículo mais integrado em que efetivamente se dê a articulação entre ensino, pesquisa e extensão.

Observa-se que os que responderam que não participaram dos Programas de Iniciação Científica e de Extensão, conforme demonstra os mapas 32 e 33, estão em quase todas as UFs.

No caso da extensão, Bahia, Mato Grosso, Mato Grosso do Sul, Piauí, Ceará, Paraíba, Sergipe, Alagoas e Paraná são as UFs com pouca participação em atividades de extensão.

Tocantins aparece novamente como o estado cuja participação foi menor em todo o território nacional, tanto em extensão quanto em iniciação científica, assim como o Amapá, situações que serão melhor explicitadas na seção 5 .

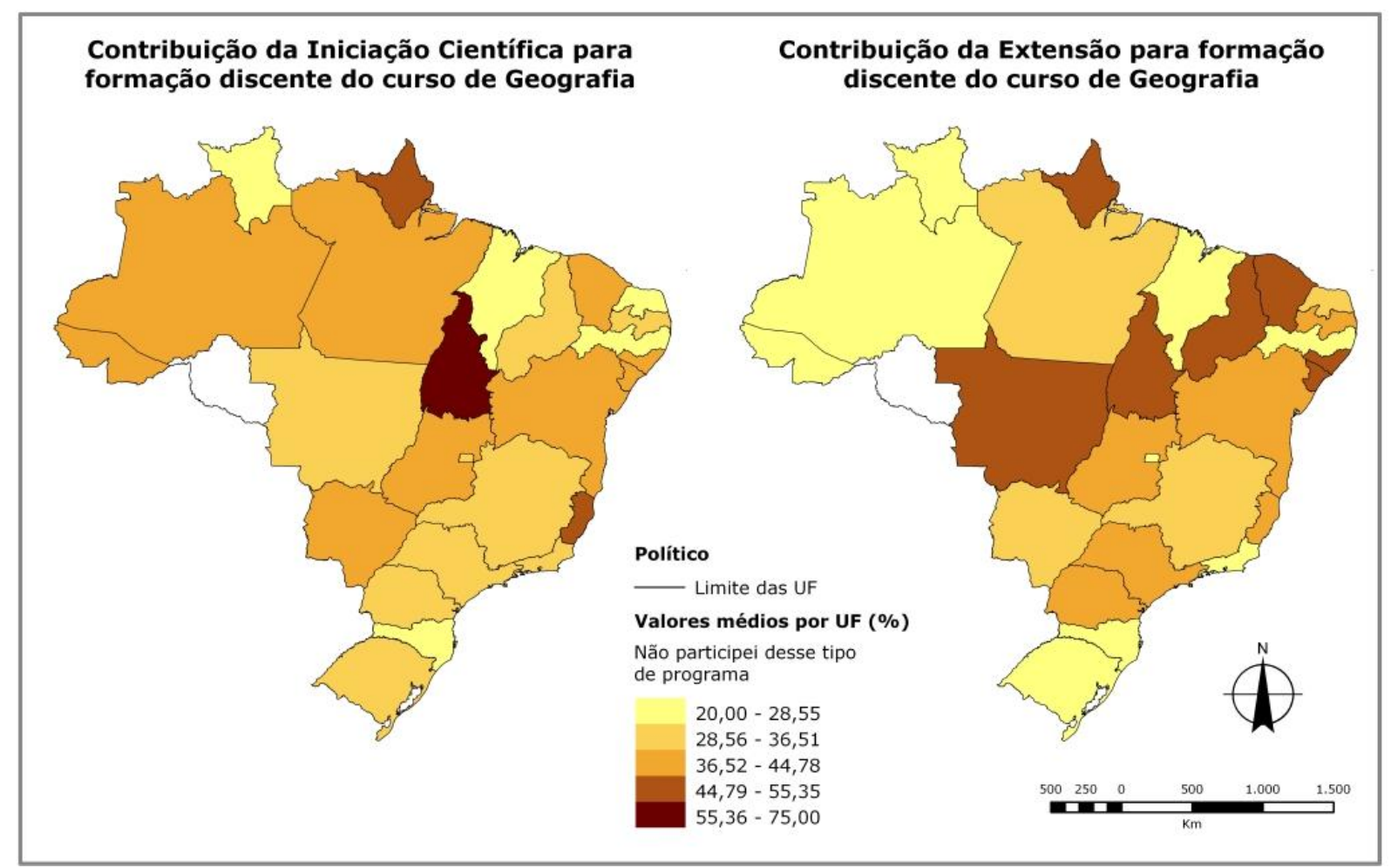

Mapa 32-33: Fonte Inep, Relatórios de Cursos de Geografia no Enade, por IES, 2008.

Elaborado por Vivian Fiori e Mauricio Yamada, 2010. 
Assim, a falta de articulação entre ensino, pesquisa e extensão não é apenas de cunho prático, mas também teórico à medida que a concepção que se tem de ensino como reprodutor do conhecimento está no cerne desse problema.

Cabem aqui alguns questionamentos. Ao fazer extensão não se faz pesquisa? Extensão é só prática? E a ideia de prática também está desconectada da teoria? $E$, no ensino, também não se faz pesquisa? A pesquisa e a extensão não deveriam ser inerentes ao ensino?

A concepção, nesta tese, é que a pesquisa e a extensão são inerentes e indissociáveis ao processo de ensino-aprendizagem. E, portanto, deveriam estar associadas a todos os elementos curriculares dos cursos de licenciatura em Geografia, podendo ser definidos como elementos opcionais os casos de iniciação científica e de projetos de extensão que requeiram maior aporte de verbas.

O termo "opcionais", neste caso, não se refere à opção de ter ou não programas de iniciação científica e extensão, mas da opção do estudante de participar ou não, considerando-se as normas existentes.

No caso da extensão, além dos Programas de Extensão, os quais mediante elaboração de projetos, que, se aprovados terão recursos para o desenvolvimento das atividades de extensão, há possibilidades de criação de projetos interdisciplinares no curso, tanto com a criação de uma disciplina que integraria este projeto, com projetos que sejam compartilhados por diversas disciplinas.

De um lado, é fundamental reconhecer, na extensão, uma possibilidade de práxis educativa, na qual a interação entre teoria e prática se dá, concomitantemente, ao processo do fazer a atividade.

A concepção equivocada de que a extensão é algo mais do que o ensino, uma "extensão" da sala de aula, ou seja, sala de aula é ensino e extensão é algo fora, a mais, traz uma crença de que esta atividade é só para alguns, quando, na verdade, deveria ser para todos que cursam o Ensino Superior. 
Não deve ser descartado, neste caso, que, para além da participação de todos os alunos do curso, ao menos, em algum semestre, possa haver também projetos com recursos externos que possibilitem a extensão e pesquisa para apenas alguns discentes.

Há, pois, uma psicosfera, uma crença, um hábito, uma tradição, de se pensar extensão e pesquisa separadas do ensino, quando, na verdade, tudo deveria ser considerado inerente ao ensino. Outro equívoco é a concepção de que, no ensino, basta reproduzir conhecimentos já existentes. Neste sentido, a inserção de monografias, sobretudo com o trabalho de conclusão de curso como componente curricular obrigatório, é fundamental para os cursos de licenciatura.

Para isso, a finalidade do curso é imprescindível, devendo ser explicitada nos documentos e também vivida no cotidiano das atividades curriculares.

A formação de professores de Geografia requer, tanto quanto a do bacharelado, que exista pesquisa, assim como atividades em laboratório, teorias etc. Ao entrevistar docentes e discentes de alguns cursos, ficou explicita a ideia de que o bacharelado tem de ter laboratório, e a licenciatura requer menos pesquisa e infraestrutura.

Esta tradição, que vem de longe na Geografia brasileira precisa ser repensada. Sendo assim, não basta mudar apenas disciplinas da matriz curricular, mas pensar a concepção, a finalidade do curso que se tem.

Para isso ocorrer, é necessário corpo docente qualificado, com tempo disponível para desenvolver atividades, atrelando pesquisa e extensão ao ensino, com investimentos maiores na educação, nos docentes e na infraestrutura dos cursos.

Fundamental também é que o planejamento das atividades do curso seja uma possibilidade de troca entre docentes e que o currículo seja pensado de uma forma mais integrada, com atividades conjuntas.

O problema são as experiências dos docentes enquanto alunos do Ensino Superior em que todas as dicotomias geralmente estavam 
expressas em currículos fragmentados, o que acabam reproduzindo na condição de docentes.

A licenciatura ainda tem certa esquizofrenia de ter de pensar o conhecimento produzido e reproduzido no Ensino Superior e sua finalidade no Ensino Escolar.

A crença persistente de que só o Ensino Superior tem produção de conhecimento, sobretudo no bacharelado, desconsidera o fato de que a reflexão sobre a interação do Ensino Superior e do conhecimento geográfico, que se produz na mediação com o Ensino Escolar, também é produção do conhecimento, não uma simples transposição.

Seria utopia pensar em extensão e pesquisa de ponta nas quais participassem todos os discentes e docentes considerando-se a realidade social e espacial no Brasil. No entanto, fazer pesquisa, produzir monografias, realizar pesquisas de campo e em laboratórios, participar de eventos geográficos e educacionais, participar de projetos comunitários são fundamentais para uma boa formação de professores.

Logo, esta condição não deve ser vista como algo a mais, mas deve ser inerente ao currículo de todos os cursos de Geografia, de uma forma integrada, e não fragmentada e pontual como vem ocorrendo.

Para entender melhor como estas dimensões e elementos se imbricam, na próxima seção, haverá a análise de alguns cursos mediante a abordagem da situação. 


\section{ANÁlise de SITUAÇÃo dOS CURSOS DE LICENCIATURA EM GEOGRAFIA NO BRASIL}

Após analisar-se o processo de existência dos cursos de Geografia, principalmente na mediação com a dinâmica do território nacional, nas dimensões das características docente, discente e de elementos curriculares, tendo, portanto, um panorama de tais cursos nestas dimensões e dos diversos elementos e variáveis que os compõem, buscase, nesta seção, enfatizar algumas situações existentes no território brasileiro em relação às licenciaturas.

Nas seções anteriores, por uma questão de recurso analítico, fragmentou-se a análise destas dimensões, mas considera-se que tais dimensões e seus elementos não devem ser entendidos na relação causa e efeito, tampouco de uma forma separada, pois constituem-se em elementos integrados dos cursos.

A análise de situação considera as ideias desenvolvidas por Maria Laura Silveira (1999), segundo a qual é fundamental analisá-la levando em conta o contexto, os eventos e o conjunto de elementos ou variáveis analisadas no lugar. Portanto, a situação tem relação com o tempo e espaço geográfico, com a periodização e arranjo espacial na qual ocorre.

A situação tem um tempo espacial, um arranjo que leva a uma peculiaridade de um processo que, em princípio, é universal, mas deve ser considerada num processo histórico, num tempo e em um lugar. Logo, a situação é uma peculiaridade, uma singularidade na indissociável relação espaço e tempo. Conforme diz Silveira:

A situação decorreria de um conjunto de forças, isto é, de um conjunto de eventos geograficizados, porque tornados materialidade e norma. Muda, paralelamente, o valor dos lugares porque muda a situação, criando uma nova geografia. Assim, ao longo do tempo, os eventos constroem situações geográficas que podem ser demarcadas em períodos e analisadas na sua coerência (SILVEIRA, 1999, p. 22). 
Analisar a situação pressupõe entendê-la como um recorte espacial, não apenas no sentido de extensão, limite, escala e localização, tradicionalmente usado, mas considerando o espaço como um sistema de ações e de objetos, buscando reconstituir a totalidade do espaço geográfico em movimento, verificando os arranjos existentes.

Dessa forma, considera-se que os eventos pós 1996, tais como a LDBEN no 9394, a legislação própria para as licenciaturas (2001) e o sistema de avaliação de cursos de Geografia, são eventos nacionais, mas se realizam concretamente no lugar, com seus elementos e variáveis que, em conjunto, formam arranjos espaciais singulares que podem ser apreendidos por uma análise de situação.

Os elementos e variáveis escolhidas podem ser os mesmos para os diversos lugares, mas modificam-se a cada situação, num movimento dialético. Como diz Milton Santos (2008b, p. 21), "[...] cada lugar atribui a cada elemento constituinte do espaço um valor particular". Assim, os elementos e as variáveis podem ser os mesmos, mas seu valor varia no tempo e no espaço.

Sejam como for, elementos e variáveis não têm sentido a priori, senão no contexto no qual ocorrem e no conjunto integrado no qual existem. Portanto, há relação com o lugar onde acontecem e com o tempo social no qual estão inseridos.

Há, portanto, tempos espaciais distintos dos cursos. Por tempo espacial, adota-se o conceito de Milton Santos (2008b, p. 116), segundo o qual "[...] cada lugar é o resultado da combinação espacialmente seletivas de variáveis diferentemente datadas [...] e a combinação particular de variáveis diversamente datadas constitui o tempo espacial próprio a determinado lugar".

Logo, é necessário entender esta combinação e não só a medida simples de uma variável, pois a informação estatística, só contém valor à medida que for analisada no contexto e no lugar onde está inserido. Assim, destaca-se, como exemplo, a avaliação dos discentes sobre "qual é contribuição do curso para sua formação" (mapa 34) as respostas foram 
as seguintes, em 2008: boa para $49,2 \%$; muito boa para $31 \%$ e regular para $14,2 \%$ dos discentes. Dos que avaliam a contribuição como "muito boa", estão principalmente os cursos de São Paulo, Rio Grande do Sul, Roraima, Maranhão, Piauí e Rio de Janeiro. Verifica-se que, mesmo com problemas e algumas deficiências, os alunos tendem a avaliar a contribuição do curso de forma positiva.

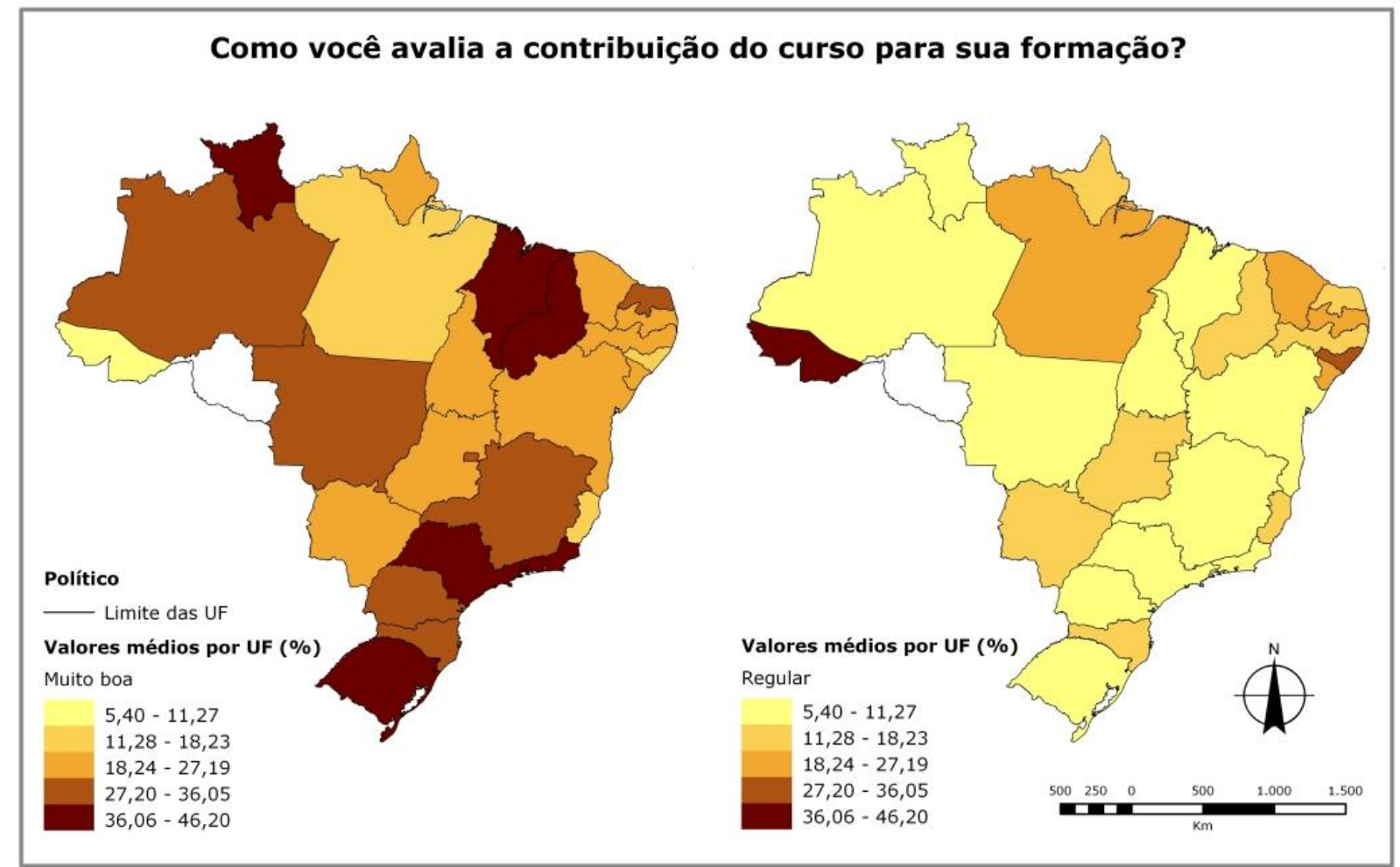

Mapa 34: Fonte Inep, Relatórios de Cursos de Geografia no Enade, por IES, 2008.

Elaborado por Maurício Yamada e Vivian Fiori, 2010.

Este item de avaliação teve resposta "muito boa" no Maranhão, Piauí e Roraima, respectivamente da região Nordeste e da Amazônia brasileira. Trata-se de uma situação diferenciada da que ocorre em São Paulo e Rio Grande do Sul.

No primeiro grupo, estão os lugares em que os cursos chegaram recentemente, geralmente onde se encontram estudantes de baixa renda, formados em IES públicas, principalmente estaduais, nos quais um curso superior tem um valor distinto de outros lugares do Brasil, porque são lugares onde a disponibilidade de cursos de Ensino Superior é pequena.

Portanto, não basta considerar as políticas do Ensino Superior em sua universalidade, é fundamental que sejam consideradas as mediações dos tipos de IES e do território na análise de cursos. 
Igualmente, não bastam comparações, pois nem sempre o mesmo valor das variáveis tem os mesmos significados para os diferentes lugares.

Assim, apesar dos problemas verificados nos cursos, por exemplo, do Maranhão e do Piauí, eles produzem uma existência que leva os estudantes a considerar sua contribuição como "muito boa", porque o que é um novo curso, num contexto diferente da Região Concentrada, que chega a num novo território, com peculiaridades sociais e econômicas, ou seja, produz uma situação específica, não cabendo assim uma simples comparação pela métrica das variáveis.

Outro exemplo refere-se às situações vividas pelas IES privadas em lugares de grande densidade de sistemas técnicos, de produção e eventos acadêmicos da Geografia, de concentração de IES e de diversidade de cursos como é comum nas metrópoles da Região Concentrada.

Em princípio, considerando-se como exemplo a dimensão discente, há maior possibilidade nestes territórios de escolha pelo estudante, já que há proximidade métrica com vários tipos de IES e de cursos de Geografia. Contudo, a extensão, aqui vista não apenas como distância no sentido geométrico, mas também existencial, reduz estas possibilidades de acesso.

Ao entrevistar duas professoras de Geografia, recém formadas em licenciatura em cursos de IES privadas do município de São Paulo, uma Universidade localizada na Zona Sul da cidade, outra situada na Zona Leste, verifica-se que a escolha da IES e do curso é mediada pela proximidade da IES, pelo valor da mensalidade e pelas condições de formação anterior, que dificultam o acesso ao Ensino Superior público que é mais seletivo em São Paulo.

A proximidade da IES se dá pela facilidade de transporte, sobretudo porque são alunos trabalhadores, geralmente se movimentam diariamente dos extremos da Zona Sul e Leste de São Paulo para trabalharem em outras regiões, e voltam para suas casas, preferindo, portanto, estudar em IES próximas de suas residências. 
Outro elemento da análise que pode ser considerado neste caso refere-se à participação em eventos externos à própria IES, que, segundo as duas ex-estudantes, nunca ocorreu em suas turmas. Uma das professoras, formada na turma de 2009-2011, disse: "De Encontro e Congressos não participávamos; fora nunca íamos, só dos Encontros realizados na própria Universidade". A outra professora, formada em outra IES, da turma 2007-2010, disse:

Eu senti falta no curso de ir a encontros de Geografia, de fazer pesquisa. Fazíamos trabalhos bem básicos, quase de Ensino Médio, copiados, porque a turma que vai estudar lá é bem defasada em relação à leitura e redação de texto. Por isso tinha uma disciplina de Língua Portuguesa, que ensinava a fazer resumos, dissertação etc. Acho que uma disciplina só não resolve. Houve um professor de Filosofia, que usou um texto denso e eu não entendia nada. Ele dizia para continuarmos lendo que um dia íamos entender. Mas, no geral não solicitavam isso, pois sabiam que os alunos tinham dificuldades. Não nos incentivam a fazer pesquisa, não tínhamos nem TCC no curso de licenciatura.

A dificuldade de leitura de textos acadêmicos e as deficiências de formação na Educação Básica dificultam o acesso aos cursos mais seletivos, assim como a própria apropriação das atividades acadêmicas em seus cursos, com leituras diversificadas, elaboração de artigos para participação em Encontros de Geografia, elaboração de texto próprio, segundo as normas acadêmicas.

Esta situação não é uma determinação intrínseca a todas as IES privadas, mas ocorre em maior medida nelas, já que o ingresso a estes cursos geralmente é menos seletivo.

Tampouco significa que todos os estudantes que ingressam nestes cursos apresentem as mesmas dificuldades já apontadas, mas de fato há um maior número de estudantes com tais dificuldades nestas IES em São Paulo.

Como professora do curso de Geografia pela Universidade Cruzeiro do Sul, em São Paulo, tive experiências que corroboram esta situação discutida sobre a seleção de alunos. Esta IES, embora privada, tem um curso de Geografia matutino, gratuito, com 30 vagas para licenciatura, 
desde 2003; a partir de 2007, também, o bacharelado. Seu processo seletivo requer que o estudante tenha um aproveitamento de $50 \%$ no vestibular, cuja prova é composta de questões de múltipla escolha e de uma redação.

Verificou-se desde 2003, que em vários anos, sobraram vagas em virtude da dificuldade de ingresso, sobretudo pelas baixas notas de redação. Ou seja, existe a possibilidade de cursar gratuitamente Geografia em São Paulo, contudo sobram vagas, na cidade considerada a maior centralidade econômica, de densidade de Ensino Superior do Brasil, devido à dificuldade em elaborar uma redação.

Como exemplo, houve, em 2008, 400 candidatos e só passaram cinco, situação que levou a Instituição a recorrer a mais processos seletivos.

Outra peculiaridade neste caso é que os alunos do curso, em função da gratuidade, não são apenas da região do entorno da instituição, embora, em sua maioria, venham de escolas públicas e sejam alunos trabalhadores.

Logo, não é possível definir as condições de um curso de uma IES antes de entendê-las em seu contexto e situação no espaço e no tempo. Contudo, não se pode confundir a análise de situação com estudo de caso, já que a situação surge do contexto, mediante uma análise de elementos e variáveis já destacados dos cursos de licenciatura em Geografia no território brasileiro.

Esta análise de algumas situações se dá em recortes espaciais do presente, mas contêm cristalizações do passado, assim como estão sempre em movimento na história e no território.

Levando em conta essas premissas, considera-se a análise das seguintes situações dos cursos de licenciatura no Brasil, a saber:

- Nos cursos de IES estaduais com recente processo de interiorização no Maranhão e no Piauí;

- Nas IES municipais do interior de Pernambuco; 
- Na Amazônia e seu processo de interiorização em IES públicas;

- Nos cursos de Educação a Distância (EAD).

Estas escolhas basearam-se na analise dos cursos nas seções anteriores e serão pormenorizadas, enfatizando-se as situações dos cursos que se interiorizaram, porque eles possuem os arranjos mais peculiaridades.

\subsection{Os cursos em IES municipais do interior de Pernambuco}

A escolha para análise dos cursos de licenciatura no interior de Pernambuco se deu devido ao fato da maioria ser formada por instituições municipais, conforme se verifica no mapa 11 (p.135), da seção 3.

São mantidas por pessoa jurídica de direito público municipal, ou seja, são autarquias municipais e constituem-se em uma peculiaridade já que apesar de públicas, não são gratuitas. Além disso, deve-se ao fato de Pernambuco ser o único estado que concentra IES municipais com cursos de licenciatura em Geografia no Brasil.

Por outro lado, como foi discutido na seção 3, as IES municipais têm as piores avaliações pelo MEC (tabela 3, p. 98), considerando-se o sistema do Exame Nacional de Curso (ENC) em 2003 e Enade (2005 e 2008) e as avaliações institucionais. Embora com ressalvas a tal sistema de avaliação, cabia, então, analisar se havia peculiaridades que as diferenciava das demais.

Numa análise mais ampla, ao verificar as situações existentes em Pernambuco, sobre a existência das IES e da graduação em geral, verifica-se que há uma seletividade espacial dos tipos de IES e cursos com diversas condições de seletividade.

Uma condição é a seletividade temporal-espacial por tipo de curso, pois os mais interiorizados são os relacionados à educação, com formação de professores, depois vieram cursos de outras áreas do conhecimento. 
Esta situação também é comum em outros lugares do Brasil onde há menos densidade econômica, de serviços e de população.

Outra seletividade espacial ocorre em razão do tamanho e porte das cidades; assim, nas cidades de médio porte ou situadas na Região Metropolitana de Recife, há maior diversidade e concentração de cursos, criando um conjunto de possibilidades de escolha para os estudantes, que, no entanto, não se traduzem em possibilidade de acesso a todos interessados, da mesma forma conforme já explicitado sobre a cidade de São Paulo.

Há também uma seletividade por tipo de IES, já que as municipais estão presentes em cidades de pequeno porte; as privadas, principalmente nas de médio porte ou situadas na Região Metropolitana de Recife, e as Federais, especificamente na capital.

No caso específico dos cursos de licenciatura em Geografia há uma configuração territorial que diferencia os municípios do Sertão e da capital.

Em Recife, há apenas os cursos das IES públicas federais na Universidade Federal de Pernambuco (UFPE) e no Instituto Federal de Pernambuco (IFPE). Recife, que além de capital do estado, configura-se como a metrópole da região Nordeste, possui a maioria dos cursos e IES de Pernambuco, assim como tem maior diversidade de cursos de graduação e pós-graduação, tanto públicos como privados. No entanto, os cursos de licenciatura em Geografia em Recife estão exclusivamente nas federais, assim como mestrado e doutorado há apenas na UFPE.

Nas cidades de porte médio ou situadas na Região Metropolitana, há cursos em IES privadas: na Universidade de Pernambuco (UPE) em Garanhuns, Petrolina e Nazaré da Mata; e em Olinda, na Faculdade de Olinda (FOCCA) e na União de Escolas Superiores da FUNESO (UNESF).

Nas cidades de pequeno porte, há cursos em duas IES privadas recém-criadas e oito em IES municipais, havendo a maior concentração de IES municipais do Brasil, estas situadas no Agreste e no Sertão pernambucano. 
Dessa forma, a seletividade espacial se dá pelo porte da cidade, de sua capacidade de atrair maior número de serviços educacionais de Ensino Superior, cuja variação se dá em razão das condições de renda da população, das funções urbanas e do nível de centralidade de serviços e da economia em geral.

Verificando-se a tabela 6 , observa-se que nas cidades onde há cursos de licenciatura em Geografia pelas IES municipais, o número de IES é pequeno. Geralmente só há uma IES, com pouca diversidade de cursos, e, em sua maioria absoluta, são de formação de professores. Isso se dá em virtude destes municípios serem de pequeno porte, mas possuírem turmas de Educação Básica e, portanto, terem mercado de trabalho para a formação de professores.

\begin{tabular}{|c|l|c|c|}
\hline \multicolumn{1}{|c|}{ Tabela 6- Dados das Cidades com cursos de Licenciatura em Geografia em } \\
IES municipais - Pernambuco (2012)
\end{tabular}

Fonte: Site do E-MEC, 2012. Elaborado por Vivian Fiori, 2012.

Os cursos situam-se em municípios de pequeno porte, com destaque para Serra Talhada, um centro sub-regional, localizado na mesorregião do Sertão Pernambucano, que possui duas IES e o maior número de cursos de Ensino Superior deste grupo de cidades, demonstra a maior centralidade do município em relação às atividades de serviços educacionais de Ensino Superior no Sertão. 
Salgueiro, Serra Talhada, Arcoverde e Belo Jardim estão interligadas pelo eixo rodoviário (BR-232) com Recife, conforme se verifica no mapa 35.

Nestes municípios, os cursos, em sua maioria, eram de Estudos Sociais e, nos anos oitenta foram transformados em licenciatura em Geografia; o único criado recentemente foi o da Faculdade de Ciências Humanas do Sertão Central (FACHUSC), em 2009, no município de Salgueiro.

\section{Cursos de Licenciatura em Geografia em IES públicas Pernambuco}

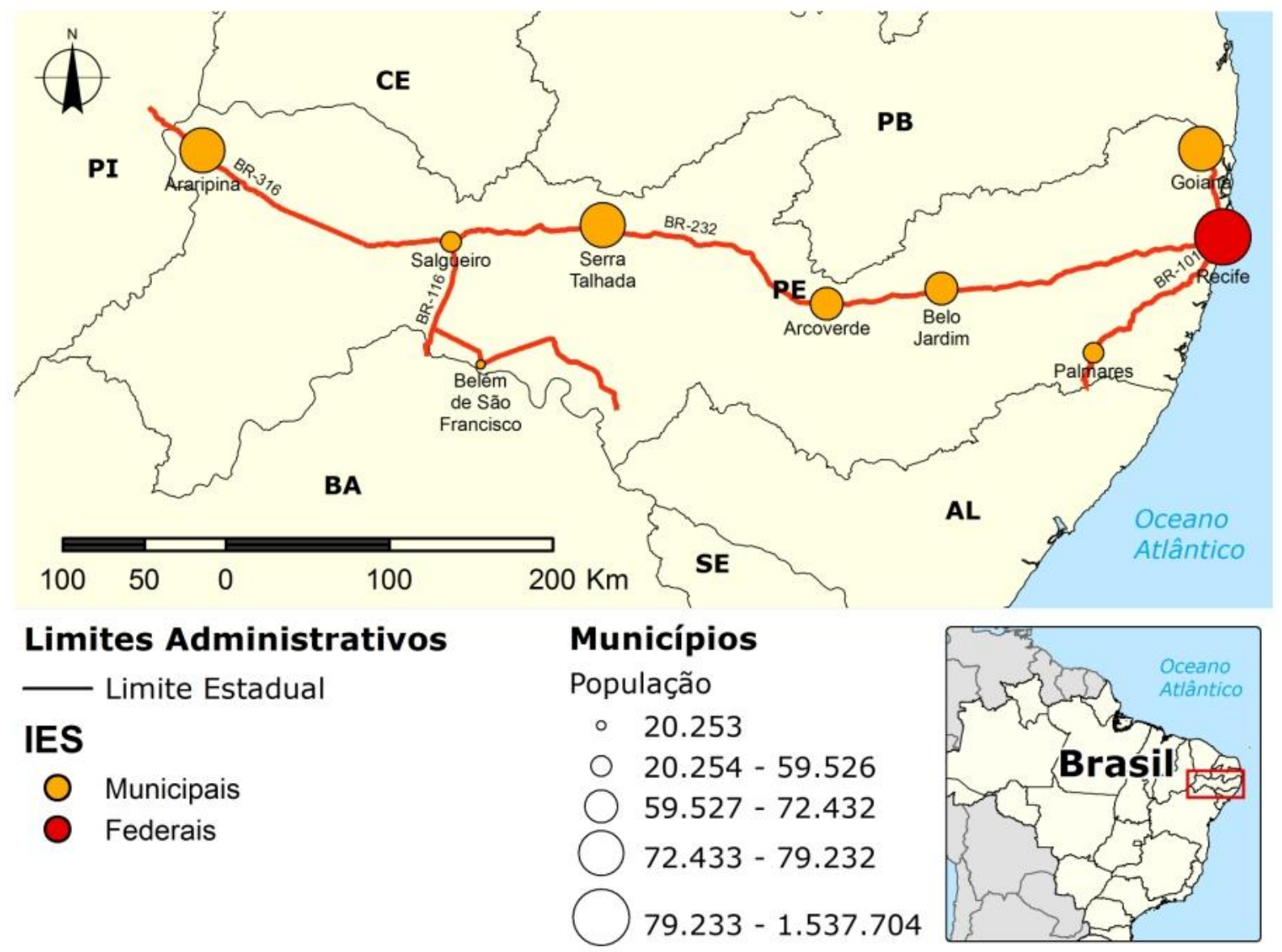

Mapa 35: Fonte: Dados E-MEC, 2012; IBGE, 2010.

Elaborado por Vivian Fiori e Mauricio Yamada, 2012.

Salgueiro apresenta atualmente o maior dinamismo do Sertão Pernambucano, principalmente com a transposição do Rio São Francisco e a construção da ferrovia Transnordestina, cujo ramal central fica neste município. 
Isto tem ampliado a oferta de empregos na cidade e aumentado a renda da população, o que certamente contribuiu para a criação de uma IES privada na cidade em 2002, atualmente com dois cursos: Filosofia e Pedagogia.

Já a FACHUSC, cuja mantenedora é a Autarquia Educacional de Salgueiro, foi criada em 1985. Naquela época, criaram-se os cursos de Pedagogia e Letras, para os quais o mercado de trabalho é maior. Só recentemente, em razão do maior dinamismo econômico, criaram-se outros, como História, Ciências Biológicas e Geografia.

Há, assim, uma seletividade espacial em relação ao tipo de curso, pois os que se descentralizaram primeiro foram os de formação de professores, mas os de maior demanda, como Pedagogia e Letras, primeiramente.

A maioria dos docentes de Geografia destas IES é especialista; os docentes com mestrado e doutorado são raros. Esta situação se dá devido aos baixos salários e ao fato de muitos professores serem horistas, o que, em geral, não atraí mestres e doutores. Também, a distância da capital e o tamanho da cidade não despertam o interesse de professores com pós-graduação stricto sensu.

Como exemplo, cita-se a FACHUSC, onde dos cinco professores específicos de Geografia, em 2012, há um mestre, três especialistas e uma graduada, embora tenha havido concurso em 2010.

Por outro lado, para estes professores fazerem mestrado e voltarem a IES é complicado, porque não há condição formal para se ausentarem da IES enquanto cursam pós-graduação stricto sensu em outras cidades. Neste sentido, a distância da capital ou de outras cidades de outros estados com cursos de pós-graduação torna-se um elemento dificultadora distância pensada do ponto de vista métrico.

Na tabela 7, com dados do Inep, em 2009, havia, nas IES municipais, os docentes dos cursos municipais, poucos mestres, apenas um doutor, e a maioria absoluta de professores era horistas. 
Exceção é a Faculdade de Formação de Professores de Belo Jardim (FABEJA), da cidade de Belo Jardim, no agreste pernambucano, que tem mais docentes mestres, e quatorze em regime de tempo integral sem dedicação exclusiva.

\begin{tabular}{|c|c|c|c|c|c|c|c|}
\hline \multicolumn{6}{|c|}{$\begin{array}{c}\text { Tabela 7- Características dos docentes das licenciaturas em Geografia - } \\
\text { IES Municipais - Pernambuco - 2009 (números absolutos) }\end{array}$} \\
\hline \multirow{2}{*}{ Municípios } & \multicolumn{5}{c|}{ FORMAÇÃo DocENTE } & \multicolumn{2}{c|}{ REGIME DE TRABALHo } \\
\cline { 2 - 8 } & Graduação & $\begin{array}{c}\text { Especia- } \\
\text { lização }\end{array}$ & Mestrado & Doutorado & $\begin{array}{c}\text { Tempo } \\
\text { Integral }\end{array}$ & $\begin{array}{c}\text { Tempo } \\
\text { Parcial }\end{array}$ & Horista \\
\hline Araripina & 0 & 23 & 3 & 0 & 0 & 1 & 25 \\
\hline Arcoverde & 0 & 10 & 5 & 0 & 0 & 0 & 15 \\
\hline $\begin{array}{c}\text { Belém de São } \\
\text { Francisco }\end{array}$ & 0 & 8 & 1 & 0 & 2 & 6 & 1 \\
\hline Belo Jardim & 0 & 9 & 9 & 0 & 14 & 4 & 0 \\
\hline Goiana & 0 & 16 & 5 & 0 & 0 & 0 & 21 \\
\hline Palmares & 0 & 19 & 5 & 1 & 0 & 0 & 25 \\
\hline Salgueiro & 1 & 5 & 1 & 0 & 0 & 0 & 7 \\
\hline $\begin{array}{c}\text { Serra } \\
\text { Talhada }\end{array}$ & 0 & 9 & 1 & 0 & 0 & 0 & 10 \\
\hline
\end{tabular}

Fonte: INEP, 2009. Elaborado por Vivian Fiori, 2012.

Isso demonstra que a situação em si não depende apenas da distância geométrica em relação à capital, mas também das condições da política da própria IES. Então, a extensão pensada do ponto de vista geométrico não é uma determinação em si, mas uma condicionante que pode ser modificada pela ação dos mantenedores das IES.

Observando o Currículo Lattes de alguns docentes destas IES municipais, verifica-se que o movimento no território deles para estudar no Ensino Superior e na pós-graduação ocorre principalmente no próprio estado de Pernambuco, já que a maioria destes professores tem graduação principalmente nas próprias IES municipais, mas se deslocam para fazer pós-graduação, geralmente, em Recife ou numa cidade de porte médio de Pernambuco.

Há também casos de docentes que estudaram na Paraíba e outros no Ceará, na Universidade Regional do Cariri (URCA), que se localiza no sertão do Ceará, em região limítrofe a Pernambuco. Esta condição é mais comum nos municípios de Salgueiro e Araripina, mais próximos do Ceará 
(mapa 35), cuja dinâmica econômica e proximidade com o Sertão de Pernambuco é maior do que com Recife.

A coordenadora do curso de Geografia da FABEJA, em Belo Jardim, cuja instituição tem o maior número de mestres das IES municipais do estado, graduada em Geografia pela Universidade Estadual da Paraíba (UEPB) e mestre em "Manejo de Solo e Água" pela Universidade Federal da Paraíba (UFPB), revela:

Eu sou da Paraíba, mas tem seis anos que moro aqui, passei no concurso da autarquia e ainda estou no estágio probatório. A maioria dos professores é concursado recentemente pela autarquia. Temos um bom quadro, com sessenta e um porcento de mestres e doutores. A maioria fez em Recife, porque existe a facilidade de transporte para Recife todos os dias, mas tem alguns que fizeram ou estão concluindo em João Pessoa (UFPB) por meio de um convênio. Além disso, há um programa do estado de Pernambuco, que destina bolsas para as autarquias, e destas é destinado cinco por cento para capacitação de professores.

Logo, o movimento no território para a formação destes professores se dá principalmente no estado de Pernambuco ou nos estados, cujas cidades estão próximas a Pernambuco. Na maioria dos casos, são cursos de especialização.

A ação das IES como mediadoras neste processo e do próprio governo estadual é fundamental, pois possibilita ampliar a qualificação dos docentes. Assim, esta situação não depende apenas do professor.

É necessário investimento público para que exista acesso à pósgraduação, assim como uma política também da IES que dê condições ao professor de ter uma vida mais estável, que lhe permita utilizar parte de seu tempo para estudar, algo que se torna complicado com professores horistas.

Todos os cursos de licenciaturas em Geografia nestas IES são noturnos, pagos e contam com alunos trabalhadores de baixa renda. Conforme se verifica na tabela 8 , a maioria absoluta destes discentes vive com renda de até três salários mínimos, estudou só em escolas públicas, utiliza raramente a biblioteca e quer ser professor. 


\begin{tabular}{|l|c|c|c|c|}
\hline \multicolumn{5}{|c|}{ Tabela 8 - Características dos discentes dos cursos de Geografia } \\
IES municipais- Pernambuco- 2008 (\%)
\end{tabular}

Fonte: Inep, Relatórios dos cursos de Geografia por IES, Enade, 2008. Elaborado por Vivian Fiori, 2012.

A exceção fica por conta dos discentes da FABEJA que utilizam mais a biblioteca e dos da Faculdade de Formação de Professores de Serra Talhada (FAPOST), em Serra Talhada, que, em sua maioria, não querem ser professores.

Segundo os discentes dos cursos a infraestrutura é um dos problemas dos cursos; falta acervo adequado na biblioteca, laboratórios e espaços adequados para as atividades acadêmicas, cujas condições influenciam no processo de ensino-aprendizagem.

Segundo um coordenador de curso de Geografia da região:

A nossa avaliação é feita pelo Conselho Estadual porque é uma autarquia, nas próximas semanas estamos passando pela avaliação estadual. Estamos revendo o curso, reestruturando ementas e estamos solicitando novas bibliografias básicas. A maior dificuldade é na infraestrutura e na renovação dos laboratórios. Outro problema está na participação dos alunos que deixa a desejar, porque trabalham e só sobra final de semana para estudar o que dificulta muito o processo de ensino-aprendizagem.

A afirmação do coordenador corrobora a ideia de que, geralmente, quando se aproxima a avaliação do curso, modifica-se sua organização, mediante alterações nas ementas e são adquiridos novos títulos para o acervo.

A questão do pequeno uso de biblioteca remete ao uso maior de apostilas e resumos (média de $76,7 \%$ ) nestas IES, tanto porque o acervo da biblioteca é, em geral, bastante incipiente, quanto porque os alunos têm dificuldades na leitura de textos mais densos. Isto contribui para uma formação deficiente em leituras diversificadas. Segundo um coordenador, 
isto ocorre também porque os alunos trabalham e estudam à noite e têm pouco tempo para ler.

Além disso, há também uma resistência de alguns professores em mudar esta forma de seleção do material a ser usado na disciplina, porque assim foram formados. A qualificação de novos professores com mestrado e doutorado provavelmente contribuirá para a mudança desta estratégia de ensino.

Serra Talhada, embora se destaque como um subcentro regional em serviços do Sertão Pernambucano, tem um curso de licenciatura em Geografia, que apresenta alguns problemas, entre eles: infraestrutura inadequada; professores, em sua maioria, horistas (100\%); pouco uso pelos alunos da biblioteca; uso de apostilas e resumos. Provavelmente, esta situação de dificuldade faça com que poucos discentes desejem ser professores $(35,7 \%)$.

Assim, há, na situação das IES municipais de Pernambuco, uma série de condicionantes que criam um arranjo espacial e uma situação peculiar. Por serem públicas, mas pagas, por terem a maioria dos professores sem mestrado e doutorado e contratados como horistas, intensificam-se os problemas que certamente contribuíram para os baixos índices nas avaliações realizadas pelo governo federal, mediante ENCEnade.

Por outro lado, verifica-se, como em São Paulo, menor presença das IES federais, em razão do processo de interiorização ter sido municipal, no lugar de federal ou estadual.

Contudo, as medidas de avaliação são estaduais, assim como os mecanismos de apoio ao docente vêm do governo estadual, pois estes municípios têm ainda um dinamismo econômico menor se comparado à capital e às cidades de médio porte.

Mas, em Salgueiro, esta condição do movimento no território da dinâmica econômica, juntamente com o sistema de circulação de transportes, tem possibilitado uma maior circulação de dinheiro, o que permitiu inclusive a criação de uma IES privada. 
Há necessidade, ainda, de mais investimentos na qualificação docente destas IES e de melhoria na condição de trabalho com a diminuição de professores horistas, como vem ocorrendo com a FABEJA, em Belo Jardim. Isto, por certo, poderá contribuir para a melhoria das condições dos cursos das IES municipais do interior de Pernambuco.

\subsection{As situações dos cursos na Amazônia}

Na Amazônia ${ }^{107}$ há várias peculiaridades em relação aos cursos de licenciatura em Geografia e nas situações existentes devido ao seu processo de interiorização.

Há coexistência de diversas temporalidades na região- do tempo rápido dos grandes empreendimentos minerais e do agronegócio, ao tempo social mais lento, os quais está submetida a maior parte da região.

Ao mesmo tempo, há o transporte mais rápido, por meio de aviões, cujas rotas só existem para o alto escalão das empresas mineradoras em diversas porções do território da região. Neste sentido, as formas de organização do território privilegiam os atores hegemônicos em detrimento do uso social da maioria da população.

Não se trata de considerar que o tempo mais rápido é o melhor, mas, nos mesmos rios em que trafegam embarcações mais modernas, coexistem diferentes formas de transporte, que levam diversificados tipos de mercadorias e pessoas. Como aponta Daniel Monteiro Huertas em sua pesquisa (2009), em boa parte do território amazônico, o tempo é ditado pelo ritmo das águas, e as densidades de outros modos de transportes,

107 Em 1953, através da Lei n 1806 foram incorporados à Amazônia Brasileira, o Estado do Maranhão (oeste do meridiano $44^{\circ}$ ), o Estado de Goiás (norte do paralelo $13^{\circ}$ de latitude sul, atualmente Estado de Tocantins) e Mato Grosso (norte do paralelo $16^{\circ}$ latitude Sul). Pelo artigo n० 45 da Lei Complementar no 31/1977, a Amazônia Legal tem seus limites aumentados. Nesta seção considera-se a definição dos limites da Amazônia com os estados do Acre, Rondônia, Mato Grosso, Tocantins, Pará, Amazonas, Roraima e Amapá, excetuando-se o estado do Maranhão, já que é fundamental pensar na ação do governo estadual na questão da implantação dos cursos. Dividindo-se este Estado esta análise ficaria prejudicada. 
além do fluvial, são rarefeitos e com diversificados tipos de problemas de infraestrutura e de falta de manutenção.

Entretanto, o padrão urbano dendrítico em torno dos rios amazônicos não é o único padrão de circulação na Amazônia, já que, sobretudo, após os anos 1960 cada vez mais o sistema viário tornou-se meio de transporte e indutor de ocupação urbana, mais comumente em Rondônia e na porção oriental do Pará.

Contudo, devido à precariedade destes sistemas de movimento na Amazônia, o que está distante em termos geométricos pode tornar-se ainda mais longe. Esta é uma condição que leva, por exemplo, à necessidade de cursos de Geografia modulares em municípios como Juruti no Pará, já que da Universidade Federal do Pará, em Belém, até o município, situado a cerca de $850 \mathrm{~km}$ da capital (ver mapa 36), gastam-se 14 horas, primeiramente indo de avião até Santarém e depois de barco, dificultando a ida e vinda dos professores da capital.

Logo, numa região como a Amazônia, a distância continua sendo uma variável importante, produzindo extensões existenciais mediadas pela distância geométrica, mas também pela seletividade de usos dos elementos que compõem a modernização do território, caso dos meios de transporte (SILVEIRA, 2006).

Assim, o uso do território é seletivo e as modernizações empreendidas não são acessíveis a todos, portanto produzem também extensões que não criam capilaridade a todos os lugares e nem a todas as pessoas que desejam alcançar o Ensino Superior.

\subsubsection{Os cursos do Pará e do Amapá}

No Pará, a cidade de Belém ${ }^{108}$ é considerada uma metrópole regional, que comanda as atividades econômicas, como centro de gestão

108 A centralidade de Belém já é bastante antiga na região, ocorre desde o período colonial, quando se tornou a capital da capitania do Grão Pará, no século XVII. No período do ciclo da borracha (1850-1920) disputou com Manaus a hegemonia pela exportação da borracha. 
de negócios e administrativo, e, no Ensino Superior, concentra a maioria das IES e cursos no estado do Pará.

O processo de interiorização dos cursos de Geografia no estado, principalmente das licenciaturas, ocorreu primeiramente por meio da Universidade Federal do Pará (UFPA). Este processo ocorreu nos municípios de Abaetetuba, Altamira, Bragança, Brejo Grande do Araguaia, Breu Branco, Breves, Cametá, Castanhal, Juruti, Marabá, Oriximiná, Ourilândia do Norte, Parauapebas, Rondon do Pará, Santarém, Soure e Tucuruí, cidades de pequeno e médio porte.

As licenciaturas promovidas pela UFPA foram as responsáveis pela totalidade da formação de professores em Geografia no interior do Pará até 2009, com a sede em Belém. Somente, em 2009, as cidades de Altamira e Marabá passaram a ter cursos desvinculados da sede, e a recém-criada Universidade Federal do Oeste do Pará (UFOPA), em 2009, deu continuidade ao curso em Santarém.

Além disso, em 2010 e 2012, a Universidade do Estado do Pará (UEPA) iniciou três cursos de licenciatura em Geografia no interior, nos municípios de Conceição do Araguaia, Vigia e Igarapé-Açu.

A maioria dos cursos do interior da UFPA não se constituía em cursos de turmas regulares e sua abertura dependia da relação do município com a Universidade, conforme disse a geógrafa formada pela USP, coordenadora dos cursos no período de 2008-2011, pela Faculdade de Geografia da UFPA:

[...] antes do Parfor, já havia outros movimentos das prefeituras com a universidade a respeito da formação de professores. Na UFPA essa interiorização ocorre desde o final da década de oitenta, para formação de licenciados em várias áreas, tais como Geografia, História, Filosofia, Letras, Ciências, Matemática e Pedagogia. As prefeituras fazem contratos ou convênios com a UFPA utilizando o recurso federal que é destinado à educação básica, ou algum outro recurso que os municípios possam dispor em conjunto. No passado existiam os municípios pólos, que concentravam as aulas. Nem sempre havia campus da UFPA ou um núcleo universitário. Por isso, muitas escolas públicas foram utilizadas para realização das disciplinas. Hoje, ainda há uma demanda que tem sido atendida, parcialmente pelo Parfor. 
Há, portanto, parcerias entre a IES e os municípios para a existência desses cursos temporários ou modulares, como geralmente os denominam. Devido a estas condições, vão abrindo e fechando novas turmas de licenciatura em Geografia, em novos municípios, tanto dos cursos do Parfor ${ }^{109}$, quanto dos modulares.

Em 2012, pela UFPA, existem licenciaturas em Geografia no interior (mapa 36), em Juruti, Parauapebas e Oriximiná. Estes cursos têm relação com o núcleo em Belém e são modulares.

Em condição diferente, encontram-se as licenciaturas em Geografia de Marabá e Altamira, que se constituem em cursos regulares com concursos específicos para estas cidades desde 2009. Há também licenciatura em Geografia na UFOPA em Santarém. Este curso foi transferido da UFPA para a UFOPA em 2009, com a mudança administrativa da instituição.

Considerando-se as especificidades territoriais da região e das dificuldades para o transporte intermunicipal, os cursos não regulares são condensados no período de férias, já que os docentes são provenientes de Belém. Em Soure, por exemplo, na Ilha do Marajó, havia a peculiaridade dos discentes se deslocarem até Belém, utilizando-se assim de toda a infraestrutura do curso existente na capital, tais como biblioteca, laboratórios, softwares etc.

Já nos demais municípios, o movimento tem sido o contrário; os professores da UFPA, de Belém, deslocam-se no período de janeirofevereiro e depois em julho-agosto, ficando cerca de 10 dias ministrando suas disciplinas. Tais professores geralmente aproveitam para realizar pesquisas nestes municípios e trabalham no período de férias, ganhando separadamente em contratos específicos para ministrarem estas aulas.

109 Cabe lembrar que os cursos do Parfor são destinados apenas a quem já é professor em escolas públicas e não tem graduação na área específica que leciona. A tendência com institucionalização do Parfor é que os cursos modulares comecem a diminuir. 


\section{População dos Municípios com Cursos de Licenciatura em Geografia nas IES Públicas dos Estados do Pará e Amapá 2012}

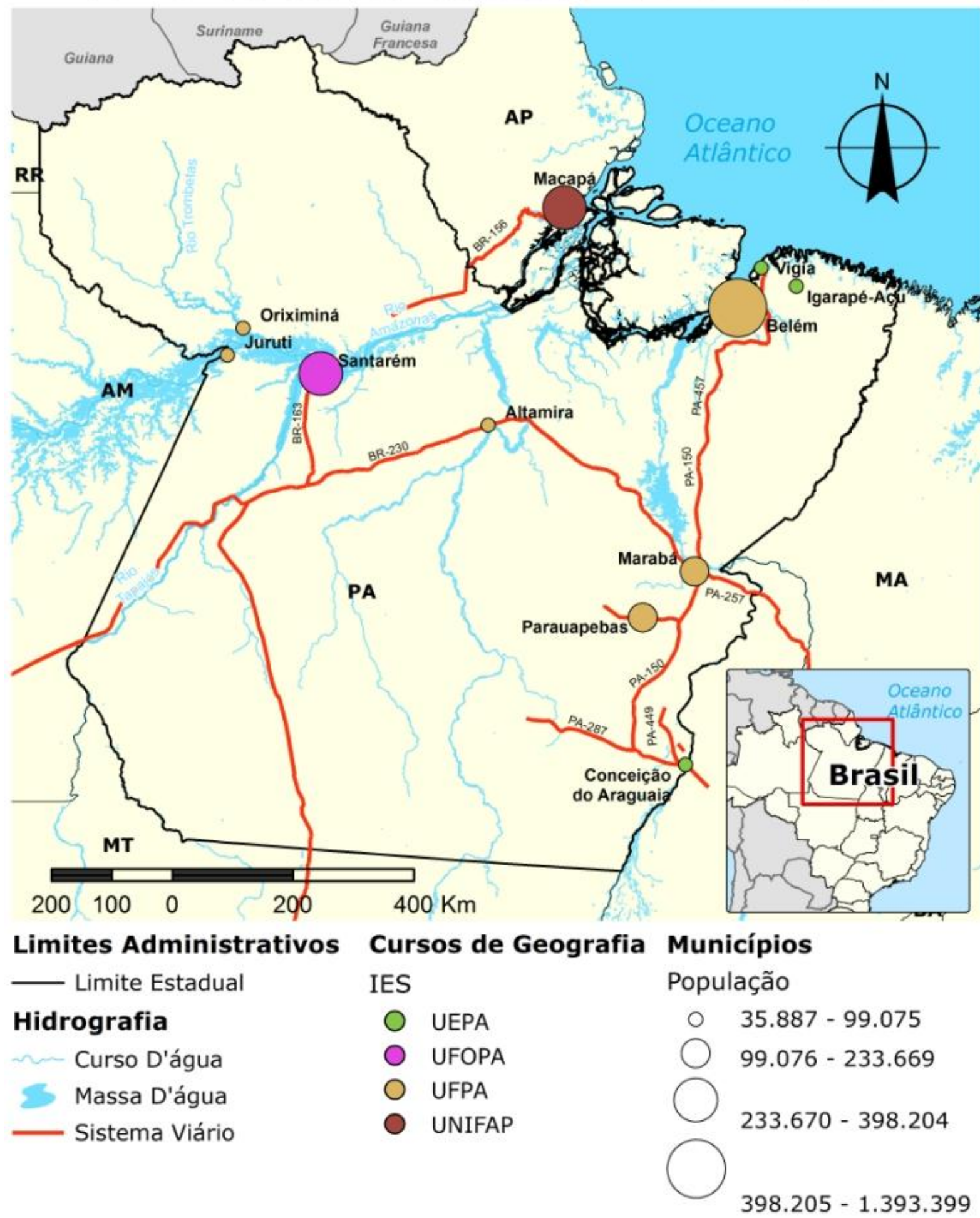

Mapa 36: Fonte: Dados do Censo 2010 publicados no Diário Oficial da União do dia 04/11/2010.

Dados das IES organizados por Vivian Fiori, 2012. Elaborado por Vivian Fiori e Maurício Yamada, 2012. Obs. As vias e rios estão destacados apenas devido a sua proximidade com os municípios onde se encontram os cursos de licenciatura em Geografia. 
Conforme se observa no mapa 36, os municípios de Oriximiná, Juruti e Santarém estão mais integrados ao sistema fluvial; Altamira é cortada pela BR-230 (Transamazônica), e o leste do Pará está mais integrado pelo sistema de rodovias federais e estaduais.

Os cursos da UEPA em Conceição do Araguaia, Vigia e Igarapé-Açu também são modulares com professores lecionando suas disciplinas de $80 \mathrm{~h}$ num período de dezesseis dias; isto faz com que o docente se desloque e fique morando no município enquanto leciona sua disciplina, principalmente no caso de Conceição do Araguaia (ver mapa 36). Nas demais cidades, por serem mais próximas a Belém, há possibilidade do ir e vir, com viagens de cerca de $2 \mathrm{~h}$.

Os professores da UFPA do núcleo Belém, conforme quadro apresentado no Apêndice $H$, têm, em sua maioria absoluta, formação em Geografia, bacharelado e/ou licenciatura pela UFPA. No mestrado, há um número maior de docentes formados pela UFPA, assim como na USP, Universidade Federal Rural da Amazônia (UFRA), UFRJ, UNESP, UFPE e UFRN, e, por fim, doutores principalmente em áreas fora da Geografia pela UFPA, e, em Geografia, pela USP e UNESP.

Há casos de professores que são atendidos pelo Programa de Doutorado Interinstitucional (DINTER ${ }^{110}$ ), podendo ser liberados para cursar as disciplinas do doutorado e parte do período para a produção da tese. Este processo criado pelo governo federal acaba favorecendo as IES públicas federais e algumas estaduais e tem sido utilizado muito recentemente pelas IES.

Um dos atuais cursos modulares da UFPA é em Oriximiná, município paraense desmembrado de Óbidos em 1934. Situa-se às margens do Rio Trombetas e dista $810 \mathrm{~km}$ de Belém, com 61125 habitantes (IBGE, 2010).

110 Segundo o site da Fundação Coordenação de Aperfeiçoamento de Pessoal de Nível (CAPES), este Programa recebe das IES detentoras de programas credenciados de pós-graduação stricto sensu propostas de Programas de Doutorado Interinstitucional (DINTER), com a finalidade de capacitar recursos humanos de sua própria IES e de instituições parceiras, buscando oferecer a um grupo ou turma de alunos a formação de doutorado. 
$\mathrm{Na}$ parte oeste do estado, que se constituiu desde o período colonial, geralmente estão as famílias mais antigas no Estado.

O percurso de Belém a Oriximiná é feito de avião até Santarém e depois por barco, pelos rios Tapajós, Amazonas e Trombetas, viajando-se a noite toda.

Uma aluna do curso em Oriximiná, de 32 anos, que trabalha na Universidade, como bolsista, deu-nos o seguinte depoimento sobre a licenciatura em Geografia na cidade:

A gente não tem muita opção aqui no interior do Pará. Em Oriximiná, o curso é de julho-agosto e janeiro a março. Para a gente é bem puxado, a maior parte trabalha e muitos são casados. Nós recebemos uma apostila com os textos, no decorrer das aulas a gente vai lendo. Tem de se dedicar muito; a gente entra às $14 \mathrm{~h}$ e vai até as $21 \mathrm{~h}$. Eu gosto mais da área de pesquisa, mas aqui tem mais espaço para professores. É complicado sair daqui para participar de eventos geográficos.

Esta situação é comum no interior, onde o número de opções de curso de Ensino Superior é pequeno, o que faz com que as possibilidades de escolha sejam menores e geralmente vinculadas à Educação.

Tanto docentes como discentes citam que a prática de aulas em que seriam necessários equipamentos de laboratório é complicada, devido à inexistência destes recursos nestas cidades com cursos modulares.

As disciplinas mais prejudicadas são as que usam computadores, imagens, programas/softwares, mapas e o Trabalho de Conclusão de Curso (TCC), devido à falta de biblioteca com acervo diversificado. Neste sentido recorrem a referências digitais, utilizando-se da internet sob orientação à distância, pois o professor retorna a Belém, não sendo possível tê-la presencialmente.

Em depoimento, um professor da UFPA, geógrafo formado pela mesma instituição, com doutorado em Geografia Humana pela USP, faz uma reflexão sobre as aulas no interior do Pará:

Se fosse possível fazer um curso regular, seria melhor. Mas considerando que não há esta situação, acho melhor ter do que não ter um curso modular. Eu acompanhei doze TCC e sete estavam no mesmo nível dos que estão em Belém, com a mesma qualidade. Muito em função da qualidade do aluno, 
de seu esforço. Hoje devido à informação em rede, há acesso de pesquisas pela internet e podemos também enviar por e-mail alguns textos para os alunos.

Esta opinião do professor é compartilhada pela ex-coordenadora e por outros professores que lecionam no interior do Pará entrevistados. São unânimes em dizer que os alunos são esforçados e mais focados nos estudos, e que existem problemas decorrentes da falta de infraestrutura.

Apesar das dificuldades decorrentes da formação anterior dos discentes, e da falta de infraestutura, o fato de os docentes terem formação em pós-graduação stricto sensu contribui para a importância que é dada à pesquisa e extensão, assim como para atividades de pesquisa de campo e para a diversificação de leituras.

Segundo depoimentos, atualmente acham referências sobre o Pará em teses, dissertações e artigos da própria Geografia e das Ciências Sociais, muitas digitais, principalmente por causa da importância da mineração e dos impactos ambientais e sociais da região.

Outra cidade com curso modular é Parauapebas (mapa 36) cujo município foi criado em torno da produção mineral de Carajás, interligando-se ao sistema viário da porção oriental do Pará. Em 1981, a Companhia Vale do Rio Doce criou a Vila de Parauapebas, que em 1988 tornou-se município, emancipado de Marabá.

São cidades que surgem em torno das grandes empresas, as quais Roberto Lobato Corrêa (2006a) denomina company towns, comuns na Amazônia, devido à necessidade de se criar infraestrutura para as empresas e moradia para os trabalhadores, especialmente de seus quadros médio e superior, ou seja, a demanda urbana é criada pelas empresas que lá se instalam.

Para a região de Parauapebas-Marabá (mapa 36) migraram principalmente maranhenses, gaúchos, piauienses, goianos, mineiros, paulistas, capixabas, entre outros, na condição de fazendeiros, madeireiros, garimpeiros e trabalhadores do Projeto Carajás, além dos funcionários públicos. 
Trata-se, pois, de uma cidade de porte médio, com 149411 habitantes (IBGE, 2010), com forte dinâmica econômica, relacionada aos empreendimentos minerais e do agronegócio, principalmente pecuária.

Uma estudante, de 32 anos, do curso de licenciatura e bacharelado em Geografia em Parauapebas, diz:

Aqui em Parauapebas não tem universidade, eu pensei em fazer Engenharia Florestal fora, mas como a UFPA estava oferecendo licenciatura e bacharelado em Geografia fui fazer. Sou da turma de 2007 e acabei me apaixonando pela Geografia. [...] Nossa região tem muito espaço para trabalho para geógrafo e carência de mão de obra. Aquele desejo de ser professora não tenho, pela desvalorização em relação ao trabalho do professor. Com minha vivência nos estágios fui empolgada para dar aula, mas me decepcionei.

É comum, também em outros lugares do Brasil, que o estudante, interessado no Ensino Superior, por falta de opção, faça o curso de Geografia e acabe dele gostando, passando a ter outra concepção do que seja Geografia. Isto se confirma em dados do Enade- 2008 e em depoimentos para esta pesquisa.

Em Parauapebas há uma diferença já que existe oferta de bacharelado e licenciatura, num só curso, contrariamente o que definia a norma. A existência do bacharelado em Geografia trouxe novas possibilidades de campo de trabalho e fez com que o interesse em ser professor fosse menor, como apontado anteriormente na seção 4, sobretudo numa região que é dinamizada por grandes empreendimentos que possibilitam o trabalho para o bacharel.

Outra cidade com curso de Geografia é Marabá, a principal centralidade da mesorregião do Sudeste Paraense, com 224014 habitantes (IBGE, 2010). Nela há hoje uma economia e vida urbana mais articulada com o sistema viário da porção oriental do Pará, com os grandes empreendimentos minerais e agrícolas.

Nesta cidade havia cursos modulares que se iniciaram em 1987, que não existem mais nessa modalidade. Recentemente, em 2009, houve mudanças na IES, pois, assim como Altamira, ainda está vinculada à UFPA, mas agora é um campus com curso regular de Geografia e sem 
relação direta com o núcleo de Belém. Isso se deve à centralidade existente destas cidades nas regiões existentes no interior do Pará.

Há um projeto, entregue ao MEC em 2011, que pretende tornar o campus de Marabá numa nova Universidade, provavelmente denominada Universidade Federal do Sul-Sudeste do Pará (UNIFESSPA).

O projeto também é fruto da política federal do REUNI e pretende criar cursos noturnos e ampliar a formação de profissionais na região, dada a dinâmica econômica e populacional regional.

Neste caso, a cidade de Marabá será a cidade-sede, com outros campi menores em Rondon do Pará, São Felix do Xingu, Xinguara, Santana do Araguaia e talvez venha a ser encampada futuramente a cidade de Parauapebas.

O curso de Geografia em Marabá é de licenciatura e bacharelado e, pelo fato de o ingresso do aluno ser por um único sistema da UFPA, há alunos de várias cidades, conforme depoimento do coordenador do curso, com graduação e mestrado em Geografia pela Universidade de Maringá e doutorado em Geociências e Meio Ambiente pela UNESP. Disse ele sobre os discentes:

A maioria da cidade é gente de fora e os alunos vêm de
todos os lugares: de Belém, do estado do Tocantins, da
própria Marabá. De 2012, especificamente a maioria vem de
fora de Marabá. Estes que vieram de fora são geralmente do
estado mesmo, da Região Metropolitana, de Tucuruí e
cidades vizinhas, como Conceição do Araguaia, Parauapebas,
São Domingos e de Rondon do Pará. Eles vêm com a
intenção de depois mudar de curso, mas por enquanto ainda
não se efetivou. Nós temos muitos cotistas, por cota
indígena. Temos alunos de várias etnias indígenas. Eles
falam bem Português, a maioria é formada por homens, já
que geralmente as mulheres ficam mais nas aldeias e não
falam tão bem Português.

Como ainda há relação com o curso de Belém (UFPA), os alunos pensam em pedir transferências, mas, como disse o coordenador, isso não tem ocorrido. Ao mesmo tempo, devido à centralidade de Marabá, o curso acaba atendendo à demanda dos municípios da sua região do entorno pela formação de professores. 
A questão das cotas indígenas, mais comum na Amazônia, traz peculiaridades para as características dos discentes dos cursos de Geografia. Um aluno do campus Marabá, morador da aldeia gavião Kyikatejê, deu-nos o seguinte depoimento:

$\mathrm{Na}$ verdade meu interesse era História, mas na região não tinha, daí optei por Geografia e gostei, porque tem relação com a comunidade, e vou poder atuar como professor indígena na comunidade [...] Penso no futuro me tornar professor, faltam professores, a maioria é pedagogo dando aula de Geografia. A comunidade fica em volta de Marabá. Estou no terceiro semestre. [...] No Ensino Médio a gente vê mapas, lugares, mas na Universidade é diferente tem vários autores e textos, eu gostei.

O depoimento dele reforça o que já se mencionou anteriomente: o estudante ingressa no curso de Geografia e acaba gostando dele. Neste caso, a concepção inicial de Geografia trazida do Ensino Básico, como ciência dos lugares, dos mapas, das localizações, vai sendo substituída por outras concepções, teorias e análises do espaço geográfico de forma mais profunda, com o uso de categorias geográficas.

Já em Santarém (mapa 36), atualmente com curso regular, constitui-se numa centralidade das mesorregiões do Baixo Amazonas e do Sudoeste Paraense, tendo a cidade e os municípios de seu entorno uma forte relação com os rios no seu cotidiano, mantendo, em parte, o padrão de ocupação e articulação dendrítico-ribeirinho.

Em Santarém há o curso de licenciatura em Geografia, agora pela UFOPA, cuja criação tem relação com a política federal do REUNI em expandir as IES pelo interior e, ao mesmo tempo, com o discurso separatista da região oeste do Pará.

A UFOPA foi credenciada em novembro de 2009 pelo MEC. Em seu projeto inicial, com o nome de Universidade Federal da Integração da Amazônia (UNIAM), evidencia-se o intuito de ser uma universidade modelo, com uma estrutura diferente das existentes comumente no Brasil, com cursos concebidos com um currículo inicial aberto, conforme explica o documento de criação da instituição:

Sua concepção curricular modular e flexível também atenderá a esta condição, buscando a integração entre seus 
conteúdos, numa concepção modular [...] com variado grau de presencialidade, especialmente possibilitados pela mediação tecnológica que se pretende dar ao processo formativo acadêmico regular [...] Dada a flexibilidade curricular, o aluno poderá candidatar-se a cursar gradativamente habilitações diferentes, mas complementares. Disporá de três ciclos de estudos: 10 Ciclo Básico de Estudos Amazônicos, com a duração de um ano; 20 Ciclo de Graduação Profissional, com diversas possibilidades de duração para as variadas habilitações profissionais; e o 3 Ciclo de Pós-Graduação (UNIAM, 2009, p.13).

Esta flexibilidade criou situações inusitadas e irregulares conforme normas das Diretrizes Curriculares dos cursos definidas pelo MEC, tais como as licenciaturas integradas de História e Geografia; Química e Biologia; Matemática e Física; Pedagogia e Psicopedagogia; e Português e Inglês.

Os cursos de História e Geografia, historicamente começaram juntos, foram separados na década de 1950, unidos novamente em Estudos Sociais a partir dos anos 1960, e novamente separados nos anos 1990. Agora surge nova proposta que volta a uni-los, sem que as Diretrizes Curriculares sejam consideradas.

Observa-se, novamente, a concepção de flexibilidade, termo comumente usado no atual período, que passa a ser sinônimo de curso aligeirado, sem contemplar as condições mínimas de uma formação acadêmica que requer tempo para estudar, para amadurecer academicamente.

Esta situação deve ser reforçada a partir do discurso do atual Ministro da Educação, Aloizio Mercadante, em agosto de 2012, ao tratar dos dados de avaliação do Ensino Médio pelo Índice de Desenvolvimento da Educação Básica (IDEB ${ }^{111}$ ), em que se menciona a intenção de agrupar as disciplinas em grandes áreas do conhecimento.

\footnotetext{
${ }^{111}$ Segundo informações do Inep, em seu site, o IDEB é uma das formas de avaliação usada no Brasil, promovida pelo INEP/MEC, cujo indicador é calculado a partir dos dados sobre aprovação escolar, obtidos no Censo Escolar, e médias de desempenho nas avaliações do Inep, para o Sistema de Avaliação da Educação Básica (SAEB) e a Prova Brasil.
} 
Se a proposta vier a ser aprovada pelo Conselho Nacional de Educação, disciplinas como Geografia, História, Filosofia e Sociologia ficarão agrupadas em Ciências Humanas, já que, segundo o ministro, "O aluno não vai ter mais a dispersão de disciplinas" (FOLHA DE SÃO PAULO, 2012 , p. 1). Mais uma verticalidade que deve alterar não apenas o Ensino Médio, mas também o Ensino Superior.

No caso da UFOPA, o aluno ingressa na Universidade via sistema do ENEM, tendo como opção dois cursos dentro dos cinco institutos da Universidade. Todos os institutos têm um núcleo comum de Estudos Amazônicos em dois semestres, só depois, dependendo das notas dos discentes, cria-se uma classificação pela qual o discente vai cursar as disciplinas ditas interdisciplinares. A partir daí, depois do terceiro semestre e conforme sua classificação irá para o curso escolhido.

Caso seu desempenho esteja aquém do esperado, ele terá mais uma chance como aluno especial, sendo, por fim, aluno do curso pretendido. Se não obtiver êxito, não ingressará no curso pretendido, mas receberá um certificado em Estudos Amazônicos.

Assim, há um primeiro ciclo básico igual para todos, com dois semestres; um segundo ciclo de um semestre com disciplinas "interdisciplinares", e por fim, o curso específico. Espera-se que no final do segundo ano ele receba um certificado que o habilite a alguma atividade.

Em princípio, a concepção de um curso que se inicia com Estudos Amazônicos, passa por uma estrutura denominada interdisciplinar e depois disciplinar, pode parecer inovadora e interessante já que há tempo para o aluno definir melhor sua carreira.

Contudo, na prática, transforma-o em estudos gerais, porque o tempo para o curso disciplinar é pouco e ainda possibilita haver duas habilitações. Sem dizer que a ideia de interdisciplinar só pode ocorrer quando há conhecimento do que seja o disciplinar, ou seja, não há disciplinas interdisciplinares em si. Além disso, as opções de escolha 
continuam entre duas possibilidades e dependentes de sua classificação geral.

A proposta de integração entre História e Geografia ainda não estava fechada no Plano Pedagógico, ou seja, a primeira turma neste processo entrou em 2011 e ainda não está claro o percurso do curso. Afinal, produzir um plano integrado destas licenciaturas contraria tudo o que foi produzido nas redes de afinidades da Geografia, assim como formalmente pelo próprio MEC; ir contra a integração contraria o Plano do Projeto da instituição.

Há, pois, duas racionalidades: a formal do MEC e outra da UFOPA. Existem, ainda, novas possibilidades de mudança que podem ocorrer devido às transformações no Ensino Médio, produzidas também pelo MEC.

Segundo um estudante da Geografia, ao falar sobre a estrutura do curso da UFOPA:

Ainda esta a desejar, o campus tinha uns dez cursos da UFPA e Federal Rural da Amazônia, daí abriram vinte cursos. Hoje a Universidade tem salas alugadas e outros setores, pois não tem espaço na própria instituição. Não tem infraestrutura nem para os cursos antigos nem para os novos.

Logo, esta expansão está começando sem clareza no projeto pedagógico sobre a formação específica de Geografia, tampouco com infraestrutura de laboratórios, salas de aulas e biblioteca adequada. Os professores chegam a levar seus próprios livros e emprestam aos alunos, realidade também comum em outras IES pelo Brasil.

Por outro lado, por ser IES pública federal, há bolsas de iniciação científica e extensão, e professores, em sua maioria, estudaram em Belém, com graduação pela UFPA, atualmente com mestrado. Há alguns docentes fazendo doutorado em Goiás, Pará e Ceará, e o atual professor doutor estudou na UNESP.

Outra cidade que tem influência de Belém é Macapá, no Amapá, já que, apesar das mudanças empreendidas no território brasileiro nos últimos anos, a relação de Belém com Macapá em relação ao Ensino Superior ainda é grande, ao menos nos cursos de Geografia. 
Há, neste sentido, uma contiguidade territorial que aproxima e leva, por exemplo, os docentes provenientes do Pará para Macapá, cuja cidade configura-se como uma cidade de porte médio, com uma população de 387539 (IBGE, 2010).

Segundo a classificação das Regiões de Influência das Cidades (IBGE, 2007), Macapá é uma capital regional; classificação que a coloca entre o nível hierárquico da metrópole e os centros sub-regionais. Na conceituação de Márcio Amaral (2010) é uma cidade média, que tem influência maior exercida por Belém e Manaus, esta última, sobretudo a partir da criação da Superintendência da Zona Franca de Manaus (SUFRAMA). Diz ainda o autor em sua tese:

[...] das políticas de desenvolvimento regional para a produção de cidades médias como Marabá, Santarém e Castanhal, deve-se destacar que na região existem cidades médias capitais, dentre elas, Macapá, Rio Branco, Boa Vista e Porto Velho, cuja gênese está relacionada à criação dos antigos Territórios Federais pela União, que para transformálos em capitais administrativas fizeram nas mesmas uma série de investimentos em sua infra-estrutura e em sua dinamização econômica que acabaram, posteriormente, fazendo com que elas se constituíssem em cidades médias. (AMARAL, 2010, p. 140).

O fato de ser capital a transforma numa cidade importante em termos de serviços educacionais do Ensino Superior, mas, ao mesmo tempo, não se compara a Belém em termos de centralidade econômica e de serviços, entre eles, do Ensino Superior.

Em 2009, havia curso regular em Macapá e dois cursos modulares em duas cidades de pequeno porte: Laranjal do Jari, com 38170 habitantes, e Oiapoque, com 19941 habitantes, com aulas condensadas no período de férias.

Há muita semelhança com o processo de interiorização que ocorreu no Pará, já que a equipe que ministrava aulas no interior vinha da sede na capital, da Universidade Federal do Amapá (UNIFAP).

Oiapoque fica na região de fronteira com a Guiana Francesa e Laranjal do Jari mais próxima do Pará. Devido a esta localização e distâncias, formas e possibilidades de circulação, os alunos de Oiapoque 
do curso de licenciatura em Geografia eram do próprio Amapá; em Laranjal do Jari ${ }^{112}$, havia também estudantes oriundos do Pará.

Laranjal do Jarí é um município ao sul do Pará, situado no vale do Rio Jarí, a 320 km da capital, emancipado em 1987, bastante pobre e sem infraestrutura. A sede do município é conhecida como beiradão, pois se localiza à beira do rio, com muitas construções de palafitas.

Nenhuma das duas cidades tem um campus ou uma IES no próprio município, portanto a existência destes cursos modulares no interior teve muita importância para a formação de professores no local.

Contudo, havia grandes problemas no curso, conforme destaca um antigo professor:

Oiapoque e Laranjal do Jari tinham núcleos, com cinco salas de aula. Uma sala de administração, uma biblioteca pequena, com alguns livros; em geral não tinham os livros que colocávamos nas referências. O coordenador do núcleo organizava o material via copia ou escaneava os textos que pedíamos. No Oiapoque o coordenador do núcleo era o mesmo de Macapá, mas o coordenador de Geografia ficava em Macapá.

Em suma, eram cursos sem infraestrutura, sem laboratórios, de biblioteca, com referências básicas da Geografia, com pouco tempo para o desenvolvimento dos módulos.

Segundo dados de 2008, conforme tabela 9, percebe-se uma diferença entre o curso de Geografia nas cidades do interior e da capital.

\begin{tabular}{|l|c|c|c|c|c|}
\hline \multicolumn{6}{|c|}{ Tabela 9 - Características dos cursos de licenciatura em Geografia da UNIFAP, } \\
\hline Município & $\begin{array}{c}\text { Uso de } \\
\text { Apostilas } \\
\text { no curso }\end{array}$ & $\begin{array}{c}\text { Raramente } \\
\text { utiliza a } \\
\text { biblioteca }\end{array}$ & $\begin{array}{c}\text { Uso da } \\
\text { Internet para } \\
\text { pesquisar }\end{array}$ & $\begin{array}{c}\text { Estudou só } \\
\text { em Escola } \\
\text { Pública }\end{array}$ & $\begin{array}{c}\text { Quer Ser } \\
\text { Professor }\end{array}$ \\
\hline Macapá & 36 & 44 & 24 & 72 & 60 \\
\hline Laranjal do Jari & 75 & 25 & 50 & 100 & 75 \\
\hline Oiapoque & 100 & 100 & 0 & 100 & 100 \\
\hline
\end{tabular}

Fonte: Inep, Relatórios dos cursos de Geografia por IES, Enade, 2008. Elaborado por Vivian Fiori, 2012.

${ }^{112}$ Informações obtidas por meio de depoimentos de professores da UNIFAP e no site do IBGE -Cidades, revelam que a região é conhecida pelo Projeto Jari Florestal, com início em 1967, empreendimento que, no período dos governos militares, concedeu ao americano Daniel Ludwig, terras do tamanho do Estado do Sergipe. O empreendimento ficava entre o Amapá e Pará. Houve a construção de uma company town, onde hoje é o município de Monte Dourado, cidade planejada do Pará; do outro lado do rio, está Laranjal do Jari, no Amapá, sobre palafitas. 
Em Macapá, o interesse em se tornar professor é menor, assim como o uso de apostilas no curso, mais difundido no interior. O uso da biblioteca pelos alunos é pequeno, sendo que, em Oiapoque, a situação é pior, pois, além de não usarem biblioteca, também não acessam internet para pesquisar. Considera-se que, neste município de fronteira do Brasil, o território esteja pouco tecnificado, assim como o uso de novas tecnologias de informação sejam menos comuns entre a população.

Por outro lado, a Universidade Federal do Amapá (UNIFAP), em 2009, tinha a maioria dos docentes com mestrado, conforme dados do INEP. Em 2012, segundo o coordenador do curso, o grupo de professores das disciplinas específicas em Geografia é constituído por: um graduado; dois especialistas, sete mestres e seis doutores.

São professores oriundos do Pará (7), Amapá (3), São Paulo (2), e os demais, com um professor, do Rio de Janeiro, Mato Grosso do Sul, Rio Grande do Sul e Maranhão. A contiguidade territorial com o Pará faz com que alguns docentes formados no Pará migrem para o Amapá para lecionarem no Ensino Superior. Há também professores com qualificação de mestrado ou doutorado que são atraídos pelos concursos públicos e pela possibilidade de uma jornada integral, vindos principalmente do Centro-Sul do país. O mais comum é que sejam jovens recém-formados na pós-graduação, movimento bastante recente no Amapá.

Verifica-se, assim, uma dinâmica territorial em relação ao docente, pela qual as capitais, Belém e Macapá, recebem professores do Centro Sul, ou ainda, que saem para fazer pós-graduação principalmente na Região Concentrada, assim como, no caso de Macapá, há uma relação grande com os docentes formados pela UFPA, em Belém. Os cursos regulares do interior também recebem professores do Centro-Sul, mas ainda existe a maioria teve sua formação pela UFPA, na pós-graduação em Belém.

Então, Belém tem fundamental importância na produção de conhecimento na Geografia na graduação e pós-graduação na região da porção oriental da Amazônia. 


\subsubsection{O Amazonas}

No Amazonas, há diferenças em relação ao Pará, pois o processo de interiorização é mais recente e se deu mediante a criação de cursos principalmente regulares por uma IES estadual.

Em 2012, no Amazonas, há cursos de licenciatura em Geografia em Manaus pela Universidade Federal do Amazonas (UFAM), pelo Centro Universitário do Norte (UNINORTE) e pela Universidade do Estado do Amazonas (UEA); no interior, nos municípios de Parintins, Tefé, Manacapuru e Tabatinga, apenas pela UEA.

No Amazonas, a situação é peculiar porque Manaus é uma metrópole, cuja centralidade é bem maior do que as demais cidades do estado. Enquanto Manaus tem 1718584 habitantes (IBGE, 2010), todas as demais cidades têm menos de cem mil habitantes.

Esta centralidade de Manaus já vem do período do ciclo da borracha (1850-1920), quando disputou com Belém a exportação da borracha, em seu porto. Com a decadência do ciclo da borracha muitas cidades arrefeceram e houve muita migração para a capital do Amazonas, intensificando o processo de crescimento urbano da cidade.

Nos anos 1960-80, com a criação da Superintendência da Zona Franca de Manaus (SUFRAMA), em 1967, desenvolveu-se um polo industrial em Manaus, o que intensificou ainda mais sua centralidade, não só em relação ao estado do Amazonas, mas também na porção ocidental da Amazônia.

Segundo dados do sistema E-MEC (2012), o número de IES em Manaus é vinte, tendo os demais municípios de uma a duas IES apenas, sendo a maioria formada por cursos relacionados à Educação ${ }^{113}$, com formação de professores. O padrão dendrítico e a dependência dos rios é grande nestas cidades (mapa 37), onde estão instalados os campi da

113 Em Parintins, de dezoito cursos, onze são relacionados à formação de professores; em Tefé, de dez, nove são relativos à Educação e, em Manacapuru, de dez cursos, sete são nesta área (E-MEC, 2012). 
Universidade do Estado do Amazonas e dos cursos de licenciatura em Geografia.

\section{População dos Municípios com Cursos de Licenciatura em Geografia nas IES Públicas do Estado do Amazonas 2012}

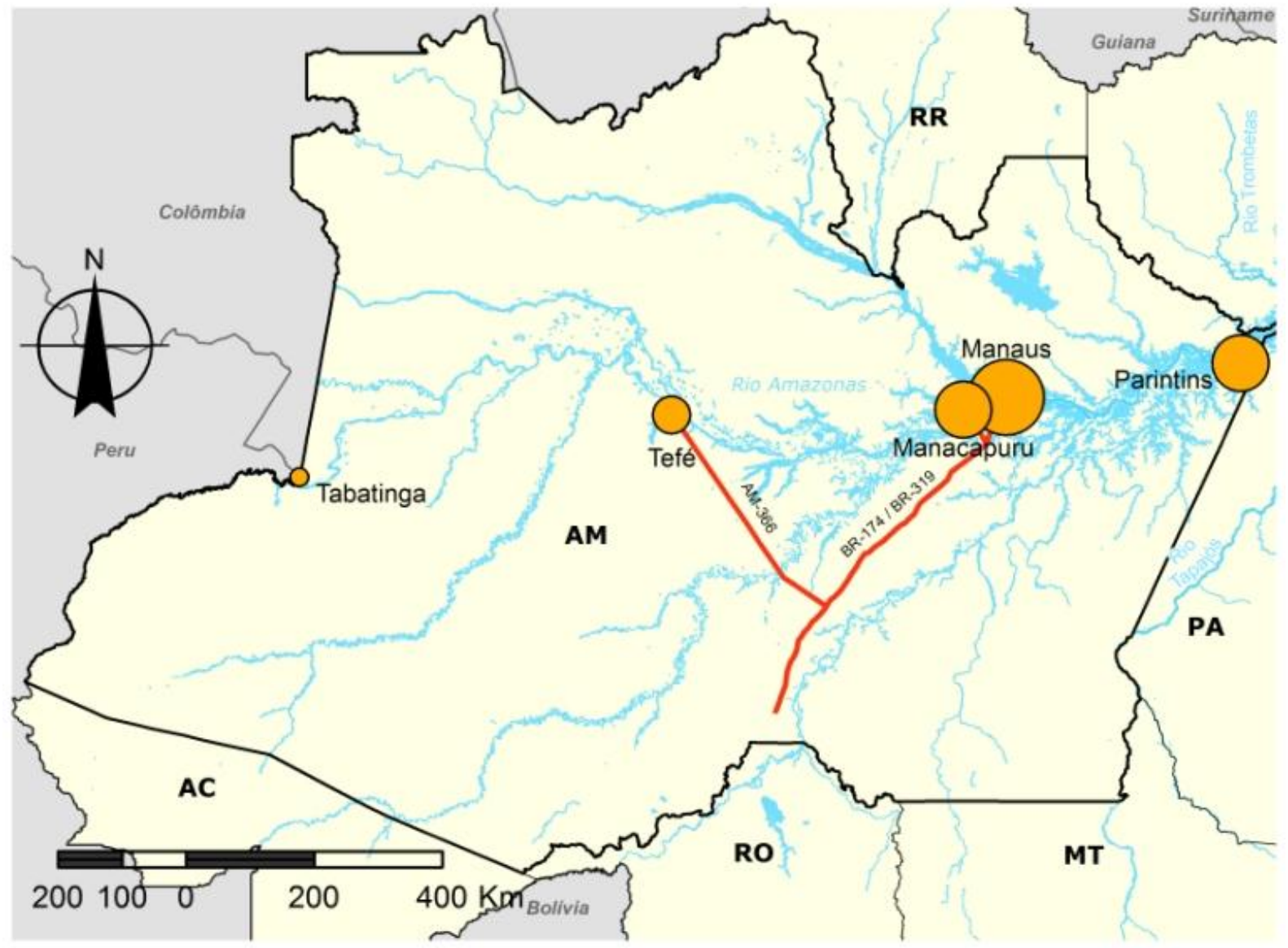

\section{Limites Administrativos Municípios}

- Limite Estadual

População

\section{Hidrografia}

Curso D'água

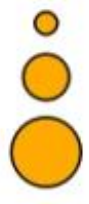

52.272

Massa D'água

Sistema Viário

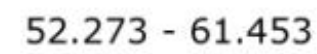

$61.454-102.033$

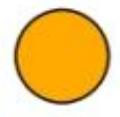

$$
102.034-1.802 .014
$$

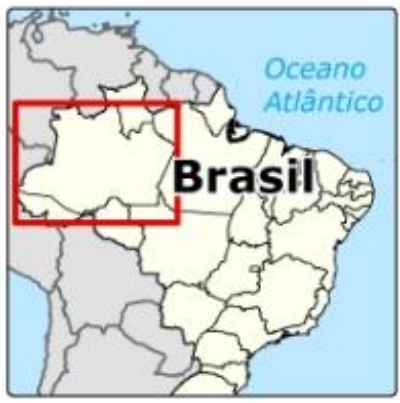

Mapa 37: Fonte: Dados do Censo 2010 publicados no Diário Oficial da União do dia 04/11/2010.

Dados das IES organizado por Vivian Fiori, 2012. Elaborado por Vivian Fiori e Maurício Yamada, 2012.

A UEA foi criada em 2001, com a estratégia principal de criar cursos no interior do Amazonas, com a instalação de Centros de Estudos Superiores. Portanto, as licenciaturas em Geografia, nesta instituição, são recentes: em Tefé (2001), Tabatinga (2003), Parintins (2001), Manaus 
(2007) e Manacapuru (2011) e, em Manicoré, com curso apenas do Parfor (2010). Não há cursos de bacharelado em Geografia nesta IES.

Como os professores estão em estágio probatório, a possibilidade de fazerem doutorado em outras cidades é menor. Contudo, alguns professores conseguem condensar suas disciplinas em alguns períodos, saem para cursar as disciplinas do doutorado e depois voltam.

Devido à intensa urbanização em Manaus, a diversidade dos discentes é maior, considerando-se a renda, as características de formação, comparativamente aos do interior, cujo padrão socioeconômico tende a ser menos diversificado.

Conforme diz um professor da UEA, geógrafo formado pela UFAM, mestre pela UFSC:

Em Manaus, a UEA tem uma variedade grande do perfil socioeconômico e sociocultural dos estudantes; a UEA tem sistema de cotas, por bolsa, portanto, tem alunos de cotas assim como vindos das escolas top da cidade. O curso é novo, só agora se formou a primeira turma em Geografia. Quase todos os professores estão concursados, e quatro já aprovados no mestrado. Em Manaus não tem nenhum professor doutor neste momento, mas quase todos estão se qualificando. Tem dois na USP, um em Brasília, um na França. Agora estamos terminando estágio probatório. Para estudar doutorado fazemos acordo e damos a disciplina condensada.

Esta maior diversidade dos alunos em Manaus reflete o nível de centralidade da metrópole, com maior número de população e de candidatos à Universidade. Ao mesmo tempo, o sistema de cotas possibilita acesso por estudantes de baixa renda, de cotas por etnia etc.

Já em Manacapuru (mapa 37), com 83479 habitantes (IBGE, 2010), município situado na Região Metropolitana de Manaus, há curso de licenciatura em Geografia temporário, cuja equipe geralmente vem da capital, mas as aulas ocorrem ao longo do semestre e não apenas no período de férias, devido a distância não ser tão grande.

Há uma distribuição das aulas, num horário especial, que é feito de forma que os professores da capital possam se deslocar para Manacapuru e, ao mesmo tempo, serem docentes em Manaus. 
Como o curso é temporário, cabe à coordenação procurar um professor que esteja disponível, providenciar passagens, além de coordenar a distância, ir e vir de Manaus.

Assim como os demais cursos modulares, utilizam-se apostilas, digitais, como material didático nas disciplinas, e alguns textos de livros. Segundo a coordenadora do curso de licenciatura em Geografia, do núcleo em Manacapuru, formada em Serviço Social pela UFAM e com mestrado em Geografia Humana pela USP, existe muita bibliografia sobre a Amazônia, muitos artigos publicados, capítulos livros e periódicos, principalmente de Geografia Humana.

Diz também sobre a condição do trabalho docente:

No começo tinha professor que abandonava o curso da capital e ia para o interior, porque os valores são maiores no interior, conforme a titulação. Atualmente a maior parte dos professores é formada por mestres e temos duas especialistas. Só eu não sou formada em Geografia. Quando dei aulas em Parintins eu morava lá, tem adicional pela localidade, por distância. Mas hoje, cada concurso é específico. Quando começamos éramos professores contratados e em 2008 teve concurso. O governo não queria fazer concurso, então tínhamos um contrato precário, foi o Ministério Público quem requereu os concursos.

Esta condição da falta de concursos ainda é bastante comum em algumas IES estaduais e municipais do Brasil, caso, por exemplo, da Universidade do Estado de Goiás (UEG), o que torna as condições de trabalho no Ensino Superior mais precárias e explicam o baixo número de mestres e doutores em algumas IES públicas.

Por outro lado, o adicional para trabalhar no interior do Amazonas tem atraído mais professores com mestrado, também porque são concursados, com regime de tempo integral, e há mais estabilidade no emprego.

Logo, a ação proveniente do estado do Amazonas, com a pressão do Ministério Público em criar algumas condições para atrair professores mais qualificados ampliou-se à medida que foram feitos os concursos, com normas que trouxeram melhores condições para o trabalho docente, o que atraiu inclusive professores de outros estados, como Santa Catarina, Rio 
Grande do Sul, Goiás, Distrito Federal e São Paulo, embora também exista docentes formados pela UFAM e UEA, do próprio estado.

Assim, apesar da distância métrica da capital Manaus e também em relação às principais centralidades do país, as ações provenientes do estado podem interferir neste processo de interiorização dos cursos de licenciatura de Geografia, criando melhores possibilidades de existência para tais cursos.

Contudo, ainda há problemas de infraestrutura nos cursos da UEA, mesmo em Manaus, devido à falta de laboratórios, de acervo bibliográfico mais diversificado, como relata um aluno da turma de Manaus:

O curso é novo. É a segunda turma a se formar e a biblioteca tem poucas obras, temos de ir a UFAM que é mais antiga. O nosso acervo é muito deficiente, com pouca coisa da Geografia. O bom em Manaus são os vários eventos acadêmicos; a gente também viaja para Belém e Boa Vista para eventos. Vai por conta própria, às vezes tem bolsa, mas só quem é bolsista de pesquisa. [...]. Já atividade de extensão não tem muita, só um professor que fez, mas era sobre saúde.

Dessa forma, ainda há necessidade de outras ações que contribuam para a melhoria dos cursos no Amazonas, tais como: que haja maior participação dos discentes em atividades acadêmicas, em projetos de extensão, ampliação do acervo bibliográfico, espaços de convivência para docentes e discentes próprios, já que há espaços da UEA que ainda são alugados.

Outra situação peculiar ocorre em Tabatinga (mapa 37), campus da UEA, com curso regular de licenciatura em Geografia. Trata-se de uma cidade com cerca 53000 habitantes (IBGE, 2010), localizada às margens do rio Solimões, com população predominantemente urbana, cuja localidade surgiu com os fortes portugueses pombalinos, no século XVIII. Entretanto, como município emancipado, tem apenas 29 anos, pois pertencia a Benjamin Constant.

A cidade situa-se na mesorregião do Alto Solimões e tem sua vida e conexões muito ligadas aos rios, principais interligações e acesso aos municípios da região, tais como São Paulo de Olivença, Atalaia do Norte e 
Benjamin Constant. Além disso, é uma cidade de fronteira, vizinha ao Peru e geminada com Letícia, departamento colombiano.

Devido à distância da capital (mapa 37), onde se concentram os eventos de Geografia, os docentes e discentes de Tabatinga participam em geral de atividades no município em seu entorno, na própria IES ou de outras áreas do conhecimento em Benjamin Constant, onde há cursos da UFAM.

Como afirma o coordenador do curso em Tabatinga, catarinense, geógrafo formado pela Fundação Universidade de Rondônia (UNIR) em Rondônia, mestre em Ciências Biológicas (Ecologia) pelo Instituto Nacional de Pesquisas da Amazônia:

Eventos geográficos se restringem a atividades da IES, algumas em Letícia e em Benjamin Constant que tem sede da UFAM. Nos grandes eventos, é mais difícil participar, mesmo para os professores. Para uma viagem daqui para Florianópolis é praticamente o mesmo preço de Tabatinga a Manaus, fica muito caro. Se for de barco de Tabatinga a Manaus são três dias, na volta são seis dias.

Então, a distância geométrica, acentuada pela dificuldade de mobilidade entre a cidade de Tabatinga e Manaus, em decorrência do pequeno número de voos e de seu alto custo, dificulta a participação de professores e alunos de eventos acadêmicos nacionais e mesmo na capital do estado.

Assim, há, ao menos, quatro situações de existência dos cursos de licenciaturas de Geografia no Amazonas pela UEA, a saber:

- Um de Manaus com curso regular e diversificado perfil de alunos, com maior possibilidade de participação em eventos geográficos;

- Outro de Manacapuru, município próximo a Manaus, com curso modular, com as peculiaridades do uso de apostila digital e de professores que vêm de Manaus;

- Em Manicoré, com curso pelo Parfor, para professores do Ensino Básico que já atuam na rede de Ensino, apenas no período de férias; 
- E, por fim, de Tabatinga, distante de Manaus, já na fronteira do Brasil com o Peru e Colômbia.

Verificam-se, nestas situações, que há especificidades que são produzidas pela própria IES, outras pela dinâmica do território e ainda provenientes do governo federal, como a política do Parfor.

Sendo assim, não há como entender a situação sem refletir sobre as ações existentes dos diferentes agentes que atuam no processo, nem tampouco sem considerar a dinâmica das IES no território.

\subsubsection{A situação dos cursos no interior do Acre}

A cidade de Rio Branco, capital do Acre ${ }^{114}$, centraliza a produção de bens e serviços do estado, entre eles a produção de conhecimento no Ensino Superior, mas, ao mesmo tempo, é uma cidade de porte médio, com 319825 habitantes (CENSO, 2010), que foi dotada de infraestrutura e funções administrativas, que a dinamizaram economicamente, como um centro diversificado, desde que se tornou capital do antigo território do Acre.

Considerando-se a premissa que toda centralidade e hierarquia urbanas são sempre relacionais, a cidade de Rio Branco é a principal centralidade do Acre, seguida do município de Cruzeiro do Sul. Em termos de Amazônia está distante do papel desempenhado por Manaus e Belém, as principais centralidades da região, constituindo-se, assim, num subcentro regional.

No que concerne à totalidade do território brasileiro, visto das cidades que são as principais centralidades da Região Concentrada, como é o caso de São Paulo e Rio de Janeiro, Rio Branco está distante dos principais centros de produção de bens e serviços, entre eles a Educação Superior.

114 O Acre foi incorporado ao Brasil em 1903, pelo Tratado de Petrópolis, e elevado a território em 1904, condição que durou até 1962, com administração direta do governo federal. 
Não há IES no interior do Acre, todas se concentram na capital e a única com curso de Geografia atualmente é a Universidade Federal do Acre (UFAC), cuja origem começou com a abertura de curso de Estudos Sociais no início da década de 1970; em 1979, foi criada a licenciatura plena em Geografia.

Os cursos de Geografia são oferecidos apenas em Rio Branco, nas modalidades licenciatura e bacharelado; somente licenciatura em Geografia nos municípios do interior: Brasiléia, Cruzeiro do Sul, Sena Madureira, Senador Guiomard e Tarauacá, cuja oferta ocorre em períodos intervalares, portanto não há campus no interior.

\begin{tabular}{|c|c|c|}
\hline \multicolumn{3}{|c|}{$\begin{array}{l}\text { Tabela 10- Dados dos municípios com cursos de } \\
\text { Licenciatura em Geografia no Acre }\end{array}$} \\
\hline Município & $\begin{array}{l}\text { População } \\
\text { (2010) }\end{array}$ & $\begin{array}{c}\text { Distância aproximada } \\
\text { da capital }(\mathrm{Km})\end{array}$ \\
\hline Rio Branco & 319825 & --- \\
\hline Brasiléia & 21011 & 234 \\
\hline Cruzeiro do Sul & 77323 & 648 \\
\hline Sena Madureira & 35555 & 145 \\
\hline Senador Guiomard & 19902 & 24 \\
\hline Tarauacá & 35058 & 400 \\
\hline
\end{tabular}

Fonte: Dados do Censo 2010 publicados no Diário Oficial da União do dia 04/11/2010.

Organizado por Vivian Fiori, 2012.

Conforme se observa, na tabela 10 , os dados de população revelam que se trata de municípios de pequeno porte, destacando-se Cruzeiro do Sul, com cerca de setenta e sete mil habitantes.

O coordenador do curso de licenciatura de Geografia da UFAC, formado em licenciatura em Geografia pela mesma instituição, com mestrado em Planejamento e Avaliação Educacional pela UFRJ, deu-nos um depoimento, em março de 2012, sobre as situações encontradas nos cursos do interior do Acre.

Segundo o coordenador, os cursos no interior foram criados mediante as novas leis de formação de professores, sobretudo devido à necessidade de os professores terem formação no Ensino Superior.

Esta norma federal levou a UFAC a criar dois Programas de formação de professores no interior do Estado: um na zona urbana, que começou em 1999; outro para professores da zona rural, a partir de 2005. 
Devido ao fato do corpo docente ser da capital, do curso sede, em Rio Branco, e considerando as dificuldades de deslocamento para o interior, todos os cursos do interior são modulares, ou seja, ministrados em períodos diferentes do funcionamento na capital.

$\mathrm{Na}$ área urbana, as aulas ocorrem ao longo do ano, dependendo da disponibilidade do docente; na zona rural, ocorre no período das férias de janeiro a março. Há seis polos com cursos de Geografia na capital e no interior.

As turmas formam-se com estudantes provenientes de seus municípios, que se deslocam para uma cidade sede do interior, sendo que, a cada quinze dias, as disciplinas são ministradas no Programa para a área urbana.

No interior, o perfil dos alunos tem as seguintes características: a maioria é formada por mulheres, na faixa etária de 30-40 anos, que já eram professoras e ministravam aulas há muito tempo. Segundo o coordenador, a maioria dos alunos tinha muita dificuldade de leitura e interpretação de textos acadêmicos, já que estudaram os Ensinos Fundamental e Médio principalmente em modalidades alternativas de ensino, mais aligeiradas ou a distância.

$\mathrm{Na}$ cidade de Rio Branco, os discentes são mais jovens, a maioria trabalha, e muitos têm dificuldades de se manter no curso devido à baixa renda; pela manhã oferece-se o curso de licenciatura e à tarde de bacharelado.

Em relação às leituras e bibliografia usadas nos cursos do interior, o coordenador disse:

No caso da bibliografia, fazíamos uma coletânea de textos, com um planejamento das disciplinas e como o curso era muito intensivo usávamos apostilas. Na capital tem uma biblioteca central com internet etc., mas para o interior, fazíamos um "apostilamento" do material da maneira mais compacto possível, para que ao menos eles tivessem uma noção das disciplinas, porque o aprofundamento que era comum nos cursos regulares não era possível devido ao tempo que o curso ocorria. 
Ocorrem, nestes casos, parcerias entre os municípios e a UFAC. As sedes dos cursos localizam-se em espaços públicos municipais ou estaduais, escolas ou não. São, portanto, espaços adaptados para o Ensino Superior, sendo assim não há bibliotecas, condição que tem relação com a produção de apostilas, cujo material didático é elaborado pelos professores de Rio Branco.

Os problemas oriundos das dificuldades de leitura na Educação Básica, que não tem diminuído mesmo com os processos avaliativos do governo, aliados à falta de acesso ao acervo de livros acadêmicos, dificultam o contato destes discentes com uma formação que Ihes possibilite uma análise crítica de textos do próprio curso.

Para ministrarem as aulas no interior pela UFAC, conta-se com professores da sede, Rio Branco. Caso estes não aceitem trabalhar no período de férias no interior, contratam professores especificamente para isso, normalmente especialistas.

Para estes docentes é complicado fazer pós-graduação em outros lugares, ir para outros centros, porque geralmente são casados e nem sempre conseguem conciliar família e mudança para outro estado.

Atualmente há alguns professores do curso com mestrado, mas, na própria IES, não existe pós-graduação stricto sensu em Geografia. Apesar disso, os dados sobre formação docente melhoraram em relação à década anterior, na qual a maioria era especialista.

\begin{tabular}{|c|c|c|c|c|c|c|}
\hline \multicolumn{5}{|c|}{ Tabela 11 - Características dos docentes dos cursos de licenciatura em } \\
Geografia da UFAC- 2009 (Números absolutos) \\
\hline \multicolumn{5}{|c|}{ FORMAÇÃo DOCENTE } & \multicolumn{2}{c|}{ REGIME DE TRABALHO } \\
\hline Graduação & Especialização & Mestrado & Doutorado & Tempo Integral & $\begin{array}{c}\text { Tempo } \\
\text { Parcial }\end{array}$ & Horista \\
\hline 4 & 1 & 37 & 8 & 50 & 0 & 0 \\
\hline
\end{tabular}

Fonte: INEP, 2009. Elaborado por Vivian Fiori, 2012.

Devido ao fato de Rio Branco ser uma cidade de porte médio e capital do estado, atrai professores de outras regiões, principalmente da Região Concentrada, sobretudo porque, mediante concurso, o professor é vinculado como docente em tempo integral, conforme se observa na 
tabela 11. Tem certa estabilidade econômica e pode, depois do período probatório, solicitar dispensa por certo tempo, para fazer doutorado.

Contudo, alguns optam por outros centros quando terminam o doutorado. Conforme diz o coordenador: "A Universidade virou trampolim e há um vaivém, porque tem gente que vem só com o interesse do doutorado e isso ocorre em todos os cursos, não só de Geografia".

Interessante observar que, apesar de estar na Amazônia, o movimento no território destes docentes de Geografia da UFAC na própria região é pequeno, já que a formação ou é no próprio Acre, ou ocorre em estados situados em outras regiões, principalmente da Região Concentrada.

Dessa forma, as cidades de Belém e Manaus não exercem influência direta na formação de professores de Geografia em Rio Branco.

\subsubsection{Rondônia e suas duas formas de extensão}

O estado de Rondônia foi criado em 1981, e sua situação é peculiar na Amazônia. Recebeu o maior número de imigrantes na região, nas últimas décadas, sendo atingido pelas frentes de expansão já na década de 1980, o que leva autores como Daniel Huertas (2009) a discutir se ainda se trata de uma "frente pioneira", pois esta se apresenta cada vez mais consolidada.

A colonização de Rondônia fez parte da estratégia do III Plano Nacional de Desenvolvimento (PND), de 1980-85, no qual o governo federal criou o Programa Integrado de Desenvolvimento do Noroeste do Brasil, promovendo um forte processo de ocupação na região entre o Mato Grosso e Rondônia, principalmente de sulistas do setor agropecuário, o que gerou um dos maiores desmatamentos da região amazônica. Tal situação intensificou-se nos governos seguintes, que possibilitaram o aumento de densidade técnica, principalmente dos sistemas de engenharia no território de Rondônia. 
A ocupação recente do Estado tem relação principalmente com o sistema rodoviário e com a implantação da BR- 364, que liga Porto Velho a Cuiabá, cujo modelo rodoviarista se impôs como meio de circulação de mercadorias no Estado e como sistema de objetos, que criou novos processos de urbanização em seu entorno, sob a ótica da fluidez do território e da ocupação da Amazônia com uma lógica capitalista (HUERTAS, 2009).

Cidades localizadas em torno da BR-364, como Vilhena, Ji-Paraná, Ariquemes e Rolim de Moura, cresceram dentro desta lógica do sistema rodoviário e se beneficiaram deste sistema, sobretudo com o asfaltamento da BR, o que ampliou a capilaridade no território de Rondônia.

Em termos de educação de nível superior, também há, em Rondônia, uma situação que a diferencia dos demais estados da Amazônia, já que a Universidade Federal de Rondônia (UNIR) é a única IES pública do Estado; criada em 1982, seu curso de Geografia entrou em funcionamento em 1983, localizado apenas na capital, ainda hoje como curso regular presencial.

Em depoimento, a coordenadora do curso de Geografia da UNIR disse que a Universidade deu prioridade a determinadas áreas no processo de interiorização, e a Geografia priorizou a graduação e seu recém-criado mestrado, fortalecendo o curso da capital, para depois pensar no interior.

Apesar disso, de 2000 a 2005, a UNIR criou cursos modulares em cidades do interior, nos municípios de Colorado, Ji-Paraná, Ariquemes, Rolim de Moura, Porto Velho e Jaru. Estes cursos funcionaram com cada disciplina sendo ministrada por uma semana. Cada professor fazia sua apostila, com um roteiro para as aulas.

Ocupavam, em geral, espaços das escolas locais e formaram seiscentos e sessenta professores, que ainda não tinham formação em Geografia. Atualmente, no interior, a UNIR só tem curso de Geografia pelo Parfor em Ji-Paraná.

As condições para ministrarem as atividades no Parfor são piores, segundo a coordenadora, por que: "[...] a gente vai para o lugar às 
quintas-feiras e tenta dar $60 \%$ da carga horária presencial e o restante a distância; antes nos cursos modulares as aulas eram melhor distribuídas e rendiam mais".

Esta situação demonstra os problemas destes cursos modulares, como, neste caso citado, do Parfor, já que as condições de trabalho, infraestrutura e organização dos cursos dificultam uma formação adequada e se diferenciam dos cursos regulares da capital.

No interior, havia até 2009, dois cursos de licenciatura em Geografia em IES privadas: nas Faculdades Integradas de Ariquemes (FIAR) e Faculdade de Rolim de Moura (FAROL), nesta o curso foi extinto recentemente.

A presença das IES privadas na capital e no interior é bastante marcante, diferentemente de outros estados da Amazônia. Em 2012, segundo sistema E-MEC, há 33 IES privadas em Rondônia e apenas 1 pública, o que indica o dinamismo econômico do Estado.

Ariquemes, com população de 90353 (IBGE, 2010), é um centro sub-regional que foi desmembrado de Porto Velho em 1977, já com um novo núcleo em torno da BR-364. O curso das FIAR foi criado em 2007; formado principalmente por alunos trabalhadores, atende a formação de professores da região.

Em relação aos cursos regulares da Universidade Federal de Rondônia (UNIR), em Porto Velho, e das Faculdades Integradas de Ariquemes (FIAR), em Ariquemes, há algumas situações em comum na condição do discente, conforme se verifica na tabela 12 .

A maioria absoluta dos alunos das duas IES tem baixa renda, estudou em escola pública e trabalha. Nas FIAR, o curso é noturno e, na UNIR, vespertino, o que segundo os coordenadores, traz alguns problemas aos cursos, porque são alunos com pouco tempo para estudar e participar de pesquisas, embora, na UNIR, alguns tenham bolsas; nas FIAR, não. 


\begin{tabular}{|c|c|c|c|c|}
\hline \multicolumn{5}{|c|}{ Tabela 12- Características dos discentes dos cursos de licenciatura em } \\
Geografia em Rondônia- 2008 (\%)
\end{tabular}

Fonte: Inep, Relatórios dos cursos de Geografia por IES, Enade, 2008.

Elaborado por Vivian Fiori, 2012. Obs. Dados dos ingressantes dos cursos.

Todavia, há variáveis nas quais se evidenciam as principais diferenças dos dois cursos. O primeiro em relação à análise dos discentes sobre o curso e de como foi sua contribuição. Enquanto os das FIAR responderam que a contribuição foi muito boa (54,5\%), na UNIR, apenas $7,1 \%$ dos alunos assinalaram a mesma resposta. Assim como os discentes das FIAR têm maior interesse em se tornarem professores comparados com os da UNIR.

Em relação à formação dos docentes há a maior diferença (Tabela 13), uma vez que, nas FIAR, a maioria absoluta é de especialistas, cujo regime de trabalho é horista; enquanto, na UNIR, é formada principalmente por doutores, todos com regime integral, conforme a norma federal.

Há, portanto, duas extensões, uma que possibilita a formação de doutores ou atraí doutores formados em outros estados; outra com trabalho horista e sem permissão de ausência para cursar mestrado na capital, o que dificulta ainda mais a possibilidade de maior qualificação destes professores.

\begin{tabular}{|c|c|c|c|c|c|c|}
\hline \multicolumn{6}{|c|}{$\begin{array}{c}\text { Tabela 13- Características dos docentes dos cursos de licenciatura em } \\
\text { Geografia em Rondônia (números absolutos) }\end{array}$} \\
\hline \multirow{2}{*}{ IES/CIDADE } & \multicolumn{5}{|c|}{ FORMAça DOCENTE } & \multicolumn{2}{c|}{ REGIME DE TRABALHo } \\
\cline { 2 - 7 } & Especialização & Mestrado & Doutorado & $\begin{array}{c}\text { Tempo } \\
\text { Integral }\end{array}$ & $\begin{array}{c}\text { Tempo } \\
\text { Parcial }\end{array}$ & Horista \\
\hline FIAR- Ariquemes & 14 & 4 & 1 & 3 & 2 & 14 \\
\hline UNIR- Porto Velho & 1 & 2 & 11 & 14 & 0 & 0 \\
\hline
\end{tabular}

Fonte: INEP, 2009. Elaborado por Vivian Fiori, 2012.

Segundo a coordenadora da UNIR:

A maioria dos nossos professores veio de fora; só quatro são de Rondônia. Temos professores do Pará, Amazonas, São Paulo, Santa Catarina e Rio de Janeiro. Eu saí graduada pela Universidade Federal de Santa Catarina e fui me formar na 
pós-graduação depois. Naquela época aceitavam graduados e dou aula na UNIR desde 1989, hoje a maioria é doutor. Não tinha mestrado aqui e tínhamos que ir para o Centro-Sul fazer mestrado, hoje tem tudo aqui. Agora é mais fácil sair para fazer doutorado. Fazemos uma escala, mas priorizamos a capacitação de todos; a maioria na USP e UNESP.

A relação dessa formação docente da UNIR ocorre principalmente com o estado de São Paulo, mas também com professores do Pará e do Amazonas, diferentemente do que ocorre com a UFAC em Rio Branco.

O coordenador da licenciatura em Geografia nas FIAR, formado em Geografia pela Universidade Estadual da Paraíba, com especialização em Gestão Ambiental pelas FIAR, relaciona mais um elemento que dificulta a qualificação dos docentes de sua IES - a rede de relações as quais os docentes desta IES estabeleceram, com pouco contato com o Centro-Sul, assim como até mesmo com a capital.

Por isso, além dos elementos já citados anteriormente, os docentes das FIAR optam, talvez por falta de possibilidades, em cursar especialização na própria instituição.

Logo, há duas formas de extensão. A primeira do curso de Geografia da capital, de uma IES federal, criada em 1983, que não se interiorizou; a outra, uma IES privada, com curso de licenciatura em Geografia, no interior, com diferentes valores, sobretudo relacionados à dimensão docente, à existência de bolsas de pesquisa, e ao interesse em ser professor.

Há mais disponibilidades nos cursos da UNIR em termos de infraestutura (laboratórios), bolsas de iniciação científica e de extensão, de terem contato com professores doutores. Isto, contudo, não leva os estudantes da UNIR a aumentarem seu interesse em ser professor, quer porque tenham outras possibilidades de formação, caso do bacharelado, quer porque tenham outros interesses em sua formação. 


\subsubsection{Os cursos da Fundação Universidade Federal do Tocantins no interior do estado do Tocantins}

Tocantins é o único estado brasileiro que não tem curso de licenciatura em Geografia na modalidade regular, presencial, na capital. O estado foi criado em 1988, e mais da metade seu território é formado por áreas de preservação, de unidades de conservação e rurais. A maioria dos municípios de Tocantins é de pequeno porte, com menos de $10 \mathrm{mil}$ habitantes (IBGE, 2010).

Atualmente há cursos de Geografia apenas pela Fundação Universidade Federal do Tocantins (UFT), em Porto Nacional, com licenciatura e bacharelado, e, em Araguaína, só com licenciatura. Havia também, em 2009, um curso de licenciatura e bacharelado em Geografia no município de Colinas do Tocantins, pela Faculdade Integrada de Ensino Superior de Colinas (FIESC), mas está em processo de extinção.

O curso de Geografia na cidade de Porto Nacional é mais antigo (1998) e pertencia à Universidade do Tocantins (UNITINS ${ }^{115}$ ). Quando houve a federalização, e o patrimônio foi passado à UFT em 2000, já existia o curso de Geografia nas duas modalidades licenciatura e bacharelado.

A cidade é antiga, de pequeno porte, com 49012 habitantes (IBGE, 2010), situada a cerca de $60 \mathrm{Km}$ de Palmas, que é a sede da UFT, e foi criada para ser a capital do Tocantins. Devido à proximidade entre as cidades, alguns professores de Porto Nacional moram em Palmas.

O coordenador do curso de Geografia em Porto Nacional, formado em Geografia pela Universidade Estadual de Goiás (UEG), com mestrado em Geografia pela Universidade Federal de Uberlândia (UFU), revela que:

\footnotetext{
115 Segundo o site da UNITINS, a instituição foi criada em 1990, como autarquia estadual; depois a autarquia foi extinta e foi autorizada a criação da então Fundação Universidade do Tocantins, constituída como uma Fundação pública de direito privado, mantida por entidades públicas e particulares, com apoio do governo do estado. Em 2000, mediante acordo, passou parte de seu patrimônio para a UFT, dos cursos regulares e da infraestrutura. Em Colinas do Tocantins, onde também havia curso de Geografia, houve transferência para a Faculdade Integrada de Ensino Superior de Colinas (FIESC).
} 
Todos os professores dão aulas nos dois cursos. O aluno pode cursar as disciplinas e circular tanto na licenciatura como no bacharelado, mas nestes casos fazem novo vestibular. O curso tem melhorado muito de 2008 para cá, nós usamos a avaliação do Enade para discutir e reestruturar o curso. A maioria dos professores está qualificado com mestrado e está fazendo doutorado. São professores provenientes principalmente de Goiás, Rio Grande do Sul, São Paulo e Minas Gerais.

Até recentemente os cursos eram totalmente juntos. Há ainda relação entre os dois cursos, já que, ao fazerem novo vestibular, ficam dispensados das disciplinas consideradas específicas, comuns às duas habilitações.

Esta condição de currículos de bacharelado e licenciatura juntos é comum em cursos da Amazônia das IES federais; só muito recentemente há aplicação das normas legais dos cursos de licenciaturas, condição esta de que se tratou anteriormente no item sobre currículos de Geografia no Brasil, na seção 4.

A situação apontada pelo coordenador na melhoria do curso referese ao fato que, nas variáveis da dimensão infraestrutura, os dados do questionário aplicado aos discentes de 2008 apontam problemas nos espaços em geral, laboratórios, acervos bibliográficos etc., tanto em Porto Nacional como em Araguaína.

\begin{tabular}{|l|c|c|c|c|c|}
\hline \multicolumn{7}{|c|}{ Tabela 14- Características dos cursos de licenciatura em Geografia no } \\
MUNICípIo & $\begin{array}{c}\text { Renda do } \\
\text { Discente até } \\
\text { 3 salários } \\
\text { mínimos }\end{array}$ & $\begin{array}{c}\text { A principal } \\
\text { opção ao fazer } \\
\text { a licenciatura é } \\
\text { porque quer } \\
\text { ser professor }\end{array}$ & $\begin{array}{c}\text { Uso de } \\
\text { internet } \\
\text { para } \\
\text { pesquisar }\end{array}$ & $\begin{array}{c}\text { Não participa de } \\
\text { nenhuma } \\
\text { atividade no } \\
\text { curso, além da } \\
\text { obrigatória }\end{array}$ & $\begin{array}{c}\text { Currículo } \\
\text { integrado } \\
\text { por áreas } \\
\text { afins }\end{array}$ \\
\hline Araguaína & 85,7 & 25,0 & 46,4 & 60,7 & 39,3 \\
\hline Porto Nacional & 57,1 & 0,0 & 28,6 & 71,4 & 71,4 \\
\hline
\end{tabular}

Fonte: Inep, Relatórios dos cursos de Geografia por IES, Enade, 2008.

Elaborado por Vivian Fiori, 2012.

Como se vê, na tabela 14, a maioria dos alunos das duas licenciaturas é formado por estudantes de baixa renda, que não participam de qualquer atividade do curso, além das obrigatórias, e que não pretende ser professor.

Verifica-se que, em Araguaína, onde só há licenciatura, o desejo de ser professor é um pouco maior. Mas, nos dois cursos, o maior número de 
alunos respondeu que a principal opção ao fazer a licenciatura é "para ter outra opção se não conseguir exercer outro tipo de atividade", com aproximadamente 31\%; em Araguaína, também 25\% responderam que "este é o único curso perto de sua casa". Esta resposta dada por 25\% dos discentes demonstra a pequena inserção do Ensino Superior em Araguaína, que além da UFT tem mais duas IES privadas.

Outro elemento analisado concerne à questão da integração do currículo. Em Araguaína, a maioria respondeu que o curso "É bem integrado e há clara vinculação entre as disciplinas (53,5\%)". Em Porto Nacional, a maioria absoluta $(71,4 \%)$ assinalou a alternativa "É relativamente integrado, já que as disciplinas se vinculam apenas por blocos ou áreas de conhecimento afins"; os demais, 28,6\%, com a alternativa "É pouco integrado, já que poucas disciplinas se interligam".

Isso demonstra que, em cursos cujos currículos de bacharelado e licenciatura são juntos, é mais comum que este não seja tão integrado, bem como o desejo de tornar-se professor também seja menor. Ou seja, a mistura dos perfis, faz com que a integração curricular seja menor ou exista só por áreas afins.

Em Araguaína, o curso é também regular e presencial. O município, de médio porte, conta com 149313 habitantes (IBGE, 2010), com a segunda maior população e concentração de serviços, principalmente de saúde do estado e tem na pecuária extensiva sua principal atividade econômica. Trata-se de uma centralidade do norte de Tocantins, que dista cerca de $350 \mathrm{~km}$ de Palmas, e é cortado pela rodovia Belém-Brasília (BR-153), que dinamizou a região a partir do agronegócio, mas que coexiste com problemas de infraestrutura, migrações e pobreza.

Atualmente a equipe de professores conta com quatro doutores, e os demais, mestres, a maioria do Nordeste, principalmente da Paraíba, devido às redes de relações que se estabeleceram há algumas décadas com a Paraíba. Segundo depoimento de dois professores do curso há grande mobilidade de docentes, já que são quase todos de outros estados e nem sempre se adaptam a região. 
Alegam que a infraestrutura da cidade é pequena, com poucos serviços e, pelo fato de não possuir aeroporto há dificuldade destes professores para viajar para seus estados de origem, assim como devido ao clima quente, o que afasta o interesse de alguns docentes. Os alunos são da região, nasceram ou moram em Araguaína, mas há estudantes do Maranhão e Piauí, por exemplo, estados limítrofes com o norte do Tocantins.

Um professor do curso em Araguaína, formado em Geografia pela UFPB, com mestrado em Geografia pela UFU e doutorado pela USP, contou como foi trabalhar na cidade, vindo de João Pessoa, na Paraíba:

[...] quando surgiram duas vagas em 1994, na antiga UNITINS, e a coordenadora Jacira Garcia também conterrânea entrou em contato com a coordenação do curso na UFPB, perguntando se eu queria me submeter a ir ao Tocantins para assumir "Prática de Ensino em Geografia" e "Geografia Regional", eu aceitei. Fui submetido à avaliação do meu currículo e de imediato fui contratado, ficando na UNITINS até 2003, quando fiz o concurso para o UFT nesse mesmo ano. É importante retratar que a mão de obra qualificada era quase inexistente, 0 estado estava começando. [...] Quanto à adaptação foi difícil no inicio, pois vinha de uma capital estruturada e de repente chego numa cidade interiorana em que de certa maneira faltava muita coisa. Mas o meu objetivo era maior, era crescer profissionalmente.

A situação retratada pelo professor era muito comum no interior de vários estados, onde a formação de docentes com mestrado/doutorado era rara. Há duas décadas, era muito comum graduados serem professores universitários, tanto pelo interior como nas capitais, situação que ainda persiste, mas é menos comum.

Esta dificuldade inicial em uma nova cidade, e o desejo de ir embora à medida que se estabelece financeiramente ou consegue aprovação em novo concurso que permita sair do interior do país, foram citados por alguns dos entrevistados que lecionam na Amazônia. Embora também existam aqueles já estão adaptados e não pensam em voltar, caso do professor citado da UFT. 
Outro professor, ex-docente do campus Araguaína, atual docente da UFPA, campus Marabá, com graduação em Geografia pela UFRGS, mestrado pela UERJ, doutorado pela UFMG, comenta sobre o curso em Araguaína:

É uma cidade carente de infraestrutura. O campus se for comparado com grandes IES de SP e RJ é pequeno, mas tem uma biblioteca $[\ldots]$ a bibliografia básica tem, que consta no plano de ensino. Tinha extensão e iniciação científica, com editais, da Capes e CNPq, sempre com menos vagas, mas tem. Mas os alunos não têm cultura universitária, de ter restaurante acadêmico, de ficar estudando no campus além da sala de aula, isto ocorre também em Marabá. [...] 0 currículo não está bem integrado, a maioria trabalha numa licenciatura e quer formar um bacharel e neste curso atual caminha no mesmo sentido.

A discussão apontada pelo professor corrobora outras situações verificadas em outros lugares do Brasil. A primeira diz respeito ao fato de que há mais participação das IES federais em editais de iniciação científica e de extensão, embora não seja grande o número de bolsas, dando a possibilidade de participação dos discentes em alguns projetos.

Outra é que, se comparado a algumas IES públicas, o discente dos cursos de licenciatura em Geografia que se interiorizaram recentemente não tem tempo disponível para conviver no espaço da Universidade, além do horário da aula, tanto porque trabalha, quanto porque a IES não dispõe de espaço próprio para cada grupo de professores, nem espaços de convivência e de estudos para discentes.

Então esta convivência além do horário de aulas é pouco comum, assim como o mesmo também ocorre nas IES municipais e privadas. Esta cultura acadêmica, de estudar, ter orientação extraclasse, depende muito de outros fatores além do discente.

Depende, sobretudo, do regime de trabalho do docente, com tempo de trabalho além da sala de aula e de espaços de convivência a estudos na IES. 


\subsection{A interiorização dos cursos de Geografia no Maranhão e no Piauí}

O Maranhão e Piauí, além de serem estados contíguos, têm muito em comum em relação aos cursos de licenciatura em Geografia e seu processo de interiorização. Ambos tiveram a maior expansão de cursos de Geografia pelo interior do Brasil, nas últimas duas décadas, realizada por IES estaduais principalmente em municípios de pequeno porte.

Como se observa na tabela 15, segundo discentes que fizeram o Enade 2008, percebe-se que, em todas as variáveis analisadas, a maioria absoluta dos discentes tem renda familiar até 3 salários mínimos, estudou só em escola pública, quer ser professor e, em seu curso, usou-se apostila como principal material didático.

São os valores mais altos do Brasil para a baixa renda, para o elemento "quer ser professor" e para o uso de apostila no curso.

\begin{tabular}{|c|c|c|c|c|c|}
\hline \multicolumn{6}{|c|}{ Tabela 15 - Características de alguns cursos de licenciatura em Geografia - } \\
Maranhão e Piauí - 2008 (\%) \\
MUNICÍPIo & UF & $\begin{array}{c}\text { Renda familiar } \\
\text { do discente - até } \\
\text { 3 Salários }\end{array}$ & $\begin{array}{c}\text { O discente } \\
\text { estudou só em } \\
\text { Escola Pública }\end{array}$ & $\begin{array}{c}\text { O Discente } \\
\text { quer ser } \\
\text { Professor }\end{array}$ & $\begin{array}{c}\text { Uso de Apostila } \\
\text { no curso }\end{array}$ \\
\hline $\begin{array}{c}\text { Altamira do } \\
\text { Maranhão }\end{array}$ & MA & 78,3 & 62,5 & 78,3 & 87 \\
\hline Araioses & MA & 58,6 & 79,3 & 96,6 & 89,7 \\
\hline Barra do Corda & MA & 76,5 & 47,1 & 94,1 & 82,4 \\
\hline Bernardo do Mearim & MA & 84,2 & 63,2 & 89,5 & 78,9 \\
\hline Anísio de Abreu & PI & 100 & 94,1 & 88,2 & 100 \\
\hline Esperantina & PI & 100 & 100 & 90 & 100 \\
\hline Luzilândia & PI & 88,6 & 91,4 & 88,6 & 97,1 \\
\hline Palmeirais & PI & 100 & 78,6 & 100 & 85,7 \\
\hline
\end{tabular}

Fonte: Inep, Relatórios dos cursos de Geografia por IES, Enade, 2008. Elaborado por Vivian Fiori, 2012. Obs. Nesta tabela constam apenas alguns cursos do Maranhão e Piauí como exemplo.

Estas licenciaturas, em municípios de pequeno porte, ocorreram na forma modular, na maior parte dos casos, mas não ocorreram apenas no período de férias como na Amazônia, por exemplo.

São cursos gratuitos, ministrados por IES estaduais, principalmente no período matutino ou vespertino, que ocorrem em espaços cedidos para esta finalidade, geralmente de escolas públicas da Educação Básica, sem a 
infraestrutura básica necessária para o desenvolvimento das atividades acadêmicas.

Destaca-se, como exemplo, o município de Palmeirais, com 13745 habitantes (IBGE, 2010), situado na porção oeste do Piauí, no limite com o Maranhão - com o rio Parnaíba. Trata-se de uma cidade de pequeno porte, com a maioria da população trabalhando na área de serviços, geralmente funcionários públicos, cujo curso atendeu principalmente àqueles professores que tinham o Magistério e precisavam se qualificar com o Ensino Superior, de acordo com a norma atual do MEC.

Conforme se verifica na tabela 16, a maioria trabalha cerca de $40 \mathrm{~h}$ semanais, é de família de baixa renda, cujos pais têm baixa escolaridade. No caso de Palmeirais, $90 \%$ responderam que o pai "não tem nenhuma escolaridade" (40\%) ou tem o "Ensino Fundamental de $1^{\text {a }}$ a $4^{\text {a }}$ séries" $(50 \%)$, o que demonstra que os filhos estão alcançando maior escolaridade do que os pais, situação comum em outras regiões do Brasil.

\begin{tabular}{|c|c|c|}
\hline \multicolumn{3}{|c|}{$\begin{array}{c}\text { Tabela } 16 \text { - Dados do curso de Licenciatura em Geografia em } \\
\text { Palmeirais- Piauí- } 2008(\%)\end{array}$} \\
\hline Elemento & Resposta da maioria & $\%$ \\
\hline Declaração da cor/raça & - Pardo & 50 \\
\hline $\begin{array}{c}\text { Se trabalha ou já trabalhou, qual é } \\
\text { (ou foi) a carga horária } \\
\text { aproximada de sua atividade } \\
\text { remunerada? (Não contar estágio } \\
\text { e bolsas de pesquisa.) }\end{array}$ & $\begin{array}{l}\text { - Trabalho/trabalhei em tempo } \\
\text { integral - } 40 \text { horas semanais ou } \\
\text { mais. }\end{array}$ & 92,9 \\
\hline Grau de escolaridade do pai & - $\begin{array}{l}\text { Ensino Fundamental: de } 1^{a} \text { a } 4^{a} \\
\text { série. }\end{array}$ & 50 \\
\hline $\begin{array}{l}\text { Que tipo de curso de Ensino Médio } \\
\text { concluiu? }\end{array}$ & $\begin{array}{l}\text { - Profissionalizante magistério de } 1^{a} \\
\text { a } 4^{a} \text { (Curso Normal), no ensino } \\
\text { regular. }\end{array}$ & 92,9 \\
\hline $\begin{array}{l}\text { Que fonte(s) mais utilizou ao } \\
\text { realizar as atividades de pesquisa } \\
\text { para as disciplinas do curso? }\end{array}$ & $\begin{array}{l}\text { - Livros e (ou) periódicos de minha } \\
\text { propriedade. }\end{array}$ & 57,1 \\
\hline $\begin{array}{l}\text { Com que freqüência utiliza } \\
\text { microcomputador? }\end{array}$ & - Nunca & 42,9 \\
\hline $\begin{array}{c}\text { Como são as instalações físicas } \\
\text { (salas de aula, laboratórios, } \\
\text { ambientes de trabalho / estudo) } \\
\text { utilizadas no curso? }\end{array}$ & $\begin{array}{l}\text { - Mal arejadas, mal iluminadas, com } \\
\text { mobiliário inadequado e pequenas } \\
\text { em relação ao número de } \\
\text { estudantes. }\end{array}$ & 64,3 \\
\hline $\begin{array}{l}\text { O curso oferece cursos/projetos de } \\
\text { extensão? }\end{array}$ & $\begin{array}{ll}\text { - } & \text { Não sei responder } \\
\text { - } \quad \text { Não oferece }\end{array}$ & $\begin{array}{l}42,9 \\
42,9\end{array}$ \\
\hline
\end{tabular}

Fonte: Inep, Relatórios dos cursos de Geografia por IES, Enade, 2008.

Elaborado por Vivian Fiori, 2012. 
Em relação às instalações para o curso, 64,3\% responderam que são "Mal arejadas, mal iluminadas, com mobiliário inadequado, e pequenas em relação ao número de estudantes". Usam principalmente apostila no curso e recorrem aos seus próprios livros para estudar $(57,1 \%)$, posto que não há biblioteca. Verifica-se que o acesso ao computador também é pequeno, o que não possibilita contato com outros tipos de bibliografias.

Em suma, é um conjunto de elementos que apontam problemas que integrados dificultam à formação destes alunos. Estão relacionados à dimensão de infraestrutura e da condição do discente, bem como à dos docentes, que se discutirá a seguir.

Outro município com curso no interior do Piauí é Pedro II, com 36895 habitantes (IBGE, 2010). Situa-se ao norte do estado, no limite com o Ceará, a cerca $200 \mathrm{~km}$ da capital Teresina. Atualmente tem uma turma à noite e outra pela manhã, mas não há definição sobre se haverá continuidade desta última, provavelmente abrirão novas turmas no município de Piri-Piri. Para uso do espaço para a realização do curso, foi feito um acordo de comodato entre a UESPI e o governo do Estado do Piauí, por dez anos, podendo ser prorrogado.

Eles têm um pequeno acervo de bibliografia, mas esta dá um suporte mínimo e não atende totalmente ao curso. Os professores fazem o plano da disciplina, baseando-se no projeto pedagógico. Geralmente fazem a apostila, com conteúdos da disciplina, quando não há livro no acervo.

Os discentes de Pedro II têm baixa renda e precisam trabalhar para complementar a renda familiar, alguns trabalham em pequenos plantios; outros atuam na educação, a idade dos alunos varia de 20 a 30 anos atualmente. Um ex. aluno do curso, da turma de 2007-2011 do núcleo de Pedro II, comentou sobre as condições do curso:

O governo espalhou a UESPI no interior e não ofereceu infraestrutura adequada; existem problemas na qualidade dos cursos. Em Pedro II, no início de nossa turma, muitos professores só tinham graduação ou especialização só depois 
alguns foram fazendo mestrado [...] Com o passar do tempo, mesmo o curso, não tendo qualidade tão boa, eu gostei da área, de estudar e de ser professor. Na cidade não tem muitos cursos e optei por acaso por Geografia, mas me identifiquei. Em Pedro II só tinha licenciaturas.

Este depoimento reforça as situações comuns nos cursos do interior do Piauí, com problemas de infraestrutura e também de formação do docente, que geralmente é graduada ou especialista - embora atualmente haja exceções. Outro aspecto refere-se à afirmação de que, mesmo o curso tendo algumas deficiências, o aluno avalia que gostou de fazê-lo e que pretende ser professor de Geografia.

A possibilidade de tornar-se professor numa cidade de pequeno porte, onde não existem IES e nem variedade de cursos, onde a possibilidade de emprego público é maior, sobretudo na Educação, faz com que um curso de Ensino Superior tenha significado especial para estes futuros professores.

Os cursos do interior do Piauí são ministrados por professores da Universidade Estadual do Piauí (UESPI), concursados ou contratados especificamente para este fim, sendo normalmente horistas. Os docentes do curso de Pedro II são oriundos principalmente de Teresina ou Piri-Piri, município próximo. O coordenador do Núcleo da UESPI em Pedro II, formado em História e Letras pela UESPI, comenta sobre a questão docente:

Alguns professores têm especialização outros só são graduados. É complicado porque só tem pós-graduação na Federal do Piauí; na estadual está em projeto o mestrado em Geografia. A maior dificuldade de estudarmos é ter tempo; a administração pública alega que não pode colocar substituto o que faz com que não tenhamos tempo disponível para estudar. O horário do curso tenta contemplar interesses de todos. Quem é de Teresina, tem uma forma de horário, vem um dia e fica para o dia seguinte [...]

No Piauí, em 2012, há apenas cursos de Geografia em IES públicas: um em Teresina pela Universidade Federal do Piauí; outros pela Universidade Estadual do Piauí (UESPI), na capital e no interior.

A capital Teresina, com 797029 habitantes (IBGE, 2010), é a principal centralidade do estado do Piauí e mantém relações econômicas 
principalmente com a região Centro-Sul do Maranhão e com o norte de Tocantins. Em Teresina, que tem a peculiaridade de ser a única capital não litorânea do Nordeste brasileiro, se concentra o maior número de IES e diversidade de cursos do estado do Piauí.

\begin{tabular}{|c|c|c|c|c|c|c|c|}
\hline \multicolumn{6}{|c|}{ Tabela 17 - Características dos docentes dos cursos de licenciatura em Geografia do } \\
Maranhão e Piauí - 2009 (números absolutos) \\
\hline \multirow{2}{*}{ IES } & \multicolumn{5}{|c|}{ FORMAÇão DOCENTE } & \multicolumn{2}{c|}{ REGIME DE TRABALHO } \\
\cline { 2 - 8 } & Graduação & Especialização & Mestrado & Doutorado & $\begin{array}{c}\text { Tempo } \\
\text { Integral }\end{array}$ & $\begin{array}{c}\text { Tempo } \\
\text { Parcial }\end{array}$ & Horista \\
\hline UFPI & 10 & 9 & 35 & 29 & 75 & 8 & 0 \\
\hline UESPI & 7 & 33 & 19 & 0 & 30 & 29 & 0 \\
\hline UFMA & 1 & 3 & 7 & 11 & 22 & 0 & 0 \\
\hline UEMA & 7 & 20 & 26 & 3 & 13 & 39 & 4 \\
\hline
\end{tabular}

Fonte: INEP, 2009. Elaborado por Vivian Fiori, 2012.

Observando-se a tabela 17, sobre as características docentes dos cursos de licenciatura em Geografia, dados do Inep de 2009, referentes à Universidade Federal do Piauí (UFPI), à Universidade Estadual do Piauí (UESPI), à Universidade Federal do Maranhão (UFMA) e à Universidade Estadual do Maranhão (UEMA) revelam que a qualificação docente das IES federais é maior do que as estaduais, tendo maior número de professores mestres e doutores. Contudo, mesmo nestas IES há só graduados.

Em relação ao regime do trabalho, as melhores condições, com "tempo integral", encontram-se nas federais, mas mesmo nelas há docentes em tempo parcial. Isto faz com que a situação dos cursos tenha relação com o território, mas também com o tipo de organização da IES. A maioria dos docentes fez graduação no próprio estado, sendo incomum que haja docentes provenientes de outros estados.

No Maranhão, a UFMA só tem curso de licenciatura em Geografia na capital, São Luís. Na Universidade Estadual do Maranhão (UEMA), há o Programa de Qualificação Docente (PQD), cujos cursos são temporários, modulares. Em São Luís, Caxias e Imperatriz há campus da Universidade. Em 2012, segundo o coordenador do curso de Geografia, do campus de Caxias, apenas os cursos regulares estão ocorrendo, já que recentemente os cursos modulares, que eram temporários, situados nas cidades de pequeno porte terminaram (mapa 38 ). 


\section{População dos Municípios do Maranhão com Cursos de Licenciatura em Geografia}

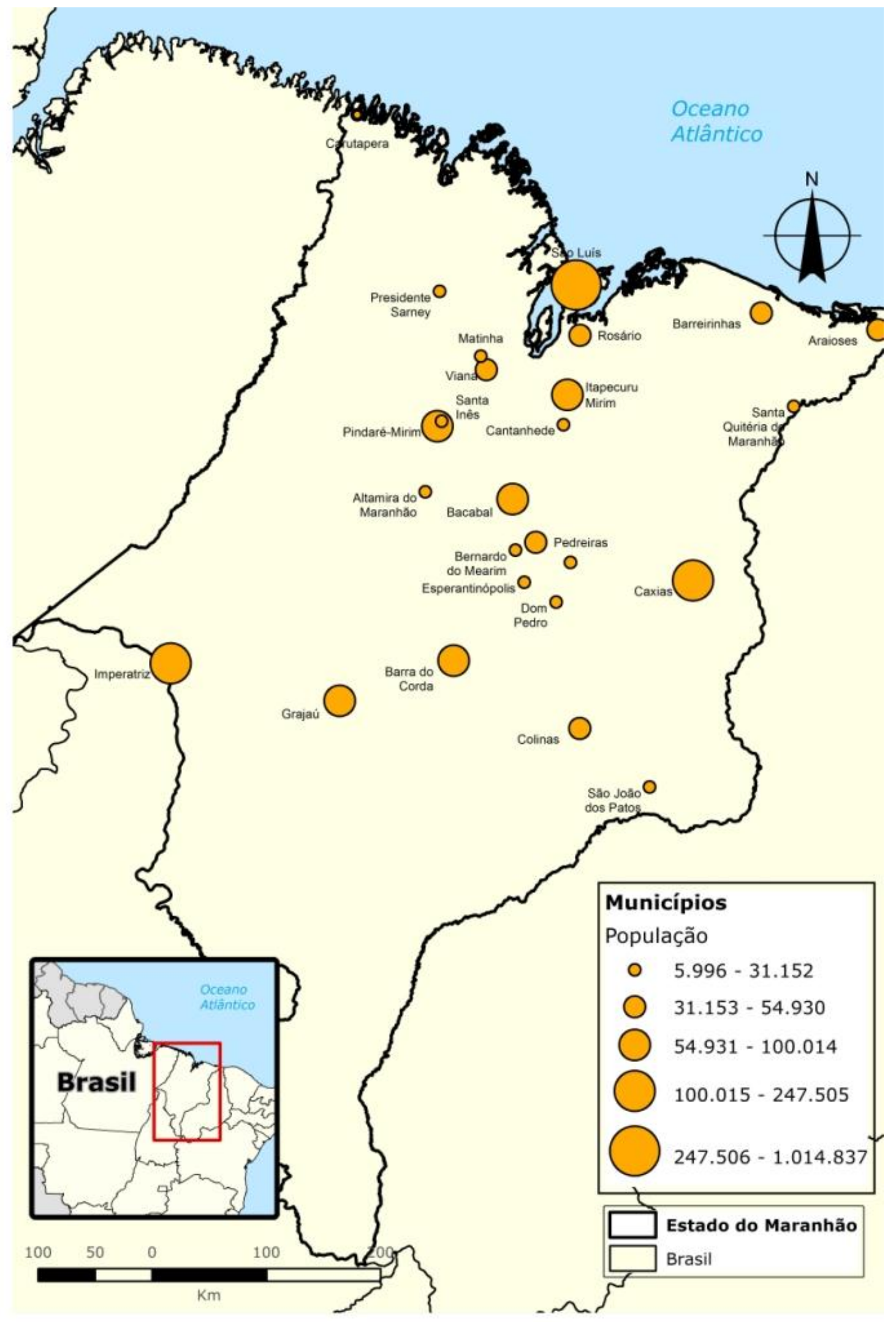

Mapa 38- Fonte: Dados E-MEC, 2009, população IBGE (2010).

Elaborado por Maurício Yamada, 2012. 
Logo, há duas situações que se integram e se relacionam aos cursos: o território, com suas condicionantes sociais, políticas e educacionais; os tipos de IES com suas ações em relação à política docente e de existência e expansão dos cursos, criando dois tipos de extensão. Como exemplos, destacam-se alguns cursos do Maranhão, tabela 18 , nos quais estas duas situações estão evidenciadas.

\begin{tabular}{|c|c|c|c|c|c|}
\hline \multicolumn{6}{|c|}{$\begin{array}{c}\text { Tabela 18- Comparação de alguns cursos de licenciatura em Geografia } \\
\text { no Maranhão }\end{array}$} \\
\hline IES & Município & $\begin{array}{c}\text { População } \\
2010 \\
\text { (habitantes) }\end{array}$ & $\begin{array}{c}\text { Renda do } \\
\text { discente até } 3 \\
\text { salários mínimos } \\
\%\end{array}$ & $\begin{array}{l}\text { Uso de apostila } \\
\text { no curso } \\
\%\end{array}$ & $\begin{array}{l}\text { O discente quer ser } \\
\text { professor } \\
\%\end{array}$ \\
\hline UFMA & São Luis & \multirow{2}{*}{966.989} & 25,5 & 0,0 & 17,0 \\
\hline \multirow{3}{*}{ UEMA } & São Luis & & 52,9 & 5,9 & 64,7 \\
\hline & Imperatriz & 245.509 & 42,9 & 47,6 & 81,0 \\
\hline & Santa Inês & 38.779 & 70,8 & 91,7 & 83,3 \\
\hline
\end{tabular}

Fonte: Inep, Relatórios dos cursos de Geografia por IES, Enade, 2008.

Elaborado por Vivian Fiori, 2012.

$\mathrm{Na}$ UFMA, onde há curso de licenciatura e bacharelado em Geografia, a renda dos alunos é maior do que os da UEMA, ambas em São Luís, ao mesmo tempo em que o percentual dos que querem ser professor é de apenas $17 \%$ em relação à UEMA cujos $64,7 \%$ dos estudantes querem ser professor.

Se considerarmos apenas os cursos da UEMA, há diferenças importantes em relação à capital, São Luís, a principal centralidade do estado. Em Imperatriz (ver mapa 38), cidade de porte médio e principal centralidade do sul do Maranhão, há campus da UEMA; em Santa Inês, há curso do Programa de Qualificação Docente (PQD), modular, temporário, sem campus.

Em Santa Inês, cidade de pequeno porte, na qual o curso não é regular, há o maior número de discentes com renda abaixo de 3 salários mínimos, maior uso de apostilas, pouca leitura diversificada e maior número de estudantes que desejam tornar-se professor.

A dinâmica da cidade e seu papel na divisão territorial do trabalho interferem na criação do campus da UEMA, influindo em várias dimensões, tais como: discente, docente e infraestrutura. No que diz respeito ao 
campus, no caso de Imperatriz, cidade importante do sul do Maranhão, a infraestrutura é melhor, o curso é regular, e os docentes vivem no próprio município ou na região deste, diferentemente ao que ocorre em Santa Inês.

Ou seja, a mesma instituição apresenta diferentes situações, com suas diferentes ações e formas espaciais, conforme mudam os lugares. $O$ território torna-se agente, na medida em que atrai o campus por ser uma centralidade de maior nível hierárquico, e isto altera o valor dos elementos destacados.

\subsection{Os cursos de Educação a Distância em Geografia}

Além deste processo complexo de interiorização dos cursos de Geografia no território brasileiro discutidos anteriormente, recentemente, devido ao avanço tecnológico e ao discurso de que são necessárias novas formas de universalizar o Ensino Superior, abriu-se a possibilidade de criação de cursos a distância ${ }^{116}$, complexificando a concepção de Ensino Superior e a formação em Geografia no atual período, o que permitiu parte deste processo de interiorização.

No período do meio-técnico-científico-informacional, a técnica além de um conteúdo normativo, ganha avanço tecnológico com objetos que permitem maior fluxo de informações, com maior rapidez.

Há inúmeras metáforas em relação a esta questão, com termos como desterritorialização, fim dos territórios, ciberespaço, espaço virtual,

\footnotetext{
${ }^{116}$ A Secretaria de Educação a Distância (SEED) foi oficialmente criada pelo Decreto no 1917, de 27 de maio de 1996. Segundo o MEC: "A Educação a Distância é a modalidade educacional na qual a mediação didático-pedagógica nos processos de ensino e aprendizagem ocorre com a utilização de meios e tecnologias de informação e comunicação, com estudantes e professores desenvolvendo atividades educativas em lugares ou tempos diversos. Esta definição está presente no Decreto 5.622, de 19.12.2005 (que revoga o Decreto 2.494/98), que regulamenta o Art. 80 da Lei 9394/96 (LDB)" (MEC, 2010, s/p). Disponível em: http://portal.mec.gov.br /index.php? Itemid=879\&id $=13105 \&$ option $=$ com_content\&view $=$ article. Acesso em 20/10/2010.
} 
compressão espaço-tempo (HAESBAERT, 2002), "mundo que encolhe" (IANNI, 2003), aldeia global, entre outros.

São discursos que tendem a enfatizar que o atual processo de globalização do mundo levou ao fim dos territórios ou também de uma desterritorialização das pessoas, das empresas e das informações, na medida em que as novas tecnologias informacionais permitem um uso diferente do tradicional, e troca de informações a distância de um novo modo.

O mundo não encolhe, tampouco há a compressão do espaçotempo, o que mudam são as relações sociais e espaciais; não há o fim dos territórios, ao contrário, o território torna-se cada vez mais ator, como dizia Milton Santos.

O capital seleciona criteriosamente o território a ser usado, ao mesmo tempo em que o próprio território com maior produtividade espacial atrai para si maiores investimentos, migrações e, no caso do Brasil, tal processo acarreta o aumento das desigualdades espaciais.

Mudam as relações sociais no espaço e no tempo, mediadas, cada vez mais por artificialidade, por objetos informacionais.

Neste período, há a possibilidade técnica, de troca de informações on-line, mas este acesso não é para todos. Igualmente é necessário materialidade no território que permita este uso, senão computadores, celulares e outras tecnologias de informação seriam inócuos, portanto, não se trata apenas de espaço virtual, pensado em oposição ao presencial. Ou seja, há necessidade de que o território seja tecnificado para que se dê o uso das tecnologias de informação.

Fala-se muito, no processo atual de globalização, de "desenraizar" pessoas, ideias, empresas, capital e informação. No entanto, cada vez mais há uma seletividade de usos sociais e dos territórios que serão tocados por tais mudanças, sendo assim o processo de globalização, no lugar de somente homogeneizar os espaços, reforça as heterogeneidades.

As tecnologias de informação em si não são portadoras de intencionalidades apenas perversas, embora hegemonicamente algumas 
vezes sejam usadas para este fim. Tampouco são portadoras somente de benesses como alguns as apresentam. Dependem de seu uso, de sua práxis social ${ }^{117}$, considerando que estas TICs mudam as relações e as dinâmicas sociais, mas também contêm discursos e intencionalidades que vão além do uso técnico dos objetos.

Neste sentido, a Educação a Distância coloca o entendimento do processo de expansão do Ensino Superior no território nacional em outro patamar. Afinal, se, no passado recente, só havia a possibilidade técnica de cursos presenciais, agora ocorre a situação em que professores e alunos, fisicamente distantes, participam de aulas on-line, mediadas pelo uso das tecnologias da informação.

Há, portanto, uma nova relação do aluno em relação à IES. Há, por exemplo, universidades públicas do Nordeste do Brasil, que certificam cursos para alunos em São Paulo, que participam de atividades presenciais e on-line em instituições conveniadas com aquelas; em alguns casos, são apenas escolas de informática.

Assim, alteram-se as sociabilidades existentes em sala de aula, as trocas de experiências entre discente e docente mais contundente numa relação presencial, as atividades definidas como práticas, como no caso da pesquisa de campo em Geografia, entre outras mudanças no processo de ensino-aprendizagem.

Num mundo onde o sistema capitalista acelera o tempo social, as formas de trabalho e emprego mudam com grande rapidez, há também influência do mercado na constituição do currículo. Termos como flexibilização, controle, eficiência e eficácia, tornam-se palavras-chaves da gestão empresarial. Neste sentido, flexibiliza-se a grade curricular, as formas de ensino-aprendizagem, o tempo do curso.

117 Há várias definições para a categoria "práxis, cuja origem etimológica vem do grego e foi utilizada, entre outros, por Aristóteles, Platão, Marx, Lênin e Gramsci (VÁSQUEZ, 2007). Tal categoria, cujas definições são oriundas de diferentes modos de pensar, de diferentes filosofias, aqui não será empregada como sinônimo de prática, cujo sentido geralmente é mais utilitarista, e leva-nos a frase dita comumente: "a prática fala por si mesma". Mas utilizamos a definição de práxis como ação que se constrói social e historicamente, como unidade do pensamento e da ação, e, sobretudo, como condição para a transformação. 
Se a norma diz que os cursos de Geografia tem de ter 2800 horas, como é o caso dos cursos de licenciatura no Brasil, flexibiliza-se a forma de como isto ocorre, podemos ter cursos presenciais, semipresenciais ou totalmente a distância.

Validam-se ou não os currículos mediante mecanismos de avaliações externas, analisando-se o desempenho de docentes e discentes, e de inserção dos formandos no mercado de trabalho. Criam-se valores não só de uso, mas também de troca, já que as avaliações também servem para destacar IES, cursos, docentes e discentes no mercado de trabalho.

Como todo processo em movimento, a história da Educação a Distância (EAD) passou por várias mudanças ao longo do tempo, tanto conceitualmente, como na forma e metodologias usadas.

No século XIX, por exemplo, eram comuns na Europa e nos EUA os cursos a distância com materiais didáticos impressos enviados por correspondência. Atualmente coexistem formas mais tradicionais com outras mais modernas, caso do uso de novas tecnologias informacionais, como a internet. Sendo assim, a EAD não é sinônima de "educação via sistema on-line".

Recentemente a EAD tem sua política (re)elaborada em organismos mundiais como a UNESCO, a OCDE e o Banco Mundial, com uma concepção cada vez mais vinculada à ideia de expansão do Ensino Superior mediante a massificação do acesso, principalmente com o uso de novas tecnologias de informação.

$\mathrm{Na}$ "Declaração Mundial sobre Educação Superior no Século XXI: Visão e Ação", em 1998, a UNESCO, em seu artigo 8, trata da "diversificação como forma de ampliar a igualdade de oportunidades":

Sistemas mais diversificados de educação superior são caracterizados por novos tipos de instituições de ensino terciário: públicas, privadas e instituições sem fins lucrativos, entre outras. Estas instituições devem ter a possibilidade de oferecer uma ampla variedade nas oportunidades de educação e formação: habilitações tradicionais, cursos breves, estudo de meio período, horários flexíveis, cursos em módulos, ensino a distância com apoio, etc. (UNESCO, 1998). 
Emana um discurso segundo o qual um novo mundo se descortina, sendo necessárias novas tecnologias de informação, que permitam a expansão da educação superior, e a EAD torna-se a principal possibilidade desta expansão.

Em Paris, na "Conferência Mundial sobre Ensino Superior 2009: as novas dinâmicas do Ensino Superior e pesquisas para a mudança e o desenvolvimento social", a UNESCO (2009) enfatiza ainda mais a importância das novas tecnologias de informação e comunicação (TIC) e da EAD, com expressões como: "Abordagens EAD e TIC apresentam oportunidades para ampliar o acesso a uma educação de qualidade" e "A aplicação de TIC para ensinar e aprender tem um imenso potencial para aumentar o acesso, a qualidade e o sucesso".

É comum aliarem a ideia de que o sucesso da expansão do Ensino Superior tem relação com o uso das TIC, que tornará possível o maior acesso de estudantes.

No Brasil ${ }^{118}$, em 1988, o governo federal criou um grupo de trabalho que iniciou a elaboração de uma política de EAD, impulsionada ainda mais com a criação da Secretaria de Educação a Distância em 1995, ganhando conteúdo normativo principalmente a partir deste período.

No mesmo ano, a Universidade Federal do Mato Grosso (UFMT) inicia o primeiro curso de graduação ofertado a distância no Brasil, junto com a Universidade Estadual do Mato Grosso (UNEMAT), criando um curso a distância de licenciatura plena em Educação Básica - séries iniciais, buscava formar professores que já atuavam na rede pública do Mato Grosso, mas que não possuíam a habilitação do Ensino Superior (SANTOS, 2008).

118 No Brasil os cursos de EAD já existem desde 1904, quando grupos americanos ofereciam no Brasil cursos por correspondência; em 1936, criaram a Rádio-Escola Municipal no Rio de Janeiro, e em 1939 foi criado o Instituto Universal Brasileiro que se tornou bastante conhecido no Brasil com cursos principalmente técnicos, por correspondência (FERREIRA, 2009). 
Os cursos a distância são, por si só, peculiares, devido à possibilidade de formação de discentes em lugares distantes da sede da IES e sem contato direto com parte dos docentes.

As situações de existência de tais cursos possuem arranjos espaciais e educacionais distintos de outros na forma regular e presencial.

Pesquisadores de EAD (FERREIRA, 2009; PRETI, s/d; BLUM, 2004) ressaltam que, entre os aspectos positivos da EAD, está a possibilidade de inserir alunos que têm pouco tempo para estudar no ensino presencial, quer porque geralmente são adultos e trabalham, quer porque vivem em lugares remotos.

Ressaltam, também, que a flexibilidade é um aspecto fundamental na EAD, pois possibilita ao estudante escolher o local e o horário em quem vai estudar. Há, então, o trinômio proposto: tecnologias de informação e comunicação, flexibilidade e cursos de formação.

Apontam, ainda, que há necessidade de desmistificar a concepção de que a Educação a Distância é necessariamente uma forma de ensino com menor qualidade, na qual não se realiza uma educação com interação dialógica que possibilite um bom nível de aprendizado por parte dos alunos.

Corroborando esta ideia, Zeila Miranda Ferreira, em sua tese, diz:

Portanto, defendemos uma EAD, numa perspectiva transformadora, que favorece não só a construção de conhecimentos, mas a busca da identidade e do desenvolvimento pessoal e profissional do professor-tutor e dos cursistas, em conformidade com o pensamento crítico, reflexivo e pesquisador sugerido por Freire. Uma EAD que enfatiza a reflexão na relação pedagógica $[\ldots]$ É esta educação a distância, sem distâncias, que interessa aqui contemplar (FERREIRA, 2009, p. 16).

A busca dessa qualidade, porém é bastante complexa e tem relação com a formação e condições de trabalho do docente e com a condição do discente que terá acesso à EAD, bem como com as metodologias usadas e a infraestrutura à disposição.

A concepção de que o estudante de EAD tem autonomia para estudar no tempo que melhor convier, com possibilidade de ser autônomo 
e autodidata na medida em que não está em contato direto a maior parte do tempo com o professor, desconsidera que esta presença muitas vezes é fundamental, sobretudo porque, geralmente, estes alunos requerem apoio presencial para orientá-los, para desenvolver interações com grupos, nas leituras e interpretações dos textos.

Oreste Preti, pesquisador do Núcleo de Educação a Distância pela UFMT, uma das IES pioneiras em EAD, diz: "[...] a presença física do professor ou do autor, isto é do interlocutor, da pessoa com quem o estudante vai dialogar, não é necessária e indispensável para que se dê a aprendizagem. Ela se dá de outra maneira, "virtualmente" (s/d, p. 24).

É fato que a possibilidade de aprendizagem ocorre mesmo sem a presença do professor, mas, considerando-se que os estudantes de Ensino Superior no Brasil, em geral, têm dificuldades em leitura e interpretação de textos, trabalham e têm pouco tempo para estudar, não será a EAD que vai resolver estas questões, sem a mediação mais direta do professor. Tampouco serão as tecnologias informacionais.

Certamente no mundo de hoje as tecnologias de informação e comunicação fazem parte de um sistema de objetos que possibilita, como ferramenta, novos meios que permitem aprendizagem. Contudo, devem ser vistas como ferramentas e não como um fim em si mesmo. O pressuposto de que as TIC vão tornar o ensino melhor é incompatível com a nossa atual situação do ensino no Brasil.

As TIC em si não são capazes de transformar a EAD em uma forma de ensino inovadora, que pode ampliar a forma de interação entre professor e aluno, pois dependem da capacidade e formação dos docentes e de suas condições de trabalho para alcançarem maior êxito, assim como dependem das condições de formação do discente. Devem-se considerar as mediações com inúmeros elementos.

A introdução de novos objetos na educação não vai torná-la uma revolução em termos de método e metodologia. Depende de sua práxis educacional. Essa afirmação não desconsidera que o atual período da história permite o uso de diferentes tecnologias que possibilitam a criação 
e uso de hipertextos, imagens, sons, gráficos, vídeos, clipes de músicas, entre outras, muitas interagindo umas com as outras.

Mas as TIC não são necessariamente específicas da EAD, podendo também ser usadas no sistema presencial, como objetos que possibilitam, na medida do seu uso, o processo de ensino-aprendizagem.

Como diz a pesquisadora em EAD pela PUC-SP, Maria Elizabeth Bianconcini de Almeida:

Entretanto, mesmo com o uso de recursos das TIC, observa-
se com maior freqüência a ocorrência de programas de EaD
centrados na disponibilidade de materiais didáticos textuais
ou hipertextuais, cabendo ao aprendiz navegar pelos
materiais, realizar as atividades propostas e dar as
respostas, muitas vezes isolado, sem contato com o
formador ou com os demais participantes do programa
(ALMEIDA, 2003, p. 334).

Esta situação apontada pela pesquisadora evidencia que as possibilidades da EAD com uso das TIC ampliam as condições técnicas, mas não garantem necessariamente uma aprendizagem interativa. É necessário que se usem técnicas que promovam o diálogo, a discussão, que se transformem em possibilidades de aprendizagem.

Essa metáfora contemporânea - que coloca na técnica e nos sistemas técnicos, principalmente nas novas tecnologias de informação e comunicação, as possibilidades de melhoria no Ensino Superior esquece-se de que há também um sistema de ações - sociais, culturais, econômicos, políticos e educacionais - que interage com os sistemas técnicos, sendo, portanto, seu uso desigual social e territorialmente, portando várias contradições.

\subsubsection{As características e o arranjo espacial dos cursos de EAD no Brasil}

Para a compreensão da EAD no Brasil, é necessário buscar o conceito e as normas definidas pelo MEC, que é agente fundamental neste processo, assim como verificar o arranjo educacional e espacial existente neste processo que tem várias peculiaridades. 
Como vimos anteriormente, o discurso atual de EAD relaciona-se a mais uma verticalidade global, um discurso de entidades supranacionais, que vai sendo desenhado como política pública nacional mais recentemente e com conteúdo normativo definido pelo MEC sobre as formas de existência de tais cursos.

Considerando a norma, a Educação a Distância tem as seguintes características e conceito, conforme Decreto $n^{\circ}$ 5622/2005, no artigo $1^{\text {ㅇ․ }}$ :

Para os fins deste Decreto, caracteriza-se a educação a
distância como modalidade educacional na qual a mediação
didático-pedagógica nos processos de ensino e
aprendizagem ocorre com a utilização de meios e
tecnologias de informação e comunicação, com estudantes e
professores desenvolvendo atividades educativas em lugares
ou tempos diversos (MEC, 2005).

A existência de tais cursos depende das normas do MEC, já que há necessidade que a IES esteja credenciada para ter cursos a distância. Em princípio, os principais aspectos normativos para estes cursos no Ensino Superior são:

- A IES ser credenciada para desenvolver ensino a distância, e os polos de apoio presencial também estarem habilitados;

- Ter componentes curriculares semelhantes aos dos cursos presenciais, quando obrigatórios, caso de estágios, atividades de laboratórios, provas presenciais, defesa de trabalho de conclusão de curso, horas mínimas do curso conforme prevê a norma etc.;

- Ter parte de atividades de forma presencial obrigatoriamente nos polos de apoio presencial, devidamente habilitados, com ao menos uma avaliação presencial principal obrigatória;

- Possuir corpo docente habilitado conforme legislações existentes;

- Ter infraestrutura adequada às necessidades do curso.

Partindo destes princípios normativos e da política para a EAD, cabe verificar como isto ocorre no território brasileiro. A primeira condição requer que a IES seja credenciada pelo MEC especificamente para ter 
cursos a distância. Conforme se verifica no mapa 39, estas IES estavam centralizadas. Ou seja, as regiões mais remotas do território brasileiro, que poderiam ser beneficiados com o uso do ensino a distância pouco se valem dele.

\section{Municípios com IES-Sede com cursos de EAD em Licenciatura Geografia -2012}

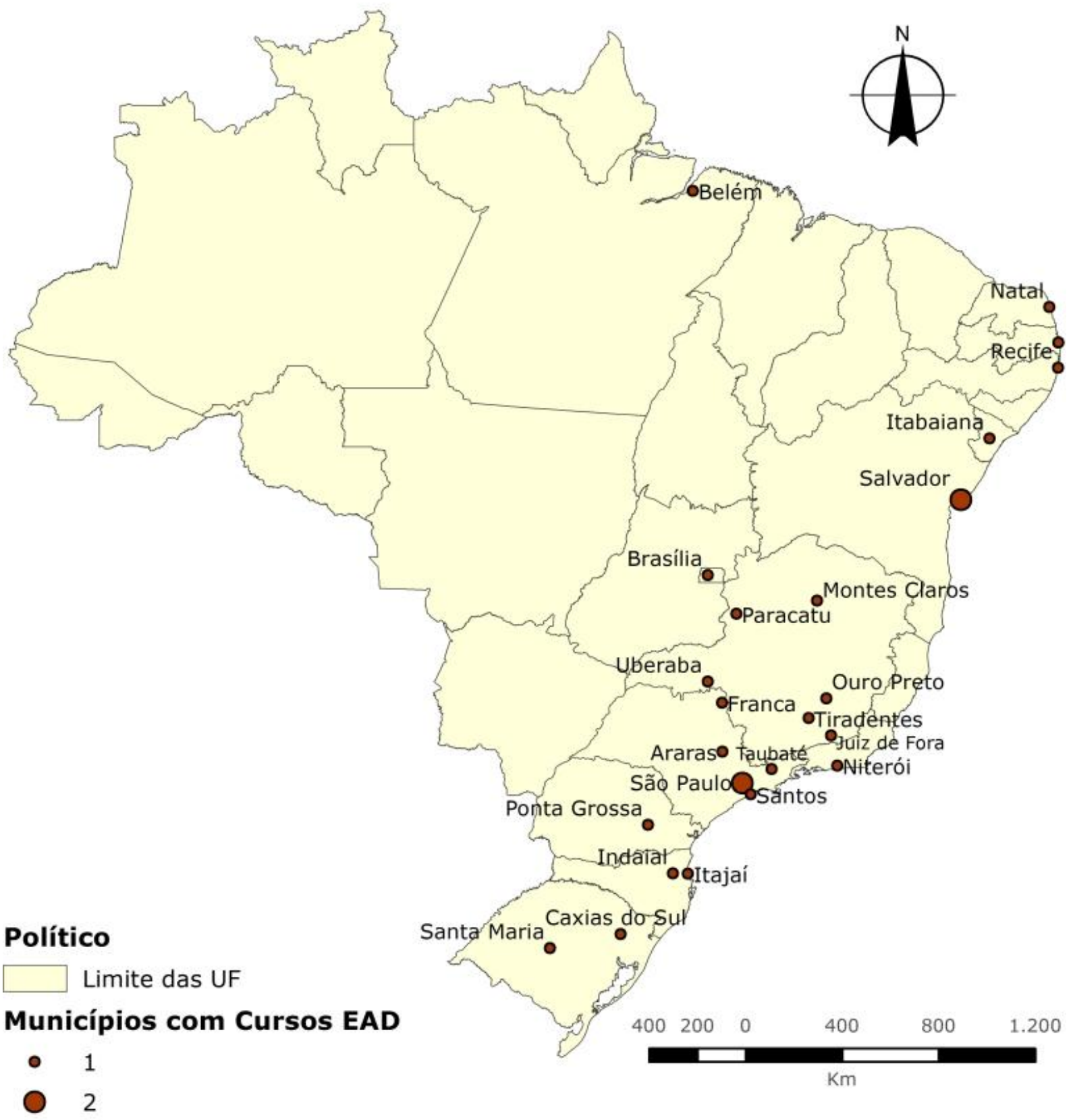

Mapa 39 - Fonte: MEC, 2009. Dados organizados por Vivian Fiori. Elaborado por Maurício Yamada, agosto de 2012.

Há uma concentração e uma centralidade da oferta desses cursos. Sua ocorrência não se concretiza em vários espaços quer porque não se 
tem acesso aos sistemas e tecnologias de informação, quer porque, embora se acesse, depara-se com cursos inadequações de todo tipo, que serão melhor explicitadas a seguir.

No mapa 39, verifica-se que estes cursos são oferecidos por IES principalmente situadas próximas às regiões litorâneas, com exceção de Minas Gerais, onde as sedes dos cursos estão mais interiorizadas. Das 26 IES, que oferecem licenciaturas em Geografia a distância, há 14 privadas e 12 públicas, entre elas - a Universidade de Brasília (UnB), o Instituto Federal de Pernambuco (IFPE), a Universidade Federal do Rio Grande do Norte (UFRN), a Universidade Federal do Sergipe (UFS) e a Universidade Estadual de Ponta Grossa (UEPG).

A questão é complexa, pois os cursos onde estão as IES com Educação a Distância não são necessariamente onde existe maior necessidade de cursos de Geografia. Embora na modalidade a distância, há uma tendência dos alunos serem, principalmente, das regiões mais densas.

O arranjo da Educação a Distância no Ensino Superior no Brasil nas licenciaturas em Geografia tem, geralmente, a seguinte configuração:

- Nos polos de apoio presencial, há um professor-tutor presencial, normalmente uma vez por semana, que geralmente é graduado em Geografia, com especialização em alguma área de Educação;

- Nas IES, sede do curso a distância, há professores tutores a distância, geralmente formados em Geografia, com especialização ou mestrado, responsáveis, principalmente, pela produção dos materiais didáticos, pela elaboração das provas e sua correção, pela orientação a distância, entre outras atividades;

- Os polos de apoio presencial são cadastrados pela IES junto ao MEC, à medida que ela é autorizada a ter um curso a distância. Tais polos têm de ter uma infraestrutura conforme o que se considera necessário ao curso; geralmente, no caso de 
Geografia, é formada por sala de aula com aparelho multimídia, um laboratório de informática e uma biblioteca com as referências básicas dos planos de ensino. Normalmente três referências bibliográficas básicas por disciplinas. Tais polos não necessitam ser entidades de Ensino Superior, sendo comuns entidades com cursos de informática terem este papel.

\section{Polos de Apoio de Educação a Distância Cadastrados- \\ Cursos de Licenciatura em Geografia -2012}

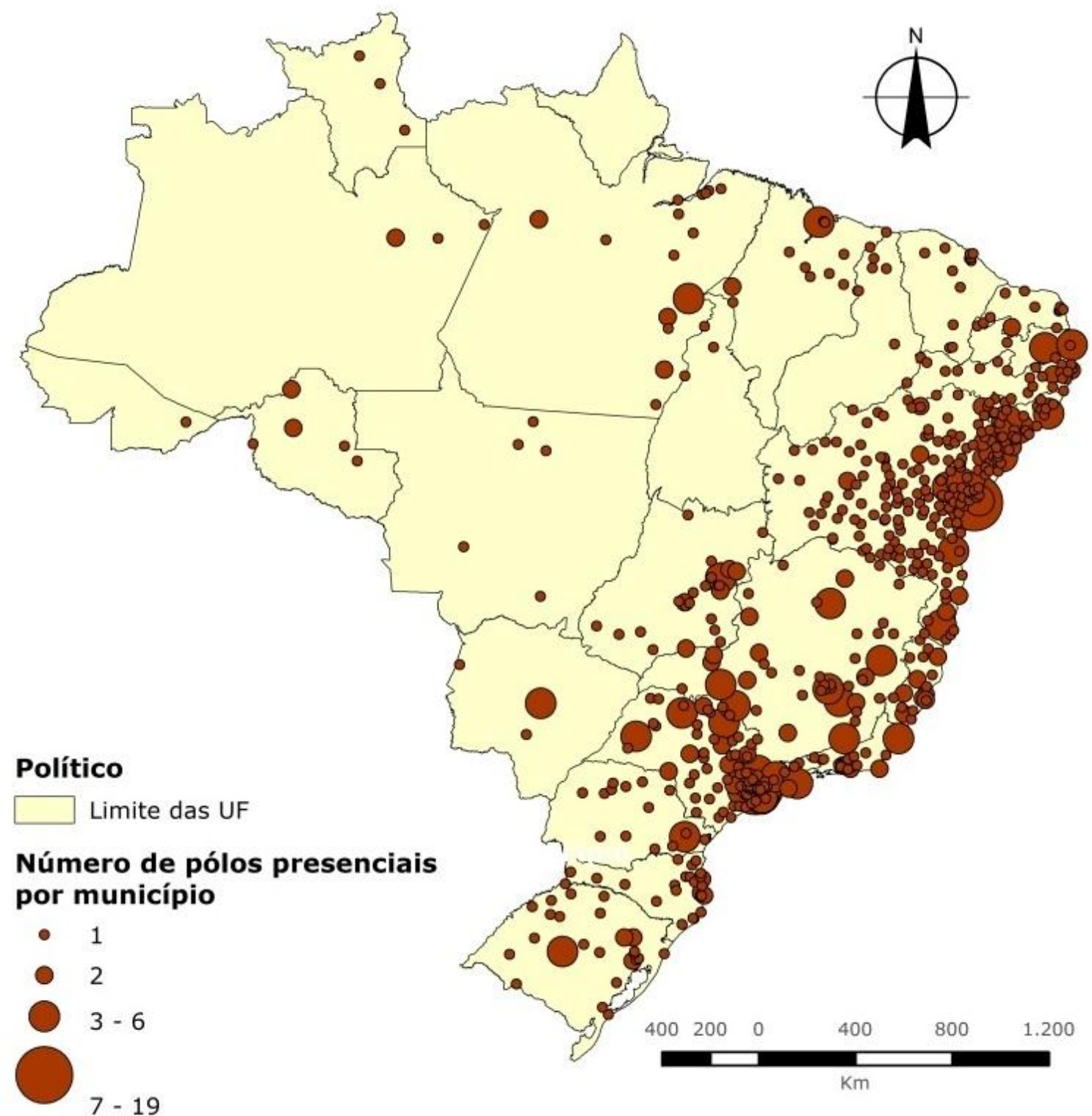


No caso dos polos presenciais cadastrados para cursos de licenciatura em Geografia, segundo informações do sistema E-MEC, em 2012, há uma quantidade bastante grande, conforme se pode verificar no mapa 40.

Há densidades maiores na Região Concentrada e no Nordeste do Brasil, mas isto não significa que todos estejam em atividade, já que a existência dos cursos depende geralmente do número mínimo de inscritos definido pelas IES, ou seja, muitos estão apenas cadastrados, mas não em funcionamento.

Ressalta-se que quase a metade dos polos de apoio presenciais em Licenciatura em Geografia é cadastrada por uma só IES, a Faculdade de Tecnologia e Ciências (FTC), instituição privada, situada em Salvador, que, embora não tenha curso de Geografia presencial, tem 413 polos de apoio a distância cadastrados, localizados, sobretudo na Bahia, mas também em outros estados do Nordeste, bem como, em número menor, nas demais regiões do Brasil.

Outra questão é a divisão social e territorial do trabalho existente na EAD, com um arranjo espacial peculiar. De um lado, há um polo de apoio presencial, com um professor de apoio presencial; de outro, há a sede da IES, com professores-tutores a distância criando e sendo responsáveis pela gestão dos cursos, observando-se a política de EAD, metodologias, forma de atuação, contratação dos professores etc.

Ao polo cabe parte dos lucros, conforme convênio firmado com a IES, a disponibilidade e cessão da infraestrutura (sala de aula, espaços de convivência). Alguns materiais, como acervo bibliográfico, apostilas e outros materiais didáticos, são de competência da IES-Sede.

$\mathrm{Na}$ sede, ficam os docentes mais qualificados, com um papel um pouco mais especializado. Já o docente-tutor presencial é geralmente um professor polivalente, com menor qualificação, geralmente especialista.

Na divisão social do trabalho, cabe ao professor a distância inúmeras atividades, variando conforme a IES, sendo mais comuns as seguintes: fazer leitura das mensagens dos alunos, responder as mensagens, atender 
e tirar dúvidas por telefone ou on-line, corrigir as provas que são presenciais, corrigir atividades propostas no ambiente de aprendizagem virtual e elaborar e propor os diversos materiais e atividades didáticas.

Há, em alguns casos, uma divisão de trabalho entre os professores a distância, por exemplo, uns ficam com as atividades de produção dos materiais e atividades didáticas, outros com as atividades de orientações on-line. Há ainda uma divisão por quantidade de alunos a serem orientados, já que geralmente há relação entre as horas-aula e o número de alunos. O tempo despendido nestas orientações é grande, o que faz com que as respostas das mensagens geralmente sejam curtas.

Esta divisão social e territorial do trabalho é explicada pelo coordenador do curso de licenciatura em Geografia a distância do Centro Universitário Leonardo da Vinci (UNIASSELVI), em Indaial, Santa Catarina, formado em Geografia pela Universidade Federal de Santa Catarina (UFSC), com mestrado em Engenharia Ambiental, pela Universidade Regional de Blumenau (FURB):

Nosso curso a distância prevê um encontro presencial por semana. Estes encontros ocorrem nos polos de apoio presencial, credenciados pelo MEC, com infraestrutura mínima, como: espaços de sala de aula climatizado e confortáveis, com projetor multimídia; sala de informática; biblioteca; laboratórios. Cada disciplina é oferecida por trinta dias com quatro encontros presenciais. Não trabalhamos com teleaulas e sim com Caderno de Estudos de cada disciplina. O Tutor presencial esclarece dúvidas referentes aos conteúdos, acompanha as provas, faz acompanhamento do estágio, orienta e corrige o Trabalho de Conclusão de Curso (TCC). Em relação à correção de provas, as dissertativas são enviadas para a sede central em Indaial/SC e corrigidas pelos tutores internos. O TCC é corrigido pelo tutor externo e postado no site da instituição. Há também o ambiente virtual de aprendizagem, onde o acadêmico pode participar de chat com tutores e colegas, consultar material de apoio, assistir aos vídeos das disciplinas, acompanhar sua vida acadêmica etc.

No caso da UNIASSELVI, atualmente com 1347 alunos, o professortutor presencial - geralmente formado em Geografia com alguma especialização - é responsável por ministrar conteúdos e orientar presencialmente, numa síntese, todas as temáticas apresentadas no 
curso, cujos temas estão no caderno das disciplinas, quer seja das disciplinas específicas, quer das demais.

Deve ser, portanto, um professor polivalente, que deve seguir a métrica e organização das aulas já determinada previamente pela sede em Indaial (SC). Há um acontecer hierárquico definido sempre na sede, desde o material didático impresso até a definição do plano das aulas, com o cronograma das atividades.

Um professor tutor presencial, mestre, formado em Geografia pela Universidade Estadual de Feira de Santana (UFES), que ministra as atividades presenciais no município de Feira de Santana, na Bahia, pela UNIASSELVI, diz sobre as atividades principais desenvolvidas por ele:

Cada curso a distância tem uma metodologia; no caso da UNIASSELVI, ela não prioriza a plataforma virtual, trabalha com material impresso, com professor uma vez por semana presencial. Cada módulo de estudo, em um mês, divide-se em quatro unidades: na primeira, discute-se todo o módulo; na segunda aula discute-se a primeira unidade e já é feito uma avaliação; no terceiro, desenvolve-se a segunda unidade, e, no último encontro, tem avaliação com questões objetivas e três dissertativas que são enviadas para a sede.

Outra docente da UNIASSELVI, formada em Estudos Sociais e Geografia, com especialização em Educação Ambiental, que atua como professora tutora em Canoas, Rio Grande do Sul, pela mesma instituição disse: "No geral se consegue fazer um bom trabalho, apesar de ser orientadora de todas as disciplinas. Acompanhamos e aprendemos com 0 tempo como passar os conteúdos e temos um bom resultado. O aluno trabalha, mas há disposição de fazer eventualmente pesquisa de campo aos sábados".

Logo, o papel do professor presencial em algumas IES de EAD nessa divisão social do trabalho é dar aulas, sobre os conteúdos disponíveis no caderno de todas as disciplinas, orientar estágios e promover semestralmente alguma atividade prática, caso de seminário, produção de um texto em grupo ou atividade de campo. Deve ser, portanto, um professor com inúmeras atribuições e que tenha conhecimentos em todas as disciplinas do curso. 
Logo, há uma hierarquia e ação entre a IES sede e o polo, aquela elabora o plano e projeto pedagógico do curso, seus conteúdos e estratégias de ensino; este com infraestrutura mínima, e um professor polivalente, responsabiliza-se pela aplicação do material.

Outra IES com vários cursos de Geografia a distância é a Universidade Metropolitana de Santos (UNIMES), que tem polos principalmente no estado de São Paulo, mas também em capitais como Manaus e São Luis, num total de 809 alunos em 2012.

A UNIMES, diferentemente da UNIASSELVI, atua com plataforma virtual, cujas ferramentas usadas podem ser em tempo real ou não, tais como: textos e links de textos, fóruns, chats, informações de grupo, banco de dados etc.

A coordenadora do curso, com graduação em Geografia, mestrado em Geografia Humana, ambos pelas USP, retratou um pouco de seu trabalho e de seus alunos de EAD:

Eu trabalhava na UNIMES no curso presencial. No começo é difícil trabalhar no EAD e também tinha preconceito em relação ao processo de aprendizagem no $E A D$, mas hoje verifico o quanto o aluno avança no curso; no começo o aluno vem com muitas dificuldades, mas temos um nivelamento de Língua Portuguesa. Você percebe diferença de nível dos alunos; há diferença do nível do Sudeste-Sul para o restante do país. Os de São Paulo, por exemplo, têm menos dificuldades de acesso ao computador também.

Praticamente todos os coordenadores, professores tutores ou professores dos polos de apoio presenciais entrevistados relatam que tinham inicialmente algum preconceito em relação à EAD, mas, com a experiência, acabaram percebendo as possibilidades de aprendizagem nesta modalidade.

Há problemas na formação de Ensino Básico destes discentes, o que faz com que a UNIMES, assim como outras IES, recorra à disciplina de Língua Portuguesa, para minimizar a dificuldade de entendimento dos textos.

Se há dificuldades em entender e redigir textos, situação com a qual em princípio, todos estão familiarizados, o que pensar das dificuldades de 
usos das novas tecnologias de informação, além da dificuldade de acessar a internet para realizar as atividades e do pequeno tempo disponível no dia de aula presencial.

Outra questão citada por outros coordenadores de EAD é a diferença dos alunos pelo território brasileiro, tanto no acesso ao computador e internet quanto em relação às deficiências da formação na Educação Básica o que dificulta a apropriação dos conhecimentos nos cursos de licenciatura em Geografia.

Citam que os alunos do Centro-Sul têm mais facilidade de buscar a autonomia que um curso de EAD requer, e novamente a forma de minimizar estes problemas é a inserção da disciplina de Língua Portuguesa no curso, comum também em outros cursos presenciais, como observado anteriormente.

Além disso, há a falta de participação em programas de iniciação científica, de extensão e mesmo de pesquisas de campo, uma vez que, em um dos cursos contatados pela pesquisa, obteve-se a seguinte resposta sobre a questão das atividades de campo: "Incentivamos nossos alunos a fazer pesquisa de campo por conta própria".

Considerando-se tais condições, verifica-se, na prática, que a visão que se tem, por exemplo, da necessidade ou não de laboratórios para um curso de licenciatura em Geografia, refere-se ao laboratório de informática. A concepção aceita é de que cursos de licenciatura não requerem laboratórios, pois a pesquisa nestes cursos parece não ser fundamental.

Então, em curso de licenciatura em EAD, o laboratório aceito pelo MEC é o de informática e o modelo de formação de professores na maioria dos casos acaba sendo o aplicacionista, de reprodução do conhecimento, pois há pouco espaço para pensar pesquisa, debater, ter leituras diversificadas. Estar próximo dos outros alunos e professor para debater é visto como perda de tempo pelo sistema.

O modelo da UNIASSELVI, por exemplo, não prioriza as tecnologias de informação, e isto faz que ela tenha maior capilaridade no território 
brasileiro do que outras IES de EAD, porque para usar o chamado "ambiente virtual" como principal ferramenta no processo de ensino aprendizagem, é necessário que o aluno saiba usar o computador, tenha computador e internet disponíveis, não apenas no núcleo de apoio presencial.

Sabe-se que as densidades técnicas para uso das tecnologias de informação no Brasil não estão ainda totalmente disseminadas, nem socialmente nem no território brasileiro. Portanto, a falta do uso da plataforma virtual dá condições a UNIASSELVI de "captar" um aluno que não usa tais TICs e que pode se deslocar para o polo de apoio presencial, criando, assim, maior capilaridade, que lhe permite chegar a municípios tais como: Manaus, Salvador, Florianópolis, São Luis, Porto Alegre e Campo Grande; a municípios do interior, como Cametá (PA); em Santa Catarina, em Xaxim, Rio do Sul, Criciúma, Indaial, Palhoça, Lajes, Camboriu, Blumenau; no Rio Grande do Sul, em Capão da Canoa e Camaquã; e ainda em Colíder (MT), Rolim de Moura (RO), Feira Santana $(B A)$, Maringá (PR) etc.

Verifica-se, assim, que há várias capitais, muitos municípios de Santa Catarina, onde há vários cursos de licenciatura em Geografia regulares, modulares ou do Parfor, e demais cidades que não são necessariamente cidades onde não existem outros cursos de Geografia.

Ainda assim, há casos como de Feira de Santana, que alcança maior capilaridade, pois os alunos do polo presencial da cidade são também provenientes de outros municípios, como diz em depoimento um professor tutor:

O perfil dos alunos é o do PROUNI, de professores que buscam se qualificar para atender a solicitação do MEC. Com faixa etária variada. A grande maioria trabalha. Além de Feira de Santana temos alunos de outros municípios. Como é uma vez por semana, algumas prefeituras acabam disponibilizando ônibus para trazer os alunos, casos de Santo Estevan, situada a $60 \mathrm{~km}$, Santo Amaro, Santa Barbara e Santo Gonçalo.

Logo, há casos de maior capilaridade no território, ocasionada pela estratégia escolhida pela IES, com aula presencial uma vez por semana, e 
uso de material didático apostilado, o que facilita o ingresso e inclusão de mais estudantes.

Há outra inversão, pois existe literalmente uma busca por este aluno, já que a IES sede detecta as demandas existentes pela formação de professores no território brasileiro e vai organizando uma rede de polos presenciais que são disputados por mais de uma IES.

Segundo depoimentos de alguns coordenadores de cursos de EAD, há uma disputa territorial pelas IES por tais polos e pelas cidades onde estão inseridos. Alguns disseram que é difícil a inserção em alguns estados, porque são territórios de determinadas IES.

Como há uma disputa e, ao mesmo tempo, parte da demanda vai sendo absorvida por outras IES que atuam nestes lugares, também há casos de IES que tinham várias turmas, mas atualmente são poucas.

Uma coordenadora de curso de uma IES em São Paulo, com curso em EAD deu o seguinte depoimento sobre seu curso:

Estou recebendo e-mail do Brasil inteiro, mas estão fechando turmas. Alegam que não conseguem abrir turmas nos polos. Temos ainda em Paraupebas, por exemplo, o dono dele contrata professores de lá; a obrigação é que tenha graduação em Geografia. As apostilas estão também no ar, nelas têm exercícios - os temas das disciplinas, com dez aulas web.

Sendo assim, as IES entram numa disputa por novos territórios, ao buscarem a parceria de entidades que sirvam de apoio presencial. Há uma disputa, também, com outras modalidades de ensino de Geografia, caso, por exemplo, dos cursos do Parfor.

Portanto, embora haja um processo de interiorização destes cursos, seguem uma lógica de uma política específica, definida pelo governo federal para a EAD e possuem arranjos espaciais peculiares, devido à questão da divisão social e territorial do trabalho entre a IES-Sede e os polos de apoio presencial, assim como das diferenças entre as metodologias de ensino, que se utilizam os não das TICs. 
Ao sintetizar as situações expostas nesta seção 5, das licenciaturas em Geografia na Amazônia, no Maranhão e Piauí, nos cursos de EAD e no interior de Pernambuco, verificou-se que há peculiaridades em cada caso, que tem relação com os seguintes aspectos:

- Quanto ao tipo de IES, a maioria absoluta dos cursos que se interiorizou é de IES públicas. Com a exceção feita aos cursos de EAD, cujas licenciaturas em Geografia têm maior capilaridade no território por meio das IES privadas;

- Quanto ao tipo de IES públicas, já que as municipais de Pernambuco têm mais professores horistas e geralmente especialistas, assim como as estaduais do Maranhão e Piauí. Já nas federais, no interior há professores mestres e doutores, com maior incentivo à pesquisa;

- Pela modalidade oferecida de licenciatura - caso de EAD, Parfor, regular, regular-modular. Estas características vão se relacionar principalmente com a dimensão de infraestrutura existente e com as estratégias de ensino-aprendizagem e materiais usados nos cursos. É o caso do maior uso de apostilas nos cursos de EAD e modulares, por exemplo.

- Pela dinâmica do território, pela divisão territorial do trabalho e nível hierárquico dos lugares onde estão as licenciaturas. Nas capitais há maior diversidade de cursos, mais opções para se escolher a carreira, prevalecendo a mistura dos perfis de cursos de bacharelado e licenciatura. Já no interior há maioria absoluta de licenciaturas, com pouca infraestrutura, muitos cursos modulares e do Parfor, maior uso de apostilas, etc. Há ainda, entre estes elementos, a relação com o maior desejo em seguir a carreira de professor.

Dessa forma, a maioria absoluta dos cursos que se interiorizaram necessita de maiores investimentos em infraestrutura (laboratórios, acervo bibliográfico etc.), para atividades curriculares (ensino, pesquisa e extensão) e no corpo docente - sobretudo as IES municipais, estaduais e dos cursos de EAD. 


\section{CONCLUSÃO}

Ao refletir sobre os resultados desta pesquisa, constata-se que é fundamental o uso das categorias espaciais para o entendimento das condições em que se realizam os cursos de Geografia. Categorias como espaço geográfico, território, lugar, centralidade, extensão e situação são importantes para a compreensão da Geografia do ensino de Geografia.

Verifica-se também que existem dois grandes movimentos no entendimento da existência dos cursos de licenciatura em Geografia no Brasil, que são indissociáveis.

O primeiro movimento vem do passado para o presente, que traz, para o presente, problemas que foram detectados no passado: a divisão entre bacharelado e licenciatura; a dicotomia entre ensino e pesquisa; a falta de professores formados em Geografia em todos os níveis de ensino, assim como o uso indiscriminado de resumos e apostilas, como principal material didático, entre outros.

Estas problemáticas, ainda não resolvidas, mostram que se trata de um processo dialético, não linear, em cuja história há um período de longa duração. As antigas problemáticas permanecem, ainda que sob novos contextos educacionais, políticos e espaciais.

O segundo movimento refere-se à existência de tempos espaciais distintos na oferta dos cursos no território. Há um tempo espacial que diz respeito aos cursos, por exemplo, no estado de São Paulo e outro no interior do Maranhão e do Acre.

O que é aparentemente velho em um lugar pode ser novo em outro, ou seja, a idade dos elementos ou as condições das variáveis nos cursos se imbricam com o lugar. Decorre desta condição que o novo e o velho estão associados ao tempo espacial dos cursos no lugar no qual são ofertados.

Um dos velhos problemas em que permanece diz respeito à mistura dos perfis do bacharelado e da licenciatura, mais comum na Região 
Concentrada e nas capitais, onde há maior oferta de trabalho para bacharéis, bem como nas IES federais e em algumas estaduais.

Contudo, há também muitos cursos de licenciatura com currículos que denotam um mosaico de perspectivas geográficas, disciplinas pouco integradas, cujo perfil para a formação de professores de Geografia pode ser questionado. Esta condição é comum em todo território nacional e em diferentes tipos de IES, tanto em relação às disciplinas específicas e pedagógicas, quanto da inserção de significativo número de disciplinas não específicas.

Outra condição que permanece é a concepção equivocada de que, na licenciatura, basta realizar a reproduzir conhecimento existente; no bacharelado, desenvolver pesquisa; por isso, neste requerem-se mais laboratórios do que naquela.

Sabe-se que com professores horistas, com pouca verba destinada à pesquisa e à extensão, fica difícil pensar em pesquisa. Contudo, as pesquisas corriqueiras das disciplinas ou mesmo o Trabalho de Conclusão de Curso constituem-se em formas de pesquisa que podem ser realizadas pelo futuro professor, sendo fundamentais a sua formação.

Para isso, é necessário, além de outras ações, um regime de trabalho com pagamento de horas-atividade aos professores, para que, além da docência, possam realizar outras atividades importante para a formação do futuro profissional.

Outra situação comum com o passado refere-se à falta de professores de Geografia na Educação Básica por todo território nacional. Atualmente, há maior capilaridade dos cursos no território, devido às políticas públicas federais que ampliaram à formação de professores no Brasil. Todavia, ainda há um descompasso entre as políticas de criação destes cursos e as condições de trabalho dos professores que não atraem os jovens para esta profissão, prova disto é que muitos licenciados buscam outros tipos de trabalho. 
É necessária, pois, uma política de valorização acadêmica e financeira do trabalho do professor, sem a qual a questão não poderá ser resolvida apenas no nível do Ensino Superior.

Apesar disso, há a mediação dos lugares interferindo no interesse em ser professor: desde a oferta e possibilidades de ter ou não outros cursos no município; a existência concomitante de bacharelado e licenciatura, assim como na possibilidade de empregabilidade em cidades de pequeno porte onde a oferta de trabalho docente é maior do que emprego em outras áreas.

Outra dimensão analisada, que remete ao passado, concerne ao uso de apostilas e resumos. Em São Paulo, por exemplo, já é menos comum este uso, devido à maior densidade econômica e técnica, à concentração de produção acadêmica e de incorporação de novos tipos de materiais compatíveis com a formação dos docentes. Em contrapartida, no interior do Maranhão, por exemplo, esta mesma variável tem outro valor, com maioria absoluta dos cursos que se utilizam de apostilas no Brasil, porque os cursos estão em outra situação, em outro lugar.

Ou seja, as variáveis mudam de valor conforme o tipo de IES e os lugares onde se encontram, não podendo ser entendidas apenas como processos históricos lineares. Há tempos espaciais distintos que precisam ser considerados.

Em relação ao segundo movimento, que leva a diferentes tempos espaciais de oferta dos cursos no território brasileiro, evidenciou-se que a expansão dos cursos de Geografia ocorreu lentamente até 1960, ocorrendo, no estado de São Paulo, a maior expansão pelo interior nesta época. Havia, neste período, uma concentração maior de cursos no estado de São Paulo e no DF (atual Rio de Janeiro), bem como de entidades geográficas e de produção acadêmica.

Com a criação dos cursos de Estudos Sociais (1964), houve aumento significativo do número de professores de Geografia, provenientes de cursos em instituições, principalmente, privadas e municipais, sobretudo por meio das licenciaturas curtas, criadas em 1972. 
Nesta época dos anos 1960-70, houve um processo de interiorização dos cursos de Geografia ainda circunscrito mais à Região Concentrada e a Pernambuco.

Só recentemente, pós 1996, houve maior capilaridade das licenciaturas no território brasileiro, cujo movimento alcançou as frentes de expansão do território nacional e o interior de estados da Amazônia e Nordeste, possibilitada pelas dinâmicas econômicas, pela estabilidade monetária e pelo recente crescimento econômico, que possibilitaram planejamento a longo prazo.

Além disso, este processo é decorrência, principalmente, das políticas do governo federal, que contribuíram para as mudanças e expansão das IES e das licenciaturas, tais como: a nova LDBEN (1996b), com a necessidade de formação de Ensino Superior para os professores da Educação Básica; a nova legislação específica das licenciaturas (2001), garantindo-Ihe, pela norma, terminalidade própria em relação aos bacharelados; as Diretrizes Curriculares Nacionais de Geografia (2001) e o Plano de Expansão das IES federais, o REUNI, em 2007.

Desse modo, na seção 5, destacou-se este movimento recente de interiorização das licenciaturas em Geografia no Brasil, evidenciando as situações existentes neste novo processo de interiorização que levou cursos, por exemplo, ao interior do Maranhão, Piauí, Pará, Amazonas e Tocantins.

De alguma forma, estes cursos promovem mudanças nestes lugares ainda que com algumas condições de ensino inadequadas. Portanto, não basta dizer que são deficientes, pois a chegada de uma IES ao interior do Brasil dá a possibilidade de criação de nova massa crítica e é importante para a formação de novos professores na área de Geografia ou de antigos professores que ainda não tinham formação no Ensino Superior.

Entretanto, são cursos que requerem maiores investimentos em sua infraestrutura, nas atividades acadêmicas e no corpo docente, de modo a melhorar as condições de oferta. 
Há um novo processo, cuja capilaridade alcançou não apenas as regiões de frentes de ocupação, mas também o interior de regiões onde a ocupação já existia, e onde não havia cursos de Geografia - caso da expansão da UEA, no Amazonas, em cidades como Parintins, Tefé, Manacapuru e Tabatinga. Trata-se de um processo que é importante de ser compreendido como um novo processo espacial.

Assim, em cidades como Tabatinga no Amazonas, há ainda a distância métrica interferindo no acesso de docentes e discentes a eventos geográficos de caráter nacional ou regional. Há, também, pouca variedade de cursos em Tabatinga, assim como no interior da Amazônia e Nordeste, em detrimento das capitais onde há maior possibilidade de escolha profissional.

Logo, este movimento recente de interiorização das licenciaturas em Geografia produziu algumas singularidades. Mas, mesmo entre estes cursos, há diferenças, já que, no interior do Maranhão e Piauí ocorrem em IES estaduais, onde só há cursos de licenciatura; no Tocantins, ocorre na UFT, instituição federal com cursos de licenciatura e bacharelado em Porto Nacional. Portanto, a possibilidade de outros interesses profissionais, além da docência, torna-se maior entre os discentes do Tocantins em Porto Nacional.

Em outra situação e tempos espaciais distintos, estão os cursos em São Paulo e Rio de Janeiro, onde se localiza a maior quantidade de cursos e produção acadêmica da Geografia brasileira. São lugares onde há maior densidade técnica e de informação, bem como centralidade de produção acadêmica, mas que possuem, em seus territórios, condições diferenciadas, quando analisadas as IES públicas estaduais e federais e as IES privadas.

Quando comparamos dados de regime de trabalho e formação docente, por exemplo, há grande disparidade, conforme se mostrou anteriormente. Nesta situação não podemos considerar apenas a extensão geométrica, pois a proximidade com os cursos de pós-graduação, em princípio, permitem cursar, de forma mais fácil, uma pós-graduação. 
Contudo, as relações que se estabelecem nas IES privadas, em alguns casos com baixos salários e principalmente com um significativo número de docentes horistas, afastam 0 interesse de doutores em lecionarem em tais instituições. Professores horistas têm menos tempo para dedicar-se a um doutorado, e nem sempre estão tão integrados à rede de relações que Ihes permitam acessar a pós-graduação, no nível de doutorado, gratuitamente.

Assim, é fundamental integrar as diversas dimensões dos cursos. Não se deve isolar um elemento ou uma variável do seu contexto, nem desconsiderar o tempo espacial dos cursos, tampouco isolar apenas uma dimensão para entendê-los. Há inúmeras combinações entre os elementos e dimensões destacadas ao longo deste texto, que tornam os cursos diferentes.

Em algumas IES responsabilizam-se os docentes ou os discentes pelas notas baixas em provas do Enade. Como se o resultado da medida da prova ocorresse apenas na relação professor-aluno e nos conteúdos e metodologias existentes. Há as dimensões de ensino, dos discentes, dos docentes, da infraestrutura, além de outros elementos, que não são propriamente internos aos cursos, interferindo neste processo.

Uma das dificuldades destacadas é a precariedade em leitura e produção de texto acadêmico, que revelam muitos discentes, e denota os problemas de formação da Educação Básica. Tais dificuldades são mais sentidas nas licenciaturas onde, via de regra, o processo seletivo é menos concorrido - caso dos cursos modulares/temporários, do Parfor, de EAD, das IES privadas e dos cursos recentes do interior da Amazônia e Nordeste.

Logo, este elemento tem relação com o território, com o tipo de curso ofertado, com o tipo de IES e com a formação anterior do discente, entre outros fatores, que demonstram que uma análise só de uma destas mediações pode incorrer em erro.

Igualmente, é muito comum a mídia brasileira e mesmo o Inep divulgarem notas do Enade ou mesmo o Conceito Preliminar dos Cursos 
(CPC) por tipo de IES, mas sem atentarem para as situações espaciais onde estão inseridos os cursos. Não se trata do espaço visto como palco, como determinação das condições dos cursos, mas como um conjunto de possibilidades do período e dos lugares.

A comparação simples de dados, em situações tão específicas, pode induzir a leituras desconexas com as condições existentes nos lugares e não permite dar às variáveis significado.

Nas licenciaturas de IES municipais do interior de Pernambuco, por exemplo, destacaram-se problemas na formação docente, falta de investimentos e disponibilidade de tempo para os docentes se qualificarem, problemas nas condições dos docentes com pouco tempo para estudar e pagar o curso, dificuldades dos discentes de compreensão de textos acadêmicos mais densos, uso de apostilas e resumos como material didático principal, infraestrutura inadequada, ou seja, um conjunto de problemas que integrados refletem as condições dos cursos.

Logo, a existência destas licenciaturas só tem sentido se analisadas no espaço geográfico, no tipo de IES, com os elementos integrados.

Nas políticas de avaliação desenvolvidas pelo governo federal, ao transformarem a avaliação dos cursos de Geografia em um índice, perdeuse a oportunidade de transformar o processo avaliativo em uma dimensão qualitativa, bem como de mostrá-la de forma integrada e como processo espacial.

Portanto, as abordagens e formas de avaliação ou análise dos cursos de licenciaturas em Geografia devem considerar que estes não são um produto final, interno, sem observar o contexto histórico de cada período, sem relacioná-los ao espaço geográfico.

Há relações entre a dimensão discente, docente e dos elementos curriculares dos cursos, interagindo num processo dialético, que dá aos cursos características peculiares, quando relacionados ao espaço geográfico. 
É necessário pensar o espaço com suas rugosidades, com sua diversidade de usos e formas, considerando que o processo de interiorização das licenciaturas demonstra o movimento destas no território, cujo movimento em parte é efêmero, temporário, chega por meio de cursos modulares, do Parfor ou da EAD.

Uma situação efêmera analisada foi o arranjo espacial no qual acontecem os cursos de Educação a Distância no Brasil. A EAD é uma verticalidade proveniente do discurso global, da UNESCO e de outros órgãos internacionais, cuja política no Ensino Superior brasileiro foi ampliada recentemente. Por meio do uso de tecnologias de informação e comunicação dizem poder resolver a questão da qualidade dos cursos e ampliar o acesso ao Ensino Superior.

Mais um equívoco, pois esquecem-se das condições das características discentes, da formação e das condições do trabalho docente, da forma como o currículo é vivenciado nos cursos de EAD.

Esta pesquisa mostrou que, a despeito da seriedade e dedicação de professores e coordenadores que nos deram depoimentos, há vários problemas nas condições do próprio sistema de Educação a Distância, já que não permitem ou dificultam atividades comumente existentes nos cursos presenciais - como as atividades de campo, orientação de trabalhos e pesquisas presencialmente- além de alguns casos atribuírem ao professor tutor presencial uma série de atividades que, muitas vezes, o tornam um professor polivalente, sem condições de atender adequadamente às demandas definidas pela IES-Sede.

Em relação ao processo de interiorização dos cursos de EAD, verifica-se que algumas licenciaturas em Geografia se interiorizaram, mas há ainda muitos cursos mais circunscritos a lugares onde já existem IES ou já foram ofertados cursos na modalidade modular ou agora também do Parfor, caso de São Luís, Manaus, Parauapebas, Salvador, entre outros.

Outra condição demonstrada sobre as licenciaturas em Geografia foi a relação entre o nível de centralidade urbana e da modalidade na qual o curso é oferecido. Assim, verifica-se, no Maranhão, Pará e Piauí, por 
exemplo, que a maior centralidade das cidades onde estão inseridas as licenciaturas relaciona-se com o fato do discente querer ser professor, com o uso ou não de apostilas no curso, maior possibilidade de ter ou não acervo bibliográfico de Geografia, entre outras variáveis.

Ao mesmo tempo, há diferenças quando se comparam as IES públicas federais e estaduais na Amazônia, em vários estados do Nordeste, caso do Rio Grande do Norte, Maranhão e Piauí, em relação às condições da formação e do trabalho docente. Nas licenciaturas das IES federais há mais professores doutores em regime de tempo integral, com dedicação exclusiva, do que as estaduais. Portanto, neste caso, o tipo de IES interfere diretamente nas condições do trabalho docente.

O mesmo pode-se dizer caso se observe a condição contrária, analisando-se o curso de licenciatura da mesma IES em diferentes lugares. Neste caso, há interferência de dois elementos: a condição da cidade em relação ao nível hierárquico e centralidade; e o tipo de modalidade do curso.

Como se verificou no caso da Universidade Estadual do Maranhão (UEMA), as condições dos cursos variam conforme a modalidade do curso e do nível de centralidade da cidade, condições estas que são indissociáveis. Por isso, há diferenças nos elementos analisados nas licenciaturas nas cidades de São Luís, Imperatriz e Santa Inês.

Ou seja, a mesma IES pode ter curso de Geografia a distância, temporário ou modular, pelo Parfor e regular-presencial. Assim, a modalidade na qual o curso é ofertado, e as características dos lugares onde estão inseridos; também, refletem suas condições.

O espaço subordina-se às verticalidades existentes, mas, ao mesmo tempo, é um agente, já que, nas cidades de maior porte hierárquico, ficam os cursos regulares e presenciais. Isto não tem a ver apenas com o número de habitantes, mas refere-se também ao papel na divisão territorial do trabalho daquela cidade em relação ao seu entorno ou a outros níveis hierárquicos. 
Então, ao considerar-se a existência das licenciaturas em Geografia há inúmeras mediações que precisam ser pensadas: mediações dos processos históricos existentes; da permanência de antigas problemáticas, que viram tradição; de como se realizam nos lugares e nos diferentes tipos de IES, bem como das diversas modalidades nas quais as licenciaturas são ofertadas. Nem todas as mudanças empreendidas nas ações das redes de afinidade geográfica ou nas políticas públicas chegam do mesmo modo nos diferentes cursos e lugares.

Por isso, propôs-se que o entendimento da existência dos cursos tenha como possibilidade de estudo, análise e avaliação, o entendimento do espaço geográfico e da situação como possibilidade de método. Esta proposição parte do princípio que este método pode ser usado em outros estudos que se relacionem ao Ensino Superior, IES e cursos.

Evidenciando o papel que o espaço tem para entender as condições das licenciaturas em Geografia, sobretudo nas seguintes premissas:

- O papel da cidade na hierarquia urbana neste processo de existência dos cursos e as novas qualidades da rede urbana;

- A tensão dialética entre a polarização das metrópoles e das capitais dos estados com o interior, que interferem nas diversas dimensões, elementos e variáveis;

- As especificidades dos lugares, que tornam algumas características dos cursos peculiares;

- O território como ator ou agente e sua relação dialética à medida que interfere na existência das licenciaturas, mas também se subordina a elas;

- Os arranjos espaciais e a análise de situação que nos permitem integrar dimensões, elementos e variáveis com os conteúdos do lugar;

- A concepção de que é necessário pensar o espaço como forma de entender a história da Geografia no Brasil; 
- A visão do espaço e tempo como categorias indissociáveis, e, derivada desta premissa o uso do conceito de tempos espaciais para a análise das condições dos cursos;

- A divisão territorial e social do trabalho nas IES com licenciaturas em EAD, na divisão entre IES-Sede e nos polos onde os cursos se realizam.

Há muitas premissas naturalizadas e inúmeros paradoxos que foram demonstrados nesta tese e que ao analisá-lo do ponto de vista do espaço geográfico, puderem evidenciar outra forma de estudar a questão. Uma delas é a visão dos centros, principalmente de São Paulo e Rio de Janeiro sobre a Geografia brasileira, quando na verdade existem várias Geografias dos cursos de Ensino Superior sendo produzidas em outros lugares do Brasil, com diferentes condições e situações.

Outra premissa é a de que os maiores problemas dos cursos estão circunscritos às IES privadas, quando também existem várias inadequações nos cursos das IES públicas que se interiorizaram recentemente.

Além disso, há novas qualidades das redes urbanas que levam IES e licenciaturas em Geografia a municípios de pequeno porte, que recebe um novo tipo de serviço, mas muitos deles são temporários e funcionam como uma expansão intermitente.

Há paradoxos de todos os tipos em relação à existência dos cursos de Geografia e da formação para a docência no Brasil, entre outras, as que se referem:

- Aos discentes estudando por meio de apostilas em pleno início do século XXI, período no qual em princípio há maior disponibilidade de produção acadêmica;

- Aos licenciados que não querem ser professores;

- Aos professores de outras áreas de conhecimento lecionando Geografia em diversos níveis; 
- Aos cursos de EAD concentrados em regiões onde já existe formação presencial e também de licenciaturas em EAD que não usam TICs;

- Da incapacidade da Geografia de ter uma epistemologia própria, dividindo o trabalho do geógrafo ora na técnica, ora na Pedagogia;

- Da avaliação do MEC que desconsidera o território em sua análise, sem levar em conta as rugosidades e diversidades existentes nos lugares;

- Da ideia de que o bacharelado forma o pesquisador e a licenciatura um reprodutor de conhecimento;

- Das IES municipais do interior de Pernambuco, que embora públicas são pagas e têm maioria de professores horistas e especialistas.

Logo, há inúmeras questões levantadas que certamente podem ser aprofundadas em outras pesquisas por geógrafos ou por profissionais de outras áreas de conhecimento.

Espera-se que, desta forma, esta tese tenha contribuído um pouco mais para desvendar as condições nas quais se encontram as licenciaturas em Geografia no Brasil atualmente e que possa servir de método para outras análises que forem realizadas, sejam da Geografia ou não. 


\section{REFERÊNCIAS}

AB'SABER, Aziz Nacib. Pierre Monbeig: a herança intelectual de um geógrafo. Estudos Avançados, São Paulo, Universidade de São Paulo, 8 (22), 1994, p. 221-232.

Vinte e cinco anos de Geografia em São Paulo. (1934-1959). Comentário. Boletim Paulista de Geografia, AGB, São Paulo, no 34, 1960, p. 71-81.

ABREU, Maurício de Almeida. Pierre Monbeig e os primórdios da Geografia Urbana no Brasil. In: SALGUEIRO, Heliana Angotti (org.). Pierre Monbeig e a Geografia Humana brasileira. Bauru, Edusc, 2002, p. 129-159.

AFONSO, Almerindo Janela. Avaliação educacional: regulação e emancipação. São Paulo: Cortez, 2005.

ALBUQUERQUE, Maria Adailza Martins de. Currículos de Geografia: da abertura política aos PCN's. Mercator - Revista de Geografia da UFC, Fortaleza, ano 4, no 7, 2005, p. 57-74.

ALMEIDA, Maria Elizabeth Bianconcini de. Educação a distância na internet: abordagens e contribuições dos ambientes digitais de aprendizagem. Pontifícia Universidade Católica de São Paulo, Educação e Pesquisa, São Paulo, v.29, no 2, jul./dez. 2003, p. 327-340.

AMARAL, Márcio Douglas Brito. Dinâmicas econômicas e transformações espaciais: a metrópole de Belém e as cidades médias da Amazônia Oriental- Marabá (PA) e Macapá (AP). Tese (Doutorado em Geografia Humana), FFLCH, USP, 2010.

AMORIM, Cassiano Caon. $\mathbf{O}$ uso do território brasileiro e as Instituições de Ensino Superior. Tese (Doutorado em Geografia Humana) - FFLCH, Universidade de São Paulo, São Paulo, 2010.

ANDRADE, Manuel Correia de. A Geografia no contexto das Ciências Sociais em Pernambuco. Revista Brasileira de Ciências Sociais, São Paulo, v. 22, ano 65, outubro de 2007, p. 9-15.

. O pensamento geográfico e a realidade brasileira. Boletim Paulista de Geografia, AGB, São Paulo, no 54, 1977, p. 5-28.

Pierre Monbeig e o pensamento geográfico no Brasil. Boletim Paulista de Geografia, AGB, São Paulo, no 72, 1994, p. 63-82.

ANSELMO, Rita de Cássia M.S; KNYCHALA, Junia de Freitas. O curso de Geografia em Uberlândia - MG no contexto da interiorização das universidades no Brasil. II Encontro Nacional de História do Pensamento Geográfico. Depto de Geografia, Universidade de São Paulo, São Paulo, 2009, p.1-13.

ARAUJO, Sonia Marcela. Evaluación, incentivos a la actividad investigadora y trabajo académico: algunas conclusiones em el estúdio de um caso em la Argentina. In: $\mathrm{KROTSCH}$, Pedro. (org.). La universidad cautiva: legados, marcas y horizontes. La Plata, p. 230-251, 2002. 
. Los universitarios em la lupa: evaluación de la calidad, incentivos a la actividad investigadora y SUS efectos em la profesión acadêmica. In: Pensamiento Universitario. Buenos Aires, no 9, abr.2001, p. 23-37.

ARENDT, Hannah. A condição humana. Tradução de Roberto Raposo. Rio de Janeiro: Forense Universitária, 2008, p. 188-338.

ASSOCIAÇÃO DOS GEÓGRAFOS BRASILEIROS (AGB). A AGB e o documento final do Projeto Diagnóstico e Avaliação do Ensino de Geografia no Brasil 76. Revista Terra Livre, São Paulo, ano 1, no 1, 1986, p.76-77.

AZEVEDO, Aroldo de. Dez anos de Ensino Superior de Geografia. Revista Brasileira de Geografia. Comentários. Rio de Janeiro, IBGE, ano VIII, no 2, abr-jun, 1946, p. 227-242.

. Notas sobre o ensino da Geografia em Universidades dos Estados Unidos. Boletim Paulista de Geografia, AGB, São Paulo, no 37, 1961, p. 66-90.

;SILVEIRA, João Dias da. O Ensino da Geografia na Faculdade de Filosofia da Universidade de São Paulo. Boletim Paulista de Geografia, São Paulo, AGB, no 3, out. 1949, p. 77-83.

BACELAR, Tânia. Dinâmica regional brasileira nos anos noventa: rumo a desintegração competitiva? In: CASTRO, Iná (et.alii. orgs.). Redescobrindo o Brasil: 500 anos depois. Rio de Janeiro: Bertrand do Brasil, 2000, p. 72-99.

BACKHEUSER, Everardo. Fronteiras da Geologia e da Geografia e a unidade desta ciência. Revista Brasileira de Geografia. Comentários. Rio de Janeiro, IBGE, ano III, no 3, jul-set. 1941, p. 637-647.

BARONI, José Marcelo Biagioni. Acesso ao Ensino Superior público: realidade e alternativas. Tese (Doutorado da Faculdade de Educação), USP, 2010.

BARREIRO, Iraíde Marques de Freitas; TERRIBILI FILHO, Armando. Educação superior no período noturno no Brasil: políticas, intenções e omissões. Ensaio: aval. pol. públ. Educ., Rio de Janeiro, v.15, no 54, p. 81-102, jan./mar. 2007, p. 81-100.

BARROS, Nilson Cortez Crocia de. A historiografia da Geografia: apreciação de um debate. Revista de Geografia, Recife, UFPE DCG/NAPA, v. 24, no 1, jan/abr. 2007, p. 223-239.

Delgado de Carvalho e a geografia no Brasil como arte da educação liberal. Estudos Avançados, Universidade de São Paulo, São Paulo, 22 (62, 2008), p. 327-333.

BASALLA, George. The spread of western science. In: Science, 156, maio 1967, p. 611-622.

BELLETATI, Valéria Cordeiro Fernandes. Dificuldades de alunos ingressantes na universidade pública: indicadores para reflexões a docência universitária. Tese (Doutorado na Faculdade de Educação), USP, São Paulo, 2011. 
BERDOULAY, Vincent. Do contexto ao relato: revisitar a modernidade. In: CASTRO, Iná Elias de et alli (orgs.). Redescobrindo o Brasil: 500 anos depois. Rio de Janeiro: Bertrand do Brasil/FAPERJ, 2000, p. 315-322.

La formation de L'école française de geographie (18701914). Paris: Biblioteque Nationale, 1981.

BERNARDES, Nilo. A influência estrangeira no desenvolvimento Geografia do Brasil. Revista Brasileira de Geografia. Rio de Janeiro, IBGE, ano 44, no 3, jul/set. 1982, p. 519-528.

BERTALANFFY, Ludwig Von. Teoria geral dos sistemas. Tradução de Francisco Guimarães. Petrópolis: Vozes, 1975. 315p.

BLUM, Edinéia Aparecida. A formação de formadores na educação a distância: redescobrindo o papel do professor-tutor. Dissertação (Mestrado na Educação), Universidade Estadual de Ponta Grossa, 2004.

BONNEMAISON, Joel. Viagem em torno do território. In: ROSENDAHL, Zeny e. CORRÊA, Roberto Lobato (orgs). Geografia cultural: um século (3). Rio de Janeiro: Eduerj, 2002, p. 83-132.

BOURDIEU, Pierre; PASSERON, Jean-Claude. A reprodução: elementos para uma teoria do sistema de ensino. Petrópolis: Ed. Vozes Ltda, 2008.

BRASIL. Constituição da República Federativa do Brasil de 1988. Brasília: Presidência da República, Casa Civil, 1988. Disponível em: http://www.planalto.gov.br/ccivil_03/constituicao/constitui\%C3\%A7ao.ht m. Acesso em 20/08/2009.

. Decreto 19.851, de 11 de abril de 1931. Dispõe sobre o sistema universitário. Disponível em: http://www2.camara.gov.br/legin/fed/ decret/1930-1939/decreto-19851-11-abril-1931-505837-publicacao-1pe.html. Acesso em 20/10/2010.

Decreto no 2.026, de 10 de Outubro 1996. Estabelece procedimentos para o processo e avaliação dos cursos e instituições de ensino superior. Brasília: Presidência da República. Casa Civil, 1996a. Disponível em: http://www.planalto.gov.br / ccivil_03/decreto/Antigos/ D2026.htm. Acesso em 01/11/2008.

. Decreto no 5.773/2006. Dispõe sobre o exercício das funções de regulação, supervisão e avaliação de instituições de educação superior e cursos superiores de graduação e seqüenciais no sistema federal de ensino. Brasília: 2006. Disponível em: http://portal.mec.gov.br/seed/ arquivos/pdf/legislacao/decreton57731.pdf. Acesso em 20/01/2012.

Decreto no 6.755, de 29 de janeiro de 2009. Institui a Política Nacional de Formação de Profissionais do Magistério da Educação Básica, disciplina a atuação da Coordenação de Aperfeiçoamento de Pessoal de Nível Superior - Capes no fomento a programas de formação inicial e continuada, e dá outras providências. Brasília: Presidência da República. Casa Civil, 2009a. Disponível em: http://www.planalto.gov.br/ccivil_03 /_Ato20072010/2009/Decreto/D6755.htm. Acesso em 20/05/2010. 
. Decreto-Lei 2306/97. Disponível em: http://www.planalto.gov.br /ccivil_03/decreto/D2306.htm. Acesso em 20/01/2012.

. Lei 5.540/68. Fixa normas de organização e funcionamento do ensino superior e sua articulação com a escola média, e dá outras providências. Brasília: DF, 1968. Disponível em: https://www.planalto.gov.br/ccivil_03/leis//5540.htm. Acesso em 07/01/2012.

. Lei no 10861, de 14 de abril de 2004. Institui o Sistema Nacional de Avaliação da Educação Superior - SINAES e dá outras providências. Brasília: Presidência da República. Casa Civil, 2004. Disponível em http://portal.mec.gov.br/arquivos/pdf/leisinaes.pdf. Acesso em 20/10/2008.

. Lei no 9131, de 24 de novembro de 1995. Altera dispositivos da Lei no 4.024, de 20 de dezembro de 1961, e dá outras providências. Brasília: Presidência da República. Casa Civil, 1995. Disponível em http://www.planalto.gov.br/ccivil_03/leis/L9131.htm. Acesso em 01/11/2008.

. Lei no 9394 de 20 de dezembro de 1996. Estabelece as Diretrizes e Bases da Educação Nacional. Diário Oficial da União. Brasília: DF, 23 dez. 1996b. Disponível em: http://portal.mec.gov.br/arquivos/pdf/ldb.pdf. Acesso 20/10/10.

. Portaria Normativa n no 40, dezembro de 2007. Brasília, 2007. Disponível em: http://www.abmes.org.br/abmes/public/arquivos /legislacoes/Port_Norm_040_2007_12_12_Republicada_2010_12_29.pdf. Acesso 03/03/2012.

. Resolução no 48, de 4 de setembro de 2009. Diário Oficial da União no 171, terça-feira, p. 28-30, 8 de set. 2009b. Estabelece orientações e diretrizes para concessão e pagamento de bolsas de estudo e de pesquisa a participantes das instituições públicas de educação superior que atuam nos cursos especiais presenciais de primeira e segunda licenciatura e de formação pedagógica do Plano Nacional de Formação dos Professores da Educação Básica, a serem pagas pelo FNDE. Disponível em: http://www.in.gov.br/imprensa/visualiza/index.jsp?data= 08/09/2009 \&jornal=1\&pagina=28\&totalArquivos=128. Acesso em 20/04/2010.

BRAY, Silvio Carlos. O pensamento e o método na obra de Pierre Monbeig: análise dos trabalhos produzidos nas décadas de 30-40. Revista de Geografia, Unesp, São Paulo, v. 2, 1983, p. 83-90.

CABRAL, Eddy Flores. O ensino da Geografia. Boletim Geográfico, IBGE, Rio de Janeiro, Ano XVI, no 145, Jul-Ago. 1958, p. 534- 554.

CACETE, Núria Hanglei. A formação do professor de Geografia: uma questão institucional. Boletim Goiano de Geografia, Goiânia, Instituto de Estudos Sócio-Ambientais/Geografia, UFG, v. 24, no 1-2, jan/dez 2004, p. 24-30. 
A formação do professor para a escola secundária e sua localização institucional: Da Faculdade de Filosofia ao Instituto Superior de Educação. A referência da formação do professor de Geografia. Tese (Doutorado em Geografia Física) - FFLCH, Universidade de São Paulo, 2002.

CANO, Wilson. Raízes da concentração industrial em São Paulo. Apêndice Estatístico. Rio de Janeiro: Difel, 1977, p. 263-311.

CARDOSO, Luciene Pereira Carris. Tradição e modernidade no processo de institucionalização do saber geográfico no Brasil: o caso da Sociedade de Geografia do Rio de Janeiro. II Encontro Nacional da História do Pensamento Geográfico, São Paulo, Depto de Geografia, USP, 2009, p. 1-16.

CARVALHO, Ana Beatriz Gomes. O curso de licenciatura em Geografia à distância no âmbito do pró-licenciatura e a mudança de paradigma na formação dos professores. Anais do VII Encontro Nacional da Anpege, Niterói, 2007.

CARVALHO, Delgado de. O Ensino de Geografia no Curso de Humanidades. Boletim Geográfico. Rio de Janeiro, CNG/IBGE, Ano I, no 10, jan. 1944, p. 7-13.

CASSAB, Clarice. Geografia científica e Geografia escolar: o diálogo necessário. $12^{\circ}$ Encuentro de Geografos de America Latina, Montevideo, Uruguay, p. 1-15, 2009. Disponível em: http://egal2009. easyplanners.info/area03/3054_Cassab_Clarice.pdf. Acesso em 10/07/2009.

CASTILHO, Fausto. $\mathbf{0}$ conceito de universidade no projeto da Unicamp. Organização de Alexandre Guimarães Tadeu de Soares. Campinas: Ed. da Unicamp, 2008.

CAVALCANTI, Lana de Souza. A problemática do ensino de Geografia veiculada nos Encontros Nacionais da AGB (1976-1986): um levantamento preliminar. Boletim Goiano de Geografia, Goiânia, Departamento de Geografia, Instituto de Química e Geociências, UFG, v. 15, no 1, jan/dez 1995, p. 35-55.

CHAVEIRO, Eguimar Felício. A importância do estágio num curso de licenciatura. Boletim Goiano de Geografia, Goiânia, Departamento de Geografia, Instituto de Química e Geociências, UFG, v. 12, no 1, jan/dez 1992, p. 35-55.

CHRISTOFOLETTI, Antonio. Perspectivas e critérios para a organização da estrutura curricular no Ensino de Geografia. Boletim Goiano de Geografia, Goiânia, Instituto de Estudos Sócio-Ambientais/Geografia, UFG, v. 17, no 1, jan/jun 1997, p. 1-20.

CIAVATTA, Maria. Os centros federais de educação tecnológica e o ensino superior: duas lógicas em confronto. Revista Educação e Sociedade. Campinas, v. 27, no 96 - Especial, out. 2006, p. 911-934. 
COMTE, Auguste. Curso de filosofia positiva; Discurso sobre o espírito positivo; Discurso preliminar sobre o conjunto do positivismo; Catecismo positivista. Seleção de textos de José Arthur Gianotti. Coleção os Pensadores. São Paulo: Abril Cultural, 1978.

CONTI, José Bueno. A reforma do ensino em 1971 e a situação da Geografia. Boletim Paulista de Geografia, AGB, São Paulo, no 51, 1976, p. 57-70.

CORRÊA, Roberto Lobato. A rede urbana. São Paulo: Ática, 1990.

Brasil, 2006a.

Estudos sobre a rede urbana. Rio de Janeiro: Bertrand do

. Espaço: um conceito-chave da Geografia. In: CASTRO, Iná de Elias; GOMES, Paulo César da Costa; CORRÊA, Roberto Lobato (orgs.). Geografia: conceitos e temas. Rio de Janeiro: Bertrand do Brasil, 2006b, p. $15-48$.

CUNHA, Luiz Antônio. A universidade crítica: o ensino superior na república populista. São Paulo: Ed. UNESP, 2007a.

A universidade reformanda: o golpe de 1964 e a modernização do ensino superior. São Paulo: Ed. UNESP, 2007b.

. O ensino superior na era Vargas. In: A universidade temporã:

O ensino superior, da colônia à era Vargas. São Paulo: editora UNESP, 2007c, p.205-296.

O ensino superior no octênio FHC. Revista de Educação e Sociedade, Campinas, v. 24, no 82, abr. 2003, p. 37-61.

CUNHA, Maria Isabel da. Ensino como mediação da formação do professor universitário. In: MOROSINI, Marília Costa (org.). Professor do ensino superior: identidade, docência e formação. Brasília: Instituto Nacional de Estudos e Pesquisas Educacionais, 2000, p. 45-52.

DEFFONTAINES, Pierre. Dez anos de trabalhos geográficos. Revista Brasileira de Geografia. Depoimentos. Rio de Janeiro, IBGE, ano VIII, no 2, abr-jun, 1946, p. 251-252.

DIAS SOBRINHO, José. Avaliação educativa: produção de sentidos com valor de formação. In: DIAS SOBRINHO, José; RISTOFF, Dilvo; GOERGEN, Pedro. Universidade e sociedade: perspectivas internacionais. Sorocaba: Eduniso, Raies, p. 169-182, 2008.

Educação superior: flexibilização e regulação ou avaliação e sentido público. In: DOURADO, Luiz Fernandez (org.) et alli.. Políticas e gestão da educação superior: transformações recentes e debates atuais. São Paulo: Editora Alternativa, Xamã, 2003, p. 97-116.

DIAS, Carmen Lúcia et alii. Políticas para avaliação da qualidade do Ensino Superior no Brasil: um balanço crítico. Revista de Educação e Pesquisa, São Paulo, Revista da Fac. de Educação da USP, v. 32, no 3, set-dez, 2006, p. 435-464. 
DURHAM, Eunice R. A autonomia universitária: extensão e limites. In: STEINER, João E.; MALNIC (orgs.). Ensino superior: conceito e dinâmica. São Paulo: Edusp, 2006, p. 79-123.

ENGELS, Friedrich. A dialética da natureza. Rio de Janeiro: Paz e Terra, 1979.

FAZENDA, Ivani. (org.). Metodologia da pesquisa educacional. São Paulo: Cortez, 1989. 145 p.

FERREIRA, Zeila Miranda. Prática pedagógica do professor-tutor em EAD no curso "Veredas - formação superior de professores". Tese (Doutorado da Faculdade de Educação), USP, 2009.

FIGUEIREDO, Marcus Faria;FIGUEIREDO, Argelina Maria Cheibub. Avaliação política e avaliação de política: um quadro de referência teórica. Análise e Conjuntura, Belo Horizonte, 1986. Disponível em fjp.mg.gov.br. Acesso em 20/09/2008.

FLEUISS, Max. História da Geografia. Revista Brasileira de Geografia. Depoimento. Rio de Janeiro, IBGE, Ano II, no 3, 1940, p. 446-447.

FOLHA DE SÃO PAULO. MEC vai propor a fusão de disciplinas no Ensino Médio. São Paulo, Caderno Cotidiano, 16 ago 2012, p. 1;4.

FÓRUM DAS ENTIDADES REPRESENTATIVAS DO ENSINO SUPERIOR PARTICULAR. Carta ao ministro da Educação. Impresso, São Paulo, 2008. FÓRUM DE PRÓ-REITORES DE EXTENSÃO DAS INSTITUIÇÕES DE EDUCAÇÃO SUPERIOR PÚBLICAS BRASILEIRAS (FORPROEX). Política nacional de extensão universitária. Manaus, 2012. Disponível em: http://www.renex.org.br/documentos/20120628-Política-Nacional-deExtensao-Universitaria.doc. Acesso em 04/07/2012.

FUENZALIDA, Eugenio Rodríguez. A avaliação de sistemas educacionais: a experiência chilena e seus efeitos na qualidade da Educação(1). Disponível em http://www.crmariocovas.sp.gov.br /pdf/ideias_30_p089-121_c.pdf. Acesso 20/10/2008.

GERALDI, Corinta Maria Grisolia; FIORENTINI, Dario; PEREIRA, Elisabete Monteiro de (orgs.). Cartografias do trabalho docente: professor(a)pesquisador(a). Campinas: Mercado das Letras, 2001.

GIROUX, Henry. Os professores como intelectuais: rumo a uma pedagogia crítica da aprendizagem. Tradução de Daniel Bueno. Porto Alegre: Artmed, 1997.

GOERGEN, Pedro. Ensino superior e formação: elementos para um olhar ampliado de avaliação. In: DIAS SOBRINHO, José; RISTOFF, Dilvo I. (orgs.). Avaliação democrática: para uma universidade cidadã. Florianópolis, 2002, p. 69-98.

GOMES, Alba. "60 ANOS DA GEOGRAFIA UFRGS". Depoimento. Pet Geografia. Revista eletrônica. Para onde? Porto Alegre, UFRGS, no 1, jul-dez, p. 90-97, 2007. Disponível em: http://www6.ufrgs.br /seerparaonde/ojs/artigos/Edicoes_anteriores/revista_n01.pdf. 
GOMES, Paulo Cesar da Costa. Geografia e modernidade. Rio de Janeiro: Bertrand Brasil, 2007.

GONÇALVES, Carlos Walter Porto. A Geografia está em crise. Viva a Geografia!. Boletim Paulista de Geografia, São Paulo, AGB, no 55, 1978, p. 5-30.

GOODSON, Ivor F. Currículo: teoria e história. Petrópolis: Ed. Vozes, 2005.

GRAMSCI, Antonio. Cadernos do cárcere. Volume I. Tradução Carlos Nelson Coutinho, coedição Luiz Sérgio Henriques e Marco Aurélio Nogueira. Rio de Janeiro: Civilização Brasileira, 2006.

HAESBAERT, Rogério. Territórios alternativos. São Paulo: Contexto, 2002.

HELENE, Otaviano. O que as avaliações permitem avaliar. In: STEINER, João E.; MALNIC, Gerard (orgs.). Ensino Superior: conceito e dinâmica. São Paulo: Edusp, 2006.

HERNÁNDEZ, Fernando. Transgressão e mudança na educação: os projetos de trabalho. Porto Alegre: Artmed, 1998.

.;VENTURA, Montserrat. A organização do currículo por projetos de trabalho. Porto Alegre: Artes Médicas, 1998.

HISSA, Cássio Eduardo Viana; OLIVEIRA, Janete Regina de. O trabalho de campo: reflexões sobre a tradição geográfica. Goiânia, Boletim Goiano de Geografia, Instituto de Estudos Sócio-Ambientais/Geografia, UFG, v. 24, no 1-2, jan/dez 2004, p. 32-41.

HUERTAS, Daniel Monteiro. Da fachada atlântica à imensidão amazônica: fronteira agrícola e integração territorial. São Paulo: Annablume, 2009.

HUMBOLDT, Guilherme de. Sobre a organização interna e externa dos estabelecimentos científicos superiores em Berlim. Memorando. Tradução de Fausto Castilho. In: CASTILHO, Fausto. $\mathbf{O}$ conceito de universidade no projeto da Unicamp. Campinas: Ed. da Unicamp, anexo, 2008, p. 179-201.

IANNI, Octavio. A sociedade global. Rio de Janeiro: Civilização Brasileira, 2003.

INSTITUTO BRASILEIRO DE GEOGRAFIA E ESTATÍSTICA (IBGE). Anuário Estatístico do Brasil, Rio de Janeiro, Ano XI, 1950, Serviço Gráfico do Instituto Brasileiro de Geografia e Estatística, 1951.

. Cadastro de professores de Geografia. Ensino Superior. Boletim Geográfico, CNG, Rio de Janeiro, ano XVI, no 142, Jan-Fev. 1958, p. 102-105.

Conselho Nacional de Geografia. Depoimento. Revista Brasileira de Geografia. Noticiário. Rio de Janeiro, ano XXIV, no 2, Abr/Jun.1962a, p. 289-298. 
. I Reunião Pan-Americana de consulta sobre Geografia. Revista Brasileira de Geografia. Noticiário. Rio de Janeiro, Ano XI, n० 3, Jul/set. 1949, p. 451-464.

. Programa do curso de Geografia. Faculdade de Filosofia, Ciências e Letras da Universidade de São Paulo. Rio de Janeiro, Boletim Geográfico, CNG, ano XVI, no 143, mar-abril. 1958, p. 275-293.

.Curso de aperfeiçoamento de professores de nível secundário. Revista Brasileira de Geografia. Noticiário. Rio de Janeiro, ano VII, no 2, abr-jun. de 1945, p. 347-348.

Curso de férias para professores de Geografia. Revista Brasileira de Geografia. Noticiário. Rio de Janeiro, ano VII, no 2, jan.mar. 1963 , p. $139-149$.

- Curso de férias para aperfeiçoamento de professores de Geografia do Ensino Médio. Revista Brasileira de Geografia. Noticiário. Rio de Janeiro, ano VII, no 2, jan-mar, 1965, p. 175-179.

O Ensino de Geografia na Lei de Diretrizes e Bases. Revista Brasileira de Geografia. Noticiário. Rio de Janeiro, ano XXIV, no 3, julset., 1962 b, p. 165-168.

. Regiões de influências das cidades 2007. Rio de Janeiro, 2008. Disponível em: http://www.ibge.gov.br/home/geociencias/geografia /regic.shtm. Acesso em: 20/01/2012.

INSTITUTO NACIONAL DE ESTUDOS E PESQUISAS EDUCACIONAIS ANÍSIO TEIXEIRA (INEP). Enade 2005: Relatório síntese - Curso de Geografia. Brasília: Inep, 2006.

Novo indicador aponta qualidade de instituições de educação superior. Brasília: Assessoria de Imprensa do Inep, 8 set. 2008a. Disponível em: http://www.inep.gov.br/imprensa/ noticias/edusuperior/institucional/news08_02.htm. Acesso 28/09/2009.

Portaria Normativa no 12, de 5 de Setembro de 2008. Brasília: Inep, 2008b. Disponível em: http://www.inep.gov.br/download/condicoes_ensino/2008/PORTARIA_NO RMATIVA_12.pdf. Acesso em 30/10/2008.

ENC 2003. Prova de Geografia. Brasília: Inep, 2003a. Disponível em: http://www.inep.gov.br/download/enc/2003 /provas/ Prova-Geo-Tipo1.pdf. Acesso 20/10/2008.

2003b.

. Relatório do Exame Nacional de Cursos 2003. Brasília: Inep,

Resultado do Indicador de Diferença entre os Desempenhos Observado e Esperado - IDD. Nota Técnica. Brasília: Inep, p. 1-8, 2008c. Disponível em: http://enade2005.inep. gov.br/doc/ nota_tecnica_IDD.pdf. Acesso 21/10/2008.

BRASIL Decreto no 19851, de 11 de abril de 1931. Informações. Brasília, Conselho Administrativo, 2010. Disponível em: http://www.inep. 
gov.br/pesquisa/thesaurus/thesaurus.asp?te $1=31674 \&$ te $2=38835 \&$ te $3=$ 39299\&te $4=32443 \&$ te $5=32453 \&$ te $6=32462$. Acesso $10 / 02 / 2010$.

Conceito Preliminar de Cursos de Graduação. Brasília: Inep, p. 1-5, 2008. Disponível em: http://www.inep.gov.br/download/enade /2007/CONCEITO_PRELIMINAR_Educacao_Superior.pdf. Acesso 21/10 /2008.

Quem quer ser professor no Brasil? O que o Enem diz. Na Medida. Boletim de estudos educacionais. Brasília, Inep, ano $1, n^{\circ} 3, \mathrm{p}$. 4-9 set. de 2009.

KOSIK, KAREL. Dialética do concreto. Tradução de Célia Neves e Alderico Toríbio. Rio de Janeiro: Paz e Terra S/A, 2002.

KRAWCZYK, Nora Rut. Políticas de regulação e mercantilização da educação: socialização para uma nova cidadania? In: Revista de Educação e Sociedade, Campinas, v. 26, no 92, Especial - out. 2005, p. 799-819.

$\mathrm{KROTSCH}$, Pedro. Las tensiones en el proceso de formación e implementación de las políticas de evaluación de calidad en la Argentina. In: TRINDADE, Hélgio; BLANQUER, Jean Michel (orgs.). Os desafios da educação na América Latina. Petrópolis: Vozes, 2002, p. 157-186.

KUHN, Thomas S. A estrutura das revoluções científicas. São Paulo: Perspectiva, 2007.

LANGENBUCH, Juergen Richard. Os vinte e cinco anos da Geografia em Rio Claro. Revista de Geografia, Unesp, São Paulo, v. 2, 1983, p. 1-12.

LATOUR, Bruno. Ciência em ação: Como seguir cientistas e engenheiros sociedade afora. São Paulo: Ed. Unesp, 2000.

LEÃO, Vicente de Paula. A influência das Diretrizes Curriculares Nacionais do Ministério da Educação e Cultura para a formação de professores de Geografia da Educação Básica em nível superior. Tese (Doutorado em Geografia) - Depto. de Geografia, UFMG, Belo Horizonte, 2008.

LEFEBVRE, Henri. Lógica formal. Lógica dialética. São Paulo: Civilização Brasileira, 1995.

LEHER, Roberto. Para silenciar os campi. Revista Educação e Sociedade, Campinas, v. 25, no 88, p. 867-891, Especial - Out. 2004. Disponível em <http://www.cedes.unicamp.br. Acesso em 20/08/2008.

LENCIONI, Sandra. Uma nova determinação do urbano: o desenvolvimento do processo de metropolização do espaço. In: CARLOS, Ana Fani A.;LEMOS, Amália Inês Geraiges (orgs.). Dilemas urbanos: novas abordagens sobre a cidade. São Paulo: Contexto, 2003.

LIMA, Licínio; AZEVEDO, Mário Luiz Neves de; CATANI, Afrânio Mendes. O processo de Bolonha, a avaliação da educação superior e algumas considerações sobre a universidade nova. In: DIAS SOBRINHO, José; RISTOFF, Dilvo;GOERGEN, Pedro. Universidade e sociedade: perspectivas internacionais. Sorocaba: Eduniso, Raies, 2008, p. 45-71. 
LIMA, Manolita Correia; CONTEL, Fabio Betioli. Internacionalização da Educação Superior: nações ativas, nações passivas e geopolítica do conhecimento. São Paulo: Alameda, 2011, p. 11-89.

LOPES, Claudivan Sanches. O professor de Geografia e os saberes profissionais: 0 processo formativo e 0 desenvolvimento da profissionalidade. Tese (Doutorado em Geografia Humana) - FFLCH, Universidade de São Paulo, 2010.

MACHADO, Lia Osório. Origens do pensamento geográfico no Brasil: meio tropical, espaços vazios e a ideia de ordem. (1870-1930). In: CASTRO, Ina Elias de; CORRÊA, Paulo César da Costa; CORRÊA, Roberto Lobato (orgs.). Geografia: conceitos e temas. Rio de Janeiro: Bertrand, 1995, p. 309-353.

MACHADO, Mônica Sampaio. A construção da Geografia Universitária no Rio de Janeiro. Rio de Janeiro: Apicuri, 2009.

MARX, Karl; ENGELS, Friedrich. A ideologia alemã. Tradução de Luis Claudio de Castro e Costa. São Paulo: Martins Fontes, 2002.

MELO, Mario Lacerda de. Os estudos regionais e o papel das universidades. São Paulo, AGB, Boletim Paulista de Geografia, no 20, jul. 1955 , p. 56-75.

MENDONÇA, Francisco. Geografia Física: ciência humana? São Paulo: Contexto, 1989.

MIMESSE, Eliane. A implantação dos Estudos Sociais nas grades curriculares das escolas estaduais nos anos de 1970 e a formação acadêmica do professor. Educere et Educare. Revista de Educação da Unioeste, Cascavel, v. 2, no 4, jul/dez. 2007, p. 193-204.

MINISTÉRIO DA EDUCAÇÃO (MEC). Cursos de Geografia. Brasília: MEC, 2009a. Disponível em: http://www.educacaosuperior.inep.gov.br /curso.stm. Acesso: 01/09/2009.

. Decreto no 5622/2005. Regulamenta o art. 80 da Lei $n^{\circ} 9394$, de 20 de dezembro de 1996, que estabelece as diretrizes e bases da educação nacional. Disponível em: http://www.planalto.gov.br /ccivil_03/_Ato20042006/2005/decreto/D5622.htm. Acesso: 07/07/2012.

. Parecer CNE/CP 009/2001. Diretrizes Curriculares Nacionais para a Formação de Professores da Educação Básica, em nível superior, curso de licenciatura, de graduação plena. Brasília: Conselho Nacional de Educação, 2001a, p. 1-70. Disponível em: http://portal.mec.gov.br /cne/arquivos/pdf/009.pdf. Acesso em 20/02/2007.

- Parecer CNE/CES 1363/2001. Retificação do Parecer CNE/CES 492/2001, que trata da aprovação das Diretrizes Curriculares Nacionais dos Cursos de Filosofia, História, Geografia, Serviço Social, Comunicação Social, Ciências Sociais, Letras, Biblioteconomia, Arquivologia e Museologia. Brasília: CNE, 2001b, p. 1-11. Disponível em: http://www.abepss.org.br/briefing/documentos/legislacao _parecercne_1363.pdf. Acesso em 20/05/2010. 
. Parecer CNE/CES 492/2001. Diretrizes Curriculares Nacionais dos cursos de Filosofia, História, Geografia, Serviço Social, Comunicação Social, Ciências Sociais, Letras, Biblioteconomia, Arquivologia e Museologia. Brasília: CNE, 2001c, p. 1-38. Disponível em: http://portal.mec.gov.br/cne/arquivos/pdf/CES0492.pdf. Acesso em 20/08/2009.

. Plano Nacional de Formação dos Professores da Educação Básica.

Brasília, Plataforma Freire, 2010. Disponível em: http://freire.mec.gov.br/index/principal. Acesso em 15/06/2010.

. Portaria normativa no 9, de 30 de Junho de 2009. Institui o Plano Nacional de Formação dos Professores da Educação Básica no âmbito do Ministério da Educação. Brasília, MEC, 2009b, p. 1-3. Disponível em: http://portal.mec.gov.br/dmdocuments /port_normt_09_300609.pdf. Acesso em 15/06/2010.

MONBEIG, Pierre. A Geografia no Ensino Secundário. Boletim Geográfico, Rio de Janeiro, CNG/IBGE, Ano III, no 26, maio 1945, p. 163-171.

Análise sumária do moderno conceito de geografia. Boletim Geográfico, Rio de Janeiro, CNG/IBGE, ano VII, no 81, dez. 1949, p. 937-994.

Estudos geográficos. Boletim Geográfico. Rio de Janeiro, CNG/IBGE, Ano I, no 11, dez.1944, p. 7-11.

. Os modos de pensar na Geografia Humana. Boletim Paulista de Geografia, São Paulo, AGB, no 15, out. 1953, p. 43-51. MONBEIG, Pierre. Papel e valor do ensino de Geografia e sua pesquisa. Boletim Carioca de Geografia, Rio de Janeiro, SGRJ, ano VII, n० 1 e 2, 1954, p- 52-73.

MONTEIRO, Carlos Augusto de Figueiredo. A Geografia no Brasil (19341977): avaliação e tendências. São Paulo: IGEOG-USP, Série Teses e monografias, no $37,1980$.

60 anos da Geografia da UFRGS. Depoimento. Pet Geografia. Revista eletrônica. Porto Alegre, Para onde? UFRGS, no 1, jul-dez, 2007, p. 74-89. Disponível em: http://www6.ufrgs.br/seerparaonde/ojs/ artigos/Edicoes_anteriores/revista_n01.pdf. Acesso em 20/05/2010.

MORAES, Antonio Carlos Robert. Geografia: pequena história crítica. São Paulo: Hucitec, 1995.

Ideologias geográficas: espaço, cultura e política no Brasil. São Paulo: Annablume, 2005a.

Notas sobre identidade nacional e institucionalização da Geografia. Estudos Históricos, Rio de Janeiro, v. 4, 8, 1991, p. 166176.

Território e história no Brasil. São Paulo: Annablume, 2005b.

MOREIRA, Ruy. O pensamento geográfico brasileiro: as matrizes brasileiras. v. 3. São Paulo: Contexto, 2010. 
O pensamento geográfico brasileiro: as matrizes clássicas originárias. v. 1. São Paulo: Contexto, 2008.

o pensamento geográfico brasileiro: as matrizes da renovação. v. 2. São Paulo: Contexto, 2009.

. O que é Geografia? São Paulo: Brasiliense, 1995.

NASCIMENTO JÚNIOR, Francisco das Chagas do. O fenômeno de expansão das instituições de ensino superior e o território brasileiro. Geografia, Universidade Estadual de Londrina, Departamento de Geociências, v. 15, no 1, jan./jun, 2006, p. 145-171.

NOGUEIRA, André Magalhães et alli. Universidade e regime de trabalho. Documento n 56. Observatório Universitário. Agosto, 2006.

NOGUEIRA, Maria das Dores Pimentel. Extensão universitária: diretrizes conceituais e políticas. Belo Horizonte: PROEX, UFMG, 2000.

OLIVEIRA, Ariovaldo Umbelino de (org.). Para onde vai o ensino de Geografia? São Paulo: Contexto, 2001.

. Ensino de Geografia no Brasil: horizontes no final do século. São Paulo, Boletim Paulista de Geografia, AGB, no 72, 1994, p- 3-28.

PALUMBO, Dennis J. A abordagem de política pública para o desenvolvimento político na América. Trad. Adriana Farah. In: Política de capacitação dos profissionais da educação. Depto. TécnicoPedagógico. Belo Horizonte: Divisão de Produção de Materiais e Publicações, FAE/IRHJP, 1989.

PEREIRA, José Veríssimo da Costa. A Geografia do Brasil. In: AZEVEDO, Fernando (org.). As ciências no Brasil. V. 1. São Paulo: Melhoramentos, 1955, p. 315-412.

A moderna produção geográfica do Brasil e seus aspectos metodológicos. Boletim Paulista de Geografia, São Paulo, AGB, no 27, out, 1957., p. 95-110.

PEREIRA, Sérgio Luiz Nunes. Geografias: caminhos e lugares da produção do saber geográfico no Brasil 1838/1922. Dissertação (Mestrado em Geografia Humana). FFLCH, Universidade de São Paulo, São Paulo, 1997.

. De "ciência auxiliar" a saber autônomo: dois momentos da Geografia brasileira no século XIX. Boletim Goiano de Geografia, Goiânia, Instituto de Estudos Sócio-Ambientais/Geografia, UFG, v. 24, no 1-2, jan/dez 2004, p. 12-22.

PETRONE, Pasquale. Anotações sobre o Departamento de Geografia. Revista do Departamento de Geografia, São Paulo, FFLCH, USP, $n^{\circ} 1$, 1982, p.7-19.

PIMENTEL, Carla Silvia. Aprender a ensinar: a profissionalidade docente nas atividades de estágio em Geografia. Tese (Doutorado em Educação), Faculdade de Educação da Universidade de São Paulo, São Paulo, 2010. 
PIZZATO, Maria Dilonê. A geografia no contexto das reformas educacionais brasileiras. Geosul, Florianópolis, Ed. UFSC, v. 16, no 32, jul/dez, 2001, p. 95-138.

PONTUSCHKA, Nídia Nacib. A Geografia: pesquisa e ensino. In: CARLOS, A. F. A. (org.) Novos caminhos da Geografia. São Paulo: Contexto, 1999.

PRETI, Oreste. Educação a Distância: uma prática educativa mediadora e mediatizada. Cuiabá, UFMT, S/D. Disponível em: http://www.nead.ufmt.br /publicacao/download/EDUCACAO2.doc. Acesso: 07/07/2012.

RAFFESTIN, Claude. Por uma geografia do poder. Tradução Maria Cecília França. São Paulo: Ática, 1993.

REAL, Giselle Cristina Martins. A qualidade revelada na educação superior: impactos da política de avaliação no Brasil. Tese (Doutorado em Educação) - Faculdade de Educação, Universidade de São Paulo, São Paulo, 2007.

REGO, Nelson. "60 ANOS DA GEOGRAFIA UFRGS". Depoimento. Pet Geografia. Revista eletrônica. Para onde? Porto Alegre, UFRGS, no 1, juldez, 2007, p. 98-115. Disponível em: http://www6.ufrgs.br/seerparaonde /ojs/artigos/Edicoes_anteriores/revista_n01.pdf. Acesso 13/04/2010.

REVISTA GEOSUL. Entrevista com a professora Dirce Suertegaray. Geosul, Florianópolis, Ed. UFSC, v. 16, no 32, jul/dez, 2001, p. 167-192.

Entrevista com a professora Maria Adélia Aparecida de Souza.

Geosul, Florianópolis, Ed. UFSC, v. 18, no 350, jan/jun, 2003, p. 173-21.

. Entrevista com o professor José Bueno Conti. Geosul, Florianópolis, Ed. UFSC, v. 17, no 33, jan/jul, 2002, p. 184-205.

Entrevista com o professor Oswaldo Bueno Amorim Filho. Geosul, Florianópolis, Ed. UFSC, v. 20, no 40, jul/dez, 2005, p. 191-209.

ROCHA, Genylton Odilon Rêgo da Rocha. A política do conhecimento oficial e a nova Geografia dos (as) professores (as) para escolas brasileiras: o ensino de Geografia segundo os Parâmetros Curriculares Nacionais. Tese (Doutorado em Geografia Física) - FFLCH, Universidade de São Paulo, São Paulo, 2001.

Por uma Geografia moderna na sala de aula: Rui Barbosa e Delgado de Carvalho e a renovação do ensino de Geografia no Brasil. Mercator, Fortaleza, Revista de Geografia da UFC, ano 8, no 15, 2009, p.75-94.

ROCHA, Tadeu. A Geografia moderna em Pernambuco. Boletim Paulista de Geografia, São Paulo, AGB, no 17, jul.1954, p. 43-53.

RODRIGUES, Cleide. A teoria geossistêmica e sua contribuição aos estudos geográficos e ambientais. São Paulo, Revista do Departamento de Geografia, Universidade de São Paulo, 14, 2001, p. 69-77.

RUELLAN, Francis. Orientação científica dos métodos de pesquisa geográfica. Revista Brasileira de Geografia, Rio de Janeiro, IBGE, ano V, 4, out/dez. 1943 , p. 51-60. 
SACRISTÁN, J. Gimeno. O currículo: os conteúdos do ensino ou uma análise prática. In: SACRISTÁN, J. Gimeno; Gómez, A. L. Pérez. Compreender e transformar o ensino. São Paulo: Artmed, 2000a, p. 119-148.

. O currículo: uma reflexão sobre a prática. Porto Alegre: Artmed, 2000b.

SALGADO, Fernando C.F. O curso de Geografia do campus de Presidente Prudente completou 25 anos. Revista de Geografia, Unesp, São Paulo, v. 3, 1984, p. 1-8.

SALGUEIRO, Heliana Angotti (org.). Pierre Monbeig e a Geografia Humana brasileira: a dinâmica da transformação. Bauru: Edusc, 2006.

SANTOS, Catarina de Almeida. A expansão da educação superior rumo à expansão do capital: interfaces com a educação a distância. Tese (Doutorado na Faculdade de Educação) USP, 2008.

SANTOS, Milton. \& SILVEIRA, Maria Laura. O Brasil: território e sociedade no início do século XXI. São Paulo: Ed. Record, 2001a.

O Ensino Superior público e particular e o território brasileiro. Brasília: ABMES, 2001b.

SANTOS, Milton. A natureza do espaço: Técnica e tempo. Razão e emoção. São Paulo: Edusp, 2006.

A urbanização brasileira. São Paulo: Edusp, 2008a

Espaço e método. São Paulo: Edusp, 2008b.

O espaço do cidadão. São Paulo: Edusp, 2002.

. O retorno do território. In: SANTOS, Milton; SOUZA, Maria Adélia; SILVEIRA, Maria Laura. Território: globalização e fragmentação. São Paulo: Hucitec, p.15-20, 1996.

Por uma Geografia nova: da crítica da Geografia à Geografia Crítica. São Paulo: Edusp, 2004.

Técnica, espaço, tempo: globalização e meio técnico-científico informacional. São Paulo: Hucitec, 1994.

SANTOS, Wlademir dos. Desvelando a retórica do provão. In: CAPPELETTI, Isabel Franchi (org.). Avaliação de políticas educacionais. São Paulo: Ed. Articulação Universidade/Escola Ltda, 2002.

SARTRE, Jean-Paul. Crítica da razão dialética. (Precedido por Questão do método). Trad. Guilherme João de Freitas Teixeira). Rio de Janeiro: DP\&A editora, 2002.

SCHÄFFER, Neiva Otero. Os Estudos Sociais ocupam novamente o espaço... da discussão. Revista Terra Livre, São Paulo, AGB. Geografia e lutas sociais, no 4, jul., 1987, p. 97-104.

SCHWARTZMAN, Simon. 0 "conceito preliminar" e as boas práticas de avaliação do ensino superior. Brasília: ABMES, 2008. 
SGUISSARDI, Valdemar; SILVA JR. João dos Reis. 0 trabalho intensificado nas federais: pós-graduação e produtivismo acadêmico. São Paulo: Xamã, 2009.

SHAPIN, Steven. Disciplinas e delimitacion: la historia y sociología de la ciencia a luz del debate externismo-internismo. In: MARTINEZ, Sergio F. y GUILLAUMIN, Godfrey. (org.). Historia, Filosofia y Enseñanza de la ciencia. Mexico: UNAM, 2005, p.67-119.

SILVA, José Borzacchiello da. Milton Santos: A geografia, o Brasil, a França, o mundo. Entrevista. Mercator, Fortaleza, Revista de Geografia da UFC, ano 01, no 01, 2002, p. 7-17.

; OLIVEIRA, Márcio Piñon de. A trajetória da pós-graduação no

Brasil e a ANPEGE: algumas questões. Revista da ANPEGE, v. 5, 2009, p. 106-122.

SILVA, Maria José da; SANTOS, Acácia Aparecida Angeli dos. A avaliação da compreensão em leitura e o desempenho acadêmico de universitários. Psicologia em Estudo, Maringá, v. 9, no 3, set./dez. 2004, p. 459-467.

SILVA, Valdenildo Pedro. A formação do professor de Geografia na era da informação. Geosul, Florianópolis, Ed. UFSC, v. 22, no 43, jan/jul 2007, p. 167-195.

SILVEIRA, Maria Laura. O espaço geográfico: da perspectiva geométrica à perspectiva existencial. Geousp - Espaço e Tempo, São Paulo, no 19, 2006, p. $81-91$.

Uma situação geográfica: do método à metodologia. Revista Território, ano IV, no 6, jan/jul, 1999, p.21-28. Disponível em: http://www.revistaterritorio.com.br/pdf/06_3_silveira.pdf. Acesso em 20/12-2010.

SORRE, MAX. A Geografia Humana (Introdução). Traduzido de El Hombre en La Tierra. Introduccion. Editorial Labor, Barcelona, 1967, In: GEOgraphia, Ano V - no 10, 2003, p. 137-145.

SOUSA NETO, Manoel. A formação e o exercício profissional dos professores de geografia antes da institucionalização universitária no Brasil (1838-1934). Actas do VII Congresso Luso-Brasileiro de História da Educação. Porto, Faculdade de Psicologia e Ciências da Educação. Universidade do Porto, junho de 2008.

SOUSA, Ana Luiza Lima. A história da extensão universitária. Campinas: Editora Alínea, 2000.

SOUSA, Sandra Zákia. OLIVEIRA, Romualdo Portela. Políticas de avaliação e quase mercado no Brasil. In: Educação e Sociedade. 24 (84). São Paulo: Cortez; Campinas: Cedes, set. 2003, p.873-895.

SOUZA, Marcelo Lopes de. A prisão é a ágora: reflexões em torno da democratização do planejamento e da gestão das cidades. Rio de Janeiro: Bertrand do Brasil, 2006a.

O território: sobre espaço e poder, autonomia e desenvolvimento. In: CASTRO, Iná de Elias; GOMES, Paulo César da 
Costa; CORRÊA, Roberto Lobato (orgs.). Geografia: conceitos e temas. Rio de Janeiro: Bertrand do Brasil, 2006b, p. 77-116.

SOUZA, Vanilton Camilo de. A prática docente de professores de Geografia e a construção do seu saber. Boletim Goiano de Geografia, Goiânia, Instituto de Estudos Sócio-Ambientais/Geografia, UFG, vol 21, no 1, jan/jul 2001, p. 119-137.

SPOSITO, Eliseu Savério. A questão do método e a crítica do pensamento geográfico. In: CASTRO, Iná Elias de et alli (orgs.). Redescobrindo o Brasil: 500 anos depois. Rio de Janeiro: Bertrand do Brasil/FAPERJ, 2000, p. 347-359.

STAKE, Robert. Novos métodos para avaliação de programas educacionais. In: SOUSA, Eda. C. B. Machado de. Curso de especialização em avaliação a distância. Avaliação de currículos e de programas, Apostila (3). Brasília: UNB, Faculdade de Educação-Cátedra Unesco de Educação à Distância, 1997.

TEIXEIRA, Anísio. Educação no Brasil. São Paulo: Cia. Editora Nacional, 1997, p. 229-260.

TRINDADE JR., Saint-Clair Cordeiro da; PEREIRA, José Carlos Matos. Reestruturação da rede urbana e importância das cidades médias na Amazônia Oriental. In: SPOSITO, Maria Encarnação Beltrão. Cidades Médias: espaços em transição. São Paulo: Expressão Popular, 2007, p. 313-342.

UNESCO. Declaração Mundial sobre o Ensino Superior: para o século XXI: visão e ação. 1998. Disponível em: http://translate.google.com.br/translate?hl=pt-

BR\&langpair=en\%7Cpt\&u=http://www.unesco.org/education/educprog/w che/declaration_eng.htm. Acesso em 10/07/2012.

VALVERDE, Orlando. Pré-História da AGB carioca. Revista Terra Livre. Geografia e Memória. AGB, Sagres Editora, São Paulo, no 1, ano 10, 1994, p. 117-122.

VÁSQUEZ, Sánchez Adolfo. Filosofia da práxis. Buenos Aires: Clacso; São Paulo: Expressão Popular, 2007.

VESENTINI, José William. O método e a práxis (Notas polêmicas sobre Geografia Tradicional e Geografia, Crítica).In:AGB. .O ensino de Geografia em questão e outros temas. Revista Terra Livre, São Paulo, no 2, jul. 1987, p. 59-90.

Para uma Geografia Crítica na escola. São Paulo: Ática, 1992, p. 83-100.

VIANNA, Heraldo Marelim. Avaliação educacional: Teorias, planejamento, modelos. São Paulo, Ibrasa, 2000.

WAIBEL, Leo. O que eu aprendi no Brasil. Comentários. Revista Brasileira de Geografia, Rio de Janeiro, IBGE, no 3, 1950, p. 419-428. WITTER, João Sebastião. USP 50 anos: registros de um debate. São Paulo: Edusp, 1984. 
ZAGO, Nadir. Do acesso a permanência no ensino superior: percursos de estudantes universitários de camadas populares. Revista Brasileira de Educação, v. 11 no 32 maio/ago. 2006, p. 226-370.

ZAINKO, Maria Amélia Sabbag; PINTO, Maria Lúcia Accioly Teixeira. Gestão da instituição de ensino e ação docente. Curitiba: Ibpex, 2008.

ZANCHET, Beatriz Maria B. Atrib et. alli. A prática avaliativa do Exame Nacional dos Cursos e as falas dos estudantes. Disponível em: http://rapes.unsl.edu.ar/Congresos_realizados/Congresos/IV\%20Encuent ro\%20-\%200ct-2004/eje7/15.htm. Acesso em 20/10/2008.

ZARUR, Jorge. Geografia: ciência moderna ao serviço do homem. Revista Brasileira de Geografia, Rio de Janeiro, IBGE, ano VI, no 3, jul/set. 1944, p. 313-326. 


\section{APÊNDICE A}

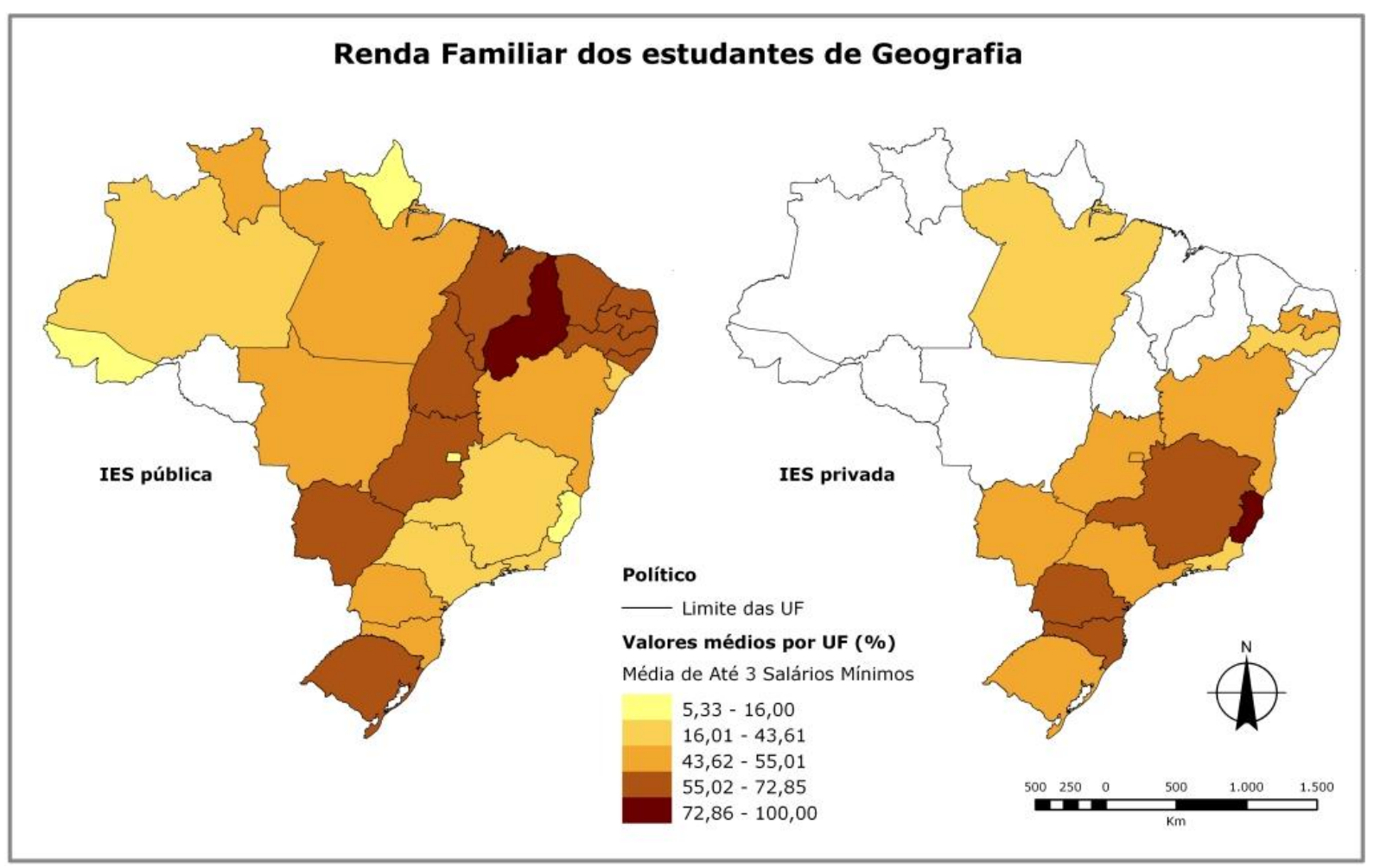

Fonte Inep, Relatórios de Cursos de Geografia no Enade, por IES, 2008.

Elaborado por Vivian Fiori e Mauricio Yamada, 2010.

\section{APÊNDICE B}

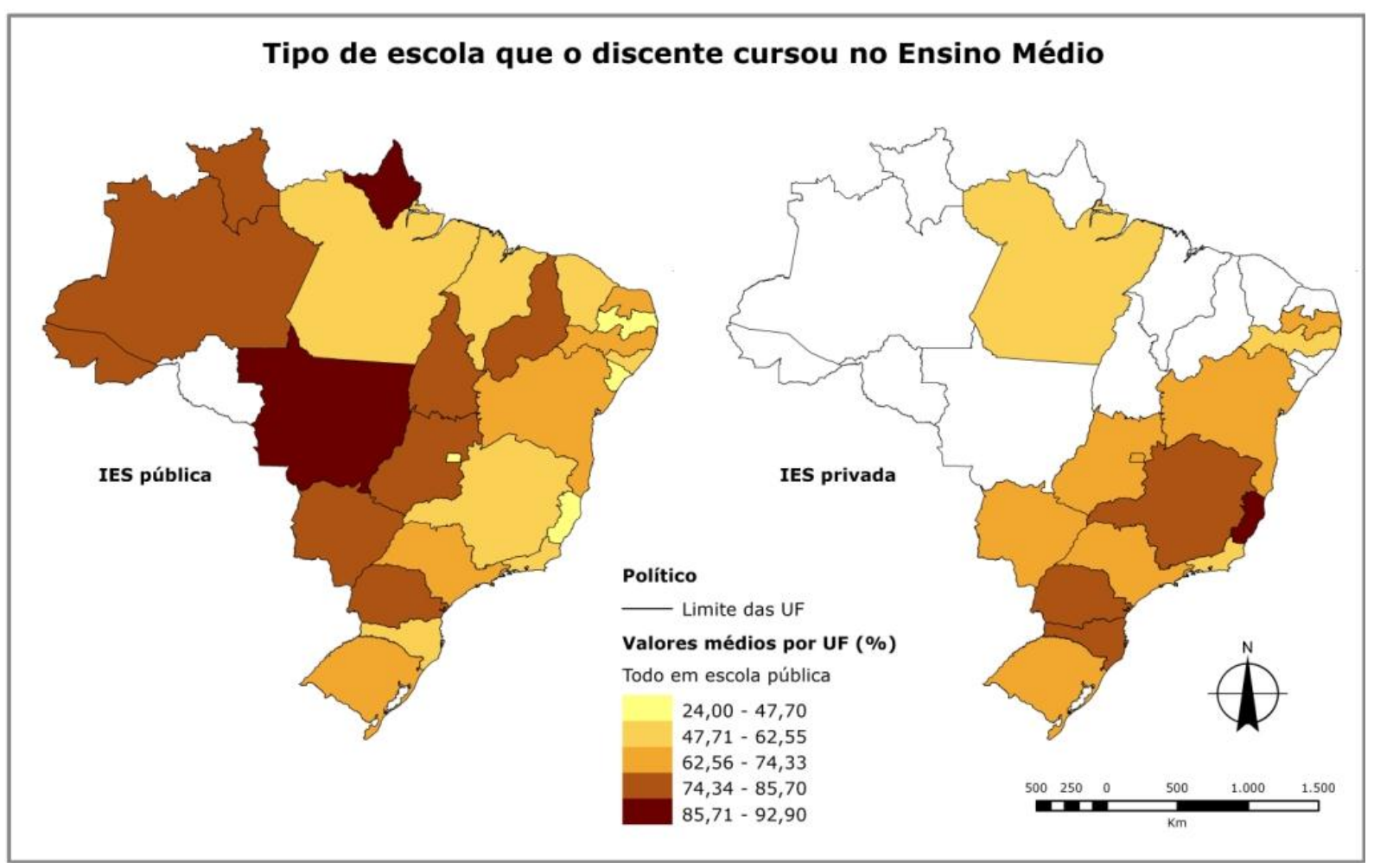

Fonte Inep, Relatórios de Cursos de Geografia no Enade, por IES, 2008.

Elaborado por Vivian Fiori e Mauricio Yamada, 2010. 


\section{APÊNDICE C}

\begin{tabular}{|c|c|c|}
\hline \multicolumn{3}{|c|}{ Nome dos cursos de pós-graduação em Geografia no Brasil } \\
\hline IES & UF & Nome \\
\hline UFAM & AM & Amazônia: Território e Ambiente \\
\hline UFBA & $\mathrm{BA}$ & Análise do Espaço Geográfico \\
\hline UFC & CE & $\begin{array}{l}\text { Dinâmica Territorial e Ambiental, Estudo Socioambiental da Zona } \\
\text { Costeira e Natureza, Campo e Cidade no Semi-Árido }\end{array}$ \\
\hline UECE & CE & $\begin{array}{l}\text { Análise Geoambiental, Ordenamento do Território em Regional } \\
\text { Semi-Árida e Litorânea }\end{array}$ \\
\hline UNB & DF & Gestão Ambiental e Territorial \\
\hline UFES & ES & Natureza, Técnica e Território \\
\hline UFG & GO & Natureza e a Apropriação do Espaço no Cerrado \\
\hline UFG & GO & Geografia e Ordenamento do Território \\
\hline UFG & GO & Organização do Espaço nos Domínios do Cerrado Brasileiro \\
\hline UFMG & MG & Análise Ambiental e Organização do Espaço \\
\hline UFU & MG & Geografia e Gestão do Território \\
\hline PUC/MG & MG & Análise Espacial \\
\hline UFMS & MS & Análise Geoambiental e Produção do Território \\
\hline UFGD & MS & Produção do Espaço Regional e Fronteira \\
\hline UFMT & MT & Ambiente e Desenvolvimento Regional \\
\hline UFPA & PA & Organização e Gestão do Território \\
\hline UFPB / J.P. & PB & Território, Trabalho e Ambiente \\
\hline UFPE & PE & Regionalização e Análise Regional \\
\hline FUFPI & PI & $----\cdot----$ \\
\hline UFPR & PR & Espaço, Sociedade E Ambiente \\
\hline UEL & PR & Dinâmica Espaço Ambiental \\
\hline UEM & PR & Análise Regional E Ambiental \\
\hline UEPG & PR & Gestão do Território: Sociedade e Natureza \\
\hline UNICENTRO & PR & Dinâmica da Paisagem e dos Espaços Rurais e Urbanos \\
\hline UNIOESTE & PR & Produção do Espaço e Meio Ambiente \\
\hline UFRJ & RJ & $\begin{array}{l}\text { Organização e Gestão do Território e Planejamento e Gestão } \\
\text { Ambiental }\end{array}$ \\
\hline UFF & RJ & Ordenamento Territorial e Ambiental \\
\hline UERJ & RJ & Gestão e Estruturação do Espaço Geográfico \\
\hline PUC-RIO & RJ & Geografia e Meio Ambiente \\
\hline UFRN & RN & Dinâmica e Estruturação do Território \\
\hline UNIR & RO & Amazônia e Políticas de Gestão Territorial \\
\hline
\end{tabular}




\begin{tabular}{|c|c|l|}
\hline IES & UF & \multicolumn{1}{|c|}{ Nome } \\
\hline UFRR & RR & ---------- \\
\hline UFRGS & RS & Análise Ambiental e Territorial \\
\hline UFSM & RS & Análise Ambiental e Dinâmica Espacial \\
\hline FURG & RS & Análise Urbano-Regional e Ambiental \\
\hline UFSC & SC & $\begin{array}{l}\text { Desenvolvimento Regional e Urbano e Utilização e Conservação de } \\
\text { Recursos Naturais }\end{array}$ \\
\hline FUFSE & SE & Organização e Dinâmica dos Espaços Agrário e Regional \\
\hline UNICAMP & SP & Análise Ambiental e Dinâmica Territorial \\
\hline UNESP/PP & SP & Produção do Espaço Geográfico \\
\hline UNESP/RC & SP & Organização do Espaço \\
\hline PUC/SP & SP & Territorialidades e Análise Sócio-Ambiental \\
\hline USP & SP & Geografia Física \\
\hline USP & SP & Geografia Humana \\
\hline UFT & TO & ------------ \\
\hline
\end{tabular}

Fonte: Capes, 2012. 


\section{APÊNDICE D}

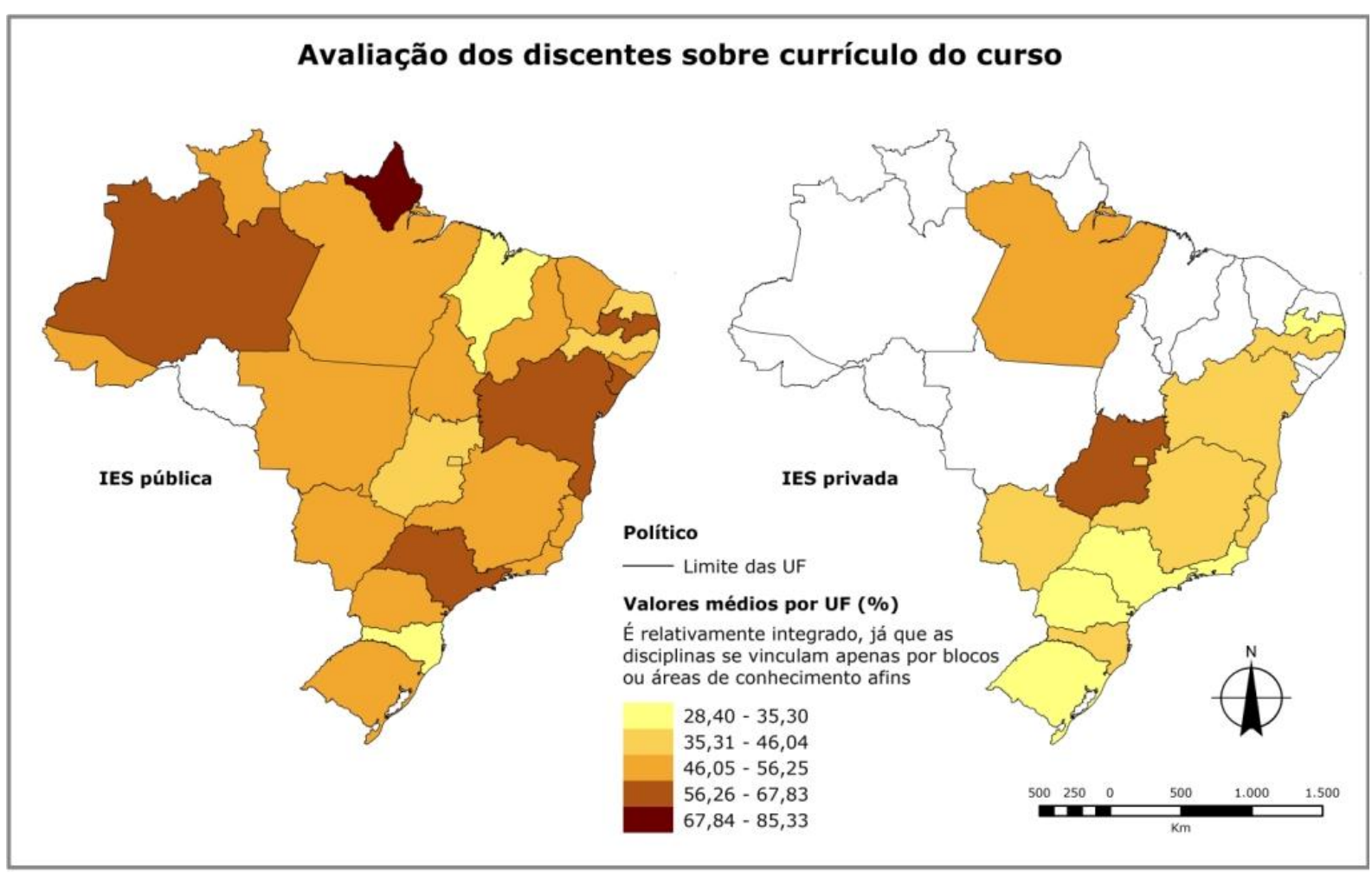

Fonte Inep, Relatórios de Cursos de Geografia no Enade, por IES, 2008.

Elaborado por Vivian Fiori e Mauricio Yamada, 2010. 


\section{APÊNDICE E}

\section{ALGUMAS REFLEXÕES SOBRE GEOGRAFIA CRÍTICA}

Há, nesta rede, aqueles que assumem claramente sua abordagem ou leitura do mundo ou do espaço pelo viés marxista, assim como os que buscam entender a relação sociedade-espaço ou sociedade-natureza, com outras matrizes teóricas e ideológicas.

Alguns autores ${ }^{119}$, como Milton Santos (2004), Antonio Carlos Robert Moraes (1995) e Ruy Moreira (2009), reforçam que tal mudança da Geografia Tradicional para a Crítica vai se dar pelo próprio movimento da história do mundo, que o torna mais complexo, mais global, o que faz com que a forma de ler o mundo da Geografia Tradicional e suas categorias não sejam mais suficientes para compreendê-lo.

De fato, esta idéia de que são criados novos conceitos ou que se buscam novas abordagens para a explicação do "mundo", à medida que ele vai mudando e que novos fenômenos vão surgindo, é válida. Contudo, existem outras mediações - como a questão ideológica - que perpassam as ciências, bem como as forças que as engendram, que são providas de poder, além da tradição do que seja Geografia.

Assim, parte dos geógrafos que aderiram à rede da Geografia Crítica só, na segunda metade do século XX, vão buscar em Marx a base das teorias do valor e outras teorias marxianas, criadas no século XIX. Não é, portanto, uma abordagem inteiramente nova, mas algo trazido à Geografia, à luz da compreensão do espaço ou do território ${ }^{120}$, numa visão social, que considera

119 Segundo Moraes (1995), "O desenvolvimento das ciências e do pensamento filosófico ultrapassara em muito os postulados positivistas, que apareciam agora como por demais simplistas e pueris" (MORAES, 1995, p. 96).

120 A partir dos anos 1980-90, categorias e conceitos como espaço e território retornam ao discurso geográfico, com mais força. O conceito de território que foi usado por Ratzel no século XIX retorna na Geografia Crítica e passa a ser utilizado, considerando-se outras dimensões de estudos, além do cunho político e da escala nacional. Passamos a ter estudos de território também evidenciando os usos econômicos e sociais em diversas escalas geográficas. A questão teórica e epistemológica ganha força neste período em artigos e livros publicados, principalmente sobre o objeto da Geografia e história do pensamento geográfico, em obras, tais como: de Milton Santos (2004), "Por uma Geografia Nova: da crítica da Geografia a uma Geografia Crítica", originalmente publicada em 1978; de Antonio Carlos Robert Moraes (1995), "Geografia: pequena história crítica", com a primeira edição em 1983; e de Ruy Moreira (1995), "O que é Geografia", de 1985. 
como fundamental o entendimento da existência de uma sociedade desigual, a qual precisa ser analisada espacialmente.

As maiores críticas feitas aos autores da Geografia Crítica são decorrentes da visão de que esta abordagem desconsidera o quadro natural ou a "Geografia Física", portanto, para a maioria deste grupo ou rede, a Geografia é uma ciência humana.

Mas mesmo nesta questão há divergências, pois há os que, embora se denominem críticos, buscam entender o espaço geográfico na inter-relação da sociedade com a natureza. Há, portanto, que se considerar o momento histórico em que se dão tais mudanças nos diversos lugares do mundo, assim como perceber as mudanças empreendidas na história do pensamento geográfico, na epistemologia, e como concretamente isto foi sendo vivenciado nos cursos de Geografia no Brasil. 
APÊNDICE F

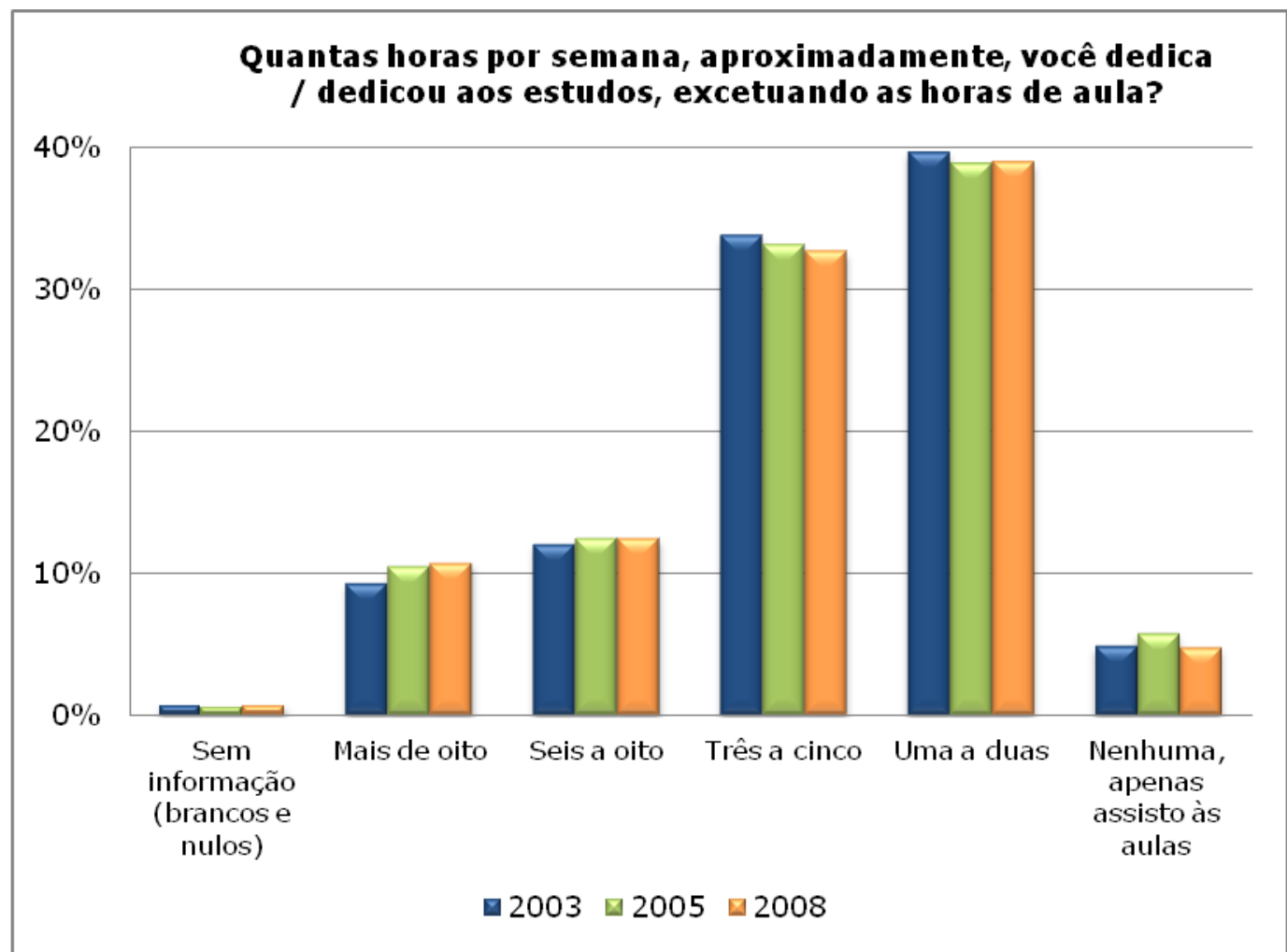

Fonte: Inep, Relatórios Sínteses/Cursos, Área de Geografia, ENC 2003 e Enades 2005 e 2008. Dados organizados por Vivian Fiori, 2009.

\section{APÊNDICE G}

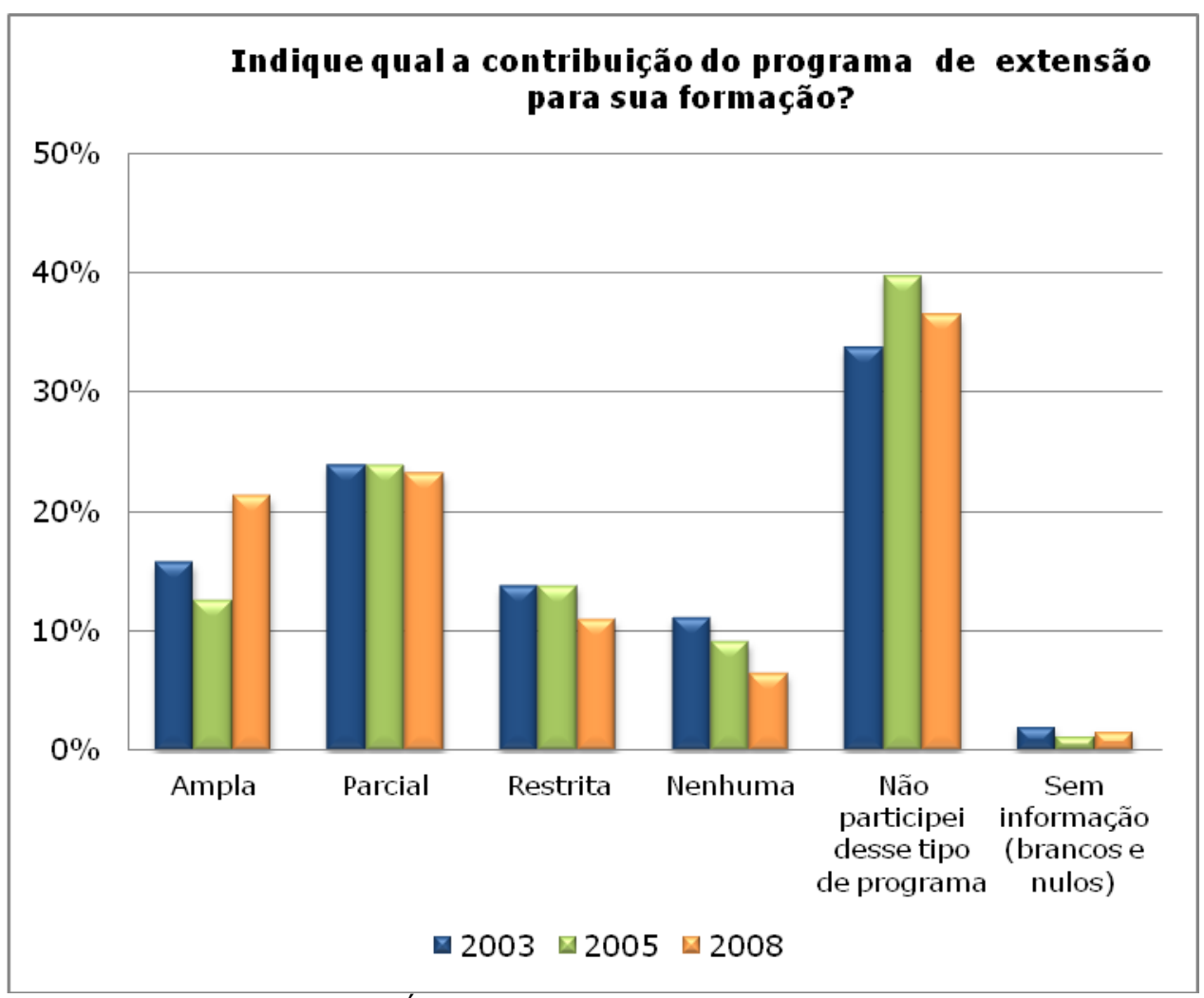

Fonte: Inep, Relatórios Sínteses/Cursos, Área de Geografia, ENC 2003 e Enades 2005 e 2008. Dados organizados por Vivian Fiori, 2009. 


\section{APÊNDICE H}

\begin{tabular}{|c|c|c|}
\hline \multicolumn{3}{|c|}{ Formação Docente- UFPA- 2011} \\
\hline Graduação & Mestrado-UF & Doutorado \\
\hline Geografia - UFPA & $\begin{array}{l}\text { Agronomia Ciências do Solo }- \\
\text { Univers. Rural da Amazônia - UFRA }\end{array}$ & --- \\
\hline Geografia - UFPA & $\begin{array}{l}\text { Mestrado em Geografia Humana - } \\
\text { USP }\end{array}$ & --- \\
\hline Geografia - UFPA & $\begin{array}{l}\text { Mestrado em Geografia Física - } \\
\text { USP }\end{array}$ & $\begin{array}{l}\text { Geologia e Geoquímica - } \\
\text { UFPA }\end{array}$ \\
\hline Geografia - UFPA & Mestrado em Geografia - UNESP & $\begin{array}{l}\text { Desenvolvimento } \\
\text { Sustentável do Trópico } \\
\text { Úmido - UFPA }\end{array}$ \\
\hline Geografia - UFPA & $\begin{array}{l}\text { Desenvolvimento Sustentável do } \\
\text { Trópico Úmido - UFPA }\end{array}$ & $\begin{array}{l}\text { Desenvolvimento } \\
\text { Sustentável do Trópico } \\
\text { Úmido - UFPA }\end{array}$ \\
\hline Geografia - UFPA & Geografia - UFPA & --- \\
\hline Geografia - UFPA & --- & --- \\
\hline Geografia - UFPA & Agronomia - UFRA & --- \\
\hline Geografia - UFPA & Geografia - UFPA & --- \\
\hline Geografia - UFPA & Geografia - UFPE & Geografia Humana- USP \\
\hline Geografia - UFPA & $\begin{array}{l}\text { Desenvolvimento Sustentável do } \\
\text { Trópico Úmido - UFPA }\end{array}$ & Geografia- UNESP \\
\hline Geografia - UFPA & $\begin{array}{l}\text { Desenvolvimento Sustentável do } \\
\text { Trópico Úmido - UFPA }\end{array}$ & Geografia- UNESP \\
\hline Geografia - USP & Geografia - UFPA & --- \\
\hline Geografia - UFPA & Geografia - UFPA & --- \\
\hline Geografia - UFPA & Geografia - UFRJ & --- \\
\hline Geografia - USP & Geografia Física - USP & Geografia Física - USP \\
\hline $\begin{array}{l}\text { Geografia - UFPA } \\
\text { Direito - UFPA }\end{array}$ & Geografia - UFRJ & Geografia- UFRJ \\
\hline $\begin{array}{l}\text { Pedagogia - UEPA e } \\
\text { Geografia - UFPA }\end{array}$ & $\begin{array}{l}\text { Planejamento do Desenvolvimento } \\
\text { - NAEA }\end{array}$ & Geografia Humana - USP \\
\hline Geografia - UFRN & Geografia - UFRN & --- \\
\hline
\end{tabular}

Fonte: Site da IES (sede Belém) e currículos do Sistema Lattes, 2012. 


\section{ANEXO A}

\section{Questão Dissertativa do ENC-2003}

Questão 4. O saber e o fazer geográfico no ensino fundamental implica a necessidade de o professor levar em conta o aluno enquanto sujeito do conhecimento, cuja construção constitui um processo.

Guilherme, meu neto de 3 anos de idade, tem ido com freqüência ao aeroporto, quando das viagens de seus parentes para a Europa. Tchau, tia! E esta desaparecia, entrando no avião. No seu retorno, Guilherme ia recepcioná-la:

Oi, tia, tudo bem? Em outra oportunidade, outra tia também foi para a Europa. Idem, idem: Tchau! Oi, tia!

Um dia, provoquei-o: Guilherme, vamos para a Europa? Ele me lançou um olhar entre assustado e receoso e me respondeu: Ai,vovó, não sei se vou agüentar ficar tanto tempo dentro do avião!...

A partir da situação apresentada,

a. De acordo com as referências da psicologia da aprendizagem analise a noção de espaço da qual Guilherme é portador.

b. O que se espera de Guilherme, ao término do Ensino Fundamental, a respeito da noção de espaço?

Fonte: Inep, Prova de Geografia, ENC-2003, 2003a, p. 17. 
ANEXO B

\section{Questão Dissertativa do Enade 2005}

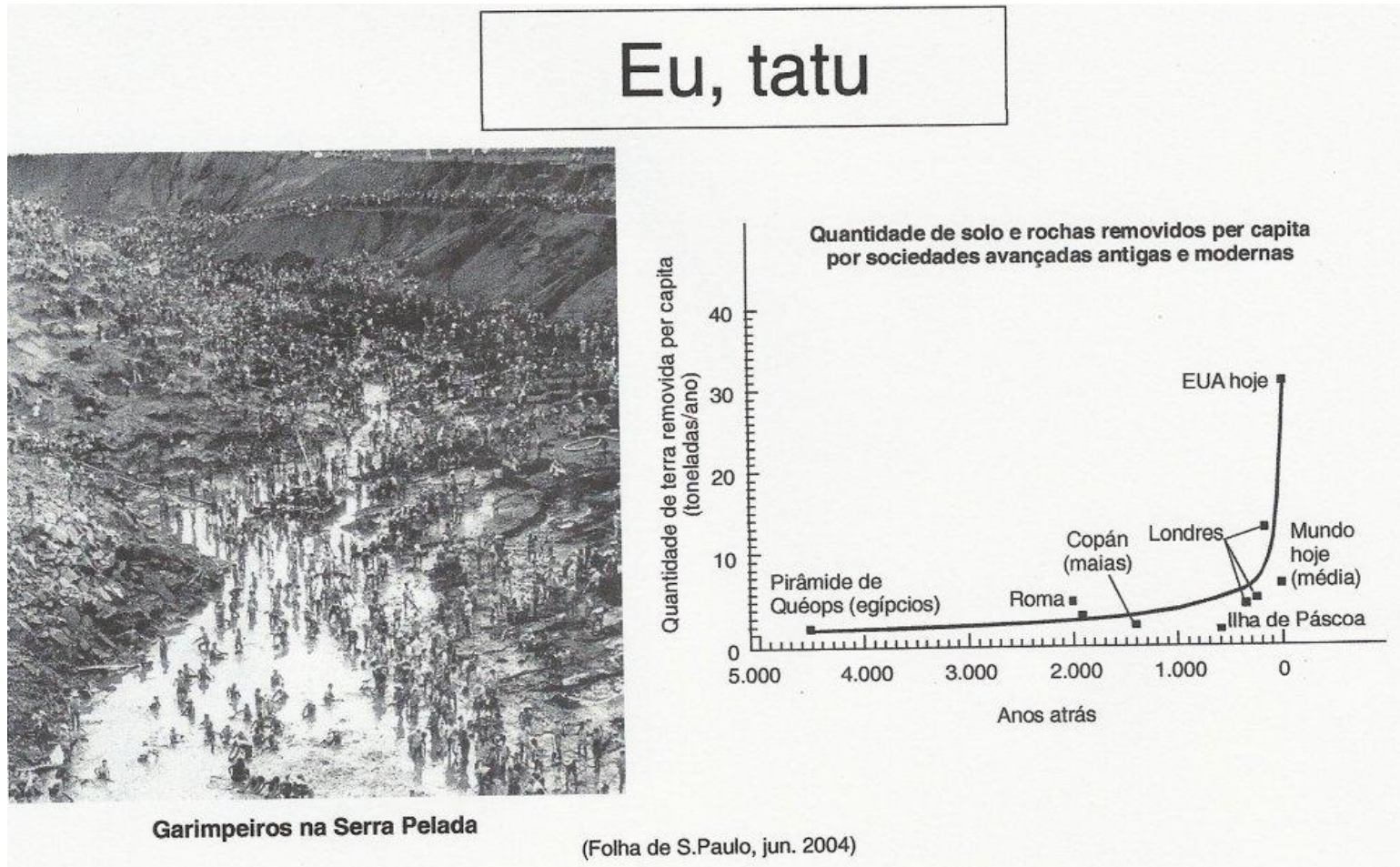

a. Identifique e conceitue o processo geomorfológico assunto da matéria que envolve a foto e o gráfico. (Valor: 4,0 pontos)

b. Explique porque as sociedades humanas ampliaram seu poder de remanejar solos e rochas a partir da época evidenciada no gráfico. Utilize ao menos dois exemplos, descartando a mineração.

(Valor: 6,0 pontos)

Fonte: Prova Enade 2005, INEP, 2006. 
ANEXO C: Exemplo de currículo de uma IES da Amazônia

\begin{tabular}{|c|c|c|c|}
\hline \multicolumn{4}{|c|}{ ESTRUTURA CURRICULAR NOVA (vigora desde 2010) - Licenciatura em Geografia } \\
\hline 10 PERÍODO & Teoria & Prática & Total \\
\hline O Mundo Globalizado e suas transformações & 40 & 0 & 40 \\
\hline Ética, Diversidade e Direitos Humanos & 80 & 0 & 80 \\
\hline Literatura e suas Interfaces & 80 & 0 & 80 \\
\hline A Pesquisa e sua Estrutura & 80 & 0 & 80 \\
\hline Produção Textual: Texto Oral, Texto Escrito & 80 & 0 & 80 \\
\hline Aplicação de Projetos I & 0 & 80 & 80 \\
\hline TOTAL & 400 & 80 & 440 \\
\hline $2^{\circ}$ PERÍODO & Teoria & Prática & Total \\
\hline Políticas Públicas, Legislação Educacional e Currículo & 80 & 0 & 80 \\
\hline O Contexto Escolar: Planejamento de Curso, de Aula e Avaliação & 80 & 0 & 80 \\
\hline Aprendizagem e Desenvolvimento & 80 & 0 & 80 \\
\hline Estratégias de Estudo e de Ensino & 40 & 0 & 40 \\
\hline Prática Interativa em Sala de Aula & 20 & 20 & 40 \\
\hline Pedagogia da Inclusão/ LIBRAS & 40 & 0 & 40 \\
\hline Aplicação de Projetos II & 0 & 80 & 80 \\
\hline TOTAL & 340 & 100 & 440 \\
\hline $3^{\circ}$ PERÍODO & Teoria & Prática & Total \\
\hline Geografia Física & 30 & 10 & 40 \\
\hline Geografia Humana & 40 & 0 & 40 \\
\hline Cartografia Aplicada ao Ensino & 50 & 30 & 80 \\
\hline Metodologia de Ensino de Geografia & 40 & 40 & 80 \\
\hline Teoria Regional e Regionalização & 80 & 0 & 80 \\
\hline Projetos Integrados I & 0 & 40 & 40 \\
\hline Geografia Ambiental & 30 & 10 & 40 \\
\hline Estágio Supervisionado I & 0 & 80 & 80 \\
\hline TOTAL & 270 & 210 & 480 \\
\hline $4^{\circ}$ PERÍODO & Teoria & Prática & Total \\
\hline Geografia Econômica & 30 & 10 & 40 \\
\hline Geotecnologias Aplicadas ao Ensino & 50 & 30 & 80 \\
\hline Climatologia & 40 & 40 & 80 \\
\hline Geomorfologia & 40 & 40 & 80 \\
\hline Geografia do Brasil & 40 & 40 & 80 \\
\hline Projetos Integrados II & 0 & 40 & 40 \\
\hline Estágio Supervisionado II & 0 & 80 & 80 \\
\hline TOTAL & 200 & 280 & 480 \\
\hline $5^{\circ}$ PERÍODO & Teoria & Prática & Total \\
\hline Formação e Organização do Espaço Amazônico & 40 & 40 & 80 \\
\hline Geografia Urbana & 50 & 30 & 80 \\
\hline Geografia Agrária & 50 & 30 & 80 \\
\hline Geografia Política e Geopolítica & 50 & 30 & 80 \\
\hline Trabalho de Curso I & 10 & 30 & 40 \\
\hline Projetos Integrados III & 0 & 40 & 40 \\
\hline Estágio Supervisionado III & 0 & 80 & 80 \\
\hline TOTAL & 200 & 280 & 480 \\
\hline $6^{\circ}$ PERÍODO & Teoria & Prática & Total \\
\hline Trabalho de Curso II & 0 & 40 & 40 \\
\hline Ecossistemas e Biodiversidade Mundial e Regional & 40 & 40 & 80 \\
\hline Organização e Dinâmica do Espaço Paraense & 40 & 40 & 80 \\
\hline Hidrografia & 50 & 30 & 80 \\
\hline Geografia da População & 30 & 10 & 40 \\
\hline Estágio Supervisionado IV & 0 & 80 & 80 \\
\hline TOTAL & 160 & 240 & 400 \\
\hline
\end{tabular}

Fonte: http://www.fibrapara.edu.br/curso_geografia/pfd/GRADE_GEOGRAFIA.pdf. Acesso 2012. 